\title{
Cultural Resources Survey for a Joing Task Force Six (JTF-6) Action in Webb, Maverick, and Dimmit Counties, Texas
}

Jeffrey D. Owens

Geo-Marine, Inc.

Johnna L. Buysse

Geo-Marine, Inc.

Steve Gaither

Geo-Marine, Inc.

Follow this and additional works at: https://scholarworks.sfasu.edu/ita

Part of the American Material Culture Commons, Archaeological Anthropology Commons, Environmental Studies Commons, Other American Studies Commons, Other Arts and Humanities Commons, Other History of Art, Architecture, and Archaeology Commons, and the United States History Commons

Tell us how this article helped you.

This Article is brought to you for free and open access by the Center for Regional Heritage Research at SFA ScholarWorks. It has been accepted for inclusion in Index of Texas Archaeology: Open Access Gray Literature from the Lone Star State by an authorized editor of SFA ScholarWorks. For more information, please contact cdsscholarworks@sfasu.edu. 


\section{Cultural Resources Survey for a Joing Task Force Six (JTF-6) Action in Webb, Maverick, and Dimmit Counties, Texas}

\section{Creative Commons License}

\section{(c) (1) $\Theta$}

This work is licensed under a Creative Commons Attribution-NonCommercial-No Derivative Works 4.0 International License. 


\title{
CULTURAL RESOURCES SURVEY FOR A JOINT TASK FORCE SIX (JTF-6) ACTION \\ IN WEBB, MAVERICK, AND DIMMIT COUNTIES, TEXAS
}

\author{
by \\ Jeffrey D. Owens \\ Johnna L. Buysse \\ Steve Gaither
}

for

U.S. Army Corps of Engineers

Fort Worth District

MisCELLANEOUS REPORT OF INVESTIGATIONS

NUMBER 158

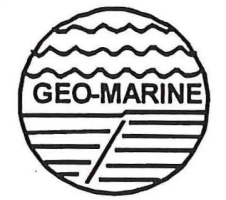

GEO-MARINE, INC

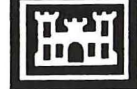

US Army Corps

of Engineers

Fort Worth District 
ळ

$\dot{*}$

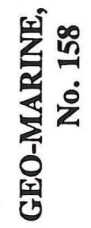

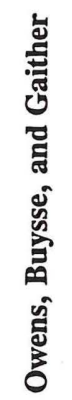

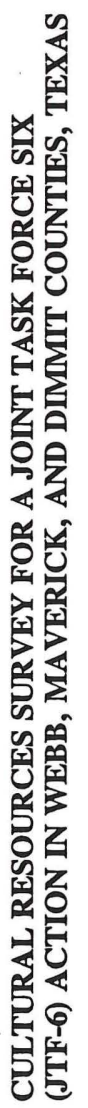


Public reporting burden for this collection of information is estimated to average I hour per response, including the time for reviewing instructions, searching existing data sources, gathering and maintaining the data needed, and completing and reviewing the collection of information. Send comments regarding this burden estimate or any other aspect of this collection of information including suggestions for reducing this burden, to Washington Headquarters Services Directorate for Information Operations and Reports, 1215 Jefferson Davis Highway, Suite 1204, Arlington, VA 22202-4302, and to the Office of Management and Budget, Paperwork Reduction Project (0704-0188), Washington, DC 20503.

\begin{tabular}{|l|c|c|}
\hline I. AGENCY USE ONLY (Leave b/ank) & $\begin{array}{c}\text { 2. REPORT DATE } \\
\text { March } 1998\end{array}$ & $\begin{array}{r}\text { 3. REPORT TYPE AND DATES COVERED } \\
\text { Final }\end{array}$ \\
\hline
\end{tabular}

4. TITLE AND SUBTITLE

Cultural Resources Survey for a Joint Task Force Six (JTF-6) Action in Webb, Maverick, and Dimmit Counties, Texas 5. FUNDING NUMBERS

6. AUTHOR(S)

Jeffrey D. Owens, Johnna L Buysse, and Steve Gaither

7. PERFORMING ORGANIZATION NAMES(S) AND ADDRESS(ES)

Geo-Marine, Inc.

550 East Fifteenth Street

Plano, Texas

75074

REPORT NUMBER

Geo-Marine, Inc.

Miscellaneous Report of Investigations

Number 158

9. SPONSORING/MONITORING AGENCY NAMES(S) AND ADDRESS(ES)

10. SPONSORING/MONITORING

U.S. Army Corps of Engineers, Fort Worth District

AGENCY REPORT NUMBER

PO Box 17300

Fort Worth, Texas

$76102-0300$

II. SUPPLEMENTARY NOTES

\begin{tabular}{|l|l|l|l|l}
\hline I2a. DISTRIBUTION AVAILABILITYSTATEMENT & I2b. DISTRIBUTION CODE
\end{tabular}

Approved for public release

13. ABSTRACT (Maximum 200 words)

This report presents the results of a cultural resources inventory survey of 239.8 miles of existing and proposed new road rights-of-way in Webb, Maverick, and Dimmit counties, south Texas. Included within the survey area are the proposed locations for three borrow pits, an equipment storage area, two helipads, one airfield, and two base camp areas. Also included in the report is an assessment of the potential eligibility of each cultural resource property for indusion in the National Register of Historic Places (NRHP).

The work was conducted by Geo-Marine, Inc. (GMI), under a contract (No. DACA63-96-D-0038, Delivery Order 0028) with the US. Army Corps of Engineers, Fort Worth District, which was acting for loint Task Force Six (JTF-6). The purpose of this study is to provide JTF- 6 with data for use in the management of the cultural resources within the project area in partial fulfillment of its obligations under the National Historic Preservation Act and other applicable cultural resources protection legislation.

The project resulted in the identification of 96 cultural resources sites and 349 nonsite localities. All of the archeological sites located date to the prehistoric period, and one contains a limited historic period component as well. Twenty-five of these cultural properties are recommended as potentially eligible for listing in the NRHP. None of the nonsite localities is recommended as potentially eligible for inclusion in the NRHP.

Name of Federal Technical Responsible Individual: Dr. Jay R. Newman

Organization: U.S. Army Corps of Engineers, Fort Worth District, CESWF-EV-EC

Phone \#: (817) 978-6388

14. SUBJECT TERMS

Cultural resources survey of 239.8 miles of existing and proposed new road rights-of-way and the proposed locations for three borrow pits, an equipment storage area, two helipads, one airfield, and two base camp areas in Webb, Maverick, and Dimmit counties, Texas.

17. SECURTYY CLASSIFICATION OF REPORT

Unclassified
18. SECURITY CLASSIFICATION OF THIS PAGE Unclassified
19. SECURITYCLASSIFICATION OF ABSTRACT Unclassified
15. NUMBER OF PAGES

16. PRICE CODE

20. LIMITATION OF ABSTRAC

UL 


\title{
CULTURAL RESOURCES SURVEY FOR A JOINT TASK FORCE SIX (JTF-6) ACTION IN WEBB, MAVERICK, AND DIMMIT COUNTIES, TEXAS
}

\author{
by \\ Jeffrey D. Owens \\ Johnna L. Buysse \\ Steve Gaither \\ with contributions by \\ Melissa M. Green \\ Steven M. Hunt \\ Mark A. Sale \\ Principal Investigator \\ Duane E. Peter
for
U.S. Army Corps of Engineers \\ Fort Worth District \\ Contract No. DACA63-96-D-0038 \\ Delivery Order No. 0028
}

MiscellaNEOUS REPORT OF INVESTIGATIONS
NUMBER 158

Geo-Marine, Inc.

550 East 15th Street

Plano, Texas 75074

March 1998 


\section{CONTRACT DATA}

The preparation of this document was accomplished under Contract No. DACA63-96-D-0038, Delivery Order No. 0028 (GMI project number 1538-111), with the U.S. Army Corps of Engineers, Fort Worth District, P.O. Box 17300, Fort Worth, Texas, 76102-0300. 


\section{MANAGEMENT SUMMARY}

In an effort to aid United States Border Patrol efforts to combat smuggling and illegal immigration in south Texas, road improvements have been proposed along the U.S.-Mexico international border in three south Texas counties by Joint Task Force Six (JTF-6). JTF-6 Operation Number JT513/515/425-98 consists of a single action in Webb, Maverick, and Dimmit counties, Texas. This action includes the repair/upgrade of approximately $211.0 \mathrm{~km}(131.1 \mathrm{mi})$ of existing roads, the construction of roughly $176.7 \mathrm{~km}(109.8 \mathrm{mi}$ ) of new roads (totaling $387.7 \mathrm{~km}$ [240.9 mi]), the excavation of three borrow pits, the construction of an equipment storage area, two helipads, one airfield, and two base camp areas for this and future JTF- 6 rotations. The proposed activities associated with this JTF- 6 action are distributed among nine separate project area segments in the Laredo and Carrizo Springs, Texas, Border Patrol sectors. These nine project segments consist of the Rio Bravo, Laredo River Road, Galvan Ranch, Stone Ranch, Swartz Ranch, State Highway 277, Farm-to-Market Road 2644, State Highway 83, and Farm-toMarket Road 3338 segments. The protection of the cultural resources falls under the jurisdiction of the U.S. Army Corps of Engineers. Geo-Marine, Inc. (GMI), was contracted to conduct a systematic cultural resources inventory survey of the proposed impact areas.

Between 20 October and 10 November 1997, personnel from Geo-Marine, Inc., conducted an intensive cultural resources survey of seven of the nine segments of the project area connected with this action. Three of the segments, the Laredo River Road, State Highway 83, and Farm-to-Market Road 3338, had been previously surveyed for cultural resources. The latter two segments had been intensively surveyed, while a reconnaissance survey had been conducted along the Laredo River Road segment. The presence of twentieth-century alluvial deposits along the Laredo River Road precluded the need for an intensive survey. Archeological monitoring for the grading of the Laredo River Road segment in 1993 verified that significant archeological deposits were not present in the proposed right-of-way. Nevertheless, at the insistence of the State Historic Preservation Office (SHPO), the existing Laredo River Road as well as .8 $\mathrm{km}$ (.5 mi) of new road right-of-way (ROW) was resurveyed for cultural resources in connection with this action. In addition, one known historic property, the site of Star Fort (41WB11, part of Fort McIntosh), is situated on the terrace above the proposed Laredo River Road segment. This site has been listed on the National Register of Historic Places (NRHP) and should be avoided during this JTF-6 action. The portion of the Laredo River Road segment that passes below Star Fort consists of an existing gravel road, and the proposed upgrading activities will not impact this National Register property provided that all activities are restricted to the existing ROW. Extensive previous disturbance was observed within the proposed impact areas on the Rio Bravo, State Highway 277, and Farm-to-Market Road 2644 segments of this action, and no cultural resources sites were identified in any of these areas. Four previously documented archeological sites along two of the segments (one site on State Highway 83 
and three sites on Farm-to-Market Road 3338) were revisited and site forms on file at the Texas Archeological Research Laboratory (TARL) were updated.

Ninety-seven previously unrecorded archeological sites and 349 nonsite localities were identified during the cultural resources survey of the Galvan Ranch, Stone Ranch, and Swartz Ranch segments of the project area. All of these cultural properties contain artifacts that can be attributed to prehistoric occupations in the project area, and one of them also contains a small historic component. Twenty-six of the archeological sites are recommended as potentially eligible for inclusion in the NRHP based on their potential to contribute significant information about the prehistoric past. It is recommended that these properties be avoided during the deployment for this action. Most (23) of the potentially eligible sites are already traversed by existing roads. In order to avoid any impacts to these cultural properties, it is recommended that no road improvement activities, including road grading, filling, and ditch construction, occur within the boundaries of the sites. Additionally, the movement of vehicles and heavy equipment along the existing roads through these sites should be restricted to the existing roadbed, with no equipment staging or turn-arounds occurring within the site boundaries. A total of four potentially eligible sites are located within the proposed ROWs of new road segments, including two sites (41WB510 and 41MV208) that also have a segment of existing road passing through them and two sites (41MV209 and 41MV229) that are traversed only by proposed new road rights-of-way. At the request of JTF-6, possible road reroutes that would ensure that these properties would not be impacted during this action were designed and inspected for cultural resources. In all cases, it was possible to locate potential reroute ROWs that would not impact any cultural resources. The presence of an archeological monitor is recommended in the vicinity of all potentially eligible sites during road construction and improvement activities.

Of the remaining 71 archeological sites, the site boundaries of 41 sites extend well beyond the project area for the current survey. Because the site limits were therefore not established, the only portions of these sites that have been evaluated are those areas that fall within the surveyed rights-of-way. The assessed areas of these 41 sites are recommended as ineligible for inclusion in the NRHP, and no further archeological work is recommended for the evaluated areas of these sites. The portions of these sites located beyond the rights-of-way, however, may yet retain some limited research potential, and should probably be investigated further in the future in the event that future construction projects or other efforts that might affect the sites are planned. The site boundaries of 30 of the 71 sites are predominantly within or very close to the surveyed rights-of-way, and the entire sites could be evaluated. These 30 sites are recommended as ineligible for inclusion in the NRHP, and no further archeological work is recommended.

By definition, nonsite localities do not meet the criteria that define a site. Therefore, none of the nonsite localities are recommended as eligible for inclusion in the NRHP. 


\section{TABLE OF CONTENTS}

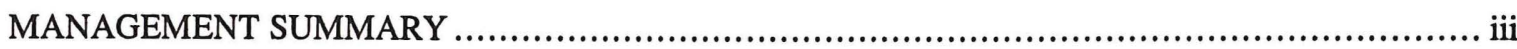

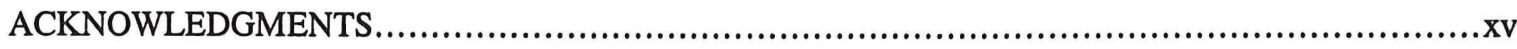

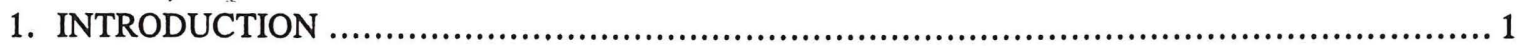

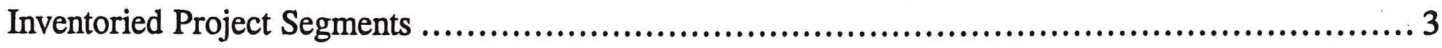

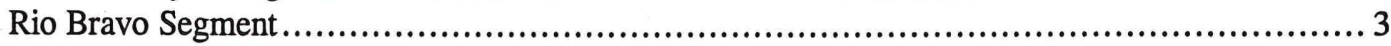

Laredo River Road Segment ................................................................... 3

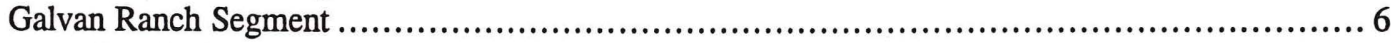

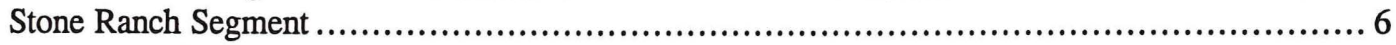

Swartz Ranch Segment .......................................................................... 11

State Highway 277 Segment ........................................................................11

Farm-to-Market Road 2644 Segment............................................................. 11

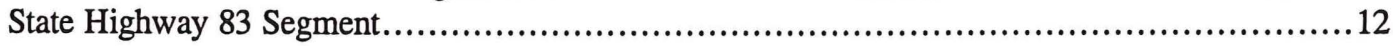

Farm-to-Market Road 3338 Segment............................................................

2. ENVIRONMENTAL AND CULTURAL OVERVIEWS ….............................................. 19

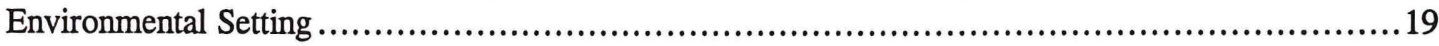

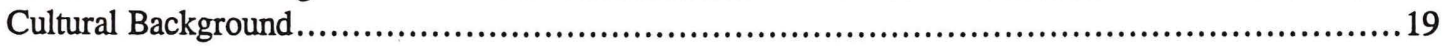

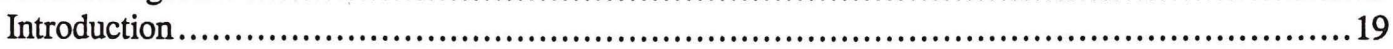

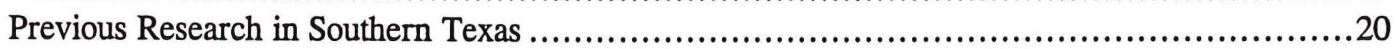

Cultural Chronology in Southern Texas .........................................................21

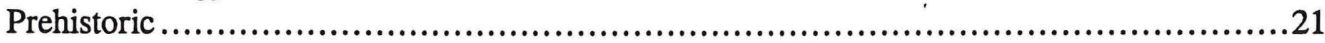

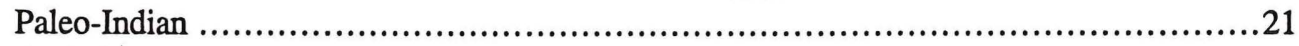

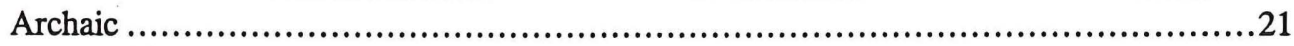

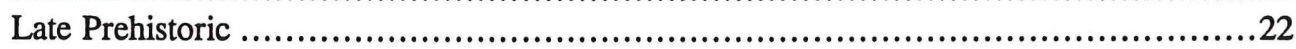

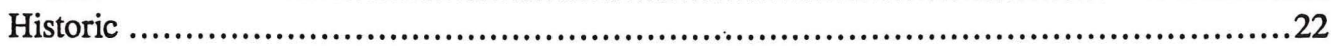

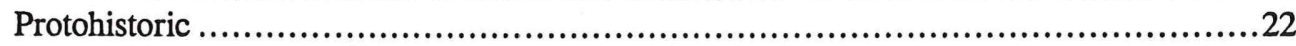

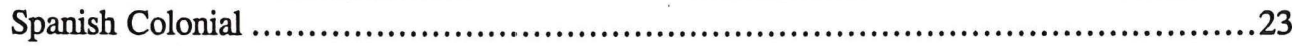

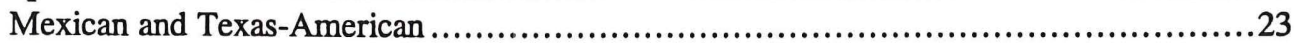

Previous Research in the Project Area ....................................................................25

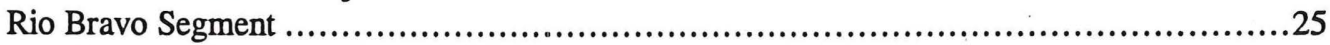

Laredo River Road Segment ..................................................................26

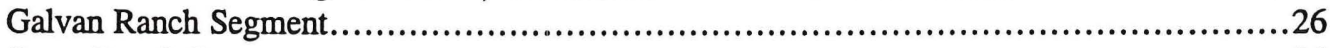

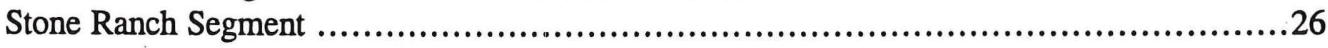


Table of Contents

(cont'd)

Swartz Ranch Segment .............................................................27

State Highway 277 and Farm-to-Market Road 2644 Segments ..............................27

State Highway 83 and Farm-to-Market Road 3338 Segments ............................27

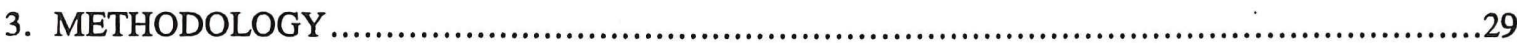

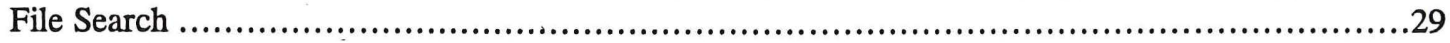

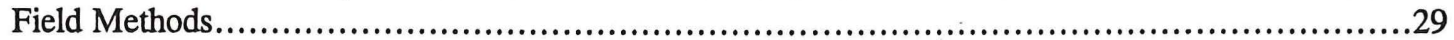

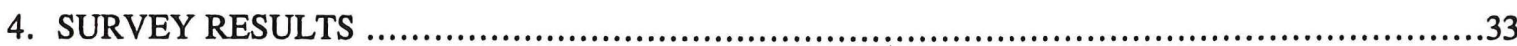

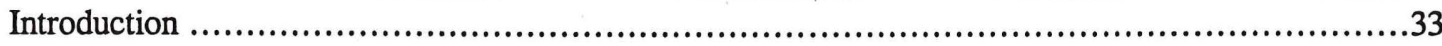

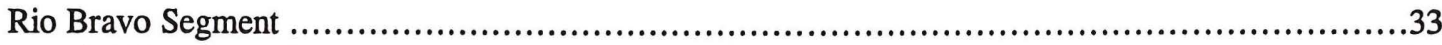

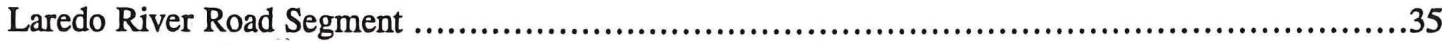

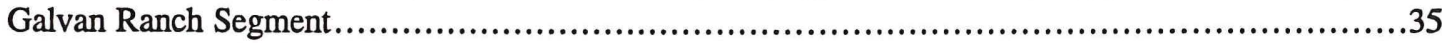

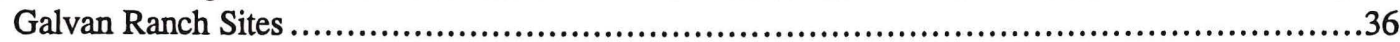

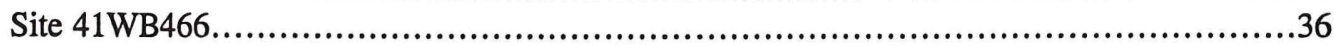

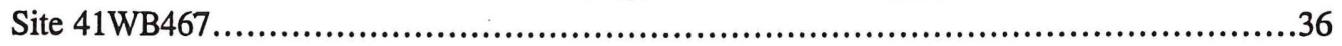

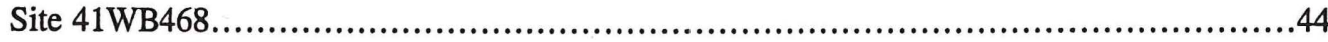

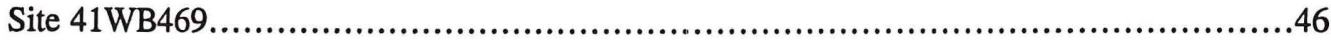

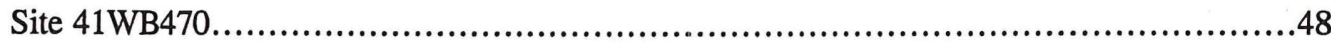

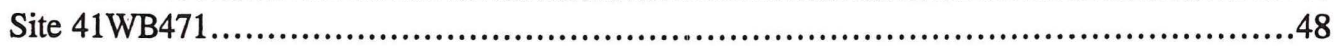

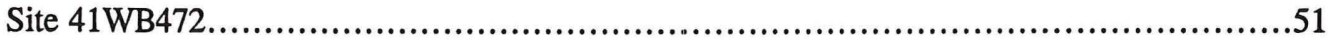

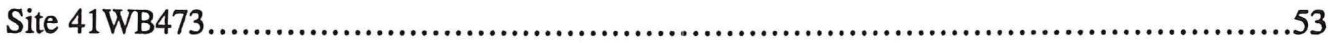

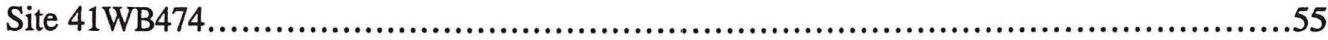

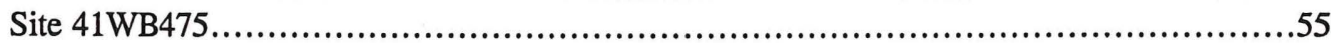

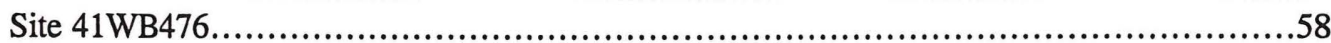

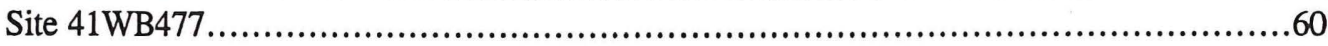

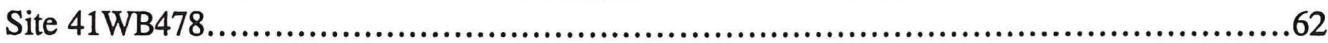

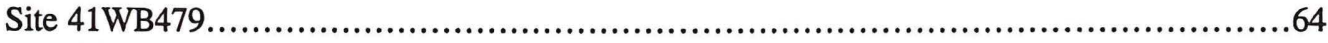

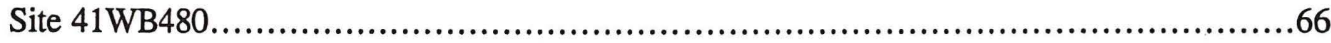

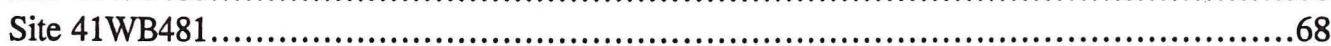

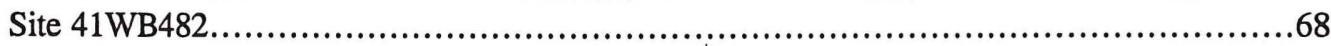

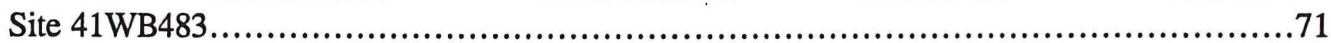

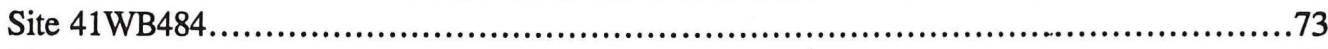

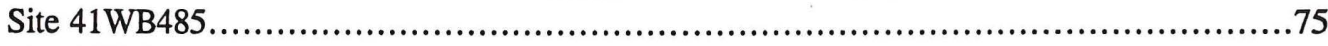

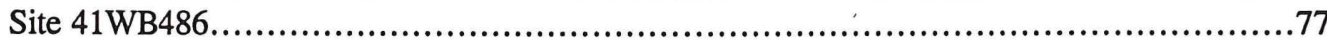

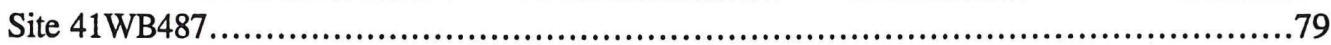

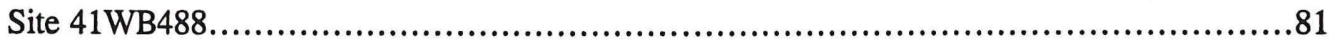

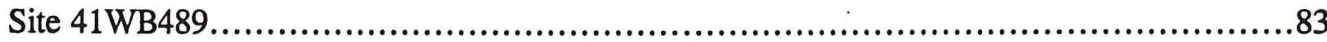

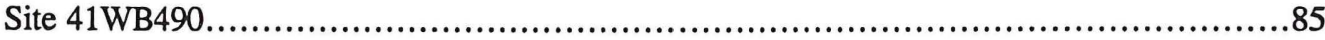

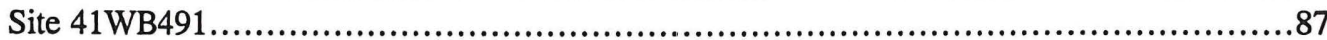

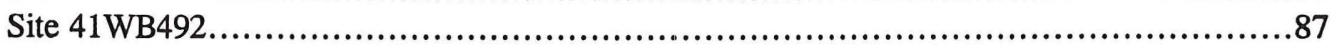

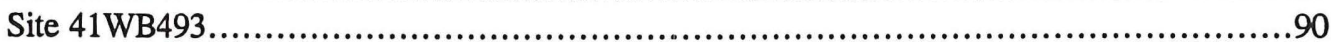

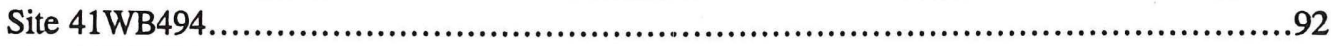

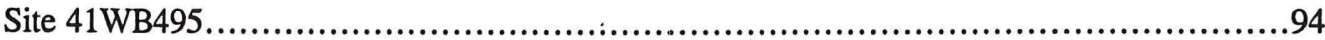

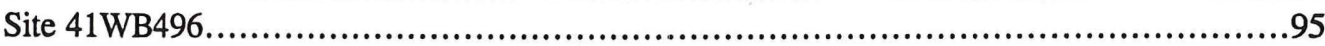

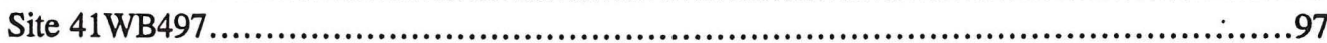


Table of Contents

(cont'd)

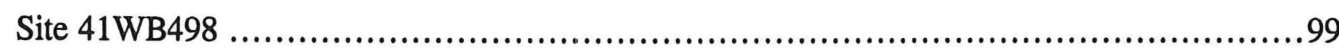

Site 41WB499

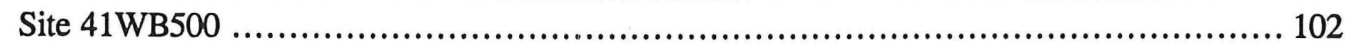

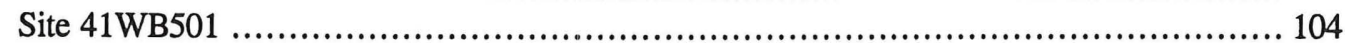

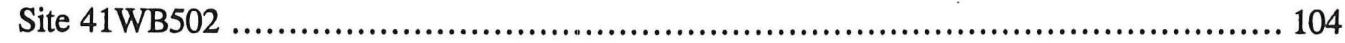

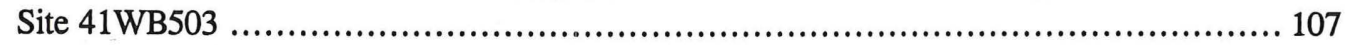

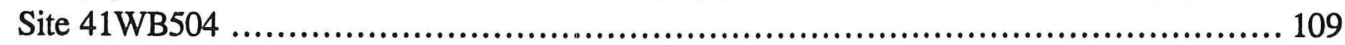

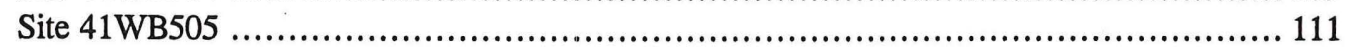

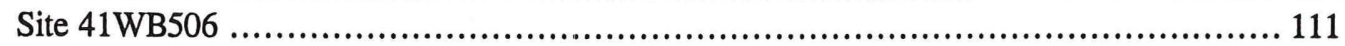

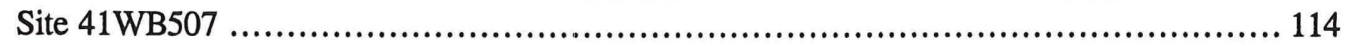

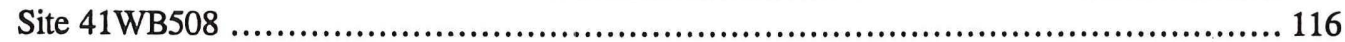

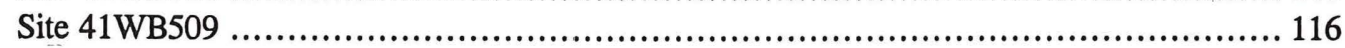

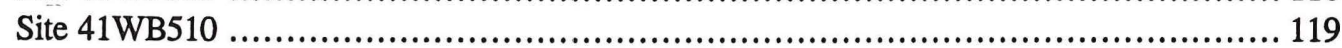

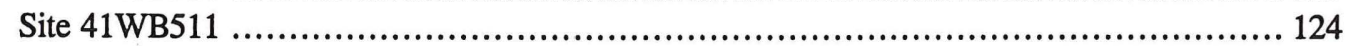

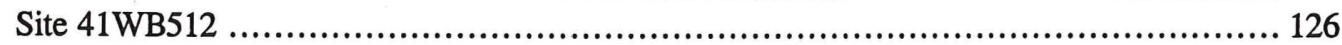

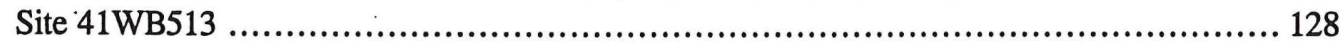

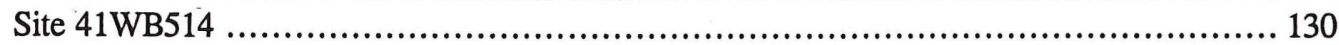

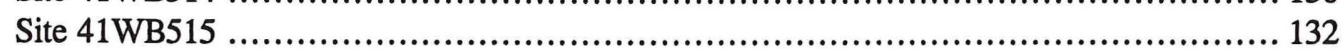

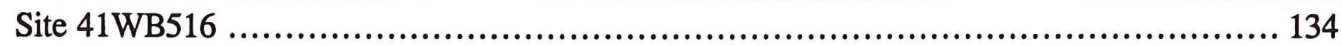

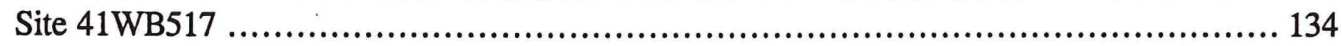

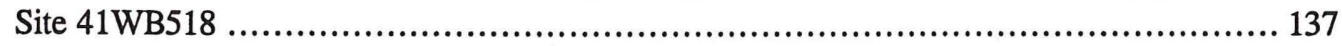

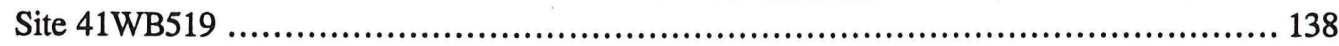

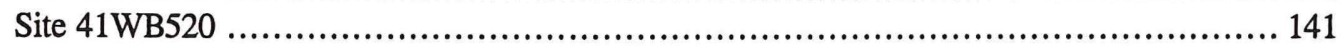

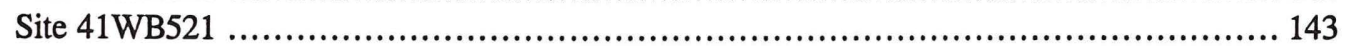

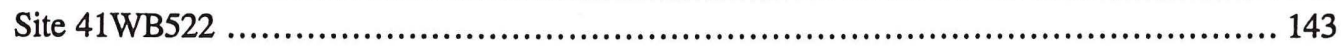

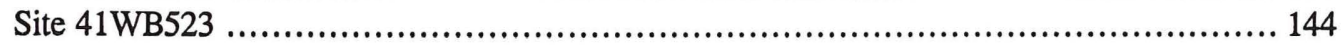

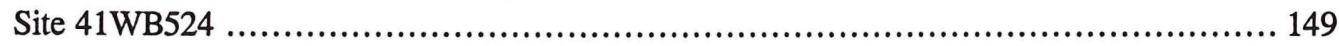

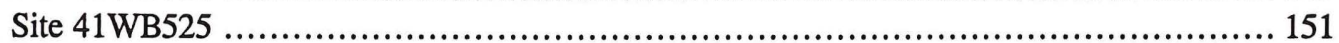

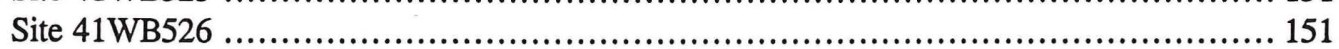

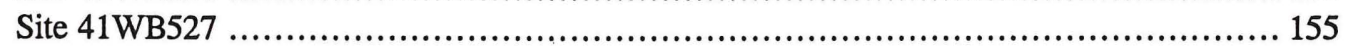

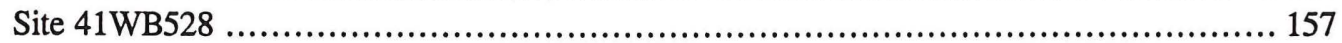

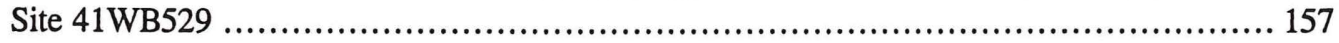

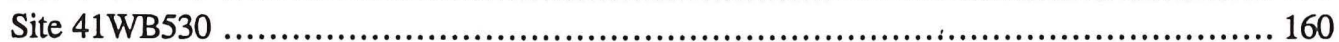

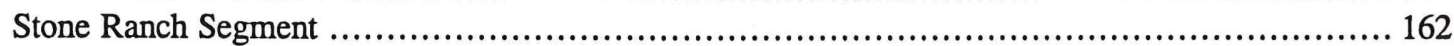

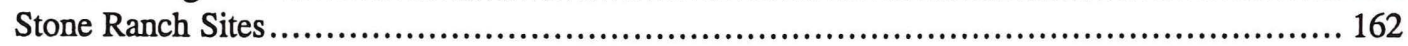

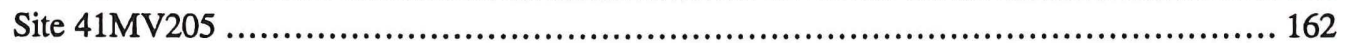

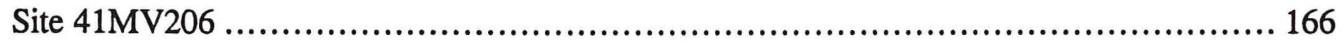

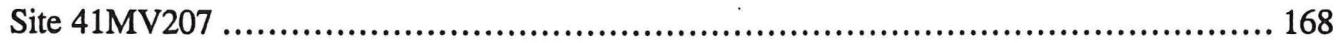

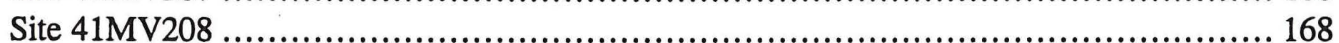

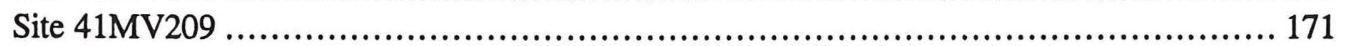

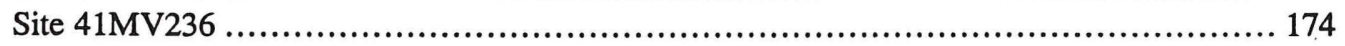

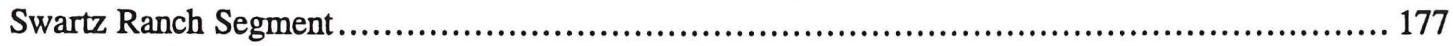

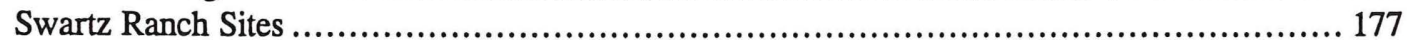

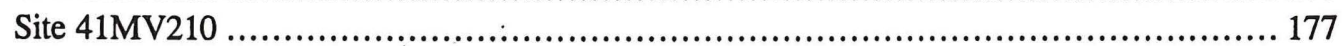

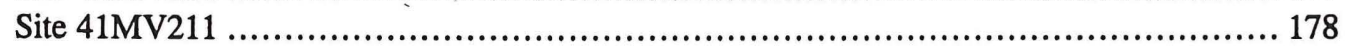

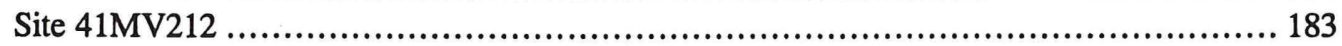


Table of Contents

(cont'd)

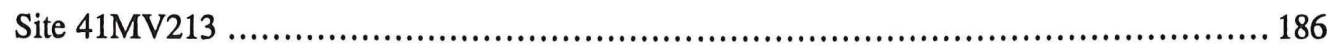

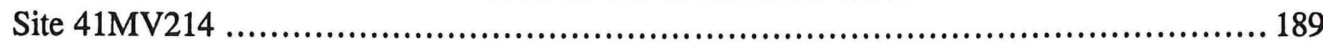

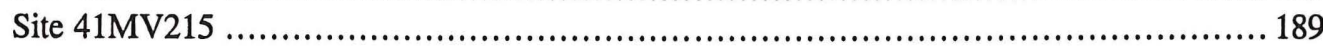

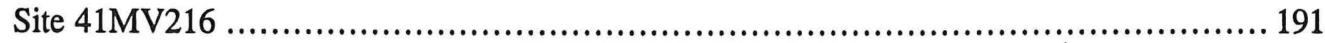

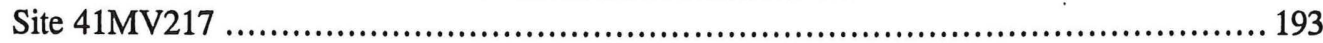

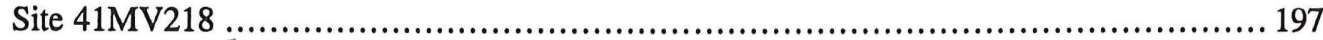

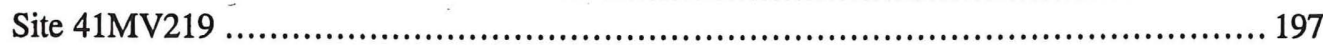

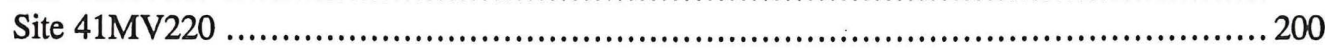

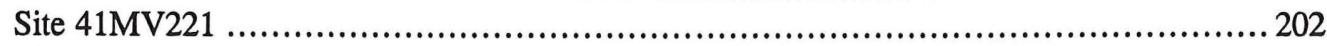

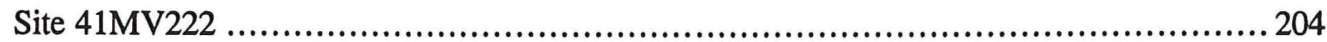

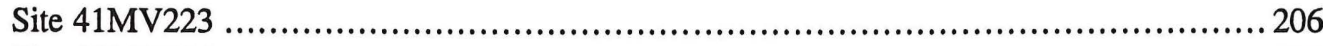

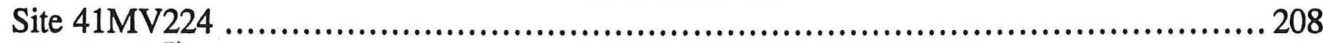

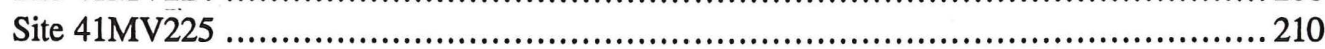

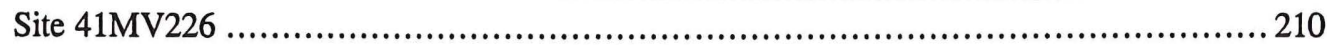

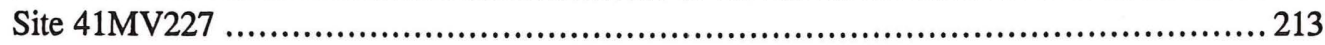

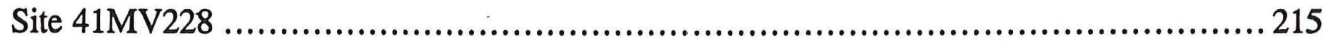

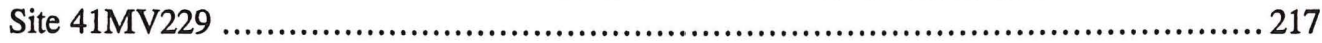

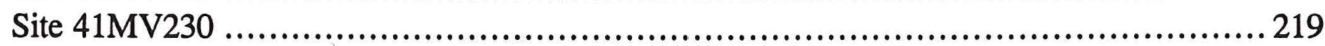

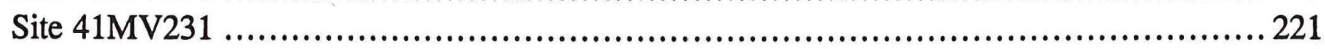

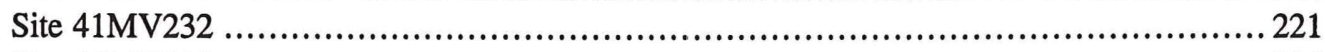

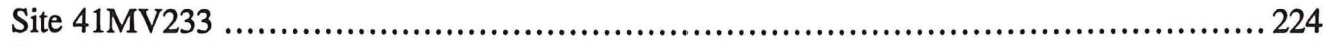

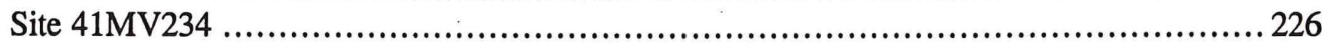

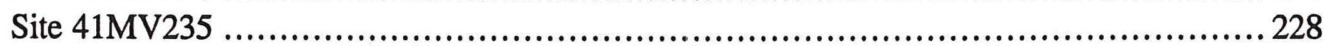

State Highway 277 and Farm-to-Market Road 2644 Segments ...................................... 228

State Highway 83 and Farm-to-Market Road 3338 Segments .................................... 230

5. SUMMARY AND RECOMMENDATIONS ................................................. 231

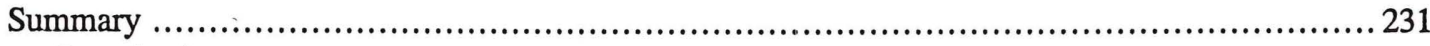

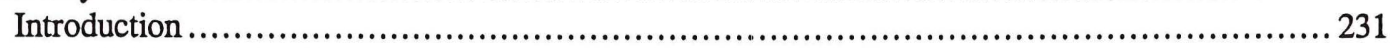

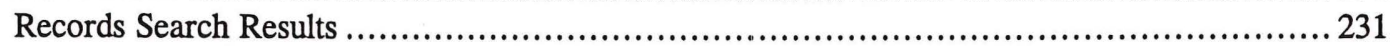

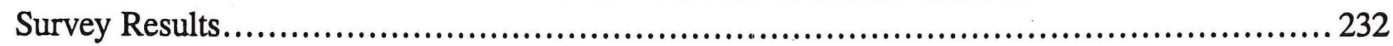

Cultural Features...................................................................... 236

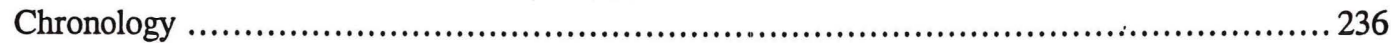

Eligibility of Sites for Inclusion in the National Register of Historic Places .......................... 239

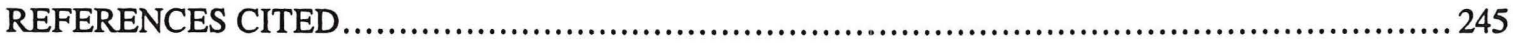




\section{LIST OF FIGURES}

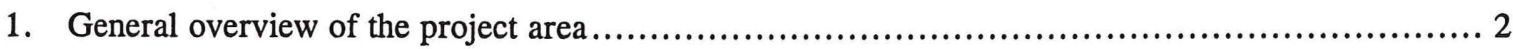

2. Rio Bravo segment .................................................................... 4

3. Laredo River Road segment ................................................................ 5

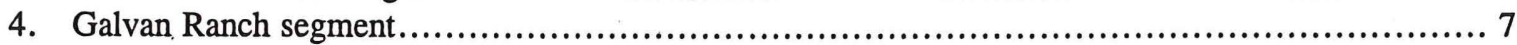

5. Stone Ranch segment......................................................................... 9

6. Swartz Ranch segment ................................................................ 13

7. State Highway 277 and Farm-to-Market Road 2644 segments ................................. 15

8. State Highway 83 and Farm-to-Market Road 3338 segments................................. 17

9. Location of sites on the Galvan Ranch segment ................................................ 37

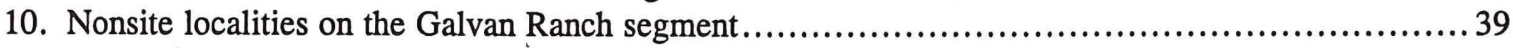

11. Plan map of site 41WB466 ................................................................ 42

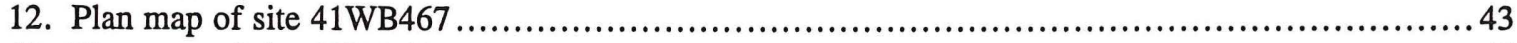

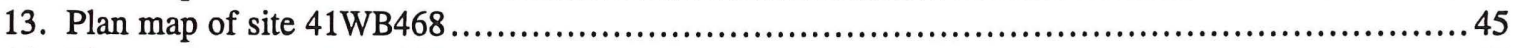

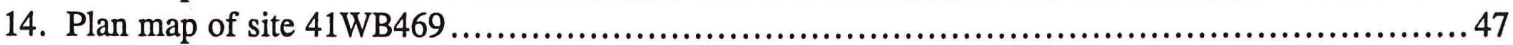

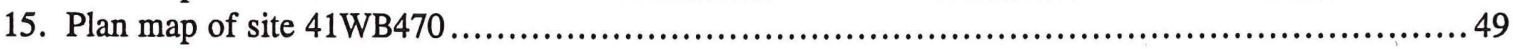

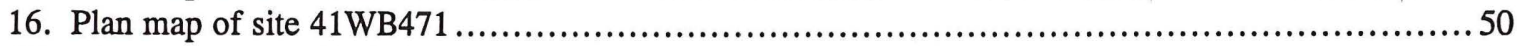

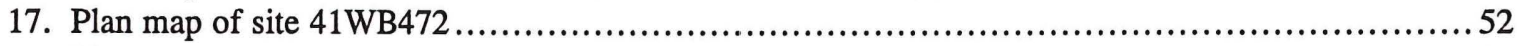

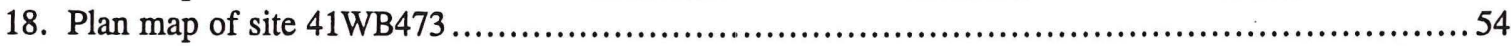

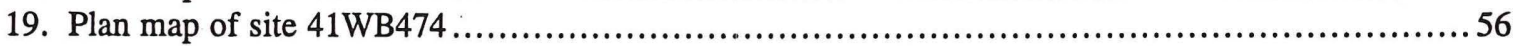

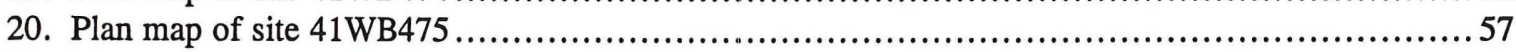

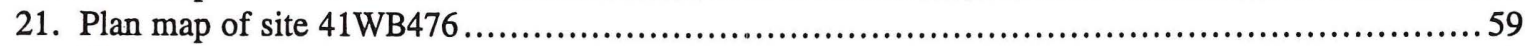

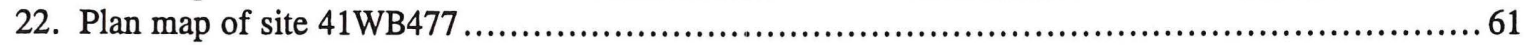

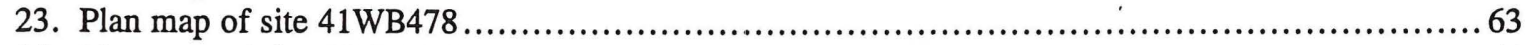

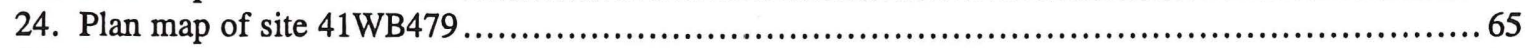

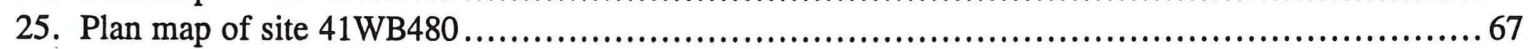

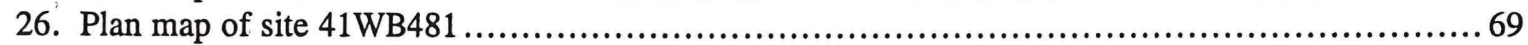

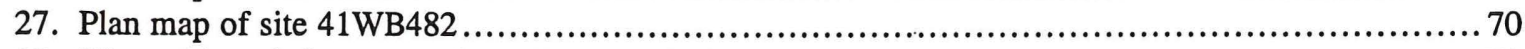

28. View of hearth feature at site 41 WB482 (facing north) ........................................ 71

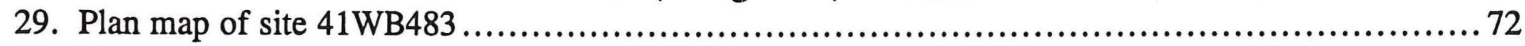

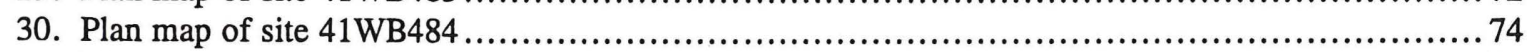

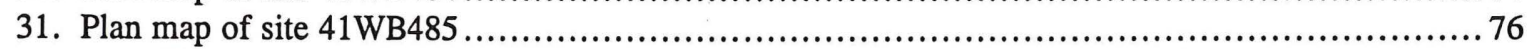

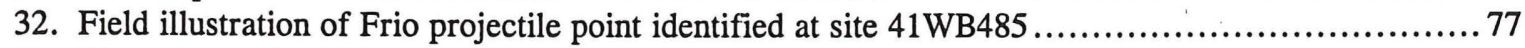

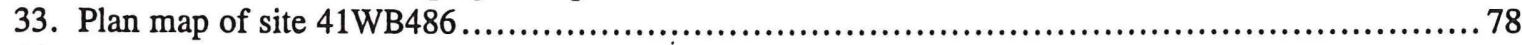

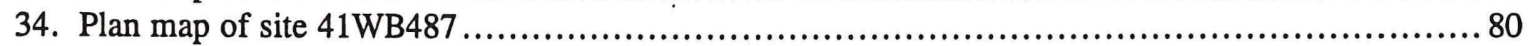


35. Field illustrations of projectile points identified at site 41WB487: (a) Gower point; (b) Refugio point; and (c) Palmillas point

36. Plan map of site $41 \mathrm{WB} 488$

37. Field illustrations of artifacts identified at site 41WB488: (a) the Early Triangular/Matamoros/

Tortugas-type point and (b) possible Nueces biface .............................................. 83

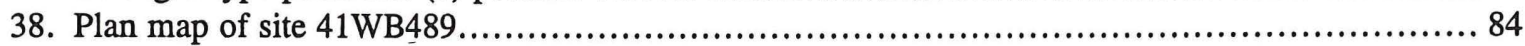

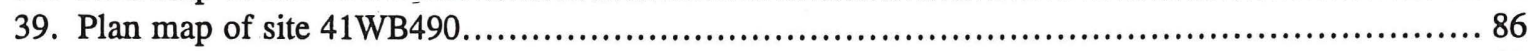

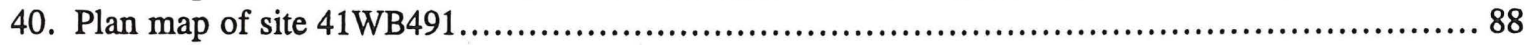

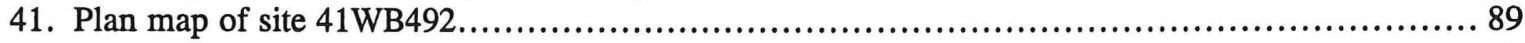

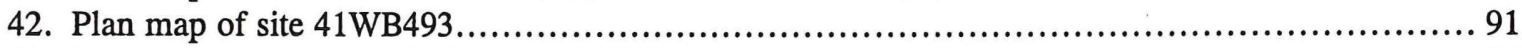

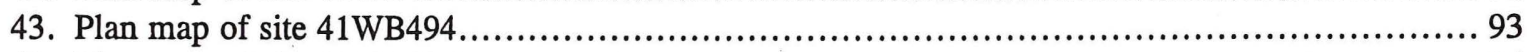

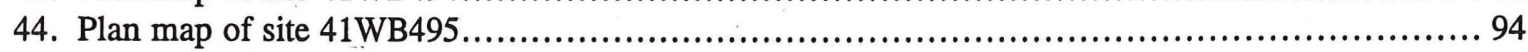

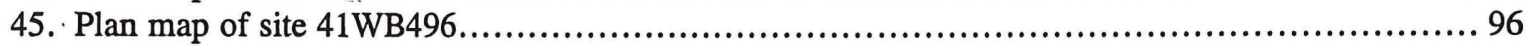

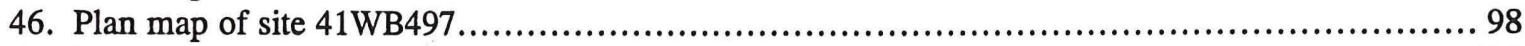

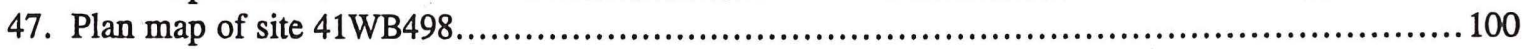

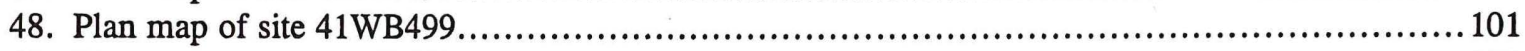

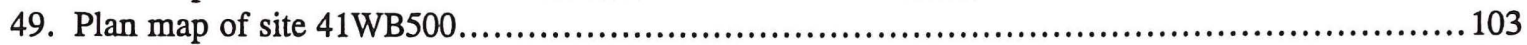

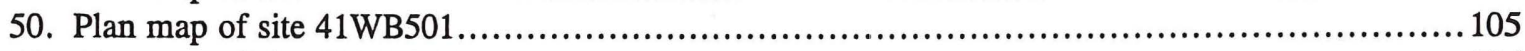

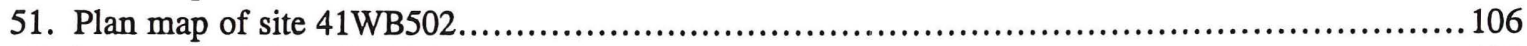

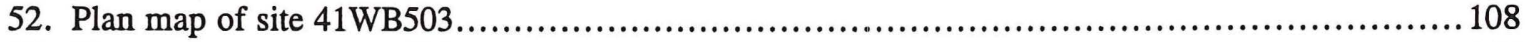

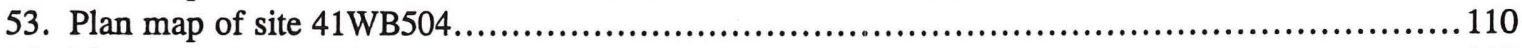

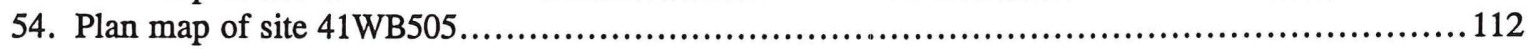

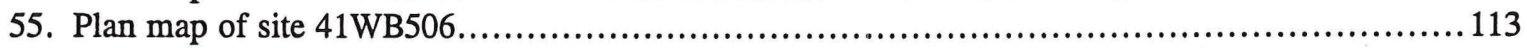

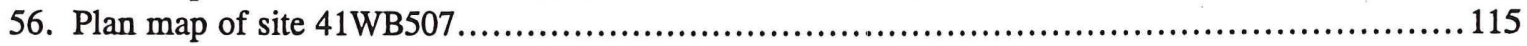

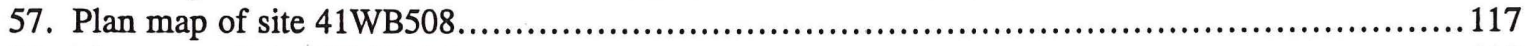

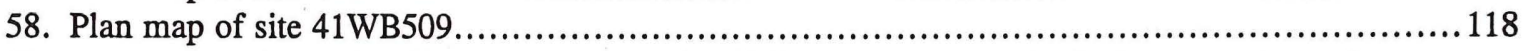

59. Field illustrations of artifacts identified at site 41WB509: (a) Catán/Refugio-type point and

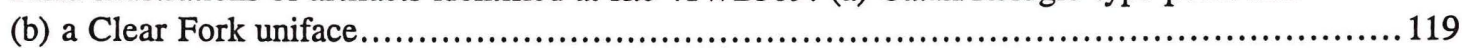

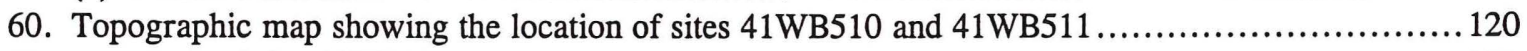

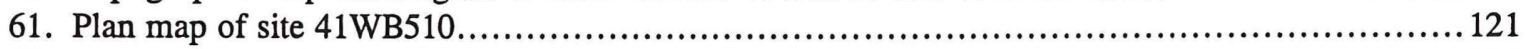

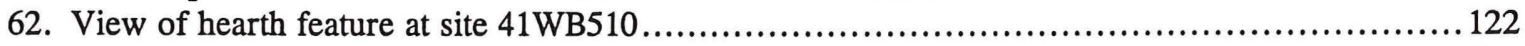

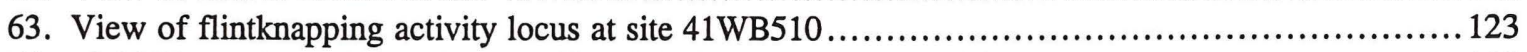

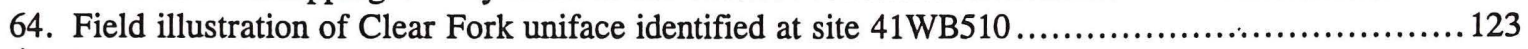

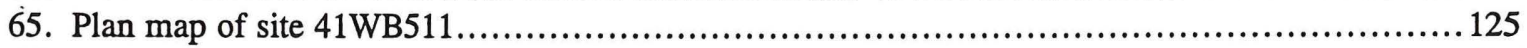

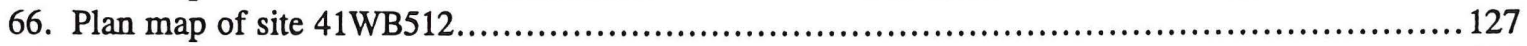

67. Field illustration of Refugio projectile point identified at site 41 WB512 ........................128

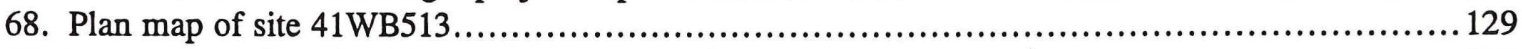

69. Field illustration of unidentified projectile point at site 41WB513 ............................... 130

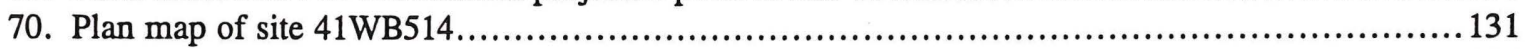

71. Field illustration of possible Carrizo projectile point identified at site 41 WB514 ...................132

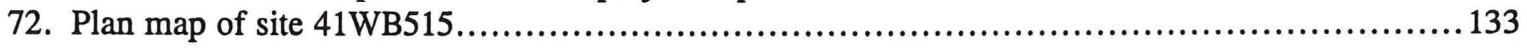

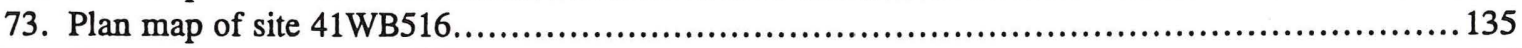

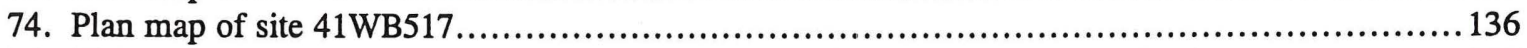

75. Field illustration of Matamoros/Tortugas-like projectile point identified at site 41 WB517 ...........137

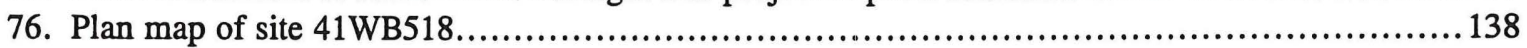

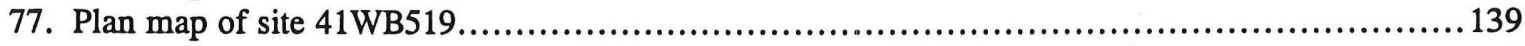


List of Figures

(cont'd)

78. Field illustrations of projectile points identified at site 41WB519: (a) Triangular/Matamoros/

Tortugas-type point; (b) Ensor point; and (c) unidentified point................................ 140

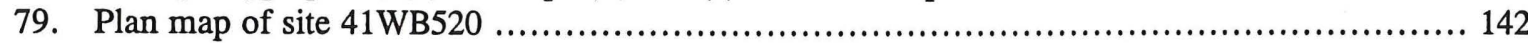

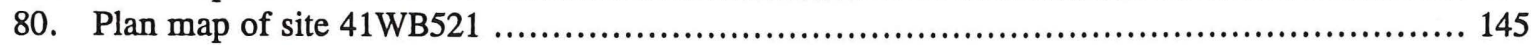

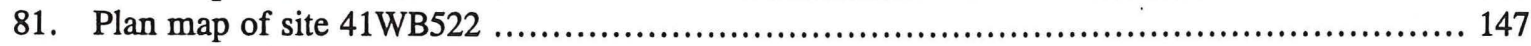

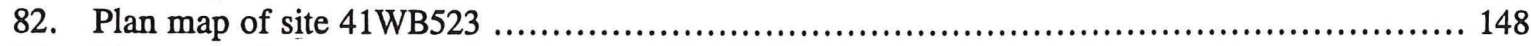

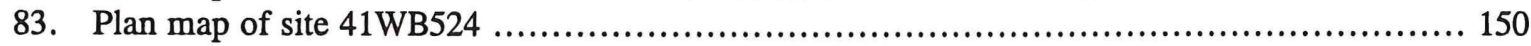

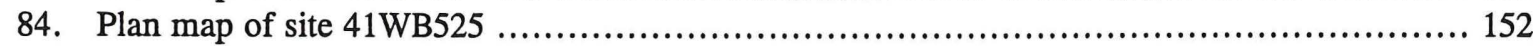

85. Field illustrations of projectile points identified at site 41WB525: (a) Fresno/McGloin-like

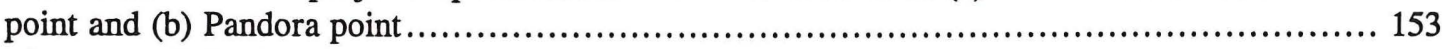

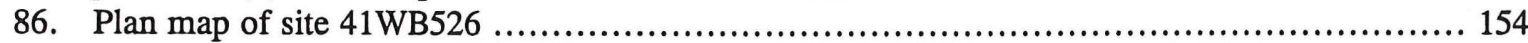

87. Field illustrations of projectile points identified at site 41WB526: (a) Catán point and

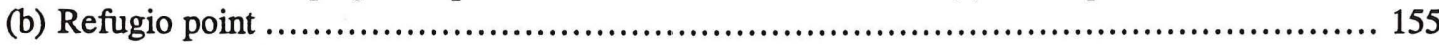

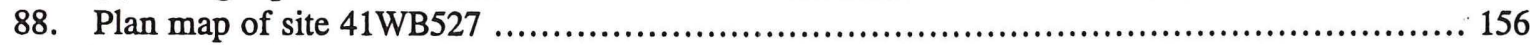

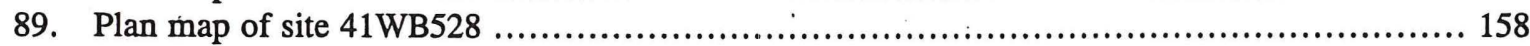

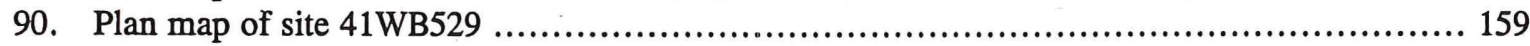

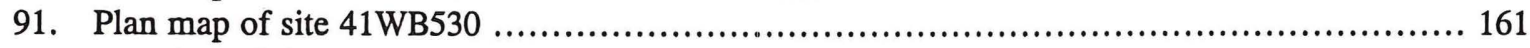

92. Location of sites and nonsite localities on the Stone Ranch segment ........................... 163

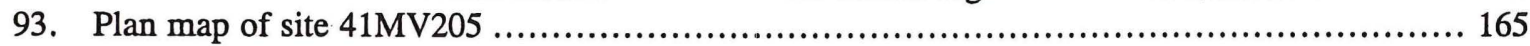

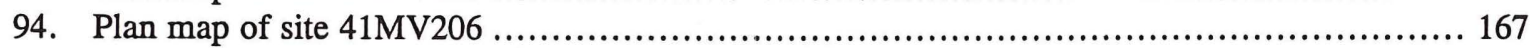

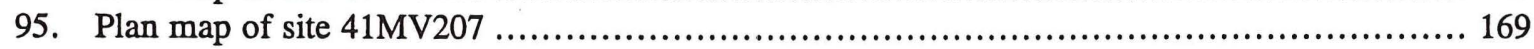

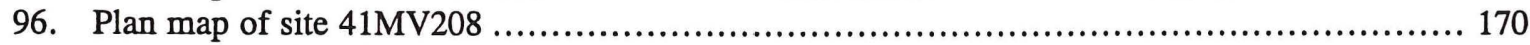

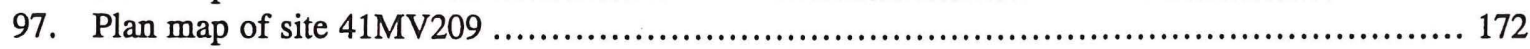

98. Field illustrations of projectile points identified at site 41MV209: (a) Pandora point;

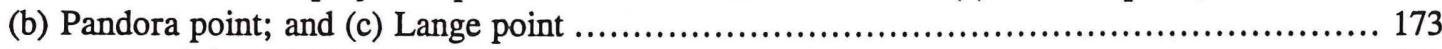

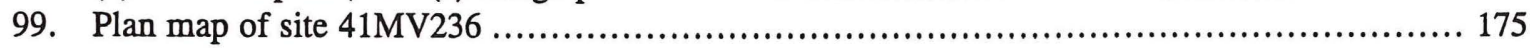

100. Location of sites on the Swartz Ranch segment .................................................. 179

101. Location of nonsite localities on the Swartz Ranch segment ................................... 181

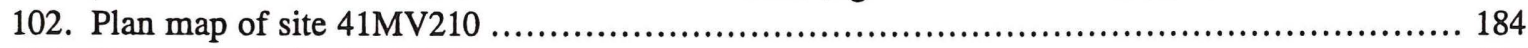

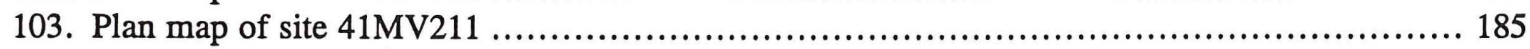

104. Field illustration of a Lange projectile point identified at site 41MV211 ........................ 186

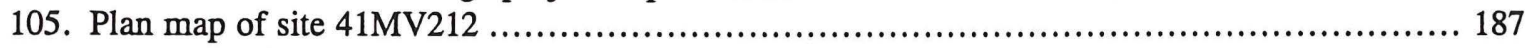

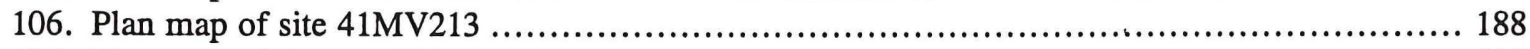

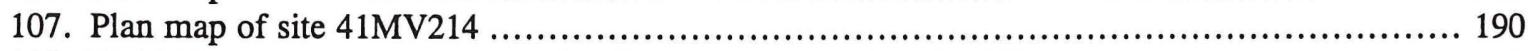

108. Field illustration of Figueroa projectile point identified at site 41MV214 ....................... 191

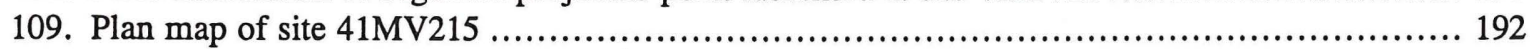

110. Field illustration of unidentified projectile point at site 41MV215 ............................ 193

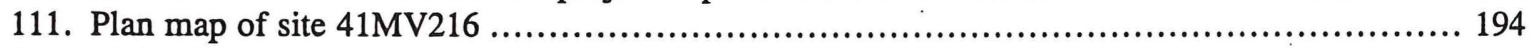

112. Field illustration of Clear Fork uniface identified at site 41MV216 ............................ 195

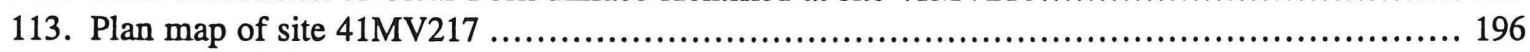

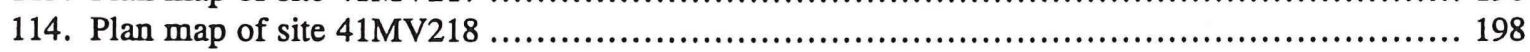

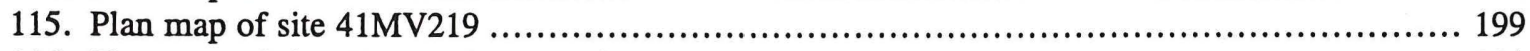

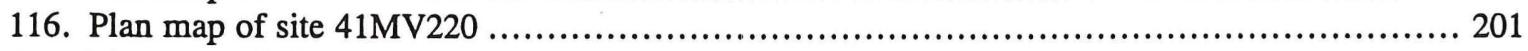

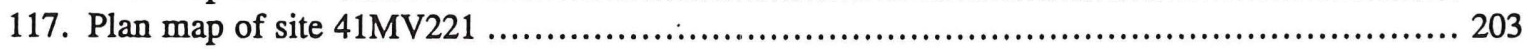

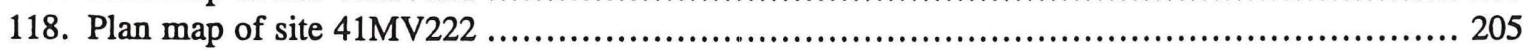

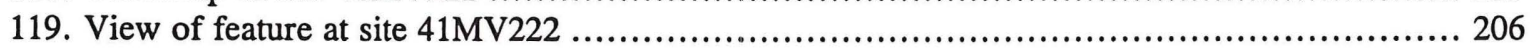


List of Figures

(cont'd)

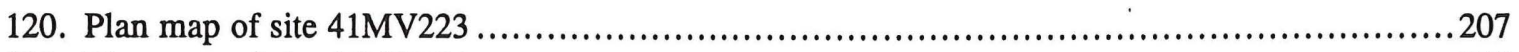

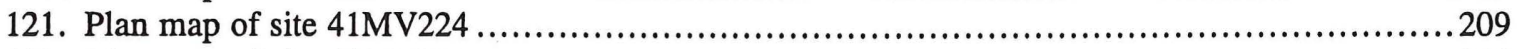

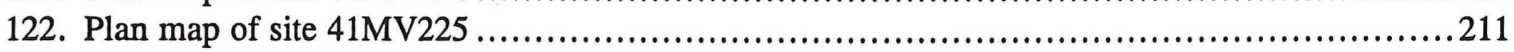

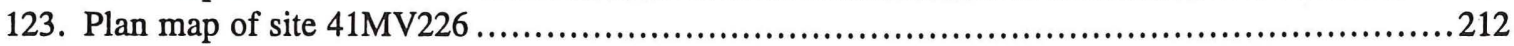

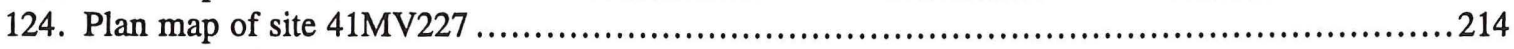

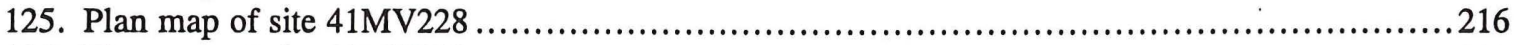

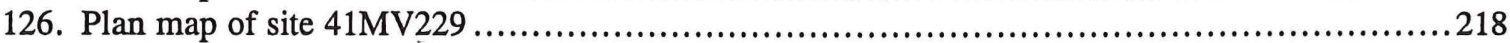

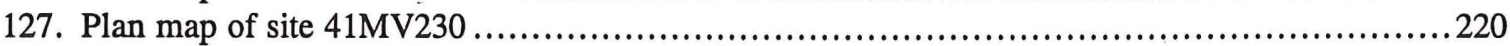

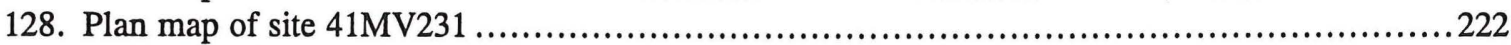

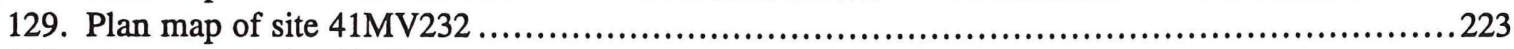

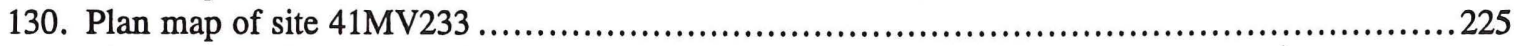

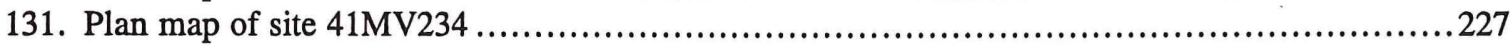

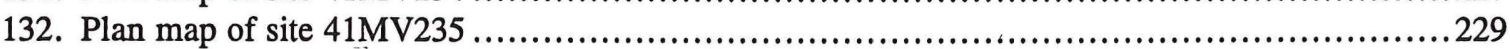




\section{LIST OF TABLES}

1. Survey Coverage and Results for Segments with Newly Recorded Sites (Galvan, Stone,

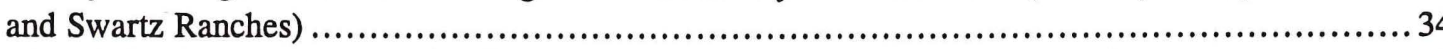

2. List of Nonsite Localities on the Galvan Ranch Segment with Artifacts other than Flakes ..............41

3. List of Nonsite Localities with Tools on the Swartz Ranch Segment.............................. 183

4. Summary of 97 Newly Recorded Archeological Sites on the Galvan, Stone, and Swartz

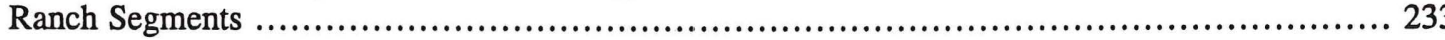

5. Features and Diagnostic Artifacts from the Survey Area ..................................... 237

6. Distribution of Temporal Components Indicated by Diagnostic Artifacts on the Galvan

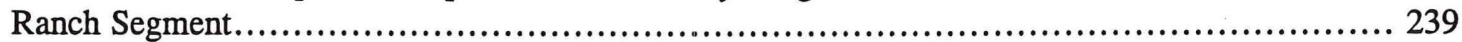

7. National Register of Historic Places Assessment and Recommendations for Archeological Sites Recorded on the Galvan, Stone, and Swartz Ranch Segments..... 


\section{ACKNOWLEDGMENTS}

The authors would like to express their appreciation to the many individuals and organizations who contributed to the successful completion of this project. In Fort Worth, Milton Blankenship and Linda Ashe, Environmental Resources Specialists for JTF-6 and the U.S. Army Corps of Engineers, respectively; Dr. Jay R. Newman, JTF-6 project archeologist; and Eric Verwers, JTF-6 project biologist, provided both administrative support and guidance. In the field, the efforts of the crew members, including Jacob Bourbon, Steven M. Hunt, Kellie A. Krapf, Thomas Marckese, and Kenneth Vander Steen were instrumental in accomplishing an enormous amount of work in a short period of time.

We would like to thank all of the landowners who graciously granted us access to their properties, particularly the Ed Rachal Foundation, owners of the Galvan Ranch; Gene Allan, owner of the Stone Ranch; and Phyllis Karcher, owner of the Swartz Ranch. Ed DuBose, foreman of the Galvan Ranch, provided assistance and information to the field crews when it was most needed.

A sincere word of appreciation is offered to the members of the U.S. Border Patrol for their administrative support, for their guidance in the field, and for the use of their radios and transmission channels. Particular gratitude is expressed to George Gunnoe, Assistant Chief of the Laredo Sector, and to Greg Murphy, Assistant Chief of the Carrizo Springs Sector, for their ongoing support and administrative acumen. Our thanks are also extended to the U.S. Border Patrol agents, including Rudy Curiel, Bob Goodman, Matt Rieckle, and Mark Butler, and to the U.S. Army engineers, including Don Jordan, Rocky Lightfoot, and Julia D'Nunzio of the 62nd Combat Engineer Battalion, Fort Hood, Texas, and Dennis Barndt of the 864th Combat Engineer Battalion, Fort Lewis, Washington, who provided invaluable guidance throughout the fieldwork phase of this project.

In the Plano office, the production of the computer-generated maps was undertaken by Shane Watson, Toar Schell, Sean Taplin, and Scott Terrell. Denise Pemberton was responsible for formatting the report, and Patricia Knowles and Sharlene Allday served as technical editors, producing the final layout and design of the report. Ms. Krapf assisted in the editing of the computer-generated site maps and prepared the artifact illustrations. 


\section{CHAPTER 1 INTRODUCTION}

Joint Task Force Six (JTF-6) Operation Number JT513/515/425-98 involves nine separate project area segments in Webb, Maverick, and Dimmit counties, Texas. This project was undertaken in an effort to assist U.S. Immigration and and Naturalization Service officials in their attempt to curtail the influx of controlled substances into the U.S. by upgrading existing roads and building new roads through privately owned properties in the U.S. Border Patrol Laredo and Carrizo Springs Sectors, Texas (Figure 1). Since these actions represent federal projects with the potential for damaging or destroying cultural resources, JTF-6 was required to conduct a cultural resources evaluation of the proposed impact area in order to be in compliance with Sections 106 and 110 of the National Historic Preservation Act (NHPA) of 1966 [P.L. 89-665; 80 Stat. 915; 16 U.S.C. $§ 470$ et seq.]; the National Environmental Policy Act of 1969 [P.L. 91-190; 83 Stat. 852; 42 U.S.C. § 4221 et seq.]; Executive Order Number 11593 of 1971, "Protection and Enhancement of the Cultural Environment"; the Archeological and Historic Preservation Act (AHPA) of 1974 [P.L. 93-291; 88 Stat. 174; 16 U.S.C. § 469 et seq.]; the American Indian Religious Freedom Act (AIRFA) of 1978 [P.L. 95-341; 92 Stat. 469; 42 U.S.C. § 12966]; and the Native American Graves Protection and Repatriation Act (NAGPRA) of 1990 [P.L. 101-601; 104 Stat. 3048; 25 U.S.C. § 3001 et seq.].

Between 20 October and 10 November 1997, a cultural resources inventory survey was conducted along approximately $387.7 \mathrm{~km}(240.9 \mathrm{mi})$ of existing roads and proposed new road rights-of-way for the proposed JTF-6 action in Webb, Maverick, and Dimmit counties, Texas. The cultural resources investigation was undertaken in order to locate any cultural properties that would potentially be impacted by the proposed road construction, upgrading, and maintenance activities. Projects included within this proposed action are the repair/upgrade of approximately $211.0 \mathrm{~km}(131.1 \mathrm{mi})$ of existing roads, the construction of roughly $176.7 \mathrm{~km}$ (109.8 mi) of new roads (totaling $387.7 \mathrm{~km}$ [240.9 mi]), the excavation of three borrow pits, as well as the construction of an equipment storage area, two helipads, one airfield, and two base camp areas for this and future JTF- 6 rotations in this area.

A total of 97 archeological sites and 349 nonsite localities was identified as a result of the cultural resources survey of seven of the nine project area segments connected with this action. All of these sites contain artifacts attributable to prehistoric occupations in the project area, and one of them contains a small historic period component as well. Twenty-six of these archeological sites are recommended as potentially eligible for inclusion in the National Register of Historic Places (NRHP).

Of the remaining 71 archeological sites, the boundaries of 41 of these sites extend well beyond the survey area of the current project. These areas of the sites that are outside the project boundaries have not been evaluated. Therefore, the only portions of these sites that have been evaluated are those areas that fall 


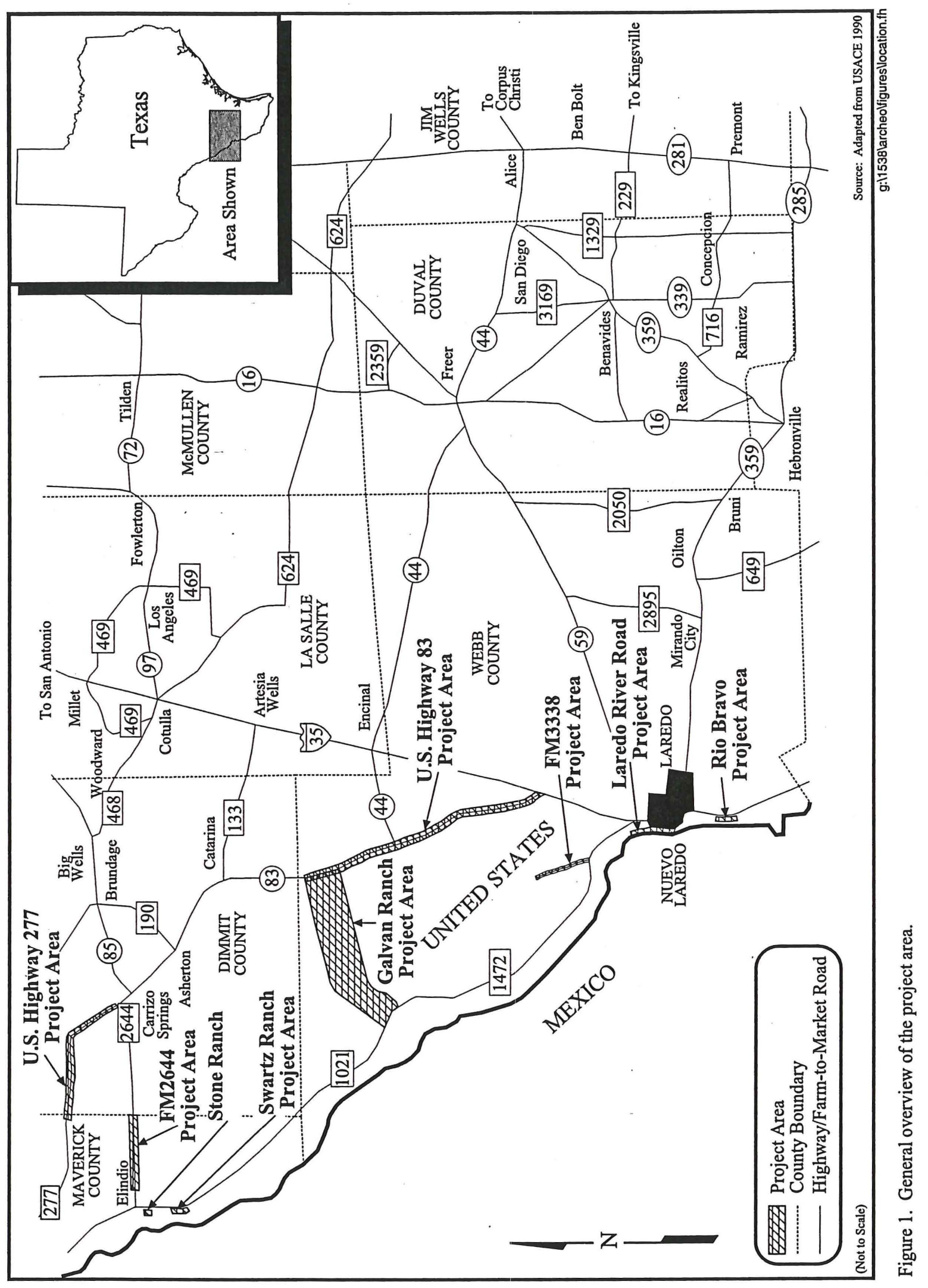


within the surveyed rights-of-way. Only the assessed areas of these 41 sites are recommended as ineligible for inclusion in the NRHP, and no further archeological work is recommended within these evaluated areas of the 41 sites. The site boundaries of the remaining 30 of the 71 sites are predominantly within or very close to the surveyed rights-of-way, and these site limits could be establised and the sites evaluated. Based on the current investigations, these 30 sites are recommended as ineligible for inclusion in the NRHP.

By definition, nonsite localities do not meet the criteria that define a site. Therefore, none of the nonsite localities are recommended as eligible for inclusion in the NRHP.

\section{INVENTORIED PROJECT SEGMENTS}

\section{Rio Bravo Segment}

Located approximately $16.1 \mathrm{~km}(10.0 \mathrm{mi})$ south of Laredo, in Webb County, Texas, the Rio Bravo segment consists of roughly $2.7 \mathrm{~km}(1.7 \mathrm{mi})$ of existing river frontage road and $2.7 \mathrm{~km}(1.7 \mathrm{mi})$ of existing road, totaling $5.4 \mathrm{~km}(3.4 \mathrm{mi})$, providing access to the riverfront from the neighboring uplands near the town of Rio Bravo, Webb.County, Texas (Figure 2). The Rio Bravo segment begins at a water pump station located approximately $2.01 \mathrm{~km}(1.25 \mathrm{mi})$ south of Centeño Lane, the central east-west street through Rio Bravo, and extends $2.7 \mathrm{~km}(1.7 \mathrm{mi})$ northward along the Rio Grande floodplain to the end of the existing road. The upland half of this survey segment diverges eastward from the floodplain segment on the north side of a paved cement drainage that enters the floodplain approximately $0.2 \mathrm{~km}(0.1 \mathrm{mi})$ south of the northern end of the existing river road, and continues along an existing road northeastward and eastward towards State Highway 83 for a distance of $2.7 \mathrm{~km}(1.7 \mathrm{mi})$. At the time of survey, the entire length of the Rio Bravo survey area had been heavily impacted by road grading activities. The upland portion had been recently devegetated, and thick grass had regrown along both sides of the existing road. Vegetation was very thick along the existing river frontage road beyond the cleared roadbed.

\section{Laredo River Road Segment}

The Laredo River Road segment consists of approximately $8.9 \mathrm{~km}(5.5 \mathrm{mi})$ of existing river frontage road encircling the western periphery of Laredo, Webb County, Texas, extending from the international railroad bridge on the south side of town approximately $8.9 \mathrm{~km}(5.5 \mathrm{mi})$ northward to a gravel pit near Island Street (Figure 3). An additional $0.8 \mathrm{~km}(0.5 \mathrm{mi})$ of proposed new road ROW extends from the Island Street gravel pit northward to an unnamed tributary of the Rio Grande that enters the floodplain just north of an existing power plant. Most of the length of this segment has been previously surveyed for cultural resources (Austin et al. 1994; U.S. Army Corps of Engineers [USACE 1990]). While conducting the 1993 investigations of the Laredo River Road segment, GMI personnel conducted a reconnaissance-level survey only of the proposed road between the international railroad bridge and the northern boundary of the Laredo Community College. This decision was based on the historic data related to twentieth-century flooding of this landform and on the field observation that several feet of twentieth-century flood deposits existed on the landform on which the road would be constructed. Daily archeological monitoring of the grading of the road in 1993 revealed that no historic properties were impacted by the construction of the presently existing road. Nevertheless, at the urging of the State Historic Preservation Office, the existing portion of the Laredo River Road was resurveyed for the current action in addition to the new survey of the $.8 \mathrm{~km}(.5 \mathrm{mi})$ of proposed new road ROW at the north end of the segment. Vegetation was fairly thick in some parts of the Laredo River Road survey area, but ground visibility was generally good. 


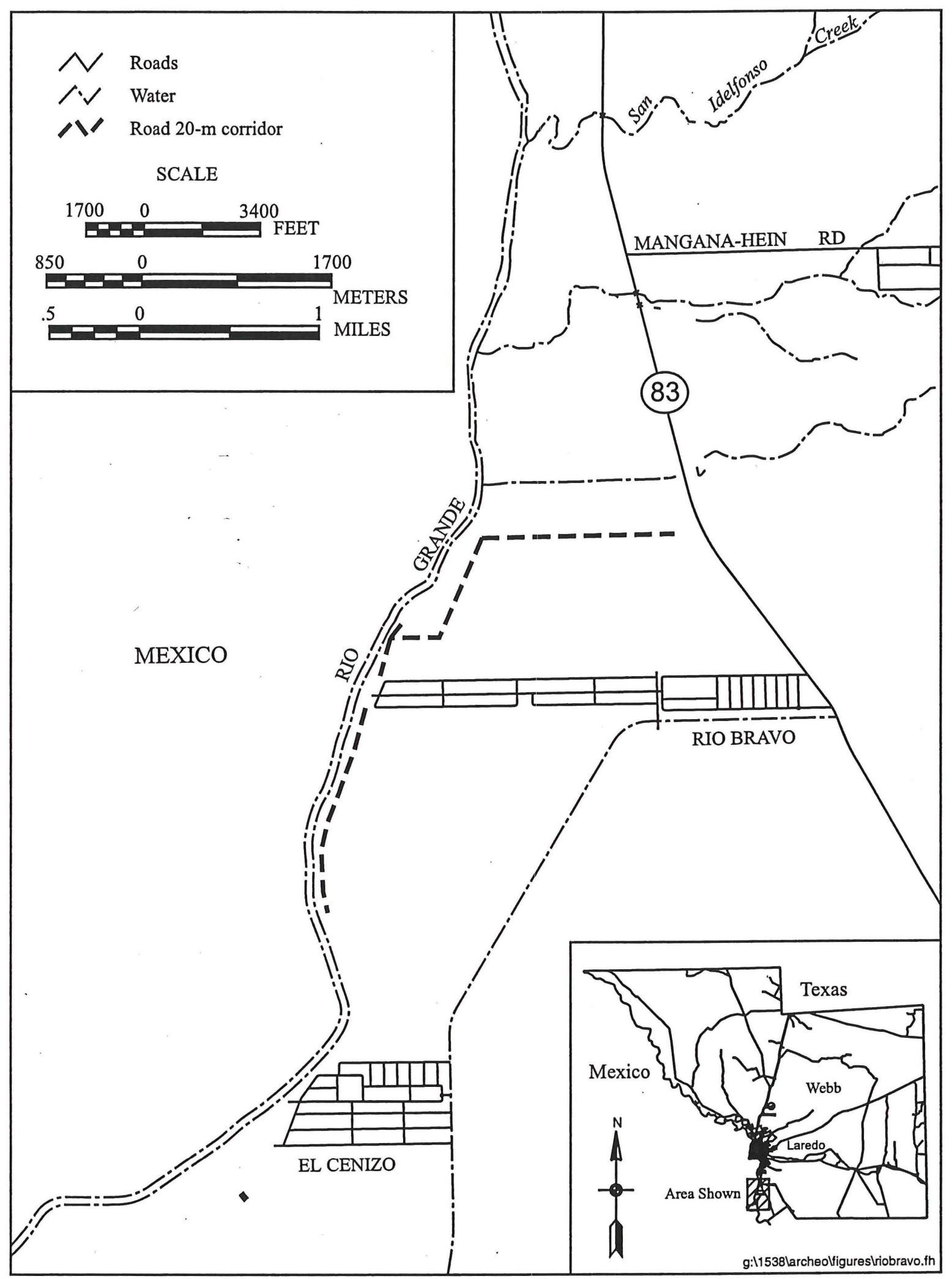

Figure 2. Rio Bravo segment. 


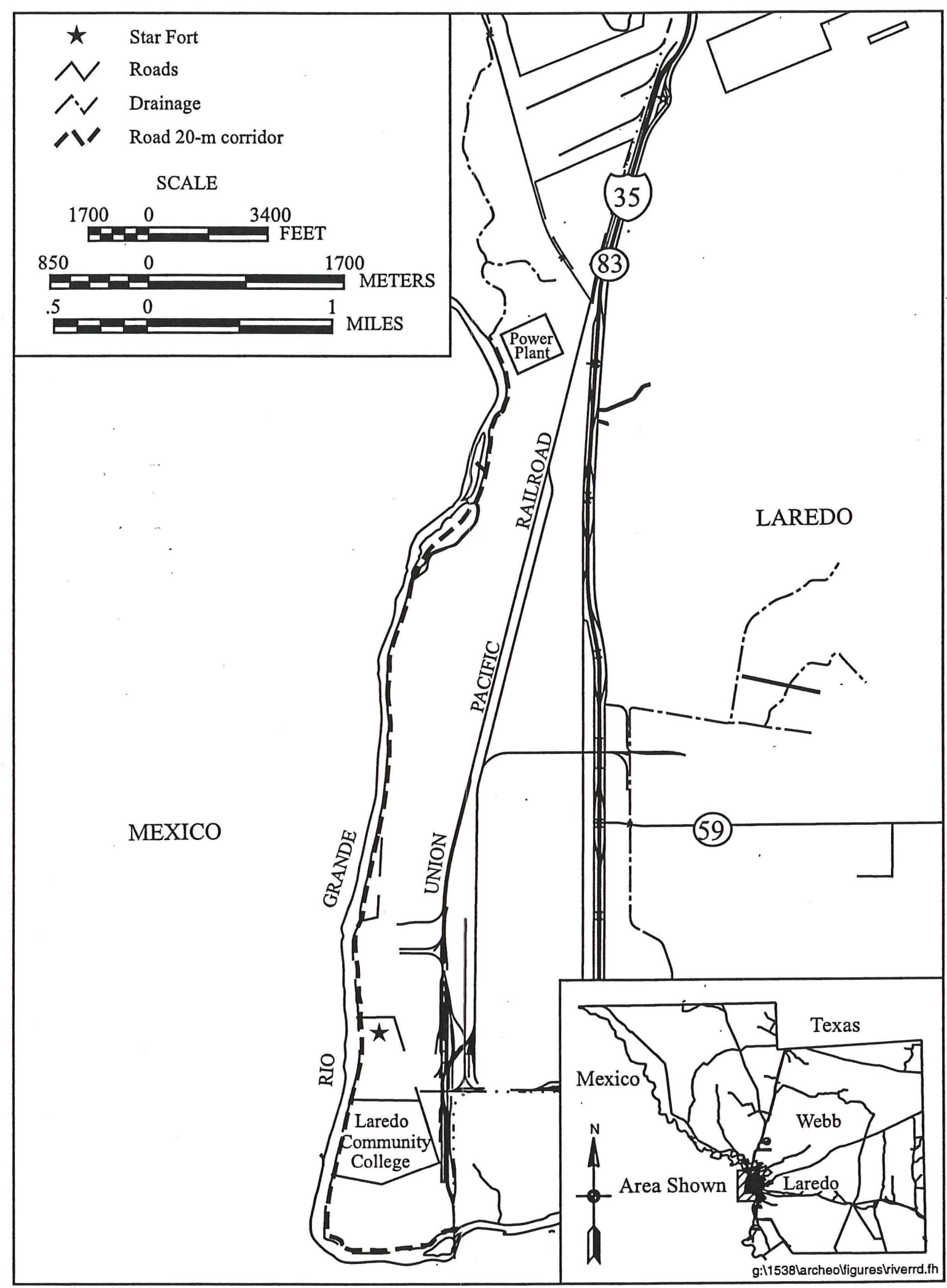

Figure 3. Laredo River Road segment. 


\section{Galvan Ranch Segment}

The Galvan Ranch segment consists of approximately $153.7 \mathrm{~km}(95.5 \mathrm{mi})$ of proposed road rights-of-way in Webb County (Figure 4). The existing road portion of the Galvan Ranch segment includes graded gravel roads as well as improved and unimproved two-tracks, many of which parallel existing fence lines. Proposed new road segments include a $2.01-\mathrm{km}$-long $(1.25 \mathrm{mi})$ base camp access road encircling the main ranch headquarters complex and approximately $9.09 \mathrm{~km}(5.65 \mathrm{mi})$ of new road along the Galvan Fence (see Figure 4). A large proportion of the road survey ROW had already been heavily impacted by construction and maintenance of the roadways and by fence construction, and portions of the Eastern Fence and the "Superhighway" had been devegetated shortly before fieldwork began. Approximately 75 percent of the Galvan Ranch survey area was heavily eroded, with very little intact surface sediment remaining. In addition, proposed locations for a $260-$ by-375-m bivouac or base camp area $\left(97,500 \mathrm{~m}^{2}\right)$, a 900 -by-550-m airfield $\left(495,000 \mathrm{~m}^{2}\right)$, and a $275-$ by- $500-\mathrm{m}$ caliche borrow pit $\left(137,500 \mathrm{~m}^{2}\right)$ were surveyed for cultural resources. The bivouac and airfield survey areas have been severely impacted by activities associated with the daily operations of the main ranch headquarters, including pasturing, clearing, limited paving, dumping, and the construction of corrals. The caliche pit survey area was covered in thick thorn scrub vegetation. A heavy rainstorm that occurred during the first days of fieldwork on the Galvan Ranch segment enhanced surface visibility substantially for several days even as it washed out many of the roads that provide access to the majority of the ranch property. Ground visibility was good throughout most of the Galvan Ranch survey area, although vegetation along the Trevino Fence was relatively thick along approximately one-third of the fence line (see Figure 4).

\section{Stone Ranch Segment}

Approximately $5.8 \mathrm{~km}$ (3.6 mi) of existing gravel roads and $2.6 \mathrm{~km}$ (1.6 mi) of proposed new road ROWs were inspected for cultural resources on the Stone Ranch segment in Maverick County (Figure 5). The existing road segment proceeds northward from the main entrance to Stone Ranch roughly $3.0 \mathrm{~km}$ $(1.9 \mathrm{mi})$ past a three-way gravel road intersection to the property boundary fence, including two east-west spur roads totaling $1.6 \mathrm{~km}(1.0 \mathrm{mi})$ in length that provide access from the northern and southern ends of this road to terraces overlooking the Rio Grande River, and two short spur roads (totaling $0.2 \mathrm{mi}$ ) providing access to the bluff edge. A $1.0-\mathrm{km}$-long $(0.6 \mathrm{mi})$ segment of existing road paralleling a paved irrigation canal was also surveyed. The Stone Ranch segment of this action also includes the proposed construction of roughly $2.1 \mathrm{~km}(1.3 \mathrm{mi})$ of new river frontage road between the two existing road spurs and a $0.2 \mathrm{~km}(0.1 \mathrm{mi})$ new road segment providing access from the existing north-south road to the new river frontage road. A short, $0.2-\mathrm{km}$-long $(0.1 \mathrm{mi})$ new road spur has also been proposed that would provide access from the new river frontage road to a terrace overlooking the Rio Grande. During the survey, it was determined that this proposed road spur passes through one of the cultural properties (41MV209) documented as a result of this project that is recommended as potentially eligible for inclusion in the NRHP. Consequently, a second location for the proposed road spur, located roughly .3 $\mathrm{km}(.2 \mathrm{mi})$ north of the original location and measuring approximately $.2 \mathrm{~km}(.1 \mathrm{mi})$ in length, was surveyed. The proposed new road ROWs have been previously impacted by erosion and grazing, but artificial disturbance is relatively limited. The existing road corridors have been heavily impacted by road and fence line construction, and the area surrounding the irrigation canal berm has been disturbed by road and irrigation canal construction. In addition, the proposed locations for an equipment storage area, measuring approximately 2.0 hectares (5.0 acres); and a 35-by-35-m helipad (1,225 $\mathrm{m}^{2}$ ); and a 500-by200 -m borrow pit $\left(100,000 \mathrm{~m}^{2}\right)$ were surveyed. Ground visibility was good throughout the Stone Ranch survey area. 
figure

4. Galvan Ranch segment

fold-out 
Cultural Resources Survey for a JTF-6 Action in Webb, Maverick, and Dimmit Counties, Texas

fig 4 
figure

5. Stone Ranch segment

fold-out 
Cultural Resources Survey for a JTF-6 Action in Webb, Maverick, and Dimmit Counties, Texas

fig 5 


\section{Swartz Ranch Segment}

The Swartz Ranch survey area consists of approximately $29.0 \mathrm{~km}(18.0 \mathrm{mi})$ of existing roads and $1.9 \mathrm{~km}$ (1.2 mi) of proposed new road construction in Maverick County (Figure 6). Most of the terrain on the Swartz Ranch is relatively rugged, consisting of the crest and moderately steep slopes of an extensive butte, although lower, more level ground is associated with the floodplain of Cuervo Creek along the northern portion of the project area and in the Rio Grande floodplain along the western edge. The existing road ROW has been heavily impacted by road construction and maintenance, and fence line construction had further impacted the northern and western road segments. Two alternate proposed new road segments were surveyed. The original new road ROW measures $.8 \mathrm{~km}(.5 \mathrm{mi})$ in length and articulates two points along an existing winding gravel road. However, this proposed new road section traverses a cultural property (41MV229) that is recommended as potentially eligible for inclusion in the NRHP. Consequently, JTF-6 requested that an alternate route for the new road, measuring $1.1 \mathrm{~km}(.7$ mi) be surveyed. The proposed locations for a 35-by-35-m helipad $\left(1,225 \mathrm{~m}^{2}\right)$, a $65-$ by-50-m borrow pit $\left(3,250 \mathrm{~m}^{2}\right)$, a base camp or bivouac area $(2.0 \mathrm{ha})$, and a 50-by-60-m equipment storage area $\left(3,000 \mathrm{~m}^{2}\right)$ were also surveyed. The entire survey area, especially the upland portions, has been impacted by erosion, and deep strata of alluvial silt have been deposited on the floodplains of Cuervo Creek and the Rio Grande. Ground visibility was good throughout the Swartz Ranch survey area.

\section{State Highway 277 Segment}

The State Highway 277 (SH 277) segment consists of an existing drag road extending along the south side of the pavement approximately $29.8 \mathrm{~km}(18.5 \mathrm{mi})$ between Carrizo Springs and a point roughly $3.0 \mathrm{mi}$ west of the Maverick/Dimmit county line (Figure 7). The SH 277 drag road runs along the northern side of a fence line which made it impossible to extend the survey corridor south of the drag road. The majority of the area between the drag road and existing pavement has been heavily disturbed by devegetation and bulldozing. Tall grass had grown along short segments of this area, but most of it was completely cleared and covered in gravel.

\section{Farm-to-Market Road 2644 Segment}

The Farm-to-Market Road 2644 (FM 2644) segment consists of an existing drag road on the south side of the pavement extending roughly $16.1 \mathrm{~km}(10.0 \mathrm{mi})$ westward from the Maverick/Dimmit county line. The SR 2644 segment also includes $17.7 \mathrm{~km}(11.0 \mathrm{mi})$ of proposed new drag road construction. Fence lines restricted access beyond the ROW of the existing drag roadbeds, and survey corridors consequently covered the drag roads proper and the area between the drag road and the pavement. This area had likewise been disturbed by devegetation and bulldozing, and was heavily overgrown in some areas. Two low-water points near the center of the FM 2644 segment have been proposed as locations for the improvement of existing culverts and the improvement of drainage away from the existing paved road berm. The proposed locations for culvert work were treated as new construction areas for survey purposes, and 40-m-wide corridors were examined extending a distance of $100 \mathrm{~m}$ from either side of the pavement. Ground visibility was good in the drag road ROWs for both survey segments, but vegetation obscured ground visibility along some portions of the area between the drag road and existing pavement. 


\section{State Highway 83 Segment}

The State Highway 83 (SH 83) segment starts at the intersection of Highway 83 and Interstate 35 (I-35) in Webb County and continues northwest along both sides of the existing pavement for $45.1 \mathrm{~km}(28.0 \mathrm{mi})$ (Figure 8). Drag roads already exist along both sides of the SH 83 pavement, and the entire area had been heavily impacted by the construction of the highway, associated drag roads, intersecting roads, and various power lines.

\section{Farm-to-Market Road 3338 Segment}

The Farm-to-Market Road 3338 (FM 3338) segment begins at the intersection of FM 3338 and Farm-toMarket Road 1472 in Webb County and continues northwest along both sides of FM 3338 for approximately $12.9 \mathrm{~km}(8 \mathrm{mi})$ to the end of the pavement. A drag road already exists on the east side of FM 3338, and the entire area lying between the existing pavement and fences that parallel the road on both sides has been heavily impacted by devegetation, drag road construction and maintenance, and bulldozing. 
figure

6. Swartz Ranch segment

fold-out 
Cultural Resources Survey for a JTF-6 Action in Webb, Maverick, and Dimmit Counties, Texas

fig 6 


\section{figure}

7. State Highway 277 and Farm-to-Market Road 2644 segments

fold-out 
Cultural Resources Survey for a JTF-6 Action in Webb, Maverick, and Dimmit Counties, Texas

fig 7 
figure

8. State Highway 83 and Farm-to-Market Road 3338 segments

fold-out 
Cultural Resources Survey for a JTF-6 Action in Webb, Maverick, and Dimmit Counties, Texas

fig 8 


\section{CHAPTER 2 ENVIRONMENTAL AND CULTURAL OVERVIEWS}

\section{ENVIRONMENTAL SETTING}

Geologically, the project area is contained within the West Gulf Coastal Plains section of the Coastal Plains province. The surface consists of consolidated and unconsolidated sedimentary and eolian deposits. The sedimentary deposits range in age from the Holocene to the Eocene, while the eolian deposits are Holocene and Pleistocene in origin. While the parent materials of the soils have a great impact upon their composition, the low rainfall and high evaporation rates characteristic of the region have led to the retention and accumulation of calcium carbonate and soluble salts in the soil, which tends to enhance similarity in the soils despite differences in age and composition (Sanders and Gabriel 1985:90-92).

The biogeography of the project area is subsumed within Blair's (1950) Tamaulipan province, which extends from eastern Mexico into southern Texas. The climate of the Tamaulipan province is semiarid and megathermal, with a moisture deficiency index of -20 to -40 percent. Summers in the region are hot, while winters are relatively mild. Annual precipitation is approximately 20 in $(51 \mathrm{~cm})$, with the majority occurring in late spring and early fall. Snow is rare during winter. The rate of evapotranspiration is high (Sanders and Gabriel 1985:3).

Plant growth is continuous throughout the year, and thorny brush dominates the vegetation of this region. The most important species include mesquite, lignum vitae, cenizo, white brush, prickly pear, tasajillo, Acacia, Mimosa, Condalia, and Castela. The vertebrate fauna in the region are composed mainly of Neotropical animals (lower Rio Grande Valley) with smaller numbers of Sonoran (arid Southwest) and Austroriparian (Eastern Woodlands) species (Blair 1950:95). Animals presently found within the region include deer, javelina, rabbit, squirrel, coyote, cougar, duck, quail, dove, geese, roadrunner, rattlesnake, Texas tortoise, and horned lizard (Sanders and Gabriel 1985:54-55).

\section{CULTURAL BACKGROUND}

Introduction

The project area forms a part of the South Texas archeological region (Hester et al. 1989). This region extends from the Edwards Plateau to the Gulf of Mexico and southward into northern Mexico. It is 
located entirely within the Tamaulipan biotic province (Hester 1989a:3). The five subdivisions of the South Texas archeological region that have been recognized within this region are: (1) Rio Grande Plain, (2) Rio Grande Delta, (3) Nueces-Guadalupe Plain, (4) Sand Sheet, and (5) Coastal Bend (Black 1989:39). Most of the study areas are found primarily within the Rio Grande Plain, while the remaining areas lie within the Nueces-Guadalupe Plain. The Rio Grande Plain contains a narrow band paralleling and draining into the Rio Grande. Reliable water sources in this region are rare away from the Rio Grande. The Nueces-Guadalupe Plain is the largest subarea of south Texas and is characterized by southeastward flowing streams that divide the region into narrow bands of riparian vegetation along streams and broad areas of grassy and thorny savanna (Black 1989:39-40).

In general, the archeology of South Texas shows great similarities with the surrounding regions of Central Texas and the Trans-Pecos, but also shares common traits (especially the Rio Grande Plain subregion) with adjacent parts of Mexico. Unfortunately, these parts of Mexico are less well-known archeologically than South Texas. A number of recent reviews on the archeology of South Texas have been published (Black 1986; Carlson et al. 1982; Hall et al. 1982:7-23; Hester 1980; Highley 1986; Mallouf et al. 1977; Shafer and Bond 1985; Usrey 1980). The following discussions are based primarily on Black's (1989) most recent archeological synthesis for South Texas.

\section{Previous Research in Southern Texas}

The earliest archeological investigations in south Texas were conducted by avocational archeologists along the Gulf Coast (Anderson 1932; Martin 1929, 1930a, 1930b, 1931; Martin and Potter n.d.; Potter 1930). Professional interest in South Texas began in 1935, when E.B. Sayles, an archeologist with the Gila Pueblo Foundation, produced an archeological synthesis that included South Texas. While Sayles' research focus (i.e., a search for the origin of Southwestern peoples and pottery) was unsuccessful, his perceptions of the archeology in South Texas form the basic chronological framework of the region. Typological studies of artifacts also began in this period (Jackson 1940; Patterson 1936; Poteet 1938). From the late 1930s, a number of significant sites in South Texas were excavated, including Buckner Ranch (Sellards 1940), Johnson (Campbell 1947), Kent-Crane (Campbell 1952), Live Oak Point (Campbell 1958), and Ayala (Campbell and Frizzell 1949). These sites, together with MacNeish's $(1947,1958)$ investigations in northern Tamaulipas and adjacent portions of Texas, were also important in defining the archeology of the region.

Beginning in the 1950s, the pace of archeological research increased as a result of planned reservoir projects that were to impact many of the larger drainage basins in the region. For example, construction of the Falcon Reservoir brought investigations under the auspices of the River Basin Survey (Cason 1952; Hartle and Stephenson 1951; Jelks 1952, 1953; Kreiger n.d.; Kreiger and Hughes 1950). Many other investigations were also conducted during this time along the coast (Campbell 1956, 1962; Corbin 1963; Fitzpatrick et al. 1964; Hester 1968b, 1969; Story 1968), the Rio Grande Delta (Hester et al. 1969; Mallouf et al. 1977:57-59;), and the inland region (Hester 1968a,b,c; Hester and Hill 1969; Hester et al. 1969; Nunley and Hester 1966; Wakefield 1968). Since the 1970s, the majority of archeological projects in South Texas have been conducted through cultural resources management (CRM) programs as a result of legislative actions requiring systematic recording and preservation of endangered historic places and archeological sites. Major CRM projects in South Texas include investigations at Choke Canyon (Hall et al. 1982; Highley 1986; Lynn et al. 1977; Wakefield 1968), Cuero I (Fox 1974), and Coleto Creek (Brown 1983; Fox 1979; Fox and Hester 1976; Fox et al. 1979). 


\section{Cultural Chronology in Southern Texas}

\section{Prehistoric}

The prehistory of South Texas can essentially be divided into three major periods: (1) Paleo-Indian (9200-6000 B.C.); (2) Archaic, which has been subdivided into the Early Archaic (ca. 6000-2500 B.C.), Middle Archaic (ca. 2500-400 B.C.), and Late Archaic (ca. 400 B.C.-A.D. 800); and (3) Late Prehistoric (A.D. 800-1600). These prehistoric periods are principally defined by the presence of particular diagnostic projectile points, but are intended to designate general cultural patterns based on ecology, technology, and subsistence strategies (Black 1989:48-57; Suhm et al. 1954).

Paleo-Indian

Evidence of Paleo-Indian occupations in South Texas (9200-6000 B.C.) usually consists of surface finds found most frequently in the Nueces-Guadalupe and Rio Grande plains. Only two stratified Paleo-Indian sites have been excavated in the region: Buckner Ranch (Sellards 1940) and Berger Bluff (Brown 1987). Both sites were deeply buried in alluvial terraces. Diagnostic projectile point styles of the Paleo-Indian period include Clovis (Meltzer 1986), Folsom (Largent et al. 1991), Golondrina, Scottsbluff, and Angostura (Black 1989:48-49). Finely flaked end scrapers fashioned on blades and bifacially worked Clear Fork tools are also diagnostic of the Paleo-Indian period. Paleo-Indian peoples have traditionally been characterized as terminal Pleistocene big-game hunters, but these highly mobile hunter-gatherers probably exploited a rich diversity of wild plant and animal foods. Investigations at Baker Cave, for instance, indicate that a diverse array of fish, snakes, and rodents was exploited by the Paleo-Indian occupants (Hester 1983). Paleo-Indian populations were probably organized into small groups that ranged over great distances across peri-glacial plains and marginally forested areas to acquire different food sources throughout the year (Black 1989:48).

\section{Archaic}

The major distinction of the Early Archaic period (6000-2500 B.C.) is the replacement of earlier lanceolate-shaped projectile points by stemmed and corner-notched types. These styles include Bell, Andice, Early Triangular, and Early Expanding Stemmed points such as Bandy, Martindale, Uvalde, and related forms (Turner and Hester 1985). Other diagnostic artifacts include Clear Fork tools and large, thin, triangular bifaces with concave bases. The beginning of the Early Archaic period marks the onset of the modern Holocene era, during which the peri-glacial climate of the late Pleistocene began to grow warmer. Available evidence from the Gulf Coastal Plain suggests that population densities remained low through the beginning of the Archaic period in South Texas, reflecting a continuation of the highly mobile adaptations of the Paleo-Indian period.

The Middle Archaic period (2500-400 B.C.) in South Texas is defined by the presence of Pedernales, Langtry, Kinney, Bulverde, and Tortugas projectile point styles (Bell 1958; Turner and Hester 1985). Distally beveled tools are also common during this period, and ground stone tools, such as tubular grinding stones and manos, appear for the first time (Black 1989:49). Site densities in South Texas increase markedly during the Middle Archaic, possibly reflecting a decrease in group mobility and/or an increase in territoriality among groups (Black 1989:51). A heavier reliance on vegetal foods may be 
indicated by the introduction of ground stone technology and the appearance of large burned rock middens throughout Central Texas.

Late Archaic (400 B.C.-A.D. 800) occupations in South Texas are defined by small corner- and sidenotched dart points, including Ensor, Frio, Marcos, Fairland, and Ellis types (Bell 1958, 1960; Turner and Hester 1985). Site densities continue to increase throughout the Late Archaic period, possibly indicating that population densities continued to rise. Cultural deposits on Late Archaic sites also tend to be deeper than during preceding periods, suggesting that occupations were either more extended in duration or that reoccupation of the same locations was more frequent (Black 1989:51). Cemeteries appear during this period, possibly indicating higher levels of social organization and increasing territoriality (Black 1989:51). During the Late Archaic, the exploitation of different ecological niches continued to intensify, becoming increasingly oriented toward the exploitation of seasonal food sources. This kind of adaptation is best illustrated by the frequent occurrence of shell middens along the coast and burned rock middens farther inland. Data collected from inland sites indicate that the economy was based primarily on vegetal resources supplemented with the hunting of small game such as rodents and rabbits (Black 1989:51).

\section{Late Prehistoric}

The onset of the Late Prehistoric period is defined by the appearance of pottery and the bow and arrow. The small dart points of the Late Archaic period were largely replaced by arrow points (Black 1989:52). The Late Prehistoric period in South Texas has been divided into two distinct time horizons, the Austin (A.D. 800-1350) and Toyah (A.D. 1350-1600) phases (Black 1986). The Austin phase is characterized by the presence of Scallorn arrow points, while the Toyah phase is defined by the presence of Perdiz arrow points. Faunal resources became increasingly important during this period, especially large mammals such as bison and deer. Lithic tool kits seem to have been manufactured for the processing of large mammals (Black 1989:51-57). Late Prehistoric sites are relatively common throughout South Texas, which might be interpreted as the result of population increases. The movement of bison from Central to South Texas may coincide with a movement of peoples and/or technology from both the Austin and Toyah phases of Central Texas (Black 1989:51-57).

\section{Historic}

The historic era of South Texas began with the arrival of Europeans in the region and can be subsumed within the overall history of Texas. In South Texas, the historic era has been divided into three time periods: (1) Spanish Exploration and Colonial (ca. A.D. 1520-1821), (2) Mexican (1821-1836), and (3) Texas-American (ca. 1836-present). The Protohistoric era in this region can generally be incorporated within the early part of the Spanish Exploration and Colonial period.

\section{Protohistoric}

Records from the initial Spanish expeditions provide the earliest ethnohistoric accounts of the Coahuiltecan-affiliated groups indigenous to the Rio Grande Plain (Hester 1989a:1-4; 1989b:77-82). Based on fragmentary ethnohistorical records, it appears that these people-part of an extinct cultural group that occupied lands stretching from South Texas deep into Mexico-were highly nomadic huntergatherers who moved in a seasonal pattern within distinctive territories (Hester 1989a). Available 
evidence suggests that Coahuiltecans living in the Rio Grande Plain (as well as in other parts of South Texas and northern Mexico) subsisted on a number of seasonal food sources, ranging from prickly pear in the fall to bison or deer in the late fall or winter, as well as small mammals and roots during offseasons, or in times of hardship (Hester 1989b:77-81).

Two causes can be cited for the early destruction of the Coahuiltecan groups on the Rio Grande plain. The primary reason stems from the great period of unrest among Native American groups generated by the introduction of the horse by the Spanish. Groups who adopted the horse (especially the Apache and the Comanche) eagerly took to raiding neighboring groups. Nomadic peoples such as the Coahuiltecans were especially vulnerable to such pressure, as they could neither consolidate for protection nor occupy defensible positions without risking starvation. Therefore, finally, the Coahuiltecans asked for missions to be established in their territories in order to protect them from the Apache and Comanche raiders. After the establishment of the Spanish missions in South Texas during the first half of the eighteenth century, the remnants of the indigenous Native American groups were rapidly integrated into the mission system or were subjected to outright extinction by depredation or disease (John 1975:171-174).

\section{Spanish Colonial}

The first European incursion into Texas was by Alvarez de Piñeda in 1513 during the course of a Spanish mapping expedition. In 1528, Cabeza de Vaca crossed South Texas after being shipwrecked along the Texas Coast near Galveston Bay (Fox et al. 1989:85). Between 1688 and 1717, Spanish explorers such as Mazanet and Espinosa passed through the Rio Grande Plain from Mexico on their way to the Caddoan settlements in northeast Texas (Hester 1989b:80-81). These early Spanish explorers recorded observations about the aboriginal groups in the region, but they were primarily engaged in consolidating territory for the Spanish Crown.

Following the founding of San Antonio in 1718, the town of Laredo was established along the Rio Grande in 1755 when rancher Tomas Sanchez de la Berrera y Gallardo was granted permission by the great Spanish colonizer, Jose de Escandon, to form a new settlement. Located in the province of Nuevo Santander, which included most of northeastern Mexico and parts of present-day Texas, Laredo was one of a series of settlements that Escandon established or authorized as part of Spain's effort to colonize the area south of the Nueces River (Clark and Juarez 1986:85; Folan et al. 1986:6).

Laredo was founded near a ford on the Rio Grande on a grant consisting of 15 sitios de ganado mayor, or 66,000 acres. In 1767, Spanish authorities visited the community and laid out San Agustin Plaza. They also granted porciones (parcels of land fronting on the river) to the settlers. The community grew steadily after its designation as a villa or town, and by 1789 the population consisted of approximately 700 individuals. The town included a stone church and a priest's house, military barracks to house the soldiers who guarded the community against frequent Indian attacks, and approximately 85 civilian dwellings. The economy was based on ranching and salt mining at Sal del Rey in modern Hidalgo County (Anonymous n.d.; Clark and Juarez 1986:87-88; Folan et al. 1986:6).

\section{Mexican and Texas-American}

Prior to the Treaty of Guadalupe Hidalgo, a Spanish garrison was established in Laredo to minimize the effects of depredations by Lipan Apache and Comanche raiders. In 1790, a daring attack on the city overran the garrison and exploded the powder magazine, deepening fears "that the Comanches' efforts to 
sweep through south Texas were succeeding" (Briggs 1982:7). Once the Texas-Mexico border was established along the Rio Grande in 1848, the role of protection in the Laredo area passed to the United States. In 1849, a company of mounted infantry under 2nd Lieutenant E. L. Viele arrived in Laredo to establish an army post on "some high flats west of the city, opposite a ford and just north of a bend in the Rio Grande" (Briggs 1982:7) on the Texas side of the river about three-quarters of a mile west of the old Spanish town of Laredo. Originally named Camp Crawford (or Camp Laredo), the name of the post was changed in 1850 to Fort McIntosh in honor of Lieutenant Colonel James S. McIntosh, who died September 1847 from wounds received at the Battle of Molino del Rey during the Mexican-American War (Frazer 1972). When construction began in 1850, the general military objective of the Fort was to provide "escort service to caravans of travelers and [to reduce] Indian depredations and general outlawry" (Briggs 1982:8).

The 5th Infantry arrived at Fort McIntosh in November 1853 and, under the direction of the Army Corps of Engineers, began construction of a field fort north of the McIntosh Cantonment. This field fort was constructed of earthen embankments and designed as an artillery emplacement. Due to its five-pointed shape, this bermed structure became known as Star Fort, as well as Field Fort McIntosh, and was located about one-half mile north of the post proper (Warren 1991:6). Star Fort was completed in less than three months, including a stone magazine within the enclosure. By the time it was abandoned in 1859, the cantonment area (south of Star Fort) included offices, storehouses, kitchens, a blacksmith shop, a sutler's store, stables, a hospital, a carpenter's shop, officers' quarters, a parade ground, and possibly even a ranch house that predated the Fort (Briggs 1982:11).

Throughout Fort McIntosh's early period, enlisted men apparently camped in tents and under brush arbors at various locations in and around the cantonment area and outside of Star Fort. After a year without Indian depredations in the area, Fort McIntosh was abandoned. The following year (1860), however, the post was reoccupied due to raiding, only to be abandoned again in 1861 as Texas took possession of it during the Civil War. At the close of the war in 1865, the infantry again arrived at Fort McIntosh. They found that much of the fort had been dismantled and removed during the war, leaving it essentially devoid of structures. By 1869 , construction was again underway and a new post hospital, storehouse, guardhouse, and bakery were completed by 1870 . During the last major construction episode in the 1880s, buildings at the fort were constructed of yellow Laredo brick. Many of these structures remain today.

Until its final military abandonment in 1949, Fort McIntosh continued to be used for military training of troops and, in 1942, became the home of the Southern Liaison Patrol of the newly formed Civil Air Patrol (Briggs 1982). According to Warren (1991:7), "[d]uring its long history, Fort McIntosh was involved in protecting local settlers and travelers from Indians and bandits, and played a role in the Civil War, the Mexican Revolution, the Spanish American War, and World Wars I and II."

Since 1946, Fort McIntosh has been utilized as a teaching facility, housing Laredo Junior College. Although the post has been altered to meet the needs of a college campus, several structures and some of its early period subsurface deposits remain potentially intact (Briggs 1982:25-26). Thus, Fort McIntosh, along with Star Fort, maintains its National Register District and State Archeological Landmark status.

Throughout the late eighteenth century and first half of the nineteenth century, the citizens of Laredo considered themselves to be politically separate from the Anglo-American settlements developing in other parts of Texas. Nevertheless, their key location on the corridor between Mexico and the United States embroiled them in Mexico's war for independence against Spain prior to 1821, in the Texas revolution during the 1830s, and in the Mexican-American War of 1846-1848. Insurgents, troops, and supplies 
passed through the town regularly, keeping the community in a constant state of flux for 50 years. Population turnover was continuous, although the number of residents changed little (Clark and Juarez 1986:89-95; Folan et al. 1986:6-7).

The organization of Webb County in 1848 and the increasing numbers of Anglo-American merchants afterwards contributed to a period of prosperity for Laredo. The town's economy was further stimulated during the Civil War, when it became a center for the Confederate cotton trade. Twenty years later, the arrival of the Texas-Mexican Railway and the International-Great Northern Railroad in 1881 caused Laredo's population to soar, and within a decade the number of residents had increased from 3,521 to 11,319 (Anonymous n.d.; Folan et al. 1986:8). A major influx of Anglo-American entrepreneurs resulted in the construction of an electric railway system, the opening of new suburban developments, and the construction of numerous residential and commercial buildings. The establishment of coal mines northwest of Laredo contributed to the general prosperity of the region (Anonymous n.d.), as did a period of agricultural development after 1900. Further significant population growth occurred during the second decade of the twentieth century as large numbers of Mexican nationals crossed the border to escape the ravages of civil war. The population swelled by 50 percent between 1910 and 1920 (Anonymous n.d.), and new immigrants created a demand for housing throughout the city while contributing to the local infrastructure as teachers, businessmen, and laborers.

Discovery of oil in Webb County in 1921 assisted Laredo in sustaining a period of growth during the 1920s and 1930s, after which the city suffered the effects of the Great Depression. Establishment of the Laredo Army Air Field in 1942 aided in a general economic recovery that continued after World War II as the community became the location of numerous service industries. Increasing trade between the United States and Mexico further stimulated the local economy, which has remained strong throughout the last few decades.

\section{Previous Research in the Project Area}

Archeological projects with direct relevance to the project area include several cultural resources surveys along the Rio Grande in the vicinity of Laredo (Austin et al. 1994; Fox and Vecker 1977; McGraw 1983; USACE 1990) and investigations of Star Fort and Fort McIntosh (Briggs 1982; Warren 1987, 1991).

Prior to archeological fieldwork, a records search was conducted at TARL for known cultural properties in the vicinity of the proposed project segments. The results of this records search are discussed separately for each segment of the project area below.

\section{Rio Bravo Segment}

No previous cultural resources investigations have been conducted in the immediate vicinity of the Rio Bravo segment, but TARL archives contain records of several archeological sites along the Rio Grande river frontage between Rio Bravo and Laredo, Texas. These sites are located along the edge of the upper terrace and consist primarily of low-density scatters of prehistoric debris, including flakes, cores, ground stone implements, and mussel shell. Historic material was observed on several of these sites, and three prehistoric burials were documented at one site (Fox 1982). 


\section{Laredo River Road Segment}

The northern segment of the Laredo River Road project area (north of Jefferson Street) was initially surveyed for cultural resources by Fox and Vecker (1977). More recently, a reconnaissance-level cultural resources survey of the entire river frontage area was conducted and road improvement activities associated with a JTF-6 action were monitored by personnel from Geo-Marine, Inc. (Austin et al. 1994; USACE 1990). No new archeological sites were located during any of these previous investigations.

The Laredo River Road survey segment passes along the western boundary of Fort McIntosh, on the floodplain below the historic features that constitute the Fort McIntosh National Register district. One documented historic property, Star Fort (part of Fort MacIntosh, 41WB11), is situated on the upper terrace of the Rio Grande floodplain approximately $75 \mathrm{~m}$ east of and above the proposed River Road segment. Star Fort was constructed in 1854 and has been included with Fort McIntosh on the listing of State Archeological Landmarks and also on the National Register of Historic Places (Austin et al. 1994). The remains of this "early" or "Field Fort McIntosh," which appear today as a series of low mounds or embankments without associated cultural debris, have been reported by several researchers (Briggs 1982; Warren 1987, 1988, 1989a, 1989b, 1991).

\section{Galvan Ranch Segment}

No previous cultural resources investigations have been conducted within the Galvan Ranch project area, and no archeological sites have been documented along any of the proposed new or existing road segments. However, the area lying immediately west of Old Mines Road, an improved gravel road that forms the western boundary of the Galvan Ranch project area, was surveyed in connection with an application by Farco Mining for a mining permit in the early 1990s (TARL site files). Numerous archeological sites were documented as a result of this survey. Most of these sites consist of low- to moderate-density lithic scatters, many of which are associated with hearth features, that have been identified as open campsites, intermediate campsites, base camps, and lithic quarries. Cultural material from a wide variety of time periods is represented at these sites, including projectile points diagnostic of the Middle Archaic (Tortugas), Late Archaic (Ensor, Catán, Matamoros, Desmuke), and Late Prehistoric (Fresno, Catán, Matamoros) periods (Turner and Hester 1985). The Trevino Mining Permit area covers approximately $13 \mathrm{~km}^{2}$ between Old Mines Road on the east side and the Rio Grande on the west. The density of archeological sites in the mining permit area is quite high, averaging approximately six sites $/ \mathrm{km}^{2}$ in some areas. The current state of investigations at the sites documented in the Trevino Mining Permit area is uncertain. Aside from the site forms on file at TARL, no written documentation could be located that describes the NRHP eligibility of any of these sites, the extent of work performed on them, or measures that were adopted to avoid impacting the sites.

\section{Stone Ranch Segment}

No previous archeological work has been conducted in the vicinity of the Stone Ranch project area, and no cultural properties were depicted on TARL maps for this area. 


\section{Swartz Ranch Segment}

No previous cultural resources investigations have been conducted in the vicinity of the Swartz Ranch project area, and no archeological sites are represented on TARL maps for this area.

\section{State Highway 277 and Farm-to-Market Road 2644 Segments}

No previous archeological work has been performed along the FM 2644 segment, and no cultural properties have been identified in this area. One archeological site depicted on TARL site file maps, 41DM59, encroaches upon the northeastern side of SH 277 approximately $6.4 \mathrm{~km}(4.0 \mathrm{mi})$ northwest of the Carrizo Springs city limits, but this site is not shown to extend into the survey corridor on the southern side of the road. Site 41DM59 consists of a scatter of artifacts, including dart and arrow points indicating occupations from the Paleo-Indian through Late Prehistoric periods, knives, and scrapers in a highly disturbed context. No previous cultural resources investigations have been undertaken along the SH 277 segment, and no archeological sites were depicted on TARL maps for this area.

\section{State Highway 83 and Farm-to-Market Road 3338 Segments}

Previous cultural resources investigations resulted in the documentation of one archeological site along the SH 83 segment and three sites along the FM 3338 segment. TARL site files describe all four sites (41WB214, 41WB295, 41WB456, and 41WB457) as open campsites and raw material quarries consisting of low-density lithic scatters without associated cultural features. Both the SH 83 and FM 3338 segments of the project area were recently surveyed for cultural resources (Austin et al. 1994) in connection with an earlier JTF-6 road improvement action. No new cultural properties were identified as a result of this survey. 


\section{CHAPTER 3 METHODOLOGY}

\section{FILE SEARCH}

A search of existing records was conducted at TARL in Austin, Texas, prior to fieldwork. TARL files were inspected in order to locate previously recorded sites within a one-mile radius of the present project ROW. This search resulted in acquisition of site data along a two-mile-wide corridor centered on the proposed construction/improvement routes. The site file search yielded information on numerous cultural resources properties located within a one-mile radius of the Rio Bravo, Laredo River Road, SH 83, FM 3338, and Galvan Ranch segments of the project area, although only four previously documented sites actually occur within the road ROW proposed for this action. The comparative scarcity or absence of previously recorded cultural resources in some areas does not reflect a lack of archeological sites in the region. The absence of records merely serves to demonstrate the limits of previous archeological investigations. The results of the records search for each segment of the project area have been presented in detail in the previous chapter.

\section{FIELD METHODS}

The cultural resources survey of $387.7 \mathrm{~km}(240.9 \mathrm{mi})$ was conducted along approximately $211.0 \mathrm{~km}$ (131.1 mi) of existing and $176.7 \mathrm{~km}(109.8 \mathrm{mi})$ of proposed new road rights-of-way in Webb, Maverick, and Dimmit counties, Texas. A 20-m-wide survey corridor was examined on either side of existing road cuts. When limiting physical barriers such as fence lines were encountered, the survey corridor was narrowed. A 40-m-wide corridor was examined along proposed new road rights-of-way. In addition, proposed construction locations for three borrow pits, two helipads, an equipment storage area, an airfield, and two base camp or bivouac areas were examined for cultural resources. Surveys of these larger areas were conducted using systematic 20 -m-wide transect intervals. Site locations and nonsite localities were plotted on USGS 7.5' quadrangle maps, State of Texas Archeological Site Data Forms were filled out and scaled site maps were drawn for each site, and universal transverse mercator (UTM) coordinates were determined for each site using a Global Positioning System (GPS) device or by extrapolating from existing topography on USGS maps.

The presence, depth, and integrity of subsurface cultural deposits on each site were determined by excavating one or more 30-by-30-cm shovel tests. Due to the time constraints on the fieldwork it was possible to excavate one or two shovel tests in order to formulate a general assessment of the depositional context on the site. Shovel tests were excavated in arbitrary $20-\mathrm{cm}$ levels unless natural stratigraphic 
breaks were observed. All sediments were screened through 1/4-inch mesh, and all artifacts recovered were described briefly on shovel test forms and redeposited. Shovel tests were generally excavated to a depth of one sterile $20-\mathrm{cm}$ level below a culture-bearing level. If no cultural material was observed, the shovel test was excavated to a minimum depth of $20 \mathrm{~cm}$ below surface (bs).

Site boundaries within the survey corridor were flagged with red surveying tape, and overview photographs were taken of each site. Site datums stamped with temporary site numbers were installed at each site. If possible, datums were established at fenceposts or trees within the site boundaries and outside the proposed ROW; when such features were not available within sites, datums were established outside the site boundaries on the nearest feature available. Diagnostic artifacts were sketched or photographed in the field. No artifacts were collected.

In distinguishing between archeological sites and "nonsite localities," three criteria were used as standard measures for evaluating the significance of cultural manifestations in the project area: surficial artifact density, contextual integrity, and depth of cultural deposits. Artifact density represented the primary criterion for determining the status of scatters of cultural material. In general, any artifact scatter that exhibited an average density of less than five artifacts per $25 \mathrm{~m}^{2}$ was considered to be a nonsite locality regardless of the overall size of the distribution. Many of these occurrences were shovel-tested in order to determine whether the cultural deposits retained any depth, but most of the tested localities proved to be surficial. Low-density artifact scatters that appeared to possess some depth and/or to have retained some contextual integrity were documented as sites.

Cultural resources identified as sites were classified as low-, moderate-, or high-density depending on the density of the artifact assemblage visible on the surface of the site. Generally, sites with an average surface density of between five and ten artifacts per $25-\mathrm{m}^{2}$ area were assigned a low-density status. Sites exhibiting an average surface density of between 11 and 20 artifacts per $25-\mathrm{m}^{2}$ area were classified as moderate-density, and sites with more than 20 artifacts per $25-\mathrm{m}^{2}$ area as high-density.

The high density of archeological sites on the Swartz and Galvan ranch segments of the project area and the strict time constraints on completion of the archeological fieldwork for this action often made it difficult to determine all of the boundaries for each site. Many of the sites located in these areas are quite large and measure hundreds or even thousands of meters across. Whenever unusually large sites were encountered, the boundaries of the site within the survey corridor were determined and an attempt was made to establish the entire boundary of the site. If the artifact scatter associated with a site continued beyond an arbitrarily determined distance of $100 \mathrm{~m}$ from existing roads, however, the search for that site boundary was abandoned and the known extent of the scatter was mapped; only the portions of sites located within the project ROW were evaluated for NRHP eligibility. All of the boundaries for sites encountered along proposed new construction rights-of-way were determined regardless of site size. In many cases, limiting physical barriers such as fences also prohibited the full documentation of site boundaries.

The potential eligibility of each archeological site for inclusion in the NRHP was assessed by determining whether the site appeared to possess sufficient contextual integrity to contribute significant information about the prehistoric past. Based on the information potential of survey data alone, full assessment for listing in the NRHP of the cultural resources located during this project is not possible. Contributing to the limitations imposed by survey level data, vandalism of sites in the project area has resulted in an overall paucity of diagnostic tools. Without these temporal indicators, period-specific research issues cannot be adequately addressed. Under these circumstances, NRHP Criterion D, Information Potential, is most applicable to the cultural properties documented during this survey. In order to meet the 
standards of this criterion, an archeological site generally needed to contain cultural features (such as hearths), discrete activity areas (such as flintknapping loci), and/or subsurface depth. Most of the subsurface deposits identified on these sites were fairly surficial (5 to $10 \mathrm{~cm}$ deep), and did not appear to retain much stratigraphic integrity given the high-energy erosional environments that characterize most of the site locations. Assessments of the potential eligibility of sites containing subsurface deposits measuring more than 10 to $15 \mathrm{~cm}$ in depth were made based on the degree of disturbance from erosion, fence and road construction, and other natural impacts evident at the site.

Several segments of the project area have been previously surveyed for cultural resources, including most of the Laredo River Road and all of SH 83 and FM 3338. The latter two project segments were not resurveyed in connection with this JTF-6 action. However, field personnel revisited the four known archeological sites that occur along these segments, including three at the southern end of the FM 3338 segment (41WB214, 41WB456, and 41WB457) and one on the SH 83 segment (41WB295), and State of Texas Additional Archeological Site Investigation Forms were filled out for each site. 


\section{CHAPTER 4 SURVEY RESULTS}

\section{INTRODUCTION}

A total of 97 newly recorded archeological sites and 349 localities was documented as a result of the cultural resources surveys for the various segments of this action (Table 1). All of these newly documented cultural resources are located on the Galvan, Stone, and Swartz ranches segments of the project area. All but one of these sites exhibit components attributable solely to prehistoric occupations. One site on the Galvan Ranch segment contains both prehistoric and historic components. Each site is described individually in the appropriate section below.

In addition to the newly documented archeological sites, 349 nonsite localities were identified as a result of the survey. Two types of localities were encountered during the survey. The first type consists of isolated artifact occurrences or concentrations of less than six artifacts. The second type consists of extensive, very low-density lithic scatters characterized by an average artifact density of less than six artifacts per $25 \mathrm{~m}^{2}$. Shovel tests were excavated on approximately 25 percent of the localities described by the latter category in order to determine if surface scatters were associated with subsurface cultural deposits. All of the tested localities failed to exhibit any indication of subsurface context that might have warranted designation as an archeological site. None of the localities are recommended as eligible for inclusion in the NRHP.

\section{RIO BRAVO SEGMENT}

No cultural resources were identified as a result of the cultural resources survey of the Rio Bravo project area. Despite the limited surface visibility, this segment of the project area is considered a lowprobability area for containing cultural resources. The upland portion of the segment has been heavily impacted by the construction of a large cement culvert and by devegetating activities, while the lowland portion represents an unlikely locus for prehistoric settlement. No further work is recommended for this segment of this action. 
Table 1

Survey Coverage and Results for Segments with Newly Recorded Sites (Galvan, Stone, and Swartz Ranches)

\begin{tabular}{|c|c|c|c|c|c|}
\hline Name of Road/Fence & Portion Surveyed & Miles & $\begin{array}{l}\text { \# of } \\
\text { Sites }^{1}\end{array}$ & $\begin{array}{c}\text { \# of } \\
\text { Localities }\end{array}$ & $\begin{array}{c}\text { Site } \\
\text { Density }\end{array}$ \\
\hline \multicolumn{6}{|c|}{ Galvan Ranch Segment } \\
\hline Main Galvan Road & Both sides of existing road & 21.05 & 13 & 60 & $0.6 / \mathrm{mi}$ \\
\hline New Base Camp Road & 40-m corridor & 1.25 & 3 & 0 & $2.40 / \mathrm{mi}$ \\
\hline Old Galvan Road & Both sides of existing road & 2.60 & 4 & 5 & $1.54 / \mathrm{mi}$ \\
\hline Chapote Pasture Road & Both sides of existing road & 1.30 & 2 & 1 & $1.54 / \mathrm{mi}$ \\
\hline Big Pinto Pasture Road & Both sides of existing road & 2.00 & 0 & 13 & $0.00 / \mathrm{mi}$ \\
\hline Vidal Cut & Both sides of existing road & 2.20 & 3 & 5 & $1.36 / \mathrm{mi}$ \\
\hline “Superhighway" & Both sides of existing road & 2.70 & 0 & 3 & $0.00 / \mathrm{mi}$ \\
\hline $\begin{array}{l}\text { Galvan Fence (east of } \\
\text { Loma Blanca) }\end{array}$ & South side of existing fence & 12.20 & 11 & 27 & $0.90 / \mathrm{mi}$ \\
\hline $\begin{array}{l}\text { Galvan Fence (west of } \\
\text { Loma Blanca) }\end{array}$ & Both sides of existing fence & 9.90 & 7 & 19 & $0.71 / \mathrm{mi}$ \\
\hline Loma Blanca Fence & South/west sides of fence & 6.70 & 3 & 10 & $0.45 / \mathrm{mi}$ \\
\hline Greengate Fence & $\begin{array}{l}\text { Both sides of existing fence and both sides } \\
\text { of existing road on west side of fence }\end{array}$ & 4.20 & 3 & 2 & $0.71 / \mathrm{mi}$ \\
\hline Chapote Fence & West side of existing fence & 2.25 & 2 & 11 & $0.89 / \mathrm{mi}$ \\
\hline Pipeline Fence & West side of existing fence & 3.40 & 2 & 5 & $0.59 / \mathrm{mi}$ \\
\hline Eastern Fence & West side of existing fence & 6.05 & 7 & 11 & $1.16 / \mathrm{mi}$ \\
\hline Trevino Fence & North side of existing fence & 17.70 & 13 & 78 & $0.73 / \mathrm{mi}$ \\
\hline Airfield & $495,000 \mathrm{~m}^{2}$ & N/A & 2 & 0 & $0.004 / \mathrm{km}^{2}$ \\
\hline Base Camp Area & $97,500 \mathrm{~m}^{2}$ & N/A & 1 & 0 & $0.01 / \mathrm{km}^{2}$ \\
\hline \multirow[t]{2}{*}{ Caliche Borrow Pit } & $137,500 \mathrm{~m}^{2}$ & N/A & 0 & 0 & $0.0 / \mathrm{km}^{2}$ \\
\hline & & 95.5 & 76 & 250 & \\
\hline \multicolumn{6}{|l|}{ Stone Ranch Segment } \\
\hline Existing Roads & Both sides of existing roads & 3.50 & 3 & 10 & $0.91 / \mathrm{mi}$ \\
\hline New Roads & 40-m corridor & 1.60 & 3 & 11 & $1.88 / \mathrm{mi}$ \\
\hline Equip. Storage Area & 2.02 ha & N/A & 0 & 1 & $0 / \mathrm{km}^{2}$ \\
\hline Helipad & $1,225 \mathrm{~m}^{2}$ & N/A & 0 & 1 & $0 / \mathrm{km}^{2}$ \\
\hline \multirow[t]{2}{*}{ Borrow Pit } & $100,000 \mathrm{~m}^{2}$ & N/A & 0 & 0 & $0 / \mathrm{km}^{2}$ \\
\hline & & 5.1 & 6 & 23 & \\
\hline \multicolumn{6}{|c|}{ Swartz Ranch Segment } \\
\hline Existing Roads & $\begin{array}{l}\text { Both sides of roads/interior (east and } \\
\text { south) sides of fences }\end{array}$ & 18.00 & 24 & 78 & $1.33 / \mathrm{mi}$ \\
\hline New Roads & $40-\mathrm{m}$ corridor & 1.20 . & 2 & 0 & $4.0 / \mathrm{mi}$ \\
\hline Base Camp Area & $2.0 \mathrm{ha}$ & N/A & 0 & 0 & $0 / \mathrm{km}^{2}$ \\
\hline Equip. Storage Area & $3,000 \mathrm{~m}^{2}$ & N/A & 0 & 1 & $0 / \mathrm{km}^{2}$ \\
\hline Helipad & $1,225 \mathrm{~m}^{2}$ & N/A & 0 & 1 & $0 / \mathrm{km}^{2}$ \\
\hline \multirow[t]{3}{*}{ Borrow Pit } & $3,250 \mathrm{~m}^{2}$ & N/A & 0 & 0 & $0 / \mathrm{km}^{2}$ \\
\hline & & 19.2 & 26 & 80 & \\
\hline & & 119.8 & 108 & 353 & \\
\hline
\end{tabular}

1 Several sites appear on more than one distinct survey segment at Galvan Ranch, resulting in an inflated total of 76 sites (actual total is 65 sites). 


\section{LAREDO RIVER ROAD SEGMENT}

As a result of the 8.9-km [5.5-mi] cultural resources survey of the Laredo River Road segment, no new cultural resources were identified. The one known historic property in the project area-Star Fort, part of the Fort MacIntosh National Register Historic Distict (41WB11) and an SAL (State Archeological Landmark)-is situated on an upper terrace above and $75 \mathrm{~m}$ east of the Laredo River Road project area. Neither associated cultural remains nor debris from Star Fort were observed along the road segment in the area near Star Fort. The road improvement proposed for the river frontage road is limited to regrading the length of the existing road. Provided that grading equipment and other construction-related activities and traffic are restricted to the existing roadbed, this road improvement plan will not result in any impacts to Star Fort. No further work is recommended for the Laredo River Road segment of this action.

During the current survey, it was noted that several feet of alluvium from floods over the past 40 years, in particular the flood of 1954, have been deposited along this stretch of the Rio Grande floodplain. Eroded cutbanks-produced by the run-off from concrete-lined drainage ditches along the terrace edge running perpendicular to the river road segment-show that at least seven feet of homogeneous alluvium have been deposited on the floodplain in the vicinity of Laredo Community College and Star Fort. Photographs taken in Laredo at the time of the 1954 flood show that the flood height reached $61.35 \mathrm{ft}$ and that much of the area near the survey segment was inundated (Thompson 1986:269-271). Therefore, the potential for buried sites under the alluvium exists. Any extant sites, however, would be at such a depth that they would not be impacted nor affected by the present action.

\section{GALVAN RANCH SEGMENT}

A total of 65 archeological sites and 250 localities was identified as a result of the cultural resources survey of the Galvan Ranch project area (Figures 9 and 10). Average site density for the Galvan Ranch survey area is approximately 0.67 sites per linear mile. This figure is somewhat deceiving, however, as many of the sites documented at Galvan Ranch measure hundreds or even thousands of meters in length. Fifteen of the archeological sites at Galvan Ranch are recommended as potentially eligible for inclusion in the NRHP, and measures should be taken to ensure that no impacts are introduced to these sites by the proposed road construction and improvement activities. Each site is discussed individually below.

Of the 250 localities identified at Galvan Ranch, 204 consist exclusively of very low-density lithic scatters that fail to meet the criteria for site designation (see Figure 10). These sparse lithic scatters are composed primarily of tested cobbles and cortical flakes indicative of low-intensity quarrying activities, and are virtually continuous across vast expanses of the terrain at Galvan Ranch. Occasionally, artifact densities achieved a sufficiently high level within a particular portion of an extensive, sparse lithic scatter to warrant site designation. These concentrations were documented as archeological sites, but the surrounding "background noise" retained the status of a locality. Because all of these localities can be described in essentially the same terms, they have not been described individually. A total of 46 of the localities at Galvan Ranch consists of isolated artifact occurrences, isolated concentrations of less than six artifacts within a $25-\mathrm{m}^{2}$ area, or low-density scatters such as those described above that also contain flake tools or diagnostic artifacts (Table 2).

Two broad types of archeological sites were recorded on the Galvan Ranch segment. Camps or campsites refer to prehistoric scatters of lithic artifacts, including cores, debitage (primarily tertiary stage thinning flakes), projectile points and other bifaces, retouched flake tools, and occasionally fire-cracked rock, mussel shell, and/or cultural features such as hearths or activity loci. Quarries are lithic resource procurement areas that are centered on extensive surface exposures of chert gravels eroding out of old alluvial terraces. Quarry sites consist of extensive, often low-density scatters of lithic debris, mainly 
tested cobbles (chert cobbles with a small number of flake scars) and unmodified cortical flakes. Quarries rarely contain any lithic tools, such as bifacial implements or retouched flakes, and never contain organic debris or cultural features.

\author{
Galvan Ranch Sites
}

\title{
Site 41 WB 466
}

Site 41 WB466 is located on a west-facing, gradual slope on the east side of Galvan Ranch, along the Eastern Fence between Galvan and La Esperanza ranches (Figure 11; see Figure 9). The site is approximately $1.4 \mathrm{~km}$ west of Highway 83 and $300 \mathrm{~m}$ northwest of the southeast Galvan Ranch property corner. Elevation at the site ranges from 244 to $255 \mathrm{~m}$ ( 800 to $835 \mathrm{ft}$ ) above mean sea level (amsl). A two-track road paralleling the Eastern Fence runs northwest to southeast through the site. An unnamed seasonal drainage is approximately $100 \mathrm{~m}$ northwest of the site and Cuchara Creek is approximately $3 \mathrm{~km}$ south. Vegetation in the area of the site consists primarily of mesquite and short grass. Ground visibility is approximately 80 percent.

The site is a small, low-density lithic scatter measuring approximately $16 \mathrm{~m}$ northwest to southeast and 3 $\mathrm{m}$ northeast to southwest. The site covers a total area of approximately $48 \mathrm{~m}^{2}$. A sparse scatter of lithic debitage extends north and south of the site along the existing two-track; however, the density of artifacts was not sufficient to warrant inclusion in the site boundaries. The sparse lithic scatters on either side of site 41WB466 were, therefore, identified as localities. The lithic assemblage consists primarily of secondary and tertiary flakes and shatter, the highest concentration of which was identified in the twotrack road. Raw material consists primarily of locally available chert. Artifact density at site $41 \mathrm{WB} 466$ is five to six specimens per $25-\mathrm{m}^{2}$ area. No ground stone, evidence of quarrying, or features were observed at the site. No diagnostic artifacts were identified.

A single shovel test was excavated at site 41WB466 in order to determine the presence of subsurface cultural deposits. The test was placed in the proposed ROW on the southwest edge of the two-track road. Soil at the site consists primarily of dark brown sandy loam to a depth of $15 \mathrm{~cm}$ bs, followed by strong brown sandy loam with caliche inclusions. Excavation of the shovel test was terminated at $40 \mathrm{~cm}$ bs and no subsurface cultural deposits were revealed.

Site $41 \mathrm{WB} 466$ is interpreted as an open campsite consisting of a low-density surface scatter of lithic artifacts. The site was identified in the two-track road paralleling the Eastern Fence and does not appear to extend beyond the road. Shovel testing revealed no buried cultural deposits. Due to the presence of the site in the existing two-track, the integrity of the site is significantly reduced. Therefore, the research potential of site $41 \mathrm{WB} 466$ is minimal. Based on these observations, the site is recommended as ineligible for inclusion in the NRHP. No further work at site $41 \mathrm{WB} 466$ is recommended.

\section{Site 41 WB 467}

Site 41WB467 is located on a northwest-facing, gradual slope along Old Galvan Road approximately 1 $\mathrm{km}$ east of the intersection with Main Galvan Road (Figure 12; see Figure 9). The site was identified in a cutbank on either side of the existing road and extends north and south beyond the project boundaries. Elevations at the site range from 221 to $227 \mathrm{~m}$ (725 to $745 \mathrm{ft})$ amsl. An unnamed seasonal drainage is approximately $520 \mathrm{~m}$ west of the site and Cuchara Creek is approximately $1.6 \mathrm{~km}$ south of the site. 
figure

9. Location of sites on the Galvan Ranch segment

fold-out 
Cultural Resources Survey for a JTF-6 Action in Webb, Maverick, and Dimmit Counties, Texas

fig 9 
figure

10. Nonsite localities on the Galvan Ranch segment

fold-out 
Cultural Resources Survey for a JTF-6 Action in Webb, Maverick, and Dimmit Counties, Texas

fig 10 
Table 2

List of Nonsite Localities on the Galvan Ranch Segment with Artifacts other than Flakes

Locality No. Description

One Abasolo point

2 One Travis point

3 One arrow point preform in a very low-density lithic scatter

$4 \quad$ One Abasolo point in a very low-density lithic scatter

5 One retouched Abasolo point in a very low-density lithic scatter

6 One Nueces scraper and one unidentified side-notched point in a very low-density lithic scatter

One Clear Fork-like beveled tool and two bifaces in a very low-density lithic scatter

One core fragment

One Nueces biface

One core fragment

One retouched Frio point in a very low-density lithic scatter

One biface, one core, and several flakes

One biface in a very low-density lithic scatter

Three cores in a very low-density lithic scatter

One biface and two flakes

One retouched flake

One Early Triangular point in a very low-density lithic scatter

One Catán point and two scrapers in a very low-density lithic scatter

One biface in a very low-density lithic scatter

One Catán and one Early Triangular point, two bifaces, and six scrapers in a very low-density

lithic scatter

Two scrapers and one retouched flake in a very low-density lithic scatter

One biface, one bifacially worked cobble, and one flake

One scraper, one unfinished biface, and six flakes

One scraper, one bifacially retouched flake, and three flakes

One core

One biface, one scraper, and one flake

One biface and two flakes

One Perdiz point and eight flakes

One scraper and three flakes

One scraper and 10 flakes

One biface in a very low-density lithic scatter

One Fresno point and one scraper in a very low-density lithic scatter

One core and four flakes

One unidentified projectile point and one biface in a very low-density lithic scatter

One core and four flakes

One core and two flakes

One biface, one core, and five flakes

One biface and several cores in a very low-density lithic scatter

One biface in a very low-density lithic scatter

One unidentified projectile point base

One unidentified projectile point base

Three cores

One scraper, one core, and seven flakes

One scraper, one biface, and 10 flakes

One unidentified projectile point base and one flake

One biface 


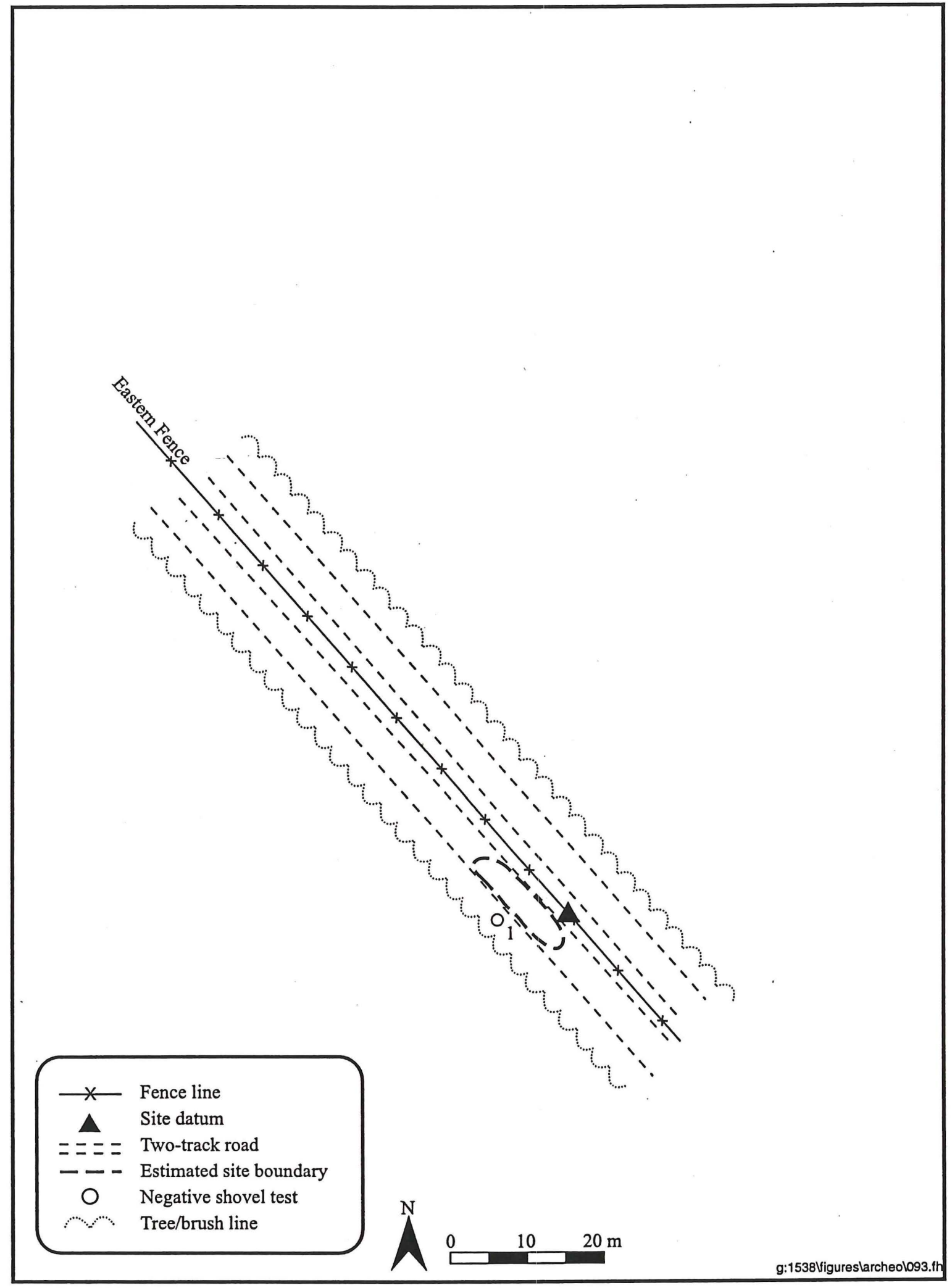

,Figure 11. Plan map of site 41WB466. 


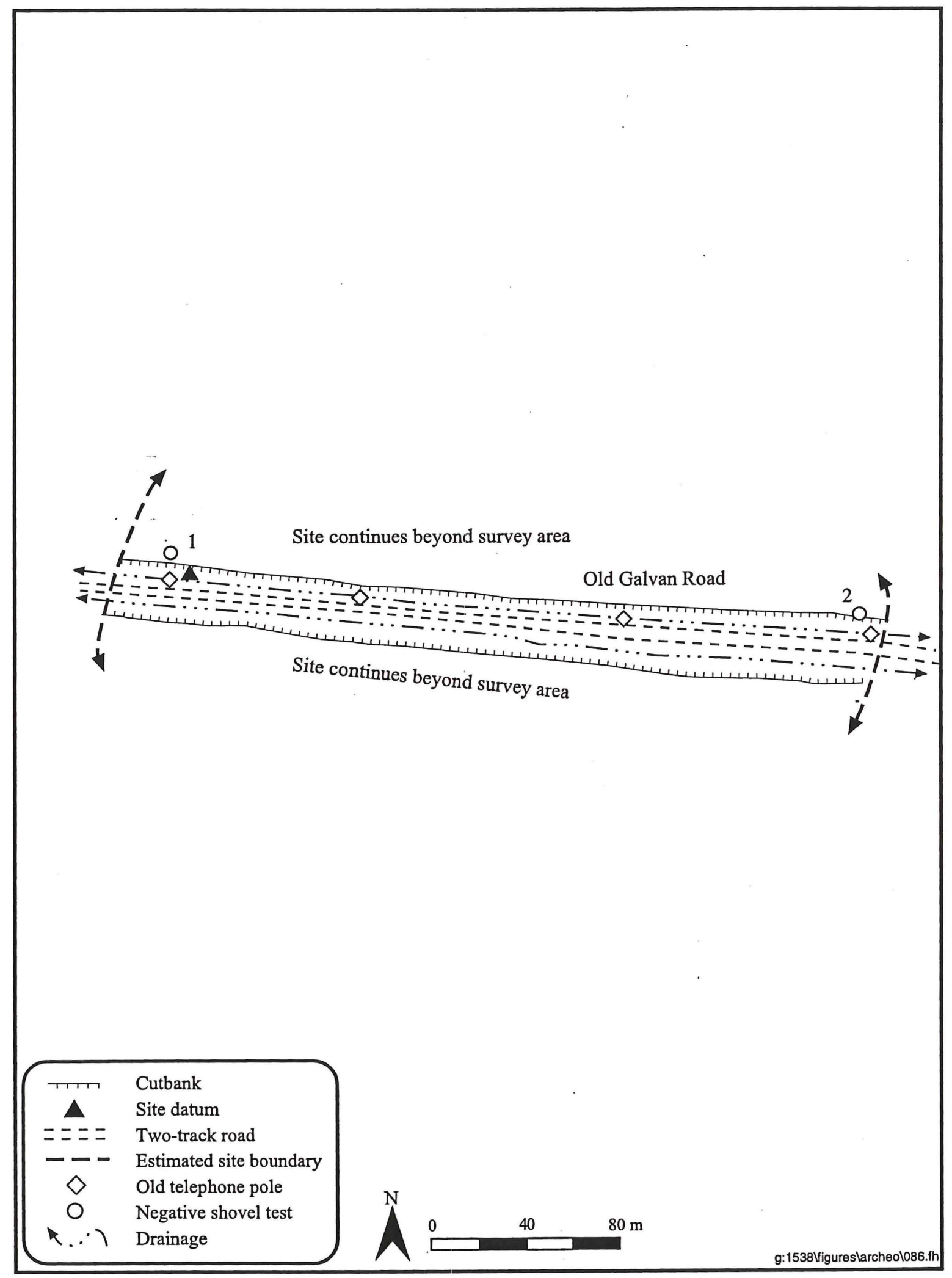

Figure 12. Plan map of site $41 \mathrm{WB} 467$. 
Vegetation in the area of the site is moderate to dense and includes mesquite, tasajillo, prickly pear cactus, and other cacti. Ground visibility is approximately 60 to 70 percent.

The site is a low-density lithic scatter measuring approximately $325 \mathrm{~m}$ east to west and over $40 \mathrm{~m}$ north to south, extending north and south beyond the project boundaries. The identified portion of the site covers a total area of approximately $13,000 \mathrm{~m}^{2}$. The lithic assemblage consists primarily of secondary and tertiary flakes and a scraper. Raw material consists of locally available chert. The density of artifacts at site $41 \mathrm{WB} 467$ is approximately six to eight specimens in a $25-\mathrm{m}^{2}$ area and no significant concentrations of artifacts were identified. No ground stone, evidence of quarrying, or features were identified. No diagnostic artifacts were observed at the site.

Two shovel tests were excavated at site $41 \mathrm{WB} 467$ in order to determine the presence of subsurface cultural deposits. The shovel tests were placed at either end of the site. Soil at the site consists of dark brown sandy silt loam to a depth of approximately $10 \mathrm{~cm}$ bs, followed by dark yellowish brown sandy loam with caliche inclusions to a depth of at least $30 \mathrm{~cm}$ bs. Both shovel tests were terminated at $30 \mathrm{~cm}$ bs. No subsurface cultural deposits were identified in the shovel tests. Because artifacts were first identified eroding out of the cutbank paralleling the existing road at approximately 15 to $20 \mathrm{~cm}$ bs, the potential for buried deposits does exist despite the negative shovel tests.

Site 41WB467 is interpreted as an open campsite consisting of a low-density lithic scatter. Disturbances identified at the site include the construction and maintenance of Old Galvan Road, the cutbank ditch paralleling the road, and erosion. Due to the potential for buried deposits, the research potential of site 41WB467 is unknown. The site is recommended as potentially eligible for inclusion in the NRHP. The portion of the site in the proposed ROW has already been disturbed by road and ditch construction and by subsequent erosion. The intact portion of the site is beyond the proposed project boundary. Avoidance of this site is recommended by prohibiting road improvement activities within the site boundaries. The presence of an archeological monitor is recommended in order to keep equipment off of undisturbed portions of site 41WB467 and to ensure that intact portions of the site are not impacted by road improvement activities.

\section{Site 41 WB 468}

Site 41WB468 is located on a hilltop along Old Main Galvan Road approximately $2.1 \mathrm{~km}$ east of the intersection with Main Galvan Road (Figure 13; see Figure 9). The site was identified in the cutbank that parallels Old Galvan Road and extends both north and south of the road. Elevations at the site range from 238 to $240 \mathrm{~m}$ (780 to $786 \mathrm{ft}$ ) amsl. An unnamed seasonal drainage is approximately $400 \mathrm{~m}$ east of the site and Cuchara Creek is approximately $1.6 \mathrm{~km}$ south of the site. Vegetation at the site is sparse and consists of mesquite, acacia, various cacti, and short grasses. Ground visibility is approximately 80 to 90 percent.

The site is a low-density lithic scatter measuring approximately $250 \mathrm{~m}$ east to west and over $40 \mathrm{~m}$ north to south, extending both north and south beyond the project boundaries. The identified portion of the site covers a total area of approximately $10,000 \mathrm{~m}^{2}$. The lithic assemblage consists primarily of tertiary flakes and projectile point fragments. Raw material consists of locally available chert. Artifact density is approximately six to eight specimens per $25-\mathrm{m}^{2}$ area. No ground stone, evidence of quarrying, or features were observed at the site. No diagnostic artifacts were identified. 


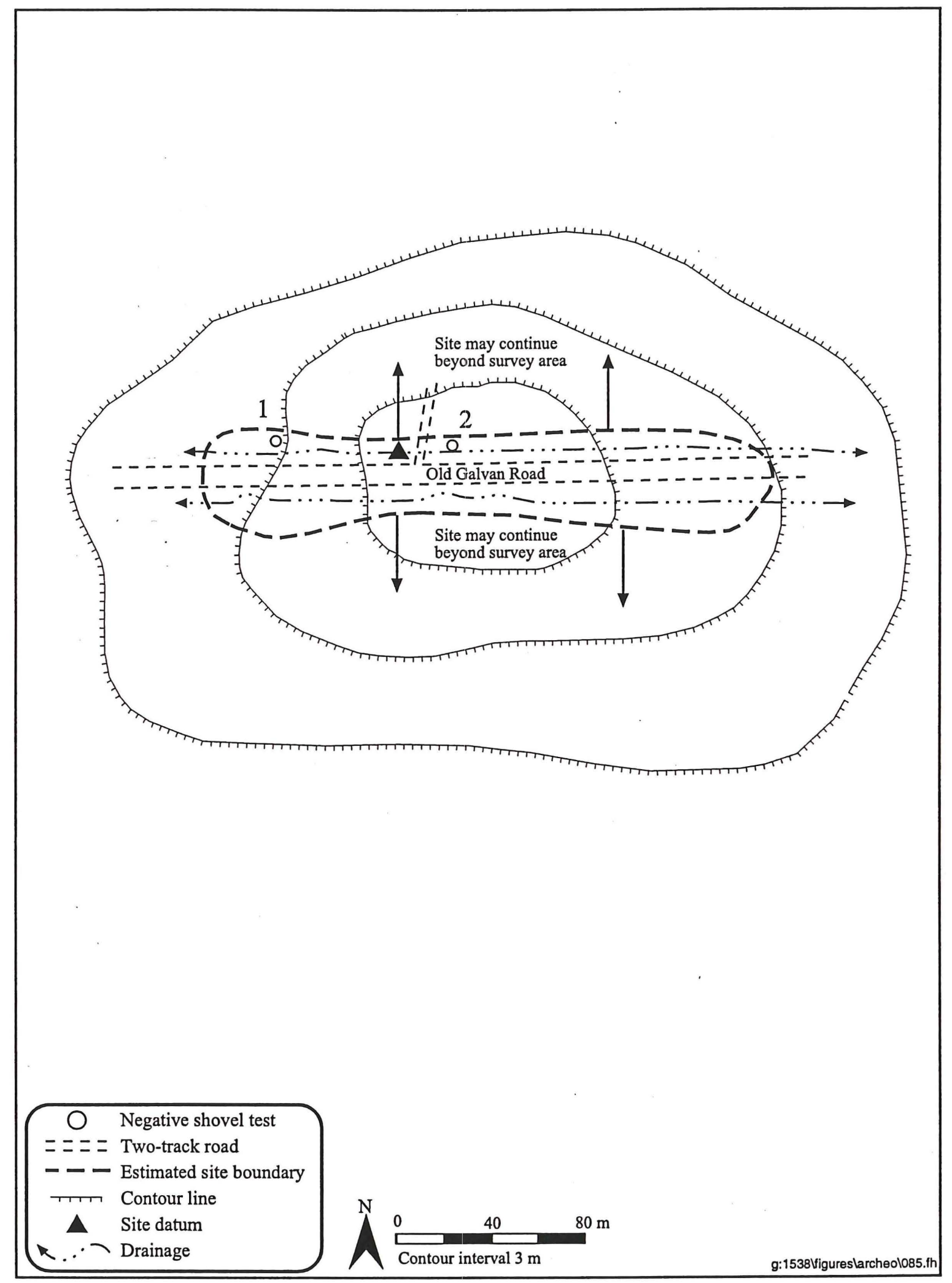

Figure 13. Plan map of site 41WB468. 
Two shovel tests were excavated at site 41WB468 in order to determine the presence of subsurface cultural deposits. Soil at the site consists primarily of yellowish brown sandy silt loam with some mottling of strong brown loam to a depth of between 15 and $20 \mathrm{~cm}$ bs. Strong brown silt loam is dominant below $15 \mathrm{~cm}$ with some mottling of very pale brown and red loam below $20 \mathrm{~cm}$. Excavation of Shovel Tests 1 and 2 was terminated at 40 and $35 \mathrm{~cm}$, respectively. No cultural material was recovered from the excavations. Because artifacts were first identified eroding out of the cutbank paralleling the existing road at approximately 15 to $20 \mathrm{~cm}$ bs, the potential for buried deposits does exist despite the negative shovel tests.

Site 41 WB468 is interpreted as an open campsite consisting of a low-density lithic scatter. Disturbances identified at the site include the construction and maintenance of Old Galvan Road, a two-track road extending north from Old Galvan Road, the cutbank ditch paralleling the road, and erosion. Due to the potential for buried deposits, the research potential of site 41WB468 is unknown and the site is therefore recommended as potentially eligible for inclusion in the NRHP. The portion of the site in the proposed ROW has already been disturbed by ditch construction and subsequent erosion, and the intact portion of the site is beyond the project boundary. Avoidance of this site is recommended by prohibiting road improvement activities within the site boundaries. The presence of an archeological monitor is recommended in order to keep equipment off of undisturbed portions of site 41WB468 and to ensure that intact portions of the site are not impacted by road improvement activities.

\section{Site 41 WB469}

Site 41WB469 is located on a south-facing, gradual slope at the eastern end of Old Main Galvan Road, directly southwest of an elongated, unnamed stock pond (Figure 14; see Figure 9). Elevation at the site is $229 \mathrm{~m}$ (750 ft) amsl. The site was identified on both the north and south sides of Old Galvan Road. An unnamed seasonal drainage is approximately $60 \mathrm{~m}$ east of the site and Cuchara Creek is approximately $1.7 \mathrm{~km}$ south. Vegetation in the area of the site is moderate and consists of mesquite, prickly pear cactus, tasajillo, and short grasses. Ground visibility is approximately 70 percent.

The site is a low-density lithic scatter measuring approximately $125 \mathrm{~m}$ west to east and over $85 \mathrm{~m}$ north to south, extending north beyond the project boundary to the north. The site covers a total area of at least $10,625 \mathrm{~m}^{2}$, depending upon the location of the unknown northern boundary. The lithic assemblage consists primarily of secondary and tertiary flakes, shatter, and two projectile point fragments that could not be typed. Raw material consists of locally available chert. Artifact density is approximately six specimens per $25-\mathrm{m}^{2}$ area. No ground stone, evidence of quarrying, or features were observed at the site. No diagnostic artifacts were identified.

A single shovel test was excavated at site 41WB469 in order to determine the presence of subsurface cultural deposits. The test was placed in the proposed ROW on the north side of Old Galvan Road. Soil at the site consists of strong brown sandy loam to a depth of approximately $15 \mathrm{~cm}$ bs, followed by yellowish red to at least $35 \mathrm{~cm}$ bs. Excavation was terminated at $35 \mathrm{~cm}$ bs and no subsurface cultural deposits were revealed.

Site 41WB469 is interpreted as an open campsite consisting of a low-density surface scatter of lithic artifacts. Disturbances include erosion, the construction and maintenance of Old Galvan Road, and a fence line across the northeast portion of the site. The surficial nature of the site, the lack of features, and the extensive disturbances identified indicate the research potential of the evaluated area of site 41WB469 is minimal. Based on these observations, the portion of the site located within the survey 


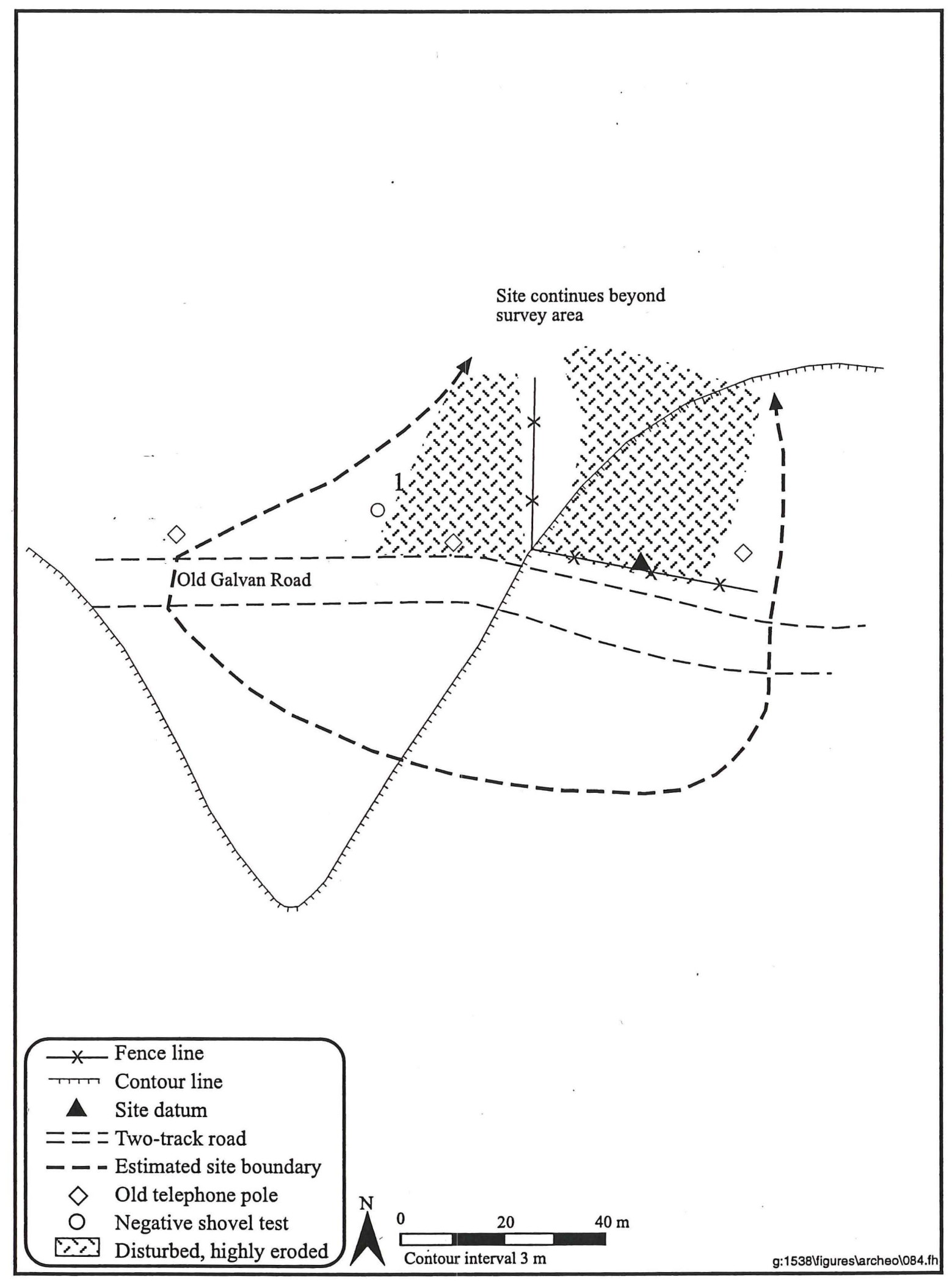

Figure 14. Plan map of site 41WB469. 
corridor is recommended as ineligible for inclusion in the NRHP. The NRHP status of the site north of the project corridor was not evaluated. No further work within the assessed portion of site 41 WB469 is recommended.

\section{Site $41 W B 470$}

Site 41WB470 is located on a northwest-facing, gradual slope at the eastern end of Old Main Galvan Road. Elevation at the site is $232 \mathrm{~m}$ (760 ft) amsl (Figure 15; see Figure 9). The site was identified on the south side of Old Galvan Road in several erosional gullies. An unnamed seasonal drainage is approximately $350 \mathrm{~m}$ west of the site and Cuchara Creek is approximately $1.3 \mathrm{~km}$ south. Vegetation in the area of the site is sparse and consists of mesquite, prickly pear cactus, tasajillo, barrel cactus, and short grasses. Ground visibility is approximately 80 percent.

The site is a small, low-density lithic scatter measuring approximately $35 \mathrm{~m}$ west to east and $27 \mathrm{~m}$ north to south, covering a total area of approximately $945 \mathrm{~m}^{2}$. The lithic assemblage consists primarily of tertiary flakes, shatter, and one biface. Raw material consists of locally available chert. Artifact density is approximately five to six specimens per $25-\mathrm{m}^{2}$ area. No ground stone, evidence of quarrying, or features were observed at the site. No diagnostic artifacts were identified.

A single shovel test was excavated at site $41 \mathrm{WB} 470$ in order to determine the presence of subsurface cultural deposits. The test was placed in the proposed ROW on the south side of Old Galvan Road and the drainage gullies. Soil at the site consists of dark yellowish brown sandy loam to a depth of $15 \mathrm{~cm} \mathrm{bs}$, followed by medium brown clay loam to at least $25 \mathrm{~cm}$ bs. Excavation of the shovel test was terminated at $25 \mathrm{~cm}$ and no subsurface cultural deposits were revealed.

Site $41 \mathrm{WB} 470$ is interpreted as an open campsite consisting of a low-density surface scatter of lithic artifacts. Disturbances include extensive erosion and the construction and maintenance of Old Galvan Road. The surficial nature of the site, the lack of features, and the extensive disturbances identified indicate the research potential of site $41 \mathrm{WB} 470$ is minimal. Based on these observations, the site is recommended as ineligible for inclusion in the NRHP. No further work at site 41 WB470 is recommended.

\section{Site 41 WB471}

Site 41WB471 is located on a southeast-facing slope along Trevino Fence approximately $2.3 \mathrm{~km}$ east of Telephone Tanks and $3 \mathrm{~km}$ southwest of the southeast corner of the Galvan Ranch property (Figure 16; see Figure 9). The site was identified in a cutbank on either side of the existing road and extends northwest and southeast beyond the project boundaries. Elevations at the site range from 226 to $229 \mathrm{~m}$ (740 to $750 \mathrm{ft}$ ) amsl. An unnamed seasonal drainage is approximately $300 \mathrm{~m}$ south and Cuchara Creek is approximately $800 \mathrm{~m}$ south of the site. Vegetation in the area of the site is moderate to dense and includes mesquite, tasajillo, prickly pear cactus, acacia, and short grasses. Ground visibility is approximately 50 percent.

The site is a moderate-density lithic scatter measuring approximately $300 \mathrm{~m}$ northeast to southwest and over $40 \mathrm{~m}$ northwest to southeast, extending northwest and southeast beyond the project boundaries. The identified portion of the site covers a total area of approximately $12,000 \mathrm{~m}^{2}$. The lithic assemblage consists primarily of secondary and tertiary flakes, shatter, and projectile point fragments that could not 


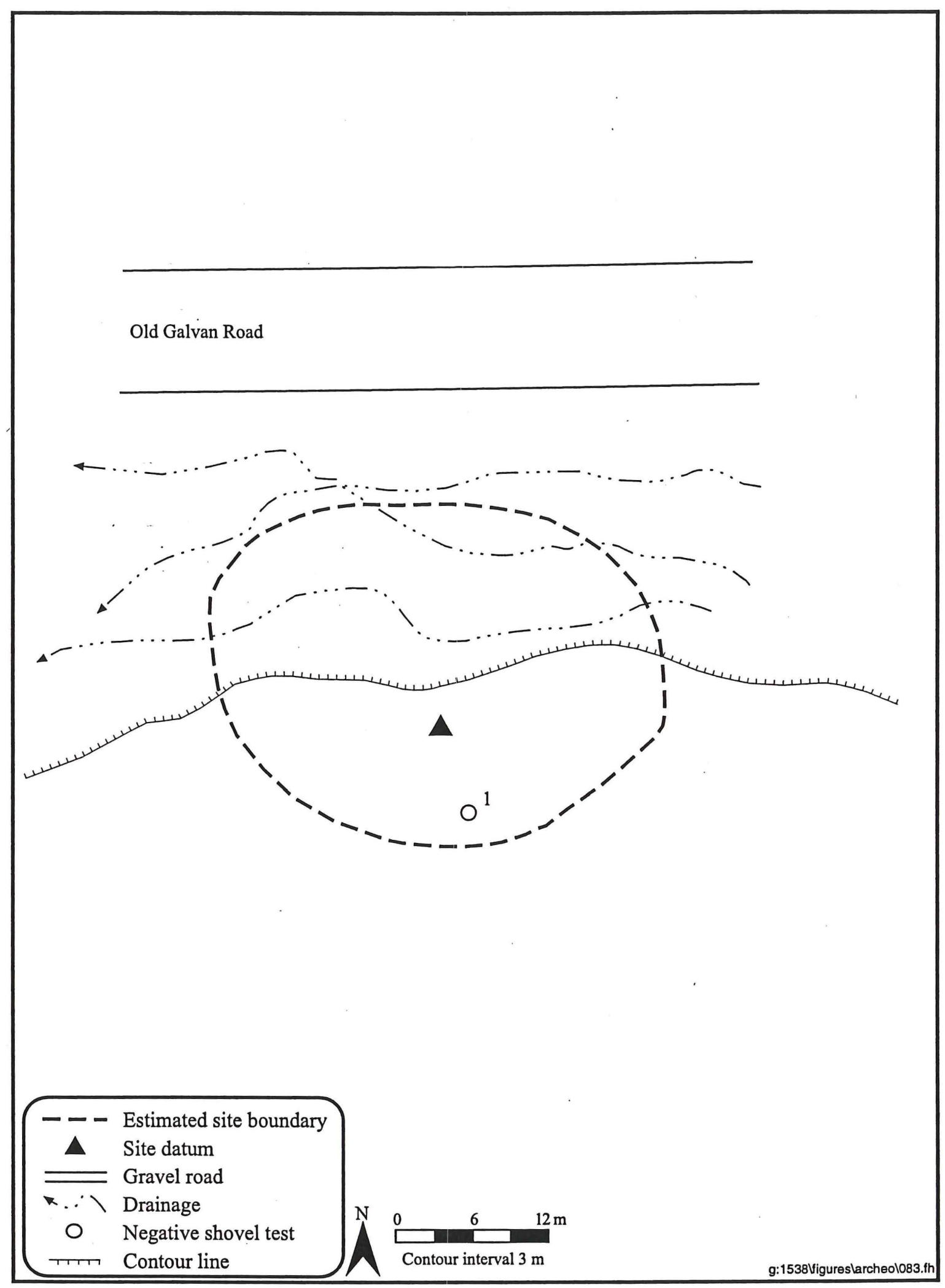

Figure 15. Plan map of site 41WB470. 


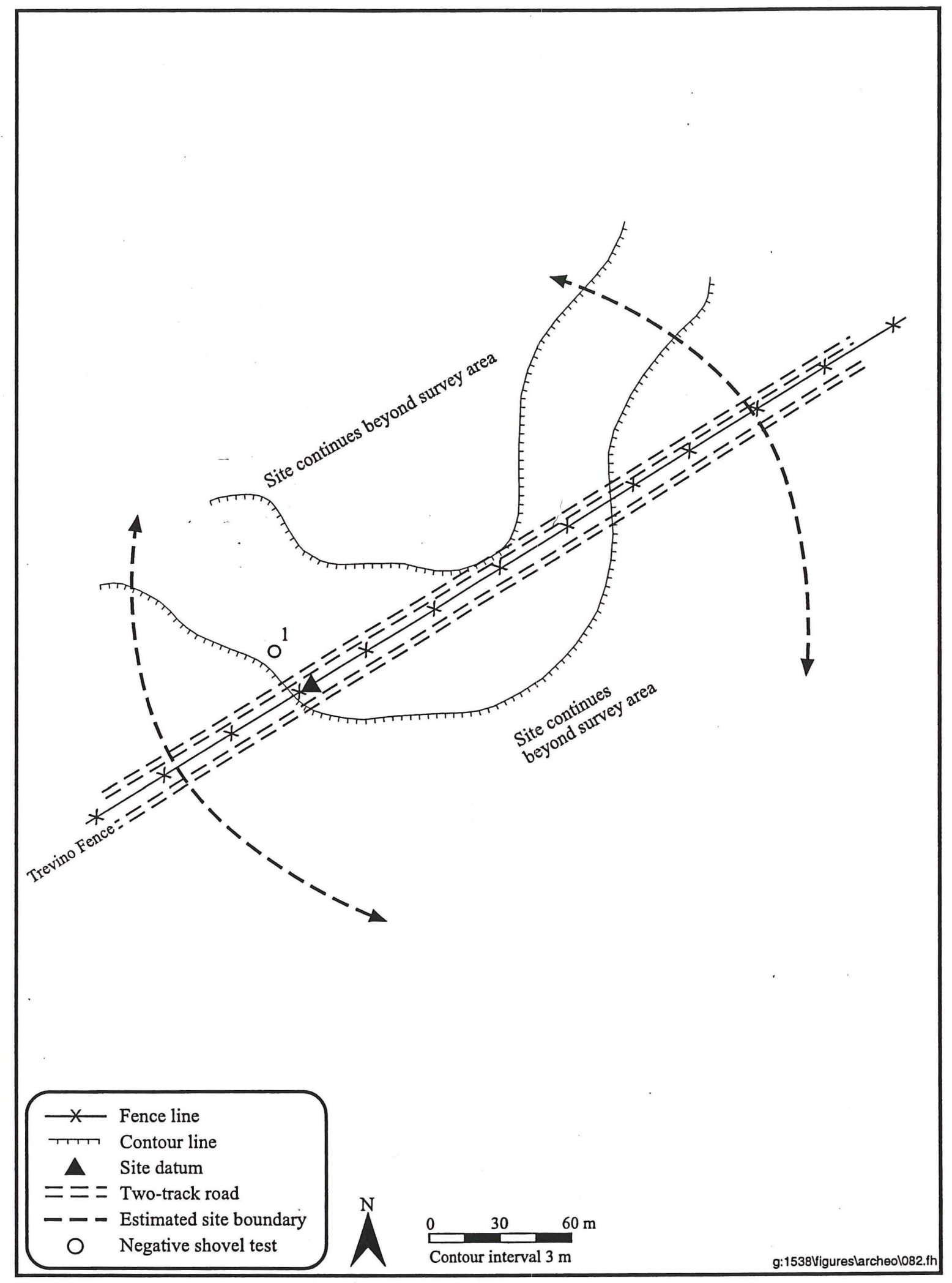

Figure 16. Plan map of site 41WB471. 
be typed due to fragmentation. Raw material consists entirely of locally available chert. The density of artifacts at site $41 \mathrm{WB} 471$ is approximately 10 to 12 specimens in a $25-\mathrm{m}^{2}$ area and no significant concentrations of artifacts were identified. No ground stone, evidence of quarrying, or features were identified. . No diagnostic artifacts were observed at the site.

A shovel test was excavated at site 41WB471 in order to determine the presence of subsurface cultural deposits. The shovel test was placed in the proposed ROW northwest of the existing road. Soil at the site consists of strong brown silty loam to a depth of $20 \mathrm{~cm}$ bs, followed by strong brown mottled with yellowish red silt and caliche inclusions. Excavation of the shovel test was terminated at $40 \mathrm{~cm}$ bs and no subsurface cultural deposits were identified. Because artifacts were first identified eroding out of the cutbank paralleling the existing road at approximately 15 to $20 \mathrm{~cm}$ bs, the potential for buried deposits does exist despite the negative shovel tests.

Site 41WB471 is interpreted as an open campsite consisting of a moderate-density surficial lithic scatter. Disturbances identified at the site include the construction and maintenance of Old Galvan Road, the cutbank ditch paralleling the road, and erosion. Due to the potential for buried deposits, the research potential of site 41 WB471 is unknown. The site is recommended as potentially eligible for inclusion in the NRHP. The portion of the site in the proposed ROW has already been disturbed by ditch construction and subsequent erosion, and the intact portion of the site is beyond the proposed project boundary. Avoidance of this site is recommended by prohibiting road improvement activities within the site boundaries. The presence of an archeological monitor is recommended in order to keep equipment off of undisturbed portions of site 41WB471 and to ensure that intact portions of the site are not impacted by road improvement activities.

\section{Site 41 WB472}

Site 41WB472 is located on a low upland ridge along Trevino Fence in the southeast portion of the Galvan Ranch, approximately $900 \mathrm{~m}$ south-southwest of Telephone Tanks (Figure 17; see Figure 9). The site was identified in the existing road and extends beyond the project boundaries to the northwest and southeast. Elevation at the site is $215 \mathrm{~m}(707 \mathrm{ft})$ amsl. An unnamed seasonal drainage is approximately $170 \mathrm{~m}$ southwest of the site and Cuchara Creek is approximately $400 \mathrm{~m}$ north. Vegetation in the area of the site is dense and consists of mesquite, prickly pear cactus, tasajillo, and short grasses. Ground visibility is approximately 70 to 80 percent.

The site is a small, low-density lithic scatter measuring approximately $110 \mathrm{~m}$ southwest to northeast and over $75 \mathrm{~m}$ northwest to southeast, extending beyond the project boundaries to the northwest and southeast. The identified portion of the site covers a total area of approximately $8,250 \mathrm{~m}^{2}$. The lithic assemblage consists primarily of tertiary flakes of local chert. Artifact density is approximately five to six specimens per $25-\mathrm{m}^{2}$ area. No ground stone, evidence of quarrying, or features were observed at the site. No diagnostic artifacts were identified.

A single shovel test was excavated at site $41 \mathrm{WB} 472$ in order to determine the presence of subsurface cultural deposits. The shovel test was placed in the proposed ROW on the north side of the road paralleling Trevino Fence. Soil at the site consists of medium brown sandy loam to a depth of $10 \mathrm{~cm} \mathrm{bs}$, followed by similar soil with caliche inclusions to a depth of $30 \mathrm{~cm}$ bs. Below $30 \mathrm{~cm}$ bs, the soil consists of a compact medium to yellowish brown sandy loam with caliche inclusions. Excavation was terminated at $40 \mathrm{~cm}$ bs; no subsurface cultural deposits were revealed. 


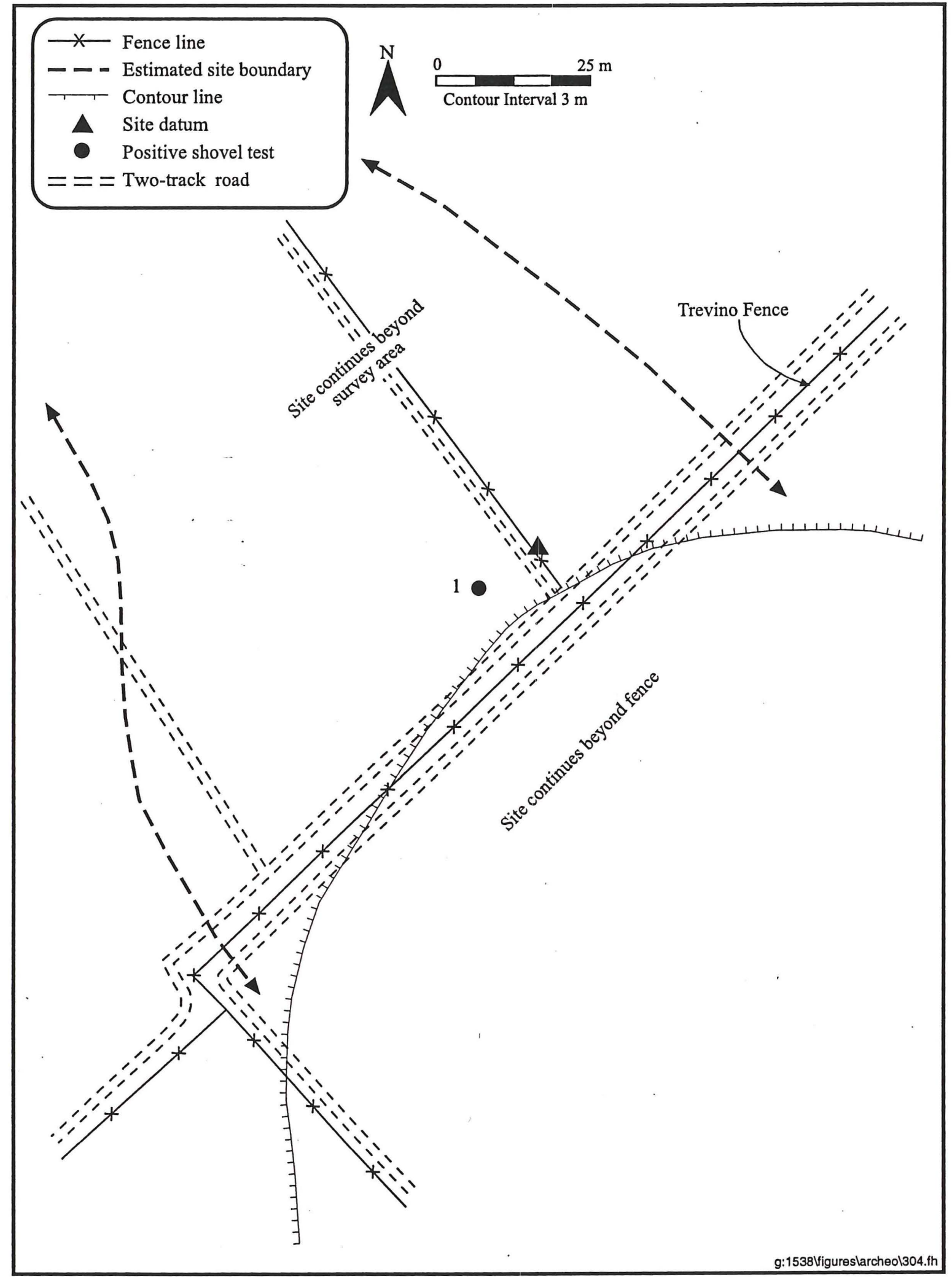

Figure 17. Plan map of site 41WB472. 
Site 41WB472 is interpreted as an open campsite consisting of a low-density surface scatter of lithic artifacts. Disturbances include extensive erosion, the construction of Trevino Fence, the two-track road paralleling Trevino Fence, and two additional two-track roads extending north through the site from the fence line. The sparse, surficial nature of the site, the lack of features, and the extensive disturbances identified indicate the research potential of the portion of 41WB472 in the ROW is minimal. Based on these observations, this part of the site is recommended as ineligible for inclusion in the NRHP. The NRHP status of those portions of the site located beyond the project boundaries was not evaluated. No further work within the assessed portion of site $41 \mathrm{WB} 472$ is recommended.

\section{Site 41 WB 473}

Site 41WB473 is located on a gradual west-facing, gradual slope on the east side of Galvan Ranch, along the Eastern Fence between the Galvan and La Esperanza ranches line (Figure 18; see Figure 9). The site is approximately $1.9 \mathrm{~km}$ west of Highway 83 and $2 \mathrm{~km}$ northwest of the southeast Galvan Ranch property corner. Elevation at the site is $255 \mathrm{~m}(835 \mathrm{ft})$ amsl. The Eastern Fence and a paralleling two-track road run northwest to southeast through the site and an additional two-track road extends from the center of the site to the southwest. An unnamed seasonal drainage is approximately $500 \mathrm{~m}$ west of the site and Las Raices Creek is approximately $1.7 \mathrm{~km}$ north of the site. Vegetation in the area of the site includes mesquite, several varieties of cacti, and bunchgrass. Ground visibility is approximately 50 percent.

The site is a moderate-density lithic scatter measuring approximately $150 \mathrm{~m}$ northwest to southeast and over $80 \mathrm{~m}$ northeast to southwest, extending beyond the project boundaries northeast of the existing fence. The portion of the site identified covers a total area of approximately $12,000 \mathrm{~m}^{2}$. The lithic assemblage consists primarily of secondary and tertiary flakes and shatter, the highest concentration of which is in the undisturbed area west of the two-track road. Raw material consists of locally available chert. A point fragment identified as a possible Catán point was observed. Catán points date from the Late Archaic to the Late Prehistoric periods (Turner and Hester 1993:89). No ground stone, evidence of quarrying, or features were observed at the site.

Two shovel tests were excavated at site 41WB473 in order to determine the presence of subsurface cultural deposits. Shovel Test 1 was placed in the proposed ROW immediately southwest of the twotrack road paralleling the Eastern Fence. Shovel Test 2 was placed at the southern edge of the site at the edge of the surface artifact scatter. Shovel Test 1 revealed brown to strong brown sandy loam to a depth of at least $30 \mathrm{~cm}$ bs; very little vertical soil variation was evident in this area of the site. Shovel Test 2 revealed strong brown sandy loan to a depth of approximately $5 \mathrm{~cm}$ bs, followed by pale brown sandy loam between 5 and $30 \mathrm{~cm}$ bs; the final level revealed in Shovel Test 2 was a mottled pinkish gray and light gray sandy loam to at least $50 \mathrm{~cm}$ bs. Excavation of Shovel Tests 1 and 2 terminated at 30 and 50 $\mathrm{cm}$ bs, respectively. No cultural materials were revealed by either shovel test.

Site 41 WB 473 is interpreted as an open campsite represented by a moderate-density surficial scatter of lithic artifacts. No subsurface cultural deposits were identified. The single diagnostic (Catán) projectile point identified has been dated in this region to the Late Archaic and the Late Prehistoric periods. The site extends beyond the project boundaries northeast of the existing fence line. Disturbances include erosion, the construction of the Eastern Fence and a two-track road that extends along the length of the site, and an additional two-track road running through the southwest portion of the site. The surficial nature of the site, the lack of features, and the extensive disturbances identified indicate the research potential of the evaluated area of site 41WB473 is minimal. Based on these observations, the portion of the site southwest of the fence is recommended as ineligible for inclusion in the NRHP. The remainder of the site could not be investigated. No further work is recommended within the assessed portion of site 41WB473. 


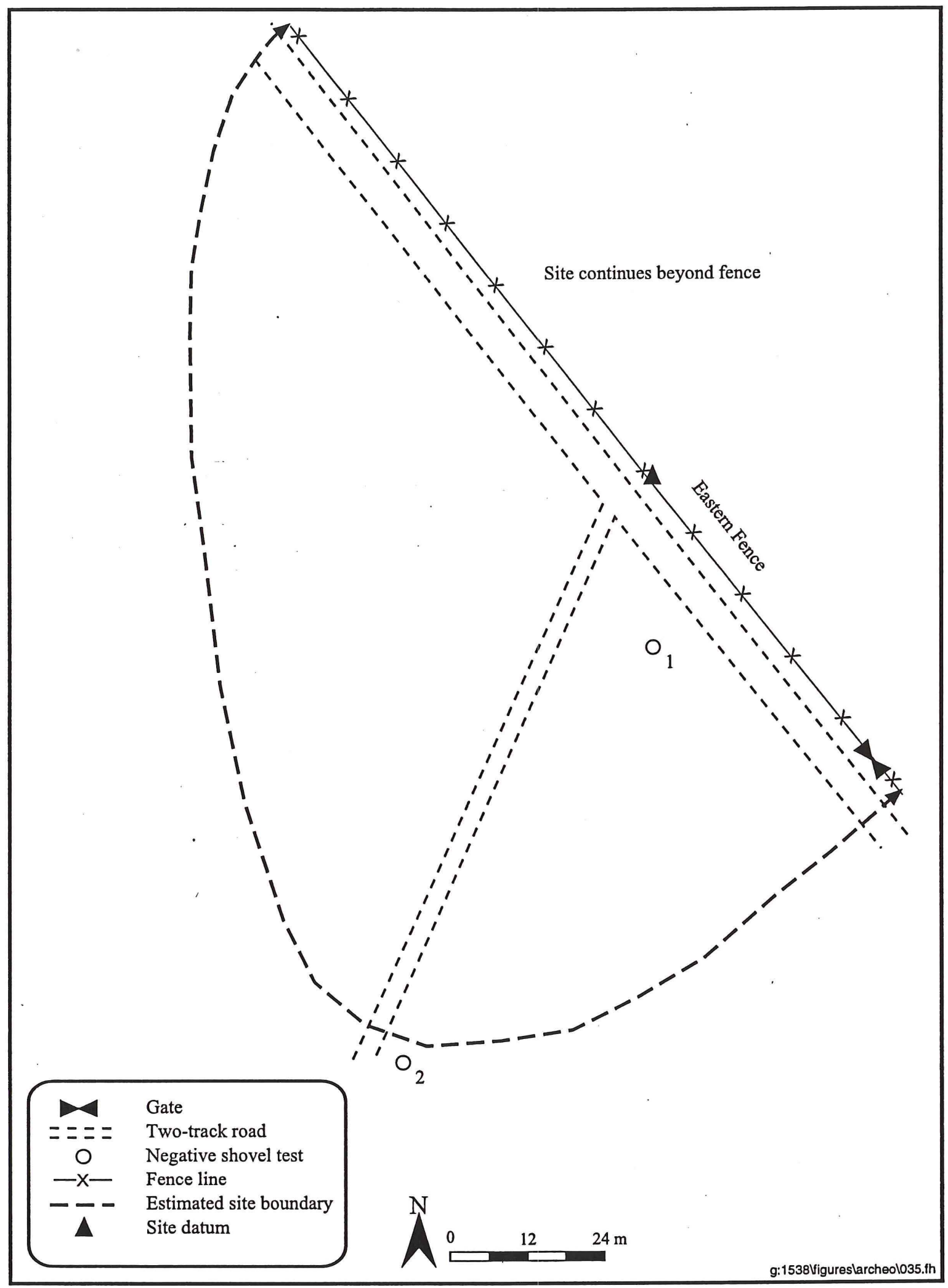

Figure 18. Plan map of site $41 \mathrm{WB} 473$. 


\section{Site 41 WB 474}

Site 41 WB474 is located on a north-facing, gradual slope on the east side of Galvan Ranch, along the Eastern Fence between Galvan and La Esperanza ranches (Figure 19; see Figure 9). The site is approximately $500 \mathrm{~m}$ west of Highway 83 and $150 \mathrm{~m}$ south of Las Raices Creek. An existing two-track road and fence line run northwest-southeast through the site. Elevation at the site ranges from 201 to 210 $\mathrm{m}(660$ to $688 \mathrm{ft})$ amsl. Vegetation in the area of the site includes mesquite, several varieties of cacti, and bunchgrass, although growth along the fence line itself has been cleared. Ground visibility is approximately 90 percent.

The site is a moderate-density lithic scatter measuring approximately $400 \mathrm{~m}$ north to south and over $30 \mathrm{~m}$ east to west, extending beyond the project boundaries east and southeast of the Eastern Fence. The portion of the site identified covers a total area of approximately $12,000 \mathrm{~m}^{2}$. The lithic assemblage consists of numerous tertiary flakes, as well as scrapers, a graver, and biface fragments. A wide variety of locally available chert is represented. In addition, a triangular, sharply pointed, contracting-stem point identified as a Late Prehistoric Perdiz point was also observed (Turner and Hester 1993:227). No ground stone, evidence of quarrying, or features were observed at the site.

Two shovel tests were excavated at site 41WB474 in order to determine the presence of subsurface cultural deposits. Both shovel tests were placed within the proposed ROW. Shovel Test 1, placed in the northern portion of the site, revealed a shallow cultural deposit represented by a bifacially retouched flake at $5 \mathrm{~cm}$ bs. Soils consisted of strong brown clayey silt to $10 \mathrm{~cm}$ bs, followed by brown clayey silt with gravel inclusions to at least $30 \mathrm{~cm}$ bs. Shovel Test 2, in the southern portion of the site, was negative. This shovel test revealed reddish brown silt with very little stratigraphic variation. Shovel Tests 1 and 2 were terminated at 30 and $20 \mathrm{~cm}$ bs, respectively.

Site 41 WB474 is interpreted as an open campsite consisting of a moderate-density scatter of lithic artifacts with a shallow subsurface deposit. Much of the site appears to extend beyond the project boundaries to the east and southeast of the Eastern Fence. A single diagnostic Perdiz projectile point dated to the Late Prehistoric period was identified at the site. Disturbances include erosion and a twotrack road and fence line which extend along the length of the site. The surficial nature of the site, the lack of features, and the extensive disturbances identified indicate the research potential of the evaluated area of site 41WB474 is minimal. Based on these observations, the portion of the site within the project corridor is recommended as ineligible for inclusion in the NRHP. The portion of the site located beyond the fence line could not be investigated. No additional work is recommended within the assessed portion of site $41 \mathrm{WB} 474$.

\section{Site 41 WB 475}

Site 41WB475 is located in the central portion of Galvan Ranch, approximately $3 \mathrm{~km}$ west of the main Galvan Ranch headquarters complex (Figure 20; see Figure 9). It spans a large area of low-lying ground with extensive cobble and gravel outcrops along Greengate Fence between Main Galvan Road and Galvan Fence. Elevations at the site range from 198 to $213 \mathrm{~m} \mathrm{(650} \mathrm{to} 700 \mathrm{ft}$ ) amsl. Santa Isabel Creek borders the west side of the site. Vegetation at the site varies from sparse prickly pear cactus and mesquite to dense grass cover. Ground visibility is approximately 40 percent. 


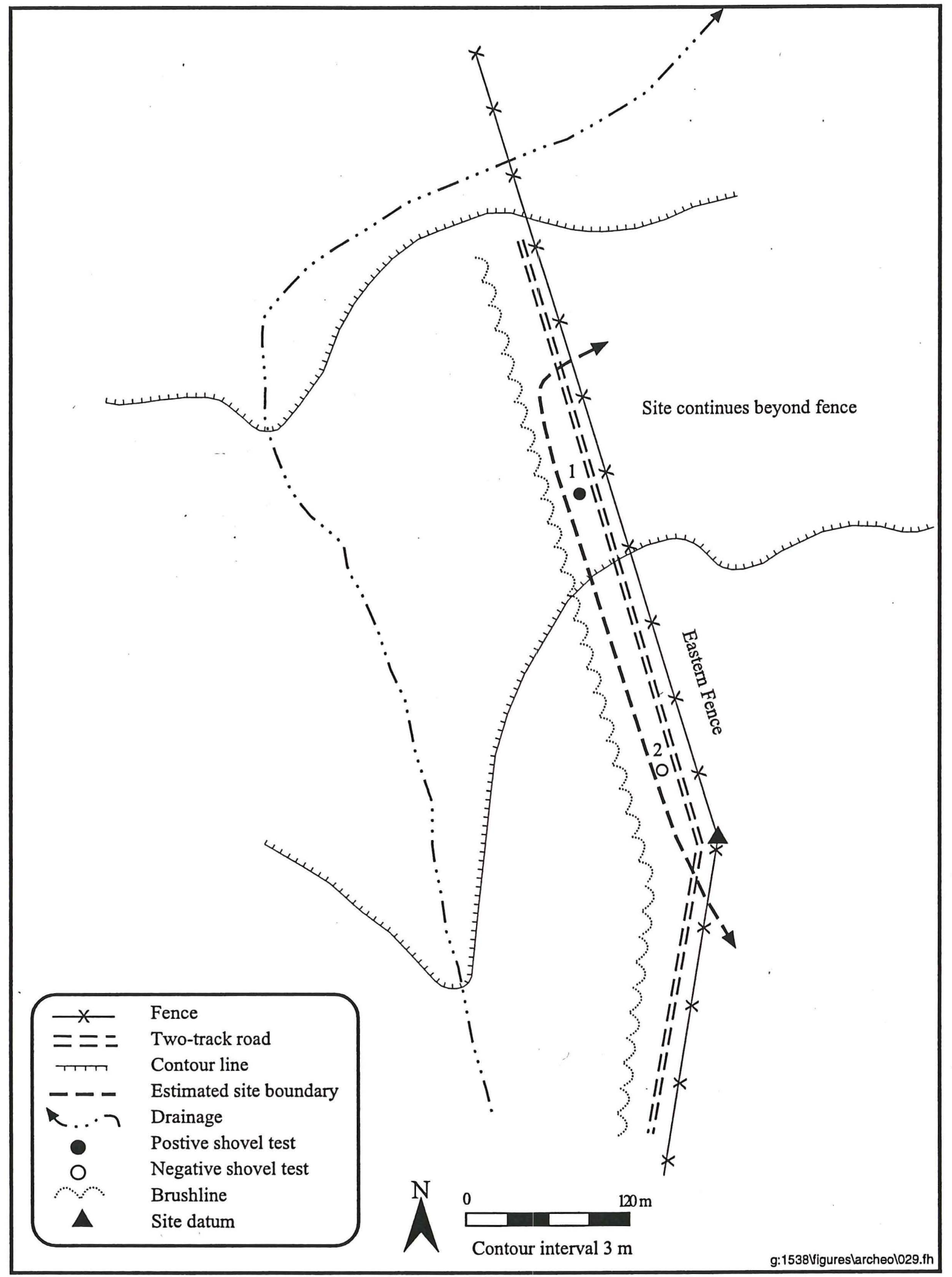

Figure 19. Plan map of site 41WB474. 


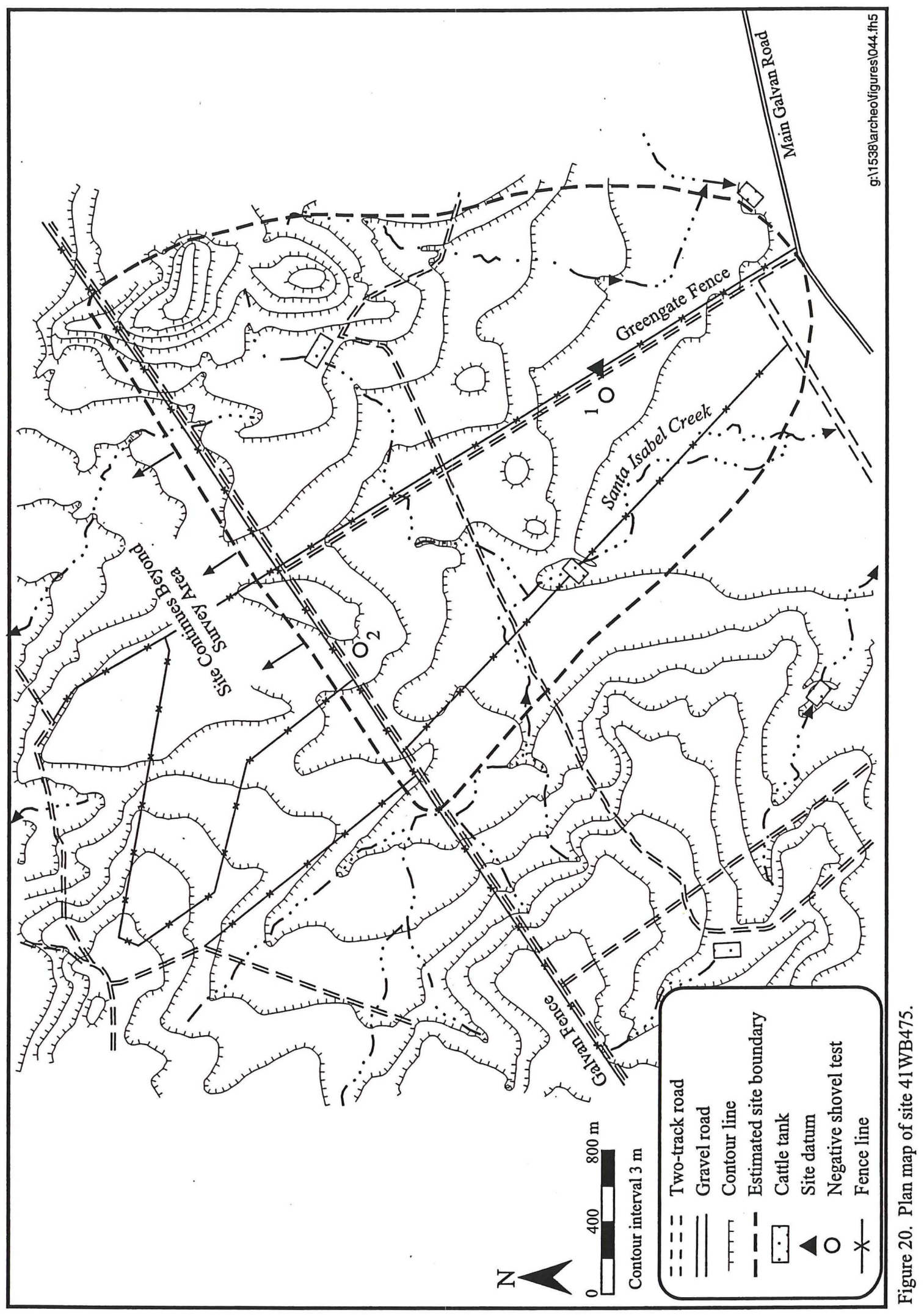


Site 41 WB475 is an extensive, low-density lithic scatter. Site boundaries within the Galvan Ranch measure approximately $3.5 \mathrm{~km}$ northwest to southeast and $3.7 \mathrm{~km}$ northeast to southwest and cover a total area of approximately $12.95 \mathrm{~km}^{2}$. The site extends beyond the property boundary to the northwest. The entire area of the site is covered by small concentrations of exposed cobbles and gravels. The lithic assemblage consists primarily of primary flakes, shatter, tested cobbles, and cores. A wide variety of material types is represented including locally available quartz, quartzite, and chert. The density of artifacts varies from less than five to about 10 artifacts per $25-\mathrm{m}^{2}$ area. No ground stone, diagnostic artifacts, or features were observed at the site.

Two shovel tests were excavated at site $41 \mathrm{WB} 475$ in order to determine the presence of subsurface cultural deposits. Shovel Test 1 was excavated at the southern end of the site within the proposed ROW west of Greengate Fence, Shovel Test 2 was placed toward the northern end of the site nearer Galvan Fence. Shovel Test 1 revealed brown silty loam with gravel inclusions to a depth of $12 \mathrm{~cm}$ bs, followed by brown silty loam to clayey silt with no gravels. Excavation of Shovel Test 1 was terminated at $20 \mathrm{~cm}$ bs. Shovel Test 2 revealed dark yellow brown clayey silt to $10 \mathrm{~cm}$ bs; excavation of this shovel test was discontinued below $10 \mathrm{~cm}$ due to the high frequency of gravels. No cultural material was identified in the shovel tests.

Site 41WB475 is interpreted as a quarry site consisting of a low-density, surface scatter of lithic artifacts in small concentrations over a large area of low-lying ground. No subsurface cultural deposits were observed. The site was identified in the proposed ROW along Greengate Fence between Main Galvan Road and Galvan Fence, and along Galvan Fence. The site appears to extend beyond the ROW to the northwest beyond the Galvan Ranch property boundary. Disturbances include the construction of Greengate Fence, maintenance of the parallel road, as well as cattle grazing. The surficial nature of the site, the lack of features or significant artifact concentrations, and the disturbances identified indicate the research potential of the evaluated area of site $41 \mathrm{WB} 475$ is minimal. Based on these observations, the portion of this site investigated is recommended as ineligible for inclusion in the NRHP. The NRHP status of the portion of the site extending northwest of Galvan Fence was not assessed. No further work within the assessed portion of site $41 \mathrm{WB} 475$ is recommended.

\section{Site $41 W B 476$}

The center of site 41 WB476 is approximately $600 \mathrm{~m}$ north-northwest of the main Galvan Ranch headquarters complex on a small terrace between two unnamed seasonal drainages that drain the uplands to the north (Figure 21; see Figure 9). The site lies on either side of a northwest-southeast-trending fence line and two-track road, between a hilltop to the north and the floodplain of Cuchara Creek to the south. The proposed ROW will cut through the southern one-third of the site following the south side of an existing northeast-southwest-trending fence line. Elevations at the site range from 213 to $223 \mathrm{~m}$ (700 to $731 \mathrm{ft}$ ) amsl. Unnamed seasonal drainages are approximately $300 \mathrm{~m}$ west and $250 \mathrm{~m}$ northeast of the site and Cuchara Creek is approximately $2.5 \mathrm{~km}$ southeast of the site. Vegetation at the site varies from dense grasses in the south to sparse mesquite, prickly pear, tasajillo, and various cacti to the north. Ground visibility is approximately 70 to 80 percent.

The site is a moderate-density lithic scatter measuring approximately $425 \mathrm{~m}$ northwest to southeast and $375 \mathrm{~m}$ northeast to southwest. The site covers a total area of approximately $159,375 \mathrm{~m}^{2}$. The lithic assemblage consists of flakes, shatter, cores, retouched flakes, scrapers, and bifaces. Artifact density varies from two to three specimens per $25-\mathrm{m}^{2}$ area at the southern edge of the site to approximately 18 to 20 specimens per $25-\mathrm{m}^{2}$ area in the northwest portion of the site near the shovel test. Raw material 


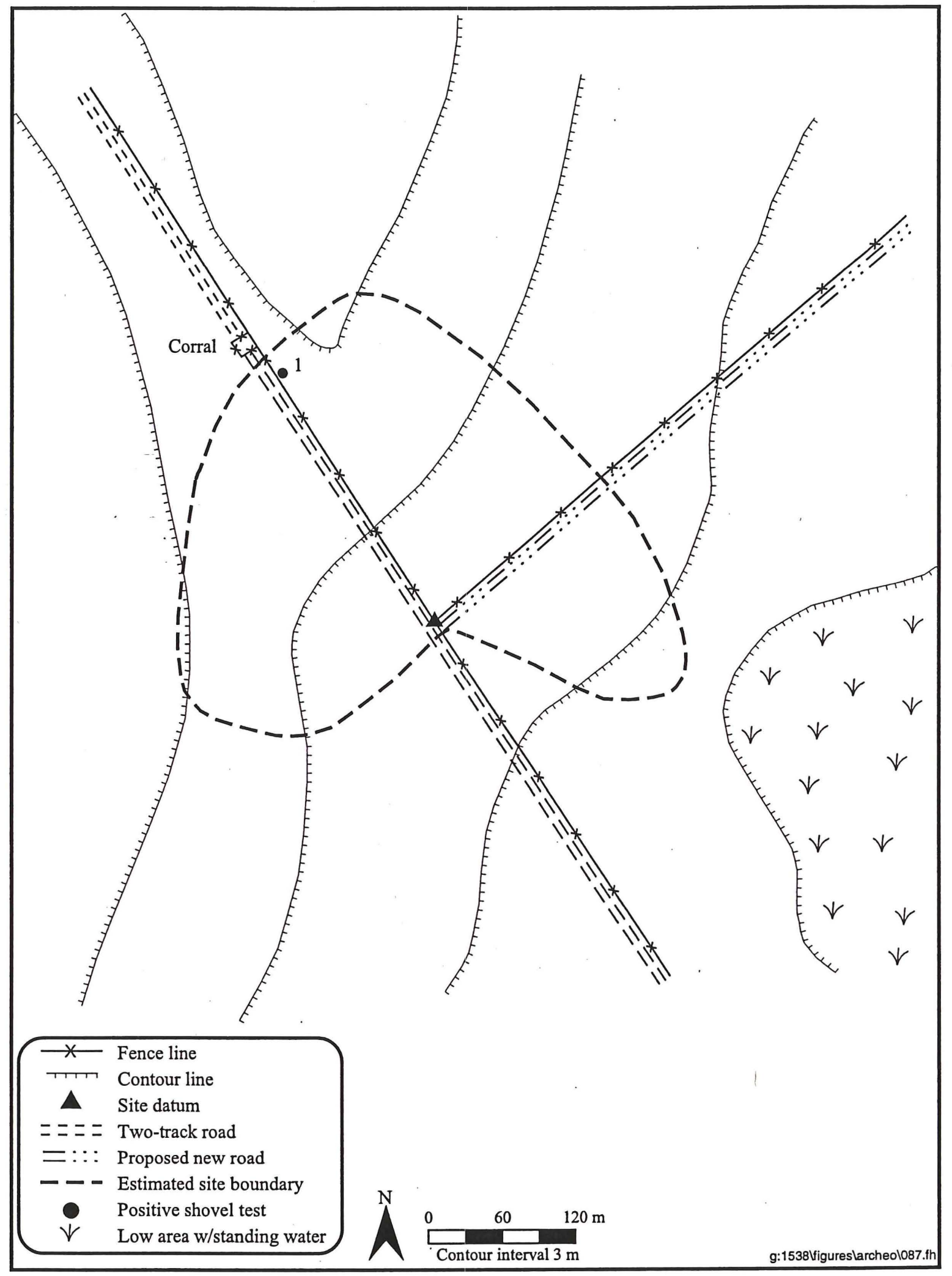

Figure 21. Plan map of site 41WB476. 
consists of good quality chert. No ground stone or features were observed at the site and no diagnostic artifacts were identified.

A single shovel test was excavated near an artifact concentration in the northern portion of the site. The shovel test resulted in the recovery of minimal cultural material-a possible core fragment at $12 \mathrm{~cm}$ bs and a flake fragment between 20 and $30 \mathrm{~cm}$. Soil at the site is a medium brown silty loam with some gravels and cobbles to a depth of $12 \mathrm{~cm}$ bs, followed by more compact but similar soil with fewer gravels and no cobbles to a depth of $30 \mathrm{~cm}$ bs. Below $30 \mathrm{~cm}$ bs the soil becomes very compact and slightly lighter; mottling with yellowish brown loam appears at a depth of $49 \mathrm{~cm}$ bs. Excavation of the shovel test continued to a depth of $50 \mathrm{~cm}$; no other cultural material was recovered below $30 \mathrm{~cm}$.

Site 41WB476 is interpreted as an open campsite consisting of a moderate-density lithic scatter. Shovel testing revealed a shallow subsurface cultural deposit. Disturbances at the site include two-track roads on either side of a fence line running northwest to southeast through the site, a two-track road and parallel fence line through the southeast corner of the site, and a corral and southwest-trending fence line at the northern edge of the site. Extensive wild animal foraging and cattle grazing were also noted throughout the site. The surficial nature of the site, the lack of features, and the extensive disturbances identified indicate the research potential of site 41WB476 is minimal. Based on these observations, the portion of this site within the ROW (see Figure 21) is recommended as ineligible for inclusion in the NRHP. The NRHP status of the portions of the site extending northwest and southeast beyond the ROW were not assessed. No further work within the assessed portion of site $41 \mathrm{WB} 476$ is recommended.

\section{Site 41 WB477}

Site 41WB477 is located on the southeast slope of a south-trending bench in the northwest corner of the Airfield survey area, approximately $1 \mathrm{~km}$ southwest of the main Galvan Ranch headquarters complex (Figure 22; see Figure 9). The site appears to extend beyone the project boundary to the west and northwest. The identified portion of the site is bordered by a northwest-southeast-trending fence line and two-track road west of the site, a southwest-northeast-trending fence line and two-track road on the north, and a large, man-made stock tank which has destroyed the eastern edge of the site. Elevation at the site is between 207 and $212 \mathrm{~m}$ (680 and $695 \mathrm{ft}$ ) amsl. An unnamed seasonal drainage borders the eastern edge of the site and Cuchara Creek is approximately $2 \mathrm{~km}$ south. Vegetation at the site is sparse to moderate and includes mesquite, creosote bush, acacia, tasajillo, prickly pear cactus, and grasses. Growth is heaviest in the east and south areas of the site near the drainage and stock pond. Ground visibility is approximately 90 percent. At the time the survey was conducted, there was a potential for the area in which site $41 \mathrm{WB} 477$ is located to be included in the proposed project, but there is currently no proposed ROW through this area.

The site is a moderate-density lithic scatter measuring approximately $550 \mathrm{~m}$ north to south and over 250 $\mathrm{m}$ east to west, extending north and west beyond the existing fence lines. The portion of the site identified covers a total area of approximately $137,500 \mathrm{~m}^{2}$. The lithic assemblage consists of secondary and tertiary flakes, shatter, cores, retouched flakes, scrapers, and bifaces. Raw material consists primarily of chert and quartzites. Artifact density varies from two to three specimens per $25-\mathrm{m}^{2}$ area at 'the eastern and southern edges of the site to approximately 20 artifacts per $25-\mathrm{m}^{2}$ area nearer the top of the bench. Chert and quartzite gravels are eroding out along the slope and in terraces on the more level area of the site to the south. No ground stone or features were observed at the site. No diagnostic artifacts were identified. 


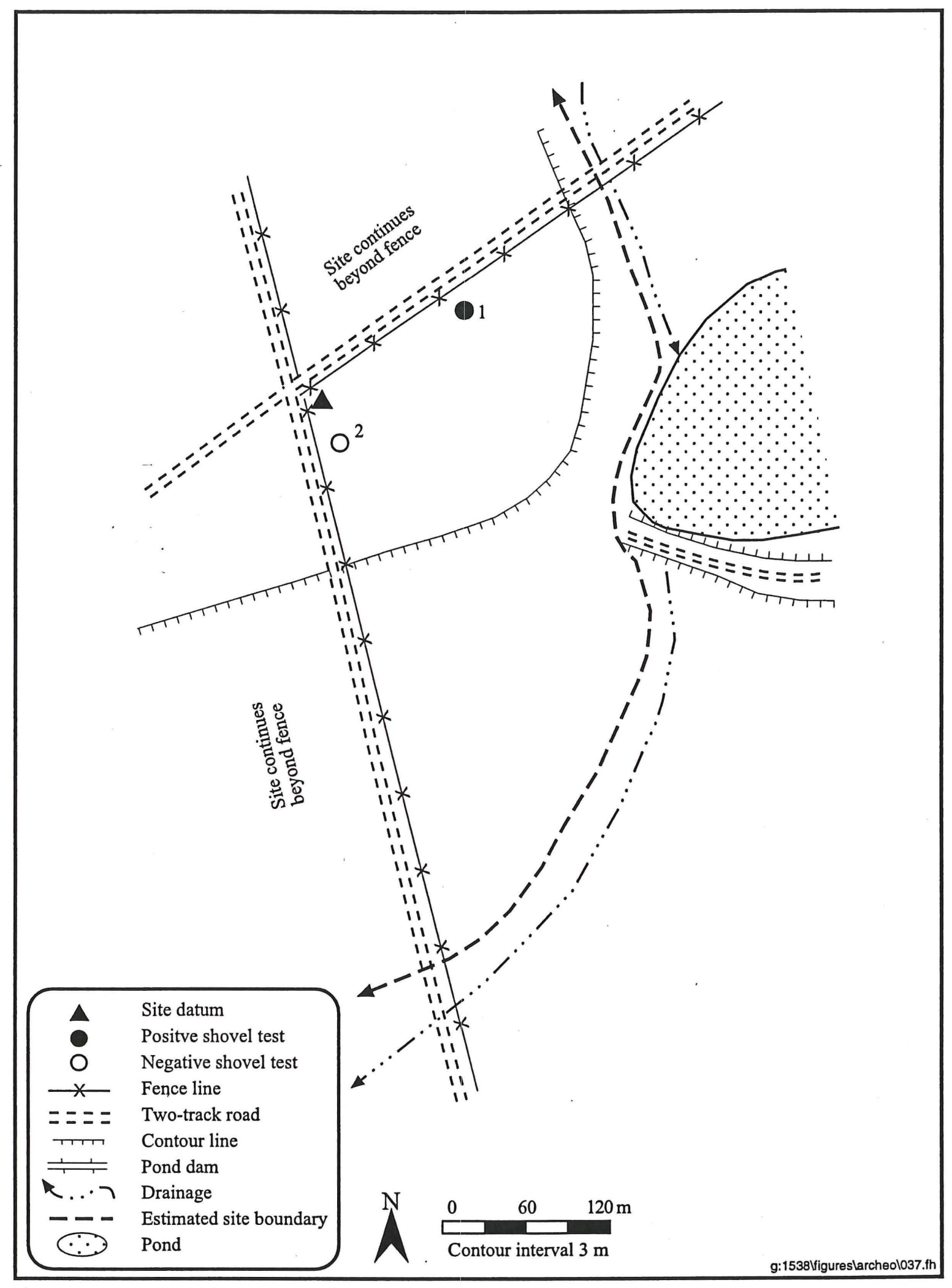

Figure 22. Plan map of site 41WB477. 
Two shovel tests were excavated at the site. Shovel Test 1 , located approximately $20 \mathrm{~m}$ inside the southwest-northeast-trending fence line, yielded three flakes recovered from the upper $15 \mathrm{~cm}$. Shovel Test 2 was excavated approximately $20 \mathrm{~m}$ inside the northwest-southeast-trending fence line and was negative. Soil at the site consists of medium brown silty loam to a depth of between 15 and $30 \mathrm{~cm}$, followed by light yellowish brown compact silty loam with caliche inclusions. Excavation of Shovel Tests 1 and 2 were terminated at 40 and $23 \mathrm{~cm}$ bs, respectively.

Site 41WB477 is interpreted as an open campsite with some evidence of quarrying of exposed chert gravels. It is a moderate-density lithic scatter with a shallow, localized subsurface cultural deposit. Extensive disturbances at the site include the two-track roads and fence lines on the northwest and southwest edges of the site. Flakes and flake tools identified on the berm of the stock tank suggest its construction has disturbed a significant portion of the eastern side of the site. Extensive erosion is evident throughout the site, particularly on the upper slopes where few areas of sedimentation were identified. The surficial nature of the site, the lack of features, and the extensive disturbances identified indicate the research potential of the evaluated area of site 41WB477 is minimal. Based on these observations, the documented portion of the site is recommended as ineligible for inclusion in the NRHP. The remaining portion of the site located beyond the survey area was not investigated. No further work within the assessed portion of site 41WB477 is recommended.

\section{Site $41 \mathrm{WB} 478$}

Site 41 WB478 is located on the southwest-facing, gradual slope occupying the eastern half of the terrace on which is situated the main Galvan Ranch headquarters complex (Figure 23; see Figure 9). The site may have originally occupied the entire terrace, but construction of ranch buildings, fence lines, and roads may have disturbed all but the southwest slope. The site is directly west of the ranch complex, and is enclosed on the northwest, northeast, and southeast by fence lines and two-track roads, and on the west by an unnamed seasonal drainage. Elevation at the site is between 210 and $219 \mathrm{~m} \mathrm{(690} \mathrm{and} 720 \mathrm{ft})$ amsl. Cuchara Creek is approximately $2 \mathrm{~km}$ south-southeast of the site. Vegetation at the site is sparse to moderate and includes mesquite, acacia, tasajillo, prickly pear cactus, and grasses. Vegetation growth increases in the western area of the site nearer the drainages. Ground visibility is approximately 40 percent in the western portion of the site near the drainage and approximately 90 percent elsewhere.

Site 41WB478 is a moderate-density lithic scatter with a small historic component. The site measures $525 \mathrm{~m}$ northeast to southwest and $400 \mathrm{~m}$ northwest to southeast and covers a total area of approximately $210,000 \mathrm{~m}^{2}$. The lithic assemblage consists of secondary and tertiary flakes, shatter, cores, retouched flakes, scrapers, bifaces, a hammerstone, and a projectile point. Raw material is predominantly chert and quartzites. The point was identified as a Catán-like type dating from the Late Archaic to the Late Prehistoric periods (Turner and Hester 1993:89). Prehistoric artifact density varies from two to three specimens per $25-\mathrm{m}^{2}$ at the western and southern edges of the site to approximately 18 to 20 specimens per $25-\mathrm{m}^{2}$ in the densest areas of the site higher on the slope. No ground stone or features were observed at the site.

The historic component of the site consists of a small, heavily disturbed concentration of historic artifacts in the southwestern portion of the site. Approximately 30 to 40 pieces of bottle and window glass and whiteware fragments were identified in an area approximately $5 \mathrm{~m}$ in diameter. The artifacts include solarized bottle glass and two molded, patent lip bottle fragments. The occasional bottle glass or whiteware fragment was also observed across the southwest slope and in the neighboring plowed field to the east, but only the one concentration of historic artifacts was identified. 


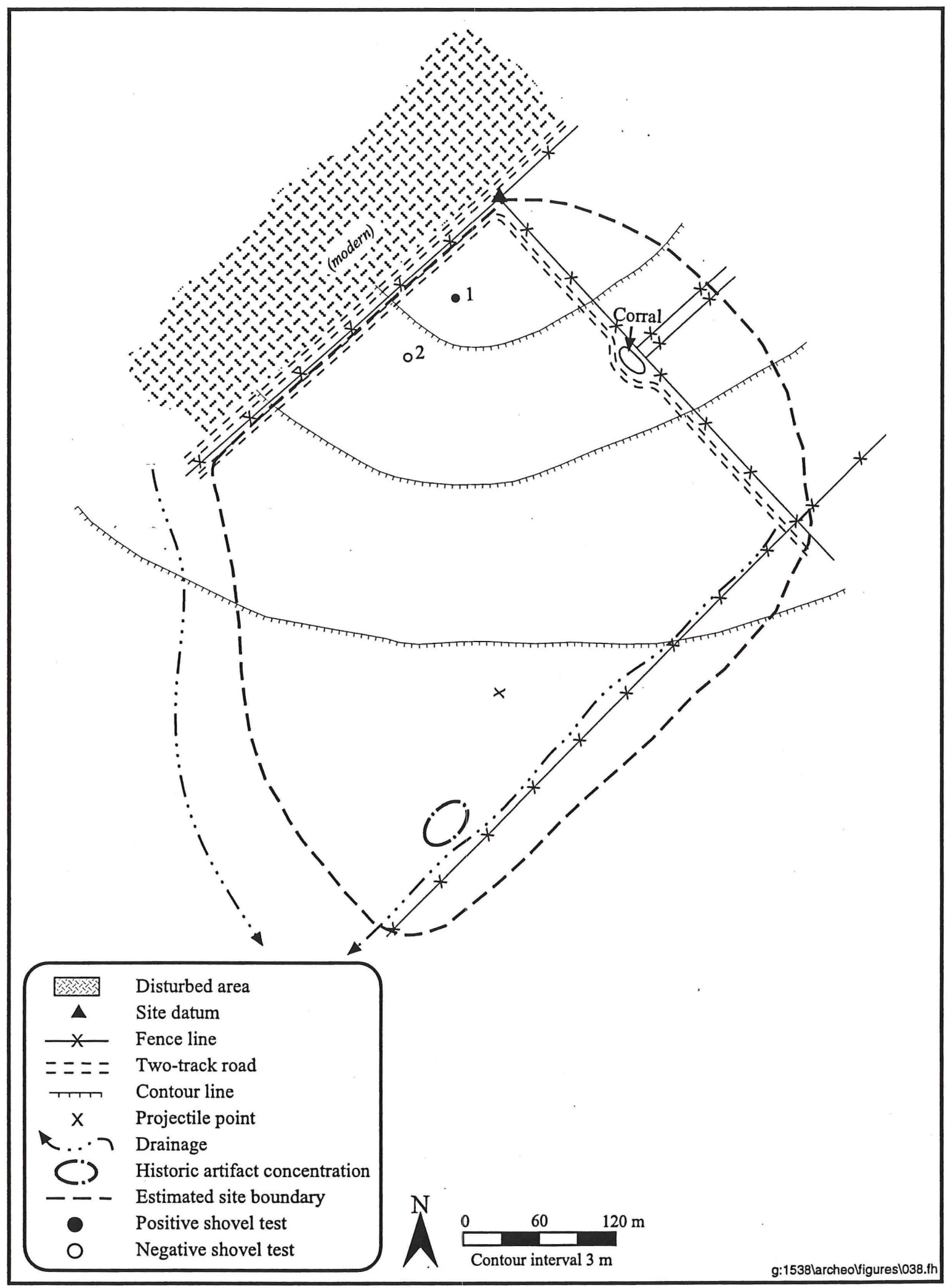

Figure 23. Plan map of site 41WB478. 
Two shovel tests were excavated at the site in order to determine the presence of subsurface cultural deposits. Shovel Test 1 , excavated near the top of the terrace, resulted in the recovery of three flakes from the upper $20 \mathrm{~cm}$. Shovel Test 2 was placed approximately $50 \mathrm{~m}$ to the south of the first shovel test and was negative. Soil at the site consists of brown compact silty loam to $20 \mathrm{~cm}$ bs, followed by very compact, light yellowish brown silt with caliche inclusions. Shovel Tests 1 and 2 were excavated to 30 and $25 \mathrm{~cm}$ bs, respectively.

Site $41 W B 478$ is interpreted as an open campsite consisting of a moderate-density lithic scatter. Shovel testing revealed a shallow, localized subsurface cultural deposit. An additional, heavily disturbed, historic trash scatter was also identified. Disturbances at the site include the two-track roads on either side of the fence lines on the northwest and northeast edges of the site, the fence line and drainage ditch on the southeast edge of the site, and the plowed fields on the eastern edge of the site. Evidence of animal foraging and grazing was also noted throughout the site. The surficial nature of the site, the lack of features, and the extensive disturbances identified indicate the research potential of site $41 \mathrm{WB} 478$ is minimal. Based on these observations, the site is recommended as ineligible for inclusion in the NRHP. No further work at site 41 WB478 is recommended.

\section{Site 41 WB 479}

The center of site 41 WB479 is approximately $750 \mathrm{~m}$ east-northeast of the main Galvan Ranch headquarters complex on a level portion of a finger ridge extending from a broad upland area south to overlook Cuchara Creek (Figure 24; see Figure 9). It extends from approximately $175 \mathrm{~m}$ south to approximately $300 \mathrm{~m}$ north of Main Galvan Road.

The proposed ROW will cut through the length of the site from Main Galvan Road to the northwest. Elevations at the site range from 213 to $220 \mathrm{~m}$ (700 to $722 \mathrm{ft})$ amsl. An unnamed seasonal drainage is approximately $200 \mathrm{~m}$ east of the site and Cuchara Creek is approximately $1.8 \mathrm{~km}$ south of the site. Vegetation at the site is sparse to moderate in density and is composed of mesquite, acacia, and prickly pear cactus. Ground visibility is approximately 80 to 90 percent.

The site is a moderate-density lithic scatter measuring approximately $475 \mathrm{~m}$ northwest to southeast and $250 \mathrm{~m}$ northeast to southwest. The site covers a total area of approximately $118,750 \mathrm{~m}^{2}$. The lithic assemblage consists primarily of secondary and tertiary flakes with a few retouched flakes, scrapers, bifaces, and cores. Raw material consists of good quality chert. Artifact density is approximately 12 to 15 specimens per $25-\mathrm{m}^{2}$ area. No ground stone or features were observed at the site and no diagnostic artifacts were identified.

Three shovel tests were excavated at site $41 \mathrm{WB} 479$ in order to determine the presence of subsurface cultural deposits. Shovel Test 2, placed in the northwestern corner of the site near an existing fence line and two-track road, produced flakes to a depth of $20 \mathrm{~cm}$ below ground surface. The remaining two shovel tests were negative. Shovel Test 2 revealed reddish brown silty clay with gravel inclusions extending down to a depth of $15 \mathrm{~cm}$, followed by more compact, yellowish brown silty clay with caliche inclusions. Soil below $20 \mathrm{~cm}$ is very compact and mottled light gray and yellowish brown with caliche inclusions. Excavation of Shovel Test 2 was terminated at $40 \mathrm{~cm}$ bs. Shovel Tests 1 and 3 revealed similar stratigraphic sequences.

Site 41WB479 is interpreted as an open campsite consisting of a moderate-density lithic scatter. Disturbances at the site include the construction and maintenance of Main Galvan Road, extensive 


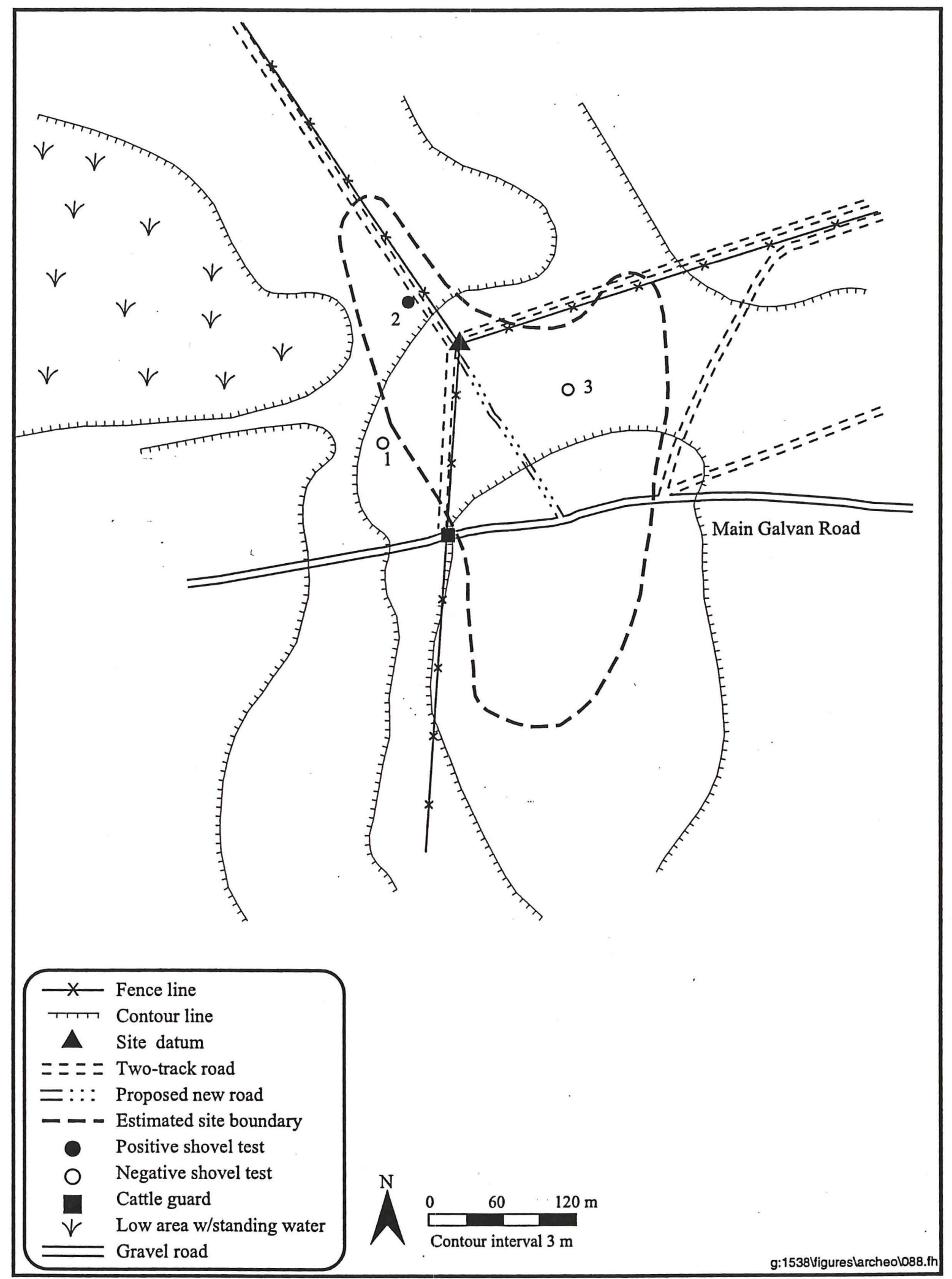

Figure 24. Plan map of site 41WB479. 
devegetation, and the construction and use of two-track roads and fence lines. Wild animal foraging and cattle grazing were also noted throughout the site. Although a localized, shallow subsurface deposit was identified at the site, shovel tests and extensive disturbances throughout the site indicate it is unlikely that intact subsurface deposits are present. The lack of features or diagnostic artifacts and the extensive disturbances identified indicate the research potential of site $41 \mathrm{WB} 479$ is minimal. Based on these observations, the portion of the site investigated, that area within the ROW, is recommended as ineligible for inclusion in the NRHP. No additional work is recommended within the assessed portion of site 41 WB479.

\section{Site 41 WB 480}

Site 41 WB480 is located on relatively level ground approximately $3 \mathrm{~km}$ east of the Galvan Ranch headquarters complex along Main Galvan Road, approximately $1.1 \mathrm{~km}$ southeast of Milk Cow Tank (Figure 25; see Figure 9). The site spans the intersection of Main Galvan Road, an oil pad road extending south, and a two-track road extending north. Elevation at the site ranges from 204 to $209 \mathrm{~m}$ (670 to $685 \mathrm{ft}$ ) amsl. An unnamed seasonal drainage is approximately $800 \mathrm{~m}$ northeast of the site and Cuchara Creek is approximately $1.8 \mathrm{~km}$ south. Vegetation in the area of the site includes mesquite, tasajillo, prickly pear cactus, cruciform cactus, acacia, and short grasses. Ground visibility is approximately 80 percent.

The site is a moderate-density lithic scatter measuring approximately $650 \mathrm{~m}$ east to west and over $300 \mathrm{~m}$ north to south, extending beyond the project boundary north of Main Galvan Road. The portion of the site identified covers a total area of approximately $195,000 \mathrm{~m}^{2}$. The lithic assemblage consists primarily of flakes and shatter, with a limited number of retouched flakes, biface fragments, and a projectile point. Artifact density varies from two to three specimens per $25-\mathrm{m}^{2}$ area in the western and southern edges of the site to approximately $15-20$ artifacts per $25-\mathrm{m}^{2}$ area in the central area of the site. Raw material consists of low- to medium-grade, locally available chert. The point was identified as a Late Archaic Desmuke point made of a low-grade chert (Turner and Hester 1993:105). No specific artifact concentrations were noted and no ground stone, evidence of quarrying, or features were observed at the site.

Two shovel tests were excavated at site $41 \mathrm{WB} 480$ in order to determine the presence of subsurface cultural deposits. Shovel Test 1 was placed approximately $75 \mathrm{~m}$ south of the main road in an area of higher artifact concentration, and Shovel Test 2 was placed in the proposed ROW along Main Galvan Road. Both shovel tests were negative. Soil at the site consists of medium to reddish brown silty loam with an increase in clay content between 15 and $30 \mathrm{~cm}$ bs. Caliche inclusions are more frequent and the soil more compact below $30 \mathrm{~cm}$ bs. Shovel Tests 1 and 2 were excavated to 37 and $35 \mathrm{~cm}$ bs, respectively.

Site 41WB480 is interpreted as an open campsite consisting of a surficial, moderate-density scatter of lithic artifacts. The site extends beyond the project boundaries north of Main Galvan Road. Disturbances include erosion and the construction and maintenance of Main Galvan Road through the length of the site, a dirt road extending south from the main road, and a two-track road running north. The surficial nature of the site, the lack of features, and the extensive disturbances identified indicate the research potential of the evaluated area of site 41 WB480 is minimal. Based on these observations, the portion of the site investigated is recommended as ineligible for inclusion in the NRHP. No additional work is recommended within the assessed portion of site 41WB480. 


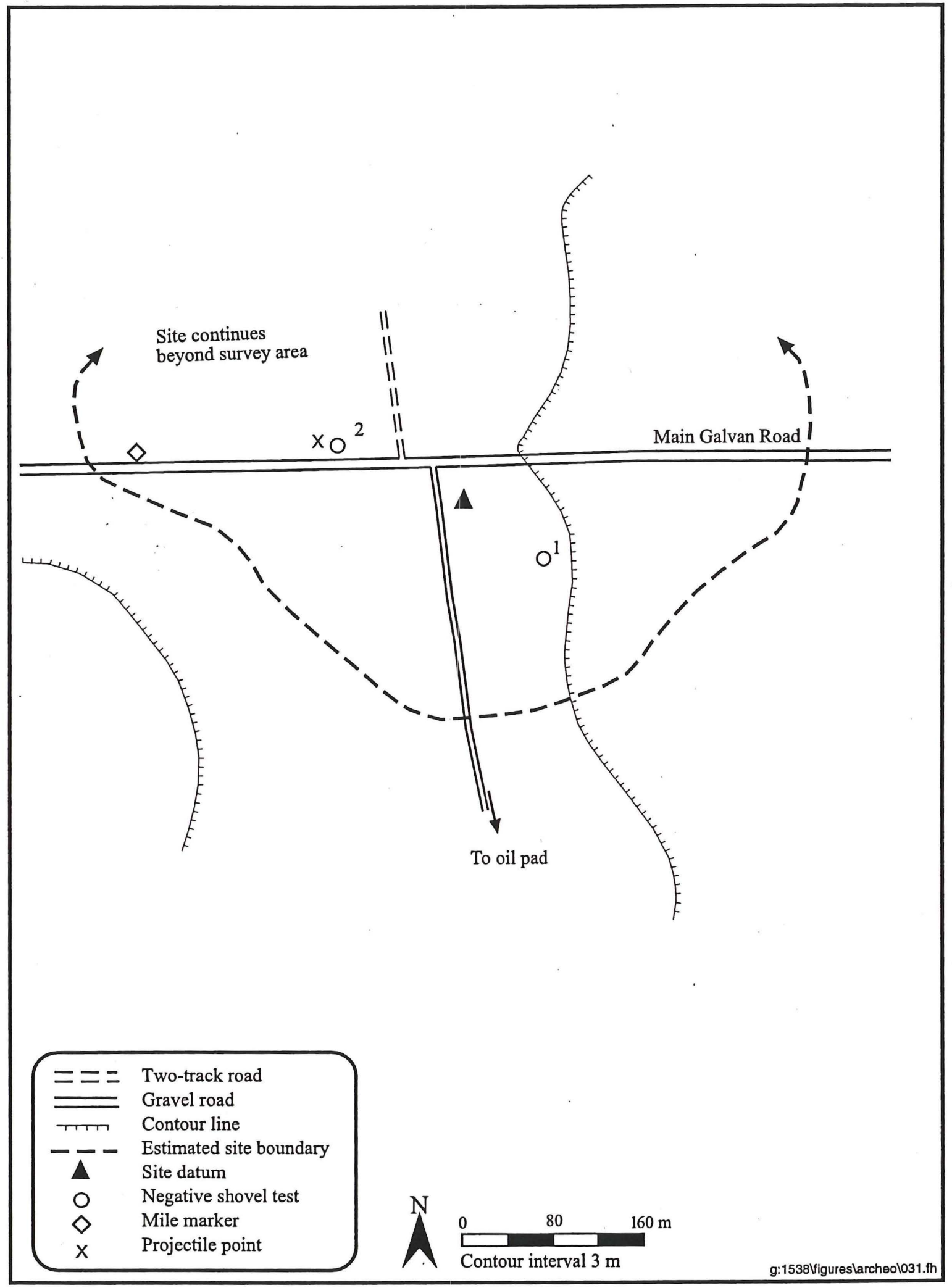

Figure 25. Plan map of site $41 \mathrm{WB} 480$. 


\section{Site 41 WB 481}

Site 41WB481 is located along Main Galvan Road, approximately 400 m east of site 41 WB480, near the intersection of Main Galvan Road and an overgrown two-track extending southwest from the main road (Figure 26; see Figure 9). The site is approximately $3.8 \mathrm{~km}$ east of the main Galvan Ranch headquarters complex and $1.7 \mathrm{~km}$ southeast of Milk Cow Tank. Elevation at the site is $210 \mathrm{~m}(690 \mathrm{ft})$ amsl. An unnamed seasonal drainage is approximately $600 \mathrm{~m}$ southeast of the site and Cuchara Creek is approximately $1.5 \mathrm{~km}$ south. Vegetation at the site includes mesquite, tasajillo, prickly pear cactus, acacia, and short grasses. Ground visibility is approximately 80 percent.

The site is a low-density lithic scatter measuring approximately $115 \mathrm{~m}$ east to west and over $40 \mathrm{~m}$ north to south. The site covers a total area of approximately $4,600 \mathrm{~m}^{2}$. The lithic assemblage consists of chert tertiary flakes and shatter with a density of approximately five to six artifacts per $25-\mathrm{m}^{2}$ area. No tools were identified. No specific artifact concentrations were noted and no diagnostic artifacts, evidence of quarrying, or features were observed at the site.

A single shovel test was excavated at site 41WB481 in order to determine the presence of subsurface cultural deposits. The shovel test, placed in the center of the site, was negative. Soil at the site consists of dark brown silty loam to a depth of $15 \mathrm{~cm}$ bs, followed by brown silty clay with caliche inclusions that extends to at least $20 \mathrm{~cm}$ bs, the level at which excavation was terminated.

Site 41WB481 is interpreted as an open campsite consisting of a low-density lithic scatter. The site is limited to a small area south of Main Galvan Road. Disturbances include the construction and maintenance of the main road just north of the site and a dirt road extending south from Main Galvan Road through the eastern portion of the site. Erosion has resulted in the surface of the site being extensively deflated. The sparse, surficial nature of the site and the lack of features indicate the research potential of site 41WB481 is minimal. Based on these observations, the site is recommended as ineligible for inclusion in the NRHP. No further work is recommended for site 41WB481.

\section{Site 41 WB 482}

Site 41WB482 is located on a north-facing, gradual slope on the east side of Galvan Ranch, along the Eastern Fence between Galvan and La Esperanza ranches (Figure 27; see Figure 9). The site is approximately $1.4 \mathrm{~km}$ west of Highway 83 and $3.5 \mathrm{~km}$ south of the main entrance to Galvan Ranch. A northeast-southwest-trending two-track road is approximately $10 \mathrm{~m}$ west of the site and a parallel fence line is approximately $8 \mathrm{~m}$ east of the site. Elevation at the site ranges from 247 to $250 \mathrm{~m}$ ( 810 to $820 \mathrm{ft}$ ) amsl. An unnamed seasonal drainage is approximately $500 \mathrm{~m}$ north of the site and Las Raices Creek is approximately one mile north. Vegetation in the area of the site includes mesquite, several varieties of cacti, and bunchgrass, although the vegetation along the fence line itself has been cleared. Ground visibility is 100 percent.

The site is a small, moderate-density lithic scatter measuring approximately $10 \mathrm{~m}$ in diameter with an associated hearth feature, covering a total area of approximately $100 \mathrm{~m}^{2}$. The lithic assemblage consists of approximately 30 tertiary chert flakes distributed throughout and around the hearth feature. The feature measures $.5 \mathrm{~m}$ in diameter and consists of approximately 20 fire-cracked rock fragments forming three-quarters of a circle, while the remaining portion of the feature shows evidence of erosion (Figure 28). The soil around the feature is discolored a dark gray, suggesting burning activity. The hearth 


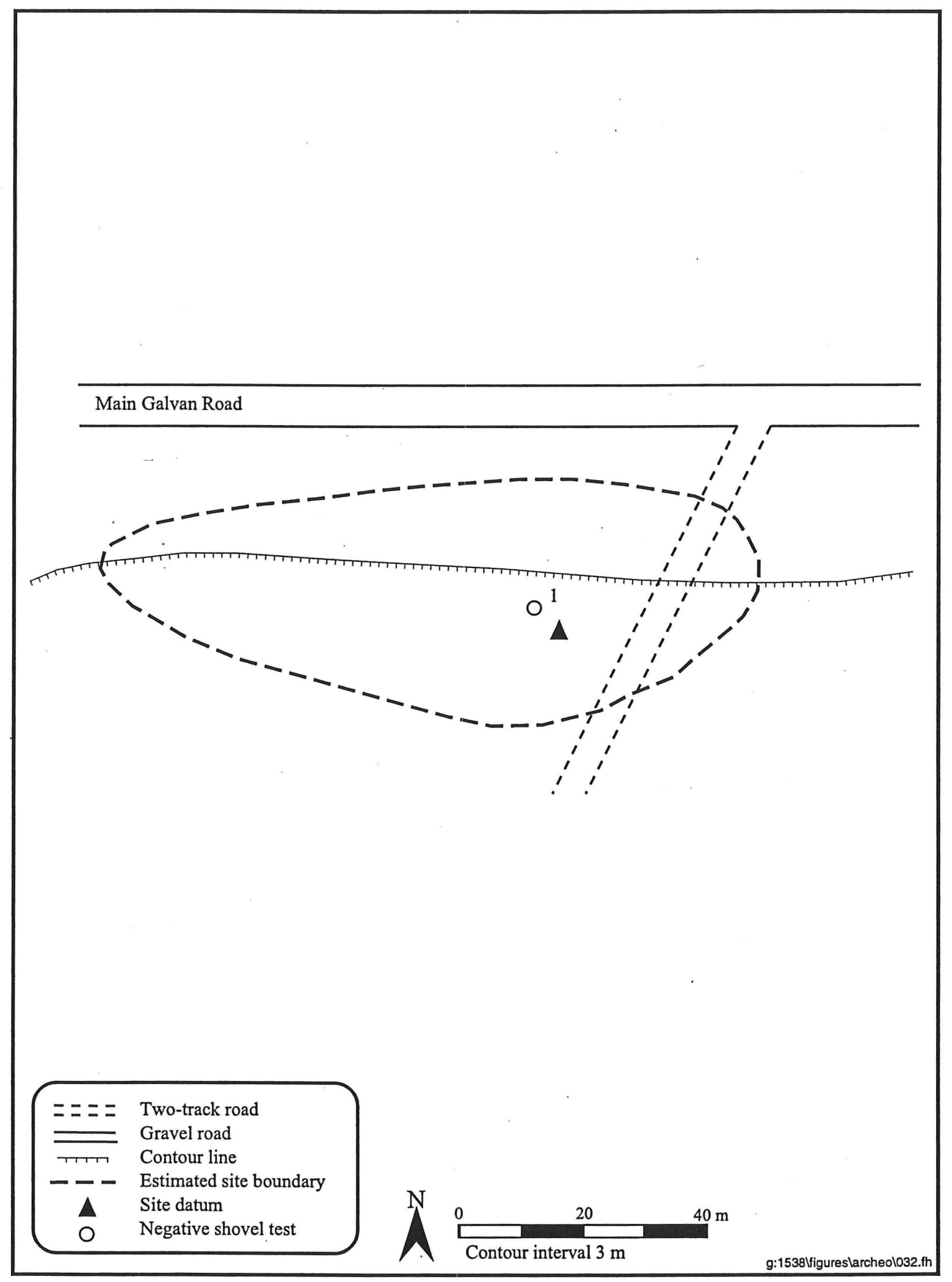

Figure 26. Plan map of site $41 \mathrm{WB} 481$. 


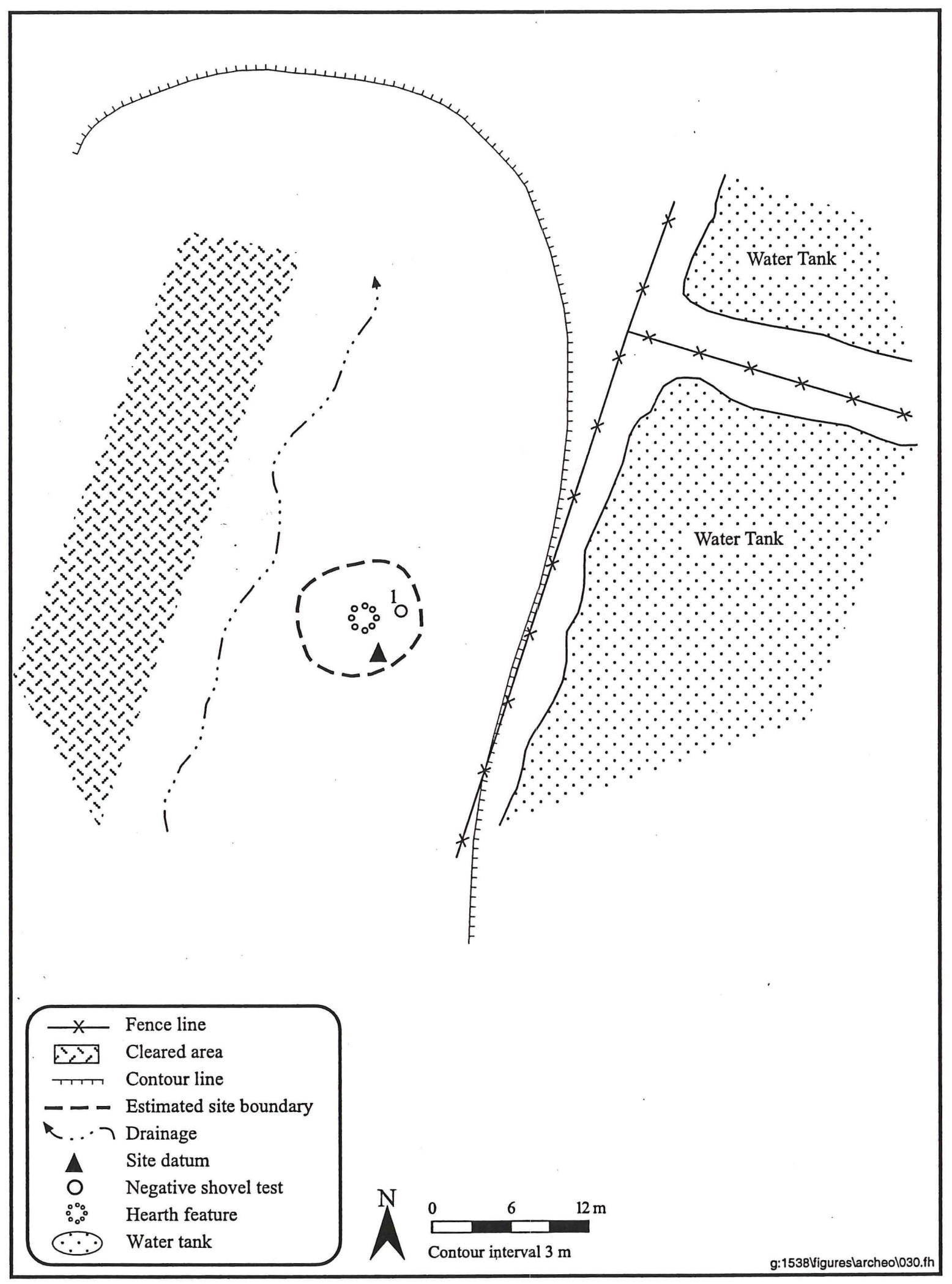

Figure 27. Plan map of site 41WB482. 


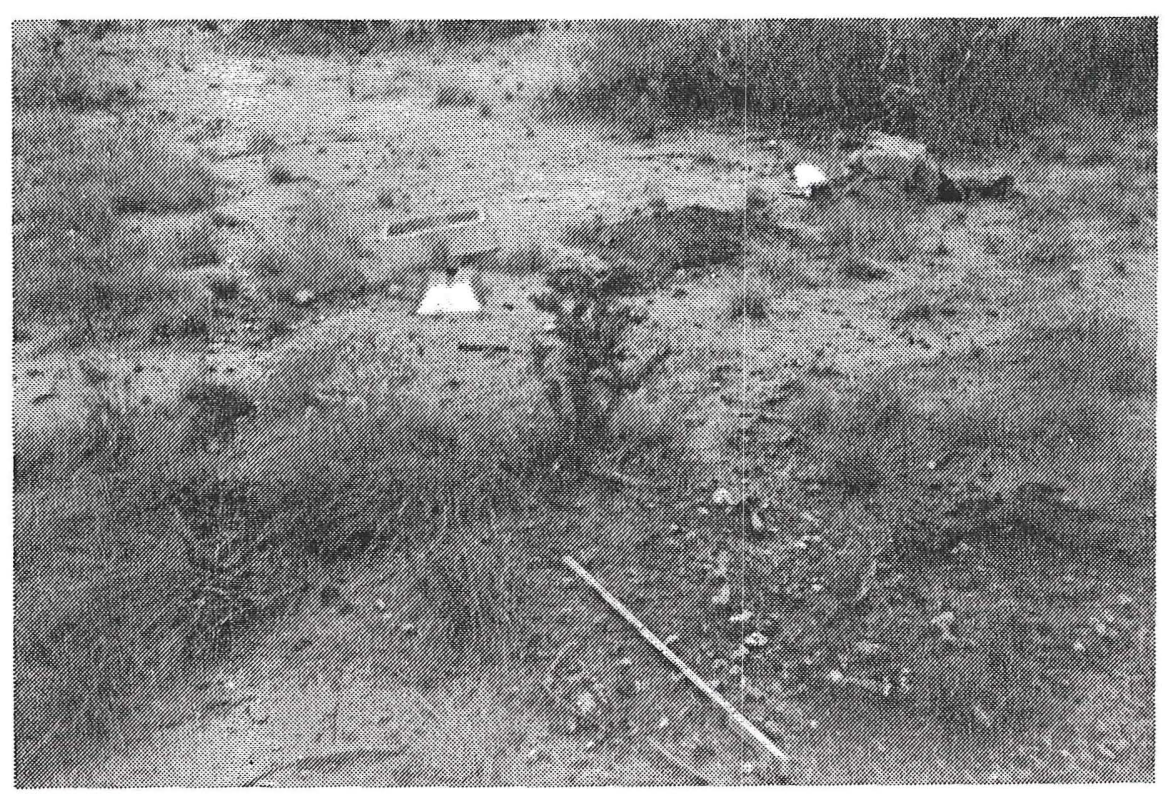

Figure 28. View of hearth feature at site 41WB482 (facing north).

feature appears to have recently eroded out of a near-surface buried context and is largely intact. No ground stone or evidence of quarrying were observed at the site, and no diagnostic artifacts were identified. An erosional gully is approximately $3 \mathrm{~m}$ northwest of the site and the existing road is approximately $9 \mathrm{~m}$ northwest of the site.

A shovel test was excavated adjacent to the hearth feature within the concentration of lithic artifacts in order to determine the presence of subsurface cultural deposits. Soil at the site consists of loose, yellowish red clayey silt to a depth of $20 \mathrm{~cm}$ bs, below which the soil becomes more compact. The shovel test was excavated to a depth of $25 \mathrm{~cm}$ bs, and no subsurface cultural deposits were revealed.

Site 41 WB482 is a hearth feature and an associated scatter of lithic artifacts. No subsurface deposit was identified. Nearby disturbances include a two-track road immediately west and a fence line east of the site. Site 41WB482 appears to be largely intact and represents a good example of a hearth-centered activity area. Based on the limited investigations conducted during the survey, the research potential of the site is unknown. Therefore, the site is recommended as potentially eligible for inclusion in the NRHP. Grading, reworking, or ground disturbance within the proposed ROW could potentially impact the site. These impacts would be avoided by not permitting any road grading, reworking, or other ground disturbance within the limits of the site. The presence of an archeological monitor is recommended in order to keep equipment off of undisturbed portions of site 41WB482 and to ensure that intact portions of the site are not impacted by road improvement activities.

\section{Site 41 WB 483}

Site 41WB483 is located on the slopes and crest of a knoll in the southcentral portion of Galvan Ranch approximately $3.5 \mathrm{~km}$ southwest of the main ranch headquarters complex (Figure 29; see Figure 9). It 


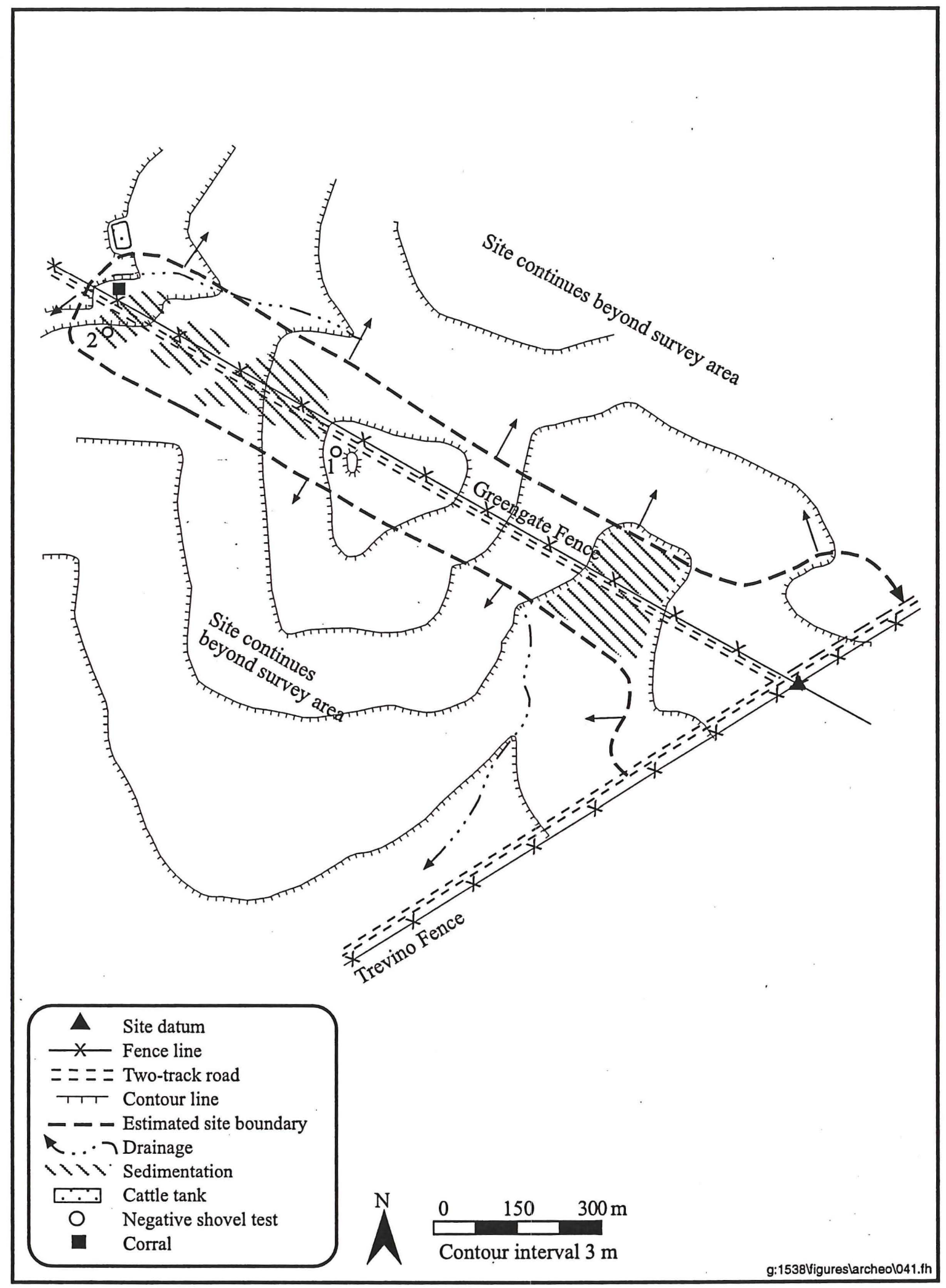

Figure 29. Plan map of site 41WB483. 
extends along Greengate Fence from Trevino Fence approximately $1.6 \mathrm{~km}$ north to Cuchara Creek. The site was identified in the existing roads and extends northeast, southwest, and southeast beyond the project boundaries. Elevation at the site ranges from 198 to $213 \mathrm{~m}(650$ to $700 \mathrm{ft})$ amsl. Cuchara Creek is approximately $100 \mathrm{~m}$ north of the northern boundary of the site. Vegetation at the site is relatively sparse and includes short grasses, prickly pear cactus, tasajillo, creosote, acacia, and mesquite. Ground visibility is approximately 80 percent.

The site is a moderate-density lithic scatter, the identified portion of which measures approximately 1.6 $\mathrm{km}$ northwest to southeast and $.7 \mathrm{~km}$ northeast to southwest. It covers a total area of approximately 1.12 $\mathrm{km}^{2}$. The knoll and slopes are covered in exposed cobbles and gravels, some of which show evidence of heat treatment. The lithic assemblage consists of primary and secondary flakes, tested cobbles, cores, and biface fragments. Raw material consists primarily of chert and quartzite. The density of artifacts varies from a moderate density of approximately 15 artifacts per $25-\mathrm{m}^{2}$ area higher on the knoll to less than five artifacts per $25-\mathrm{m}^{2}$ area lower on the slopes. No ground stone, diagnostic artifacts, or features were observed at the site.

Two shovel tests were excavated at site $41 \mathrm{WB} 483$ in order to determine the presence of subsurface cultural deposits. Very little sediment remains at the site due to extensive erosion; therefore, the shovel tests were placed in areas of increased sedimentation on the northern slope of the knoll within the proposed ROW. Soil at the site consists of yellowish red to light yellowish red silty loam with caliche inclusions; compaction and frequency of caliche inclusions increase with depth. Shovel Tests 1 and 2 were both excavated to a depth of $15 \mathrm{~cm}$ bs; no subsurface cultural deposits were revealed.

Site 41WB483 is interpreted as a quarry site consisting of a moderate-density, surficial scatter of lithic artifacts. The site was identified in the proposed ROW along Greengate and Trevino fences. Much of the site appears to extend beyond the proposed ROW to the northeast, southwest, and southeast encompassing much of the knoll and its slopes. Disturbances include the existing road along Greengate Fence which extends along the length of the site, devegetation along that same road, as well as the twotrack road paralleling Trevino Fence along the southern portion of the site. Erosion was also noted resulting in extensive surface deflation with few localized pockets of sedimentation remaining. The surficial nature of the site, the lack of features, and the extensive disturbances identified indicate the research potential of the evaluated area of site 41WB483 is minimal. Based on these observations, this portion of the site is recommended as ineligible for inclusion in the NRHP. The remaining portion of the site located beyond the survey area was not investigated. No further work within the assessed portion of site $41 \mathrm{WB} 483$ is recommended.

\section{Site 41 WB 484}

Site 41WB484 is located on level ground in the southcentral portion of Galvan Ranch approximately $3 \mathrm{~km}$ southwest of the main ranch headquarters complex (Figure 30; see Figure 9). It lies approximately 900 m south of Main Galvan Road and 400 m north of site $41 \mathrm{WB} 483$ along Greengate Fence. The site was identified in a drainage on the southwest side of Greengate Fence road and extends southwest beyond the project boundaries. Elevation at the site is $198 \mathrm{~m}(650 \mathrm{ft})$ amsl. An unnamed seasonal drainage flows through the northeast edge of the site and Cuchara Creek is approximately $350 \mathrm{~m}$ south of the site. Vegetation at the site is relatively sparse and includes short- to medium-height grasses, prickly pear cactus, acacia, and mesquite. Ground visibility is approximately 75 percent. 


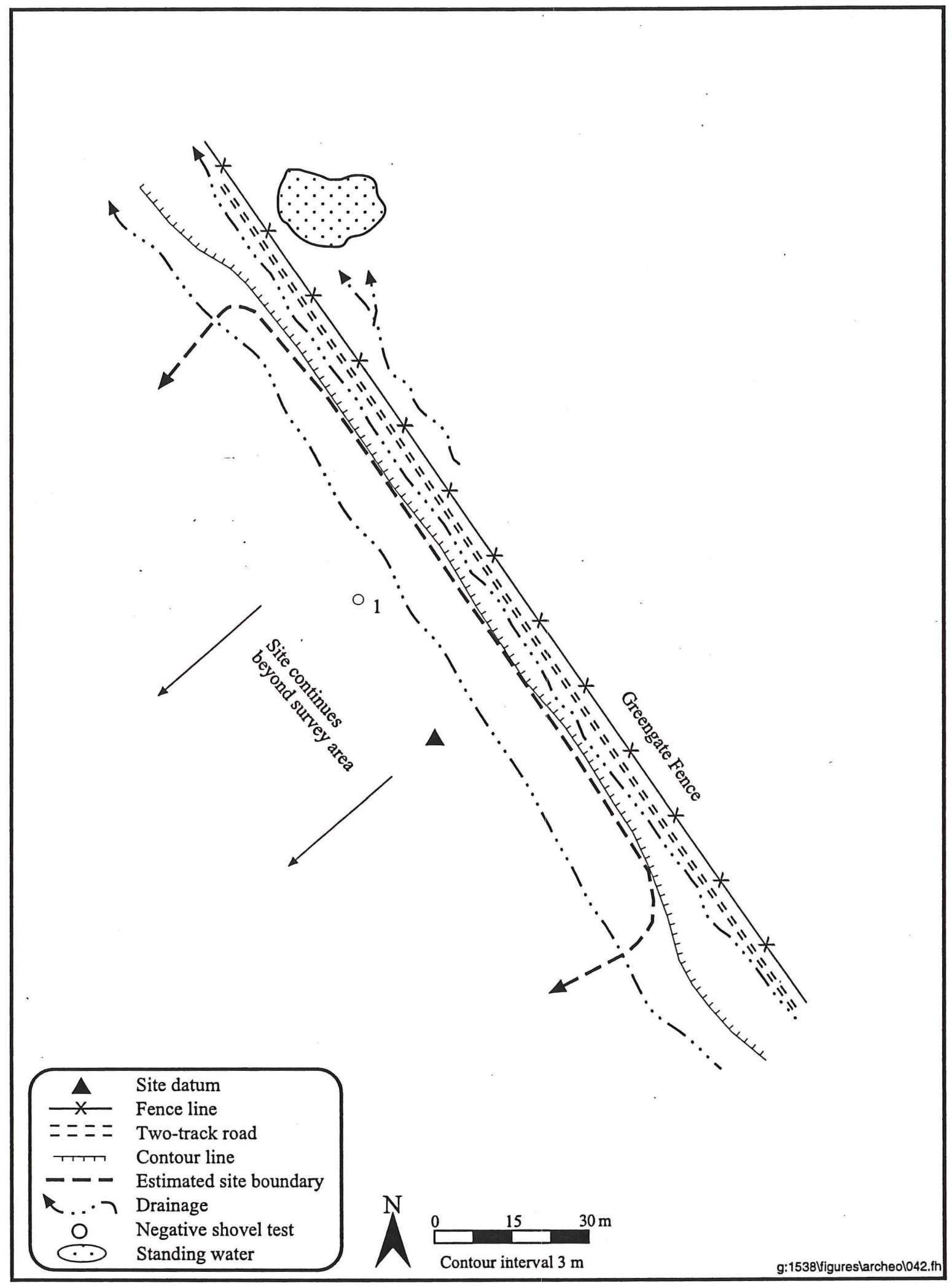

Figure 30. Plan map of site $41 \mathrm{WB} 484$. 
The site is a low-density lithic scatter measuring approximately $150 \mathrm{~m}$ northwest to southeast and over 25 $\mathrm{m}$ northeast to southwest, extending beyond the project boundaries to the southwest. The identified portion of the site covers a total area of approximately $3,750 \mathrm{~m}^{2}$. The site was originally identified by the presence of artifacts in the drainage which parallels the existing road and Greengate Fence. It is likely that these artifacts washed into the drainage from the southwest. Additional artifacts are scattered in very low densities southwest of the drainage. The lithic assemblage consists primarily of chert and quartzite tertiary flakes, cores, and a biface fragment. The density of artifacts is approximately six to eight artifacts per $25-\mathrm{m}^{2}$ area. No ground stone, diagnostic artifacts, or features were observed at the site.

A shovel test was excavated at site 41WB484 in order to determine the presence of subsurface cultural deposits. The shovel test, placed within the ROW approximately $15 \mathrm{~m}$ southwest of the road, revealed no subsurface cultural deposits. Soil at the site consists of medium brown silty loam becoming more compact below $20 \mathrm{~cm}$ bs. The shovel test was excavated to $40 \mathrm{~cm}$ bs.

Site 41WB484 is interpreted as an open campsite consisting of a low-density, surface scatter of lithic artifacts. No subsurface cultural deposits were identified. The site was identified in the ROW in the form of artifacts redeposited in a drainage ditch from slopewash, and extends to the southwest beyond the project boundary: Disturbances include the construction of the caliche road and Greengate Fence, as well as the paralleling drainage ditch. The side of the road occupied by the site has also been extensively devegetated and wild animal foraging was noted. The surficial nature of the site, the lack of features, and the extensive disturbances identified indicate the research potential of the evaluated area of site 41WB484 is minimal. Based on these observations, this portion of the site is recommended as ineligible for inclusion in the NRHP. The remaining portion of the site located beyond the survey area was not investigated. No further work within the assessed portion of site 41WB484 is recommended.

\section{Site $41 W B 485$}

Site 41WB485 is located on a southwest-trending terrace above several unnamed seasonal drainages on the east side of Galvan Ranch, along the Eastern Fence (Figure 31; see Figure 9). The site is approximately $1.6 \mathrm{~km}$ west of Highway 83 and $1.2 \mathrm{~km}$ northwest of the southeast corner of the Galvan Ranch property. Elevation at the site is $244 \mathrm{~m}(800 \mathrm{ft})$ amsl. An existing two-track road and Eastern Fence run northwest to southeast through the site. An unnamed seasonal drainage is approximately 100 $\mathrm{m}$ northeast of the site and Las Raices Creek is approximately $3 \mathrm{~km}$ northwest of the site. Vegetation in the area of the site includes mesquite, several varieties of cacti, and bunchgrass. Ground visibility is approximately 60 percent.

The site is a moderate-density lithic scatter measuring approximately $55 \mathrm{~m}$ northwest to southeast and over $50 \mathrm{~m}$ southwest to northeast, extending beyond the project boundaries northeast of the existing fence line. The portion of the site identified covers a total area of approximately $2,750 \mathrm{~m}^{2}$. The lithic assemblage consists of various grades of chert tertiary flakes and shatter; a chert projectile point, identified as a Transitional Archaic Frio point, was also observed (Figure 32; Turner and Hester 1993:122). No ground stone, evidence of quarrying, or features were observed at the site.

Two shovel tests were excavated at site 41WB485 in order to determine the presence of subsurface cultural deposits. Both shovel tests were negative. Soil at the site consists of dark yellowish brown sandy to silty loam to a depth of $20 \mathrm{~cm}$ bs, followed by a mottled brown and dark yellow brown clay loam. Shovel Tests 1 and 2 were excavated to 50 and $40 \mathrm{~cm}$ bs, respectively. 


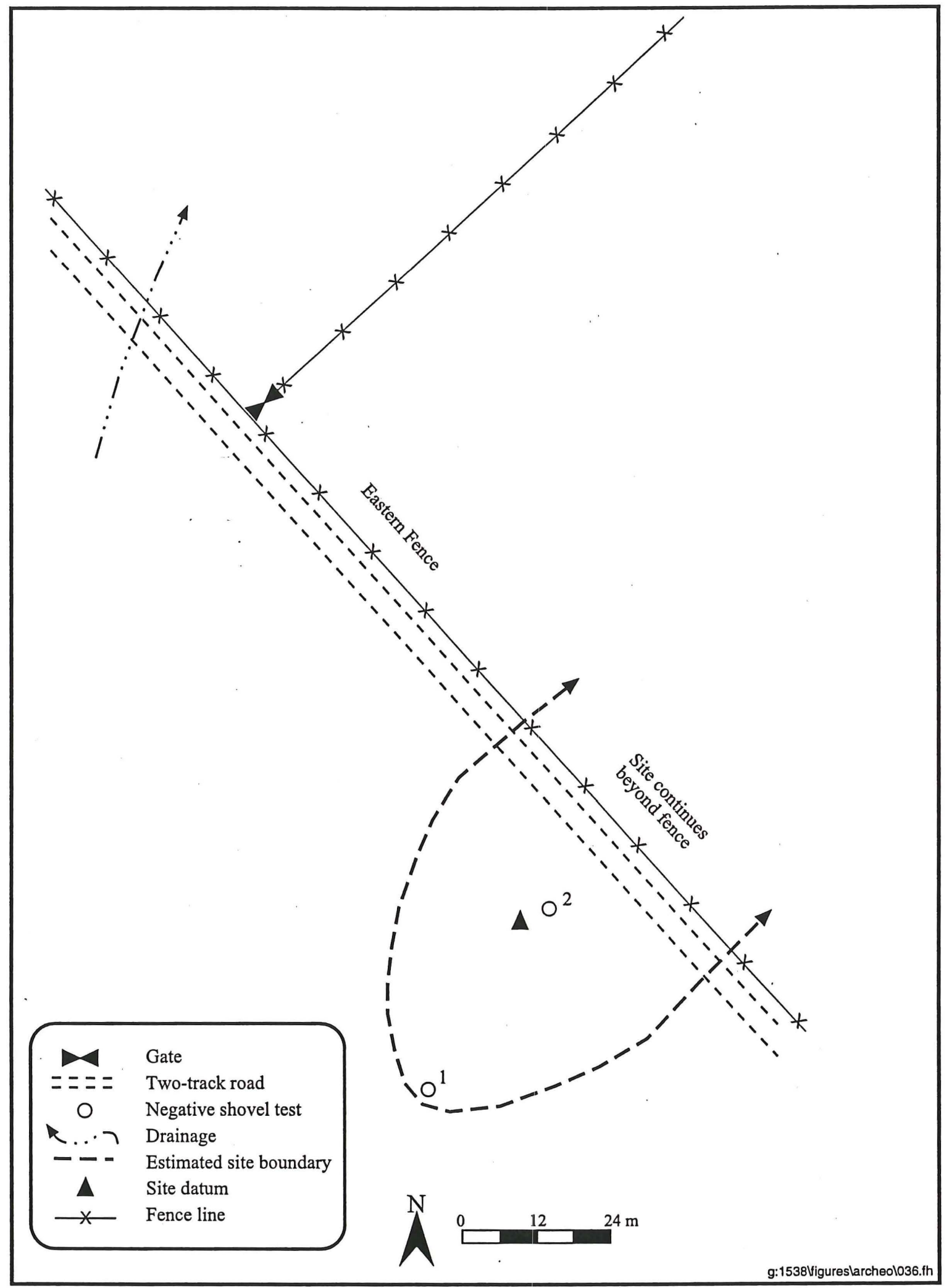

Figure 31. Plan map of site 41WB485. 


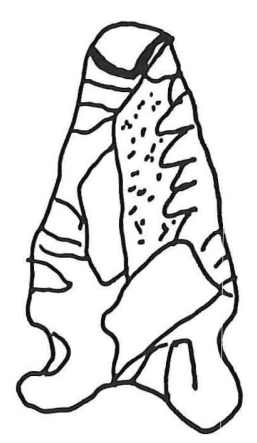

Figure 32. Field illustration of Frio projectile point identified at site 41WB485 (Scale 1:1).

Site $41 \mathrm{WB} 485$ is interpreted as an open campsite consisting of a surficial, moderate-density scatter of lithic artifacts. The single diagnostic projectile point identified dates to the Transitional Archaic period. The site extends beyond the project boundaries to the northeast of the existing fence line. Disturbances include erosion, as well as the construction of Eastern Fence and a two-track road which extend along the length of the site. The surficial nature of the site, the lack of features, and the disturbances identified indicate the research potential of the evaluated area of site $41 \mathrm{WB} 485$ is minimal. Based on these observations, the portion of the site investigated is recommended as ineligible for inclusion in the NRHP. The remaining portion of the site located beyond the survey area was not investigated. No additional work is recommended within the assessed portion of site $41 \mathrm{WB} 485$.

\section{Site 41 WB 486}

Site $41 \mathrm{WB} 486$ is located on level ground on the southwest bank of Santa Isabel Creek along Trevino Fence, approximately $2.5 \mathrm{~km}$ southeast of the intersection of Greengate and Trevino fences, in the southcentral portion of Galvan Ranch (Figure 33; see Figure 9). The site extends beyond the property boundary to the southeast. Elevation at the site is $192 \mathrm{~m} \mathrm{(630} \mathrm{ft)} \mathrm{amsl.} \mathrm{Santa} \mathrm{Isabel} \mathrm{Creek} \mathrm{borders} \mathrm{the}$ northeast edge of the site. Vegetation in the area of the site is moderate in density and includes mesquite, prickly pear, tasajillo, allthorn, and short grasses. Ground visibility is approximately 70 percent.

The site is a moderate-density lithic scatter measuring approximately $180 \mathrm{~m}$ southwest to northeast and over $80 \mathrm{~m}$ northwest to southeast, extending beyond the property boundary to the southeast. The identified portion of the site covers a total area of approximately $14,400 \mathrm{~m}^{2}$. The lithic assemblage consists primarily of secondary and tertiary flakes, shatter, and a projectile point fragment. The point was identified as a Lange point, a straight-based point with well-barbed shoulders that dates to the Late Archaic (Turner and Hester 1993:141). Raw material at the site consists of several varieties of chert. The density of artifacts at site $41 \mathrm{WB} 486$ is approximately 12 to 15 specimens in a $25-\mathrm{m}^{2}$ area. No ground stone, features, or evidence of quarrying were observed at the site.

Two shovel tests were excavated at site 41WB486 in order to determine the presence of subsurface cultural deposits. Shovel Test 1 was placed within the proposed ROW near the intersection of a twotrack road and Trevino Fence. This shovel test produced six flakes, revealing a subsurface deposit that extends to a depth of $30 \mathrm{~cm}$ bs. Shovel Test 2 was placed in the southern portion of the site, again 


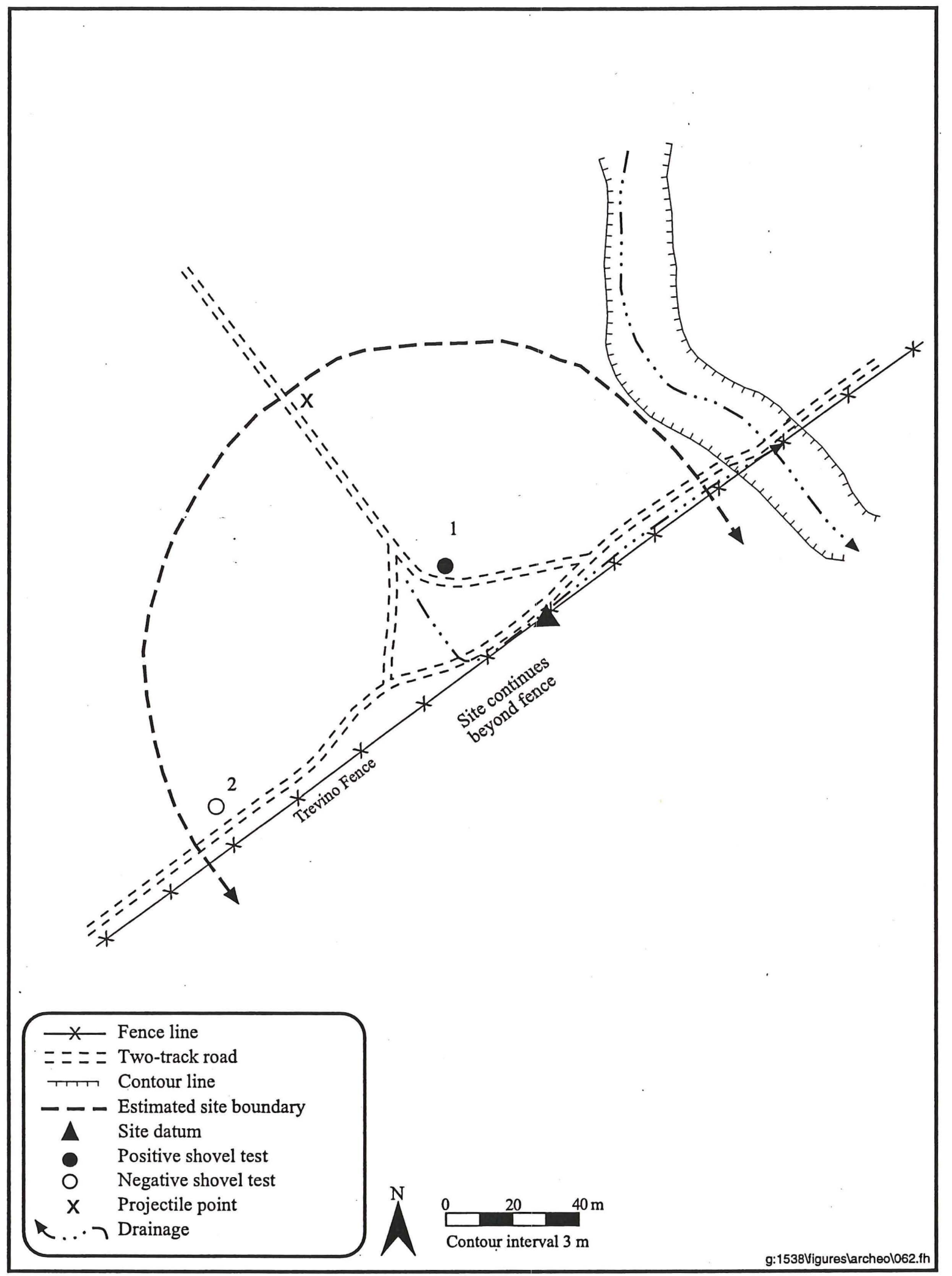

Figure 33. Plan map of site 41WB486. 
within the proposed ROW, and was negative. Soil at the site consists of grayish to yellowish brown silty loam with few caliche inclusions; the soil becomes increasingly compact as depth increases. Both shovel tests were excavated to a depth of $30 \mathrm{~cm}$ bs.

Site 41WB486 is interpreted as an open campsite consisting of a moderate-density, surface lithic scatter. Although the site has been disturbed by road cuts, a portion of the site appears to be intact. The presence of a subsurface deposit with a depth of $30 \mathrm{~cm}$ indicates the site may have some potential for buried features and/or significant subsurface deposits. Based on the possible research value of the site, the site is recommended as potentially eligible for inclusion in the NRHP. Avoidance of site 41WB486 is recommended by prohibiting additional grading, reworking, or ground disturbance within the limits of the site. The presence of an archeological monitor is recommended in order to keep equipment off of undisturbed portions of site 41WB486 and to ensure that intact portions of the site are not impacted by road improvement activities.

\section{Site 41 WB 487}

Site 41WB487 is located on a gentle, northwest-facing slope above an unnamed seasonal drainage along Trevino Fence, approximately $400 \mathrm{~m}$ southwest of the intersection of Pipeline Fence and Trevino Fence, in the southwest portion of Galvan Ranch (Figure 34; see Figure 9). The site extends beyond the property boundary to the southeast. Elevation at the site is $208 \mathrm{~m}(682 \mathrm{ft})$ amsl. An unnamed seasonal drainage is $150 \mathrm{~m}$ west-northwest of the site and Pinto Creek is approximately $4.6 \mathrm{~km}$ northwest of the site. Vegetation in the area of the site is relatively sparse and consists of mesquite, creosote, tasajillo, and short grasses. Ground visibility is approximately 80 percent.

The site is a small, moderate-density lithic scatter measuring approximately $52 \mathrm{~m}$ southwest to northeast and over $35 \mathrm{~m}$ northwest to southeast, extending beyond the property boundary to the southeast. The identified portion of the site covers a total area of approximately $1,820 \mathrm{~m}^{2}$. The lithic assemblage consists primarily of tertiary flakes, biface and uniface fragments, and three projectile points. The first point was identified as an Early Archaic Gower point with a short parallel-edged stem and a concave base (Figure 35a; Turner and Hester 1993:128). Another point was identified as a Refugio, an Archaic unstemmed elongate point (Figure 35b; Turner and Hester 1993:178). The third projectile point could not be confidently identified, but does resemble the Middle to Late Archaic Palmillas point, although slightly smaller (Figure 35c; Turner and Hester 1993:167). Three possible Nueces unifaces, which are usually dated from the Middle to Late Archaic, were also identified at the site (Turner and Hester 1993:267, 268). All artifacts consist of locally available chert. The density of artifacts at site 41WB487 is approximately 10 to 12 specimens in a $25-\mathrm{m}^{2}$ area. No ground stone, features, or evidence of quarrying were observed at the site.

A shovel test was excavated at site $41 \mathrm{WB} 487$ in order to determine the presence of subsurface cultural deposits. The shovel test was placed within the proposed ROW approximately $8 \mathrm{~m}$ northwest of the existing road. Soil at the site consists of medium brown sandy loam to a depth of approximately $5 \mathrm{~cm}$ bs, when the soil becomes slightly lighter in color and more compact. The shovel test was terminated at 30 $\mathrm{cm}$ bs and test produced seven flakes, revealing a subsurface deposit that extends to the maximum excavated depth $(30 \mathrm{~cm}$ bs).

Site 41WB487 is interpreted as an open campsite consisting of a moderate-density lithic scatter. Although the site has been disturbed by a road cut, a portion of the site appears to be intact. The presence of a subsurface deposit with a depth of $30 \mathrm{~cm}$ indicates the site may have some potential for buried features 


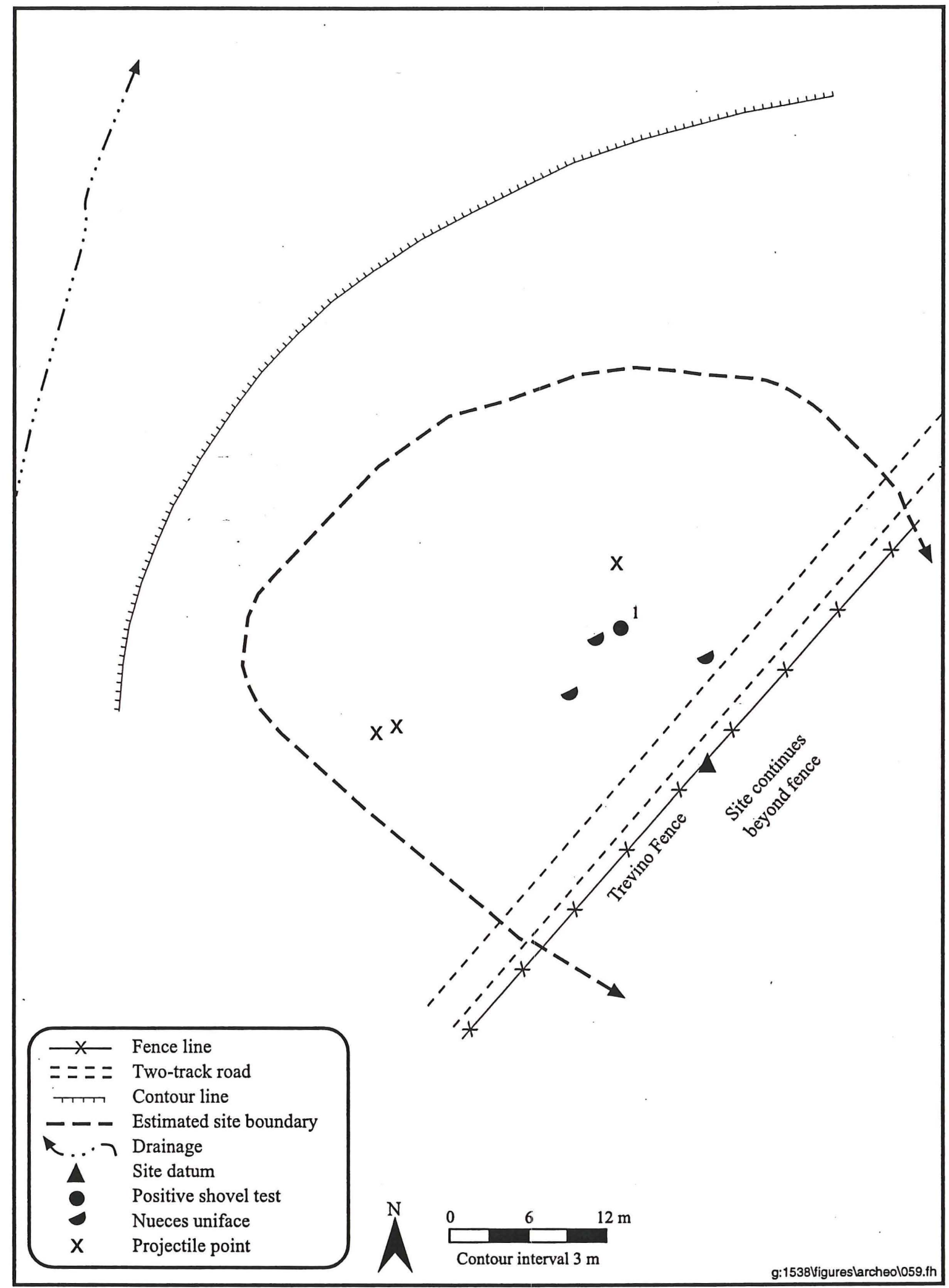

Figure 34. Plan map of site 41WB487. 


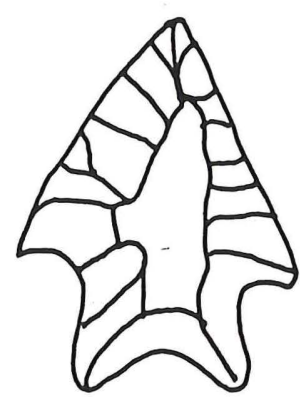

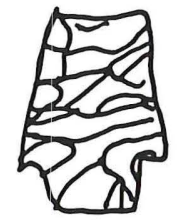

b

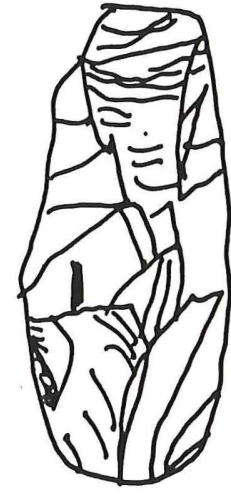

Figure 35. Field illustrations of projectile points identified at site 41WB487: (a) Gower point; (b) Refugio point; and (c) Palmillas point (Scale 1:1).

and/or significant subsurface deposits. Based on the possible research value of the site, the site is recommended as potentially eligible for inclusion in the NRHP. Avoidance of site 41WB487 is recommended by prohibiting additional grading, reworking, or ground disturbance within the limits of the site. The presence of an archeological monitor is recommended in order to keep equipment off of undisturbed portions of site 41WB487 and to ensure that intact portions of the site are not impacted by road improvement activities.

\section{Site $41 \mathrm{WB} 488$}

Site 41WB488 is located on an upland terrace overlooking a series of unnamed seasonal drainages along Trevino Fence, approximately $150 \mathrm{~m}$ southwest of the intersection of Pipeline Fence and Trevino Fence, in the southwest portion of Galvan Ranch (Figure 36; see Figure 9). The site extends beyond the property boundary to the southeast. Elevation at the site is $208 \mathrm{~m}(681 \mathrm{ft})$ amsl. An unnamed seasonal drainage is $190 \mathrm{~m}$ east of the site and Pinto Creek is approximately $4.7 \mathrm{~km}$ northwest of the site. Vegetation in the area of the site is relatively dense and consists of mesquite, creosote, tasajillo, soapbush, allthorn, and short grasses. Ground visibility is approximately $60-70$ percent.

The site is a small, high-density lithic scatter measuring approximately $100 \mathrm{~m}$ southwest to northeast and over $40 \mathrm{~m}$ northwest to southeast, extending beyond the property boundary to the southeast. The identified portion of the site covers a total area of approximately $4,000 \mathrm{~m}^{2}$. The lithic assemblage consists primarily of secondary and tertiary flakes, biface fragments, one projectile point, and several projectile point fragments. All artifacts are made of locally available chert. The projectile point is similar to the Early Triangular/Tortugas/Matamoros group of point types that consist of unstemmed, straight-based triangular points (Figure 37a; Turner and Hester 1993:110, 153, 188). Dates on this group of points range from Early Archaic (Early Triangular points) through the late Middle Archaic (Tortugas), and from the Late Archaic to the Late Prehistoric (Matamoros) (Turner and Hester 1993:110, 153, 188). The projectile point fragments could not be typed due to fragmentation. In addition, a possible Nueces biface, which dates from the Middle to Late Archaic, was also identified at the site (Figure 37b; Turner and Hester 1993:267, 268). The density of artifacts at site $41 \mathrm{WB} 488$ is approximately 20 to 22 


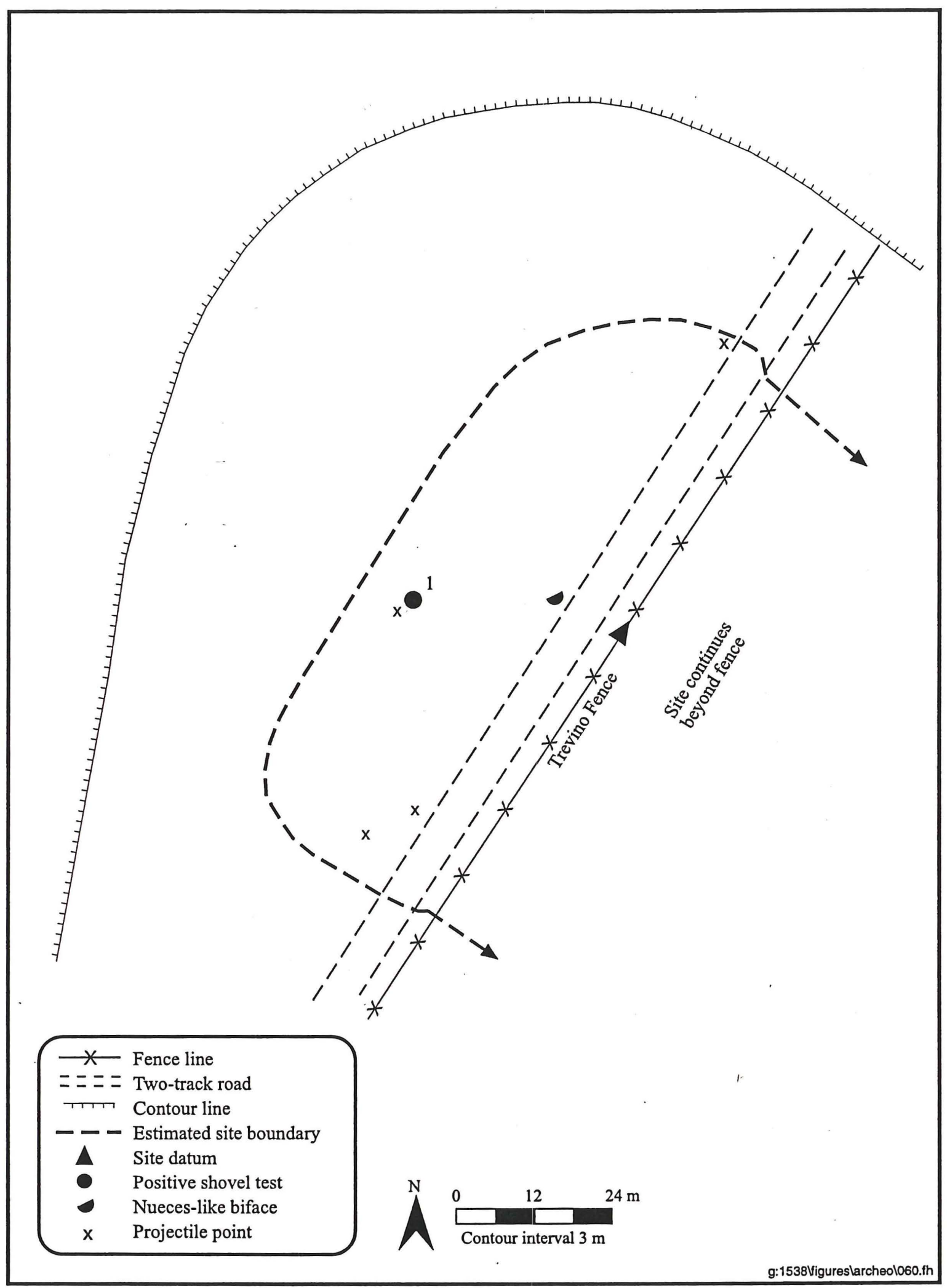

Figure 36. Plan map of site 41WB488. 


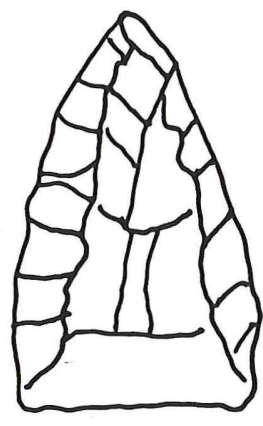

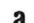

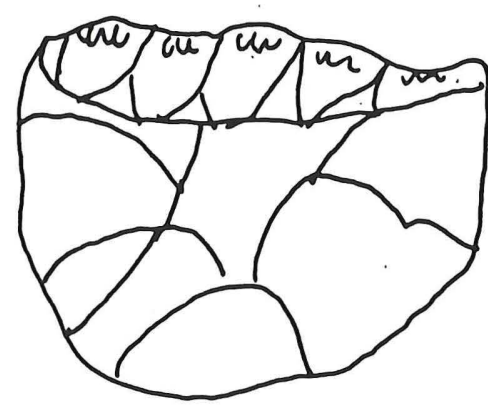

b

Figure 37. Field illustrations of artifacts identified at site 41WB488: (a) the Early Triangular/Tortugas/Matamorostype point and (b) possible Nueces biface (Scale 1:1).

specimens in a $25-\mathrm{m}^{2}$ area. No ground stone, features, or evidence of quarrying were observed at the site.

A shovel test was excavated at site 41WB488 in order to determine the presence of subsurface cultural deposits. The shovel test was placed approximately $20 \mathrm{~m}$ northwest of the existing road. Soil at the site consists of grayish brown sandy loam to a depth of $13 \mathrm{~cm}$ bs, followed by light olive brown loam with small pebble inclusions. Below $33 \mathrm{~cm}$, the soil becomes light yellowish brown and still contains small pebble inclusions. This shovel test produced 18 flakes, revealing a subsurface deposit that extends to the maximum excavated level of the shovel test which was $60 \mathrm{~cm}$ bs.

Site 41WB488 is interpreted as an open campsite consisting of a high-density lithic scatter. Although the site has been disturbed by a road cut, a portion of the site appears to remain intact. The presence of a subsurface deposit with a depth of $60 \mathrm{~cm}$ indicates the site may have some potential for buried features and/or significant subsurface deposits. Based on the possible research value of the site, the site is recommended as potentially eligible for inclusion in the NRHP. Avoidance of site 41WB488 is recommended by prohibiting additional grading, reworking, or ground disturbance within the limits of the site. The presence of an archeological monitor is recommended in order to keep equipment off of undisturbed portions of site 41WB488 and to ensure that intact portions of the site are not impacted by road improvement activities.

\section{Site 41 WB 489}

Site 41WB489 is located on a terrace directly south of a series of unnamed seasonal drainages near the bend in Trevino Fence, approximately $1.75 \mathrm{~km}$ northeast of the intersection of Pipeline Fence and Trevino Fence, in the southcentral portion of Galvan Ranch (Figure 38; see Figure 9). The site extends beyond the property boundary to the southeast. Elevation at the site is $198 \mathrm{~m}(651 \mathrm{ft})$ amsl. An unnamed seasonal drainage is $30 \mathrm{~m}$ north-northeast of the site and Pinto Creek is approximately $3.7 \mathrm{~km}$ east of the site. Vegetation in the area of the site is relatively sparse and consists of mesquite and prickly pear. Ground visibility is approximately $70-80$ percent. 


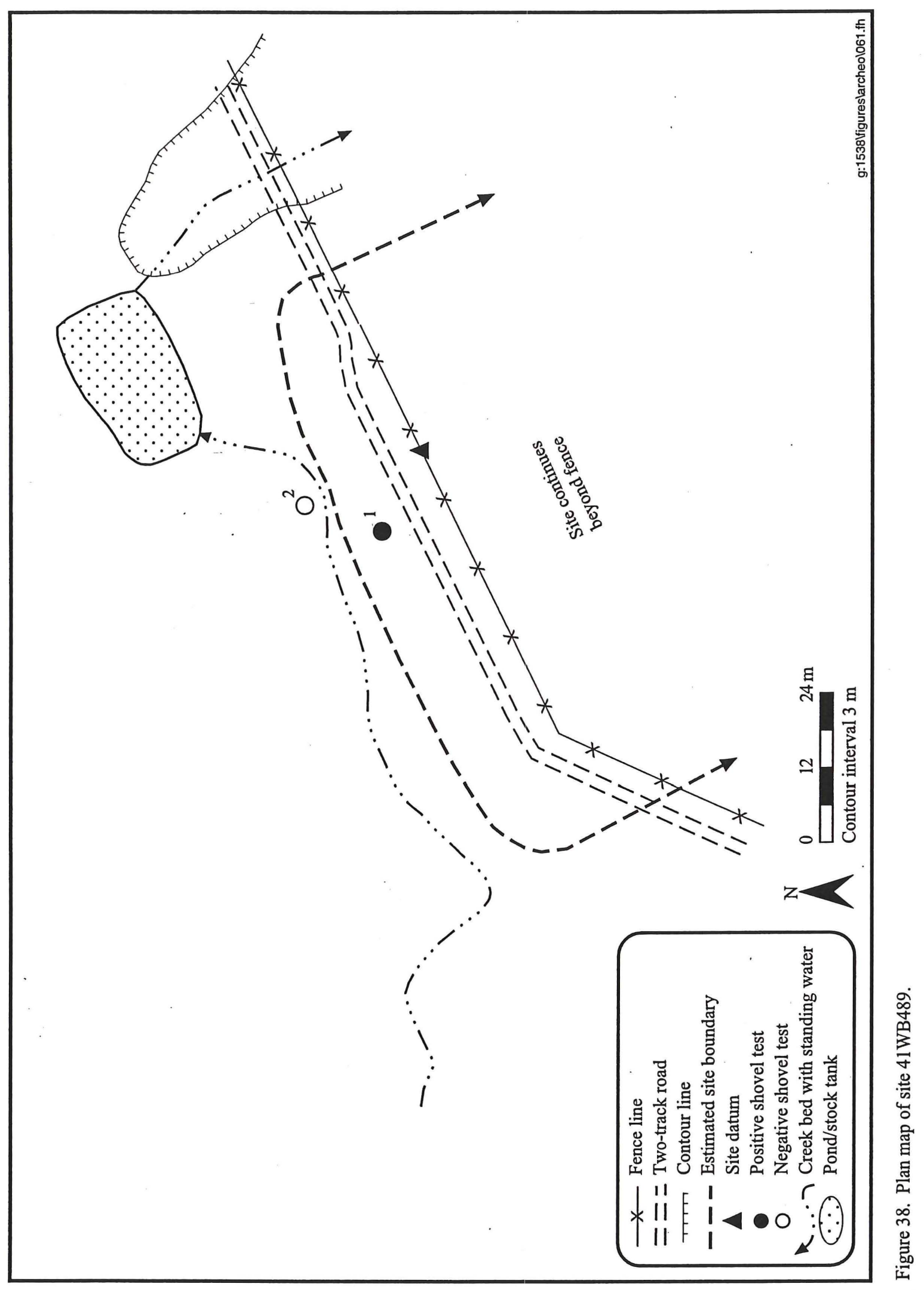

84 
The site is a small, low-density lithic scatter measuring approximately $100 \mathrm{~m}$ southwest to northeast and over $20 \mathrm{~m}$ northwest to southeast, extending beyond the property boundary to the southeast. The identified portion of the site covers a total area of approximately $2,000 \mathrm{~m}^{2}$. The lithic assemblage consists primarily of secondary and tertiary flakes of locally available chert. The density of artifacts at site 41 WB489 is approximately six to eight specimens in a $25-\mathrm{m}^{2}$ area. No ground stone, features, or evidence of quarrying were observed at the site. No diagnostic artifacts were identified.

Two shovel tests were excavated at site 41WB489 in order to determine the presence of subsurface cultural deposits. Shovel Test 1 was placed within the proposed ROW approximately $5 \mathrm{~m}$ northwest of the existing road. This shovel test produced a single flake, revealing a subsurface deposit that extends to a depth of $40 \mathrm{~cm}$ bs. Shovel Test 2 was placed directly north of the identified boundaries of the surface scatter and was negative. Soil at the site consists of dark yellowish to grayish brown clay loam that becomes slightly lighter in color below $10 \mathrm{~cm}$ bs. Shovel Tests 1 and 2 were excavated to depths of 40 and $50 \mathrm{~cm}$ bs, respectively.

Site 41WB489 is interpreted as an open campsite consisting of a low-density, lithic scatter. Although the site has been disturbed by a road cut, a portion of the site appears to be intact. The presence of a subsurface deposit with a depth of $40 \mathrm{~cm}$ indicates the site may have some potential for buried features and/or significant subsurface deposits. Based on the possible research value of the site, the site is recommended as potentially eligible for inclusion in the NRHP. Avoidance of site 41WB489 is recommended by prohibiting additional grading, reworking, or ground disturbance within the limits of the site. The presence of an archeological monitor is recommended in order to keep equipment off of undisturbed portions of site 41 WB489 and to ensure that intact portions of the site are not impacted by road improvement activities.

\section{Site $41 W B 490$}

Site 41WB490 is located on level ground along the Eastern Fence of Galvan Ranch, on the west side of Highway 83 (Figure 39; see Figure 9). It lies approximately $1.6 \mathrm{~km}$ north of the ranch main gate and adjacent to the drag road that parallels the Eastern Fence. Elevation at the site is $207 \mathrm{~m}(680 \mathrm{ft})$ amsl. An unnamed seasonal drainage is approximately $150 \mathrm{~m}$ south of the site and Las Raices Creek is approximately $3 \mathrm{~km}$ south. Vegetation in the area of the site includes mesquite, tasajillo, prickly pear, acacia, and short grasses. Vegetation along the fence line itself has been cleared. Ground visibility is approximately 75 percent.

The site is a small, low-density lithic scatter measuring approximately $40 \mathrm{~m}$ east to west and $35 \mathrm{~m}$ north to south. The site covers a total area of approximately $1,400 \mathrm{~m}^{2}$. The lithic assemblage consists of a total of approximately 15 to 20 flakes and one biface, all of locally available chert. No additional artifact types, evidence of quarrying, or features were observed at the site. No diagnostic artifacts were identified.

The two shovel tests excavated at site 41WB490 were negative. Shovel Test 1 was placed directly west of the drag road and Shovel Test 2 was placed near the biface in the western portion of the site. Soil at the site consists of reddish brown clay loam to a depth of $20 \mathrm{~cm}$ bs, followed by reddish brown to reddish yellow clay with caliche inclusions. Both shovel tests were excavated to a depth of $30 \mathrm{~cm}$ bs and no cultural material was identified. 


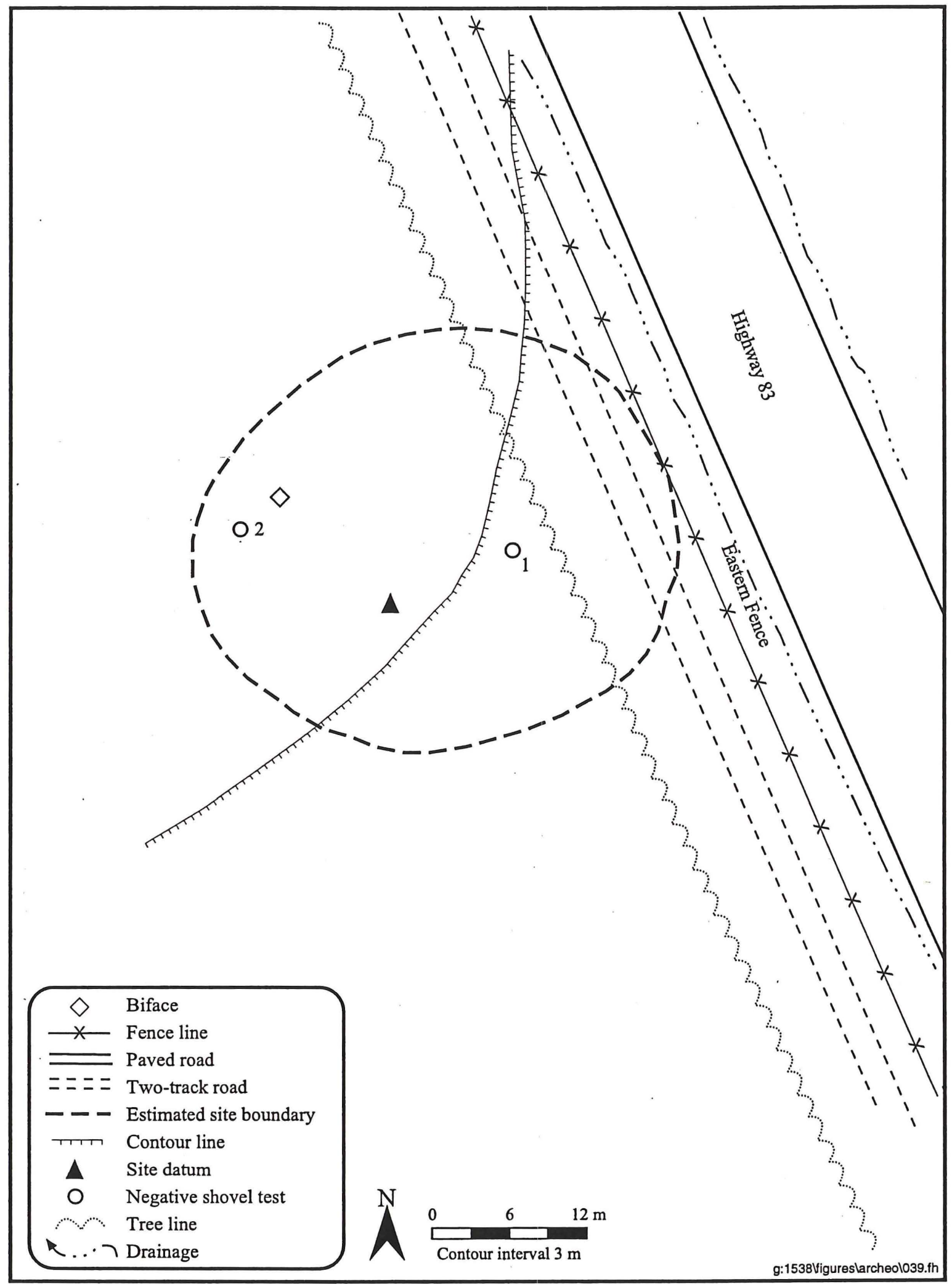

Figure 39. Plan map of site 41 WB490. 
Site 41 WB490 is interpreted as an open campsite consisting of a low-density scatter of lithic artifacts. No subsurface cultural deposit was identified and no diagnostic artifacts were observed. The eastern portion of the site has been impacted by a drag road and fence line. The sparse, surficial nature of the site, the lack of features, and the disturbances on the eastern side of the site indicate the research potential of site $41 \mathrm{WB} 490$ is minimal. Based on these observations, the site is recommended as ineligible for inclusion in the NRHP. No additional work is recommended at site 41WB490.

\section{Site 41 WB 491}

Site 41WB491 is located on level ground along the Eastern Fence of Galvan Ranch, on the west side of Highway 83 (Figure 40; see Figure 9). It lies approximately $2 \mathrm{~km}$ north of the ranch main gate and adjacent to the drag road that parallels the Eastern Fence. Elevation at the site is $210 \mathrm{~m}(690 \mathrm{ft}) \mathrm{amsl}$. An unnamed seasonal drainage borders the western and southern edges of the site and Las Raices Creek is approximately $3.3 \mathrm{~km}$ south. Vegetation in the area of the site includes mesquite, tasajillo, prickly pear, acacia, and short grasses. Vegetation along the fence line itself has been cleared. Ground visibility is approximately 80 percent.

The site is a small, low-density lithic scatter measuring approximately $60 \mathrm{~m}$ east to west and $30 \mathrm{~m}$ north to south. The site covers a total area of approximately $1,800 \mathrm{~m}^{2}$. The lithic assemblage consists of a total of approximately 10 to 15 tertiary flakes, a scraper, two biface fragments, and one projectile point tip, all of locally available chert. No diagnostic artifacts, evidence of quarrying, or features were observed at the site.

The single shovel test excavated in the center of site 41WB491 near the projectile point tip was negative. Soil at the site consists of reddish brown silty loam to a depth of $40 \mathrm{~cm}$ bs, followed by reddish yellow clay loam to the maximum depth of the shovel test which was $50 \mathrm{~cm}$ bs.

Site 41WB491 is interpreted as an open campsite consisting of a low-density surficial scatter of lithic artifacts. No subsurface deposits were identified. The eastern portion of the site has been disturbed by construction of a fence line and drag road. The sparse, surficial nature of the site, the lack of features, and the disturbances on the eastern side of the site indicate the research potential of site 41WB491 is minimal. Based on these observations, the site is recommended as ineligible for inclusion in the NRHP. No additional work is recommended at site 41WB491.

\section{Site $41 W B 492$}

Site 41WB492 is located on a northeast-southwest-trending ridge along the Galvan Fence in the northeast corner of Galvan Ranch (Figure 41; see Figure 9). The site encompasses a large portion of the property corner and extends northwest an unknown distance beyond the property boundary. Elevation at the site is $213 \mathrm{~m}$ (700 ft) amsl. Unnamed seasonal drainages are located approximately $300 \mathrm{~m}$ northwest, northeast, and southwest of the site, and two of these drainages empty into Canyon Creek approximately $1 \mathrm{~km}$ north of the site. Vegetation has been cleared along the existing road, while mesquite, creosote, tasajillo, prickly pear cactus, acacia, and dense short grasses cover the rest of the site. Ground visibility varies from 20 percent in grassy areas to 90 percent near the road. 


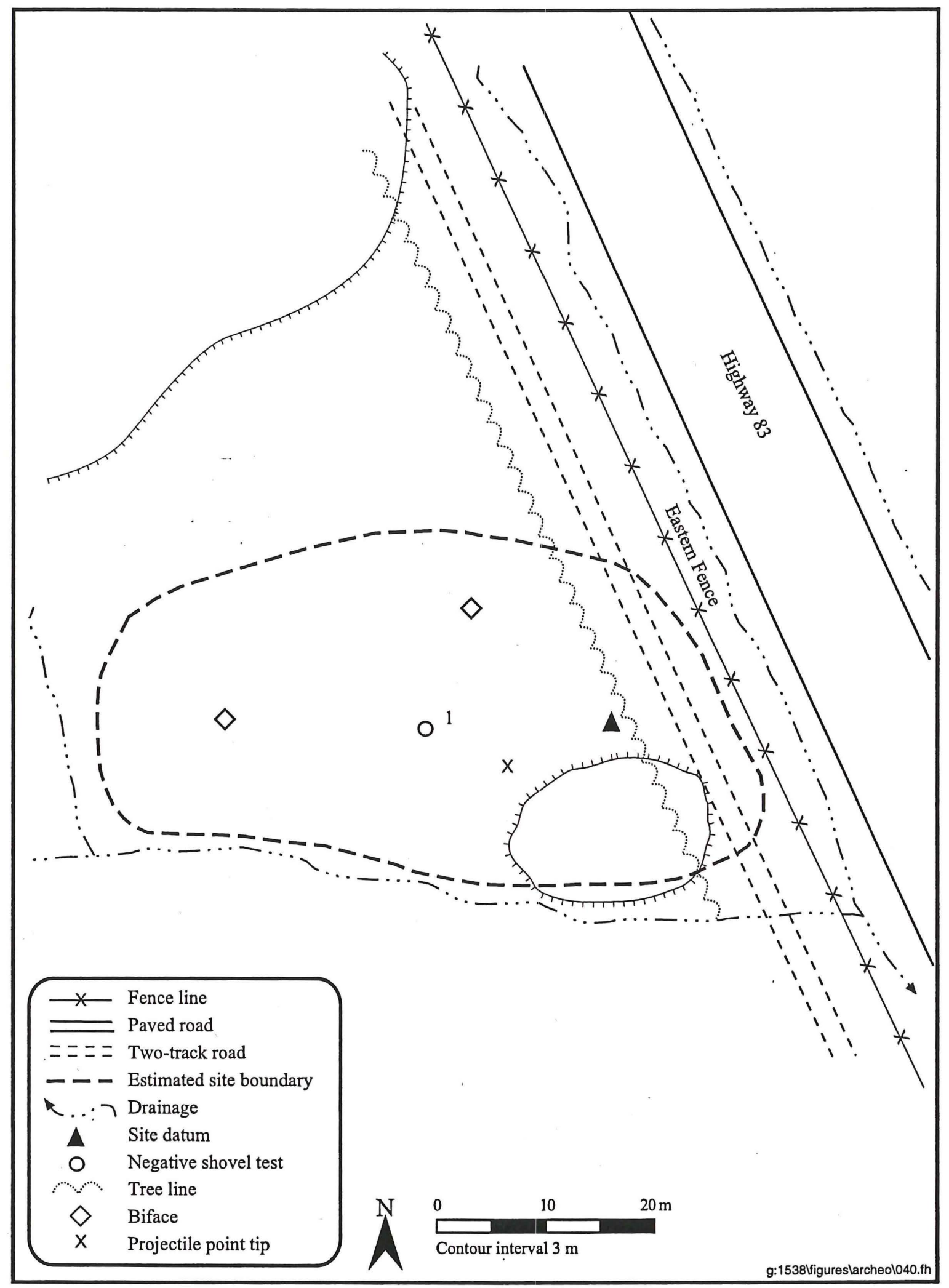

Figure 40. Plan map of site 41WB491. 


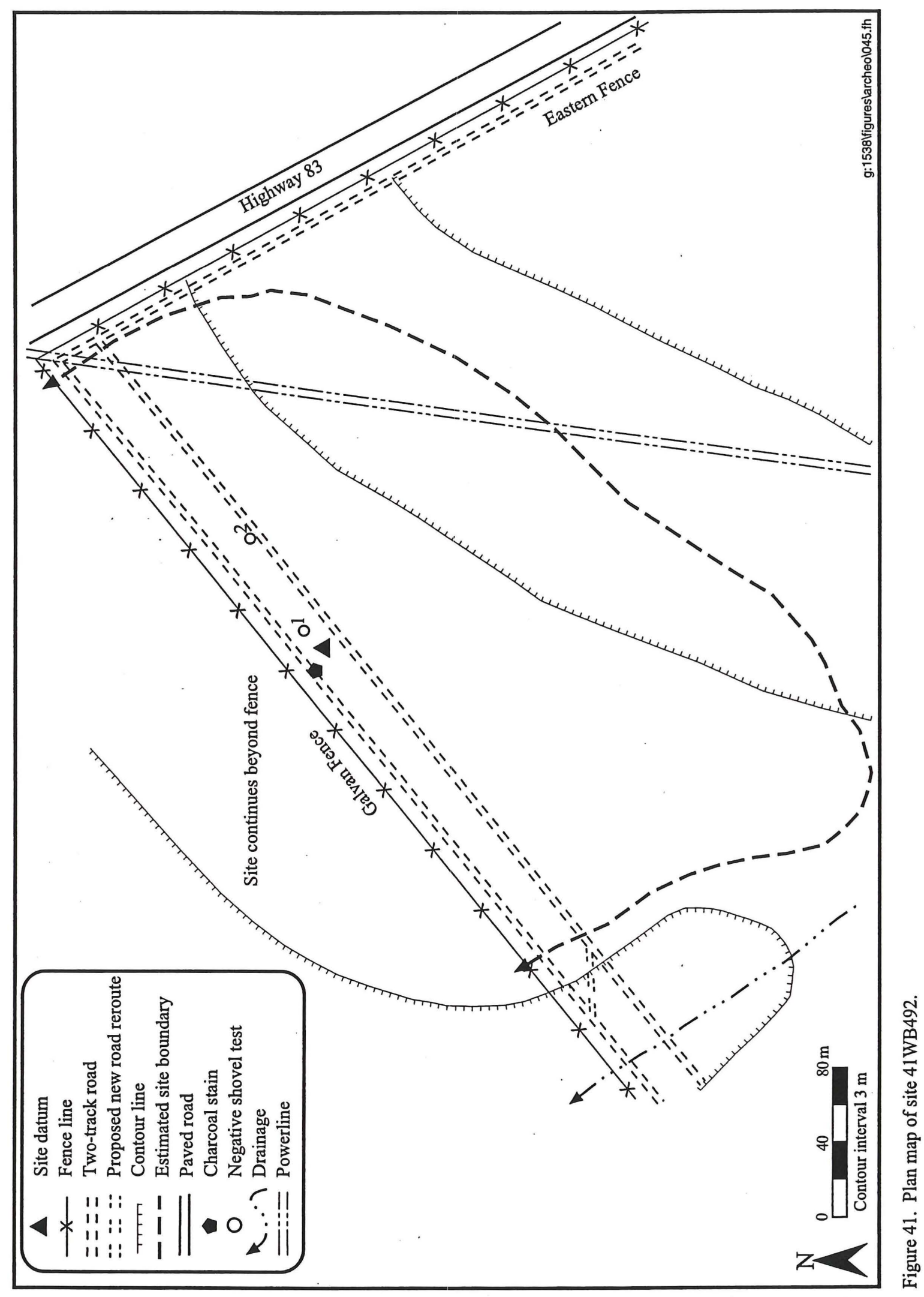


The site is a low-density lithic scatter measuring approximately $450 \mathrm{~m}$ northeast to southwest and over $200 \mathrm{~m}$ northwest to southeast, extending beyond the property boundary. The identified area of the site covers a total area of approximately $90,000 \mathrm{~m}^{2}$. The lithic assemblage consists of tertiary flakes, scrapers, three projectile points, and a biface fragment, all of locally available chert. The density of artifacts at site 41WB492 varies from two to three specimens in a $25-\mathrm{m}^{2}$ area in the area south of the proposed ROW to approximately 10 to 12 specimens in a $25-\mathrm{m}^{2}$ area along the existing roadbeds. All three of the identified projectile points were typed. The first was identified as a Perdiz point, a Late Prehistoric sharply pointed, contracting-stem point (Turner and Hester 1993:227). The second point was typed as a Catán point, a Late Archaic to Late Prehistoric unstemmed, round-based point (Turner and Hester 1993:89). The last point was identified as a Caracara point, a Late Prehistoric side-notched point with a straight base (Turner and Hester 1993:205). A feature consisting of a charcoal stain approximately $20 \mathrm{~cm}$ in diameter was identified in the two-track road closest to Galvan Fence. The three projectile points, a biface fragment, and numerous flakes were found within $5 \mathrm{~m}$ of the feature. No ground stone or evidence of quarrying was observed at the site.

Two shovel tests were excavated at site 41WB492 in order to determine the presence of subsurface cultural deposits. Shovel Test 1 was placed approximately $15 \mathrm{~m}$ east of the stain feature. Shovel Test 2 was placed approximately $75 \mathrm{~m}$ northeast of the feature in an area of heavy grass coverage. No subsurface cultural deposits were identified by the shovel tests. Soil at the site consists of brown to yellowish brown silty loam to depths of between 5 and $8 \mathrm{~cm}$ bs, followed by subsoil which consists of compact brown to light yellowish brown clay with caliche inclusions. Shovel Tests 1 and 2 were excavated to depths of 20 and $18 \mathrm{~cm}$ bs, respectively.

Site 41WB492 is interpreted as an open campsite consisting of a low-density surficial lithic scatter. The investigated portion of the site has been heavily impacted by the construction and use of two-track roads, the construction of a power line, and associated mechanical earthmoving. Although both shovel tests were negative, the presence of a stain feature indicates the site may have some potential for buried features and/or subsurface deposits. Three typed projectile points found in close proximity to the feature date to the Late Prehistoric. Based on the possible research value of the site, the site is recommended as potentially eligible for inclusion in the NRHP. Avoidance of site $41 \mathrm{WB} 492$ is recommended by prohibiting additional grading, reworking, or ground disturbance within the limits of the site. An alternative approach to avoiding impacts to any intact cultural deposits would be to reroute the road ROW along a second two-track located about $10 \mathrm{~m}$ south of the two-track that runs along Galvan Fence. The portion of the site through which this road passes has been more severely impacted than the part by the main road. Very few artifacts are evident on the ground surface in this part of the site, and a shovel test placed next to the second two-track yielded no evidence of cultural deposits. The presence of an archeological monitor is recommended in order to keep equipment off of undisturbed portions of site 41WB492 and to ensure that intact portions of the site are not impacted by road improvement activities.

\section{Site 41 WB 493}

Site 41 WB493 is located on a northwest-trending ridge between two unnamed drainages along Galvan Fence in the northeast corner of Galvan Ranch, approximately $600 \mathrm{~m}$ southwest of the northeast corner of the property (Figure 42; see Figure 9). The site was identified in the existing roadbed and extends beyond the property boundary to the northwest. Elevation at the site is $222 \mathrm{~m}(727 \mathrm{ft})$ amsl. An unnamed seasonal drainage is approximately $400 \mathrm{~m}$ northeast of the site and empties into Canyon Creek approximately $1.7 \mathrm{~km}$ northeast of the site. Vegetation in the area of the site consists of mesquite, 


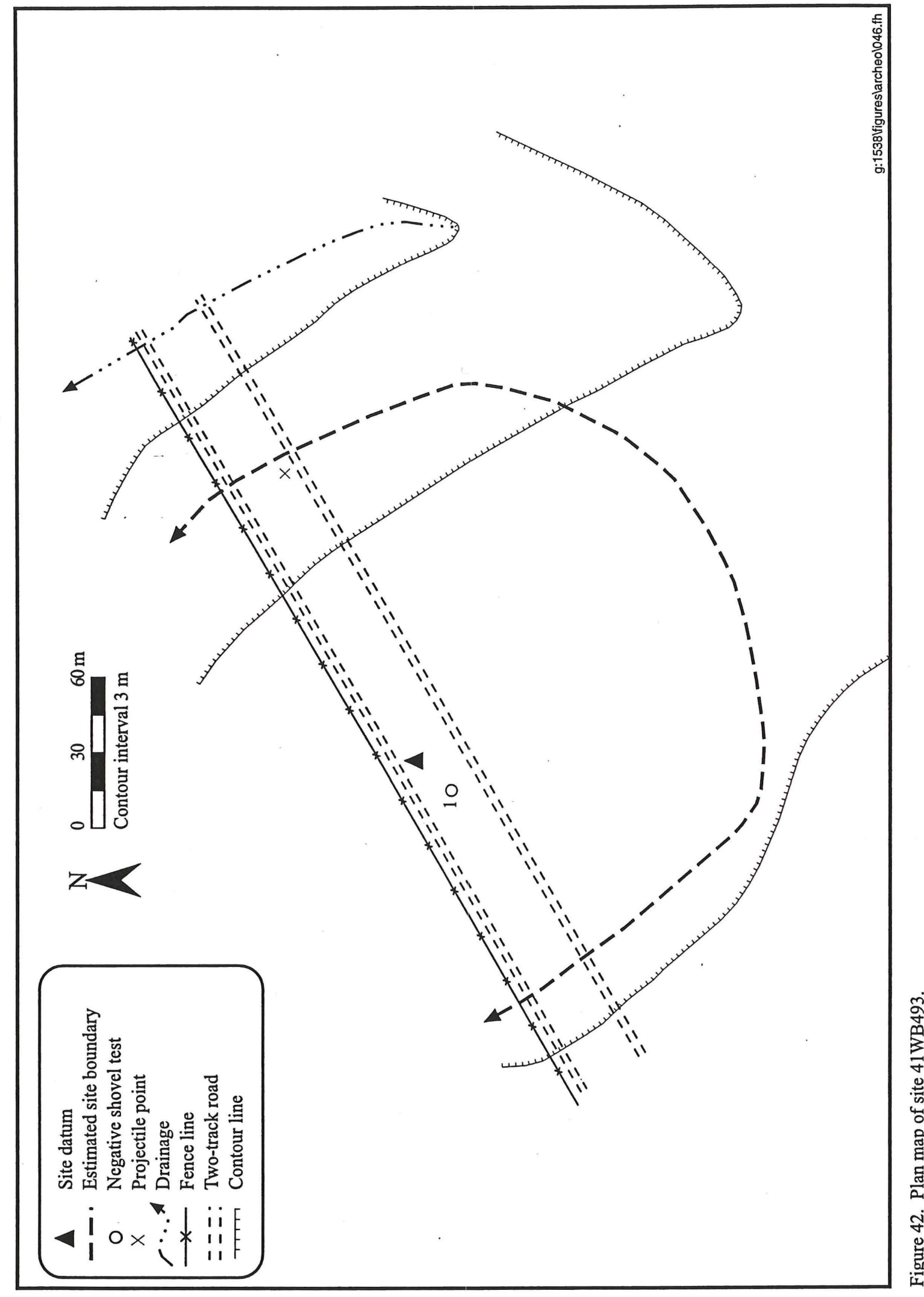


tasajillo, prickly pear cactus, acacia, and short grasses. Ground visibility varies from approximately 50 percent in the grassy area southeast of the road to 90 percent along the existing road.

The site is a low-density lithic scatter measuring approximately $225 \mathrm{~m}$ northeast to southwest and $140 \mathrm{~m}$ northwest to southeast, covering a total area of approximately $31,500 \mathrm{~m}^{2}$. The lithic assemblage consists primarily of secondary and tertiary flakes, scrapers, and two projectile points. Raw material is locally available chert. The density of artifacts at site $41 \mathrm{WB} 493$ is approximately five to eight specimens in a $25-\mathrm{m}^{2}$ area. The identified points are similar to the Early Triangular/Tortugas/Matamoros group of unstemmed, straight-based triangular points (Turner and Hester 1993:110, 153, 188). Dates on this group of points range from Early Archaic (Early Triangular points) through the late Middle Archaic (Tortugas), and from the Late Archaic to the Late Prehistoric (Matamoros) (Turner and Hester 1993:110, $153,188)$. No ground stone, features, or evidence of quarrying were observed at the site.

A shovel test was excavated at site $41 \mathrm{WB} 493$ in order to determine the presence of subsurface cultural deposits. The shovel test was placed in the proposed ROW approximately $10 \mathrm{~m}$ southeast of Galvan Fence. Soil at the site consists of yellowish brown clayey silt to a depth of $5 \mathrm{~cm}$ bs, followed by subsoil consisting of light yellowish brown clay loam with yellowish brown mottling and caliche inclusions. No subsurface cultural deposits were identified in the shovel test.

Site 41WB493 is interpreted as an open campsite consisting of a low-density surficial lithic scatter. The site extends beyond the project boundaries northwest of Galvan Fence. Disturbances include the construction of Galvan Fence and the two roads which parallel the fence through the length of the site, wild animal foraging, and cattle grazing. The surficial nature of the site, the lack of features, and the extensive disturbances identified indicate the research potential of the evaluated area of site 41WB493 is minimal. Based on these observations, the portion of the site within the ROW is recommended as ineligible for inclusion in the NRHP. The remainder of the site could not be investigated. No additional work is recommended within the assessed portion of site 41WB493.

\section{Site 41 WB 494}

Site 41WB494 is located on a relatively level terrace between two unnamed seasonal drainages along the southern half of Pipeline Fence, approximately $1.6 \mathrm{~km}$ southeast of Main Galvan Road (Figure 43; see Figure 9). Elevation at the site is $207 \mathrm{~m}(680 \mathrm{ft})$ amsl. Unnamed seasonal drainages are located $250 \mathrm{~m}$ northwest and $200 \mathrm{~m}$ southeast of the site and Pinto Creek is $3 \mathrm{~km}$ west of the site. Vegetation at the site is relatively sparse and consists of short grasses, mesquite, prickly pear cactus, acacia, and tasajillo. Ground visibility is approximately 80 percent.

The site is a small, low-density lithic scatter measuring approximately $100 \mathrm{~m}$ northwest to southeast and $75 \mathrm{~m}$ northeast to southwest, covering a total area of approximately $7,500 \mathrm{~m}^{2}$. The site was identified in the existing road and extends approximately $40 \mathrm{~m}$ on either side of the road and fence line. The lithic assemblage consists primarily of chert and quartzite flakes, shatter, tested cobbles, and cores. The density of artifacts is approximately five to six artifacts per $25-\mathrm{m}^{2}$ area. No ground stone, diagnostic artifacts, or features were observed at the site.

Since the entire area of site 41WB494 consists of an exposed cobble bed, no area of sedimentation was identified. No shovel test was excavated at site 41WB494. 


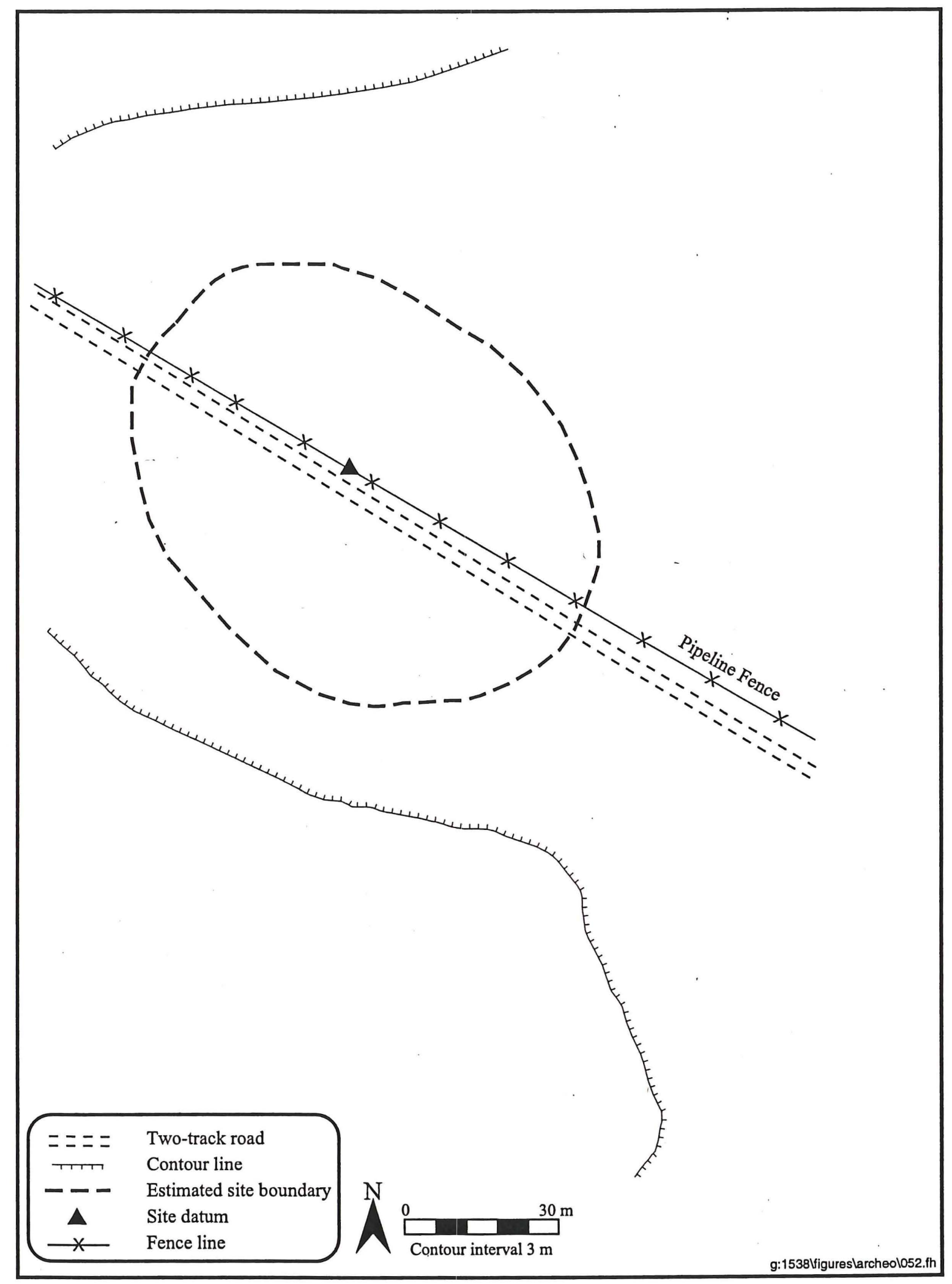

Figure 43. Plan map of site 41WB494. 
Site 41WB494 is interpreted as a quarry site consisting of a low-density; surficial scatter of lithic artifacts. Disturbances include the construction of Pipeline Fence and the parallel two-track road. Wild animal foraging and cattle grazing were also noted. The surficial nature of the site, the lack of features, and the extensive disturbances identified indicate the research potential of site $41 \mathrm{WB} 494$ is minimal. Based on these observations, the site is recommended as ineligible for inclusion in the NRHP. No further work at site 41WB494 is recommended.

\section{Site 41 WB495}

Site 41WB495 is located in an erosional drainage on a north-facing, gradual slope on the northwest side of Main Galvan Road, approximately $100 \mathrm{~m}$ southeast of the northern end of Big Pinto Pasture and Main Galvan roads, in the southwest portion of the Galvan Ranch (Figure 44; see Figure 9). Elevation at the

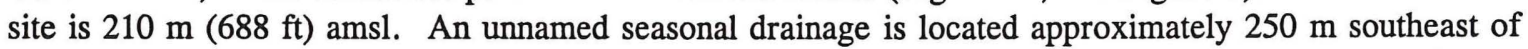
the site and Pinto Creek is $800 \mathrm{~m}$ northwest of the site. Vegetation at the site is sparse and consists of mesquite, prickly pear cactus, tasajillo, and allthorn. Ground visibility is approximately 100 percent.

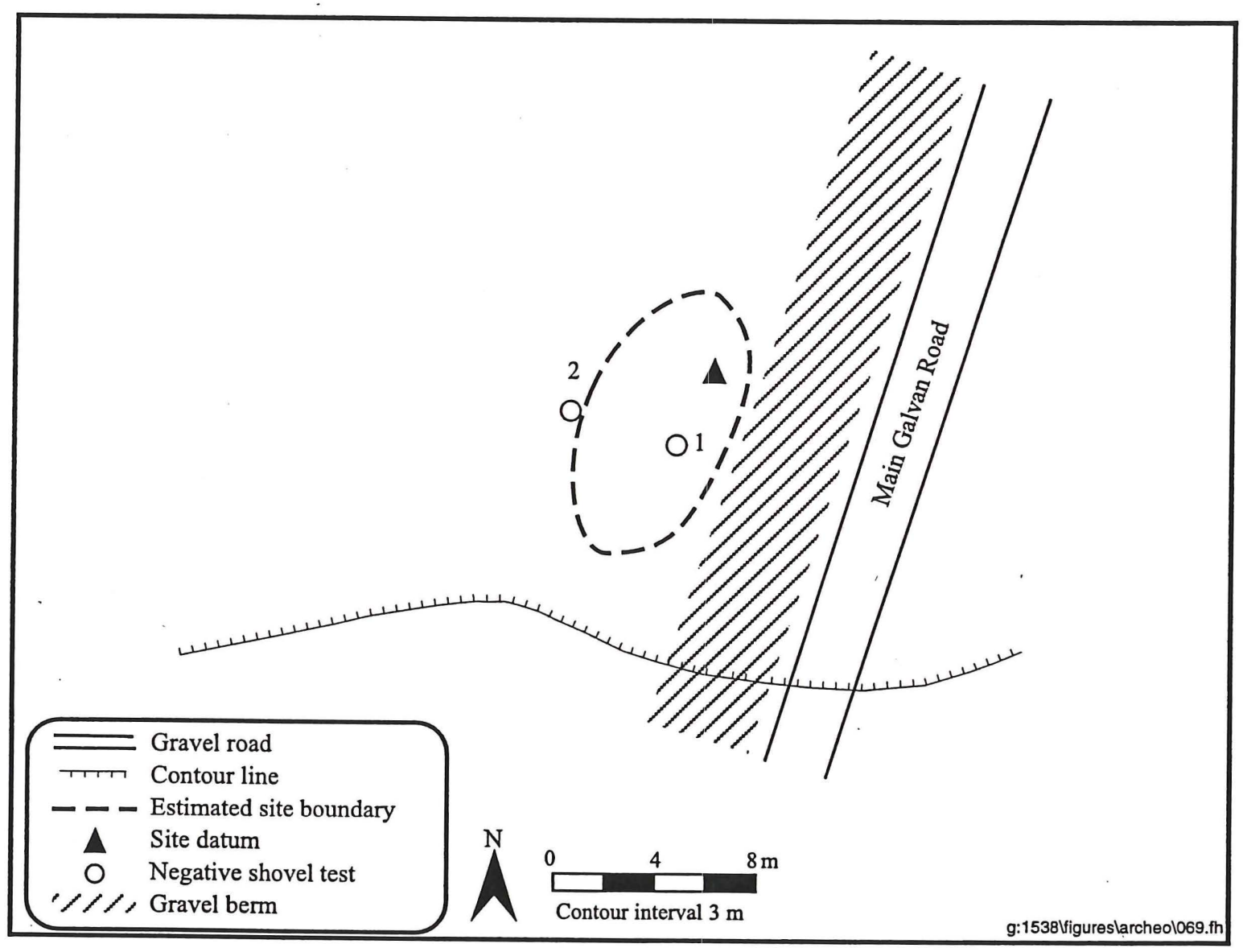

Figure 44. Plan map of site 41WB495. 
The site is a small, low-density lithic scatter measuring approximately $12 \mathrm{~m}$ northeast to southwest and approximately $8 \mathrm{~m}$ northwest to southeast, covering a total area of approximately $96 \mathrm{~m}^{2}$. The lithic assemblage consists primarily of tertiary flakes and a biface. The density of artifacts is approximately six to eight artifacts per $25-\mathrm{m}^{2}$ area. No ground stone, evidence of quarrying, or features were observed at the site. No diagnostic artifacts were identified.

Two shovel tests were excavated at site 41WB495 in order to determine the presence of subsurface cultural deposits. Shovel Test 1 was placed within the proposed ROW in the middle of the site. Shovel Test 2 was placed just west of the identified western boundary of the site. No artifacts were recovered from the shovel tests. Soil at the site consists of brown to dark brown sandy loam to the maximum depth of both shovel tests which was $30 \mathrm{~cm}$ bs.

Site 41WB495 is interpreted as an open campsite consisting of a low-density, surface scatter of lithic artifacts. No subsurface cultural deposits were identified. The site was identified in a rill or old roadbed on the west side of a gravel berm; therefore, between the maintenance of Main Galvan Road and the extensive erosion that has occurred, the site retains little integrity. The lack of features and the extensive disturbances indicate the research potential of site $41 \mathrm{WB} 495$ is minimal. Based on these observations, the site is recommended as ineligible for inclusion in the NRHP. No further work at site 41WB495 is recommended.

\section{Site 41 WB 496}

Site 41WB496 is located on both sides of an unnamed seasonal drainage that runs perpendicular to Main Galvan Road approximately $400 \mathrm{~m}$ northeast of the northern end of Big Pinto Pasture Road (Figure 45; see Figure 9). Elevations at the site range from 201 to $203 \mathrm{~m}(660$ to $665 \mathrm{ft})$ amsl. An unnamed seasonal drainage crosses the northeastern portion of the site and Pinto Creek is approximately $1.0 \mathrm{~km}$ northwest of the site. Vegetation at the site is dense over most of the site and decreases northeast of the drainage. Vegetation includes mesquite, prickly pear cactus, tasajillo, allthorn, barrel cactus, and grasses. Ground visibility is approximately 30 to 40 percent.

The site is a small, low density lithic scatter measuring approximately $130 \mathrm{~m}$ north to south and over 180 $\mathrm{m}$ east to west, extending beyond the project boundary to the west. The identified portion of the site covers a total area of approximately $23,400 \mathrm{~m}^{2}$. The lithic assemblage consists primarily of chert flakes, cores, biface fragments, and a projectile point. Raw material consists of locally available chert. The projectile point was identified as a Refugio, an Archaic unstemmed elongate point (Turner and Hester 1993:178). The density of artifacts is approximately six to eight artifacts per $25-\mathrm{m}^{2}$ area. Two areas of artifact concentrations were noted, a larger area on the south portion of the site and a smaller area on the northeast corner of the site on the far side of the drainage (see Figure 45). No ground stone or features were observed at the site.

Two shovel tests were excavated at site 41WB496 in order to determine the presence of subsurface cultural deposits. Shovel Test 1 was placed within the larger artifact concentration on the west side of Main Galvan Road. This shovel test revealed a shallow subsurface deposit consisting of three chert flakes extending to a depth of $20 \mathrm{~cm}$ bs. Shovel Test 2 was placed within the smaller artifact concentration at the northeast corner of the site, and also resulted in the recovery of three flakes to a depth of $20 \mathrm{~cm}$ bs. Soil at the site consists of brown silty loam with a few gravel inclusions to a depth of approximately 25 to $30 \mathrm{~cm}$ bs, followed by slightly darker more compact brown silty clay. Both shovel 


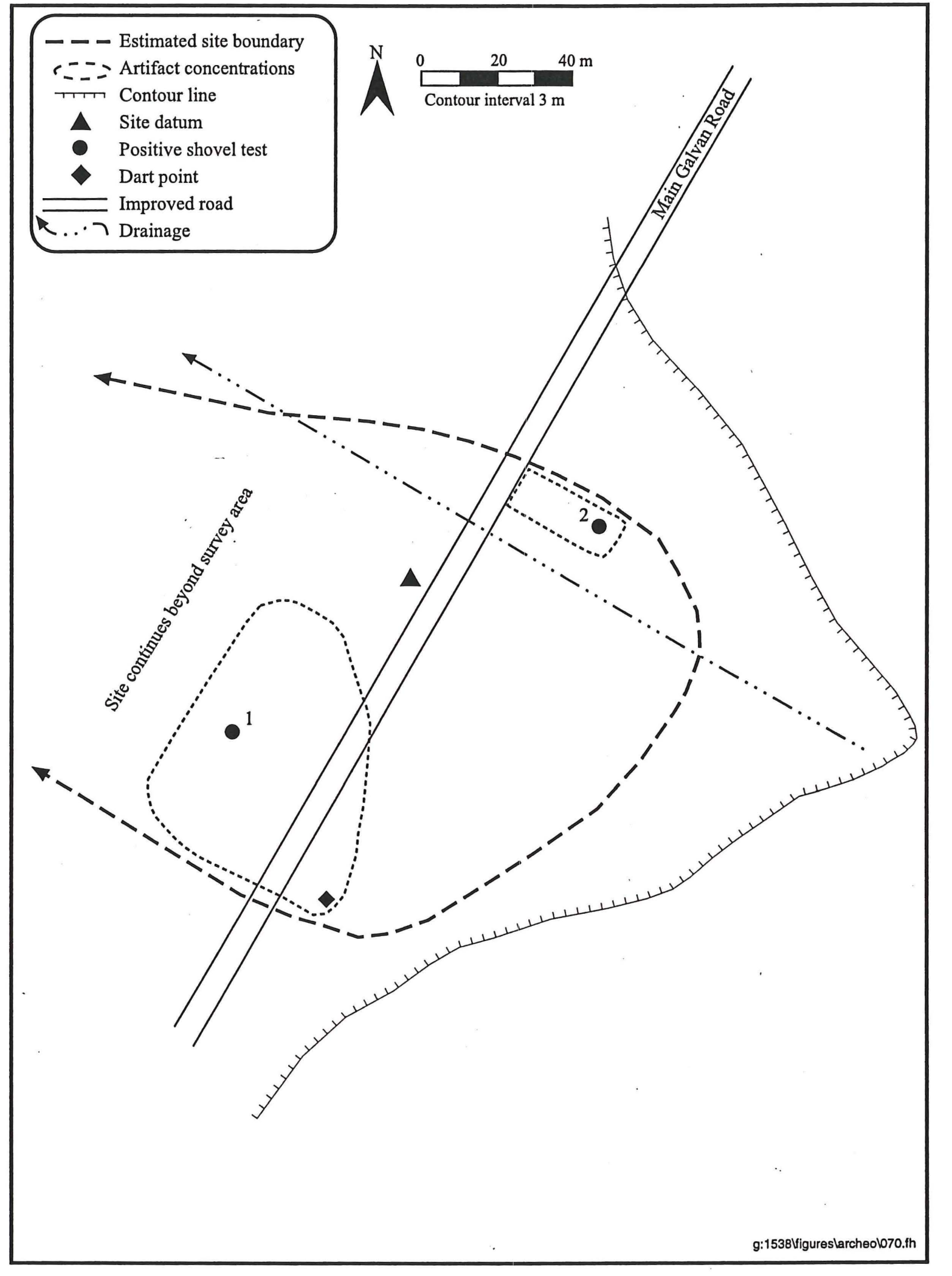

Figure 45. Plan map of site 41WB496. 
tests were excavated to $30 \mathrm{~cm}$ bs. Evidence of disturbance in the form of mechanical earthmoving, erosion, and bioturbation was identified in the first 12 to $15 \mathrm{~cm}$ bs.

Site 41WB496 is interpreted as an open campsite consisting of a low-density surficial scatter of lithic artifacts. Disturbances include the construction and maintenance of Main Galvan Road, extensive erosion, wild animal foraging, and cattle grazing. Although a subsurface deposit was identified, the impacts caused by the construction and maintenance of Main Galvan Road and extensive erosion have left little of the site intact. The lack of integrity and features indicates the research potential of the evaluated area of site 41WB496 is minimal. Based on these observations, the portion of the site within the ROW is recommended as ineligible for inclusion in the NRHP. The remainder of the site could not be investigated. No further work within the assessed portion of site 41 WB496 is recommended.

\section{Site 41 WB 497}

Site 41WB497 is located on a gently sloping surface adjacent to an unnamed seasonal drainage along Trevino Fence in the southeast portion of the Galvan Ranch, approximately $1.2 \mathrm{~km}$ northeast of the intersection of Big Pinto Pasture Road and Trevino Fence (Figure 46; see Figure 9). The site was identified in the existing road and extends beyond the project boundary to the southeast. Elevation at the site is $212 \mathrm{~m}$ (695 ft) amsl. An unnamed seasonal drainage is approximately $60 \mathrm{~m}$ north of the site and Carricitos Creek is approximately $3 \mathrm{~km}$ south. Vegetation in the area of the site is dense and consists of mesquite, prickly pear cactus, tasajillo, and short grass. Ground visibility is approximately 20 to 30 percent.

The site is a small, low-density lithic scatter measuring approximately $120 \mathrm{~m}$ southwest to northeast and over $30 \mathrm{~m}$ northwest to southeast, extending beyond the project boundary to the southeast. The identified portion of the site covers a total area of approximately $3,600 \mathrm{~m}^{2}$. The lithic assemblage consists primarily of secondary and tertiary flakes and shatter of locally available chert. Artifact density ranges from two to three specimens per $25-\mathrm{m}^{2}$ area to approximately 10 specimens per $25-\mathrm{m}^{2}$ area in areas of higher artifact concentrations located west of the existing road (see Figure 46). No ground stone, evidence of quarrying, or features were observed at the site. No diagnostic artifacts were identified.

Two shovel tests were excavated at site 41WB497 in order to determine the presence of subsurface cultural deposits. One shovel test was placed in each of the two areas of higher artifact concentrations. Soil at the site consists of grayish brown to dark grayish brown sandy clay loam to a depth of $5 \mathrm{~cm}$ in Shovel Test 1 and approximately $30 \mathrm{~cm}$ in Shovel Test 2 . This was followed by brown to strong brown clay loam to the maximum depths of the shovel tests, which was $30 \mathrm{~cm}$ bs for Shovel Test 1 and $40 \mathrm{~cm}$ bs for Shovel Test 2. No subsurface cultural deposits were identified.

Site 41WB497 is interpreted as an open campsite consisting of a low-density surficial scatter of lithic artifacts. No subsurface cultural deposits were identified. Disturbances include Trevino Fence and the two-track road paralleling the fence, as well as drainage gullies in an older roadbed that also parallels the fence line. The absence of a subsurface cultural deposit, the lack of features, and the extensive disturbances identified indicate the research potential of the evaluated area of site 41WB497 is minimal. Based on these observations, the portion of the site within the ROW is recommended as ineligible for inclusion in the NRHP. The remainder of the site could not be investigated. No further work within the assessed portion of site $41 \mathrm{WB} 497$ is recommended. 


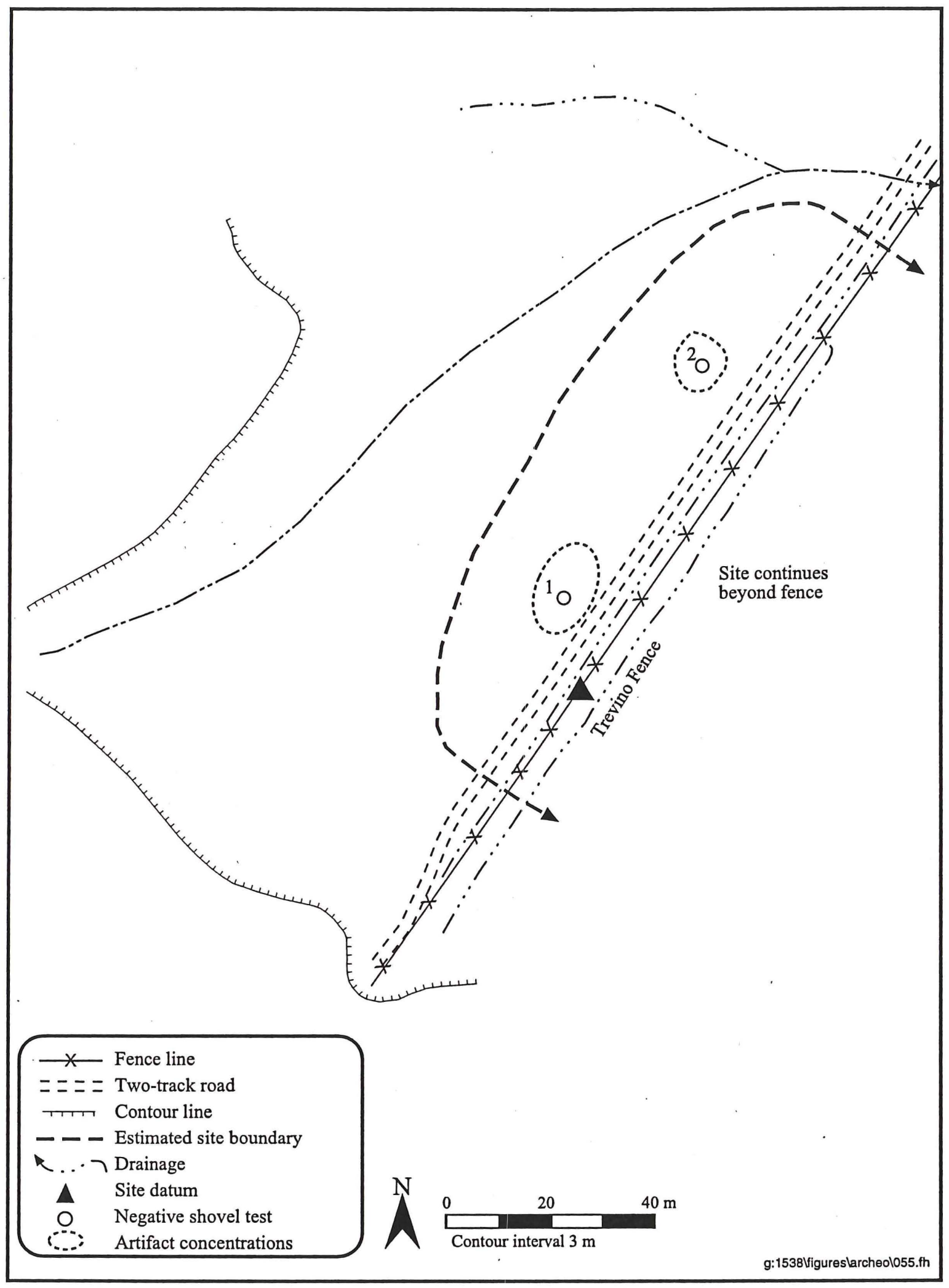

Figure 46. Plan map of site 41WB497. 


\section{Site 41 WB 498}

Site 41 WB498 is located on a small terrace adjacent to an unnamed seasonal drainage along Trevino Fence, approximately $1.5 \mathrm{~km}$ southwest of the intersection of Pipeline Fence and Trevino Fence in the southwest portion of the Galvan Ranch (Figure 47; see Figure 9). Elevation at the site is $208 \mathrm{~m}$ (681 ft) amsl. The above-mentioned seasonal drainage is approximately $30 \mathrm{~m}$ northeast of the site and Pinto Creek is approximately $4.3 \mathrm{~km}$ northwest. Vegetation in the area of the site is sparse and consists of mesquite, prickly pear cactus, tasajillo, and creosote. Ground visibility is approximately 60 to 70 percent.

The site is a small, low-density lithic scatter measuring approximately $17 \mathrm{~m}$ southwest to northeast and $10 \mathrm{~m}$ northwest to southeast, covering a total area of approximately $170 \mathrm{~m}^{2}$. The lithic assemblage consists primarily of tertiary flakes and shatter of locally available chert. Artifact density is approximately five to six specimens per $25-\mathrm{m}^{2}$ area. No ground stone, evidence of quarrying, or features were observed at the site. No diagnostic artifacts were identified.

A single shovel test was excavated at site 41 WB498 in order to determine the presence of subsurface cultural deposits. The shovel test was placed in an area of the site closest to the proposed ROW. Three flakes were identified in the first $10 \mathrm{~cm}$ of the excavation; no other cultural material was recovered. Soil at the site primarily of medium brown sandy loam to a depth of approximately $15 \mathrm{~cm}$ bs, followed by light yellowish brown clay loam to the maximum depth of the shovel test $(35 \mathrm{~cm} \mathrm{bs})$.

Site 41WB498 is interpreted as an open campsite consisting of a low-density, surface scatter of lithic artifacts. A shallow subsurface cultural deposit consisting of three flakes was identified in the first $10 \mathrm{~cm}$ bs. Disturbances consist of erosion and bioturbation. The small size of the site, the shallow nature of the subsurface cultural deposit, and the lack of features indicate the research potential of site 41WB498 is minimal. Based on these observations, the site is recommended as ineligible for inclusion in the NRHP. No further work at site 41WB498 is recommended.

\section{Site 41 WB 499}

Site 41WB499 is located on a gentle, northwest-facing slope along Trevino Fence, approximately $900 \mathrm{~m}$ southwest of the intersection of Pipeline Fence and Trevino Fence, in the southwest portion of Galvan Ranch (Figure 48; see Figure 9). The site extends beyond the property boundary to the southeast. Elevation at the site is $210 \mathrm{~m}(688 \mathrm{ft})$ amsl. An unnamed seasonal drainage is $190 \mathrm{~m}$ northwest of the site and Pinto Creek is approximately $4.5 \mathrm{~km}$ northwest of the site. Vegetation in the area of the site is relatively dense and consists of mesquite, creosote, tasajillo, and short grasses. Ground visibility is approximately 50 percent.

The site is a small, low-density lithic scatter measuring approximately $60 \mathrm{~m}$ southwest to northeast and over $20 \mathrm{~m}$ northwest to southeast, extending beyond the property boundary to the southeast. The identified portion of the site covers a total area of approximately $1,200 \mathrm{~m}^{2}$. The lithic assemblage consists primarily of tertiary flakes, with a few biface fragments, all of locally available chert. The density of artifacts at site 41WB499 is approximately 10 specimens per $25-\mathrm{m}^{2}$ area. No ground stone, features, or evidence of quarrying were observed at the site. No diagnostic artifacts were identified. 


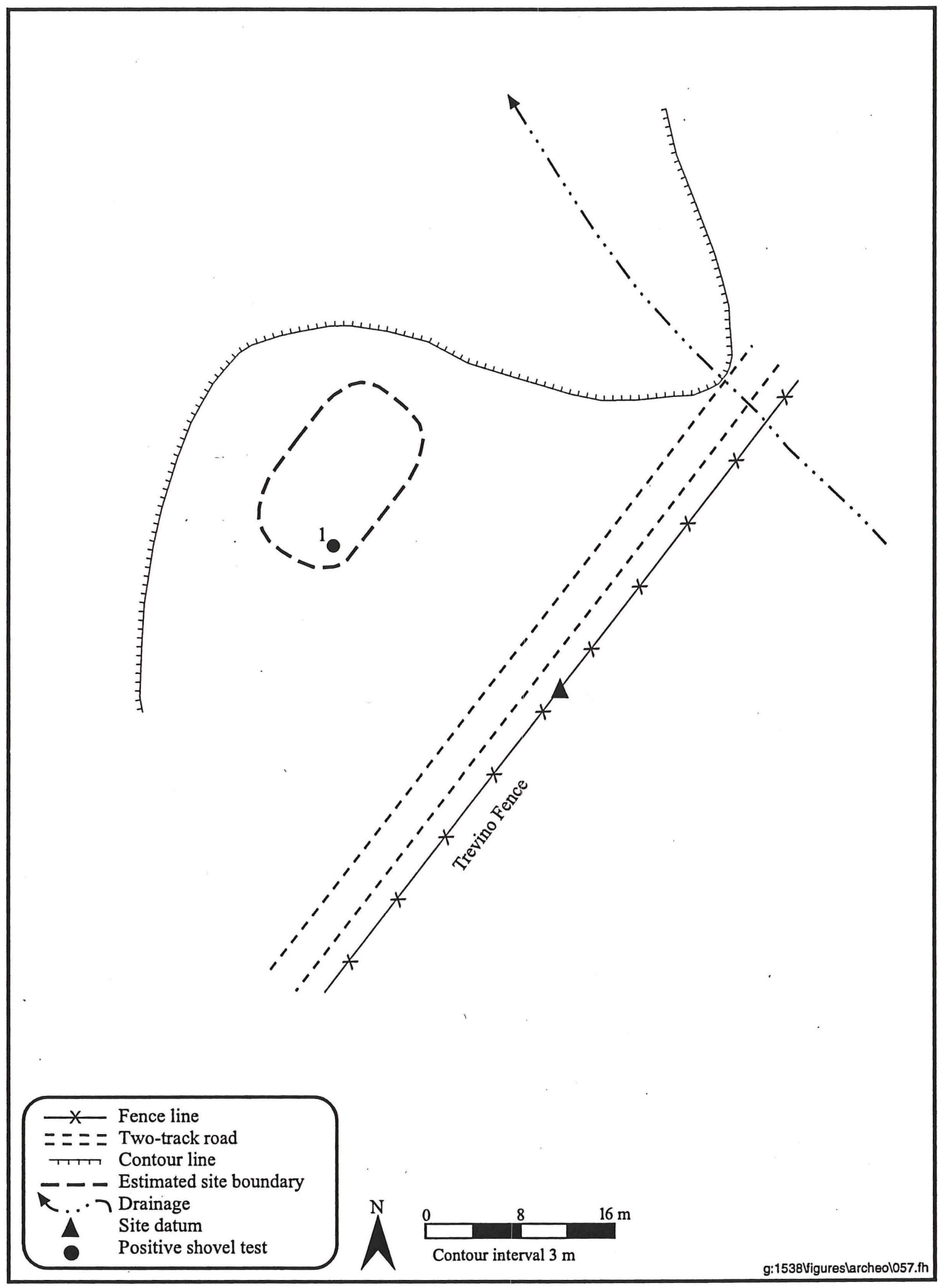

Figure 47. Plan map of site 41 WB498. 


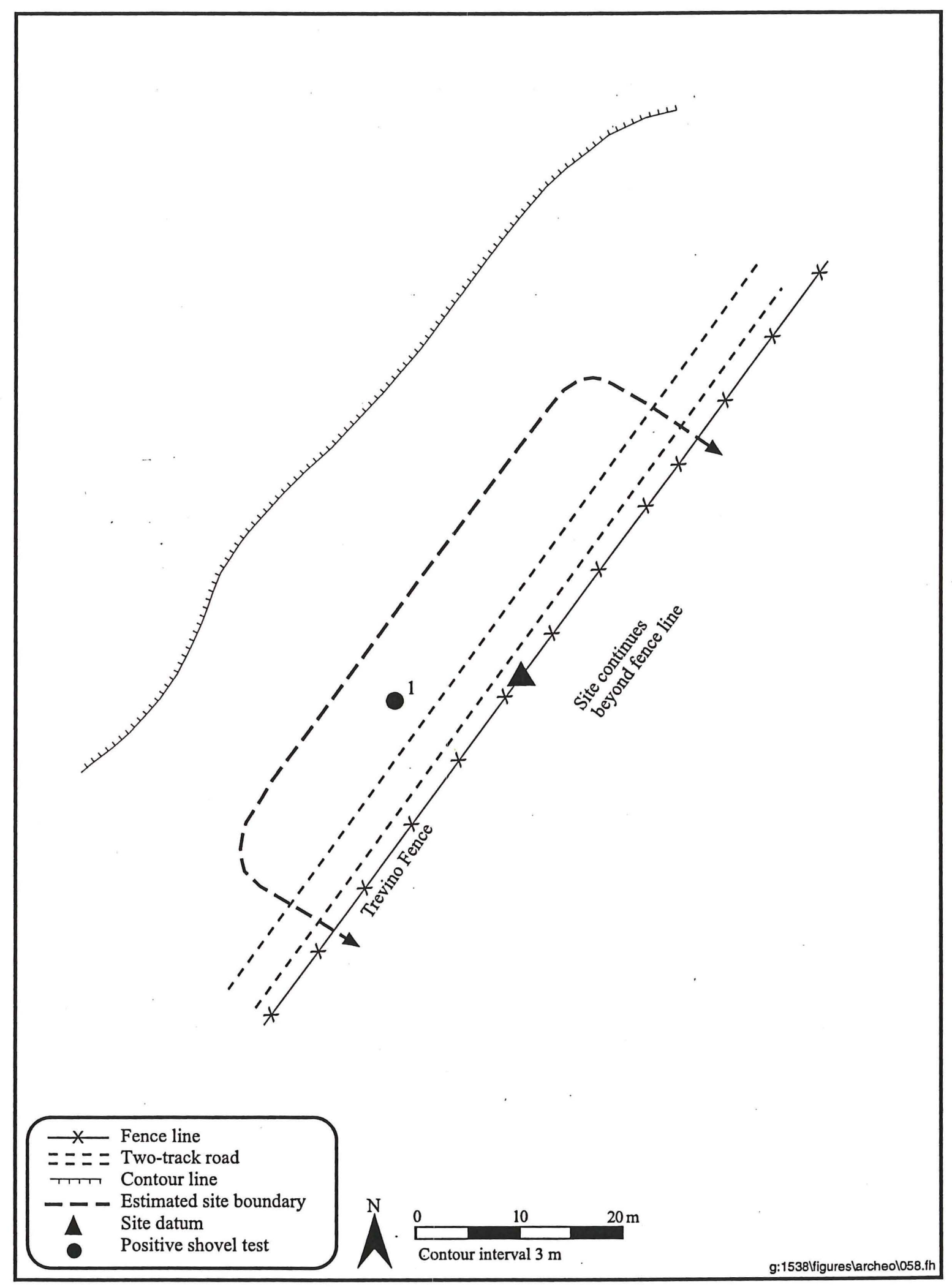

Figure 48. Plan map of site 41WB499. 
A shovel test was excavated at site $41 \mathrm{WB} 499$ in order to determine the presence of subsurface cultural deposits. The shovel test was placed within the proposed ROW approximately $3 \mathrm{~m}$ west of the existing road. Soil at the site consists of medium brown sandy loam, with color becoming lighter below $17 \mathrm{~cm}$ bs. Between 43 and $60 \mathrm{~cm}$ bs, the soil is a dark brown clay loam containing caliche and gravel inclusions. Excavation of the shovel test was terminated at $60 \mathrm{~cm}$ bs. This shovel test produced 17 flakes, revealing a subsurface deposit that extends to a depth of $60 \mathrm{~cm}$ bs.

Site 41 WB499 is interpreted as an open campsite consisting of a low-density, lithic scatter. Although the site has been disturbed by a road cut, a portion of the site appears to be intact. The presence of a subsurface deposit with a depth of $60 \mathrm{~cm}$ indicates the site may have some potential for buried features and/or significant subsurface deposits. Based on the possible research value of the site, the site is recommended as potentially eligible for inclusion in the NRHP. Avoidance of site 41WB499 is recommended by prohibiting additional grading, reworking, or ground disturbance within the limits of the site. The presence of an archeological monitor is recommended in order to keep equipment off of undisturbed portions of site 41WB499 and to ensure that intact portions of the site are not impacted by road improvement activities.

\section{Site 41 WB500}

Site 41WB500 is located on a gradual, northwest-facing slope along Galvan Fence on the west side of Galvan Ranch, approximately 800 m northeast of site 41 WB510 (Figure 49; see Figure 9). The site was identified along the existing fence line and extends northwest and southeast beyond the project boundaries. The proposed new road ROW parallels the northwest side of the existing fence. Elevations at the site range from 183 to $189 \mathrm{~m}(600$ to $620 \mathrm{ft}$ ) amsl. An unnamed seasonal drainage bisects the northern end of the site and Pinto Creek is approximately $600 \mathrm{~m}$ northwest of the site. Vegetation at the site is sparse along the fence due to devegetation but increases toward the drainage in the northern portion of the site. Vegetation includes mesquite, acacia, prickly pear cactus, tasajillo, and short grasses. Ground visibility is approximately 70 percent.

The site is a moderate-density lithic scatter measuring approximately $350 \mathrm{~m}$ northeast to southwest and over $100 \mathrm{~m}$ northwest to southeast, extending beyond the project boundary to the northwest and southeast. The identified portion of the site covers a total area of approximately $35,000 \mathrm{~m}^{2}$. Cobbles and gravels are exposed in terraces across the site. The lithic assemblage consists primarily of primary and secondary flakes, shatter, tested cobbles, cores, and bifaces, one of which had a small, unifacially flaked notch along one side of the tool. All artifacts are of the type and quality of chert and quartzite available onsite. The density of artifacts at site $41 \mathrm{WB} 500$ is approximately $15-20$ specimens per $25-\mathrm{m}^{2}$ area. No ground stone, diagnostic artifacts, or features were observed at the site.

A shovel test was excavated at site 41WB500 in order to determine the presence of subsurface cultural deposits. The shovel test was placed on the southeast side of Galvan Fence. Soil at the site consists of compact, medium brown silty loam to the maximum depth of the shovel test $(40 \mathrm{~cm} \mathrm{bs})$. No subsurface cultural deposits were identified by the shovel testing.

Site 41 WB500 is interpreted as a quarry site consisting of a moderate-density, surficial scatter of lithic artifacts. The site was identified in the proposed ROW along Galvan Fence and extends beyond the property boundary to the northwest and southeast. Disturbances include the construction of Galvan Fence and the clearance of vegetation and vehicular movement paralleling the fence, wild animal foraging, and 


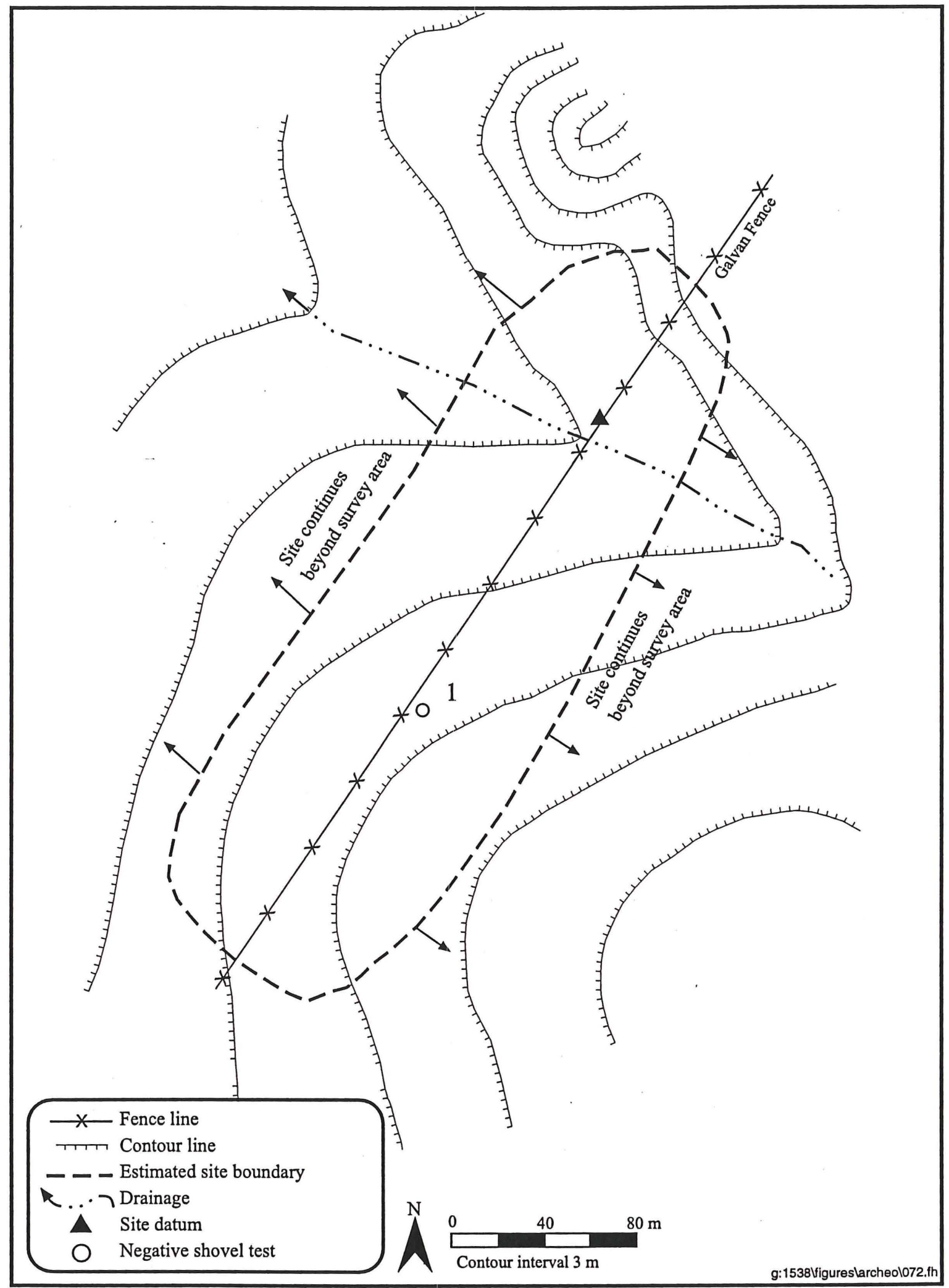

Figure 49. Plan map of site 41WB500. 
cattle grazing. Erosion was also noted resulting in extensive deflation of sediments across the site. The deflated nature of the site, the lack of features, and vehicular and fence line disturbances identified indicate the research potential of the evaluated area of site 41 WB500 is minimal. Based on these observations, this portion of the site is recommended as ineligible for inclusion in the NRHP. The remaining portion of the site located beyond the survey area was not investigated. No further work within the assessed portion of site 41WB500 is recommended.

\section{Site 41 WB501}

Site 41WB501 is located on a steep, northwest-facing slope along Galvan Fence on the west side of Galvan Ranch, approximately 300 m northeast of site 41WB500 (Figure 50; see Figure 9). The site was identified on the steep, exposed bedrock slopes and extends northwest to Pinto Creek. Elevations at the site range from 180 to $189 \mathrm{~m}(590$ to $620 \mathrm{ft}$ ) amsl. Vegetation at the site is sparse on the exposed bedrock slopes but heavy toward Pinto Creek and includes mesquite, acacia, prickly pear cactus, and tasajillo. Ground visibility is approximately 90 percent.

The site is a small, moderate-density lithic scatter measuring approximately $150 \mathrm{~m}$ northeast to southwest and measures over $100 \mathrm{~m}$ northwest to southeast, extending neyond the project boundary to the northwest. the identified portion of the site covers a total area of approximately $15,000 \mathrm{~m}^{2}$. Artifacts are exposed on the bedrock slopes and extend along the heavily eroded slopes toward Pinto Creek to the northwest. Nonartifactual cobbles are exposed across the lower slopes of the site. The lower slopes are bisected with numerous erosional gullies containing artifacts, suggesting the artifacts have washed down from the ridgetop above. The lithic assemblage consists primarily of primary and secondary flakes, shatter, tested cobbles, cores, and bifaces of chert varieties available onsite. The density of artifacts at site 41 WB501 is approximately 15 specimens per $25-\mathrm{m}^{2}$ area. No ground stone, diagnostic artifacts, or features were observed at the site.

Due to extensive erosion, very little soil was evident on the site. The only soil identified was that which had accumulated in small erosional gullies on the lower slopes of the site. Bedrock was exposed across approximately 75 percent of the higher elevations. Due to the deflated nature of the site, no shovel testing was conducted at site 41WB501.

Site 41WB501 is interpreted as a quarry site consisting of a moderate-density, surficial scatter of lithic artifacts. Disturbances include construction of Galvan Fence and extensive erosion resulting in exposed bedrock and cobble lenses. The deflated nature of the site and the lack of features indicate the research potential of site 41WB501 is minimal. Based on these observations, the portion of the site within the ROW is recommended as ineligible for inclusion in the NRHP. The remaining portion of the site located beyond the survey area was not investigated. No further work within the assessed portion of site $41 \mathrm{WB} 501$ is recommended.

\section{Site $41 \mathrm{WB} 502$}

Site 41WB502 is located on a south-facing, gradual slope along Galvan Fence on the west side of Galvan Ranch, approximately $250 \mathrm{~m}$ northeast of site 41WB501 (Figure 51; see Figure 9). The site was identified along the existing northeast-southwest road and fence line. Elevations at the site range from 186 to $192 \mathrm{~m}$ (610 to $630 \mathrm{ft}$ ) amsl. Pinto Creek is approximately $30 \mathrm{~m}$ southwest of the site. Vegetation at the site is sparse and includes mesquite, acacia, prickly pear cactus, tasajillo, and short grasses. Ground visibility is approximately 90 percent. 


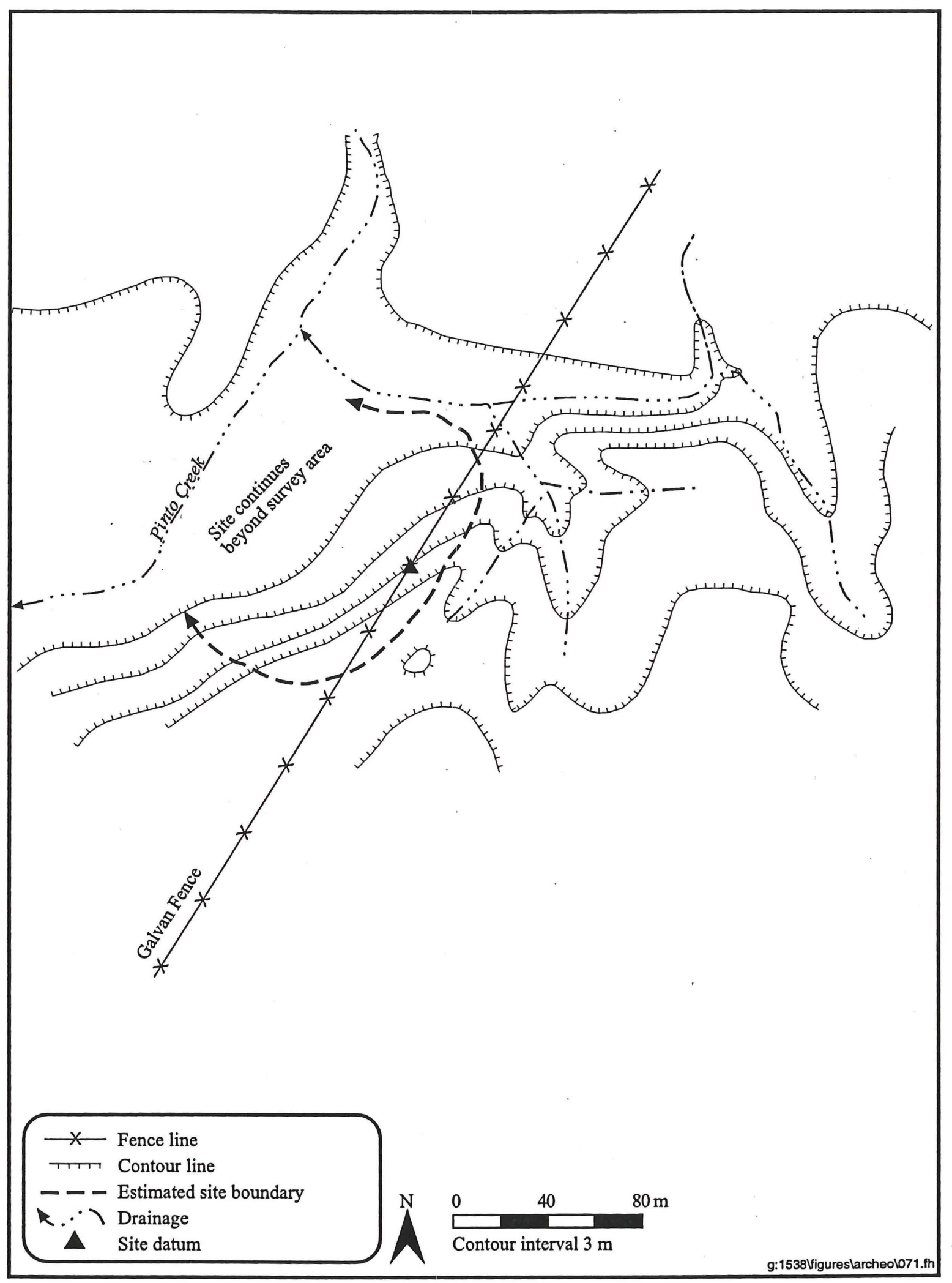

Figure 50. Plan map of site 41WB501. 


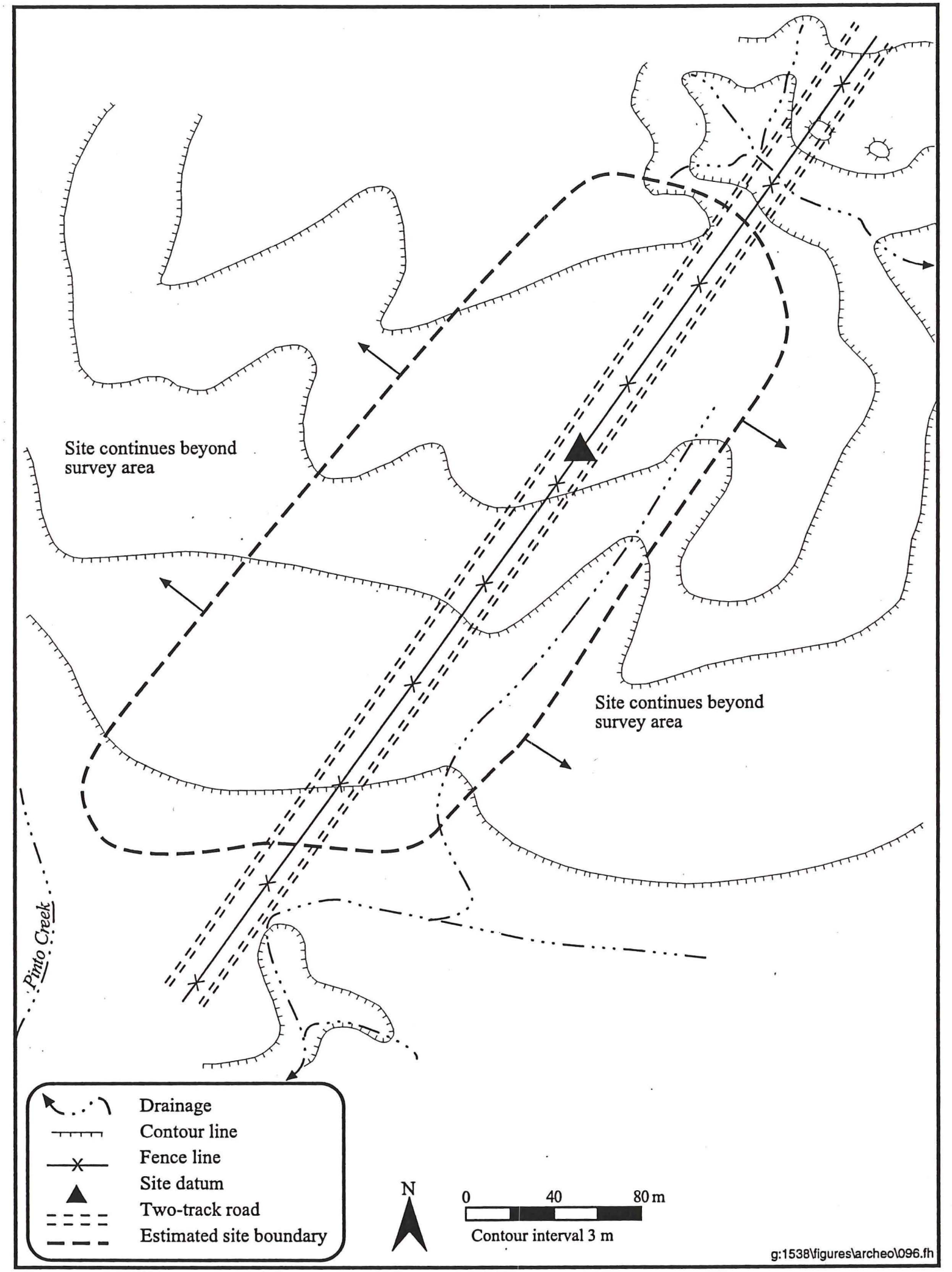

Figure 51. Plan map of site 41WB502. 
The site is a moderate-density lithic scatter measuring approximately $400 \mathrm{~m}$ northeast to southwest and over $150 \mathrm{~m}$ northwest to southeast, covering a total area of approximately $60,000 \mathrm{~m}^{2}$. Cobble and gravel lenses are exposed throughout the site. The lithic assemblage consists primarily of primary and secondary flakes, tested cobbles, cores, and bifaces, all of the type and quality of chert and quartzite available onsite. The density of artifacts at site 41 WB502 is approximately 18 to 20 artifacts per $25-\mathrm{m}^{2}$ area. No ground stone, diagnostic artifacts, or features were observed at the site.

Due to extensive erosion across the entire site, no areas of sedimentation were identified. No shovel testing was conducted.

Site $41 \mathrm{WB} 502$ is interpreted as a quarry site consisting of a moderate-density, surficial scatter of lithic artifacts. The site was identified in the existing road along Galvan Fence and extends beyond the proposed ROW to the northwest and the southeast. Disturbances include Galvan Fence and the two-track roads running parallel to the fence that extend the length of the site. Erosion was also noted resulting in extensive surface deflation with no identifiable areas of sedimentation. The deflated nature of the site, the lack of features, and road and fence line disturbances identified indicate the research potential of the evaluated area of site 41WB502 is minimal. Based on these observations, the portion of the site within the ROW is recommended as ineligible for inclusion in the NRHP. The remainder of the site could not be investigated. No further work within the assessed portion of site 41WB502 is recommended.

\section{Site 41 WB503}

Site 41WB503 is located on a small south-trending ridge along Galvan Fence on the west side of Galvan Ranch, approximately $700 \mathrm{~m}$ west of West Tank and $2.3 \mathrm{~km}$ northeast of 41WB502 (Figure 52; see Figure 9). The site was identified in the existing roadbed and extends approximately $30 \mathrm{~m}$ northwest and $150 \mathrm{~m}$ south from the road. Elevations at the site range from 210 to $213 \mathrm{~m}(690$ to $700 \mathrm{ft}) \mathrm{amsl}$. Unnamed seasonal drainages are located approximately $75 \mathrm{~m}$ southwest and $150 \mathrm{~m}$ southeast of the site and Pinto Creek is $1.2 \mathrm{~km}$ south. Vegetation at the site is moderate and includes mesquite, prickly pear cactus, tasajillo, acacia, and short grasses. Ground visibility is approximately 80 percent.

The site is a low-density lithic scatter measuring approximately $200 \mathrm{~m}$ north to south and $125 \mathrm{~m}$ east to west, covering a total area of approximately $25,000 \mathrm{~m}^{2}$. The site covers a small area of a much larger exposed cobble and gravel bed. The lithic assemblage consists primarily of primary flakes, shatter, tested cobbles, and cores of chert and quartzite available onsite in the form of cobbles and gravels. The density of artifacts at site 41 WB503 is approximately six to eight artifacts per $25-\mathrm{m}^{2}$ area. No ground stone, diagnostic artifacts, or features were observed at the site.

Due to extensive erosion, no areas of sedimentation were identified that could be tested for subsurface deposits. No shovel testing was conducted.

Site $41 \mathrm{WB} 503$ is interpreted as a quarry site consisting of a low-density, surface scatter of lithic artifacts. The site was identified in the proposed ROW on the existing road along Galvan Fence and extends northwest and southeast of the fence. Disturbances include Galvan Fence and the road running parallel to the fence. Erosion was also noted, resulting in extensive surface deflation with no identifiable areas of sedimentation. The deflated nature of the site, the lack of features, and road and fence line disturbances identified indicate the research potential of site 41 WB503 is minimal. Based on these observations, the site is recommended as ineligible for inclusion in the NRHP. No further work at site $41 \mathrm{WB} 503$ is recommended. 


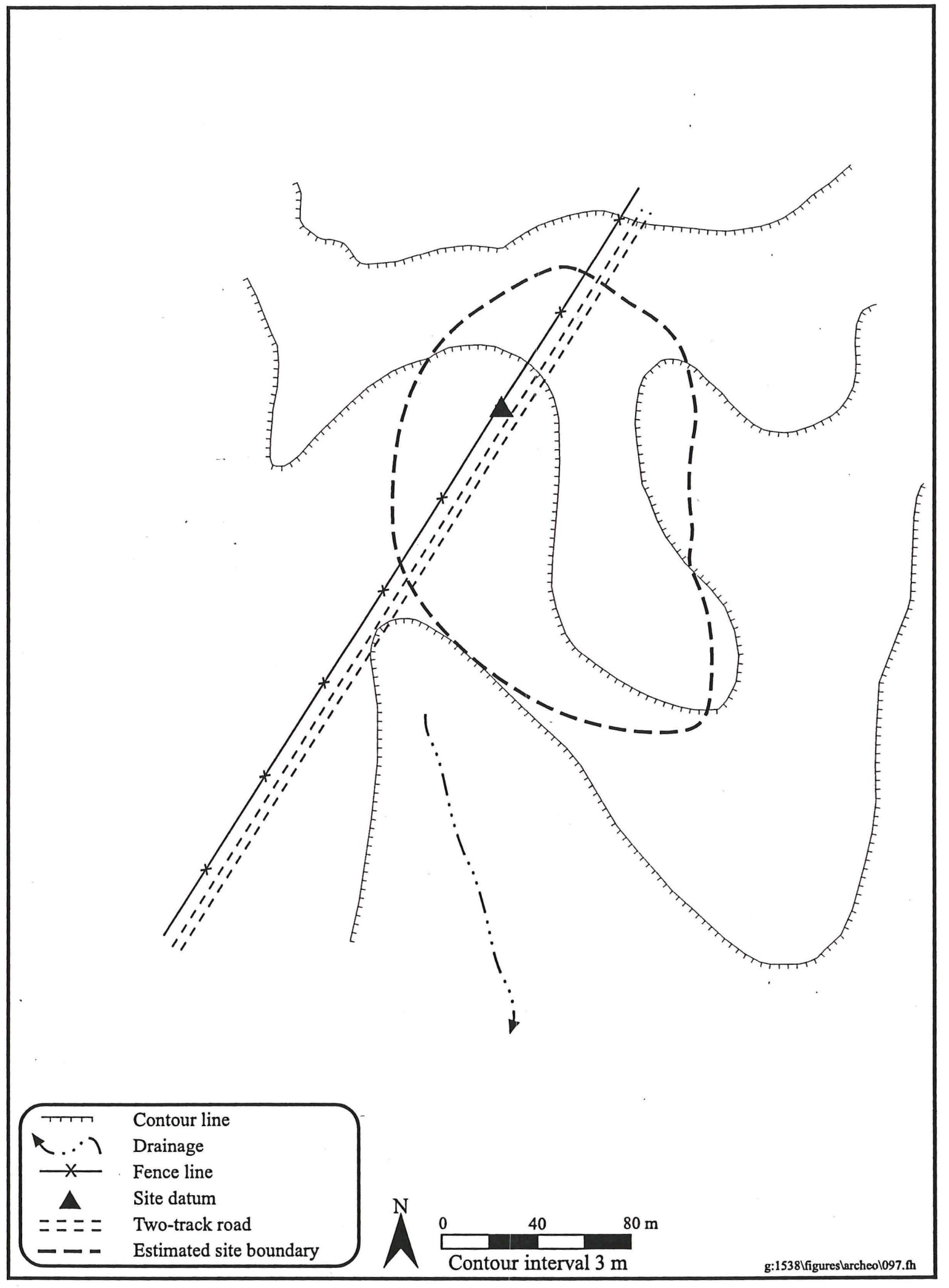

Figure 52. Plan map of site 41WB503. 


\section{Site 41 WB504}

Site 41WB504 is located on a north-facing slope along Trevino Fence, approximately $700 \mathrm{~m}$ southwest of the intersection of Big Pinto Pasture Road and Trevino Fence, in the southwest portion of Galvan Ranch (Figure 53; see Figure 9). The site extends beyond the property boundary to the southeast. Elevation at the site is $216 \mathrm{~m}$ (710 ft) amsl. An unnamed seasonal drainage is $260 \mathrm{~m}$ northeast of the site and Carricitos Creek is approximately $1.5 \mathrm{~km}$ south of the site. Vegetation in the area of the site is moderate in density and includes mesquite, creosote, tasajillo, yucca, and short grasses. Ground visibility is approximately 65 percent.

The site is a small, moderate-density lithic scatter measuring approximately $110 \mathrm{~m}$ southwest to northeast and over $80 \mathrm{~m}$ northwest to southeast, the total area of the site identified is approximately $8,800 \mathrm{~m}^{2}$. The lithic assemblage consists primarily of tertiary flakes, retouched flakes, bifaces, and projectile points and point fragments. Raw material at the site consists primarily of locally available chert. One point was identified as a Catán, a round-based point that dates from the Late Archaic to the Late Prehistoric periods (Turner and Hester 1993; 89). The two other points observed at the site are similar to the Early Triangular/Tortugas/Matamoros group of point types (Turner and Hester 1993:110, 153, 188). Dates on this group of points range from Early Archaic (Early Triangular points) through the late Middle Archaic (Tortugas), and from the Late Archaic to the Late Prehistoric (Matamoros) (Turner and Hester 1993:110, $153,188)$. The projectile point fragments could not be typed due to fragmentation. All projectile points and point fragments were of chert. The density of artifacts at site 41WB504 is approximately 12 to 15 specimens per $25-\mathrm{m}^{2}$ area. No ground stone, features, or evidence of quarrying were observed at the site.

Two shovel tests were excavated at site 41WB504 in order to determine the presence of subsurface cultural deposits. Shovel Test 1 was placed within the proposed ROW immediately west of the existing road. Shovel Test 2 was placed in the northwest corner of the site. The soil revealed in Shovel Test 1 consists of dark brown sandy clay loam to a depth of approximately $25 \mathrm{~cm}$ bs, followed by a slightly lighter, more compact sandy clay loam to a depth of $43 \mathrm{~cm}$. Below $43 \mathrm{~cm}$, the soil is a mottled brown and pinkish white sandy clay loam with caliche inclusions; Shovel Test 1 was excavated to a depth of 50 $\mathrm{cm}$ bs. This shovel test produced 15 flakes, revealing a subsurface deposit that extends to a depth of 43 $\mathrm{cm}$ bs. Shovel Test 2 revealed little soil variation to a depth of $80 \mathrm{~cm}$ bs; the soil is light yellowish brown sandy silt throughout the profile and no cultural material was identified.

Site 41WB504 is interpreted as an open campsite consisting of a moderate-density, surficial lithic scatter. Although the site has been disturbed by road cuts on both sides of the existing fence line, a large portion of the site appears to be intact. The presence of a subsurface deposit greater than $40 \mathrm{~cm}$ in depth indicates the site may have some potential for buried features and/or significant subsurface deposits. Based on the possible research value of the site, the site is recommended as potentially eligible for inclusion in the NRHP. Avoidance of site 41WB504 is recommended by prohibiting additional grading, reworking, or ground disturbance within the limits of the site. The presence of an archeological monitor is recommended in order to keep equipment off of site 41WB504 and to ensure that intact portions of the site are not impacted by road improvement activities. 


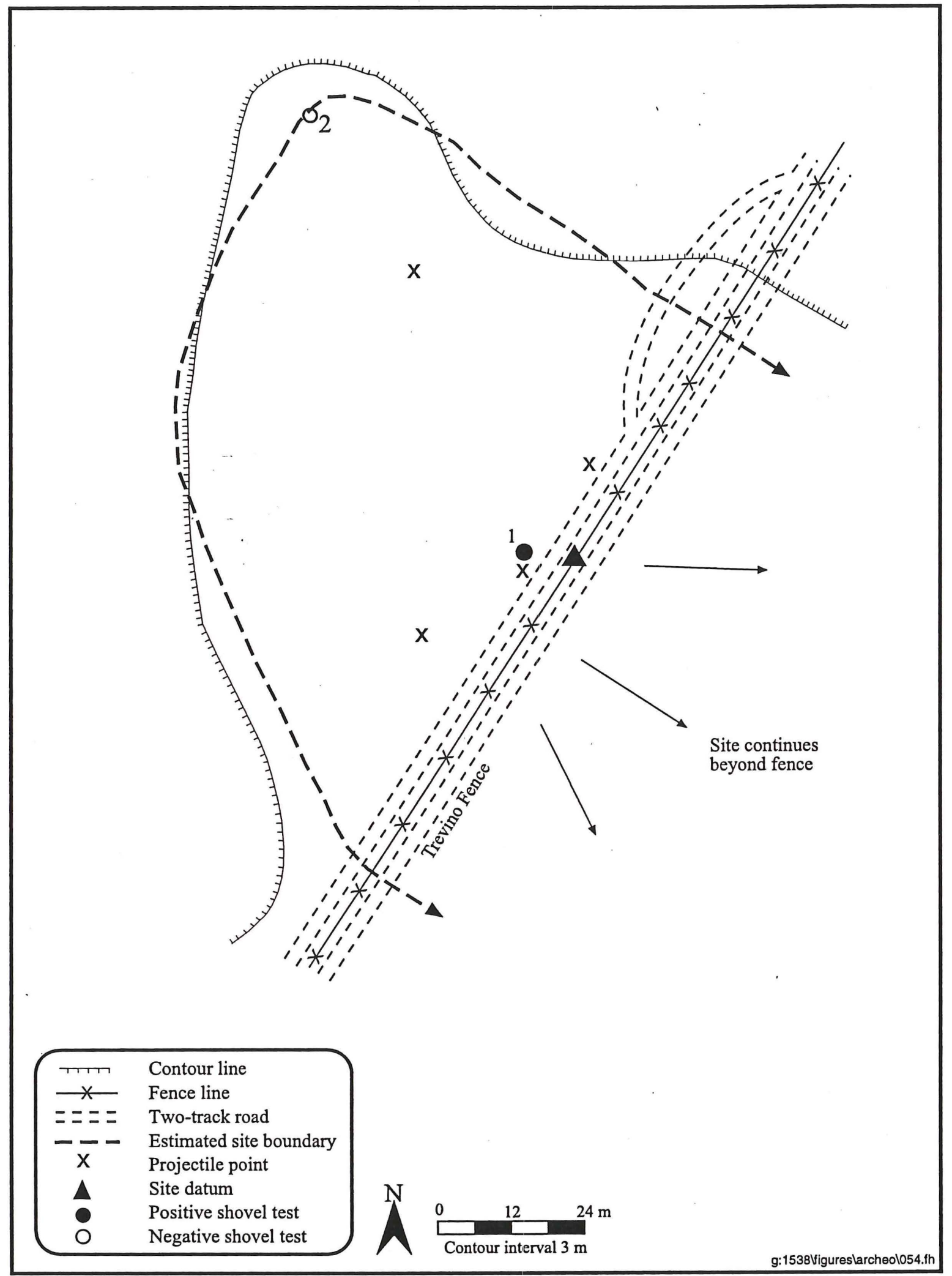

Figure 53. Plan map of site $41 \mathrm{WB} 504$. 


\section{Site 41WB505}

Site 41WB505 is located on the northwest side of Galvan Ranch Road on the lower, southern slope of a prominent north-south ridge (Figure 54; see Figure 9). The site is approximately $1.25 \mathrm{~km}$ northeast of Chapote Pasture Road, in the southwest portion of the Galvan Ranch. Elevation at the site is $203 \mathrm{~m}$ (665 $\mathrm{ft}$ ) amsl. An unnamed seasonal drainage is located approximately $80 \mathrm{~m}$ southeast of the site and Pinto Creek is approximately $1.6 \mathrm{~km}$ northwest of the site. Vegetation at the site is moderately dense and includes mesquite, prickly pear cactus, tasajillo, and allthorn. Ground visibility is approximately 70 percent.

The site is a small, low-density lithic scatter measuring approximately $50 \mathrm{~m}$ east to west and approximately $25 \mathrm{~m}$ north to south, covering a total area of approximately $1,250 \mathrm{~m}^{2}$. The lithic assemblage consists primarily of tertiary flakes, cores, and bifaces, all of locally available chert. The density of artifacts is approximately six to eight artifacts per $25-\mathrm{m}^{2}$ area. No ground stone, diagnostic artifacts, or features were observed at the site.

A shovel test was excavated at site 41WB505 in order to determine the presence of subsurface cultural deposits. The shovel test was placed within the proposed ROW approximately $8 \mathrm{~m}$ west of Main Galvan Road. A shallow subsurface deposit was identified with the recovery of two flakes and a piece of shatter to a depth of $20 \mathrm{~cm}$ below present ground surface. Soil at the site consists of yellowish brown sandy loam to a depth of $20 \mathrm{~cm}$ bs, followed by compact, light yellowish brown clay loam to the maximum depth of the shovel test (40 $\mathrm{cm}$ bs).

Site 41WB505 is interpreted as an open campsite consisting of a low-density, surficial scatter of lithic artifacts. Disturbances include the construction and maintenance of Main Galvan Road, extensive erosion, wild animal foraging, and cattle grazing. Although a subsurface deposit was identified, the impacts caused by Main Galvan Road have left little of the site intact. The small size of the site, as well as the lack of integrity and features indicate the research potential of site 41WB505 is minimal. Based on these observations, the site is recommended as ineligible for inclusion in the NRHP. No further work at site $41 \mathrm{WB} 505$ is recommended.

\section{Site 41 WB506}

Site 41WB506 is located on a small northeast-facing terrace remnant overlooking an unnamed seasonal drainage along Main Galvan Road, approximately $250 \mathrm{~m}$ northeast of the. southeast end of Chapote Pasture Road in the western portion of the Galvan Ranch (Figure 55; see Figure 9). The site was identified along the southeast side of Main Galvan Road and is bordered on the east and west by erosional gullies. Elevation at the site is $193 \mathrm{~m}(632 \mathrm{ft})$ amsl. Unnamed seasonal drainages are located approximately $100 \mathrm{~m}$ north and southeast of the site and Pinto Creek is approximately $1.2 \mathrm{~km}$ northwest. Vegetation in the area of the site is sparse and consists of mesquite, prickly pear cactus, and other cacti. Ground visibility is approximately 80 percent.

The site is a small, low-density lithic scatter measuring approximately $40 \mathrm{~m}$ west to east and over $80 \mathrm{~m}$ north to south. The identified portion of the site covers an area of approximately $3,200 \mathrm{~m}^{2}$. The lithic assemblage consists primarily of flakes and shatter. Artifact density is approximately eight to 10 specimens per $25-\mathrm{m}^{2}$ area. No ground stone, evidence of quarrying, or features were observed at the site. No diagnostic artifacts were identified. 


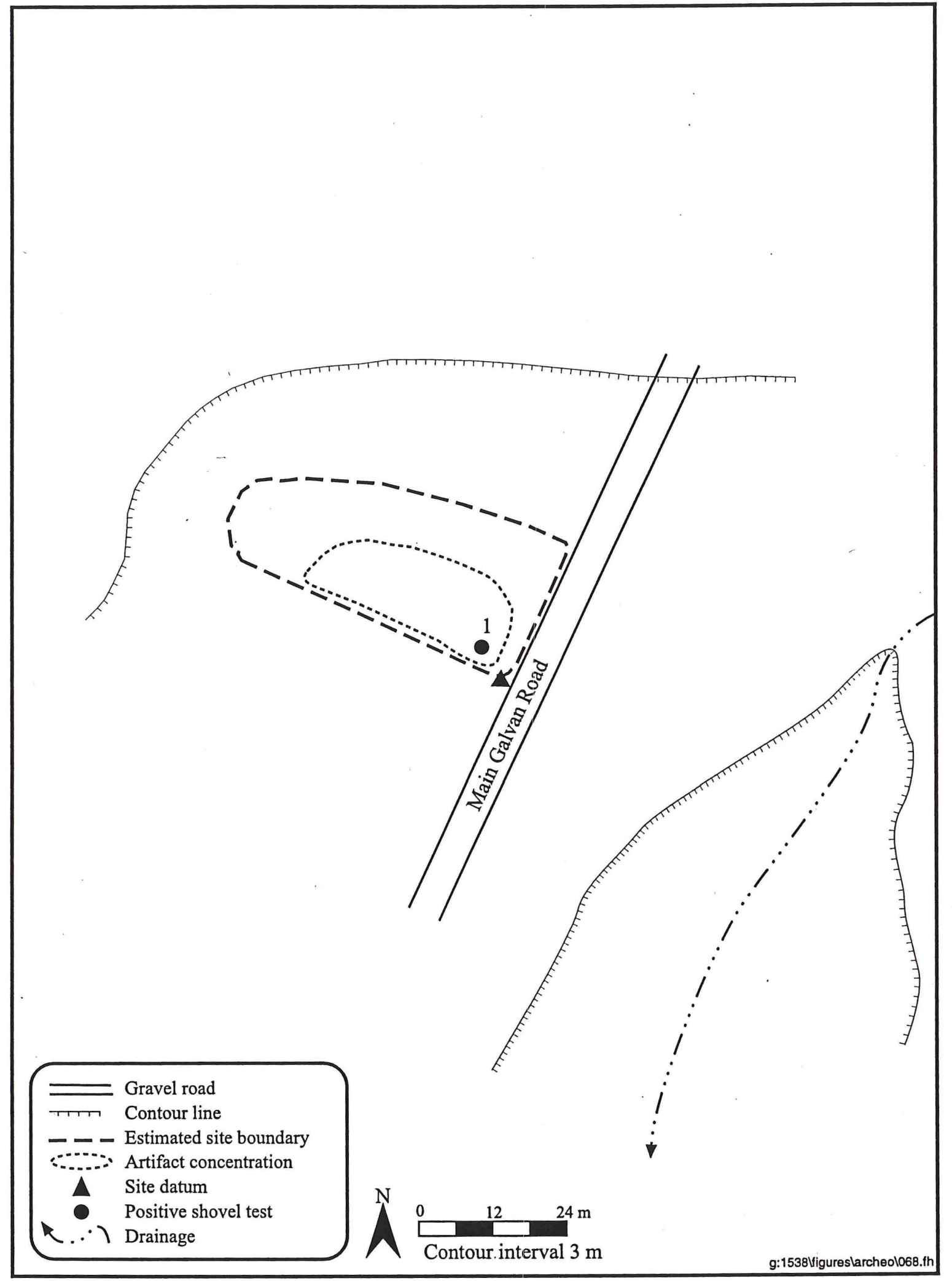

Figure 54. Plan map of site 41WB505. 


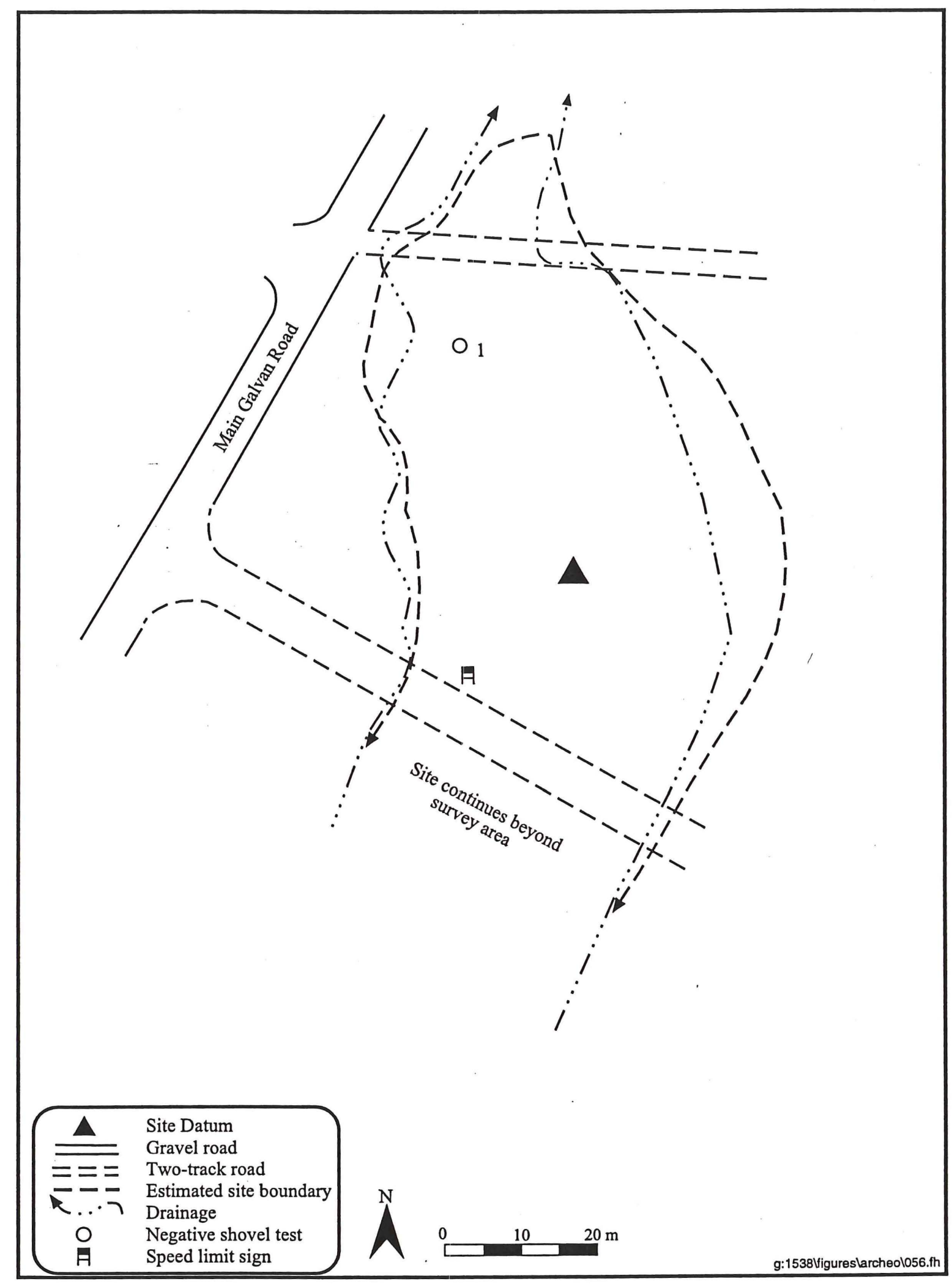

Figure 55. Plan map of site 41 WB506. 
A shovel test, placed in the proposed ROW on the southeast side of Main Galvan Road, was excavated in order to determine the presence of subsurface cultural deposits. Soil at the site consists of medium brown silty clay loam to a depth of $20 \mathrm{~cm}$ bs, followed by very compact, medium brown clay loam. No subsurface cultural deposits were identified.

Site 41WB506 is interpreted as an open campsite consisting of a low-density, surficial scatter of lithic artifacts. No subsurface cultural deposits were identified. Disturbances include the construction and maintenance of Main Galvan Road, two-track roads extending east and southeast from the main road through the north and south edges of the site, as well as drainage gullies on the east and west sides of the site. The absence of a subsurface cultural deposit, the lack of features, and the extensive disturbances identified indicate the research potential of the evaluated area of site 41WB506 is minimal. Based on these observations, the portion of the site within the ROW is recommended as ineligible for inclusion in the NRHP. The remainder of the site could not be investigated. No further work within the assessed portion of site 41WB506 is recommended.

\section{Site 41 WB507}

Site 41WB507 is located on a terrace above an unnamed seasonal drainage along Main Galvan Road, approximately $900 \mathrm{~m}$ northeast of Chapote Fence, in the southwest portion of the Galvan Ranch (Figure 56; see Figure 9). Elevations at the site range from 201 to $203 \mathrm{~m}$ (660 to $665 \mathrm{ft}$ ) amsl. An unnamed seasonal drainage is located approximately $200 \mathrm{~m}$ southwest of the site and Pinto Creek is $3.2 \mathrm{~km}$ northwest of the site. Vegetation at the site is moderately dense and includes mesquite, prickly pear cactus, tasajillo, soapbush, and short grasses. Ground visibility is approximately 70 to 80 percent.

The site is a small, low-density lithic scatter measuring approximately $200 \mathrm{~m}$ southwest to northeast and approximately $110 \mathrm{~m}$ northwest to southeast, covering a total area of approximately $22,000 \mathrm{~m}^{2}$. The lithic assemblage consists primarily of chert secondary and tertiary flakes, cores, and bifaces. The density of artifacts is approximately six to eight artifacts per $25-\mathrm{m}^{2}$ area. No ground stone, diagnostic artifacts, or features were observed at the site.

A shovel test was excavated at site 41WB507 in order to determine the presence of subsurface cultural deposits. The shovel test was placed within the proposed ROW approximately $15 \mathrm{~m}$ northwest of Main Galvan Road. A shallow subsurface deposit was identified with the recovery of two flakes and a piece of shatter to a depth of $20 \mathrm{~cm}$ below present ground surface. Soil at the site consists of pale brown silty loam to a depth of $8 \mathrm{~cm}$ bs, followed by brown to strong brown sandy silt loam. Subsoil was encountered below $20 \mathrm{~cm}$ bs, consisting of a very compact, light gray clay loam with brown mottling and caliche inclusions.

Site 41WB507 is interpreted as an open campsite consisting of a low-density, surficial scatter of lithic artifacts. Disturbances include the construction and maintenance of Main Galvan Road impacting approximately 30 to 40 percent of the site. Evidence of wild animal foraging and cattle grazing were also noted. Although a shallow, subsurface deposit was identified, such a large percentage of the site has been impacted that little of the site appears to retain an intact deposit. The lack of integrity of the site and the lack of features indicate the research potential of site 41WB507 is minimal. Based on these observations, the site is recommended as ineligible for inclusion in the NRHP. No further work at site $41 \mathrm{WB} 507$ is recommended. 


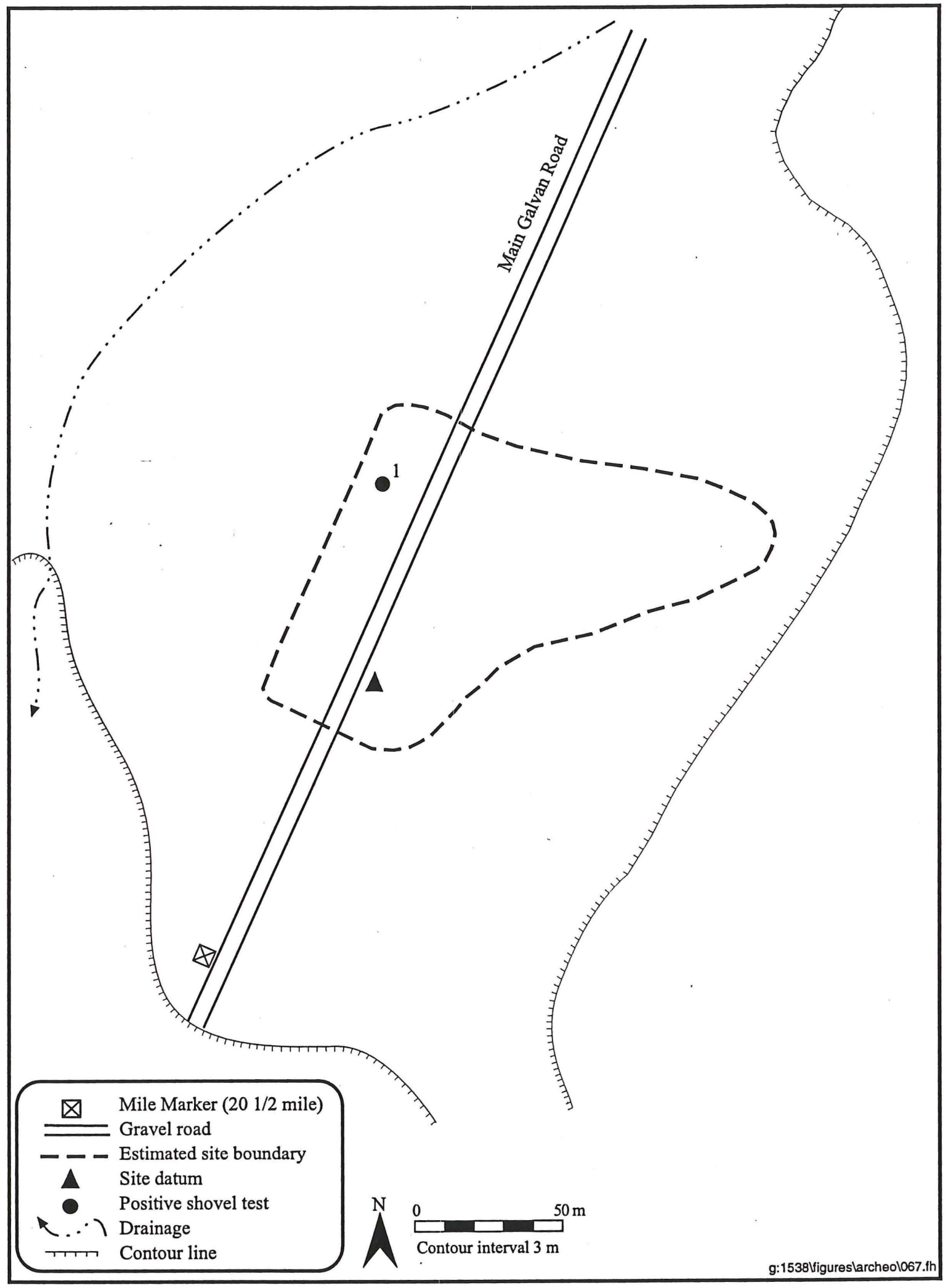

Figure 56. Plan map of site 41WB507. 


\section{Site 41 WB508}

Site 41WB508 is located on a small saddle on the southwest side of Chapote Fence directly northwest of the intersection with Galvan Ranch Road, in the southwest portion of the Galvan Ranch (Figure 57; see Figure 9). The site was identified in the existing road that parallels Chapote Fence and extends beyond the project boundaries to the north. Elevation at the site is $194 \mathrm{~m}(635 \mathrm{ft})$ amsl. Unnamed seasonal drainages are located within $100 \mathrm{~m}$ both northwest and southeast of the site and Pinto Creek is approximately $3.5 \mathrm{~km}$ northwest of the site. Vegetation growth in the area of the site is sparse and consists of mesquite, prickly pear cactus, tasajillo, allthorn, and soapbush. Ground visibility is approximately 80 percent.

The site is a small, low-density lithic scatter measuring approximately $55 \mathrm{~m}$ northwest to southeast and over $25 \mathrm{~m}$ southwest to northeast, extending beyond the project boundaries to the northeast. The identified portion of the site covers a total area of approximately $1,375 \mathrm{~m}^{2}$. The lithic assemblage consists primarily of tertiary flakes, shatter, cores, and bifaces of locally available chert. Artifact density is approximately six to eight specimens per $25-\mathrm{m}^{2}$ area. No ground stone, evidence of quarrying, or features were observed at the site. No diagnostic artifacts were identified at the site.

A single shovel test was excavated at site $41 \mathrm{WB} 508$ in order to determine the presence of subsurface cultural deposits. The test was placed in the proposed ROW approximately $10 \mathrm{~m}$ south of the road paralleling Chapote Fence. A shallow subsurface deposit was identified with the recovery of a single flake at $10 \mathrm{~cm}$ below present ground surface. Soil at the site consists of brown sandy clay loam to a depth of $6 \mathrm{~cm}$ bs, followed by dark grayish brown sandy clay loam to a depth of $20 \mathrm{~cm}$ bs. Below the 20-cm level, the soil becomes more compact and exhibits caliche inclusions.

Site 41WB508 is interpreted as an open campsite consisting of a low-density, surface scatter of lithic artifacts. A sparse, shallow subsurface cultural deposit was identified. Disturbances include erosion, the construction of Chapote Fence and the two-track road paralleling the fence, as well as wild animal foraging and cattle grazing. The sparse nature of the site, the lack of features, and the extensive disturbances identified indicate the research potential of the evaluated area of site 41WB508 is minimal. Based on these observations, this portion of the site is recommended as ineligible for inclusion in the NRHP. The remaining portion of the site located beyond the survey area was not investigated. No further work within the assessed portion of site 41WB508 is recommended.

\section{Site 41 WB509}

Site 41WB509 is located on a southwest-facing, gradual slope at the northwest end of Chapote Fence, approximately $175 \mathrm{~m}$ southeast of Galvan Fence, in the southwest portion of the Galvan Ranch (Figure 58; see Figure 9). The site was identified south of the existing road that parallels Chapote Fence and

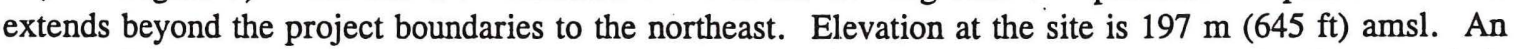
unnamed seasonal drainage is located approximately $450 \mathrm{~m}$ southwest of the site and Pinto Creek is approximately $2 \mathrm{~km}$ north of the site. Vegetation growth in the area of the site is sparse and consists of mesquite, tasajillo, soapbush, allthorn, and purple sage. Ground visibility is approximately 90 percent. 


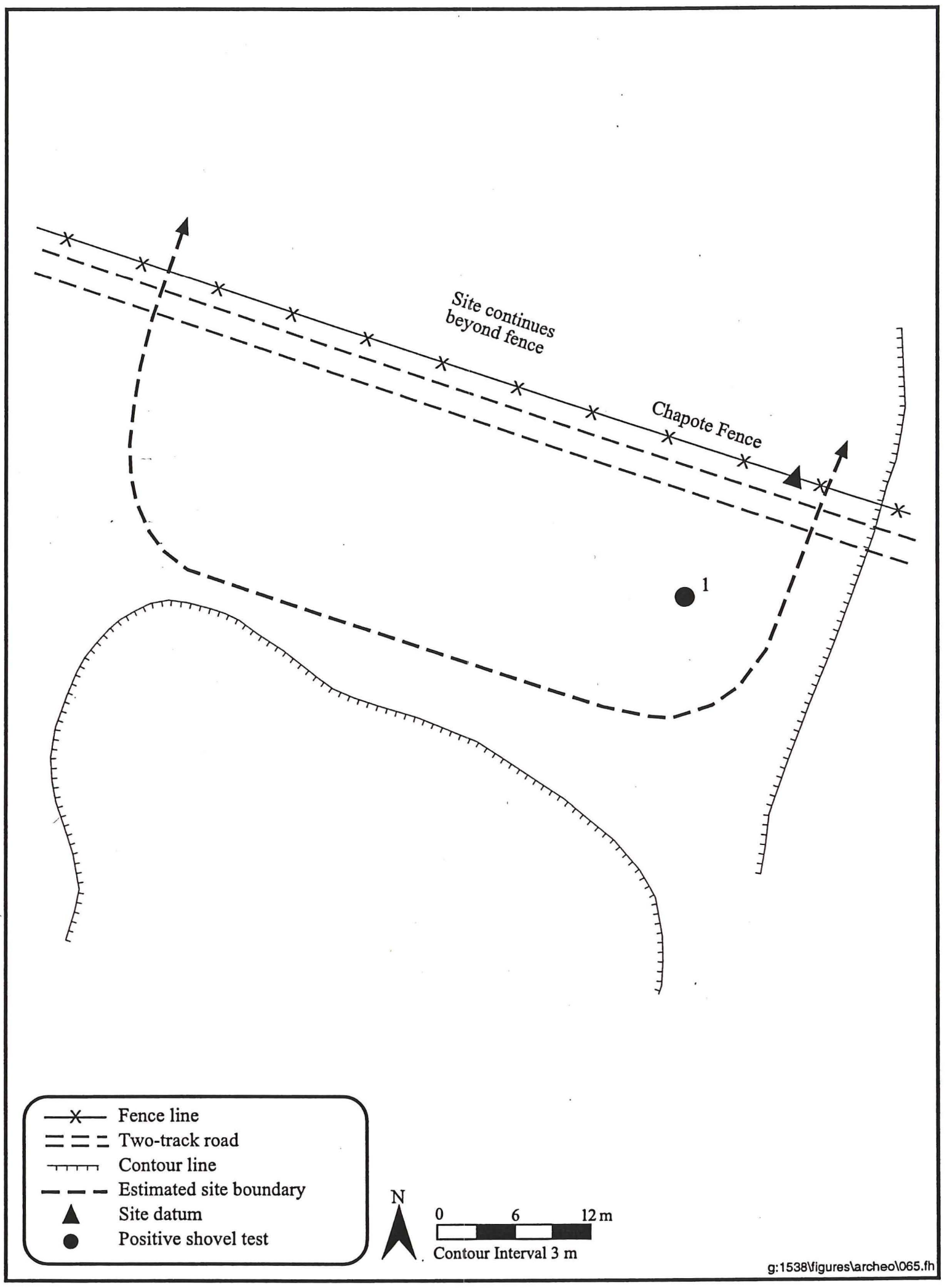

Figure 57. Plan map of site 41WB508. 


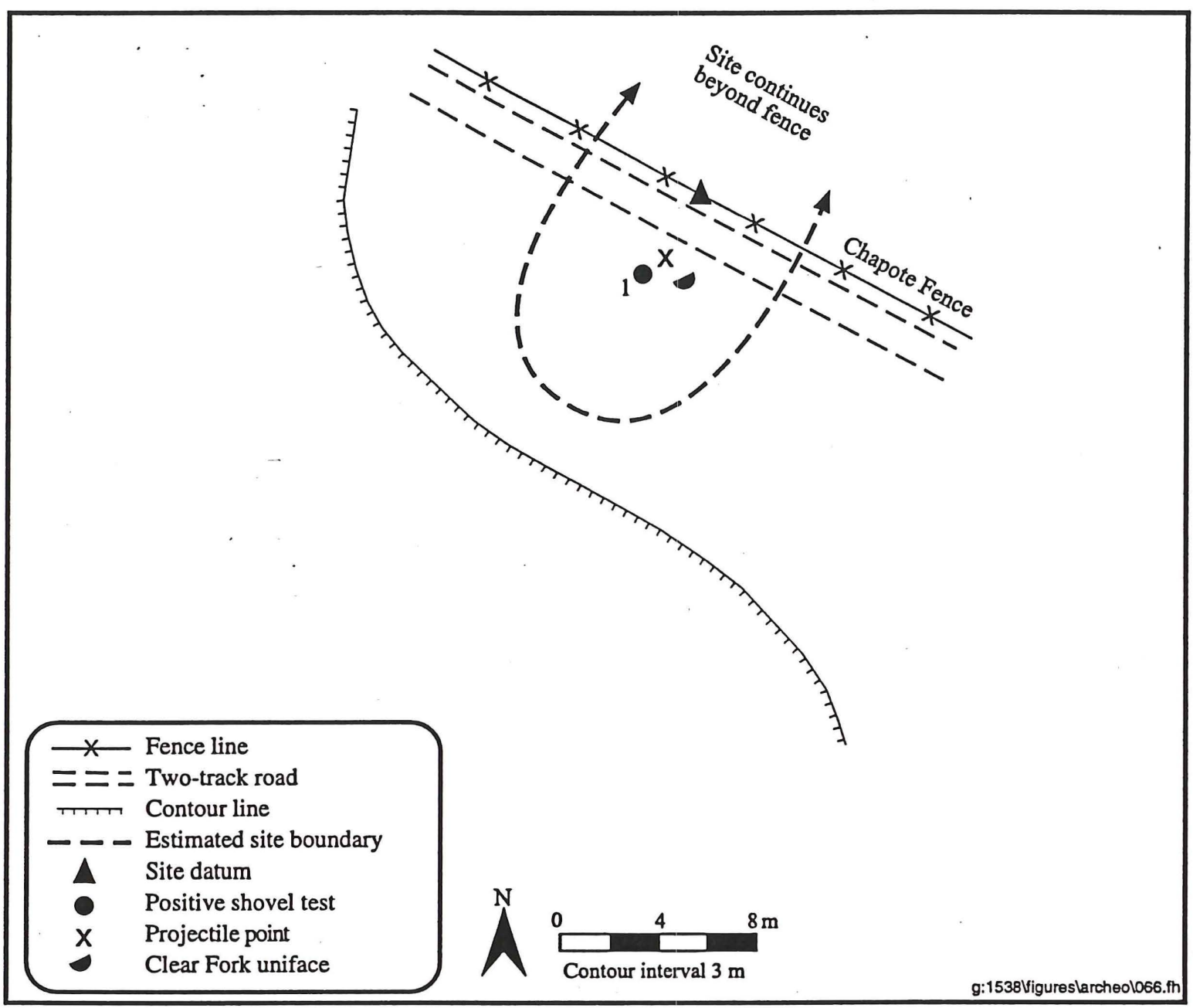

Figure 58. Plan map of site 41WB509.

The site is a small, moderate-density lithic scatter measuring approximately $10 \mathrm{~m}$ northwest to southeast and over $15 \mathrm{~m}$ southwest to northeast, extending beyond the project boundaries to the northeast. The identified portion of the site covers a total area of approximately $150 \mathrm{~m}^{2}$. The lithic assemblage consists primarily of tertiary flakes, shatter, cores, bifaces, and a projectile point, all of locally available chert. The projectile point was identified as a Catán/Refugio-type point. Catán points date from the Late Archaic to the Late Prehistoric and Refugio points date to the Archaic (Figure 59a; Turner and Hester 1993:89, 178). A Clear Fork uniface, a tool type dated from the Paleo-Indian period to the Middle Archaic, was also observed (see Figure 59b; Turner and Hester 1993:246-249). Artifact density is approximately 10 specimens per $25-\mathrm{m}^{2}$ area. No ground stone, evidence of quarrying, or features were observed at the site.

A single shovel test was excavated at site $41 \mathrm{WB} 509$ in order to determine the presence of subsurface cultural deposits. The test was placed in the proposed ROW approximately $5 \mathrm{~m}$ south of the road 


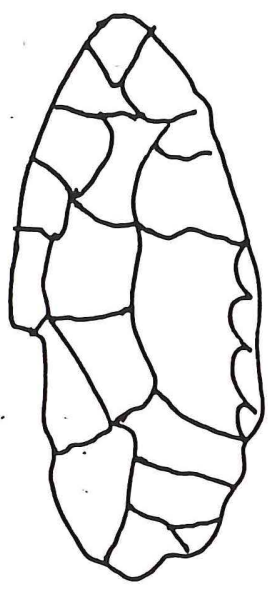

a
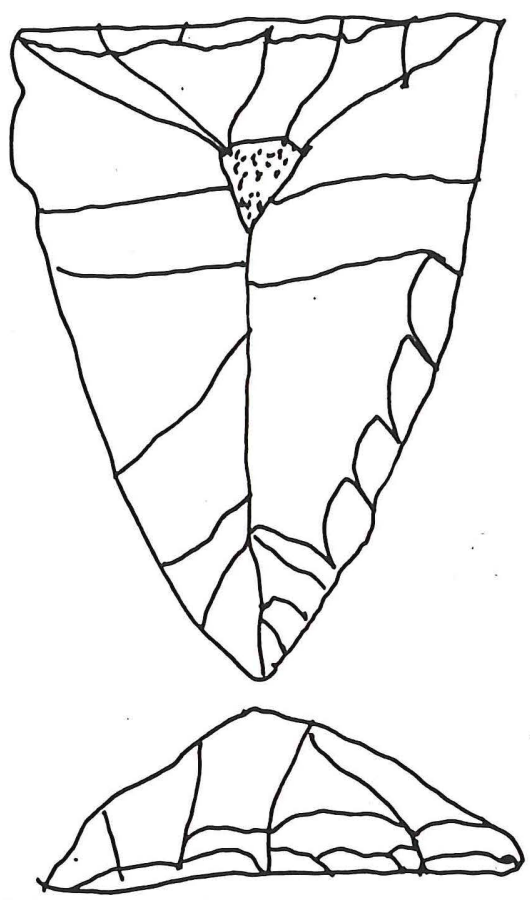

b

Figure 59. Field illustrations of artifacts identified at site 41WB509: (a) Catán/Refugio-type point and (b) a Clear Fork uniface (Scale 1:1).

paralleling Chapote Fence. A shallow subsurface deposit was identified with the recovery of a flake and a core in the first $20 \mathrm{~cm}$ below present ground surface. Soil at the site consists of medium brown fine sandy loam to a depth of $20 \mathrm{~cm}$ bs, followed by compact, medium brown sandy clay loam. Disturbance was noted in the upper $20-\mathrm{cm}$ level in the form of mechanical disturbance associated with road construction and roadside devegetation.

Site 41WB509 is interpreted as an open campsite consisting of a low-density, surface scatter of lithic artifacts. Disturbances include the construction of Chapote Fence and the two-track road paralleling the fence, as well as wild animal foraging and cattle grazing. A sparse, shallow. subsurface cultural deposit was identified; however, the small size of the site and the presence of extensive disturbances indicate little of the deposit remains intact. Based on these observances, in addition to the lack of features, the research potential of the evaluated area of site 41WB509 is minimal; this portion of the site is recommended as ineligible for inclusion in the NRHP. The remaining portion of the site located beyond the survey area was not investigated. No further work within the assessed portion of site 41WB509 is recommended.

\section{Site 41 WB510}

Site 41WB510 is located on a broad, level alluvial/colluvial fan on the west side of Galvan Ranch, just east of the intersection of Chapote Pasture Road and Galvan Fence, directly northeast of a small but prominent knoll along Galvan Fence (Figures 60 and 61; see Figure 9). The site extends from the base 


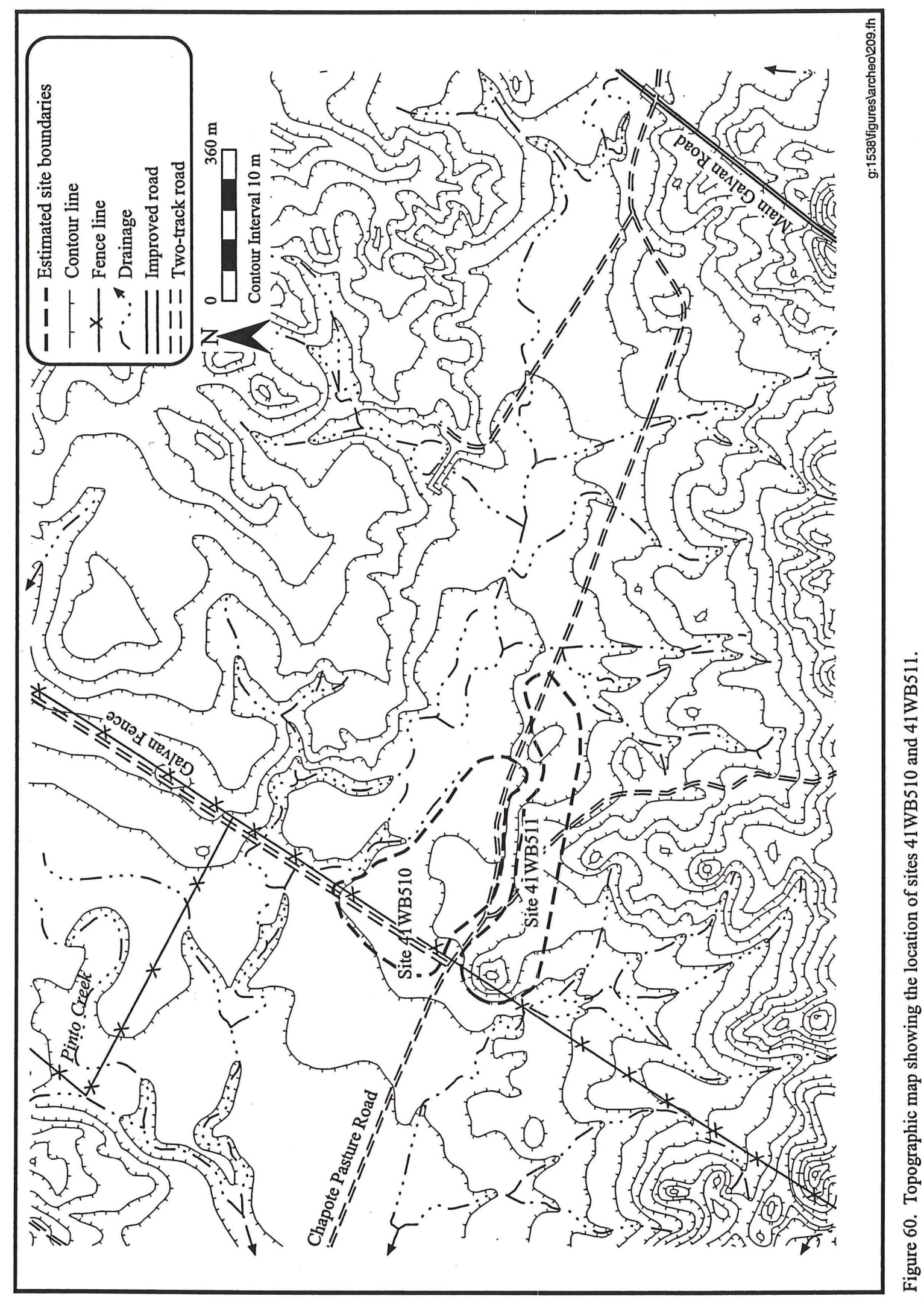




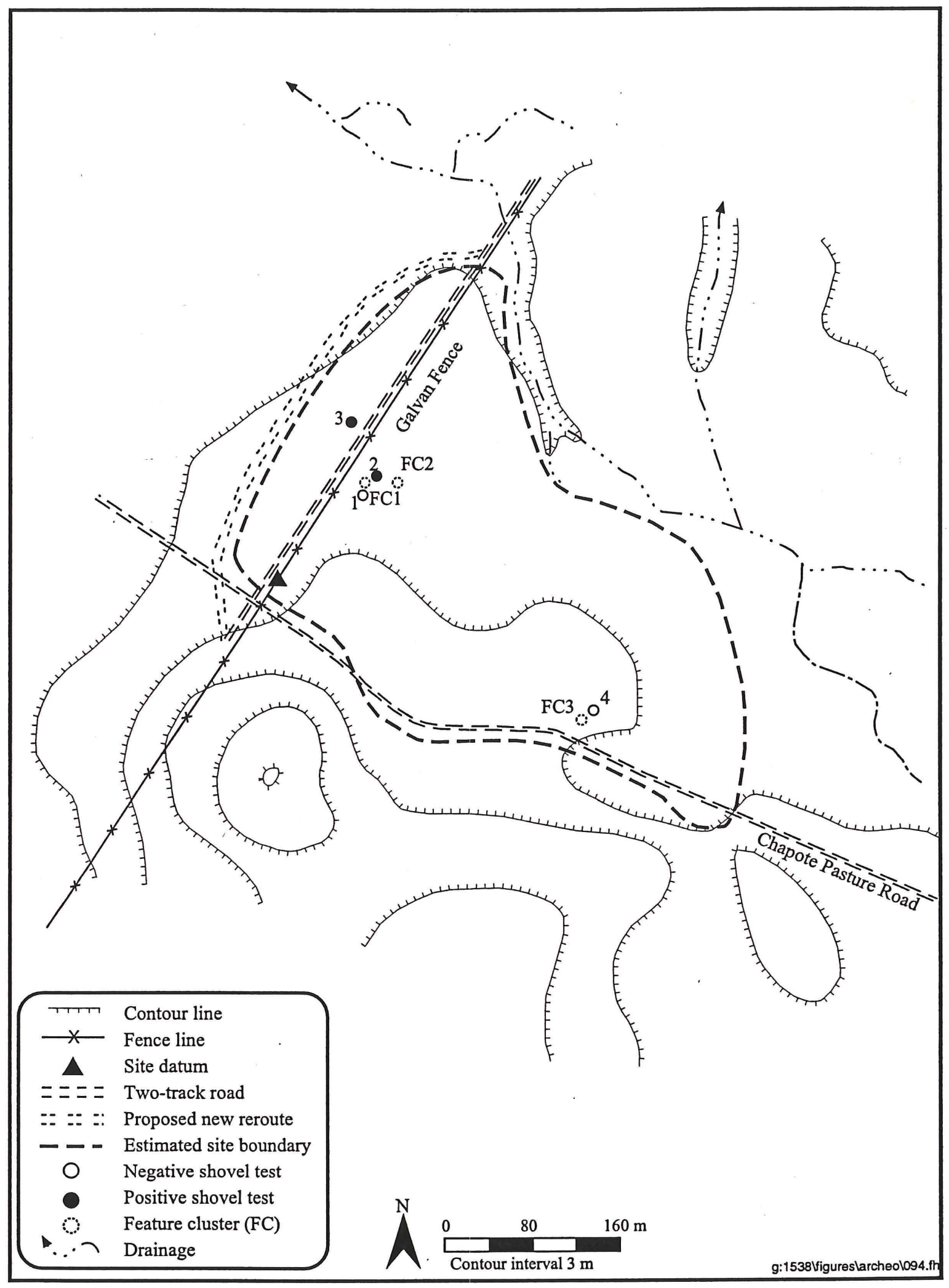

Figure 61. Plan map of site 41WB510. 
of the series of eroded terraces of which this knoll is a part down to the banks of seasonal drainages that empty into Pinto Creek. Elevations at the site range from 177 to $183 \mathrm{~m} \mathrm{(580} \mathrm{to} 600 \mathrm{ft}$ ) amsl. An unnamed seasonal drainage forms the northeast boundary of the site and empties into Pinto Creek approximately $600 \mathrm{~m}$ northwest of the site. Vegetation in the area of the site is moderate and includes mesquite, tasajillo, prickly pear cactus, acacia, and short grasses. Ground visibility is approximately 60 percent.

The site is a high-density lithic scatter measuring approximately $400 \mathrm{~m}$ southwest to northeast and over $625 \mathrm{~m}$ northwest to southeast, extending northwest beyond the project boundary. The identified portion of the site covers a total area of approximately $250,000 \mathrm{~m}^{2}$. The lithic assemblage consists of secondary and tertiary flakes, scrapers, retouched flakes, bifaces, cores, and a Clear Fork uniface, all of locally available chert and quartzite. The density of artifacts at site $41 \mathrm{WB} 510$ ranges from five to over 50 specimens per $25-\mathrm{m}^{2}$ area. A total of 15 small hearth features organized in at least three clusters (identified as Feature Cluster [FC]1, FC2, and FC3) was identified at the site. FC1 consists of three hearth features, FC2 consists of at least eight individual features, and FC3 includes at least four hearth features. The individual features generally consist of slightly to moderately deflated concentrations of between 10 and 70 fire-cracked rock fragments in areas between .5 and $1.5 \mathrm{~m}$ in diameter, often with associated flintknapping debris (Figure 62). Many of these hearth features appear to have eroded out of a near-surface cultural layer. In addition, a flintknapping locus was identified near FC1 in the proposed ROW on the northern portion of the site (Figure 63). This feature consists of a dense scatter of thinning flakes of the same fine-grained, light gray chert in an area approximately $1 \mathrm{~m}$ in diameter. The Clear Fork tool, which is generally dated from the Paleo-Indian and Early Archaic to the Middle Archaic (Figure 64; Turner and Hester 1993:246-249), was identified near Feature Clusters 1 and 2 and the flintknapping locus.

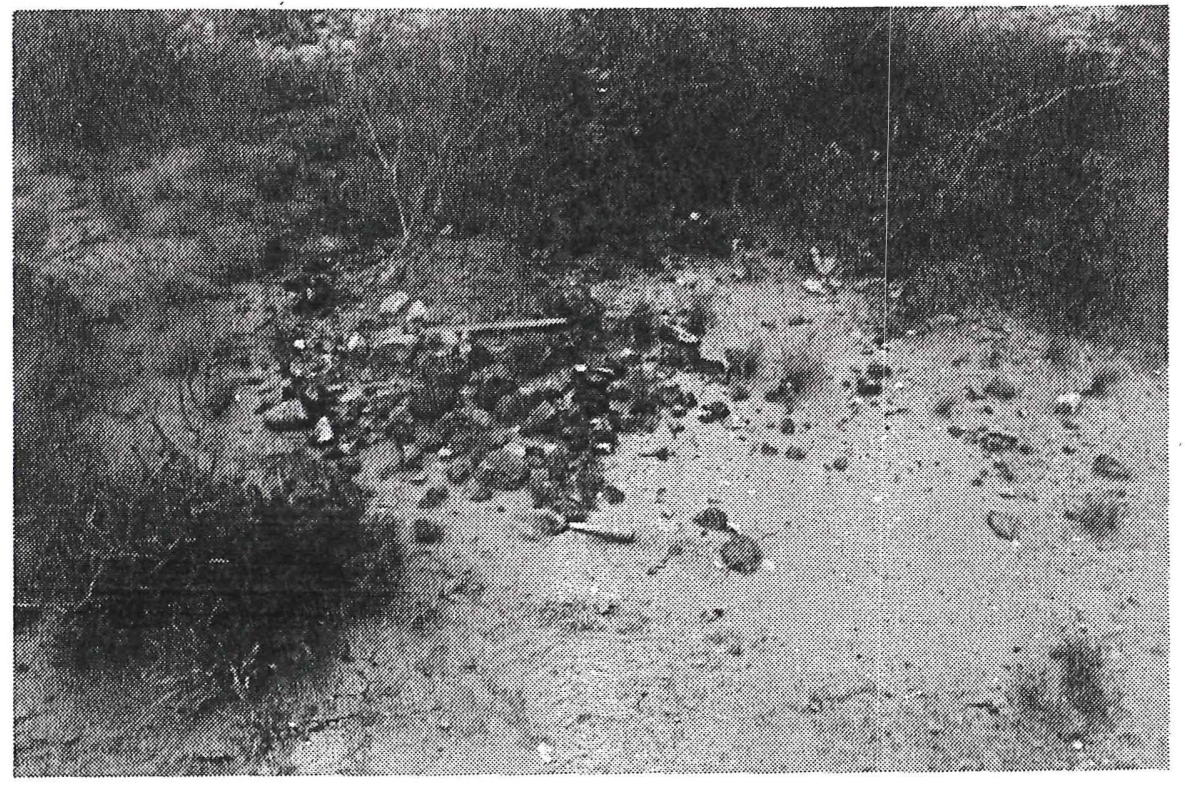

Figure 62. View of hearth feature at site $41 \mathrm{WB} 510$. 


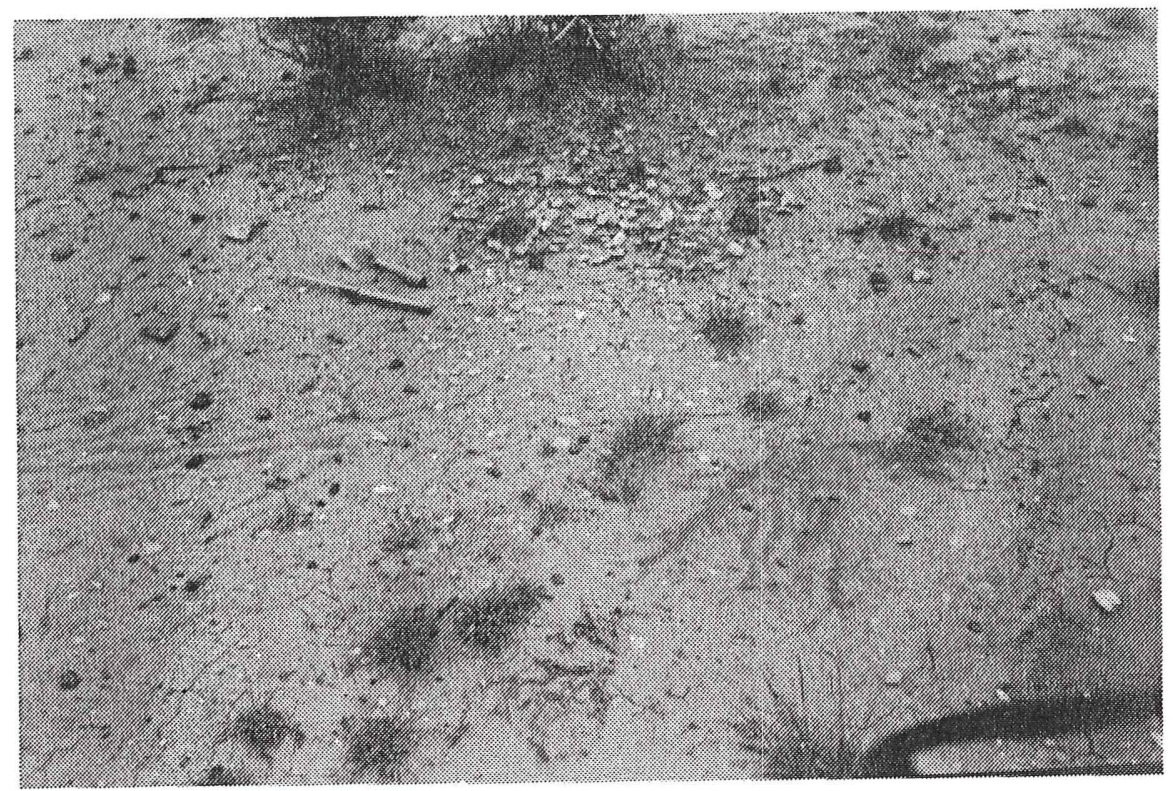

Figure 63. View of flintknapping activity locus at site $41 \mathrm{WB} 510$.

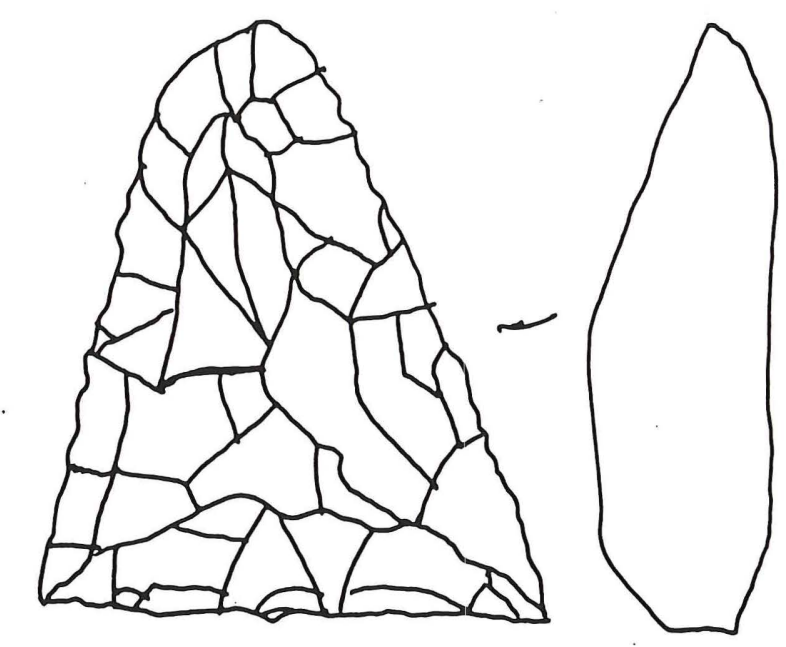

Figure 64. Field illustration of Clear Fork uniface identified at site 41 WB510 (Scale 1:1).

A total of four shovel tests was excavated at site $41 \mathrm{WB} 510$ in order to determine the presence of subsurface cultural deposits. Shovel Tests 1 and 2 were placed near FC1 and FC2 and the flintknapping locus in the northern portion of the site. Shovel Test 1 revealed dark yellowish brown clay loam to 30 $\mathrm{cm}$ and was negative. Shovel Test 2 produced a single flake in the first $10 \mathrm{~cm}$ bs and revealed very 
compact, dark yellowish brown clay loam to the maximum depth of the shovel test $(40 \mathrm{~cm}$ bs). Shovel Test 3 was excavated on the north side of Galvan Fence and produced another flake at $10 \mathrm{~cm}$. The soil profile revealed compact, brown clay loam to $20 \mathrm{~cm}$ bs where the excavation was terminated. Shovel Test 4 was placed in the southern portion of the site near FC3 and was negative. Soil in the negative shovel tests (Shovel Tests 1 and 4) consisted of very compact, yellowish brown silty loam to 30 and 20 $\mathrm{cm}$ bs, respectively.

Site 41WB510 is interpreted as an open campsite consisting of a high-density lithic scatter and a shallow cultural deposit. Although the site has been disturbed by road cuts, a large portion of the site appears intact. Many of the hearth features appear to have recently eroded out of a shallow, buried cultural layer, indicating that the site has some potential for buried features and/or significant subsurface deposits. Based on the research potential of the site, site $41 \mathrm{WB} 510$ is recommended as potentially eligible for inclusion in the NRHP. Avoidance of the site is recommended by avoiding any new impacts to the existing ROW of Chapote Pasture Road within the limits of the site by prohibiting road improvements. The portion of the proposed ROW that parallels Galvan Fence and passes through this site will require essentially new construction as only an old, slightly used two-track exists along any portion of the Galvan Fence between Old Mines Road and Chapote Pasture Road. Any road construction or improvement activities along the Galvan Fence may impact extant cultural deposits on 41WB510. This section of the proposed new road along Galvan Fence may need to be rerouted northwest of the existing fence line and northwestern site boundary. An alternate road ROW that passes by the site near its northwestern boundary was surveyed. No potentially significant resources were observed along this reroute. Impacts to cultural features would be avoided by limiting vehicular movement through the site to the existing twotrack. The presence of an archeological monitor is recommended during all construction-related activities in the vicinity of site $41 \mathrm{WB} 510$ in order to ensure that the site is not impacted by road improvement activities.

\section{Site 41 WB511}

Site 41WB511 sprawls across the crest and slopes of a series of old eroding gravel terraces that form a system of prominent bluffs at the southwest corner of the intersection of Chapote Pasture Road and the Galvan Fence, directly south of 41WB510 (Figure 65; see Figures 9 and 60). A dense scatter of artifacts was identified on the top of the crest and its slopes. The proposed new road ROW parallels the northwest side of Galvan Fence. Elevations at the site range from 189 to $213 \mathrm{~m} \mathrm{(620} \mathrm{to} 700 \mathrm{ft})$ amsl. Several unnamed seasonal drainages drain the uplands of the site and Pinto Creek is approximately $1 \mathrm{~km}$ northwest of the site. Vegetation at the site is sparse and includes occasional mesquite, prickly pear cactus, and tasajillo on the heavily eroded slopes. Ground visibility is approximately 90 percent.

The site is a high-density lithic scatter measuring approximately $750 \mathrm{~m}$ northwest to southeast and approximately $200 \mathrm{~m}$ northeast to southwest, covering a total area of approximately $150,000 \mathrm{~m}^{2}$. A lowdensity scatter of artifacts was also identified southwest of the site along Galvan Fence for approximately $2.5 \mathrm{~km}$ extending toward Mines Road. Due to the sparse nature of the scatter, this area was identified as a locality. Cobble lenses, primarily chert with some quartzite, and extensive areas of sandstone bedrock are exposed across the higher elevations of the site; small erosional drainages bisect the slopes. The lithic assemblage consists primarily of primary and secondary flakes, shatter, tested cobbles, cores, and bifaces, all of the chert and quartzite available onsite in the form of cobbles. The density of artifacts at site 41 WB511 is 20 to 30 specimens per $25-\mathrm{m}^{2}$ area. No ground stone, diagnostic artifacts, or features were observed at the site. 


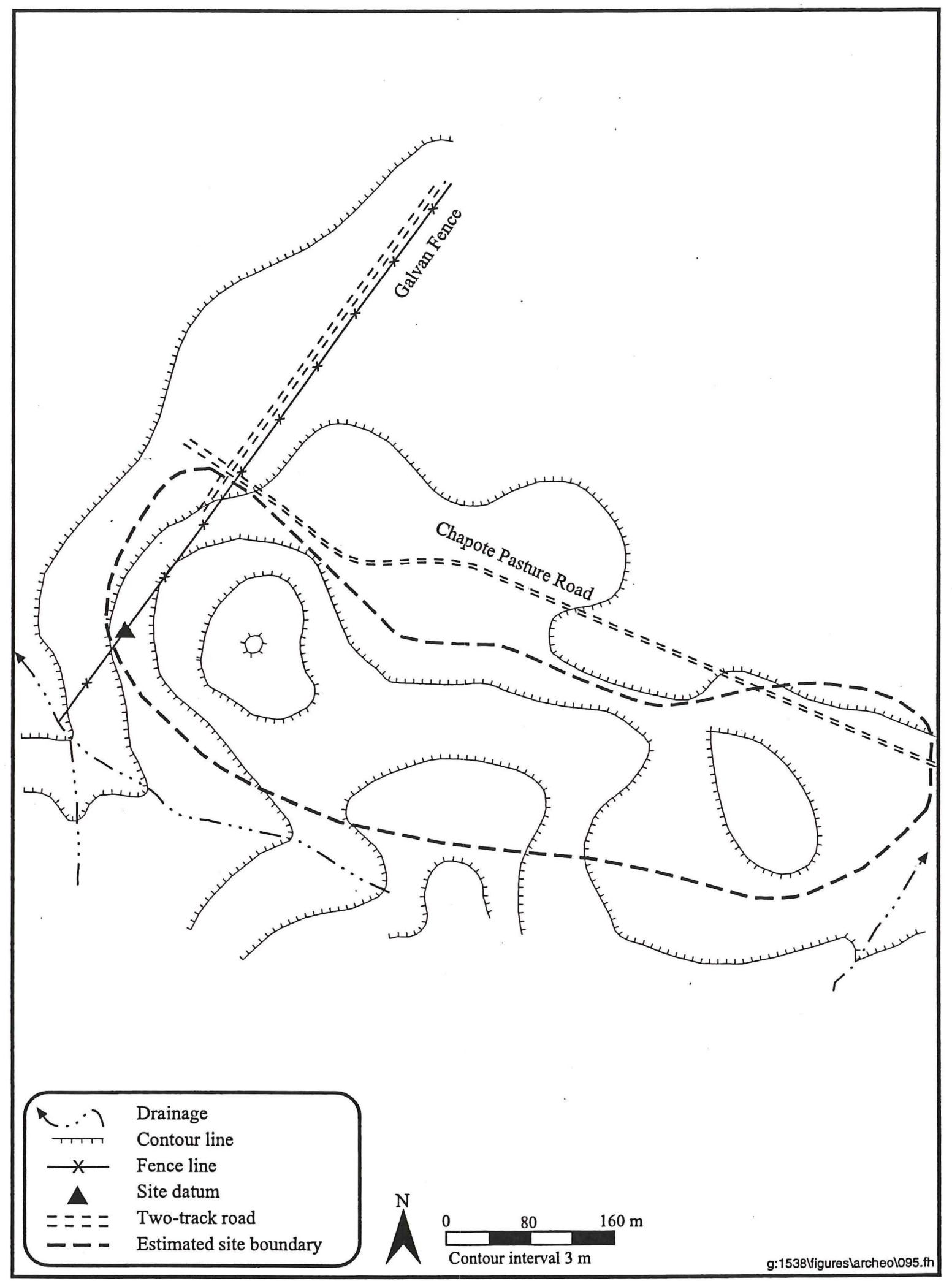

Figure 65. Plan map of site 41WB511. 
Due to extensive erosion, very little soil accumulation was evident on the site and the only soil identified was that which had accumulated in small erosional drainages. Bedrock was exposed throughout the site. Due to the deflated nature of the site, no shovel testing was conducted at site 41WB511.

Site 41WB511 is interpreted as a quarry site consisting of a high-density, surface scatter of lithic artifacts. Disturbances include the existing road and fence line along the northwestern end of the site, Chapote Pasture Road at the northeastern end of the site, and extensive erosion resulting in exposed bedrock and cobble lenses. The deflated nature of the site and the lack of features indicate the research potential of site 41WB511 is minimal. Based on these observations, the site is recommended as ineligible for inclusion in the NRHP. No further work at site 41WB511 is recommended.

\section{Site 41 WB512}

Site $41 \mathrm{WB} 512$ is located on a southeast-facing slope between two unnamed seasonal drainages in the northcentral portion of the Galvan Ranch along Galvan Fence east of Loma Blanca Fence (Figure 66; see Figure 9). It lies approximately $1.5 \mathrm{~km}$ west of Willow Tank and $2 \mathrm{~km}$ northeast of Colorado Tank. A very sparse scatter of artifacts was identified in the proposed project area and extends northwest off the property. Most of the site is located outside the proposed ROW southeast of the project area. Elevations at the site range from 207 to $216 \mathrm{~m}$ (680 to $710 \mathrm{ft}$ ) amsl. Unnamed seasonal drainages are adjacent to the site to the southwest and northeast and Santa Isabel Creek is approximately $3 \mathrm{~km}$ east of the site. Vegetation density at the site is moderate and includes mesquite, creosote bush, prickly pear cactus, tasajillo, acacia, and short grasses. Ground visibility is approximately 80 percent.

The site is a low-density lithic scatter measuring approximately $800 \mathrm{~m}$ northeast to southwest and over $100 \mathrm{~m}$ northwest to southeast, extending northwest off the property boundary. The identified portion of the site covers a total area of approximately $80,000 \mathrm{~m}^{2}$. Chert and quartzite cobble and gravel lenses are exposed in terraces across the site interspersed with small erosional gullies. The lithic assemblage consists of primary and secondary flakes, shatter, tested cobbles, cores, a biface, and a projectile point, all of the type and quality of chert and quartzite available onsite. The projectile point was identified as a Refugio, an Archaic unstemmed elongate point (Figure 67; Turner and Hester 1993:178). The density of artifacts at site $41 \mathrm{WB} 512$ varies from two to three per $25-\mathrm{m}^{2}$ area in the proposed ROW to approximately eight to 10 artifacts per $25-\mathrm{m}^{2}$ area at the eastern edge of the site over $40 \mathrm{~m}$ southeast of the existing road. No ground stone or features were observed at the site.

Due to extensive erosion, very little soil was evident on the site. The only soil identified was that which had accumulated in small erosional drainages. Due to the deflated nature of the site, no shovel testing was conducted.

Site 41WB512 is interpreted as a quarry site consisting of a low-density, surface scatter of lithic artifacts. Disturbances include the existing road and fence line along the length of the site, as well as wild animal foraging and cattle grazing. Extensive erosion has resulted in surface deflation with small pockets of sedimentation remaining in erosional drainages only. The deflated nature of the site, the lack of features, and disturbances identified indicate the research potential of the evaluated area of site 41WB512 is minimal. Based on these observations, the portion of the site within the ROW is recommended as ineligible for inclusion in the NRHP. The remainder of the site could not be investigated. No further work within the assessed portion of site 41WB512 is recommended. 


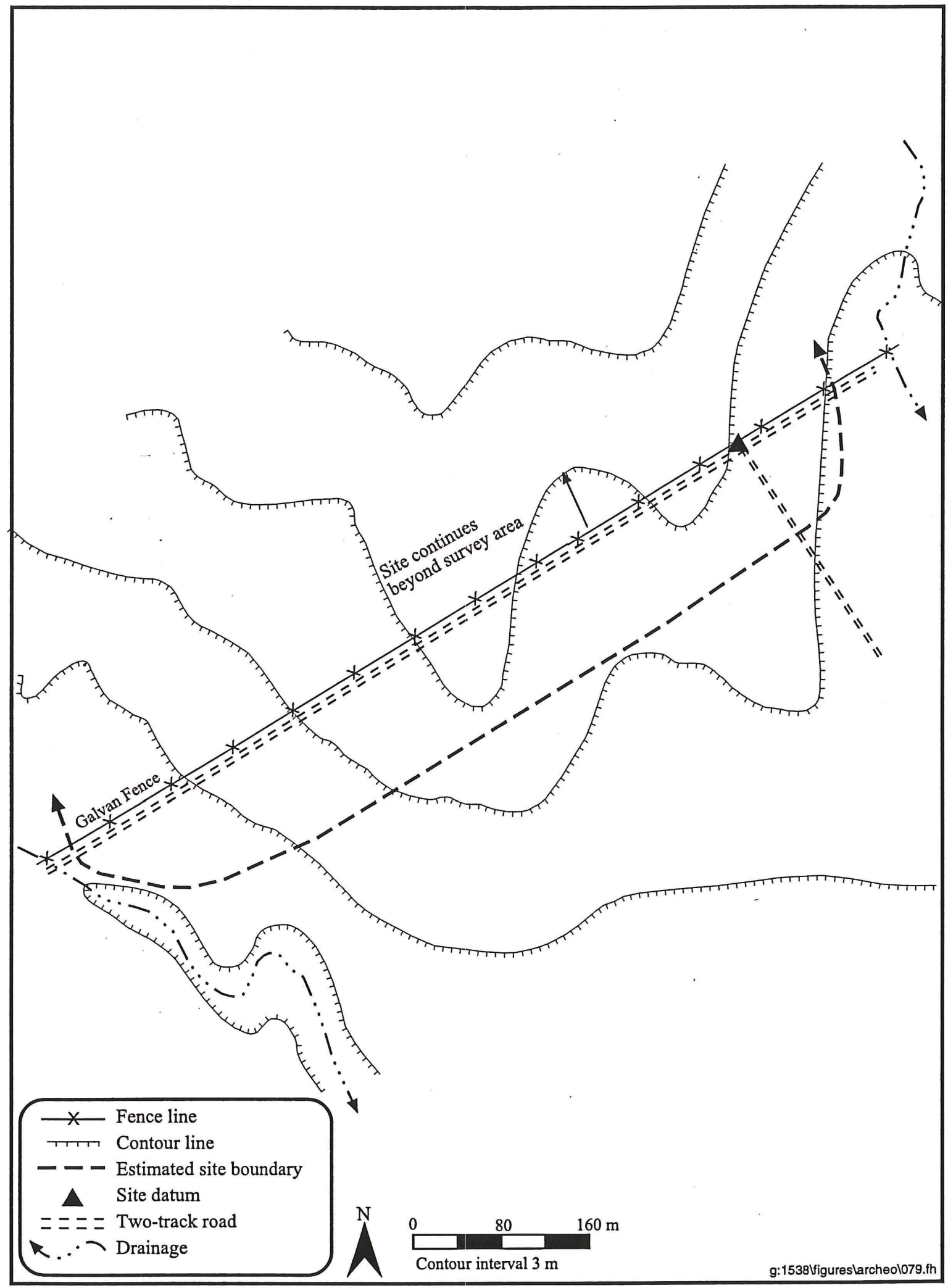

Figure 66. Plan map of site 41WB512. 


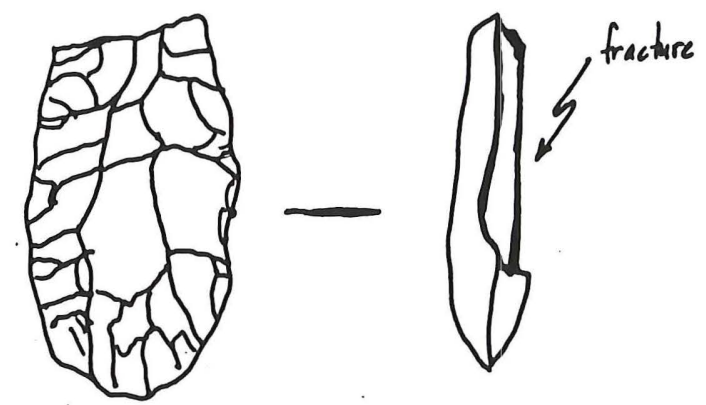

Figure 67. Field illustration of Refugio projectile point identified at site 41 WB512 (Scale 1:1).

\section{Site 41 WB513}

Site 41WB513 is located on a hilltop in the central portion of Galvan Ranch along Galvan Fence east of Loma Blanca Fence, approximately $1.3 \mathrm{~km}$ northwest of Colorado Tank (Figure 68; see Figure 9). The site was identified in the existing roads and extends northwest beyond the project boundaries. Elevations at the site range from 216 to $230 \mathrm{~m}(710$ to $754 \mathrm{ft})$ amsl. An unnamed seasonal drainage is approximately $50 \mathrm{~m}$ southwest of the western edge of the site and the head of Pinto Creek is approximately $3.5 \mathrm{~km}$ southwest of the site. Vegetation at the site is relatively sparse to moderate and includes mesquite, prickly pear cactus, tasajillo, acacia, and short grasses. Ground visibility is approximately 70 percent.

The site is a low-density lithic scatter measuring approximately $900 \mathrm{~m}$ northeast to southwest and over $100 \mathrm{~m}$ northwest to southeast, extending beyond the project boundary to the northwest. The identified portion of the site covers a total area of approximately $90,000 \mathrm{~m}^{2}$. Chert and quartzite cobble lenses and sandstone bedrock are exposed throughout the site. The lithic assemblage consists primarily of primary and secondary flakes, shatter, tested cobbles, cores, retouched flakes, and a dart point fragment, all of the type and quality of chert and quartzite available onsite. The projectile point fragment, illustrated in Figure 69, could not be positively identified. The density of artifacts at site 41WB513 ranges from one to two specimens per $25-\mathrm{m}^{2}$ area within the ROW to approximately eight to 10 artifacts per $25-\mathrm{m}^{2}$ area near the crest of the hill. No ground stone or features were observed at the site.

Due to extensive erosion, the only soil remaining on the site was that which had accumulated in small erosional drainages. Due to the deflated nature of the site, no shovel testing was conducted.

Site 41 WB513 is interpreted as a quarry site consisting of a low-density, surface scatter of lithic artifacts. The site was identified in the proposed ROW on the existing road along Galvan Fence and extends beyond the property boundary to the northwest. Disturbances include Galvan Fence and the road running parallel to the fence that extend the length of the site. Erosion was also noted resulting in extensive surface deflation with small pockets of sedimentation remaining in erosional drainages only. The deflated nature of the site, the lack of features, and road and fence line disturbances identified indicate the research potential of the evaluated area of site 41 WB513 is minimal. Based on these observations, this portion of the site is recommended as ineligible for inclusion in the NRHP. The remaining area of the site located beyond the surveyed ROW was not investigated. No further work within the assessed portion of site 41WB513 is recommended. 


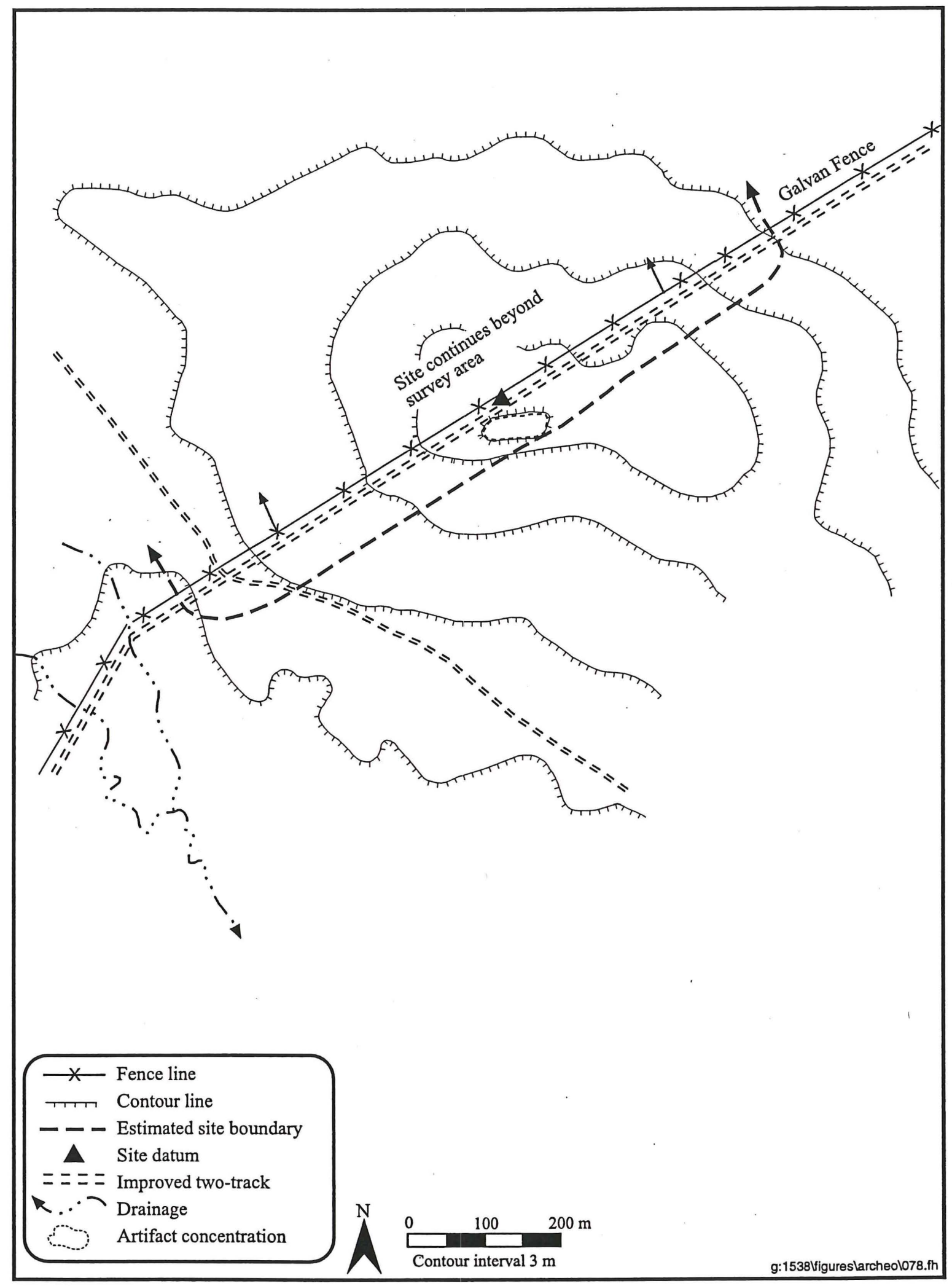

Figure 68. Plan map of site 41WB513. 


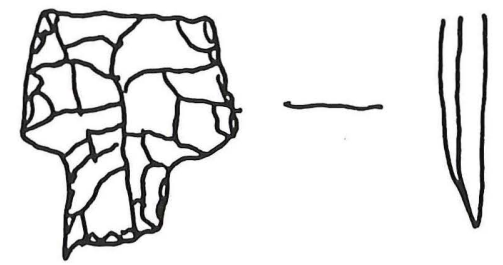

Figure 69. Field illustration of unidentified projectile point at site 41WB513 (Scale 1:1).

\section{Site 41 WB514}

Site 41WB514 is located on a southeast-facing slope in the central portion of the Galvan Ranch along Galvan Fence east of Loma Blanca Fence, approximately $1.5 \mathrm{~km}$ northwest of Colorado Tank (Figure 70; see Figure 9). The site was identified in the existing roads and extends northwest beyond the project boundaries. Elevations at the site range from 215 to $216 \mathrm{~m} \mathrm{(707} \mathrm{to} 710 \mathrm{ft}$ ) amsl. An unnamed seasonal drainage forms the northeast boundary of the site and the head of Pinto Creek is approximately $2.7 \mathrm{~km}$ southwest of the site. Vegetation at the site is moderately dense and includes mesquite, creosote bush, prickly pear cactus, tasajillo, acacia, and short grasses. Ground visibility is approximately 80 percent.

The site is a low-density lithic scatter measuring approximately $650 \mathrm{~m}$ northeast to southwest and over $100 \mathrm{~m}$ northwest to southeast, extending beyond the project boundary to the northwest. The identified portion of the site covers a total area of approximately $65,000 \mathrm{~m}^{2}$. Cobbles and gravels are exposed in terraces across the site. The lithic assemblage consists primarily of primary and secondary flakes, tested cobbles, cores, scrapers, retouched flakes, and a projectile point, all of the type and quality of chert and quartzite available onsite. The projectile point was identified as a possible Carrizo point, an unstemmed Middle to Late Archaic point with a single notch in the center of the base (Figure 71; Turner and Hester 1993:84). The density of artifacts at site 41 WB5 14 varies from two to three specimens in a $25-\mathrm{m}^{2}$ area to approximately eight to 10 artifacts per $25-\mathrm{m}^{2}$ area. No ground stone or features were observed at the site.

Due to extensive erosion, the only soil remaining onsite was that which had accumulated in small erosional drainages. Due to the deflated nature of the site, no shovel testing was conducted.

Site 41WB514 is interpreted as a quarry site consisting of a low-density, surface scatter of lithic artifacts. The single diagnostic projectile point identified dates to the Middle to Late Archaic periods. The site was identified in the proposed ROW on the existing road along Galvan Fence and extends beyond the property boundary to the northwest. Disturbances include Galvan Fence and the road running parallel to the fence which extend the length of the site. Erosion was also noted resulting in extensive surface deflation with small pockets of sedimentation remaining in erosional drainages only. The deflated nature of the site, the lack of features, and road and fence line disturbances indicate the research potential of the evaluated area of site 41 WB514 is minimal. Based on these observations, this portion of the site is recommended as ineligible for inclusion in the NRHP. The remaining portion of the site located beyond the survey area was not investigated. No further work within the assessed portion of site 41WB514 is recommended. 


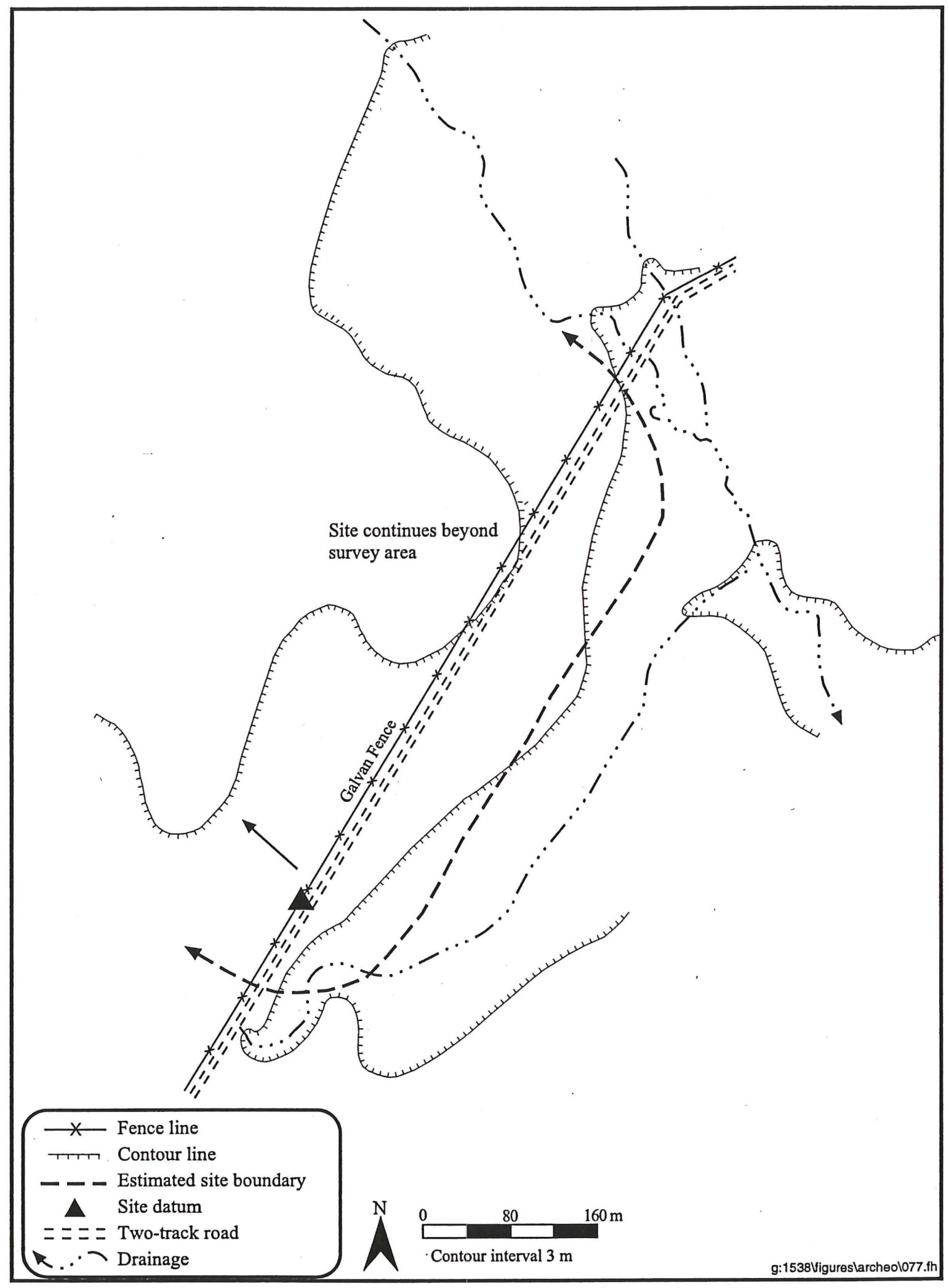

Figure 70. Plan map of site 41WB514. 


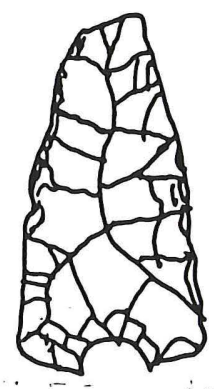

Figure 71. Field illustration of possible Carrizo projectile point identified at site 41WB514 (Scale 1:1).

\section{Site 41 WB515}

Site 41WB515 is located on a saddle in the central portion of Galvan Ranch at the intersection of a southeast-northwest-trending fence line and Galvan Fence east of Loma Blanca Fence, approximately 2 $\mathrm{km}$ west-southwest of Colorado Tank (Figure 72; see Figure 9). The site was identified in the existing roads and extends northwest beyond the project boundaries. Elevations at the site range from 219 to 220 $\mathrm{m}(720$ to $723 \mathrm{ft})$ amsl. An unnamed seasonal drainage is approximately $500 \mathrm{~m}$ southeast of the site and the head of Pinto Creek is approximately $1.6 \mathrm{~km}$ southwest of the site. Vegetation at the site consists of heavy, low ground cover, primarily grasses. Ground visibility is approximately 30 percent.

The site is a low-density lithic scatter measuring approximately $350 \mathrm{~m}$ northeast to southwest and over $125 \mathrm{~m}$ northwest to southeast, extending beyond the project boundary to the northwest. The identified portion of the site covers a total area of approximately $43,750 \mathrm{~m}^{2}$. The site coincides with an extensive cobble bed. The lithic assemblage consists primarily of flakes, tested cobbles, and cores, all of the type and quality of chert and quartzite available onsite. The density of artifacts at site 41WB515 is approximately six to eight artifacts per $25-\mathrm{m}^{2}$ area. No ground stone, diagnostic artifacts, or features were observed at the site.

Extensive erosion has resulted in very little soil remaining onsite. Due to the deflated nature of the site, no shovel testing was conducted.

Site 41 WB515 is interpreted as a quarry site consisting of a low-density surface scatter of lithic artifacts. The site was identified in the proposed ROW on the existing road along Galvan Fence and extends beyond the property boundary to the northwest. Disturbances include Galvan Fence and the road running parallel to the fence that extend the length of the site. Erosion was also noted resulting in extensive surface deflation. The deflated nature of the site, the lack of features, and road and fence line disturbances indicate the research potential of the evaluated area of site $41 \mathrm{WB} 515$ is minimal. Based on these observations, the portion of the site within the ROW is recommended as ineligible for inclusion in the NRHP. The remainder of the site could not be investigated. No further work within the assessed portion of site $41 \mathrm{WB} 515$ is recommended. 


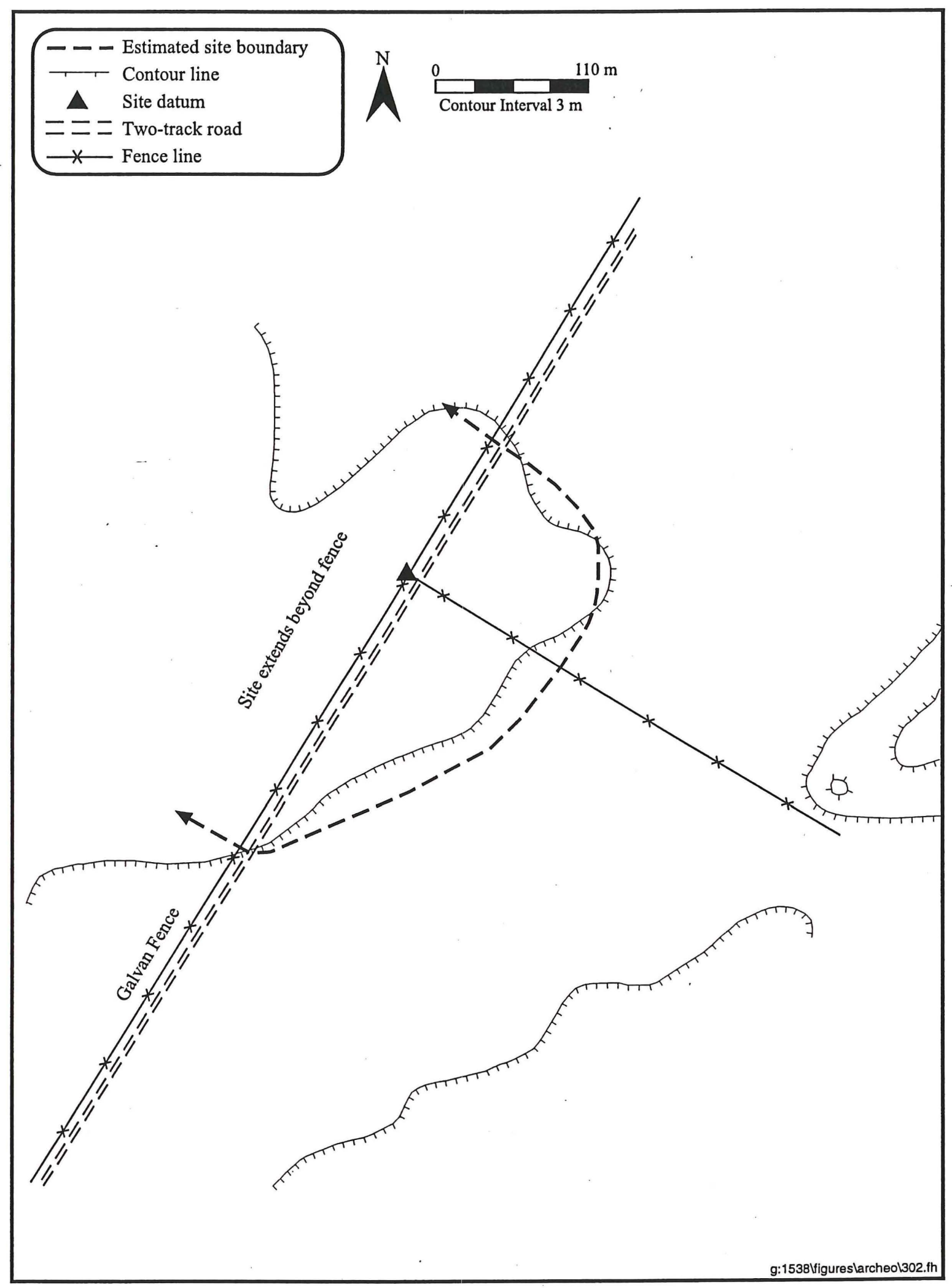

Figure 72. Plan map of site 41WB515. 


\section{Site 41 WB516}

Site 41WB516 is located on a saddle in the central portion of Galvan Ranch along Galvan Fence east of Loma Blanca Fence, approximately $2.2 \mathrm{~km}$ west-southwest of Colorado Tank (Figure 73; see Figure 9). The site was identified in the existing roads and extends northwest beyond the project boundaries. Elevation at the site is $216 \mathrm{~m}$ (710 ft) amsl. An unnamed seasonal drainage is approximately $400 \mathrm{~m}$ southeast of the site and Pinto Creek is approximately $1.4 \mathrm{~km}$ southwest of the site. Vegetation at the site consists of heavy, low ground cover, primarily short grasses. Ground visibility is approximately 30 percent.

The site is a low-density lithic scatter measuring approximately $240 \mathrm{~m}$ northeast to southwest and over 75 $\mathrm{m}$ northwest to southeast, extending beyond the project boundary to the northwest. The identified portion of the site covers a total area of approximately $18,000 \mathrm{~m}^{2}$. The site coincides with an extensive cobble bed. The lithic assemblage consists of primary and secondary flakes, tested cobbles, and cores, all of the type and quality of chert and quartzite available onsite. The density of artifacts at site 41WB516 is approximately six to eight artifacts per $25-\mathrm{m}^{2}$ area. No ground stone, diagnostic artifacts, or features were observed at the site.

Extensive erosion has resulted in very little soil remaining onsite. Due to the deflated nature of the site, no shovel testing was conducted.

Site 41WB516 is interpreted as a quarry site consisting of a low-density, surface scatter of lithic artifacts. The site was identified in the proposed ROW on the existing road along Galvan Fence and extends beyond the property boundary to the northwest. Disturbances include Galvan Fence and the road running parallel to the fence that extend the length of the site. Erosion was also noted resulting in extensive surface deflation. The deflated nature of the site, the lack of features, and road and fence line disturbances indicate the research potential of the evaluated area of site 41WB516 is minimal. Based on these observations, the portion of the site within the ROW is recommended as ineligible for inclusion in the NRHP. The remainder of the site could not be investigated. No further work within the assessed portion of site $41 \mathrm{WB} 516$ is recommended.

\section{Site 41 WB517}

Site 41WB517 is an extensive lithic scatter located just west of center of Galvan Ranch and covers a large area of hilltops and slopes with extensive cobble and gravel outcrops (Figure 74). The site spans the northern half of Pipeline Fence from just south of Main Galvan Road north to Galvan Fence. Elevations at the site range from 204 to $223 \mathrm{~m}(670$ to $730 \mathrm{ft})$ amsl. Unnamed seasonal drainages drain the southeast end of the site near Main Galvan Road, and the head of Pinto Creek is approximately $100 \mathrm{~m}$ south of the site. Vegetation at the site varies from moderately dense mesquite, acacia, tasajillo, and prickly pear cactus higher on the slopes to dense grass cover in low-lying areas. Ground visibility is approximately 60 percent.

The site is an extensive, low-density lithic scatter. Site boundaries within the Galvan Ranch measure approximately $3.7 \mathrm{~km}$ north to south and $3.1 \mathrm{~km}$ east to west and cover a total area of approximately $11.47 \mathrm{~km}$. An exposed cobble bed spans the entire area of the site. The lithic assemblage consists primarily of primary and secondary flakes, shatter, tested cobbles, cores, bifaces, and a projectile point. The projectile point was identified as a Matamoros/Tortugas-like point, a triangular, unstemmed point made of chert (Figure 75). Matamoros are dated from the Late Archaic to Late Prehistoric, while the 


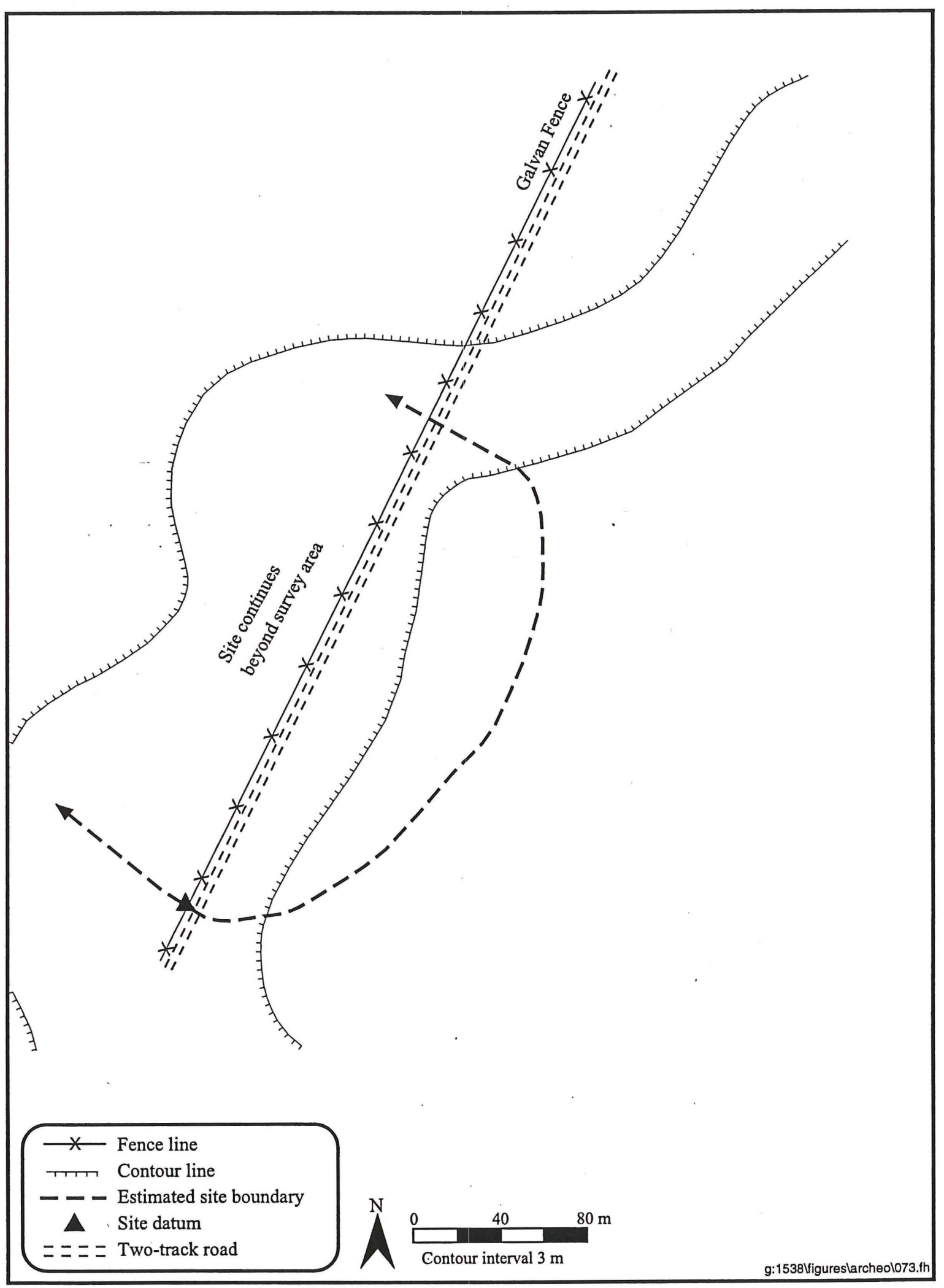

Figure 73. Plan map of site 41WB516. 


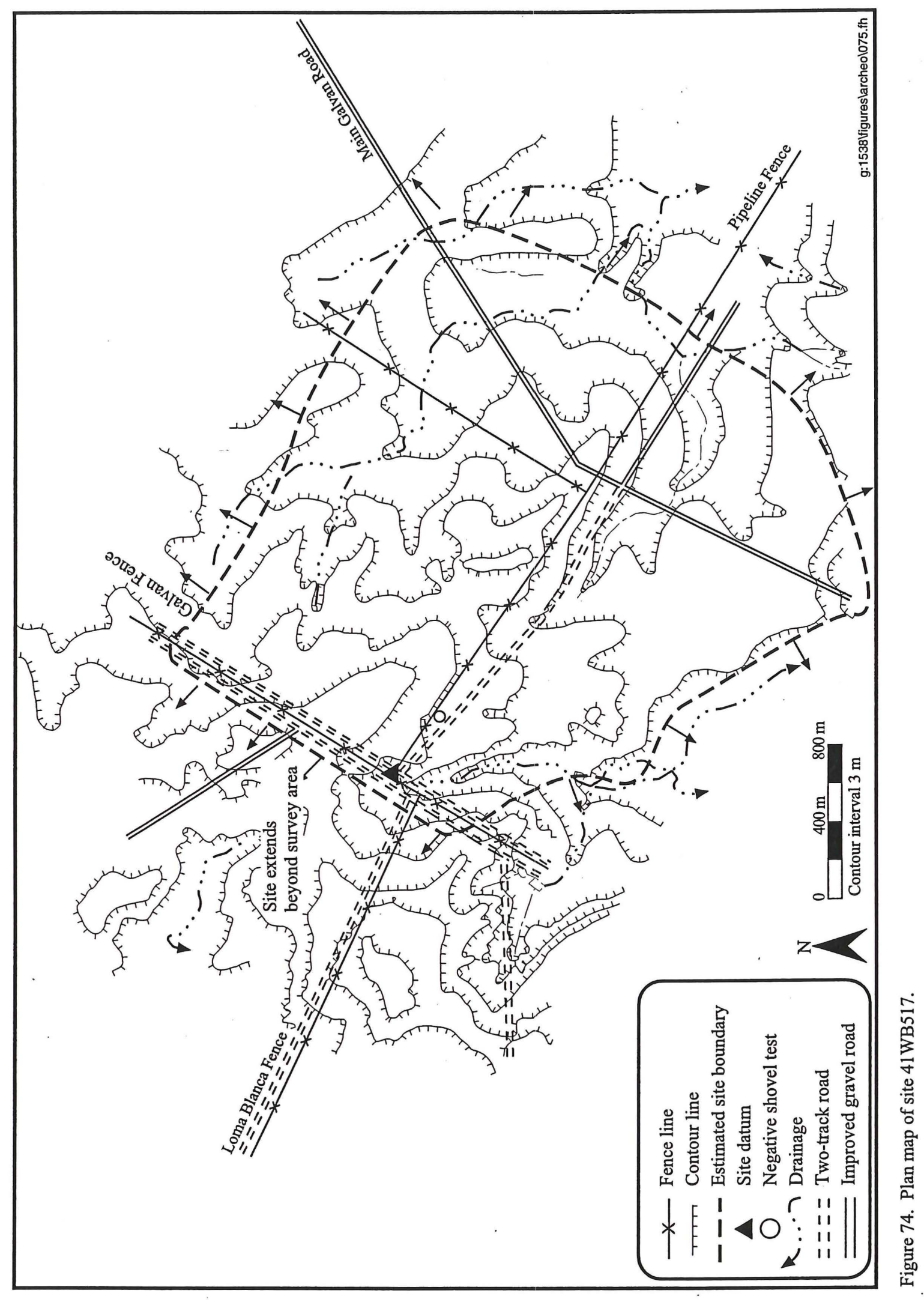




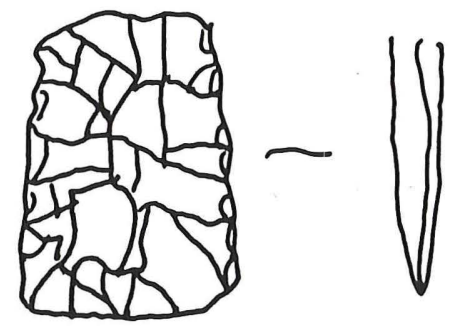

Figure 75. Field illustration of Matamoros/Tortugas-like projectile point identified at site 41WB517 (Scale 1:1).

Tortugas date to the late Middle Archaic (Turner and Hester 1993:153, 188). A wide variety of material types are represented including quartzite, chert, and some quartz, all available onsite in the form of cobbles and gravels. The density of artifacts is approximately six to eight artifacts per $25 \mathrm{~m}^{2}$ area. No ground stone or features were observed at the site.

A shovel test was excavated at site $41 \mathrm{WB} 517$ in order to determine the presence of subsurface cultural deposits. It was located at the northwest end of the site along Pipeline Fence. Soil at the site consists of medium brown clay loam with gravel inclusions to a depth of approximately $20 \mathrm{~cm}$ bs, followed by dark yellowish brown clay loam to the maximum depth of the excavation $(30 \mathrm{~cm} \mathrm{bs})$. No cultural material was identified in the shovel test.

Site 41WB517 is interpreted as a quarry site consisting of a low-density, surficial scatter of lithic artifacts in an extensive, exposed cobble bed. No subsurface cultural deposits were identified. Disturbances include the existing roads and fence lines, wild animal foraging, and cattle grazing. The surficial nature of the site, the lack of features or significant artifact concentrations, and the disturbances identified indicate the research potential of the evaluated area of site $41 \mathrm{WB} 517$ is minimal. Based on these observations, the portion of the site within the ROW is recommended as ineligible for inclusion in the NRHP. The remainder of the site could not be investigated. No further work within the assessed portion of site $41 \mathrm{WB} 517$ is recommended.

\section{Site 41 WB5 18}

Site 41 WB518 is located on a southwest-facing, gradual slope along Main Galvan Road approximately $600 \mathrm{~m}$ east of site $41 \mathrm{WB} 517$ (Figure 76). Elevation at the site is $213 \mathrm{~m}$ (700 ft) amsl. An unnamed seasonal drainage is located approximately $50 \mathrm{~m}$ northeast of the site, and Pinto Creek is $3.4 \mathrm{~km}$ southwest of the site. Vegetation at the site is relatively dense and includes mesquite, acacia, prickly pear cactus, tasajillo, and short grasses. Ground visibility is approximately 60 percent.

The site is a small, low-density lithic scatter measuring approximately $80 \mathrm{~m}$ north to south and approximately $75 \mathrm{~m}$ east to west, covering a total area of approximately $6,000 \mathrm{~m}^{2}$. The site was identified along Main Galvan Road and extends $25 \mathrm{~m}$ north and $45 \mathrm{~m}$ south of the road. The lithic assemblage consists primarily of chert flakes, cores, and bifaces. The density of artifacts is approximately eight to 10 artifacts per $25-\mathrm{m}^{2}$ area. Cobbles and gravels are exposed in terraces across the site. No ground stone, diagnostic artifacts, or features were observed at the site. 


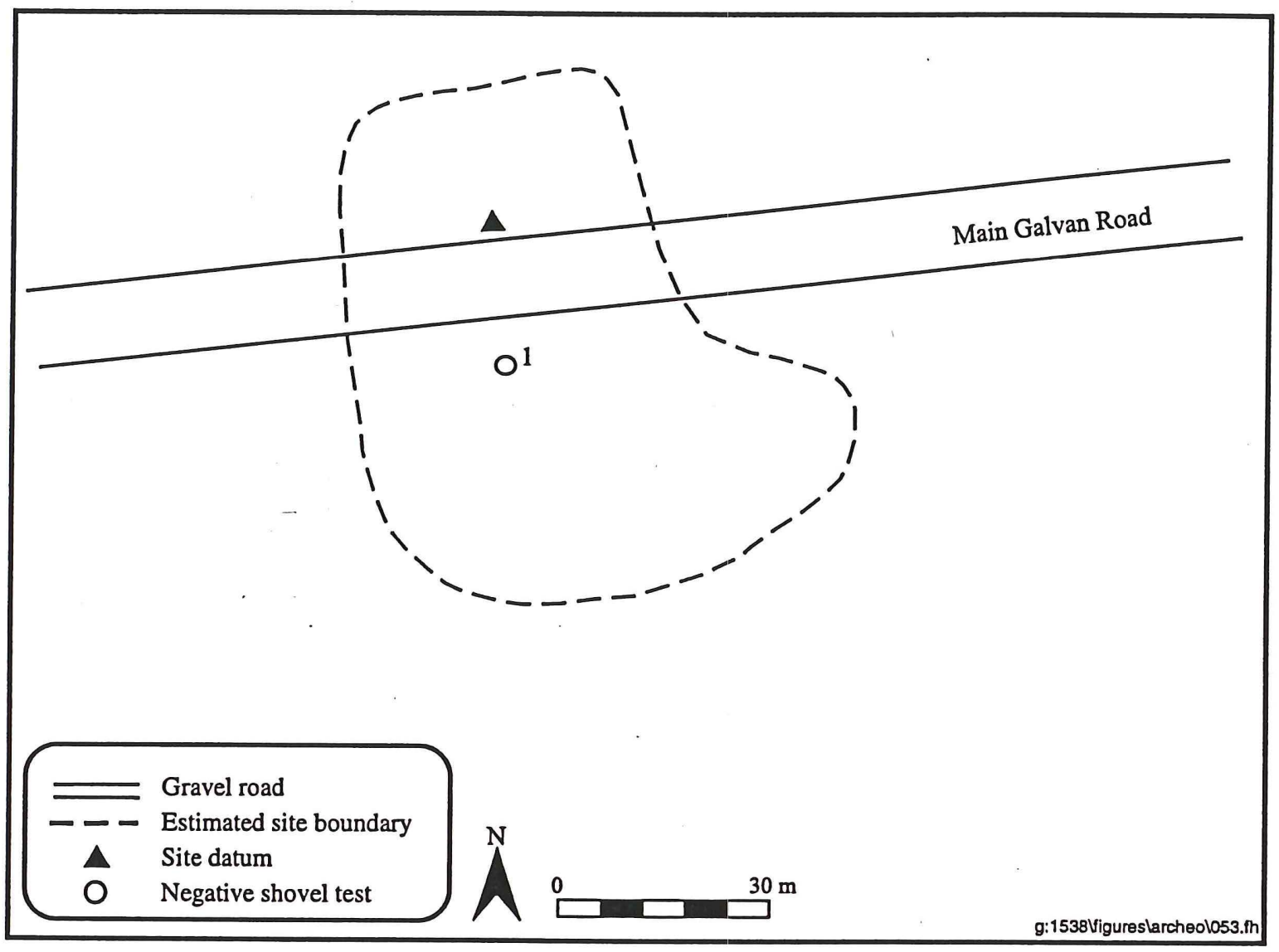

Figure 76. Plan map of site $41 \mathrm{WB} 518$.

A shovel test was excavated at site 41WB518 in order to determine the presence of subsurface cultural deposits. The shovel test was placed within the proposed ROW on the south side of Main Galvan Road. Soil at the site consists of medium brown silty loam to the maximum depth of the shovel test $(40 \mathrm{~cm} \mathrm{bs})$. No subsurface cultural deposits were identified.

Site 41 WB518 is interpreted as a quarry site consisting of a low-density, surficial scatter of lithic artifacts. Disturbances include the construction and maintenance of Main Galvan Road which has impacted approximately 40 percent of the site. Evidence of wild animal foraging and cattle grazing were also noted. The surficial nature of the site, the lack of features, and the disturbances identified indicate the research potential of site 41WB518 is minimal. Based on these observations, the site is recommended as ineligible for inclusion in the NRHP. No further work at site 41 WB518 is recommended.

\section{Site 41 WB519}

Site 41WB519 is located on the northeast end of a ridge situated at the southern end of the northwest-tosoutheast-trending section of Loma Blanca Fence in the northwest portion of Galvan Ranch (Figure 77; see Figure 9). The site was identified in the existing road paralleling Loma Blanca Fence and extends 


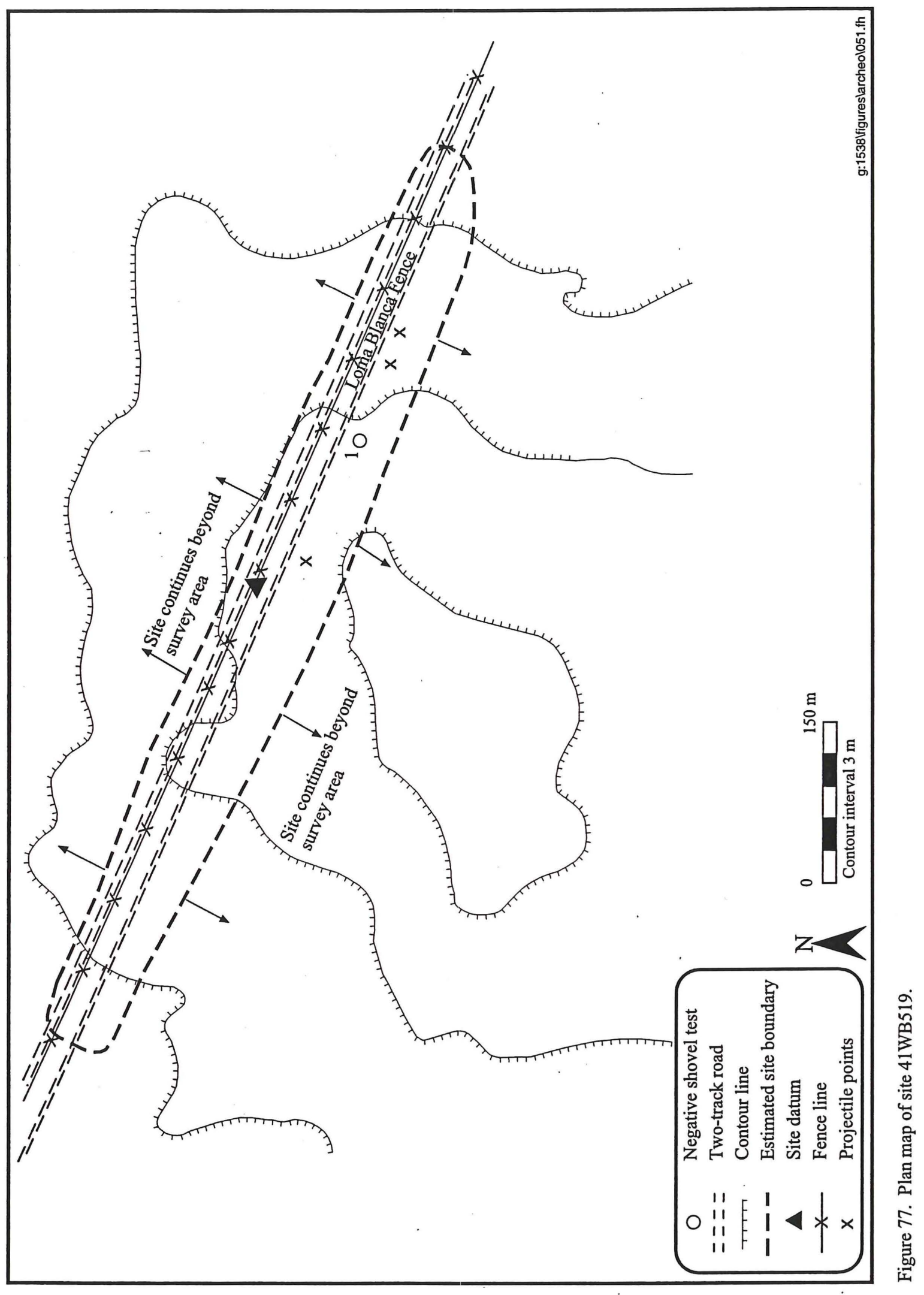


northeast and southwest beyond the project boundaries. Elevations at the site range from 223 to $232 \mathrm{~m}$ ( 730 to $760 \mathrm{ft}$ ) amsl. Unnamed seasonal drainages are located $400 \mathrm{~m}$ northwest and $300 \mathrm{~m}$ west of the site, and Pinto Creek is approximately $2 \mathrm{~km}$ south of the site. Vegetation in the area of the site is moderate to dense and includes mesquite, creosote, tasajillo, prickly pear cactus, acacia, and short grasses. Ground visibility is approximately 60 percent.

The site is a low-density lithic scatter measuring approximately $900 \mathrm{~m}$ northwest to southeast and over $100 \mathrm{~m}$ northeast to southwest, extending beyond the project boundaries to the northeast and southwest. The identified portion of the site covers a total area of approximately $90,000 \mathrm{~m}^{2}$. The lithic assemblage consists primarily of flakes, scrapers, retouched flakes, bifaces, and three projectile points, all of locally available chert and quartzite. One of the points is similar to the Early Triangular/Tortugas/Matamoros group of point types (Figure 78a; Turner and Hester 1993:110, 153, 188). Dates on this group of points range from Early Archaic (Early Triangular points) through the late Middle Archaic (Tortugas), and from the Late Archaic to the Late Prehistoric (Matamoros) (Turner and Hester 1993:110, 153, 188). Another point was identified as a Transitional Archaic Ensor point, with shallow side-notches and a straight base (see Figure 78b; Turner and Hester 1993:114). The third point could not be identified but is illustrated in Figure 78c. The points were all made of local chert. The density of artifacts at site 41WB519 is approximately eight to 10 specimens in a $25-\mathrm{m}^{2}$ area. No ground stone or features were observed at the site.

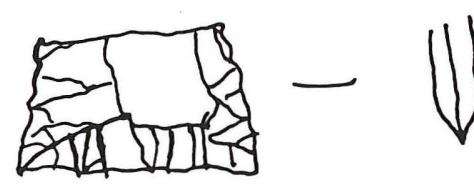

a
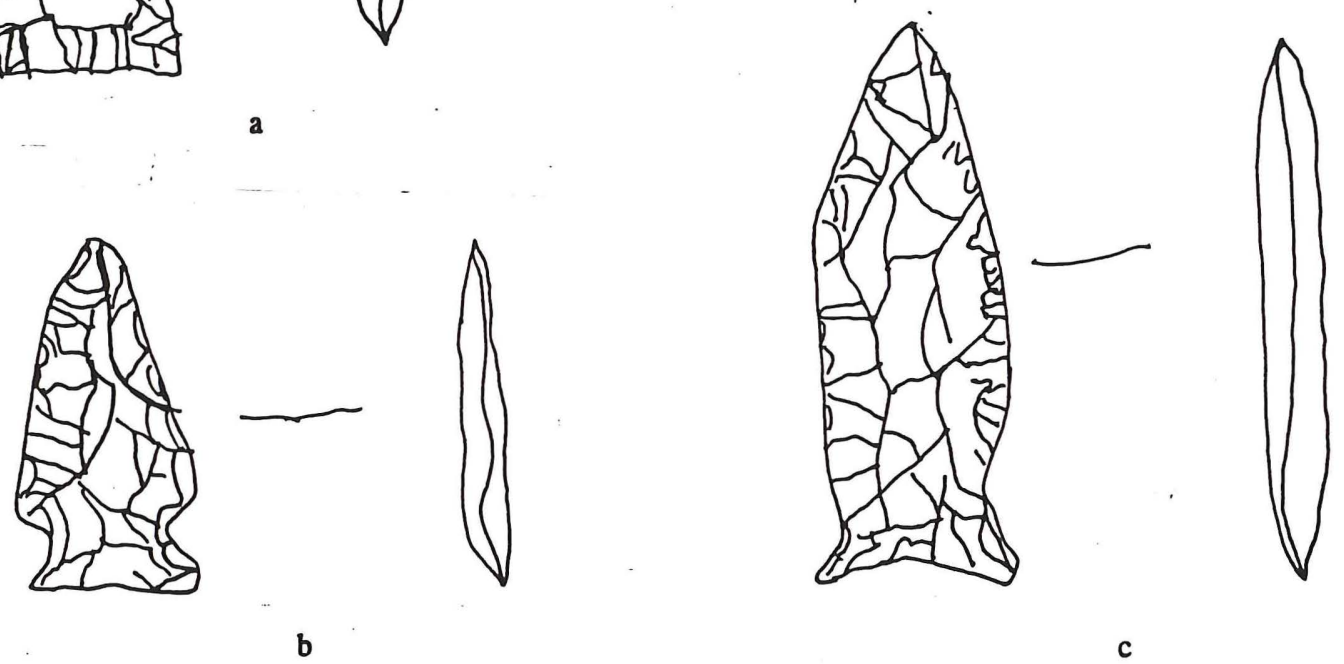

b

Figure 78. Field illustrations of projectile points identified at site 41WB519: (a) Early Triangular/Tortugas/ Matamoros-type point; (b) Ensor point; and (c) unidentified point (Scale 1:1).

A shovel test was excavated at site 41WB519 in order to determine the presence of subsurface cultural deposits. The shovel test was placed within the proposed ROW on the south side of the existing road. Soil at the site consists of light yellowish brown silt with small gravels to a depth of $20 \mathrm{~cm}$ bs, followed by similar but more compact soil to the maximum excavated depth of the shovel test $(40 \mathrm{~cm} \mathrm{bs})$. No subsurface cultural deposits were identified. 
Site 41WB519 is interpreted as an open campsite consisting of a low-density, surficial lithic scatter. No subsurface cultural deposits were identified. Disturbances include the construction of Loma Blanca Fence and the parallel two-tracks on either side of the fence, wild animal foraging, and cattle grazing. The surficial nature of the site, the lack of features, and the disturbances indicate the research potential of the evaluated area of site 41WB519 is minimal. Although diagnostic projectile points were observed at the site, the lack of stratigraphic contexts makes it impossible to identify temporal horizons. Based on these observations, this portion of the site is recommended as ineligible for inclusion in the NRHP. The remaining portion of the site located beyond the survey area was not investigated. No additional work is recommended within the assessed portion of site 41WB519.

\section{Site 41 WB520}

Site 41WB520 is located on a ridgetop along the northwest-to-southeast-trending section of Loma Blanca Fence in the northwest portion of Galvan Ranch (Figure 79; see Figure 9). The site was identified in the existing roads and extends northeast and southwest beyond the project boundaries. Elevations at the site range from 213 to $216 \mathrm{~m}$ (700 to $710 \mathrm{ft}$ ) amsl. An unnamed, north-south seasonal drainage is approximately $300 \mathrm{~m}$ west of the site, and Espada Creek is approximately $5 \mathrm{~km}$ west of the site. Vegetation at the site is relatively sparse and consists of mesquite, creosote bush, prickly pear cactus, tasajillo, acacia, and short grasses. Ground visibility is approximately 75 percent.

The site is a low-density lithic scatter measuring approximately $200 \mathrm{~m}$ northwest to southeast and over 30 $\mathrm{m}$ northeast to southwest, extending beyond the project boundary to the northeast and southwest. The identified portion of the site covers a total area of approximately $6,000 \mathrm{~m}^{2}$. Cobble and gravel lenses are exposed throughout the site. The lithic assemblage consists primarily of primary and secondary flakes and tested cobbles, all of the type and quality of chert and quartzite available onsite. The density of artifacts at site $41 \mathrm{WB} 520$ is approximately six to eight artifacts per $25-\mathrm{m}^{2}$ area. No diagnostic artifacts or features were observed at the site.

Extensive erosion has resulted in the accumulation of soil in small erosional drainages across the site. No other areas of sedimentation were identified. Due to the deflated nature of the site, no shovel testing was conducted.

Site 41WB520 is interpreted as a quarry site consisting of a low-density, surface scatter of lithic artifacts. The site was identified in the proposed ROW on the existing road along the southwest side of Loma Blanca Fence and extends beyond the project boundary to the northeast and southwest. Disturbances include Loma Blanca Fence and the two-track roads running parallel to the fence which extend the length of the site. Erosion was also noted resulting in extensive surface deflation with small pockets of sedimentation remaining in erosional drainages only. The deflated nature of the site, the lack of features, and road and fence line disturbances identified indicate the research potential of the evaluated area of site 41WB520 is minimal. Based on these observations, this portion of the site is recommended as ineligible for inclusion in the NRHP. The remaining portion of the site located beyond the survey area was not investigated. No further work within the assessed portion of site $41 \mathrm{WB} 520$ is recommended. 


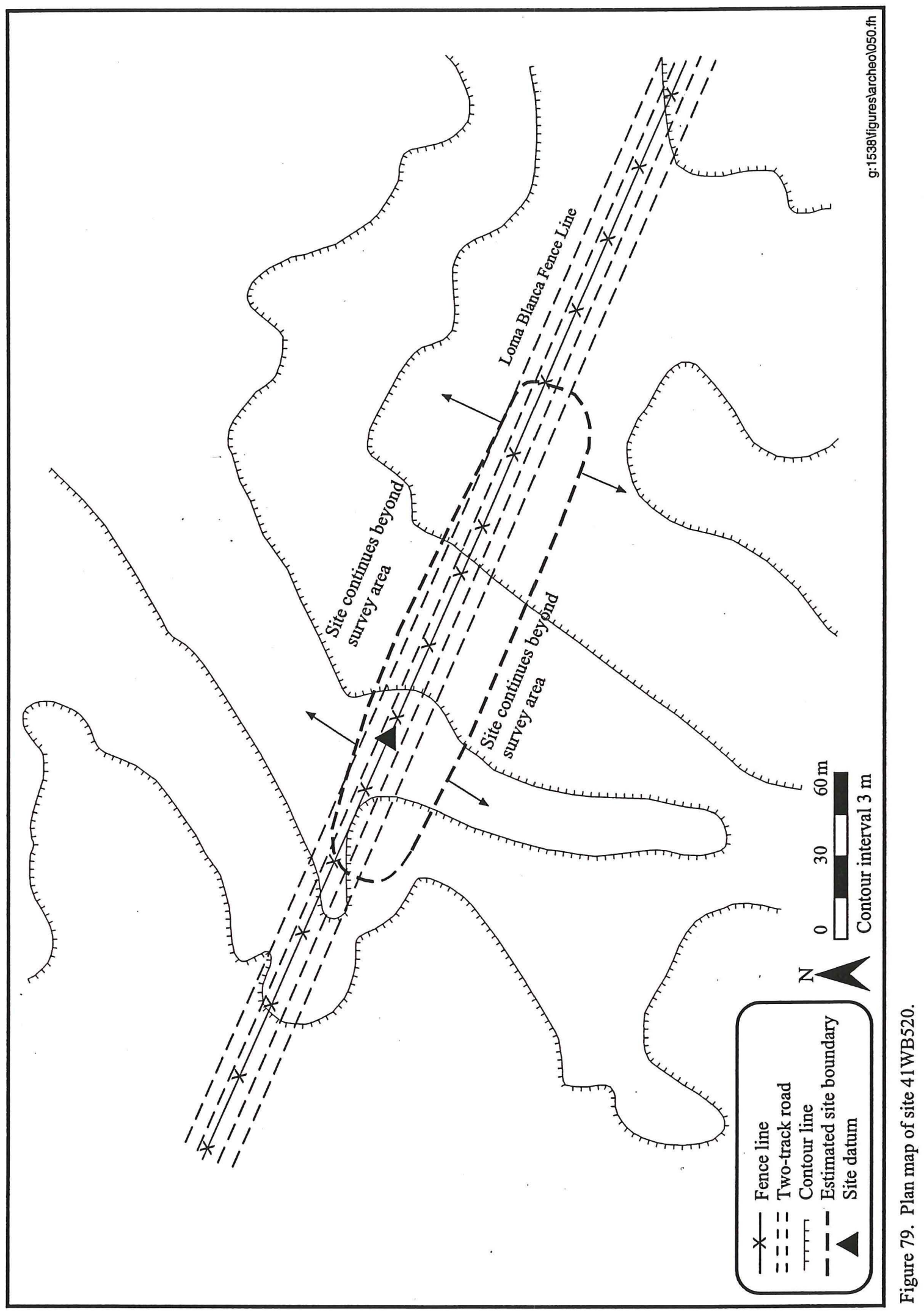




\section{Site 41 WB521}

Site 41WB521 is located on a series of knolls, ridges, and slopes along the northwest section of the Loma Blanca Fence in the northwest corner of Galvan Ranch (Figure 80; see Figure 9). The site spans a 3.3$\mathrm{km}$ stretch of the Loma Blanca Fence beginning approximately $350 \mathrm{~m}$ north of Old Mines Road and ending approximately $950 \mathrm{~m}$ south of the right angle of Loma Blanca Fence. Elevations at the site range from 201 to $216 \mathrm{~m}$ (660 to $710 \mathrm{ft}$ ) amsl. Several unnamed seasonal drainages drain from northwest to southeast across the site. Espada Creek flows north to south approximately $1.5 \mathrm{~km}$ west of the south end of the site. Vegetation at the site includes mesquite, creosote, acacia, tasajillo, prickly pear cactus, cholla, and short grasses. Ground visibility varies from 50 percent in areas of dense grass cover to approximately 90 percent in areas of exposed cobble beds.

The site is an extensive, high-density lithic scatter spanning a series of steep ridges and knolls. Site boundaries within the Galvan Ranch measure approximately $3.3 \mathrm{~km}$ northeast to southwest and over 100 $\mathrm{m}$ east to west, extending beyond the project boundaries. The identified portion of the site covers a total area of approximately $330,000 \mathrm{~m}^{2}$. The entire area of the site is dominated by an exposed cobble and gravel bed of a wide variety of material types including chert, quartz, and quartzite. The lithic assemblage consists primarily of primary flakes, shatter, tested cobbles, cores, and bifaces, all derived from the cobble and gravel material present onsite. The density of artifacts varies from approximately five to 10 specimens per $25-\mathrm{m}^{2}$ area in the southern half of the site to 40 to 50 artifacts per $25-\mathrm{m}^{2}$ area in the northern area of the site, particularly north of the point at which the existing drag road cuts away from Loma Blanca Fence to the northeast. No diagnostic artifacts or features were observed at the site.

A shovel test was excavated at site 41WB521 in order to determine the presence of subsurface cultural deposits. It was placed in the northern portion of the site, east of the existing drag road where it cuts away from Loma Blanca Fence, in one of the few areas of the site exhibiting sedimentation. A shallow deposit was identified by the recovery of a core and a flake in the first $5 \mathrm{~cm}$ of the shovel test. No other artifacts were recovered and the maximum depth of the test was $12 \mathrm{~cm}$ below present ground surface. Soil at the site consists of light yellowish brown silty loam with many cobbles to a depth of $5 \mathrm{~cm}$ bs, followed by more compact silty clay loam with fewer cobbles.

Site 41WB521 is interpreted as a quarry site consisting of a high-density, surficial scatter of lithic artifacts in an extensive, exposed cobble and gravel bed. Disturbances include the construction and maintenance of Loma Blanca Fence and the associated drag road, in addition to wild animal foraging and cattle grazing. The surficial nature of the site, the lack of features, and the disturbances identified indicate the research potential of the evaluated area of site 41WB521 is minimal. Based on these observations, the portion of the site within the ROW is recommended as ineligible for inclusion in the NRHP. The remainder of the site could not be investigated. No further work within the assessed portion of site 41 WB521 is recommended.

\section{Site 41 WB522}

Site 41WB522 is located on a prominent knoll along Galvan Fence in the northeast corner of Galvan Ranch, at the northern end of the Vidal Cut, and extends northwest beyond the property boundary (Figure 81; see Figure 9). Two roads run through the site paralleling Galvan Fence-one is the primary, maintained road approximately $2 \mathrm{~m}$ from the fence and another, overgrown road approximately 25 to 75 $\mathrm{m}$ off the fence line. Elevations at the site range from 232 to $238 \mathrm{~m}$ (760 to $780 \mathrm{ft}$ ) amsl. Unnamed seasonal drainages are located approximately $200 \mathrm{~m}$ southwest and southeast of the site and empty into 
Chalker Creek approximately $1.5 \mathrm{~km}$ southwest of the site. Vegetation in the area of the site consists of mesquite, tasajillo, prickly pear cactus, acacia, and short grasses. Ground visibility is approximately 90 percent.

The site is a moderate-density lithic scatter measuring approximately $600 \mathrm{~m}$ northeast to southwest and over $400 \mathrm{~m}$ northwest to southeast, extending northwest beyond the property boundary. The identified portion of the site covers a total area of approximately $240,000 \mathrm{~m}^{2}$. The lithic assemblage consists primarily of primary and secondary flakes and shatter of chert and quartzite available onsite in the form of exposed gravel terraces. The density of artifacts at site 41 WB522 is approximately 5-10 specimens per $25-\mathrm{m}^{2}$ area, with the highest density being on the knoll itself. Erosion has resulted in the exposure of sandstone bedrock and chert gravels over approximately 60 percent of the site. No ground stone, features, or diagnostic artifacts were observed at the site.

A shovel test was excavated at site 41WB522 in order to determine the presence of subsurface cultural deposits. The shovel test was placed within the proposed ROW on the southeast side of the primary twotrack paralleling the fence. Soil at the site consists of yellowish brown clay loam to a depth of $8 \mathrm{~cm} \mathrm{bs}$, followed by compact, medium brown silty clay with dark grayish brown mottling and caliche inclusions. The shovel test was excavated to a depth of $20 \mathrm{~cm}$ bs and no cultural deposits were identified.

Site 41WB522 is interpreted as a quarry consisting of a low-density, surface lithic scatter. The site extends beyond the project boundaries northwest of Galvan Fence. Disturbances include the construction of Galvan Fence and the two-track roads that parallel the fence through the length of the site. Extensive erosion has resulted in bedrock and gravel exposures throughout the site. The surficial nature of the site, the lack of features, and the extensive disturbances identified indicate the research potential of the evaluated area of site 41WB522 is minimal. Based on these observations, the portion of the site within the ROW is recommended as ineligible for inclusion in the NRHP. The remainder of the site could not be investigated. No additional work is recommended within the assessed portion of site 41WB522.

\section{Site 41 WB523}

Site 41 WB523 is located on a southwest-facing, gradual slope on the west side of the Vidal Cut approximately $900 \mathrm{~m}$ south of Galvan Fence, directly northwest of a stock pond in the northeast corner of Galvan Ranch (Figure 82; see Figure 9). The site was identified along and west of the existing roadbed and extends beyond the project boundary to the east. Elevation at the site is $223 \mathrm{~m}(730 \mathrm{ft}) \mathrm{amsl}$. Unnamed seasonal drainages are approximately $100 \mathrm{~m}$ southeast and $150 \mathrm{~m}$ northwest of the site, and Chalker Creek is approximately $1.2 \mathrm{~km}$ southwest of the site. Vegetation in the area of the site consists of mesquite, tasajillo, prickly pear cactus, acacia, and short grasses. Ground visibility at the site is approximately 85 percent.

The site is a low-density lithic scatter measuring approximately $60 \mathrm{~m}$ east to west and $55 \mathrm{~m}$ north to south, covering a total area of approximately $3,300 \mathrm{~m}^{2}$. The lithic assemblage consists primarily of flakes and shatter, with a small number of retouched flakes and scrapers; raw material consists of chert available in the vicinity of the site. The density of artifacts at site 41WB523 is approximately eight to 10 specimens per $25-\mathrm{m}^{2}$ area. The highest density of artifacts was identified in erosional gullies along the roadbed, suggesting the artifacts may have originated higher on the slopes to the northeast, beyond the project boundary. No ground stone, features, or evidence of quarrying were observed at the site. No diagnostic artifacts were identified. 
Figure

80. Plan map of site $41 \mathrm{WB} 521$

fold out 
Cultural Resources Survey for a JTF-6 Action in Webb, Maverick, and Dimmit Counties, Texas

fig 80 


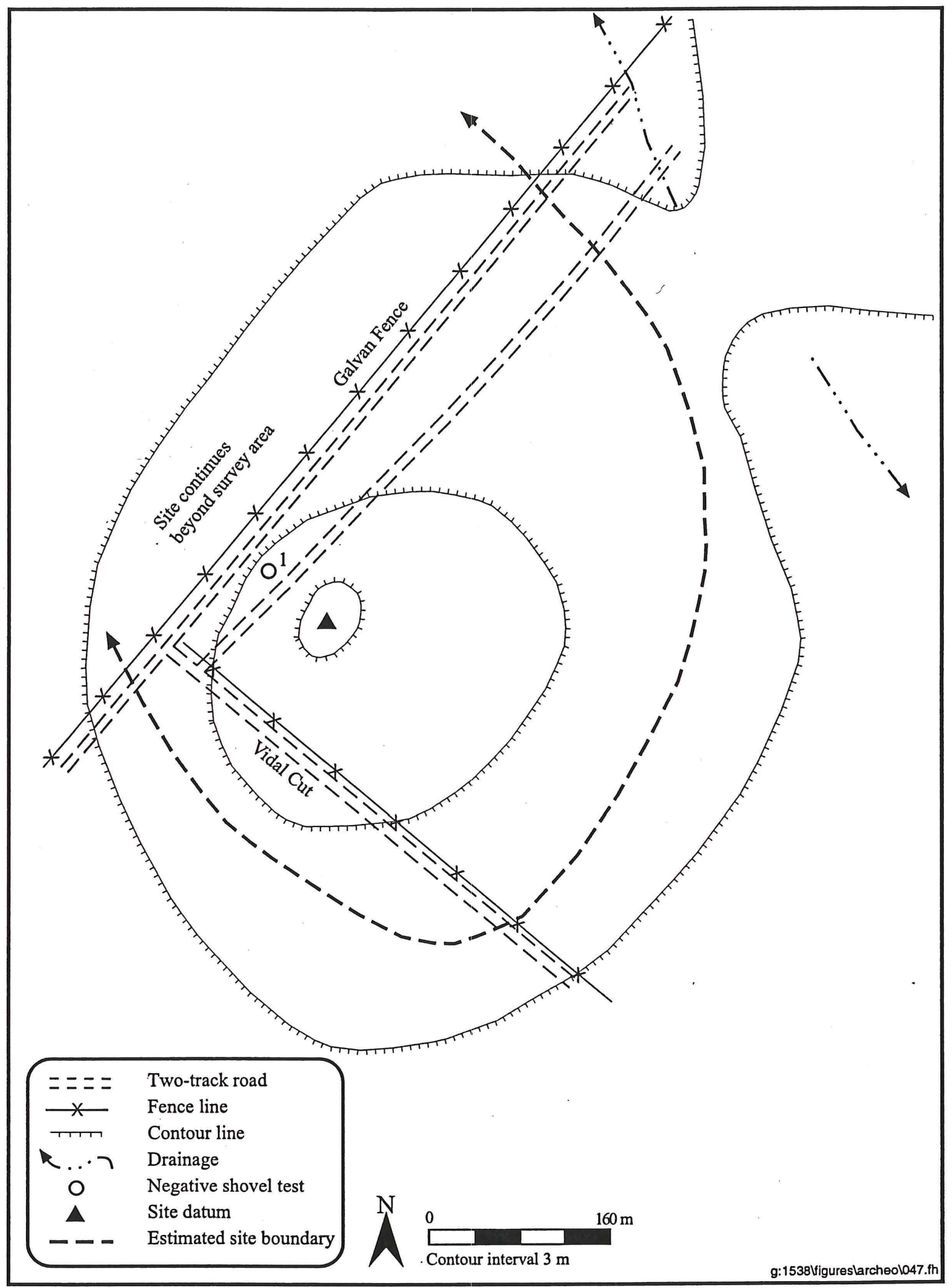

Figure 81. Plan map of site 41WB522. 


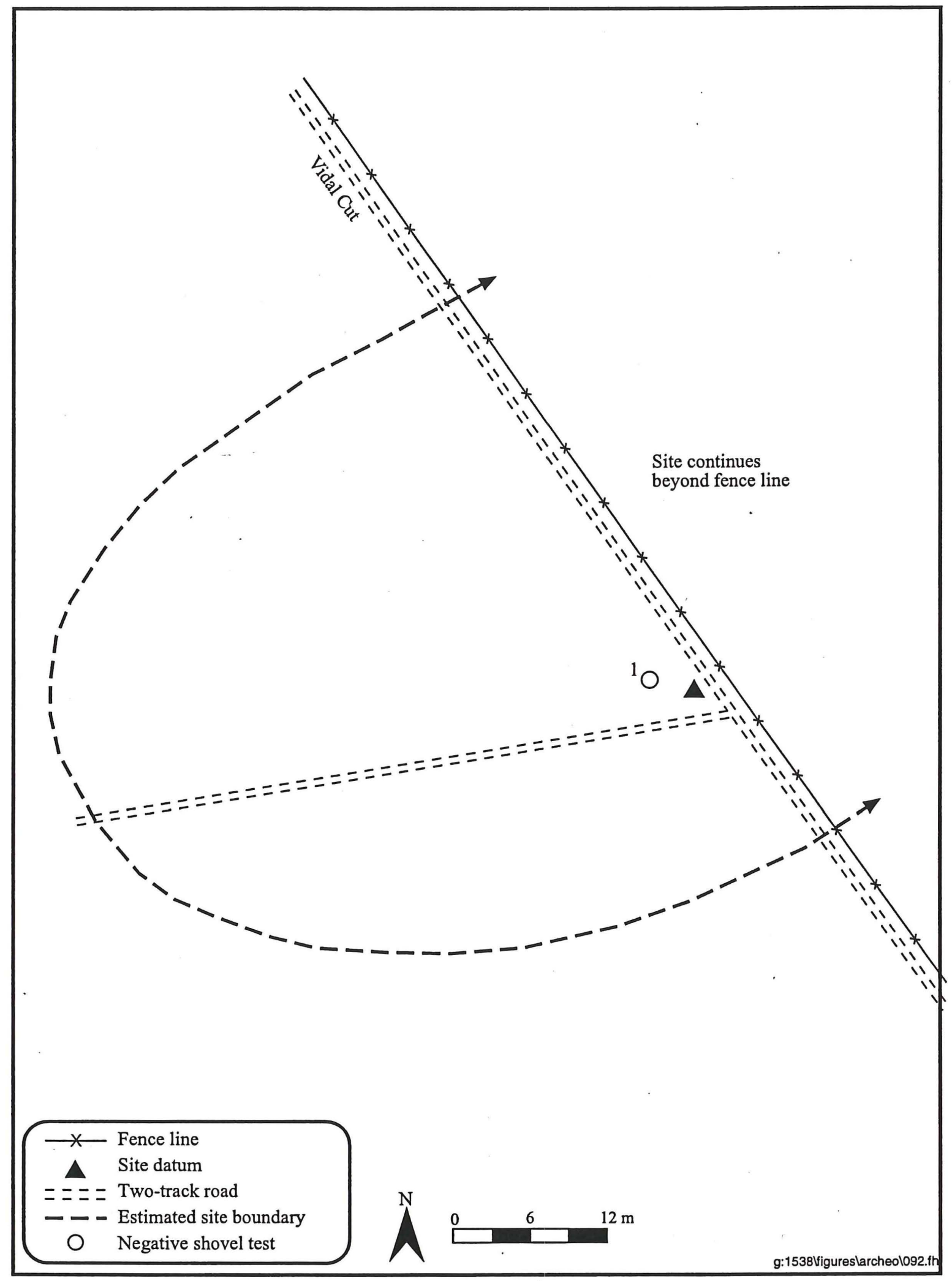

Figure 82. Plan map of site 41WB523. 
A shovel test was excavated at site 41WB523 in order to determine the presence of subsurface cultural deposits. The shovel test was placed in the proposed ROW along the existing northwest-southeast road cut. Soil at the site consists of dark yellowish brown silty loam to a depth of $8 \mathrm{~cm}$ bs, followed by a more compact, clayey soil with caliche inclusions. The shovel test was excavated to a depth of $20 \mathrm{~cm}$ bs and no subsurface cultural deposits were identified.

Site 41WB523 is interpreted as an open campsite consisting of a low-density, surficial lithic scatter. The site extends beyond the project boundaries to the northeast of the Vidal Cut fence line. Disturbances include the construction of the fence, the two-track road paralleling the fence, and a second two-track road extending west across the southern end of the site. Wild animal foraging and cattle grazing have also impacted the site. The lack of features or subsurface deposits and the extensive disturbances identified indicate the research potential of the evaluated area of site $41 \mathrm{WB} 523$ is minimal. Based on these observations, this portion of the site is recommended as ineligible for inclusion in the NRHP. The remaining portion of the site located beyond the survey area was not investigated. No additional work is recommended within the assessed portion of site 41WB523.

\section{Site 41 WB524}

Site 41WB524 is located on a flat bench on the eastern side of Galvan Ranch, at the east end of the Vidal Cut where it meets Main Galvan Road approximately $350 \mathrm{~m}$ west of the ranch main gate (Figure 83; see Figure 9). The site lies on the north side of the graded road at an elevation of $213 \mathrm{~m} \mathrm{(700} \mathrm{ft)} \mathrm{amsl.} \mathrm{An}$ unnamed seasonal drainage is approximately $300 \mathrm{~m}$ north of the site and Las Raices Creek is approximately $1.6 \mathrm{~km}$ southeast. Vegetation at the site is sparse and includes mesquite and some acacia. Ground visibility is approximately 95 percent.

The site is a low-density lithic scatter measuring approximately $220 \mathrm{~m}$ east to west and $40 \mathrm{~m}$ north to south. The site covers a total area of approximately $8,800 \mathrm{~m}^{2}$. The lithic assemblage consists primarily of small to moderate-sized chert flakes, a projectile point, and a scraper with a unifacially flaked notch, all of locally available chert. The projectile was identified as a Late Prehistoric Scallorn point, a cornernotched point with a straight base. Artifact density is approximately six to eight specimens per $25-\mathrm{m}^{2}$ area. No specific artifact concentrations were noted and no evidence of quarrying or features was observed at the site.

A single shovel test was excavated at site 41WB524 in order to determine the presence of subsurface cultural deposits. Soil at the site consists of yellowish red silty loam to a depth of $20 \mathrm{~cm} \mathrm{bs}$, followed by slightly more compact soil with caliche inclusions. The shovel test was excavated to a depth of $25 \mathrm{~cm}$ bs and was negative.

Site 41WB524 is interpreted as an open campsite consisting of a low-density, surficial lithic scatter. The single diagnostic artifact observed at the site was a Late Prehistoric projectile point. Disturbances include the construction and maintenance of the existing graded road directly south of the site. Erosion has resulted in the surface of the site being extensively deflated, and animal foraging was noted. The sparse, surficial nature of the site and the lack of features indicate the research potential of site 41WB524 is minimal. Based on these observations, the site is recommended as ineligible for inclusion in the NRHP. No additional work is recommended for site 41WB524. 


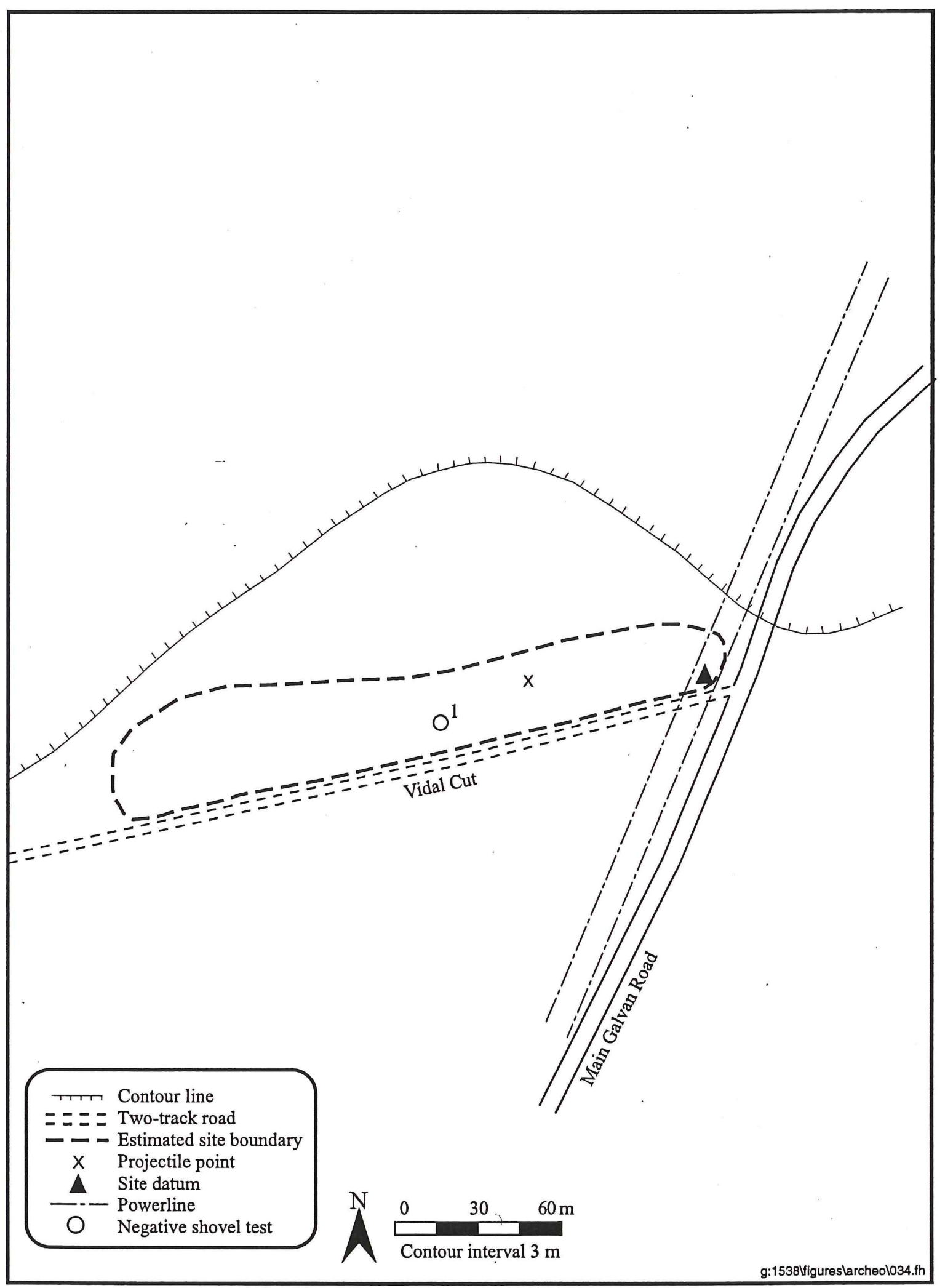

Figure 83. Plan map of site 41WB524. 


\section{Site 41 WB525}

Site 41WB525 is located on the eastern side of Galvan Ranch, $500 \mathrm{~m}$ southwest along Main Galvan Road from the ranch main gate (Figure 84; see Figure 9). The site lies on the east side of the main road, approximately $400 \mathrm{~m}$ south of a graded road which joins Main Galvan Road from the west. Elevation at the site is $213 \mathrm{~m}$ (700 ft) amsl. An unnamed seasonal drainage is approximately $300 \mathrm{~m}$ south from the center of the site and Las Raices Creek is approximately $1.2 \mathrm{~km}$ southeast. Vegetation in the area of the site includes mesquite, tasajillo, prickly pear cactus, acacia, and short grasses. Ground visibility is approximately 80 percent.

The site is a moderate-density lithic scatter measuring approximately $265 \mathrm{~m}$ northeast to southwest and over $175 \mathrm{~m}$ northwest to southeast, extending southeast beyond the project area. The portion of the site identified covers a total area of approximately $46,375 \mathrm{~m}^{2}$. The site is centered along a slightly elevated ridge approximately $100 \mathrm{~m}$ east of Main Galvan Road and extends southeast. Few artifacts were identified in the level area between the ridge and the road. Those artifacts which were observed are located in erosional gullies which bisect the level area and appear to have washed down from the ridge. Because the site is centered on the ridge approximately $100 \mathrm{~m}$ east of Main Galvan Road, the proposed ROW will not impact the site.

Investigations at the site were limited because the site lies outside the proposed ROW. The lithic assemblage consists of tertiary flakes, shatter, cores, retouched flakes, bifaces, and three projectile points. Artifact density is approximately 10-12 specimens per $25-\mathrm{m}^{2}$ area. Raw material in the form of chert gravels is exposed on the top and slopes of the ridge. Very little soil remains on the site. One of the projectile points was a small triangular point with a concave base identified as a Late Prehistoric Fresno/McGloin-like projectile point (Figure 85a; Turner and Hester 1993:213, 224). An elongate, strait-based point also observed at the site was identified as a Pandora point, dated to the Middle to Late Archaic; it is possible this point may also be a preform (see Figure 85b; Turner and Hester 1993:170). The third point was fragmented at the base and could not be typed. No ground stone, evidence of quarrying, or features were observed at the site. Shovel testing was not conducted.

Site 41WB525 is interpreted as an open campsite consisting of a moderate-density, surficial lithic scatter. Multiple occupation components are suggested by the two typed projectile points identified at the site which date from the Middle to Late Archaic and the Late Prehistoric. Because the site is beyond the proposed ROW and fieldwork conducted at the site was limited, the site does possess research potential. Therefore, the site is recommended as potentially eligible for inclusion in the NRHP. However, due to the location of site 41WB525 outside the proposed ROW, avoidance of the site will be accomplished provided there is no change to the proposed ROW. The presence of an archeological monitor is recommended in order to keep equipment off of undisturbed portions of $41 \mathrm{WB} 525$ and to ensure that no buried deposits associated with the site are encountered during construction activities.

\section{Site 41 WB526}

Site 41WB526 is located on the southwest-facing slope of a large hill in the northcentral portion of the Galvan Ranch along Galvan Fence, approximately $1.2 \mathrm{~km}$ northwest of Willow Tank (Figure 86; see Figure 9). The site was identified in the existing road and extends northwest beyond the project boundaries. Elevations at the site range from 204 to 215 (670 to $705 \mathrm{ft}$ ) amsl. An unnamed seasonal drainage forms the western boundary of the site and Santa Isabel Creek is approximately $2.5 \mathrm{~km}$ east of the site. Vegetation at the site is relatively sparse and includes mesquite, creosote bush, prickly pear cactus, tasajillo, acacia, and short grasses. Ground visibility is approximately 70 percent. 


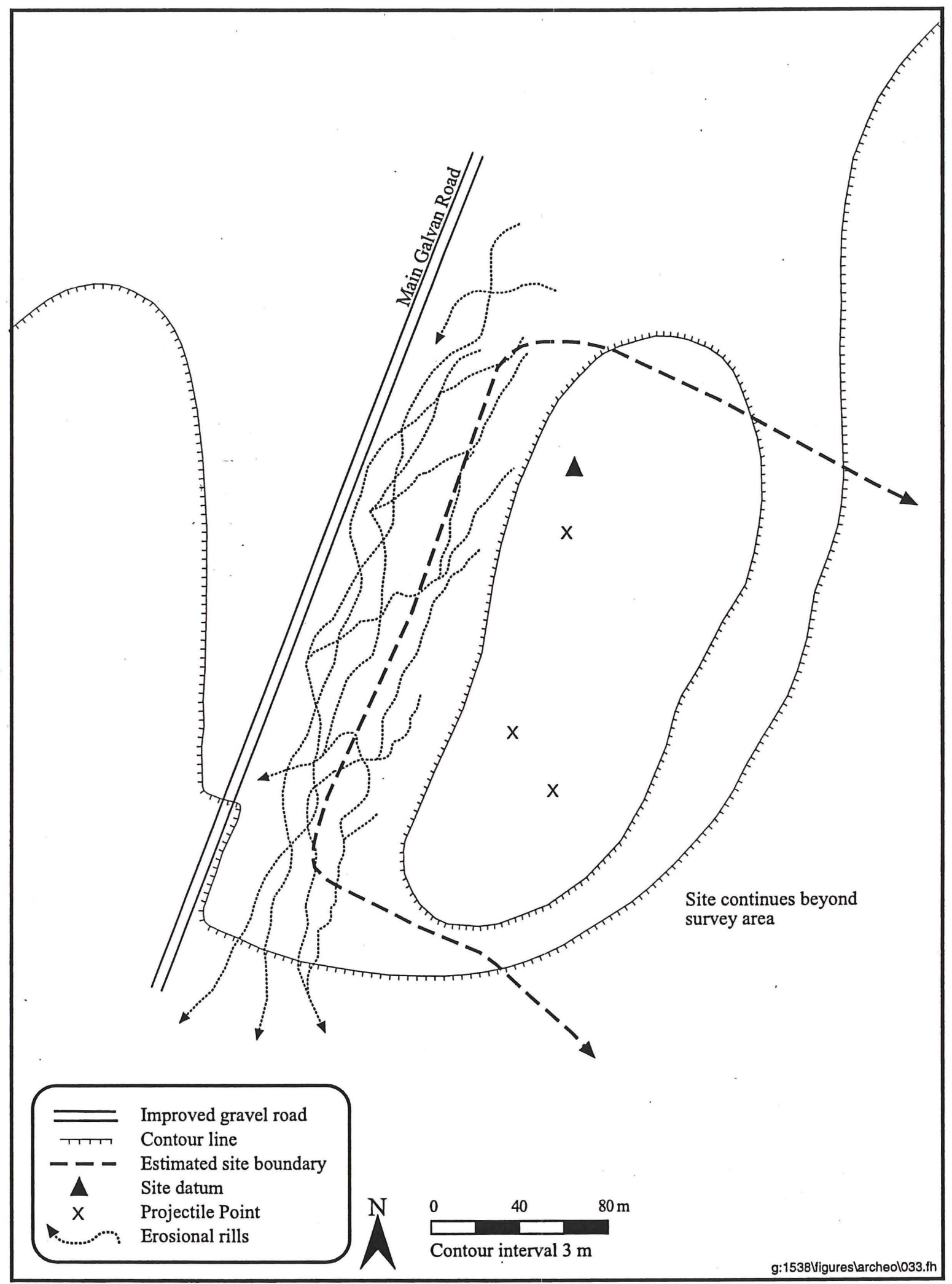

Figure 84. Plan map of site 41WB525. 

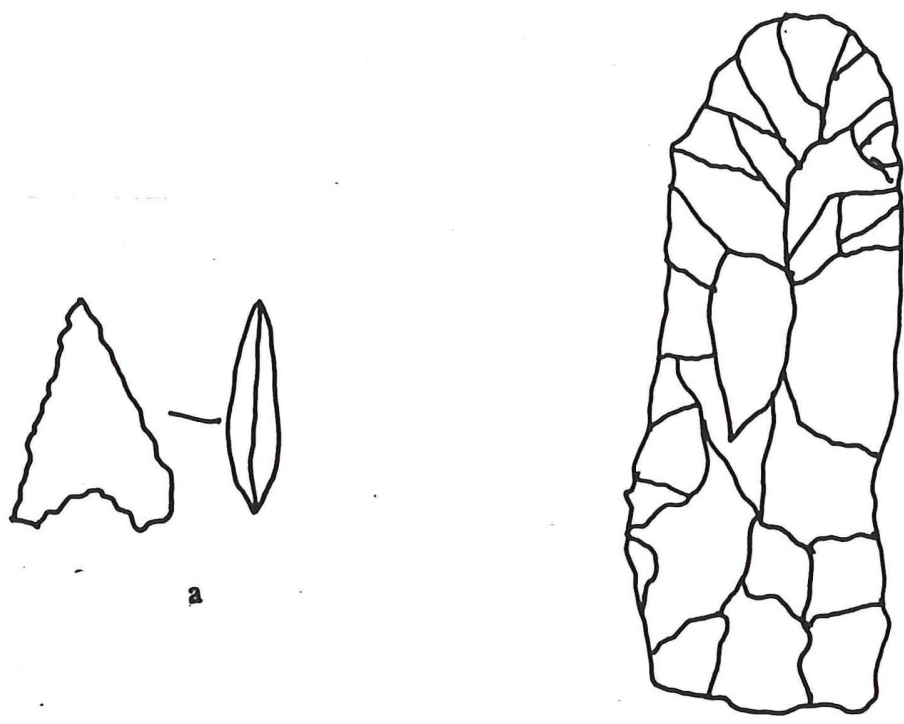

b

Figure 85. Field illustrations of projectile points identified at site 41WB525: (a) Fresno/McGloin-like point and (b) Pandora point (Scale 1:1).

The site is a low-density lithic scatter measuring approximately $650 \mathrm{~m}$ northeast to southwest and over $150 \mathrm{~m}$ northwest to southeast, extending beyond the project boundary to the northwest. The identified portion of the site covers a total area of approximately $97,500 \mathrm{~m}^{2}$. Cobble and gravel lenses are exposed throughout the site. The lithic assemblage consists primarily of primary and secondary flakes, shatter, tested cobbles, cores, and two projectile points, all of the type and quality of chert and quartzite available onsite. The projectile points were identified as Catán, a small Late Archaic to Late Prehistoric point with a well-rounded base, and Refugio, an Archaic unstemmed elongate point (Figure 87; Turner and Hester $1993: 89,178)$. The density of artifacts at site $41 \mathrm{WB} 526$ is approximately five to six artifacts per $25-\mathrm{m}^{2}$ area. No ground stone or features were observed at the site.

Due to extensive erosion, the only soil remaining onsite was that which had accumulated in small erosional drainages. Due to the deflated nature of the site, no shovel testing was conducted.

Site 41WB526 is interpreted as a quarry site consisting of a low-density, surface scatter of lithic artifacts. The site was identified in the proposed ROW on the existing road along Galvan Fence and extends beyond the property boundary to the northwest. Disturbances include Galvan Fence and the road running parallel to the fence which extend the length of the site. Erosion was also noted resulting in extensive surface deflation with small pockets of sedimentation remaining in erosional drainages only. The deflated nature of the site, the lack of features, and road and fence line disturbances identified indicate the research potential of the evaluated area of site 41WB526 is minimal. Based on these observations, the portion of the site within the ROW is recommended as ineligible for inclusion in the NRHP. The remainder of the site could not be investigated. No further work within the assessed portion of site $41 \mathrm{WB} 526$ is recommended. 


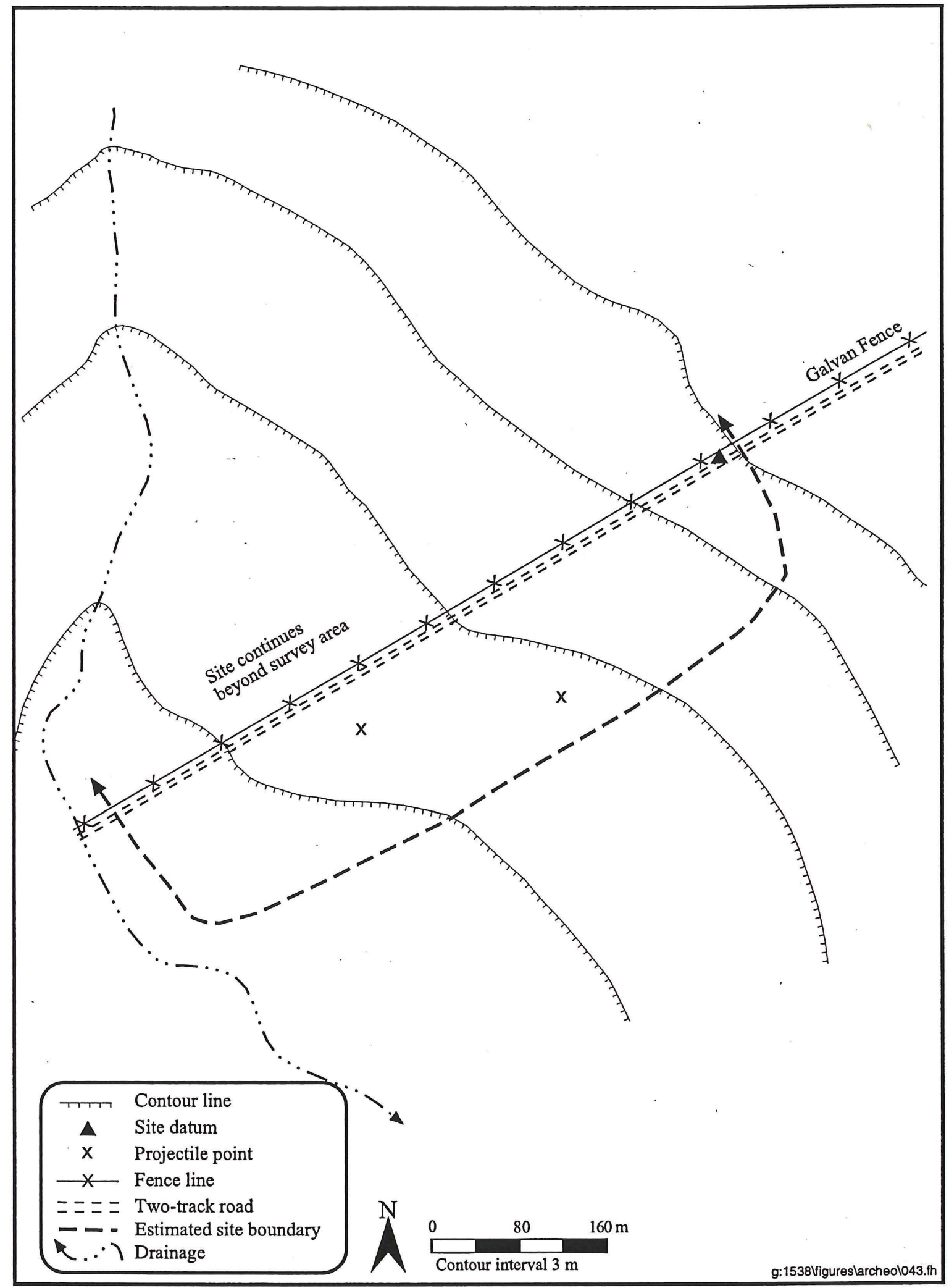

Figure 86. Plan map of site 41WB526. 


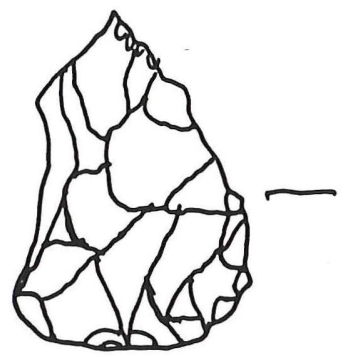

a

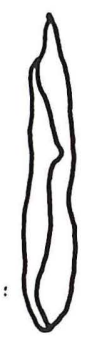

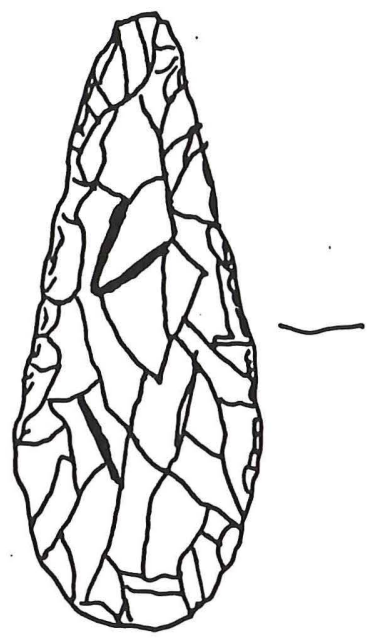

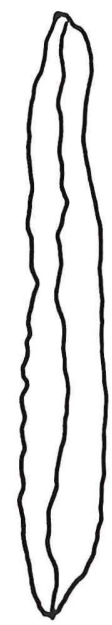

b

Figure 87. Field illustrations of projectile points identified at site 41WB526: (a) Catán point and (b) Refugio point (Scale 1:1).

\section{Site 41 WB527}

Site 41WB527 is located on a north-trending ridge along Trevino Fence in the southeast portion of the Galvan Ranch, approximately $2.4 \mathrm{~km}$ east of Huisache Tank (Figure 88; see Figure 9). The site was identified in the existing road and extends beyond the project boundaries to the northwest and southeast. Elevations at the site range from 210 to $213 \mathrm{~m}$ (690 to $700 \mathrm{ft}$ ) amsl. An unnamed seasonal drainage is approximately $170 \mathrm{~m}$ southwest of the site and Cuchara Creek is approximately $500 \mathrm{~m}$ north. Vegetation in the area of the site is dense and consists of mesquite, prickly pear cactus, and short grass. Ground visibility is approximately 60 percent.

The site is a small, high-density lithic scatter measuring approximately $225 \mathrm{~m}$ southwest to northeast and over $75 \mathrm{~m}$ northwest to southeast, extending beyond the project boundaries to the northwest and southeast. The identified portion of the site covers a total area of approximately $16,875 \mathrm{~m}^{2}$. The lithic assemblage consists primarily of secondary and tertiary flakes and bifaces of locally available chert. Artifact density is approximately 20 to 25 specimens per $25-\mathrm{m}^{2}$ area. No ground stone, evidence of quarrying, or features were observed at the site. No diagnostic artifacts were identified.

A single shovel test was excavated at site 41WB527 in order to determine the presence of subsurface cultural deposits. The test was placed in the proposed ROW on the northwest side of the road paralleling Trevino Fence. Soil at the site consists of medium brown silty loam to the maximum depth of the shovel test $(40 \mathrm{~cm}$ bs). No artifacts were recovered from the shovel test.

Site 41WB527 is interpreted as an open campsite consisting of a high-density, surface scatter of lithic artifacts. No subsurface cultural deposits were identified. Disturbances include extensive erosion, Trevino Fence and the two-track road paralleling the fence, and a drainage gully approximately $20 \mathrm{~m}$ northwest of the fence line that extends the length of the site. The absence of a subsurface cultural 


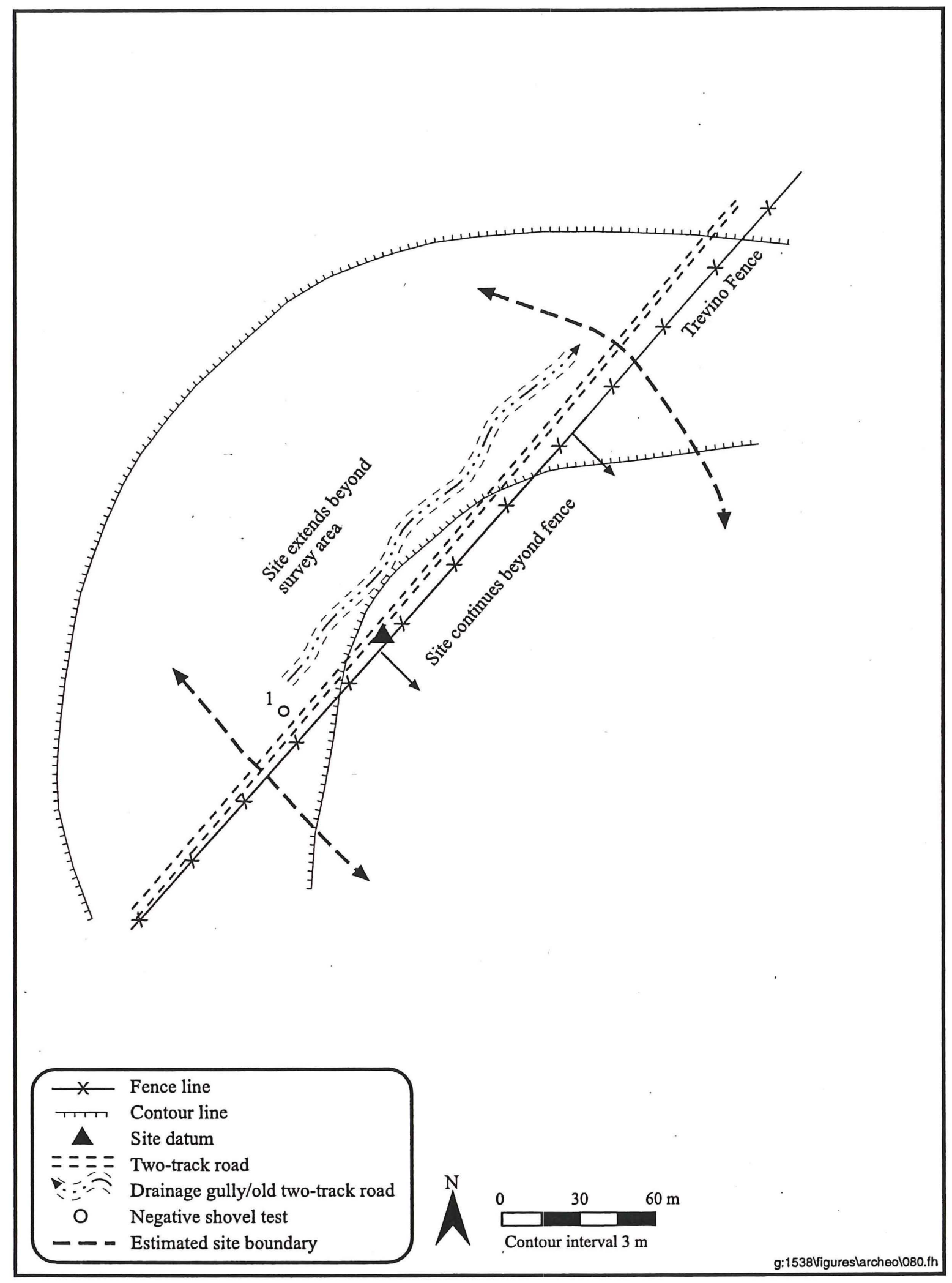

Figure 88. Plan map of site 41WB527. 
deposit, the lack of features, and the extensive disturbances identified indicate the research potential of the evaluated area of site 41WB527 is minimal. Based on these observations, the portion of the site within the ROW is recommended as ineligible for inclusion in the NRHP. The remainder of the site could not be investigated. No further work within the assessed portion of site 41WB527 is recommended.

\section{Site 41 WB528}

Site 41WB528 is located on a gradual, northwest-facing slope along Trevino Fence, approximately 3.5 $\mathrm{km}$ northeast of the intersection of Greengate and Trevino fences in the southeast portion of the Galvan Ranch (Figure 89; see Figure 9). The site was identified in the existing road and extends beyond the project boundaries to the southeast. Elevations at the site range from 218 to $221 \mathrm{~m}(715$ to $725 \mathrm{ft}$ ) amsl. Cuchara Creek is approximately $800 \mathrm{~m}$ north of the site. Vegetation in the area of the site is moderately dense and consists of mesquite, creosote, prickly pear cactus, tasajillo, allthorn, and soapbush. Ground visibility is approximately 70 percent.

The site is a low-density lithic scatter measuring approximately $270 \mathrm{~m}$ southwest to northeast and over 75 $\mathrm{m}$ northwest to southeast, extending beyond the project boundaries to the southeast. The identified portion of the site covers a total area of approximately $20,250 \mathrm{~m}^{2}$. The lithic assemblage consists primarily of tertiary flakes, shatter, cores, bifaces, and a projectile point that was identified as a Late Archaic to Late Prehistoric Catán point (Turner and Hester 1993:89). All raw material at the site is locally available chert. Artifact density is approximately six to eight specimens per $25-\mathrm{m}^{2}$ area. No ground stone, evidence of quarrying, or features were observed at the site.

A single shovel test was excavated at site 41WB528 in order to determine the presence of subsurface cultural deposits. The test was placed in the proposed ROW on the northwest side of the road paralleling Trevino Fence. Soil at the site consists of medium brown silty loam changing to a yellowish brown below $6 \mathrm{~cm}$. The shovel test was excavated to a depth of $30 \mathrm{~cm}$ bs and no artifacts were recovered from the shovel test.

Site 41WB528 is interpreted as an open campsite consisting of a low-density, surface scatter of lithic artifacts. No subsurface cultural deposits were identified. Disturbances include extensive erosion, the construction of Trevino Fence, two two-track roads that parallel the fence line, and a two-track road that extends north from Trevino Fence. The absence of a subsurface cultural deposit, the lack of features, and the extensive disturbances identified indicate the research potential of the evaluated area of site 41 WB528 is minimal. Based on these observations, this portion of the site is recommended as ineligible for inclusion in the NRHP. The remaining portion of the site located beyond the survey area was not investigated. No further work within the assessed portion of site 41WB528 is recommended.

\section{Site 41 WB529}

Site 41WB529 is located on level ground on the northeast bank of Santa Isabel Creek along Trevino Fence, approximately $2.1 \mathrm{~km}$ southeast of the intersection of Greengate and Trevino fences, in the southcentral portion of Galvan Ranch (Figure 90; see Figure 9). The site extends beyond the property boundary to the southeast. Elevation at the site is $192 \mathrm{~m} \mathrm{(630} \mathrm{ft)} \mathrm{amsl.} \mathrm{Santa} \mathrm{Isabel} \mathrm{Creek} \mathrm{is} \mathrm{approximately} 50 \mathrm{~m}$ southwest of the site. Vegetation in the area of the site is relatively sparse and consists of prickly pear cactus, grasses, and some tasajillo. Ground visibility is approximately 60 percent. 


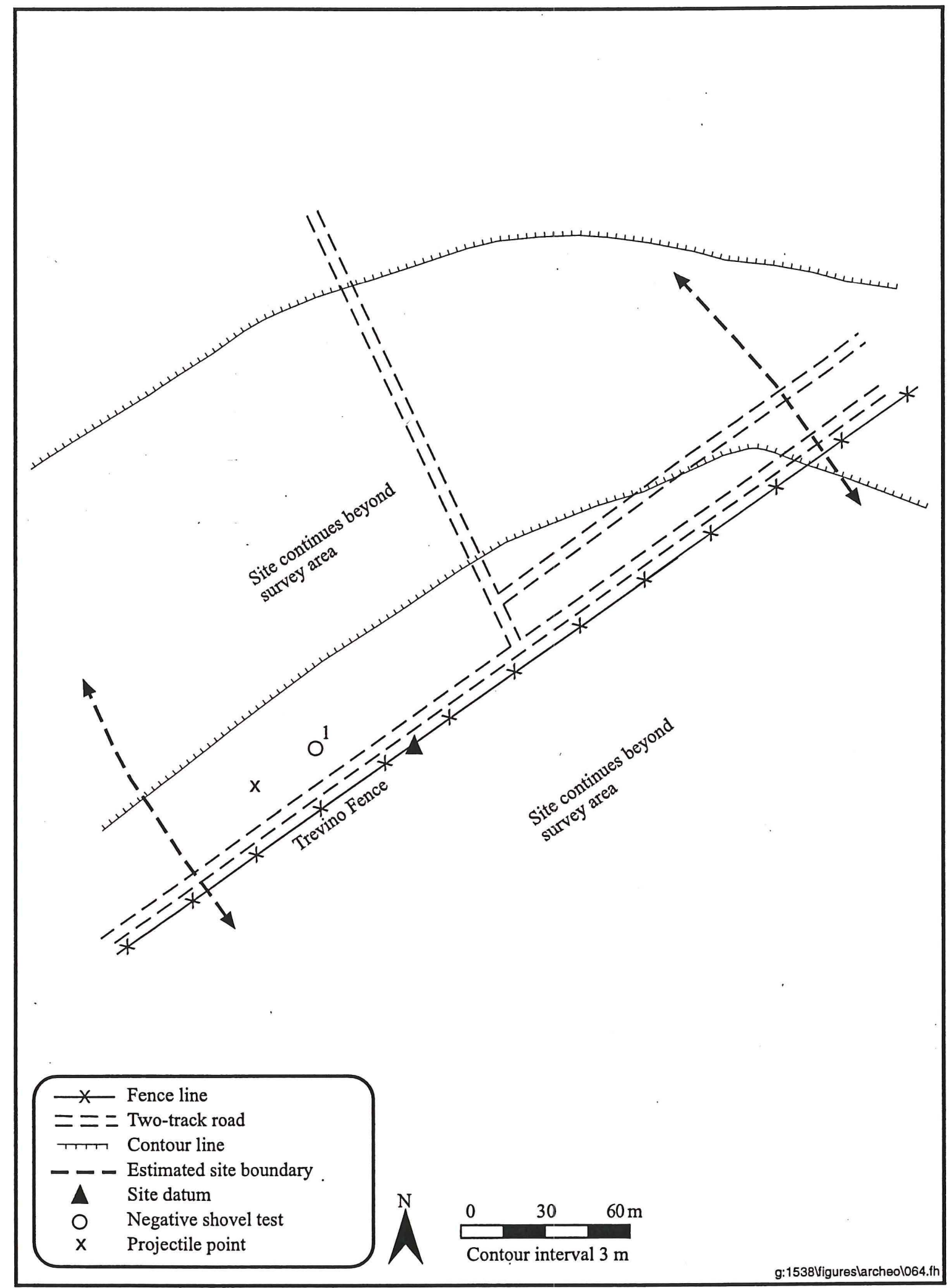

Figure 89. Plan map of site 41WB528. 


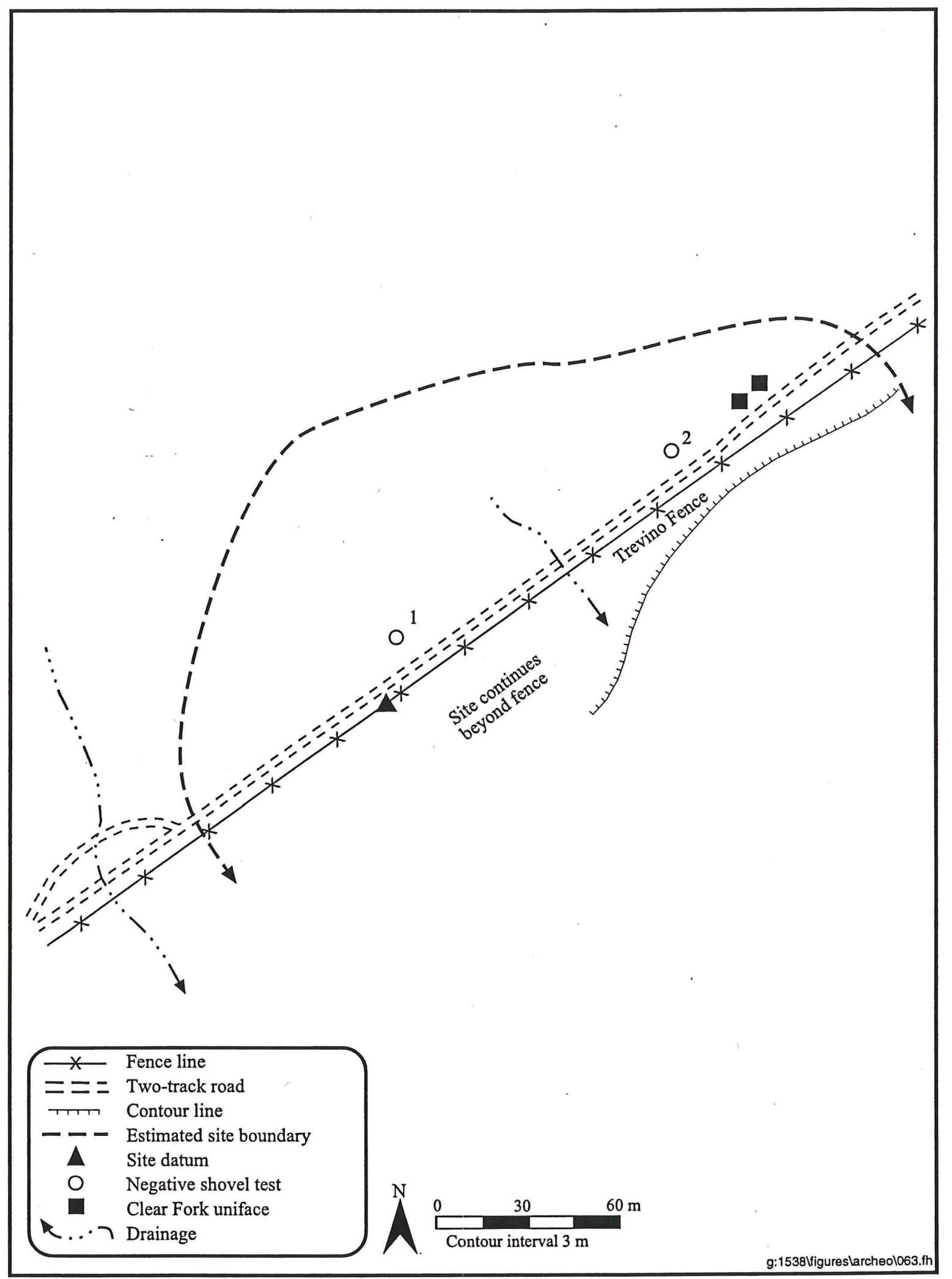

Figure 90. Plan map of site 41WB529. 
The site is a low-density lithic scatter measuring approximately $270 \mathrm{~m}$ southwest to northeast and over 80 $\mathrm{m}$ northwest to southeast, extending beyond the property boundary to the southeast. The identified portion of the site covers a total area of approximately $21,600 \mathrm{~m}^{2}$. The lithic assemblage consists primarily of tertiary flakes and a possible Clear Fork tool, all of locally available chert. The density of artifacts at site 41WB529 is approximately six to eight specimens per $25-\mathrm{m}^{2}$ area. No ground stone, features, or evidence of quarrying were observed at the site. Diagnostic artifacts identified are limited to the possible Clear Fork uniface, a tool type usually dated from the Paleo-Indian and Early Archaic into the Middle Archaic (Turner and Hester 1993:246-249).

Two shovel tests were excavated at site 41WB529 in order to determine the presence of subsurface cultural deposits. Both were placed within the proposed ROW between 15 and $10 \mathrm{~m}$ southwest of the existing road. Both shovel tests were negative. Soil at the site consists of dark grayish brown silty loam changing to an olive brown clayey loam below approximately $5 \mathrm{~cm}$. Shovel Tests 1 and 2 were excavated to depths of 30 and $20 \mathrm{~cm}$ bs, respectively.

Site 41WB529 is interpreted as an open campsite consisting of a low-density, surficial lithic scatter. Although no subsurface cultural deposits were identified at site $41 \mathrm{WB} 529$, the proximity of the site to 41WB486, one of the sites along Trevino Fence at which a subsurface deposit was identified, suggests site 41WB529 may also contain buried deposits. Based on the possible research value of the site, the site is recommended as potentially eligible for inclusion in the NRHP. Avoidance of site 41WB529 is recommended by prohibiting additional grading, reworking, or ground disturbance within the limits of the site. The presence of an archeological monitor is recommended in order to keep equipment off of undisturbed portions of site 41WB529 and to ensure that intact portions of the site are not impacted by road improvement activities.

\section{Site 41 WB530}

Site 41WB530 is located on relatively level ground at the seven-mile marker along Main Galvan Road, approximately $1.2 \mathrm{~km}$ east of the ranch headquarters complex (Figure 91; see Figure 9). The site extends approximately $40 \mathrm{~m}$ north and approximately $200 \mathrm{~m}$ south of Main Galvan Road, paralleling a graded northwest-southeast-trending road on the southwest side of the site. Elevations at the site range from 213 to $216 \mathrm{~m}$ (700 to $710 \mathrm{ft}$ ) amsl. An unnamed seasonal drainage is within $50 \mathrm{~m}$ of the southwest edge of the site and Cuchara Creek is approximately $1.8 \mathrm{~km}$ south of the center of the site. Vegetation in the area of the site is moderate and includes mesquite, tasajillo, prickly pear cactus, acacia, and short grasses. Ground visibility is approximately 65 percent.

The site is a moderate-density lithic scatter measuring approximately $310 \mathrm{~m}$ northwest to southeast and $200 \mathrm{~m}$ northeast to southwest, covering a total area of approximately $62,000 \mathrm{~m}^{2}$. The lithic assemblage consists primarily of tertiary flakes, scrapers, retouched flakes, bifaces, a projectile point, and a point tip. Raw material at the site consists of locally available chert and quartzite. The complete point was identified as an Archaic Refugio point, although this point type may represent a preform rather than a finished projectile point (Turner and Hester 1993:178). The density of artifacts at site 41WB530 is approximately 12 to 18 specimens per $25-\mathrm{m}^{2}$ area. In addition, a single fragment of mussel shell and a scatter of four fire-cracked rock fragments were identified. The fire-cracked rock was not identified as a feature. No ground stone or evidence of quarrying were observed at the site. 


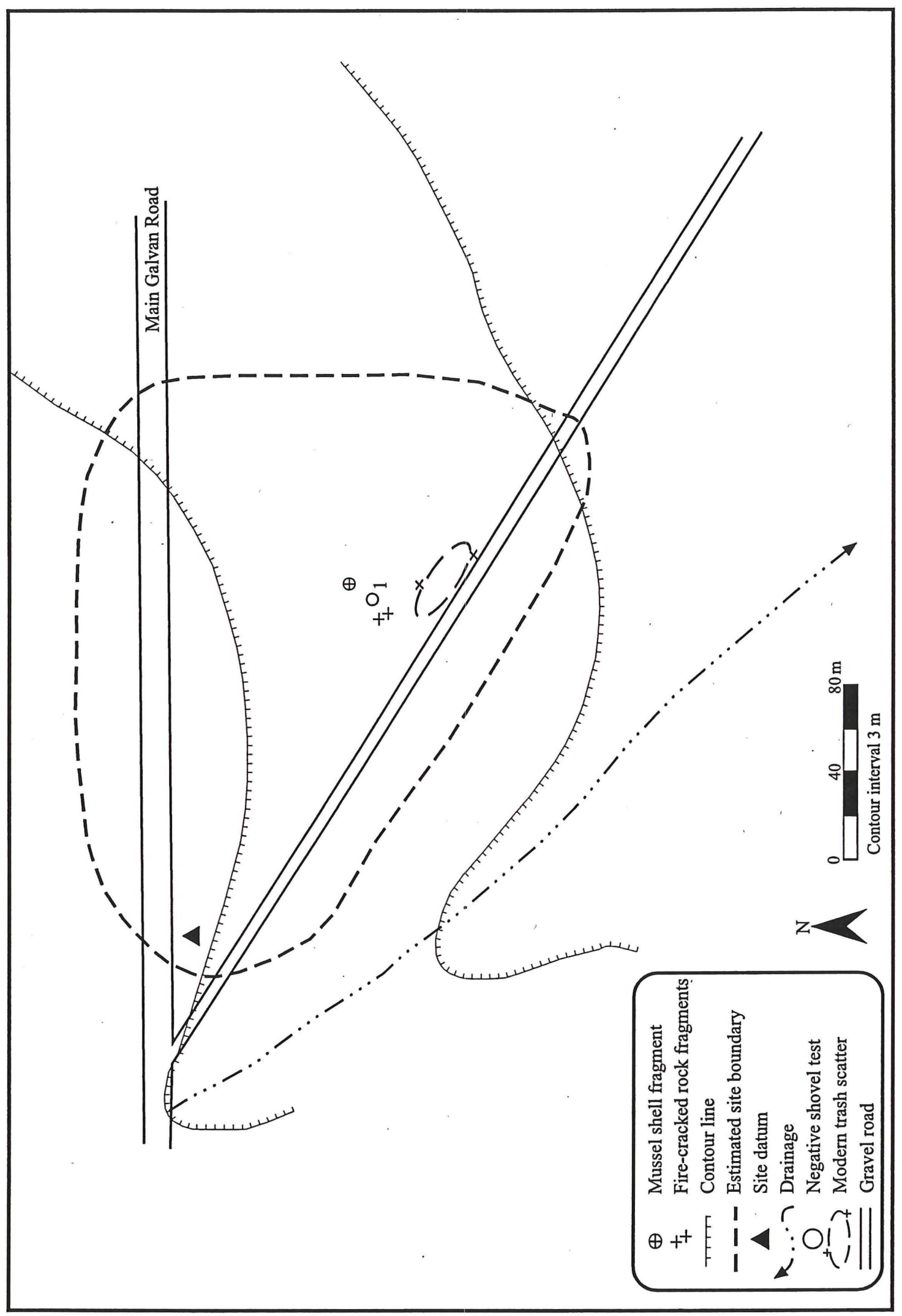

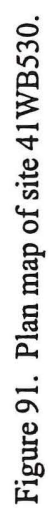


A shovel test was excavated at site 41WB530 in order to determine the presence of subsurface cultural deposits. The shovel test was placed approximately $3 \mathrm{~m}$ southwest of the shell fragment and approximately $5 \mathrm{~m}$ east of the fire-cracked rock fragments. Soil at the site consists of strong brown silty loam to a depth of $25 \mathrm{~cm}$ bs, below which the soil is slightly lighter, more compact, and contains caliche. The shovel test was excavated to a depth of $28 \mathrm{~cm}$ bs and no cultural material was identified.

Site 41WB530 is interpreted as an open campsite consisting of a moderate-density, surface lithic scatter. Although the site has been disturbed by road cuts and a small modern trash scatter in the southeast portion of the site, a large portion of the site appears to be intact. The presence of mussel shell, the only site on Galvan Ranch to produce organic material, and of fire-cracked rock fragments is often indicative of subsistence activities. The presence of organic material at $41 \mathrm{WB} 530$ suggests that preservational conditions may be better at this site than at other sites on Galvan Ranch and, therefore, indicates an increased potential for buried features and/or subsurface deposits. Based on the possible research value of the site, the site is recommended as potentially eligible for inclusion in the NRHP. Avoidance of site $41 \mathrm{WB} 530$ is recommended by not allowing additional grading, reworking, or ground disturbance within the limits of the site. The presence of an archeological monitor is recommended in order to keep equipment off of site $41 \mathrm{WB} 530$ and to ensure that intact portions of the site are not impacted by road improvement activities.

\section{STONE RANCH SEGMENT}

A total of six archeological sites and 21 localities was identified during the cultural resources survey of the Stone Ranch project area (Figure 92). Four of the archeological sites documented on the Stone Ranch segment are recommended as potentially eligible for inclusion in the NRHP, and appropriate measures should be taken to ensure that these sites are not impacted by the proposed road construction and improvement activities. Two remaining sites were identified within the proposed ROW; the entire area of each of the sites is recommended as ineligible for inclusion in the NRHP and no further work is recommended. Each site is discussed individually below.

A total of 21 localities was recorded on the Stone Ranch segment. All of these localities consist of sparse lithic scatters that fail to meet the density and subsurface context criteria used in designating archeological sites and thus have not been described individually.

Stone Ranch Sites

\section{Site $41 M V 205$}

Site 41MV205 is located in the northwest corner of the Stone Ranch project area, near the northwestern extent of a ridge overlooking the Rio Grande (Figure 93; see Figure 92). A corral is within the site boundaries, accessible by a two-track that enters the site from the east. The proposed ROW is along the existing two-track road. The elevation at the site ranges from 198 to $203 \mathrm{~m}(650$ to $665 \mathrm{ft})$ amsl across the site. An intermittent drainage parallels the north boundary approximately $20 \mathrm{~m}$ outside the site area, and the Rio Grande is about $75 \mathrm{~m}$ to the west. Vegetation is sparse, consisting of short grasses, mesquite, locust, and some prickly pear. Ground surface visibility averages about 90 percent. 


\section{Figure}

92. Location of sites and nonsite localities on the Stone Ranch segment

fold-out 
Cultural Resources Survey for a JTF-6 Action in Webb, Maverick, and Dimmit Counties, Texas

fig 92 


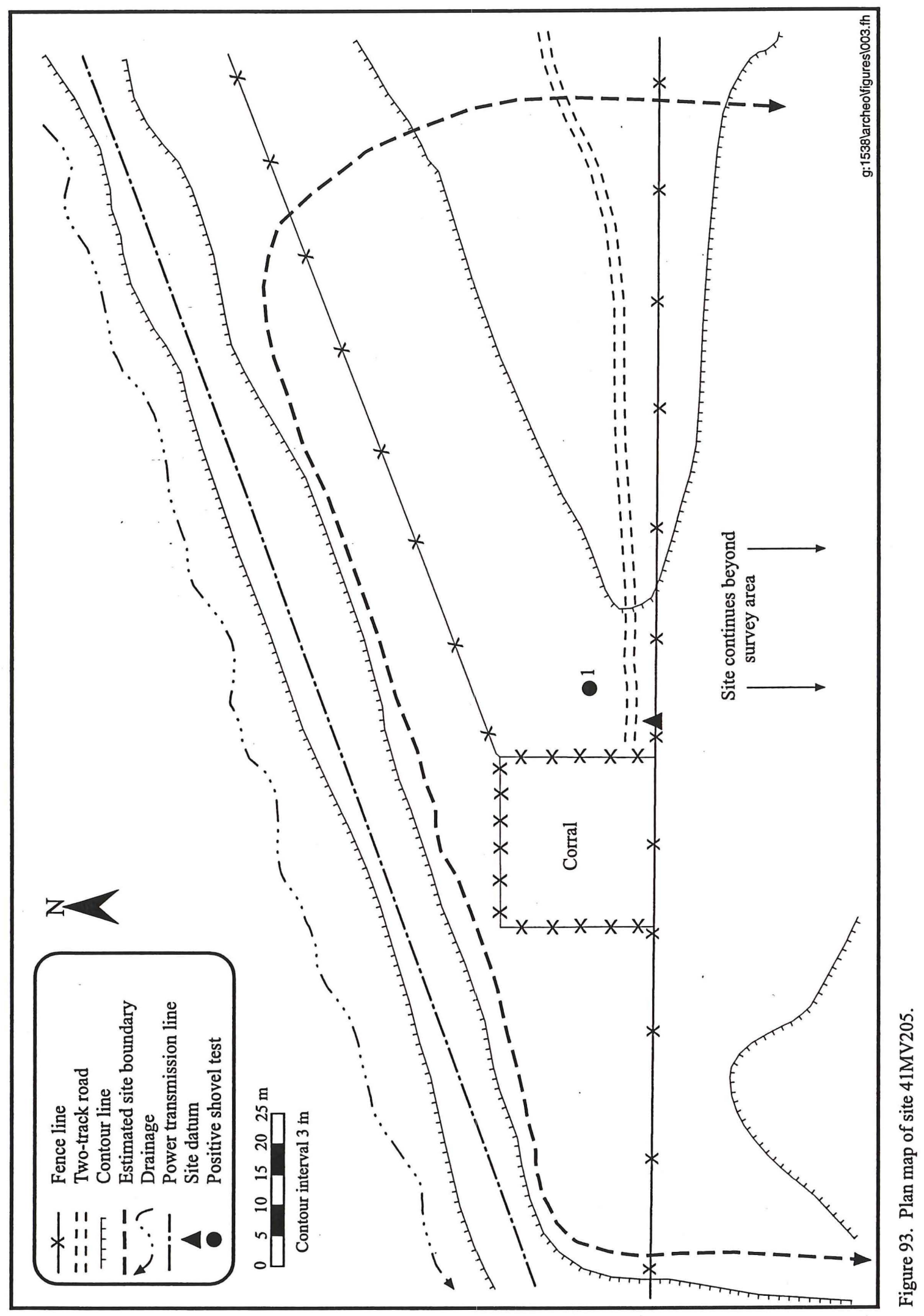


The site consists of a large, moderate-density scatter of flakes from a variety of cherts, extending $180 \mathrm{~m}$ east to west and at least $80 \mathrm{~m}$ north to south. The southern boundary was not identified because it extended outside the limits of the current survey. The total recorded area of the site is at least 14,400 $\mathrm{m}^{2}$. Most of the flakes at the site are cortical, and some of the debitage in the two-track appears to be naturally fragmented. Raw material consists primarily of locally available chert. No distinct artifact concentrations were observed at the site and no cultural features were identified.

One shovel test was placed at the site to determine the depth of soil at the site and whether subsurface cultural materials are present. The shovel test was placed near the center of the identified site area. Four flakes, a piece of mussel shell, and a possible piece of fire-cracked rock were observed in the upper $20 \mathrm{~cm}$, and two more flakes were observed between 20 and $30 \mathrm{~cm} \mathrm{bs}$. No artifacts were observed between 30 and $50 \mathrm{~cm}$. The $0-$ to- $20-\mathrm{cm}$ excavated level consisted of a medium brown silty loam with some gravels and caliche concentrations, followed by an increase in gravels and caliche concentrations between 20 and $40 \mathrm{~cm}$. The 40-to-50-cm level consisted of a lighter brown, more compact clay loam with fewer gravels and caliche concentrations. The shovel test was terminated when this subsoil was encountered.

Site 41MV205 is interpreted as an open campsite and consists of a moderate-density scatter of lithic artifacts, primarily flakes, and a subsurface deposit that extends to a depth of $30 \mathrm{~cm}$ containing mussel shell and a possible fire-cracked rock fragment. This deposit suggests that buried features may exist at the site. Site integrity has been impacted somewhat by grazing, vehicular movement, animal foraging, and by erosion that has left the surface deflated. However, an estimated 75 percent of the site remains intact. The presence of potentially significant subsurface deposits indicates that the research potential of site 41MV205 is unknown. Therefore, the site is recommended as potentially eligible for inclusion in the NRHP. Avoidance of the site is recommended by prohibiting additional grading, reworking, or ground disturbance within the limits of the site. The presence of an archeological monitor is recommended to keep equipment off of undisturbed portions of site 41MV205 and to ensure that no additional impacts to intact portions of the site are incurred.

\section{Site 41MV206}

Site 41MV206 is located near the center of the north half of the Stone Ranch project area, along the western extent of the broad upland area just east of the Rio Grande (Figure 94; see Figure 92). It is found at the intersection of two improved two-track roads, one that provides access to the northern half of the ranch, the other bisecting the ranch east to west. The proposed ROW is along both existing twotracks. The elevation at the site is approximately $210 \mathrm{~m}(690 \mathrm{ft})$ amsl. Seasonal drainages are located about $100 \mathrm{~m}$ south and $200 \mathrm{~m}$ north of the site, and the Rio Grande is approximately $500 \mathrm{~m}$ to the west. Vegetation in the area is sparse, for the most part composed of mesquite and acacia. Ground surface visibility is about 95 percent.

The site is a low-density lithic scatter extending $300 \mathrm{~m}$ east to west and $250 \mathrm{~m}$ north to south, covering a total area of approximately $75,000 \mathrm{~m}^{2}$. The artifact assemblage consists of primary and secondary flakes, shatter, tested cobbles, and cores. Raw material at the site consists of chert and quartzite available onsite in the form of exposed gravel lenses. Artifact density varies from less than five specimens per $25-\mathrm{m}^{2}$ area to between eight and 10 per $25-\mathrm{m}^{2}$ area where gravels are exposed. The gravel terraces cross the site from approximately the northeast corner to the southwest corner. Other than this higher occurrence within the gravel beds, no distinctive artifact concentrations were noticed, and no cultural features were identified at the site. 


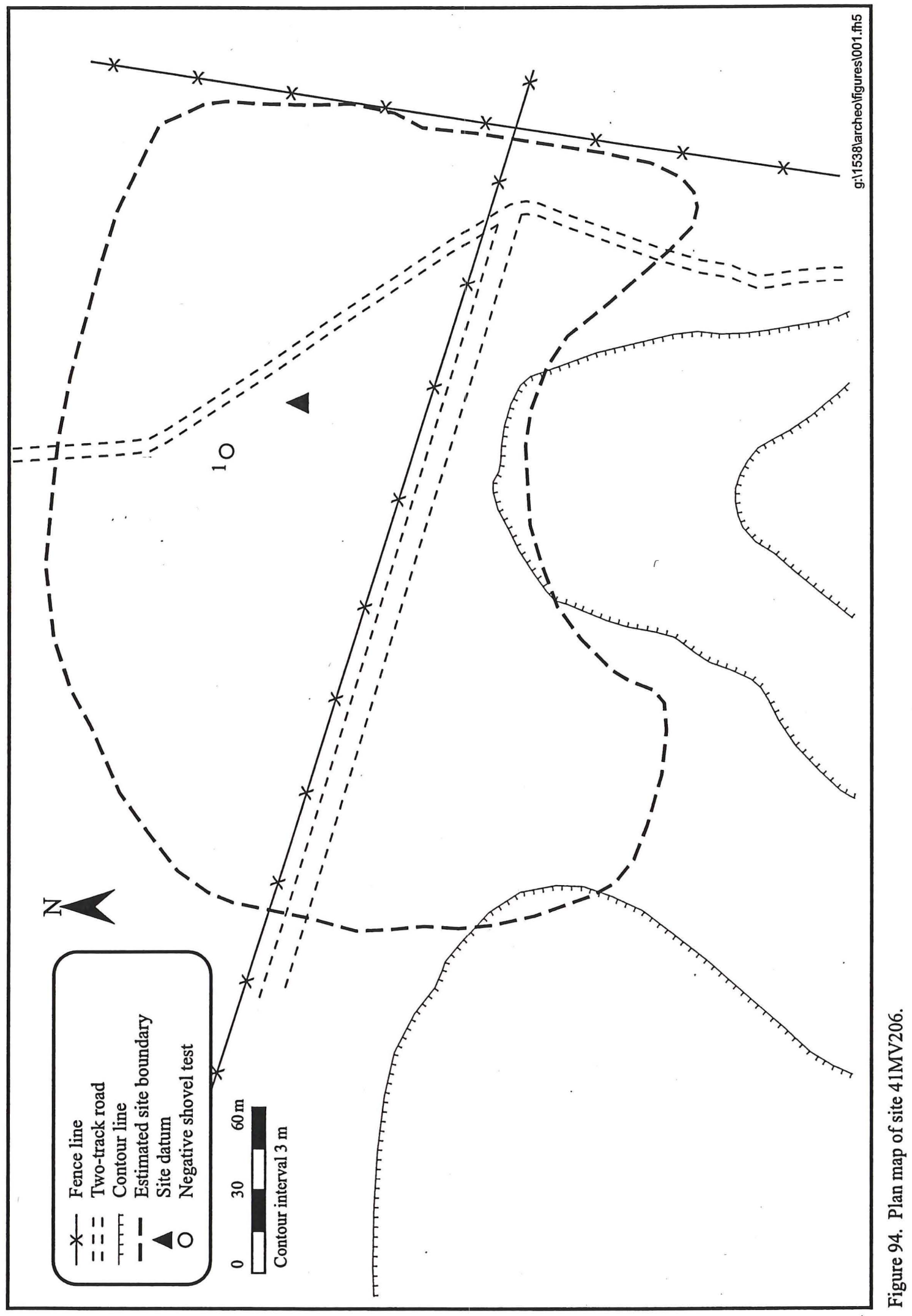


One shovel test was excavated at 41MV206 to ascertain soil depth and the presence or absence of subsurface cultural deposits. The shovel test was placed in an area of possibly intact soil in the central portion of the site. No cultural materials were encountered in the $30 \mathrm{~cm}$ of soil excavated for the shovel test. The soil consists of a medium brown compact silty loam with moderately abundant gravels between 0 and $20 \mathrm{~cm}$ bs. This was followed by a light brown, heavily compacted loam with a slightly lesser amount of gravels. The excavation of the shovel test was terminated at $30 \mathrm{~cm}$ when the sterile subsoil was encountered.

Site 41MV206 is interpreted as a quarry site and consists primarily of a low-density scatter of lithic artifacts, primarily flakes, tested cobbles, and cores. Gravels are exposed along the northeast to southwest axis of the site, and the higher density of artifacts is found among these gravels. No subsurface deposits were identified and very little sediment remains at the site. Site integrity has been impacted by road and fence construction and heavy erosion; only about 50 percent of the site is estimated to remain intact. The surficial nature of the site, the lack of features, and the disturbances caused by the existing road and fence line indicate the research potential of site $41 \mathrm{MV} 206$ is minimal. Based on these observations, the site is recommended as ineligible for inclusion in the NRHP. No further work at site $41 \mathrm{MV} 206$ is recommended.

\section{Site 41MV207}

Site 41MV207 is located near the center of the northern half of the Stone Ranch project area, along the western extent of the broad upland area just east of the Rio Grande (Figure 95; see Figure 92). It is situated at the end of a small finger ridge (the easternmost of two identical finger ridges) about $500 \mathrm{~m}$ east of the Rio Grande. Elevation at the site is $207 \mathrm{~m}(680 \mathrm{ft})$ amsl. Seasonal drainages are located along the east boundary and about $50 \mathrm{~m}$ west of the site. Vegetation in the area is moderately dense, consisting of mesquite, creosote, and acacia. Ground surface visibility averages about 95 percent.

This site is a low-density scatter of lithics that includes primary and secondary flakes, shatter, and tested cobbles, all of chert available onsite. The scatter extends over a roughly circular area about $100 \mathrm{~m}$ in diameter, covering an area of approximately $10,000 \mathrm{~m}^{2}$. The scatter is well-defined, confined to an area of exposed gravels. The artifact density is between six and eight per $25-\mathrm{m}^{2}$ area. No distinctive artifact concentrations were identified at the site, and no cultural features were observed. Since the site was limited to the area of exposed gravels, shovel testing was considered neither feasible nor necessary.

Site 41MV207 is interpreted as a quarry site and consists primarily of a small, low-density scatter of flakes, tested cobbles, and cores in a large area of exposed gravels. The site has been impacted to some extent by use of the area for grazing, but the primary impact has been erosion-the site is extremely deflated, and only about 40 percent is estimated to remain intact. The sparse, surficial nature of the site and the lack of features indicate the research potential of site $41 \mathrm{MV} 207$ is minimal. Based on these observations, the site is recommended as ineligible for inclusion in the NRHP. No further work at site $41 \mathrm{MV} 207$ is recommended.

\section{Site 41MV208}

Site 41MV208 is located in the southwestern corner of the Stone Ranch project area along the western extent of the broad upland area just east of the Rio Grande, extending south from a two-track road that provides access to the area (Figure 96; see Figure 92). An intermittent drainage that feeds straight into 


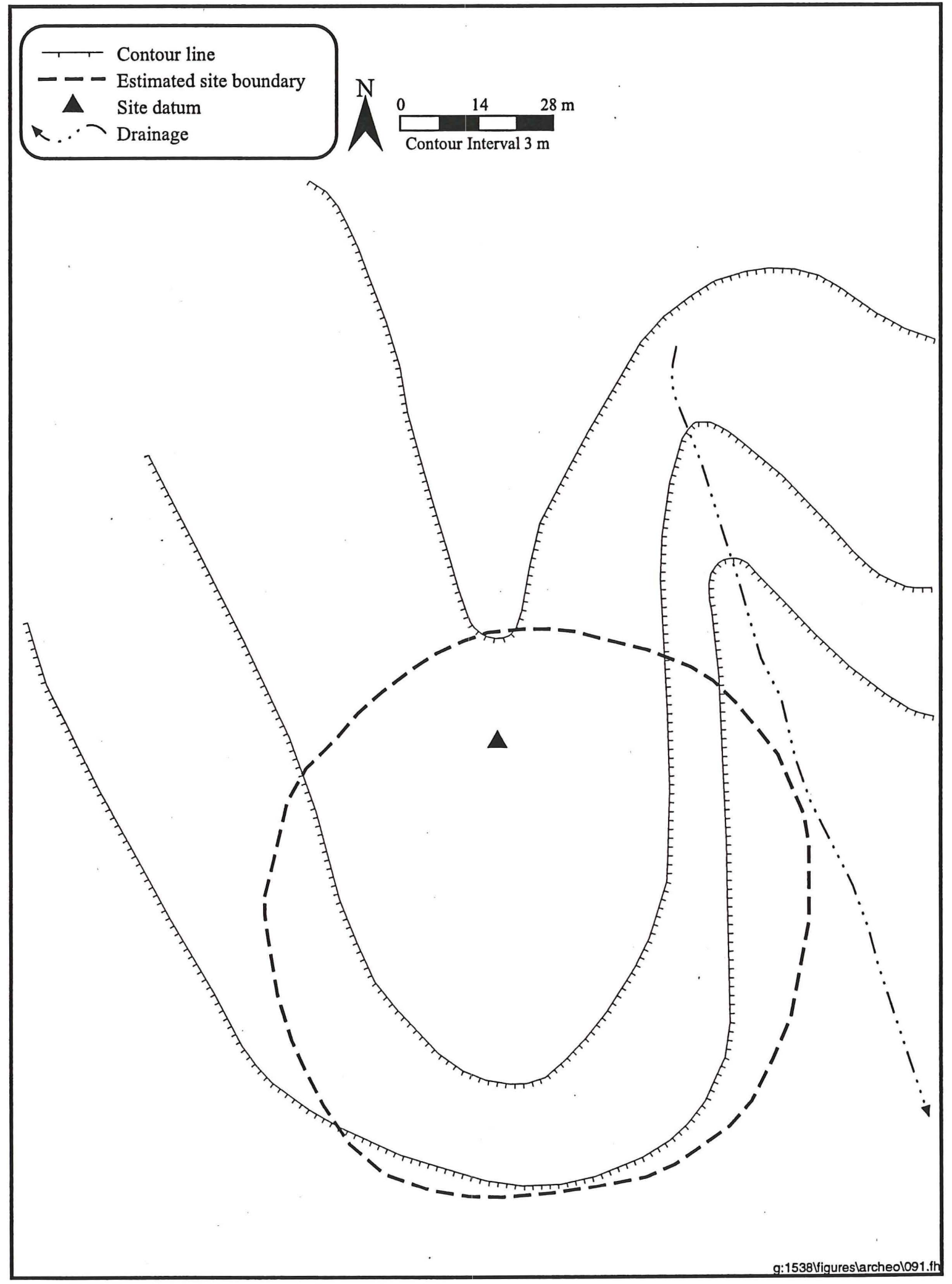

Figure 95. Plan map of site 41MV207. 


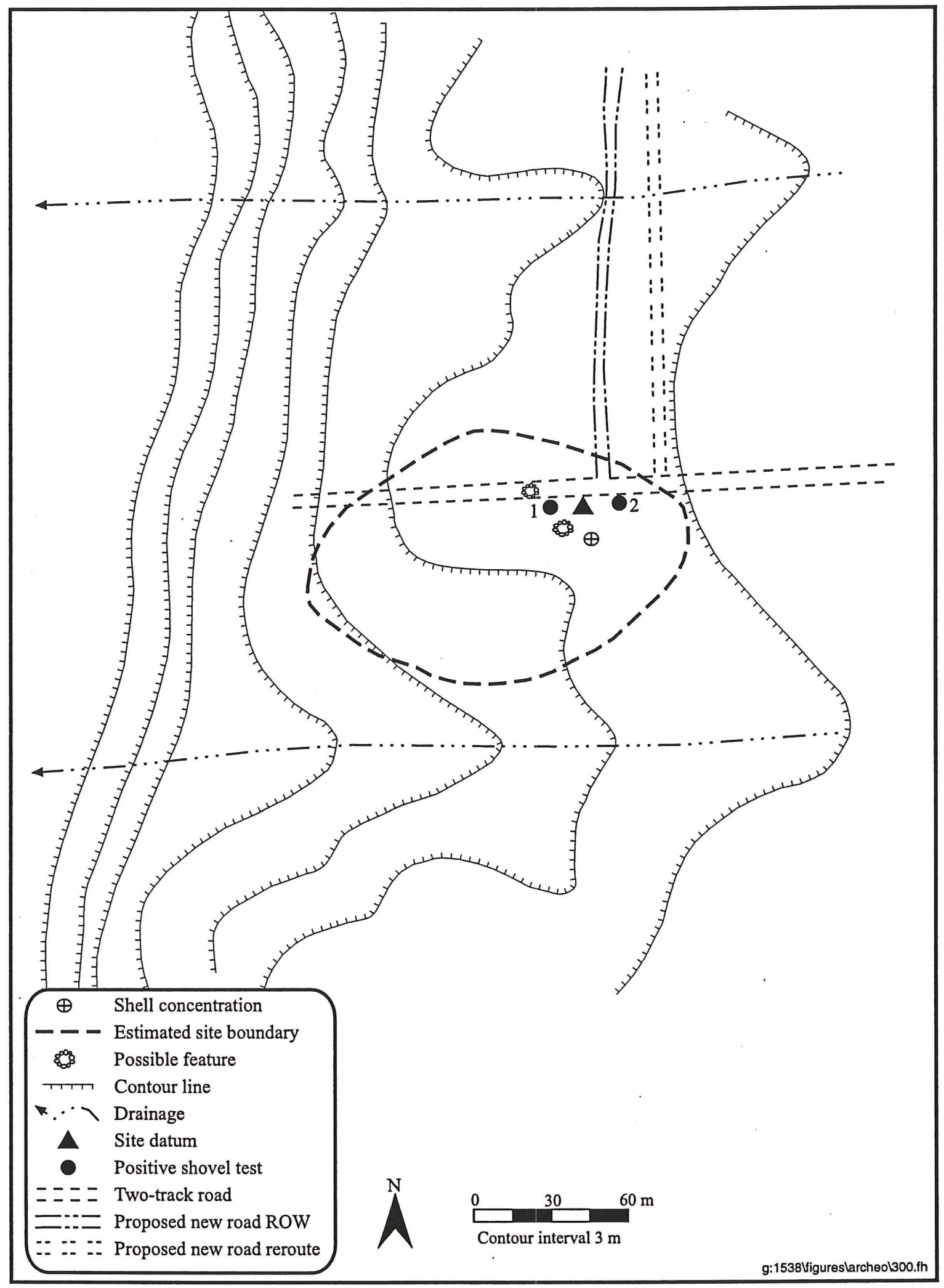

Figure 96. Plan map of site 41MV208. 
the Rio Grande begins in the north end of the site, and an intermittent drainage flows out of the south end of the site. The Rio Grande is about $300 \mathrm{~m}$ west of the site. The elevation at the site ranges from 204 to $207 \mathrm{~m}$ (668 to $680 \mathrm{ft}$ ) amsl. The vegetation in the area is fairly dense and consists of mesquite, creosote, acacia, tasajillo, and short grasses. Ground surface visibility is about 70 percent.

The site is a moderate-density scatter of lithic artifacts that extends $150 \mathrm{~m}$ east to west and $100 \mathrm{~m}$ north to south. It covers approximately $15,000 \mathrm{~m}^{2}$ and artifact density is about 15 per $25-\mathrm{m}^{2}$ area. The artifact assemblage is composed mostly of flakes, a few of which have been retouched; a few scrapers were also observed at the site. A small concentration of mussel shell was noted at the site, and two possible firecracked rock features, each containing approximately 6 fire-cracked rocks and measuring less that $.5 \mathrm{~m}$ in diameter, were identified near the shell. One of the features is exposed in the roadbed.

Two shovel tests were placed at the site to determine if subsurface cultural materials are present. Both were placed near the north end of the site, in the vicinity of the possible features and the shell scatter. One shovel test produced shell and a flake in the upper $20 \mathrm{~cm}$, and the other produced four flakes and shell from the upper $40 \mathrm{~cm}$. The soil at the site consisted of a brown silty loam, moderately compacted with some caliche concentrations between 0 and $20 \mathrm{~cm}$ bs, followed by a more compact, pale brown silty loam with a few gravels between 20 and $40 \mathrm{~cm}$ bs. Subsoil in the form of a light brown compact loam was encountered at approximately 45 to $50 \mathrm{~cm}$ bs and excavation of the shovel tests was terminated in Shovel Tests 1 and 2 at 50 and $60 \mathrm{~cm}$ bs, respectively.

Site 41MV208 is interpreted as an open campsite and consists of a moderate-density scatter of lithic artifacts, primarily flakes, retouched flakes, and scrapers, and a subsurface deposit that extends to a depth of $40 \mathrm{~cm}$. A concentration of mussel shell and two possible fire-cracked rock features, one of which lies in the existing roadbed, were identified in the proposed ROW. Disturbances at the site have been minimal; the two-track road cuts across only the northernmost portion of the site, and erosion in the area has been slight. About 85 percent of the site is estimated to remain intact. The potential for intact features and significant subsurface deposits indicates that the research potential of site 41MV208 is unknown. Therefore, the site is recommended as potentially eligible for inclusion in the NRHP. Avoidance of the site is recommended by prohibiting additional grading, reworking, or ground disturbance on existing road segments within the limits of the site. It is recommended that the segment of proposed new road ROW, which passes through the eastern edge of the site, be rerouted to connect with the existing road east of the site boundary. The presence of an archeological monitor will be necessary to keep equipment off of undisturbed portions of 41MV208 and to ensure that no impacts to intact portions of the site are incurred.

\section{Site 41MV209}

Site 41MV209 is located in the southern half of the Stone Ranch project area and is found over a broad area that encompasses two finger ridges overlooking the Rio Grande (Figure 97; see Figure 92). Between the two finger ridges is an intermittent drainage; intermittent drainages also define portions of the north and south site boundaries. The elevation of the site ranges from 204 to $207 \mathrm{~m}$ (670 to $680 \mathrm{ft}$ ) amsl. The vegetation in the area is sparse, consisting of short grasses, mesquite, prickly pear, acacia, and locust. Ground surface visibility is about 90 percent.

The site is a low- to moderate-density lithic scatter that extends $230 \mathrm{~m}$ east to west and $250 \mathrm{~m}$ north to south, encompassing about $57,500 \mathrm{~m}^{2}$. Flakes, primarily tertiary flakes and some of which are retouched, are scattered thinly but consistently across the site area, with a few pockets of higher 


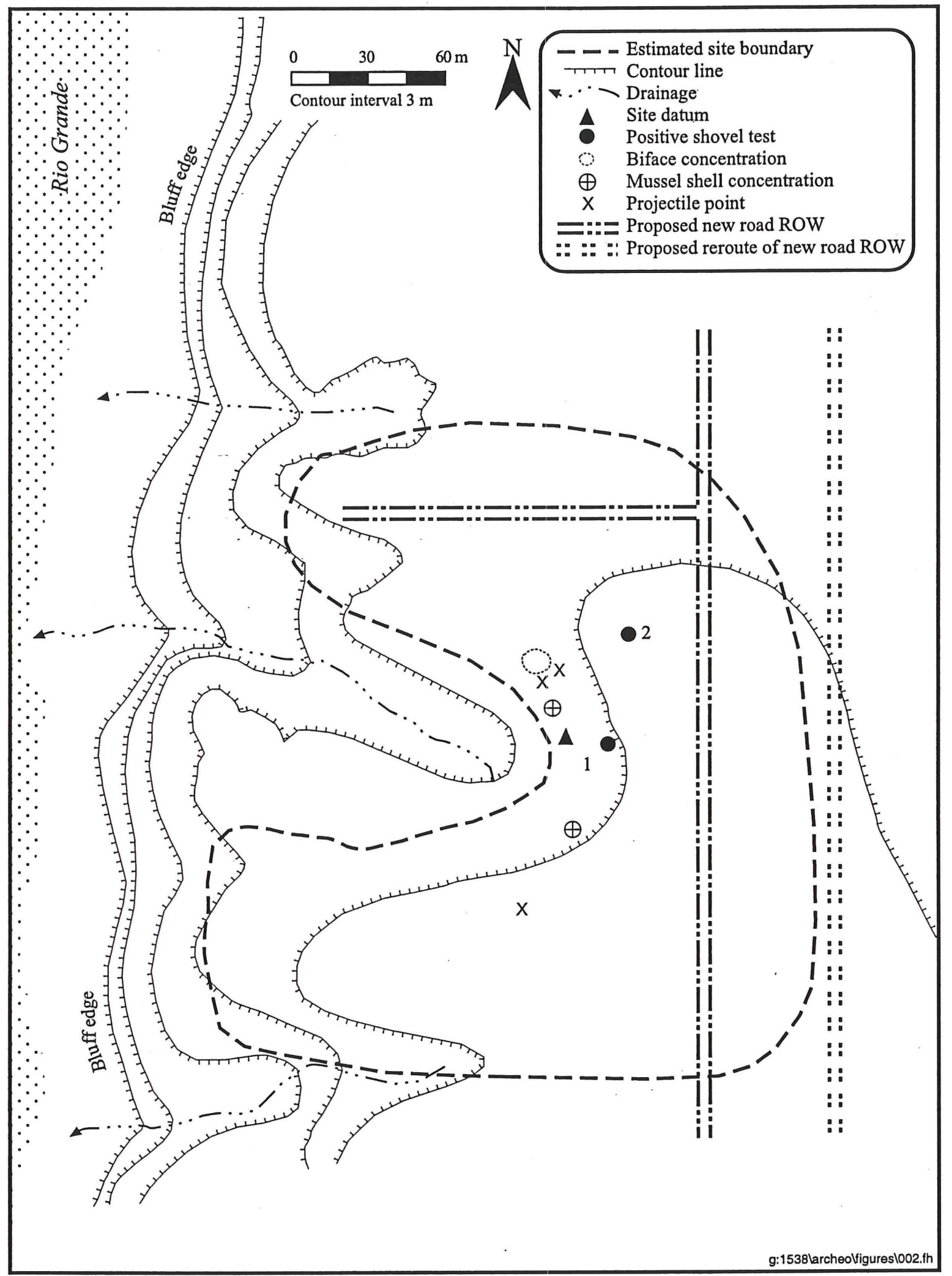

Figure 97. Plan map of site 41MV209. 
concentrations. Artifact density is slightly greater in the northern portion of the site. Raw material consists of chert types available locally. A few cores and tested cobbles are also scattered across the site, and a small concentration of three bifaces and two projectile points was noted in the site's northern half and a third projectile point was identified toward the south. Two of the projectile points were identified as Middle to Late Archaic Pandora points (Figure 98a and b), and the third was identified as a Late Archaic Lange point (see Figure 98c; Turner and Hester 1993:141-142, 170). Two concentrations of mussel shell were seen near the head of the drainage that bisects the western portion of the site.
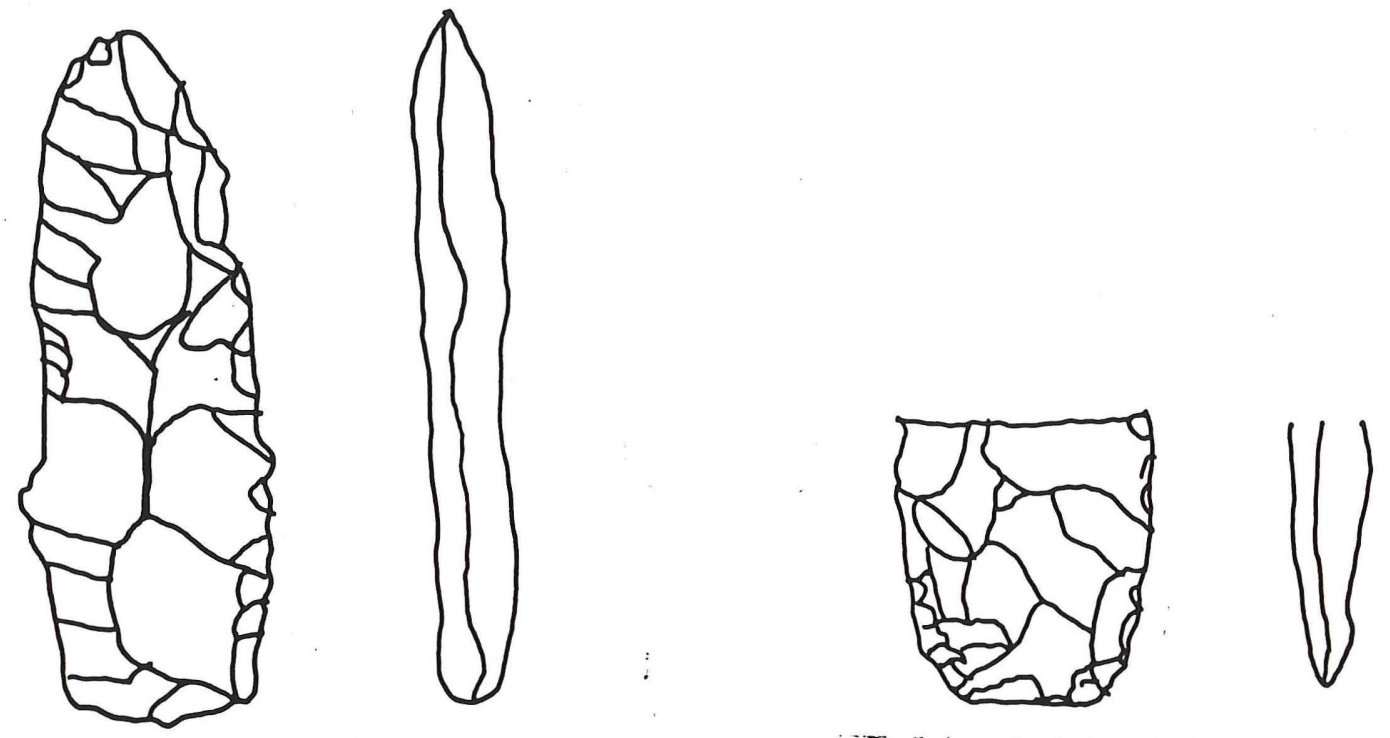

a

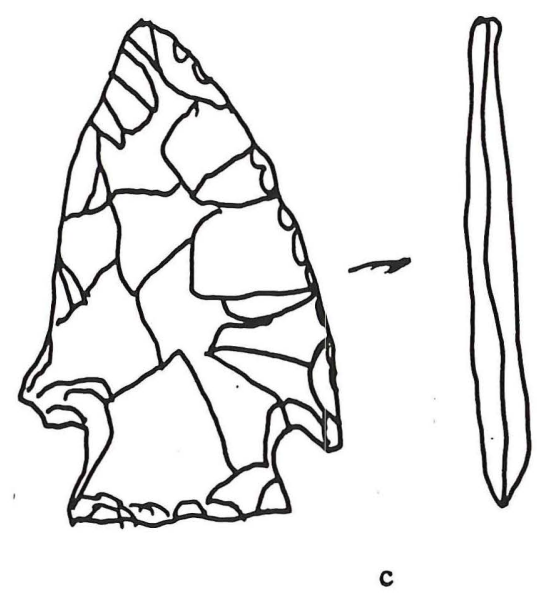

Figure 98. Field illustrations of projectile points identified at site 41MV209: (a) Pandora point; (b) Pandora point; and (c) Lange point (Scale 1:1). 
Two shovel tests were excavated at the site, one in the vicinity of the shell concentrations, the other northeast of the concentration of bifaces. The shovel test near the shell produced 12 flakes in the upper $20 \mathrm{~cm}$, and no cultural materials between 20 and $40 \mathrm{~cm}$. In the second shovel test, six flakes, two pieces of mussel shell, and a possible fire-cracked rock were observed in the upper $20 \mathrm{~cm}$, and three flakes were identified between 20 and $40 \mathrm{~cm}$. The soil at the site is yellow brown silty loam with some gravels between 0 and $20 \mathrm{~cm}$ bs, followed by a more compact loam between 20 and $35 \mathrm{~cm}$ bs. Subsoil, a very compact, light yellow brown silty loam with gravels was encountered at 35 to $60 \mathrm{~cm}$ bs. Excavation of Shovel Tests 1 and 2 was terminated at 40 and $60 \mathrm{~cm}$, respectively, when the subsoil was encountered. No cultural material was observed in the last $20 \mathrm{~cm}$ excavated.

Site 41MV209 is interpreted as an open campsite consisting of a low- to moderate-density scatter of lithic artifacts, including flakes, retouched flakes, projectile points, and bifaces. Shovel testing revealed the subsurface deposit extends to a depth of $40 \mathrm{~cm}$. Two concentrations of mussel shell and a concentration of bifaces and projectile points were observed in the center of the site near the head of the drainage. Disturbances at the site have been minimal, due mainly to use of the area for grazing and to slope erosion. The site is estimated to be about 95 percent intact. The potential for intact features and significant subsurface deposits indicates that the research potential of site 41MV209 is unknown. Therefore, the site is recommended as potentially eligible for inclusion in the NRHP. Avoidance of the site is recommended by rerouting the proposed ROW such that the proposed segment of new north-south road passes to the east of the eastern site boundary. A spur of new east-west road has been proposed to provide a lookout from the terrace spur on which the northern half of the site is located. This half of the site contains the highest densities of artifacts on the surface, including mussel shell and biface concentrations. It is recommended that this proposed spur of new road be rerouted such that it exits from the proposed new road north of the northern site boundary and does not intrude upon the site. One possible location for this spur road is discussed in connection with site 41MV236 below. The presence of an archeological monitor will be necessary to keep equipment off of undisturbed portions of site 41MV236 and to ensure that construction-related activities will not impact intact portions of the site.

\section{Site $41 M V 236$}

Site 41MV236 is located in the western half of the Stone Ranch project area on a spur ridge overlooking the Rio Grande (Figure 99; see Figure 92). A large, intermittent drainage forms the northern boundary of the site, and a smaller seasonal drainage defines the southern edge of the spur upon which the site is situated. The elevation of the site ranges from 198 to $204 \mathrm{~m}$ (650 to $670 \mathrm{ft}$ ) amsl. The vegetation in the vicinity is relatively sparse, consisting of bunchgrass, mesquite, prickly pear, acacia, and locust. Ground surface visibility is about 90 percent.

The site is a small, low- to moderate-density lithic scatter that extends $65 \mathrm{~m}$ northwest-southeast and 40 $\mathrm{m}$ northeast-southwest, encompassing a total area of approximately $2,600 \mathrm{~m}^{2}$. Flakes, primarily tertiary flakes, predominate in the assemblage, although a small number of exhausted cores and tested cobbles was observed as well. Raw material consists of gravel chert available in the vicinity. Artifact density is very low around the edges of the site and slightly higher toward the center. No artifacts other than cores and flakes were evident on the modern ground surface, and no diagnostic artifacts, ground stone, or cultural features were observed. 


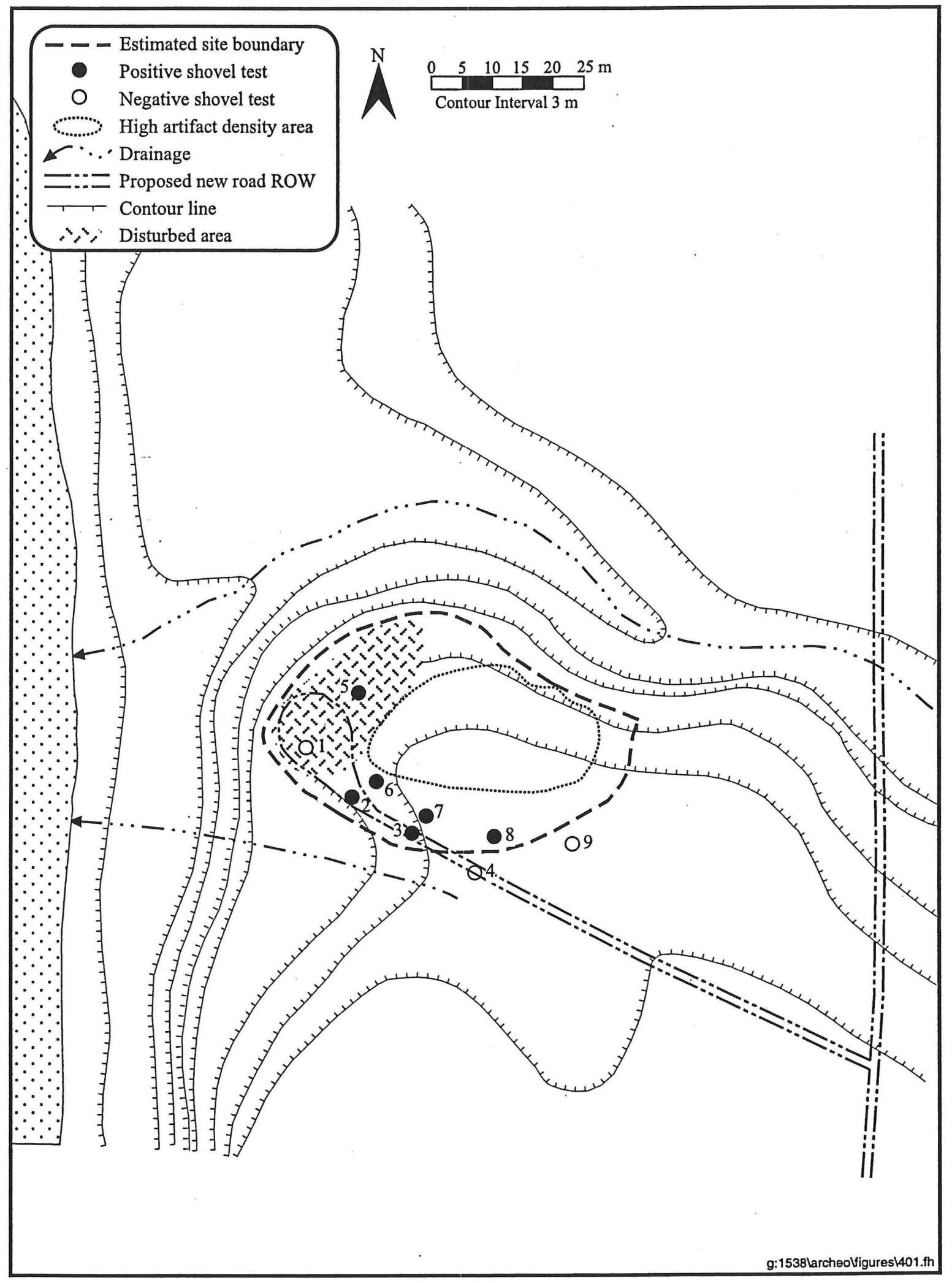

Figure 99. Plan map of site 41MV236. 
Nine shovel tests were excavated at 41MV236 to determine the subsurface context of the site. Four of these shovel tests were placed along the proposed ROW of a spur road that would provide access from the new north-south road to an overlook and vehicle turn-around on the edge of the spur ridge. The first shovel test was excavated in the southwestern corner of the site in an area that has been heavily disturbed by bulldozing and an old track that runs along the edge of the blufftop. This shovel test was excavated to a depth of $20 \mathrm{~cm}$ bs. Two flakes were observed on the surface of the shovel test unit, but no cultural materials were observed below surface. The second shovel test was excavated within the proposed ROW for the spur road to a depth of $20 \mathrm{~cm}$ bs. Three flakes were observed in the upper $10 \mathrm{~cm}$, but no artifacts were observed in the lower $10-\mathrm{cm}$ level. The third shovel test, also placed within the proposed ROW, was excavated to a depth of $40 \mathrm{~cm}$ bs. This shovel test yielded two flakes in the upper $5 \mathrm{~cm}$, but no additional artifacts were observed between $5 \mathrm{~cm}$ and $40 \mathrm{~cm}$ bs. The fourth shovel test was excavated within the proposed ROW about $5 \mathrm{~m}$ east of the eastern extent of the surface artifact scatter. No cultural materials were observed within this shovel test, which was excavated to a depth of $20 \mathrm{~cm}$ bs.

Four additional shovel tests were excavated within the boundaries of the artifact scatter observable on the surface. Shovel Test 5 was placed within the disturbed area at the western end of the site, northeast of the edge of the proposed vehicle turn-around. This shovel test, excavated to a depth of $20 \mathrm{~cm}$ bs, yielded one flake from the surface, but no additional cultural material was observed below surface. The sixth shovel test was placed outside of the proposed ROW about $5 \mathrm{~m}$ northeast of Shovel Test 2. This shovel test yielded five flakes from the upper $20 \mathrm{~cm}$ level and three flakes from between $20 \mathrm{~cm}$ and $40 \mathrm{~cm}$ bs. No cultural material was observed between $40 \mathrm{~cm}$ and $60 \mathrm{~cm}$ bs. The seventh shovel test was placed $5 \mathrm{~m}$ northeast of Shovel Test 3 outside of the proposed ROW. Four flakes were observed between 0 and 20 $\mathrm{cm}$ bs and two flakes between $20 \mathrm{~cm}$ and $40 \mathrm{~cm}$ bs. No artifacts were present in the 40-to-60-cm bs level. The eighth shovel test was excavated about $10 \mathrm{~m}$ northeast of Shovel Test 4 outside of the proposed. ROW and near the extent of the artifact scatter. Two flakes were observed in the upper $10 \mathrm{~cm}$, but no cultural material was present between $10 \mathrm{~cm}$ and $20 \mathrm{~cm}$ bs. Finally, a ninth shovel test was excavated about $5 \mathrm{~m}$ east of the eastern site boundary (as defined by the extent of the surface scatter) to a depth of $20 \mathrm{~cm}$ bs. No cultural material was observed in this shovel test. Soil at the site consists of silty loam with numerous gravel inclusions.

Site 41MV236 is interpreted as an open campsite consisting of a low- to moderate-density scatter of lithic artifacts, including flakes, cores, and tested cobbles. Based on the results of shovel tests, cultural deposits extending to a depth of $40 \mathrm{~cm}$ bs appear to be coterminous with the extent of the higher density surface scatter in the central and northern portion of the site. Cultural deposits around the periphery of the site, including the proposed ROW for the new spur road, are relatively shallow, extending to a depth of only $5 \mathrm{~cm}$ to $10 \mathrm{~cm}$ bs. Thus, the main portion of the site appears to be situated largely to the north of the proposed ROW along the crest and northern slope of the spur ridge, with the proposed ROW skirting the southern site boundary. The western portion of the site, including the area proposed as the location for a vehicle turn-around, has already been heavily impacted by mechanical earthmoving and the use of a trail that runs along the edge of the bluff.

Site 41MV236 is estimated to be about 80 percent intact. Because cultural deposits extend to a depth of $40 \mathrm{~cm}$ bs in the central and northern portions of the site, the potential for intact features and significant subsurface deposits indicates that these portions of the site may possess some research merit. These portions of the site are therefore recommended as potentially eligible for inclusion in the NRHP. The periphery of the site, however, including the disturbed western portion and the southern edge, contains only surficial cultural deposits and does not possess much potential for contributing significant information about the past. The proposed ROW of the spur along the southern edge of this site represents an attempt to relocate this critical access road from site 41MV209, through which it passed in 
the original design for the road improvement project. The spur occupied by $41 \mathrm{MV} 236$ represents the only other possible location for this road. It is recommended that the central and northern portions of the site, which contain higher densities of artifacts on the surface as well as buried cultural deposits, be avoided during this construction project. However, the southern edge of the site does not appear to represent a contributing portion of the site, and it is unlikely that construction of a narrow, one-lane gravel road in this area will impact the integrity of the site in any significant way. Furthermore, the western portion of the site has been heavily disturbed and does not appear to retain any integrity. It is not likely that construction of the vehicle turn-around in this vicinity will impact any significant cultural resources. The presence of an archeological monitor will be necessary to keep equipment off of site $41 \mathrm{MV} 236$ and to ensure that construction-related activities would not impact intact portions of the site.

\title{
SWARTZ RANCH SEGMENT
}

A total of 26 archeological sites and 78 localities was identified as a result of the cultural resources survey of the Swartz Ranch project area (Figures 100 and 101). Seven of the cultural properties recorded on the Swartz Ranch segment are considered potentially eligible for inclusion in the NRHP, and measures should be adopted to ensure that these sites are not impacted by the proposed road construction and improvement activities. Of the remaining 19 sites identified along the ROW, the boundaries of 10 sites were identified and the entire area of the sites recommended as inelgibile for inclusion in the NRHP. The boundaries of the other nine sites extend beyond the project boundary and, therefore, only the portion within the ROW is recommended as ineligible for inclusion in the NRHP; the remaining portions of these nine sites were not investigated. Each site is discussed individually below.

Of the 78 localities recorded in the Swartz Ranch segment, 74 consist of very low-density lithic scatters that lack diagnostic artifacts, subsurface context, and artifact densities sufficient to warrant designation as sites. These localities have not been described individually. The remaining four localities are composed of isolated finds of single or small numbers of artifacts or sparse lithic scatters that contain artifacts other than flakes and are described in Table 3.

\author{
Swartz Ranch Sites
}

\section{Site $41 M V 210$}

Site 41MV210, on the western side of Swartz Ranch, is located on a terrace overlooking Cuervo Creek to the north (Figure 102; see Figure 100. The site is approximately $600 \mathrm{~m}$ east of the Rio Grande, $100 \mathrm{~m}$ north of the central east-west road that bisects the ranch, and lies at an elevation of $189 \mathrm{~m}(620 \mathrm{ft}) \mathrm{amsl}$. Cuervo Creek is approximately $70 \mathrm{~m}$ north of the site. Vegetation in the area is sparse, composed of grasses, creosote, mesquite, and various cacti. The vegetation is more dense on the north side of the site closer to Cuervo Creek. Ground visibility ranges from 70 to 80 percent.

Site 41MV210 is a moderate-density lithic scatter measuring approximately $80 \mathrm{~m}$ east to west and $60 \mathrm{~m}$ north to south, covering an area of approximately $4,800 \mathrm{~m}^{2}$. The lithic assemblage consists of flakes and two biface fragments. A fragment of mussel shell was also identified. The artifact density at site $41 \mathrm{MV} 210$ is approximately 10 to 12 specimens per $25-\mathrm{m}^{2}$ area. No specific artifact concentrations were noted, and no evidence of quarrying or features was observed at the site. 
Two shovel tests were excavated at site 41MV210 to determine the presence of subsurface cultural deposits. One was placed near the northwest corner of the site, near the two biface fragments noted on the surface. The other was placed directly east of the existing north-south road through the site. No cultural materials were recovered from the shovel tests. The soil at the site consists of light, brownish gray to yellowish brown loam between 0 and $40 \mathrm{~cm}$ bs, followed by the subsoil encountered at approximately $40 \mathrm{~cm}$ which consists of a very compact light olive brown loam. Shovel Tests 1 and 2 were excavated to 50 and $80 \mathrm{~cm}$ bs, respectively.

Site 41MV210 is interpreted as an open campsite represented by a surficial, moderate-density scatter of lithic artifacts, primarily flakes and shatter, and a fragment of mussel shell. Disturbances include the construction, use, and maintenance of a road that bisects the site. The site has been heavily eroded, leaving the ground surface very deflated. The sparse, surficial nature of the site, the lack of features, and the road and erosional disturbances indicate the research potential of site $41 \mathrm{MV} 210$ is minimal. Based on these observations, the site is recommended as ineligible for inclusion in the NRHP. No further work at site $41 \mathrm{MV} 210$ is recommended.

\section{Site 41MV211}

Site 41MV211 is located on the western side of Swartz Ranch and covers a large portion of the terrace overlooking the Rio Grande directly south of Cuervo Creek (Figure 103; see Figure 100). The site, at an elevation of 194 to $195 \mathrm{~m}$ ( 635 to $640 \mathrm{ft}$ ) amsl, lies on the east terrace of the Rio Grande between Cuervo Creek on the north and an unnamed drainage on the south. The moderately dense vegetation at the site is composed primarily of grasses and forbs, with occasional creosote, mesquite, and cacti. Ground visibility is approximately 60 percent, less in scattered areas of heavy ground vegetation.

This large site is a moderate-density lithic scatter measuring approximately $800 \mathrm{~m}$ northwest to southeast by $250 \mathrm{~m}$ northeast to southwest at its widest point. The total area of the site is approximately 200,000 $\mathrm{m}^{2}$. The lithic assemblage includes tertiary flakes, shatter, and tools, including retouched flakes, scrapers, and projectile points, all of locally available chert. The single complete projectile point has been identified as a Lange point, a Late Archaic point with well-barbed shoulders and an expanding stem (Figure 104; Turner and Hester 1993:141-142). The highest concentration of artifacts is located along the terrace edge, and a possible hearth, now deflated, was observed in the southeastern half of the site. Artifact density at the site is approximately 15 to 20 specimens per $25-\mathrm{m}^{2}$ area. The possible hearth is approximately $.75 \mathrm{~m}$ in diameter and contains three large and approximately 10 smaller slabs of bedrock arranged in a rough circle. A dense scatter of artifacts nearby may be associated with this feature. A small quantity of historic or modern artifacts-including stoneware, whiteware, and window glass-was noted just south of Cuervo Creek.

Four shovel tests were excavated at 41MV211 to determine if there were subsurface cultural deposits. All shovel tests yielded cultural material; one in particular, Shovel Test 4, yielded flakes from a maximum depth of $110 \mathrm{~cm}$ bs. A greater amount of subsurface material was produced from shovel tests near the creek (Shovel Test 4) and in the flat area along the northeastern boundary of the site (Shovel Test 1). Subsurface deposits are deepest at the southern end of the site (Shovel Test 4). The soil at the site primarily consists of grayish brown to brown silt between 0 and 35 to $40 \mathrm{~cm}$ bs, followed by compact, pale brown silty loam. Excavation of Shovel Tests 1 through 4 went to $70 \mathrm{~cm}, 80 \mathrm{~cm}, 40 \mathrm{~cm}$, and $110 \mathrm{~cm}$ bs, respectively. Cultural material was recovered in the final level excavated in both Shovel Tests 1 and 4. 
Figure

100. Location of sites on the Swartz Ranch segment

fold-out 
Cultural Resources Survey for a JTF-6 Action in Webb, Maverick, and Dimmit Counties, Texas

fig 100 
figure

101. Location of nonsite localities on the Swartz Ranch segment

fold-out 
Cultural Resources Survey for a JTF-6 Action in Webb, Maverick, and Dimmit Counties, Texas

fig 101 
Table 3

List of Nonsite Localities with Tools on the Swartz Ranch Segment

\begin{tabular}{cl} 
Locality Number & Description \\
\hline 1 & One biface fragment in road \\
2 & Several flakes and one retouched flake \\
3 & Several flakes and one dart point base \\
4 & One biface and two flakes \\
\hline
\end{tabular}

The site is interpreted as an open campsite consisting of a moderate-density lithic scatter, including flakes and a variety of tools. A subsurface cultural deposit was identified that extends to a maximum depth of $110 \mathrm{~cm}$ bs. Although a portion of the site has been impacted by fence and road construction, and part of the site may have been impacted by the construction of Weir Dam, an estimated 80 to 90 percent of the site remains intact. Since potentially significant subsurface deposits appear to remain at the site, the research potential of $41 \mathrm{MV} 211$ is considered unknown. The site is recommended as potentially eligible for inclusion in the NRHP. Avoidance of the site is recommended by prohibiting additional grading, reworking, or ground disturbance within the limits of the site. The presence of an archeological monitor is recommended in order to keep equipment off of undisturbed portions of site 41MV211 and to ensure that intact portions of the site are not impacted by road improvement activities.

\section{Site $41 M V 212$}

Site 41MV212 is located in the northwestern portion of the Swartz Ranch project area, on the southeastern slope of a large terrace overlooking a tributary of Cuervo Creek to the southeast (Figure 105; see Figure 100). The site is approximately $1.5 \mathrm{~km}$ southwest of the western end of Red Gate Road. It is found along both sides of an existing fence with roads on either side, at an elevation of $203 \mathrm{~m}$ (665 $\mathrm{ft}$ ) amsl. An unnamed intermittent drainage lies adjacent to the northeast boundary of the site, and Cuervo Creek is about $600 \mathrm{~m}$ east of the site. Vegetation in the area is sparse, consisting of mesquite, creosote, tasajillo, prickly pear and horse-crippler cacti, and some grasses. Ground visibility is between 70 and 80 percent.

The site is a low-density lithic scatter measuring approximately $90 \mathrm{~m}$ northeast to southwest and at least $140 \mathrm{~m}$ northwest to southeast, extending east and west beyond the limits of the survey area for the current project. Site $41 \mathrm{MV} 212$ covers a minimum of $12,600 \mathrm{~m}^{2}$. The lithic assemblage consists primarily of secondary and tertiary flakes and shatter of locally available chert and quartzite. Artifact density at the site is approximately six to eight specimens per $25-\mathrm{m}^{2}$ area. No artifact concentrations were noted, and no evidence of quarrying or features was identified at the site.

One shovel test was excavated at $41 \mathrm{MV} 212$ to determine the presence of subsurface cultural deposits. The shovel test was placed about $10 \mathrm{~m}$ east of the road in an area that appeared to exhibit intact soil. The existing soil at the site is a very compact subsoil which prevented excavation below $12 \mathrm{~cm}$ bs; extensive erosion has heavily impacted the site. No cultural material was observed in the shovel test. 


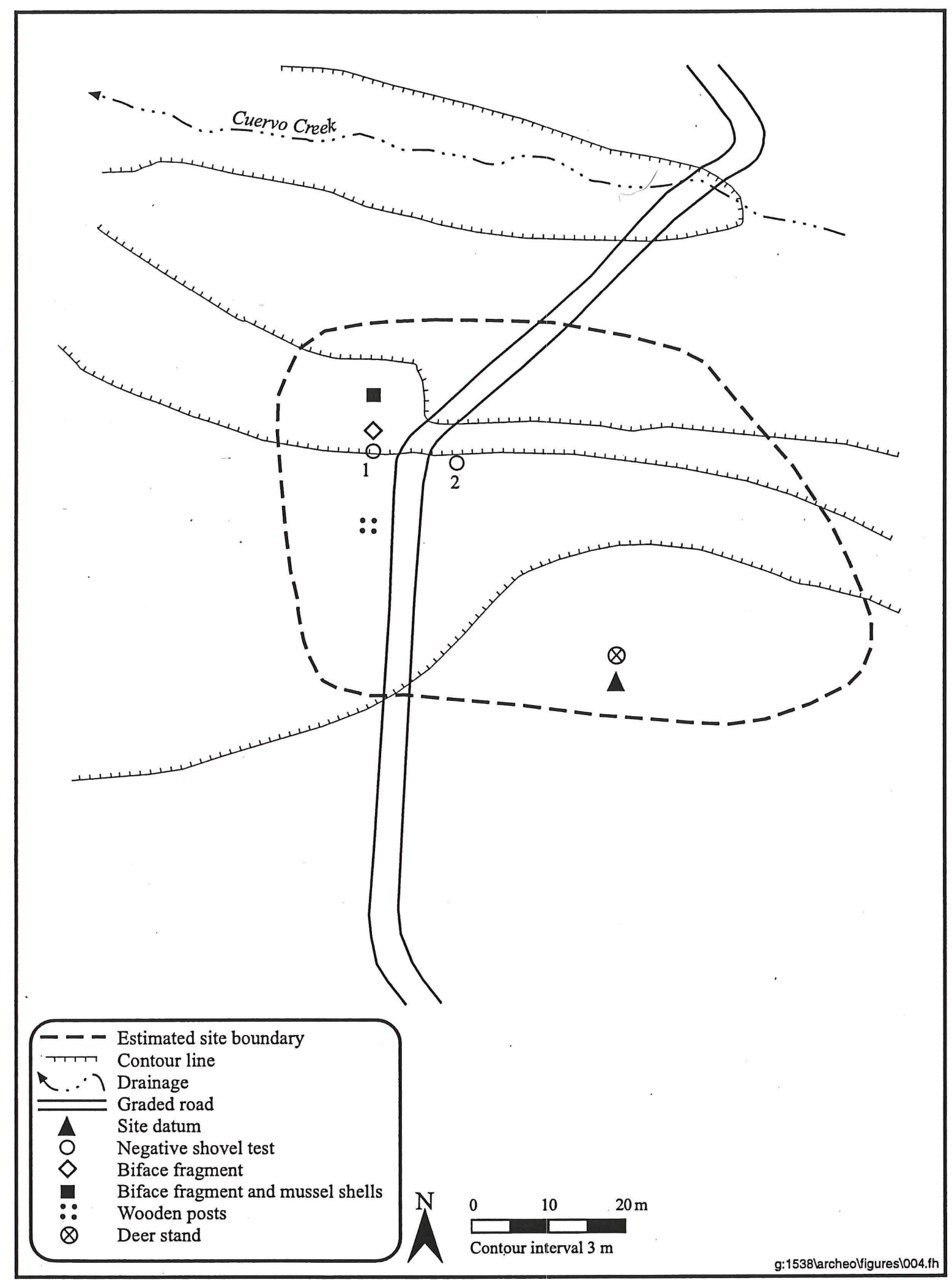

Figure 102. Plan map of site 41MV210. 


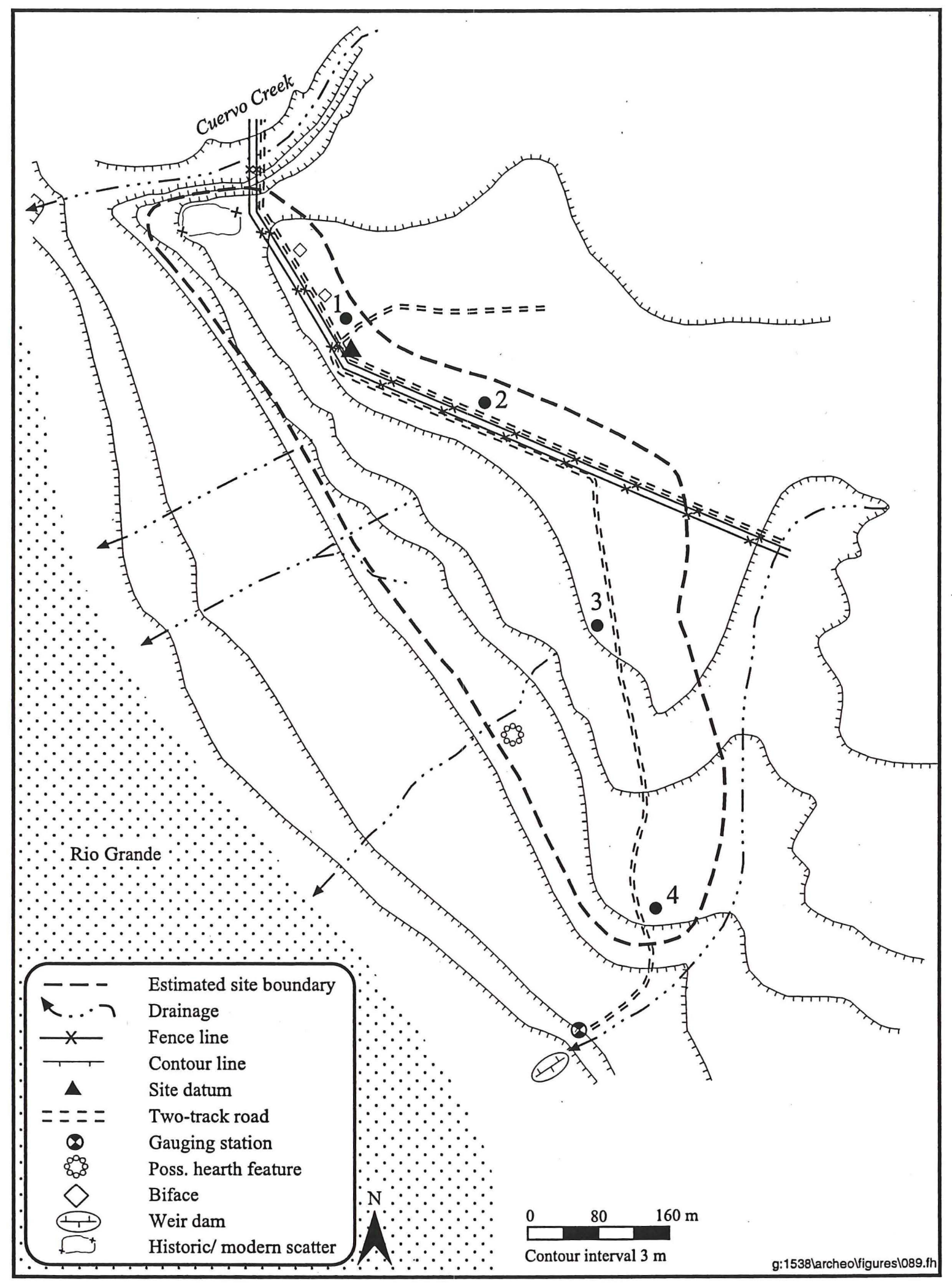

Figure 103. Plan map of site 41MV211. 


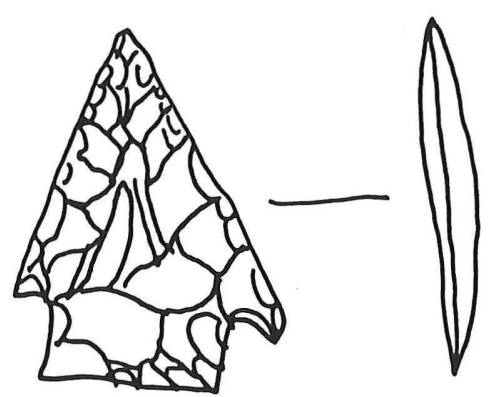

Figure 104. Field illustration of a Lange projectile point identified at site 41MV211 (Scale 1:1).

The site is interpreted as an open campsite and consists of a surficial, low-density scatter of flakes and shatter. Disturbances include the construction of two roads and a fence through the site. Erosion has heavily deflated the surface of the site and animal foraging was also noted. The sparse, surficial nature of the site, the lack of features, and the road and fence line disturbances indicate the research potential of the evaluated area of site $41 \mathrm{MV} 212$ is minimal. Based on these observations, the portion of the site within the ROW is recommended as ineligible for inclusion in the NRHP. The remainder of the site could not be investigated. No further work within the assessed portion of site $41 \mathrm{MV} 212$ is recommended.

\section{Site $41 M V 213$}

Site 41MV213 is located in the northwestern portion of the Swartz Ranch project area spanning the northern portion of a northwest-southeast-trending ridge located approximately $.7 \mathrm{~km}$ southwest of the western end of Red Gate Road (Figure 106; see Figure 100). The site lies along both sides of an existing road and fence, and crosses two additional graded roads, at elevations ranging between 204 and $207 \mathrm{~m}$ (670 and $680 \mathrm{ft}$ ) amsl. An unnamed intermittent drainage is approximately $80 \mathrm{~m}$ northeast of the site and Cuervo Creek lies about $400 \mathrm{~m}$ to the east. The moderately dense vegetation is composed primarily of mesquite, creosote, various cacti, and relatively abundant forbs. Ground surface visibility is approximately 60 percent.

This low-density lithic scatter measures about $170 \mathrm{~m}$ northeast to southwest and at least $120 \mathrm{~m}$ northwest to southeast (extending northeast and northwest beyond the limits of the current survey area). The identified portion of the site encompasses at least $20,400 \mathrm{~m}^{2}$. The lithic assemblage consists of flakes, shatter, and a single biface tip. Artifact density at the site is approximately eight to 10 specimens per 25$\mathrm{m}^{2}$ area. Most of the artifacts were observed along the road cuts and in areas of less dense vegetation. No artifact concentrations were noted, and no evidence of quarrying or features was observed at the site.

One shovel test was excavated at the site in order to determine whether subsurface cultural deposits existed. The shovel test was placed in the southwestern part of the site, in an area less impacted by road construction, where the soil also appeared to have some depth. The existing soil at the site is a very compact brownish gray subsoil which prevented excavation below $20 \mathrm{~cm}$ bs; extensive erosion has heavily impacted the site. No cultural material was observed in the shovel test. 


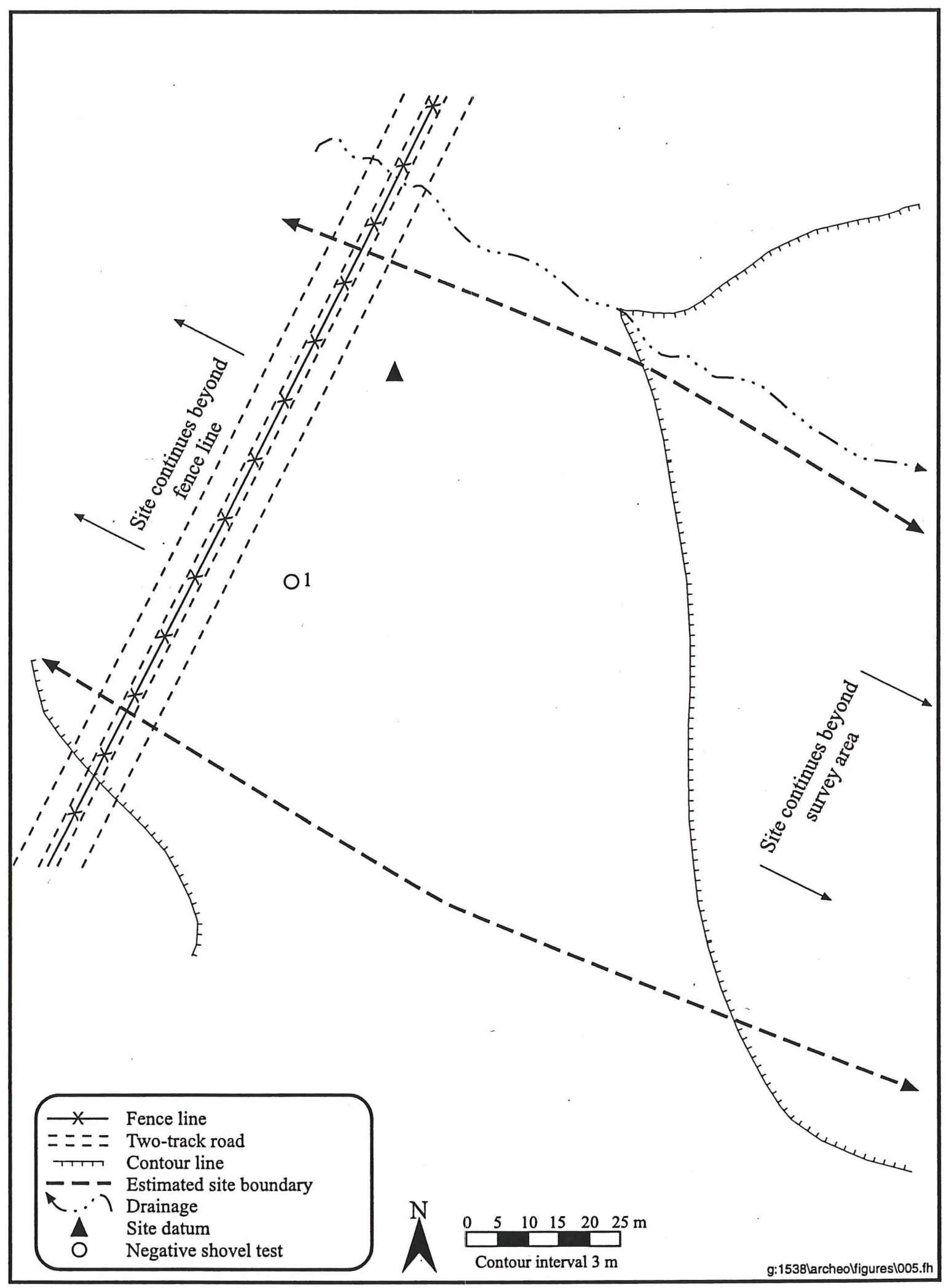

Figure 105. Plan map of site 41MV212. 


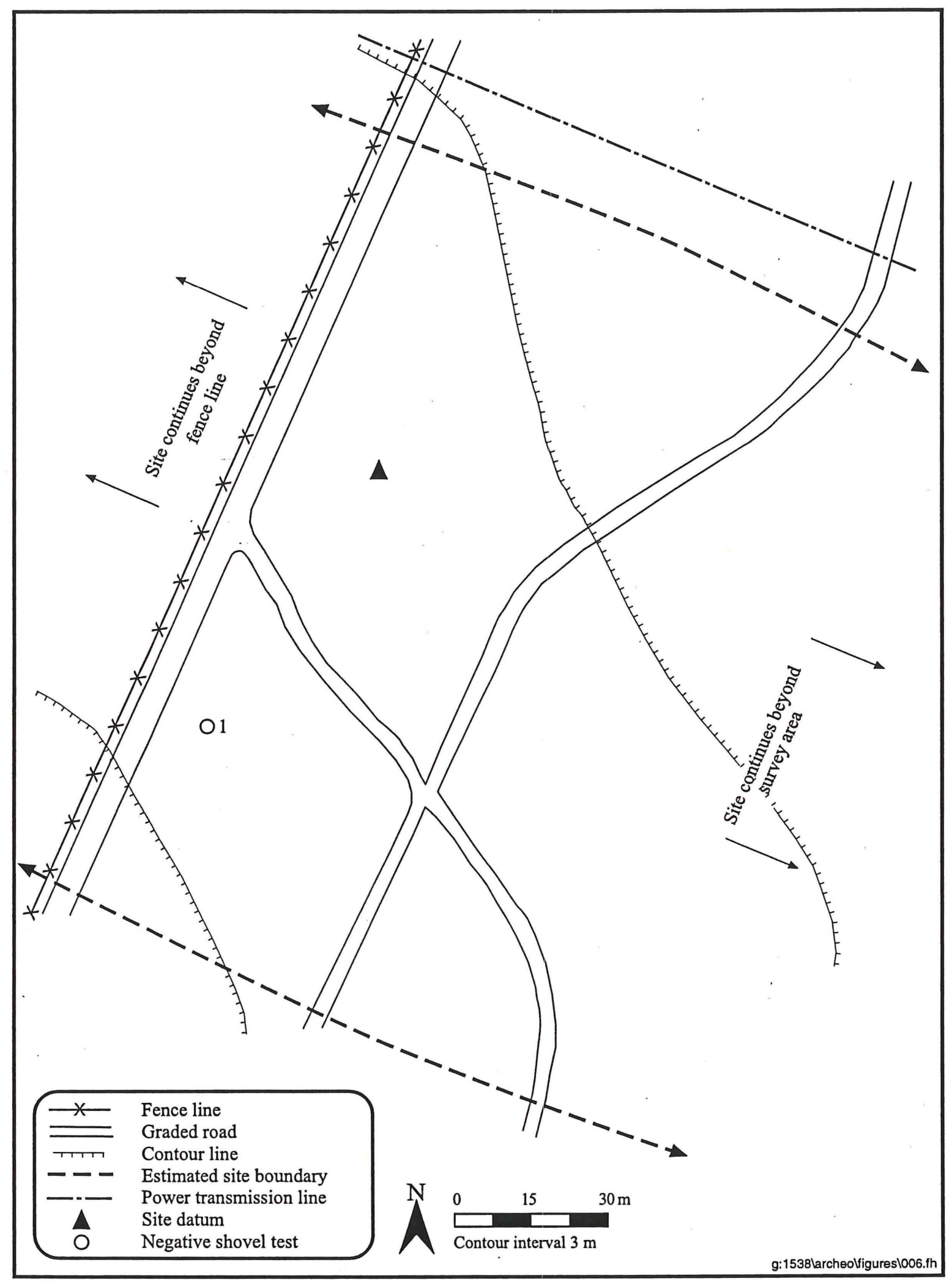

Figure 106. Plan map of site 41MV213. 
Site 41MV213 is interpreted as an open campsite consisting of a surficial, low-density scatter of lithic artifacts, primarily flakes and shatter. Artificial disturbances include the construction of the three graded roads, one along the fence line, one roughly parallel approximately 40 to the southeast, and another connecting the two, and the fence line itself. Impacts also include erosion, which has deflated the ground surface in the site area, and bioturbation. The sparse, deflated nature of the site, the lack of features, and the road and fence line disturbances indicate the research potential of the evaluated area of site 41MV213 is minimal. Based on these observations, the portion of the site within the ROW is recommended as ineligible for inclusion in the NRHP. The remainder of the site could not be investigated. No further work within the assessed portion of site 41MV213 is recommended.

\section{Site $41 M V 214$}

Site 41MV214 is located in the northern portion of the Swartz Ranch project area, on a south-facing slope near the western end of Red Gate Road (Figure 107; see Figure 100). The site sits on an upland finger ridge overlooking a small intermittent drainage about $250 \mathrm{~m}$ to the west. The elevation of the site is $240 \mathrm{~m} \mathrm{(788} \mathrm{ft})$ amsl. The vegetation in the area is sparse, consisting of mesquite, creosote, various cacti, and some grasses. Ground surface visibility ranges from 70 to 80 percent.

The site is a low-density, lithic scatter measuring $110 \mathrm{~m}$ north to south and at least $90 \mathrm{~m}$ east to west, extending west beyond the limits of the survey area for the current project. The site covers at least 9,900 $\mathrm{m}^{2}$. The lithic assemblage includes secondary and tertiary flakes, debitage, a scraper, and a projectile point. Raw material consists of locally available chert and quartzite. The projectile point has been identified as a Figueroa dart point, a Transitional Archaic point with broad side notches and an expanding stem (Figure 108). The artifact density is approximately five to six specimens per $25-\mathrm{m}^{2}$ area. No artifact concentrations were identified within the scatter and no evidence of quarrying or features was observed.

One shovel test was excavated at 41MV214 in order to determine the presence of subsurface cultural deposits. The shovel test was placed near the projectile point at the southeastern end of the site. Since most of the site sits on top of exposed bedrock, the shovel test was placed in an area that appeared to have the best possibility of retaining intact soils. Soil at the site consists primarily of pale yellow decomposing sandstone. The shovel test could not be excavated below $20 \mathrm{~cm}$ bs and no cultural deposits were identified.

The site is interpreted as an open campsite and consists of a surficial, low-density scatter of lithic artifacts, primarily flakes and shatter. Disturbances include the road and fence constructed across the site, as well as the erosion that has deflated the ground surface. The sparse, deflated nature of the site, the lack of features, and the road and fence line disturbances indicate the research potential of the evaluated area of site 41MV214 is minimal. Based on these observations, the portion of the site within the ROW is recommended as ineligible for inclusion in the NRHP. The remainder of the site could not be investigated. No further work within the assessed portion of site 41MV214 is recommended.

\section{Site $41 M V 215$}

Site 41MV215 is located along Red Gate Fence in the northern portion of the Swartz Ranch project area, on the eastern edge of a terrace overlooking Cuervo Creek (Figure 109; see Figure 100). An unnamed tributary to Cuervo Creek is $150 \mathrm{~m}$ east of the site; Cuervo Creek is located about $200 \mathrm{~m}$ to the south. 


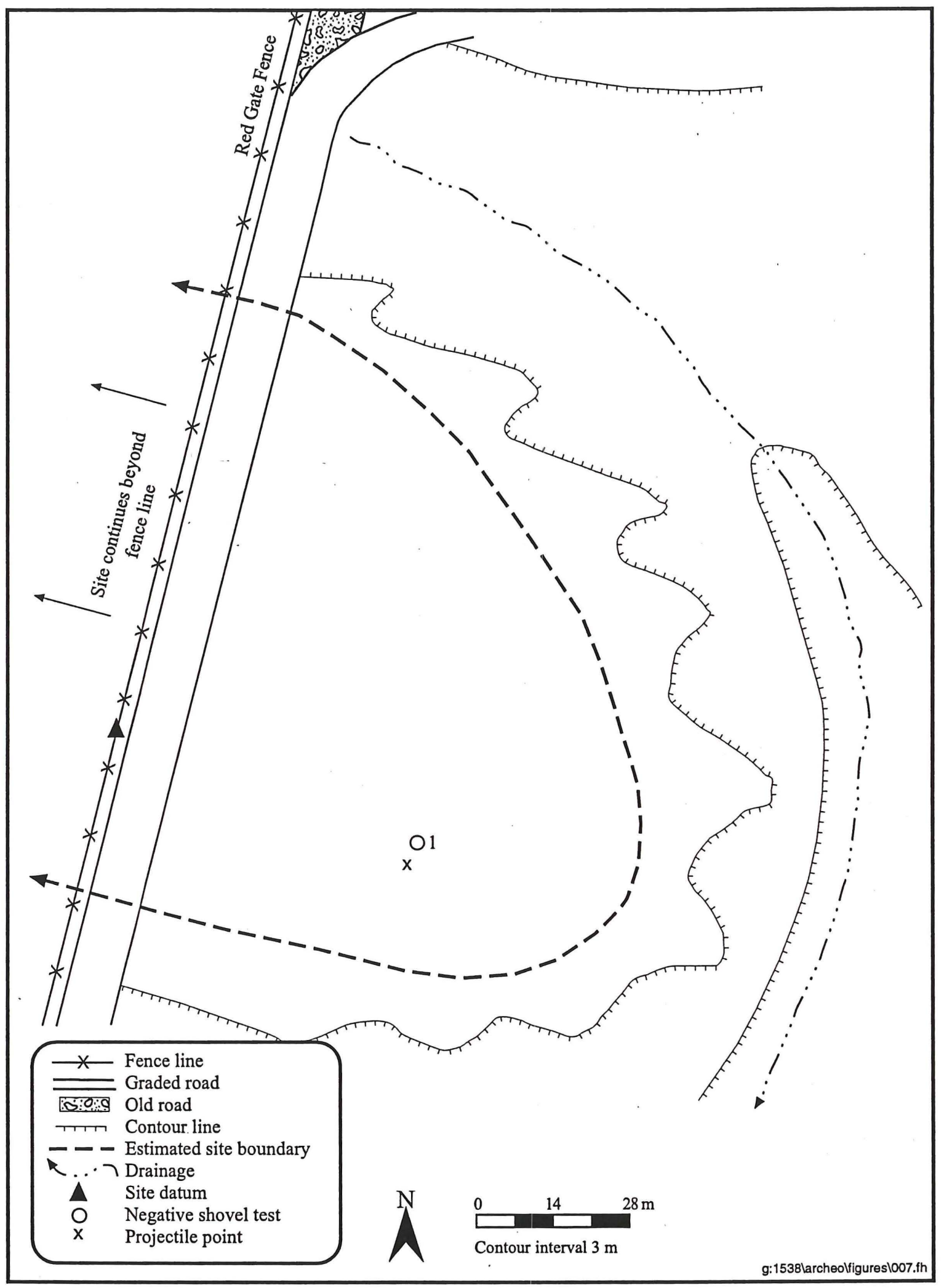

Figure 107. Plan map of site 41MV214. 


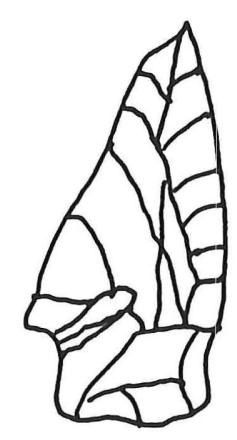

Figure 108. Field illustration of Figueroa projectile point identified at site 41MV214 (Scale 1:1).

The site lies at an elevation of $207 \mathrm{~m}(680 \mathrm{ft})$ amsl. The vegetation at $41 \mathrm{MV} 215$ is very sparse and consists of creosote, mesquite, and various cacti. Ground surface visibility ranges from 80 to 90 percent.

Site $41 \mathrm{MV} 215$ is a low-density lithic scatter measuring $50 \mathrm{~m}$ north to south and $40 \mathrm{~m}$ east to west. The total area covered by the site is approximately $2,000 \mathrm{~m}^{2}$. The lithic assemblage consists primarily of tertiary flakes, shatter, several scrapers, and a dart point which could not be typed but is illustrated in Figure 110. Raw material consists of locally available chert and quartzite. Artifact density at the site is approximately eight to 10 specimens per $25-\mathrm{m}^{2}$ area. No artifact concentrations were noted and no evidence of quarrying or features was identified at the site.

One shovel test was excavated at 41MV215 in order to determine the presence of subsurface cultural deposits. The shovel test was placed near the northwest corner of the site, in an area that appeared to have some soil accumulation. A single flake was observed in the upper $10 \mathrm{~cm}$ of the shovel test; no other cultural material was identified. Most of the site sits on top of exposed bedrock. The small amount of soil present at the site consists primarily of medium brown silt to a depth of $20 \mathrm{~cm} \mathrm{bs}$, followed by an increase in gravel inclusions to a depth of $35 \mathrm{~cm}$ bs. Subsoil was encountered at a depth of $35 \mathrm{~cm}$ bs and consisted of slightly lighter, more compact silty loam. Excavation of the shovel test was terminated at 40 $\mathrm{cm}$ bs.

The site is interpreted as an open campsite consisting of a surficial, low-density scatter of lithic artifacts, primarily flakes and shatter. Disturbances include the construction and maintenance of the road and fence that lie along the north boundary of the site; the area has also been heavily impacted by erosion, which has deflated most of the local ground surface. The completely deflated nature of the site, the lack of features, and the road and fence line disturbances indicate the research potential of site $41 \mathrm{MV} 215$ is minimal. Based on these observations, the site is recommended as ineligible for inclusion in the NRHP. No further work at site $41 \mathrm{MV} 215$ is recommended.

\section{Site $41 M V 216$}

Site 41MV216 is located in the northern portion of the Swartz Ranch project area, on a relatively level upland terrace overlooking an unnamed seasonal drainage that flows into Cuervo Creek, which is approximately $400 \mathrm{~m}$ south of the site (Figure 111; see Figure 100). The unnamed tributary to Cuervo Creek flows past the site about $150 \mathrm{~m}$ to the east, and the elevation of the site is about $215 \mathrm{~m}$ (705 ft) 


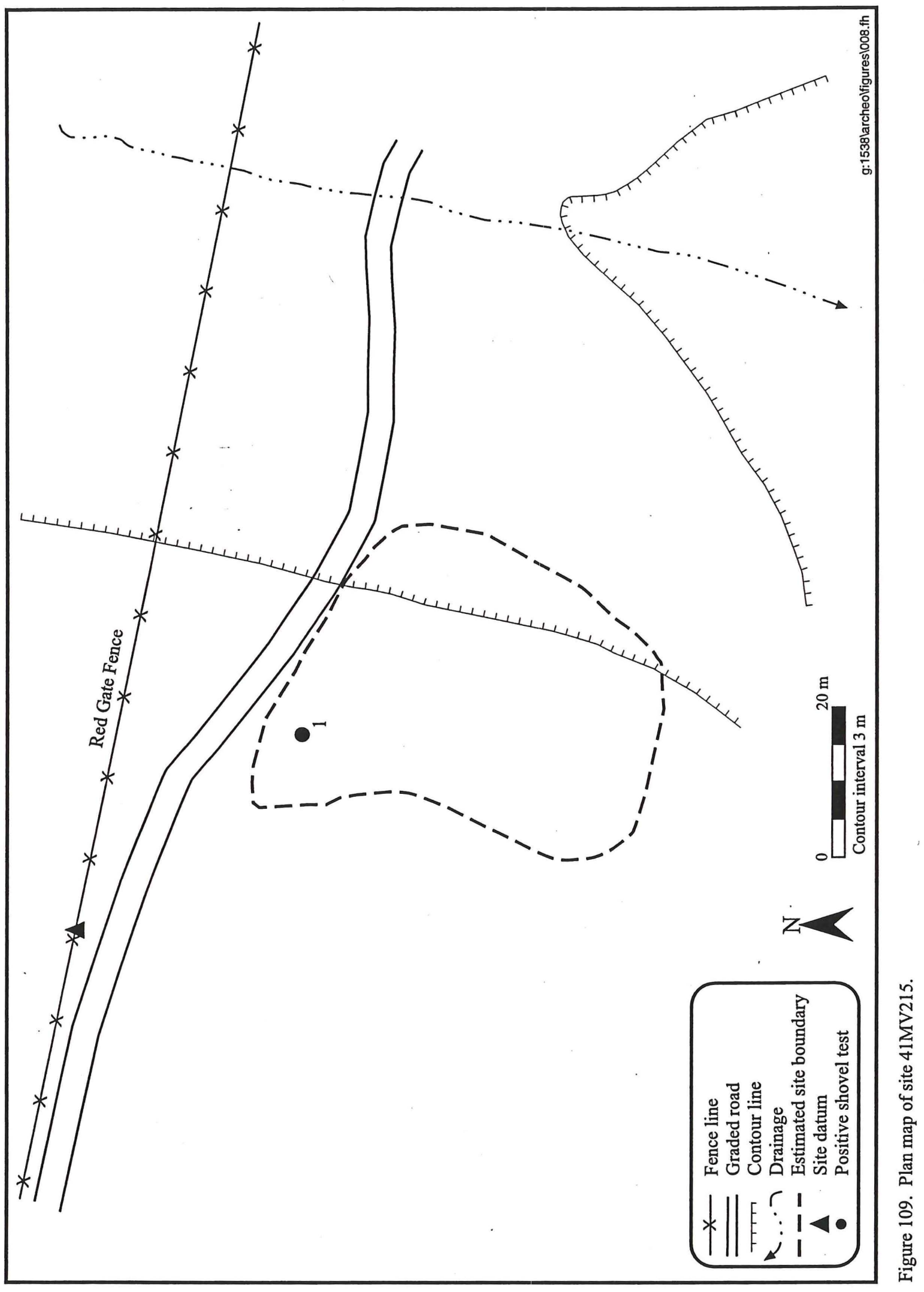




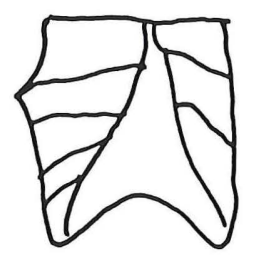

Figure 110. Field illustration of unidentified projectile point at site 41MV215 (Scale 1:1).

amsl. Vegetation on the north side of the road is relatively sparse, but on the south side it is much more dense. The ground cover mainly consists of mesquite, sparse grasses, and various cacti. Ground surface visibility is approximately 60 percent.

This small, low-density lithic scatter measures approximately $10 \mathrm{~m}$ north to south and $40 \mathrm{~m}$ east to west, encompassing about $400 \mathrm{~m}^{2}$ of total area. The lithic assemblage consists primarily of tertiary flakes, an unidentifiable projectile point fragment, and a Clear Fork uniface, a tool type that dates from the PaleoIndian period to the Middle Archaic (Figure 112; Turner and Hester 1993:246-249). All cultural material is derived from locally available chert. Artifact density is approximately five to six specimens per $25-\mathrm{m}^{2}$ area, with the highest concentration being in the southeastern edge of the site. No evidence of quarrying or cultural features was identified in the area.

One shovel test was placed in the area of slightly higher debitage concentration to determine the presence of subsurface cultural deposits. The soil at the site consists primarily of medium brown silty loam to a depth of $6 \mathrm{~cm}$ bs, followed by a mottled brown and dark brown compact loam with caliche inclusions. The excavation was terminated at $40 \mathrm{~cm}$ bs and no evidence of subsurface cultural material was identified.

Site 41MV216 is interpreted as an open campsite consisting of a surficial, low-density scatter of lithic artifacts, including flakes, an untyped projectile point fragment, and a Clear Fork uniface. The area has been impacted by the construction and maintenance of a road that crosses the site and a fence that runs nearby, as well as by erosion that has left the site surface very deflated. The sparse, deflated nature of the site, the lack of features, and the road and fence line disturbances indicate the research potential of site $41 \mathrm{MV} 216$ is minimal. Based on these observations, the site is recommended as ineligible for inclusion in the NRHP. No further work at site $41 \mathrm{MV} 216$ is recommended.

\section{Site $41 M V 217$}

Site 41MV217 is located in the northeastern corner of the Swartz Ranch project area near the eastern end of Red Gate Fence, on a gradual south-facing slope overlooking Cuervo Creek (Figure 113; see Figure 100). The site lies at an elevation of $216 \mathrm{~m}(708 \mathrm{ft})$ amsl. An unnamed intermittent drainage is located about $160 \mathrm{~m}$ east of the site and joins Cuervo Creek about $450 \mathrm{~m}$ southeast of the site. Vegetation in the area is sparse, consisting primarily of mesquite, tasajillo, and other varieties of cacti. Ground visibility is good, varying between 80 and 90 percent. 


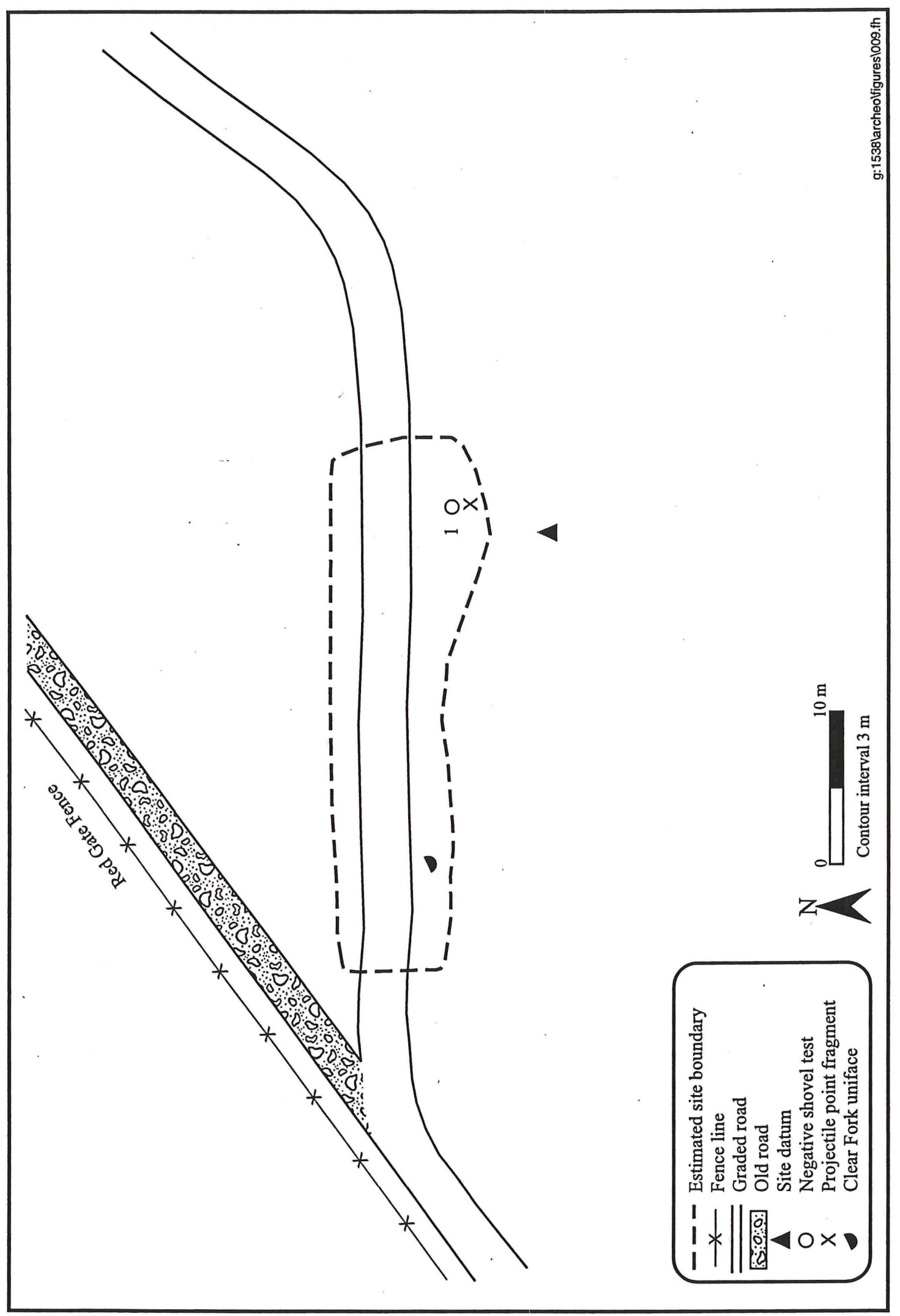

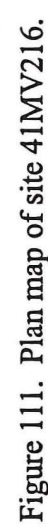




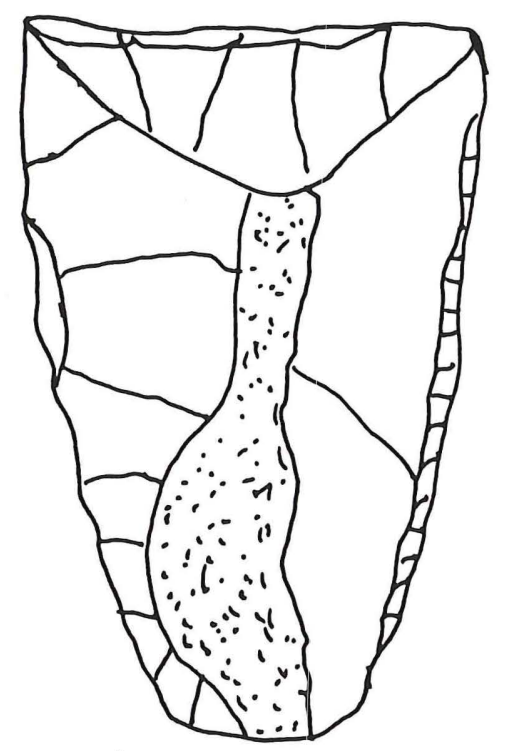

Figure 112. Field illustration of Clear Fork uniface identified at site 41MV216 (Scale 1:1).

The site is a low-density scatter of lithic materials extending for about $45 \mathrm{~m}$ north to south and about 75 $\mathrm{m}$ east to west, covering an area of approximately $3,375 \mathrm{~m}^{2}$. The lithic assemblage is composed of tertiary flakes, shatter, and bifaces, all of locally available chert. No artifact concentrations or evidence of quarrying were identified and no features were observed at the site.

Two shovel tests were excavated at the site, one near the site center and one approximately $5 \mathrm{~m}$ from the east boundary of the site. A total of three flakes was recovered from both shovel tests to a depth of 30 $\mathrm{cm}$ bs. The soil at the site consists primarily of yellowish brown clayey sand with a high density of gravels between 0 and $20 \mathrm{~cm}$ bs. A more compact dark yellowish brown sandy clay follows to a depth of $30 \mathrm{~cm}$ bs. Subsoil, encountered after $30 \mathrm{~cm}$ bs, consisted of compact sandy clay with caliche inclusions. Excavation of both Shovel Tests 1 and 2 terminated at $40 \mathrm{~cm}$ bs. Shovel Test 1 revealed two flakes in the first $20 \mathrm{~cm}$ and another flake in the 20 to $30 \mathrm{~cm}$ level; Shovel Test 2 produced a single flake in the top $10 \mathrm{~cm}$ bs.

Site 41MV217 is interpreted as an open campsite and consists of a low-density scatter of lithic artifacts, primarily flakes and flake tools. A subsurface cultural deposit that extends to a depth of $30 \mathrm{~cm}$ bs was identified. The presence of potentially significant subsurface deposits indicates that the research potential of site 41MV217 is unknown. Therefore, the site is recommended as potentially eligible for inclusion in the NRHP. Avoidance of the site is recommended; this would entail prohibiting additional grading, reworking, or ground disturbance within the limits of the site. At the request of JTF-6, a proposed road reroute was surveyed that runs along Red Gate Fence $20 \mathrm{~m}$ north of the northern site boundary, rejoining the existing road west of the site. No cultural resources were observed along the proposed reroute. The presence of an archeological monitor is recommended in order to keep equipment off of site 41MV217 and to ensure that intact portions of the site are not impacted by road improvement activities. 


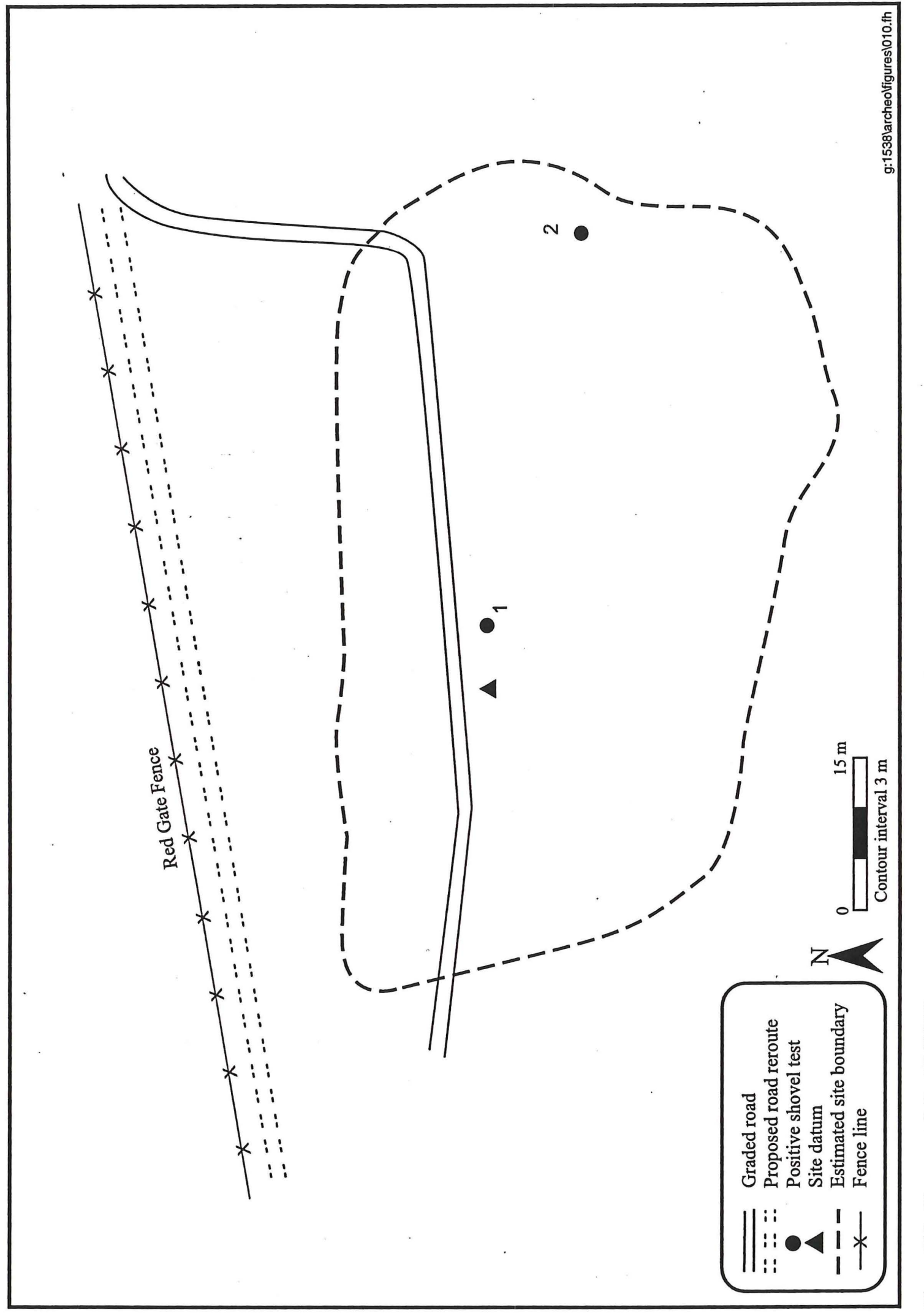

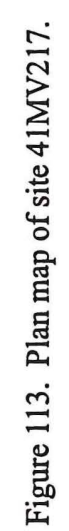




\section{Site $41 M V 218$}

Site 41MV218 is located in the southern portion of the Swartz Ranch project area on a southwest-trending ridge overlooking Tovar Creek to the south, approximately one $\mathrm{km}$ southeast of Bueno Aqua Tank (Figure 114; see Figure 100). The site appears along both sides of the two-track that connects Bueno Aqua and Mansfield tanks. The site is visible in the two-track road that bisects it lengthwise, and lies adjacent to an unnamed Tovar Creek tributary. Tovar Creek is about $600 \mathrm{~m}$ southwest of the site. The elevations at the site range from $204 \mathrm{~m}(670 \mathrm{ft})$ amsl at the southwestern end to about $210 \mathrm{~m}(688 \mathrm{ft})$ amsl at the northeastern extent of the site. Vegetation is sparse, consisting of mesquite, prickly pear, tasajillo, and other varieties of cacti. Ground visibility is about 80 percent.

This site is a large, low-density lithic scatter measuring $220 \mathrm{~m}$ northeast to southwest and $50 \mathrm{~m}$ northwest to southeast, covering an area of about $11,000 \mathrm{~m}^{2}$. The lithic assemblage primarily consists of secondary and tertiary flakes and shatter, cores, and bifaces, all of locally available chert. Artifact density is approximately six to eight specimens per $25-\mathrm{m}^{2}$ area. No definite artifact concentrations or diagnostic artifacts were identified at the site and no features were observed.

Two shovel tests were excavated at 41MV218 to determine the presence of subsurface cultural materials. Shovel Test 1 was placed on the slope at the southwestern end of the site, in an area where the surface scatter is more dense. No cultural materials were identified in this shovel test. Shovel Test 2 was placed at the opposite end of the site, near the northeastern end. Five flakes were identified in the upper $23 \mathrm{~cm}$. The soil at the site is primarily light to dark yellowish brown sandy to silty loam to a depth of between 23 and $30 \mathrm{~cm}$. This is followed by subsoil consisting of a compact brown loam with caliche inclusions and an increase in decomposed bedrock between 30 and $35 \mathrm{~cm}$ bs. Shovel Tests 1 and 2 were terminated at 35 and $30 \mathrm{~cm}$ bs, respectively.

Site 41MV218 is interpreted as an open campsite and consists of a large, low-density scatter of lithic artifacts - primarily flakes and flake tools—and a subsurface deposit that extends to a depth of $23 \mathrm{~cm}$. The site has been impacted by the construction and maintenance of the road that runs through its center, as well as by bioturbation and erosion that has caused surface deflation. The presence of potentially significant subsurface deposits and/or buried features indicates that the research potential of site 41MV218 is unknown. Therefore, the site is recommended as potentially eligible for inclusion in the NRHP. Avoidance of the site is recommended by prohibiting additional grading, reworking, or ground disturbance within the limits of the site. The presence of an archeological monitor is recommended in order to keep equipment off of site 41MV218 and to ensure that intact portions of the site are not impacted by road improvement activities.

\section{Site $41 M V 219$}

Site 41MV219 is located on a small knoll in the southern portion of the Swartz Ranch project area, on the edge of a south-trending ridge overlooking Tovar Creek (Figure 115; see Figure 100). It is approximately $1.1 \mathrm{~km}$ southeast of Bueno Aqua Tank and lies along the two-track road between Bueno Aqua and Mansfield tanks. An unnamed tributary of Tovar Creek is located $100 \mathrm{~m}$ east of the site, and Tovar Creek is about $850 \mathrm{~m}$ to the southwest. The site lies at an elevation of $213 \mathrm{~m}$ (700 ft) amsl. The light vegetation cover is composed of mesquite, creosote, soapbush, prickly pear, tasajillo, and other varieties of cacti. Bedrock is exposed at the top of the knoll and very little soil remains in the general site area. Ground surface visibility is approximately 80 percent. 


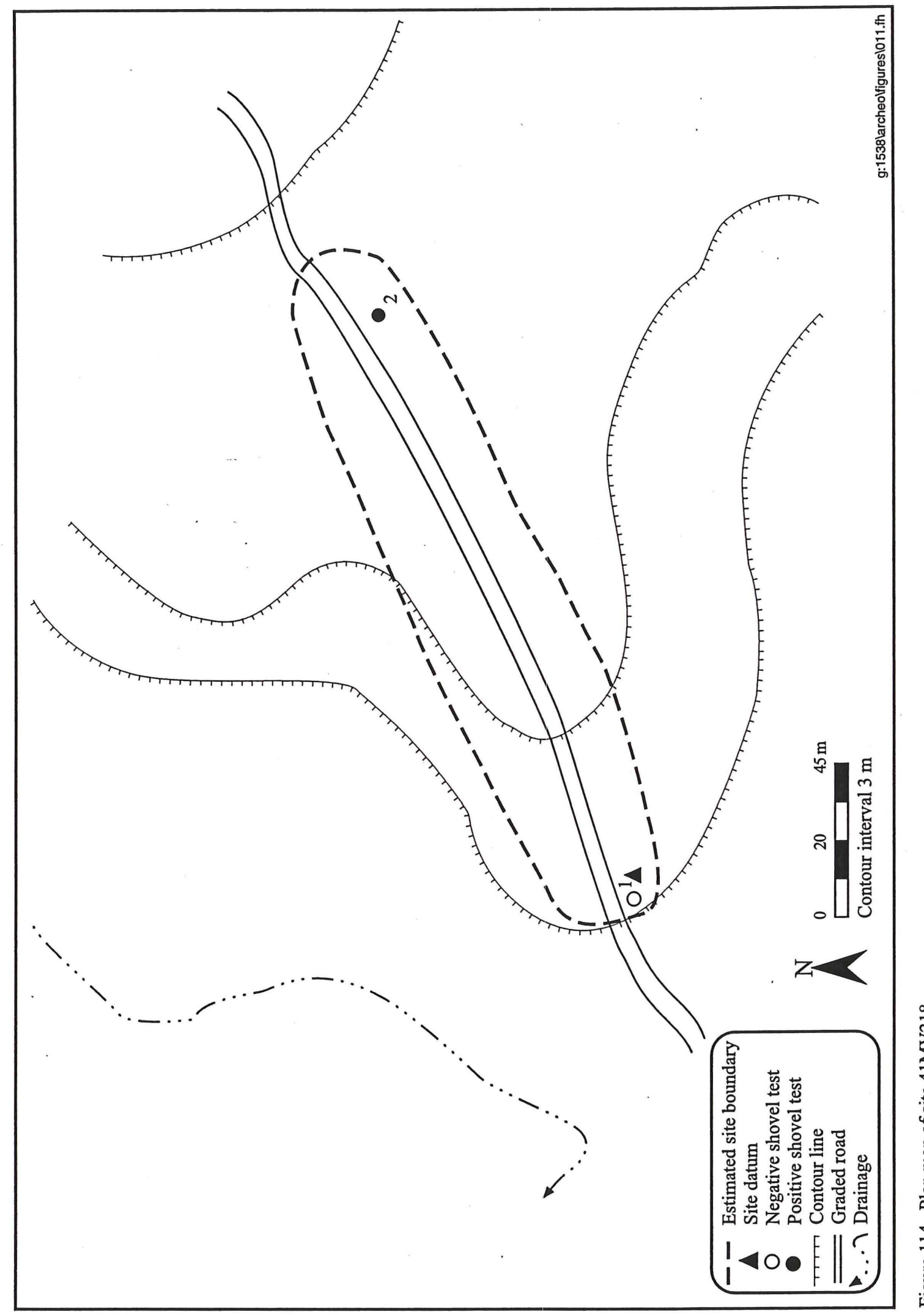




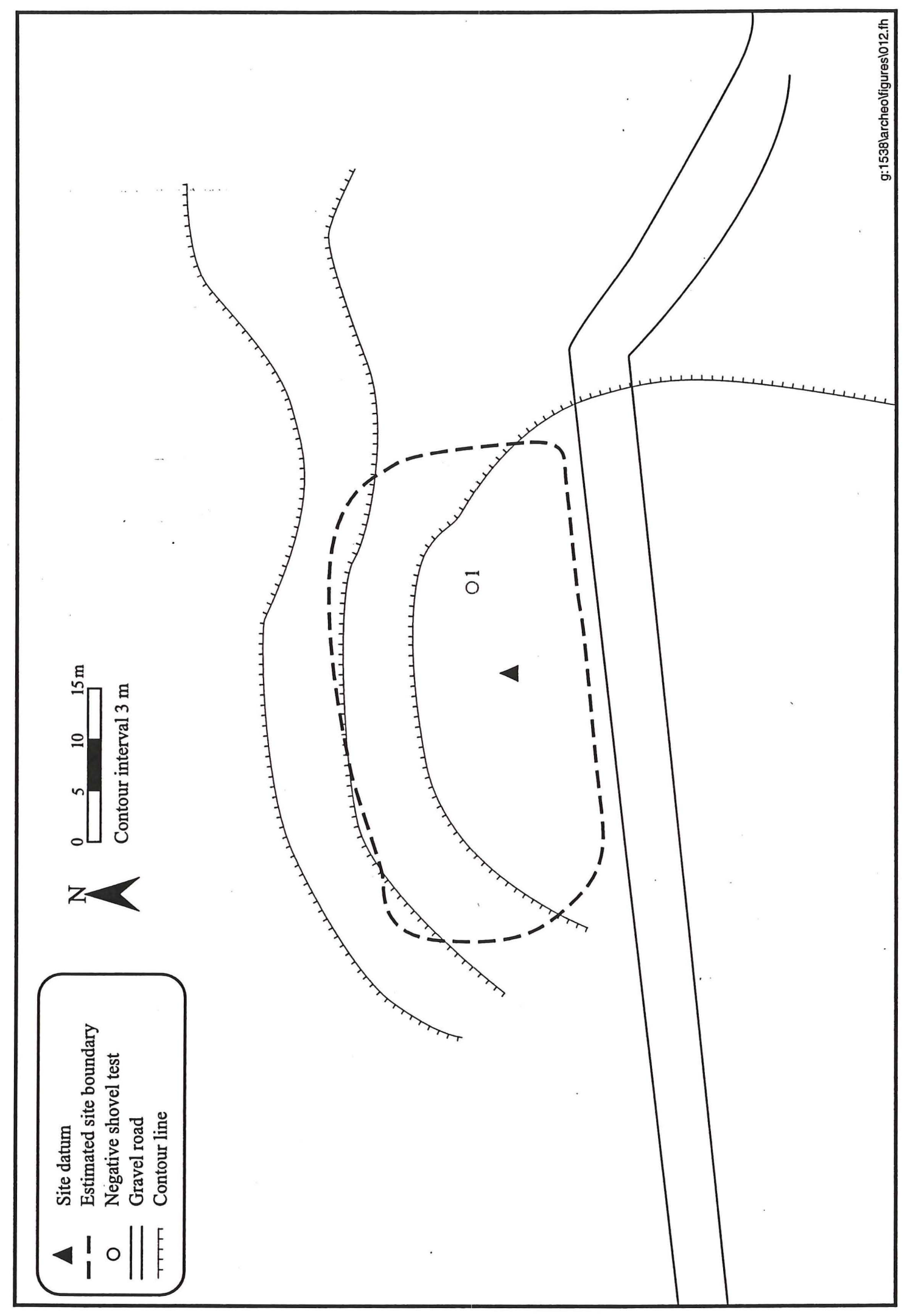

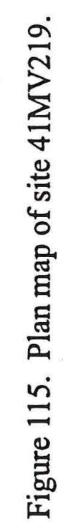


The site is a low-density lithic scatter that extends for about $30 \mathrm{~m}$ north to south and $45 \mathrm{~m}$ east to west, covering approximately $1,350 \mathrm{~m}^{2}$. The lithic assemblage consists of tertiary flakes, a biface fragment, scrapers, and shatter, all of locally available chert and quartzite. Artifact density at the site is approximately six to eight specimens per $25-\mathrm{m}^{2}$ area. No definite concentration of artifacts was observed and no features were identified at the site.

One shovel test was excavated at the site to determine the presence of a subsurface deposit. Little soil remained at the site and much of the ground surface is covered in a pebble and cobble pavement. The shovel test revealed a light olive brown silty loam to $5 \mathrm{~cm}$ bs, followed by a mottled olive brown and yellowish brown loam to $15 \mathrm{~cm}$ bs. A very pale brown mottled with light olive brown compact subsoil was encountered below $15 \mathrm{~cm}$. The shovel test was terminated at $30 \mathrm{~cm}$ bs; no cultural material was identified.

Site 41MV219 is interpreted as an open campsite consisting of a surficial, low-density scatter of lithic artifacts, including flakes, shatter, and a biface fragment. The site has been disturbed by road construction and maintenance, and by erosion that has caused the deflation of the site surface. The sparse, deflated nature of the site, the lack of features, and the disturbances caused by road construction indicate the research potential of site $41 \mathrm{MV} 219$ is minimal. Based on these observations, the site is recommended as ineligible for inclusion in the NRHP. No further work at site 41MV219 is recommended.

\section{Site 41MV220}

Site 41MV220 is located on the western side of Swartz Ranch, on a west-facing slope of the upland area overlooking the Rio Grande (Figure 116; see Figure 100). It is found along the existing northwestsoutheast-trending fence line, approximately $100 \mathrm{~m}$ southeast of the closest boundary of 41MV211. Elevation at the site ranges from 192 to $195 \mathrm{~m}$ (630 to $640 \mathrm{ft}$ ) amsl. An unnamed seasonal drainage is located approximately $50 \mathrm{~m}$ southwest of the site, and the Rio Grande is $500 \mathrm{~m}$ to the southwest. Vegetation in the area is fairly light and consists of mesquite, acacia, tasajillo, prickly pear, and short grasses. Ground surface visibility is about 70 percent.

The site is a low-density lithic scatter that extends $50 \mathrm{~m}$ northeast to southwest and $20 \mathrm{~m}$ northwest to southeast. The site extends south beyond the fence that forms the southeast boundary of the Swartz Ranch. The area of the site identified covers approximately $1,000 \mathrm{~m}^{2}$. The lithic assemblage is composed of primary and secondary flakes, shatter, tested cobbles, and cores, visible on the surface in densities of five to six artifacts per $25-\mathrm{m}^{2}$ area. The lithic material is predominantly chert, available onsite in the form of exposed cobble and gravel lenses. No definite artifact concentrations were identifiable at the site, and no cultural features were observed.

A single shovel test was excavated at the site to determine whether subsurface cultural materials are present. No cultural materials were observed in the shovel test, which was placed near the center of the site. The soil at the site is brown silt with extensive pebble and cobble inclusions to a depth of approximately $20 \mathrm{~cm}$ bs, followed by a yellowish brown compact subsoil with pebble inclusions. Excavation of the shovel test was terminated at $40 \mathrm{~cm}$ bs. Most of the ground surface at the site consists of a pebble and cobble pavement with very little soil. 


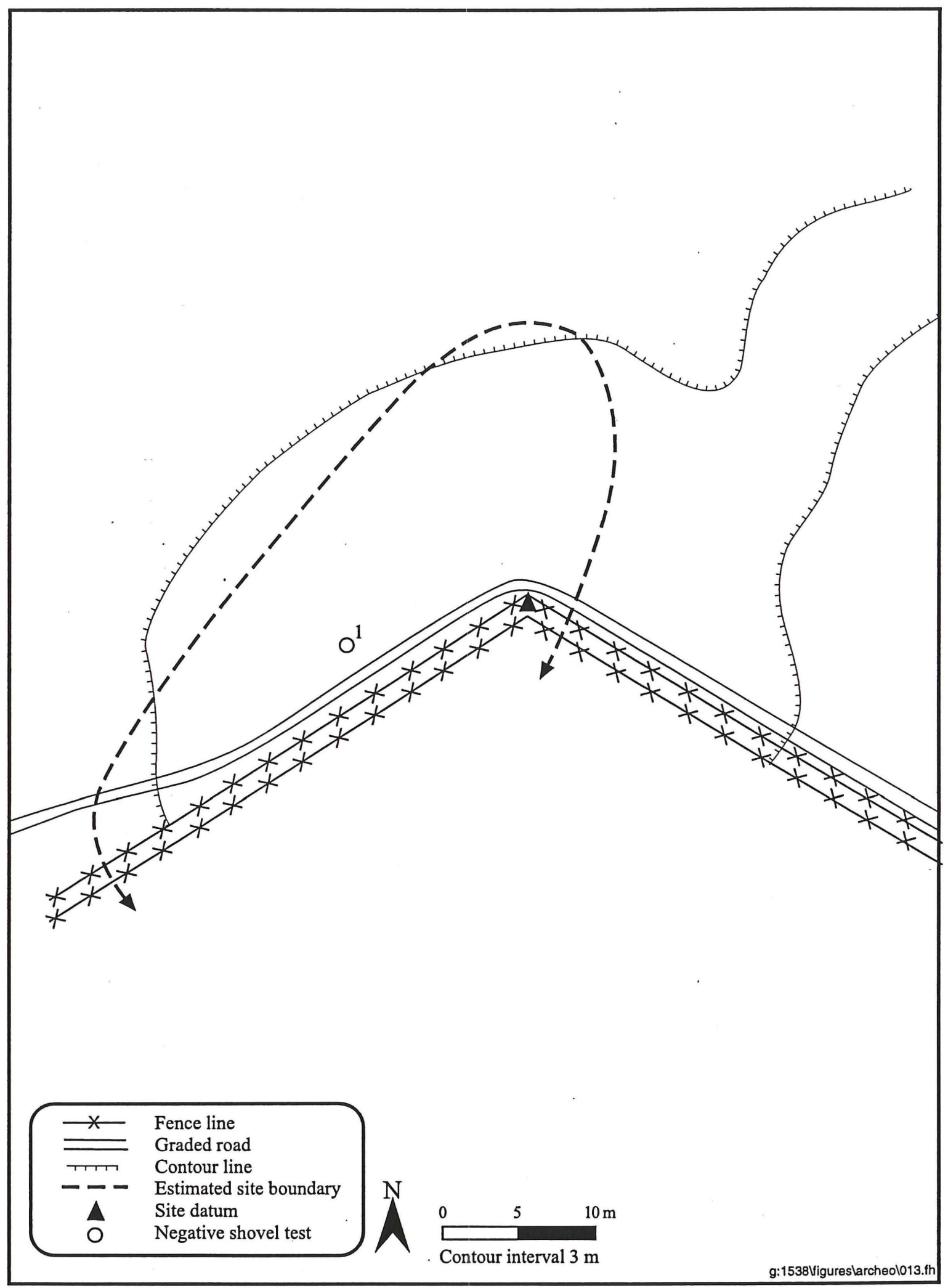

Figure 116. Plan map of site 41MV220. 
Site $41 \mathrm{MV} 220$ is interpreted as a quarry site consisting of a surficial, low-density scatter of lithic artifacts-including flakes, shatter, tested cobbles, and cores-over an area of exposed gravels and cobbles. The integrity of the site has been affected by road and fence construction and maintenance, as well as by extensive erosion that has deflated the ground surface in the site area. The sparse, deflated nature of the site, the lack of features, and the disturbances caused by road and fence line construction indicate the research potential of the evaluated area of site 41MV220 is minimal. Based on these observations, the portion of the site within the ROW is recommended as ineligible for inclusion in the NRHP. The remainder of the site could not be investigated. No further work within the assessed portion of site $41 \mathrm{MV} 220$ is recommended.

\section{Site 41MV221}

Site 41MV221 is located on the western side of Swartz Ranch, along the western portion of a terrace overlooking the Rio Grande $300 \mathrm{~m}$ to the southwest (Figure 117; see Figure 100). The site is situated along an existing northwest-southeast-trending fence line and road, approximately $175 \mathrm{~m}$ south of 41MV220. Site 41MV221 lies at an elevation of $195 \mathrm{~m} \mathrm{(640} \mathrm{ft)} \mathrm{amsl} \mathrm{and} \mathrm{is} \mathrm{situated} \mathrm{approximately} 150$ $\mathrm{m}$ east of an unnamed seasonal drainage that flows to the Rio Grande. Vegetation at 41MV221 is of moderate density and is composed of mesquite, acacia, tasajillo, prickly pear, and short grasses. Ground surface visibility averages about 70 percent.

Site 41MV221 is a low-density lithic scatter that extends $75 \mathrm{~m}$ from northwest to southeast and at least 50 $\mathrm{m}$ from northeast to southwest. The site continues beyond the fence that defines the limits of the survey area for the current project. The total area covered by the identified portion of the site is $3,750 \mathrm{~m}^{2}$. Artifacts observed at the site include primary and secondary flakes, shatter, tested cobbles, and cores, in densities of about five to six per $25-\mathrm{m}^{2}$ area. Most of the lithic material observed at the site was chert, available onsite in the form of exposed cobble and gravell lenses. No distinctive concentrations of artifacts or cultural features were identified at 41MV221.

One shovel test was excavated at the site to determine the presence of subsurface cultural materials. The shovel test was placed in an area determined likely to have more soil depth. One flake was observed in the upper $20 \mathrm{~cm}$. The soil at the site consists of a light gray silty loam with a content of approximately 60 percent gravel to a depth of $20 \mathrm{~cm}$ bs, followed by more compact but similar soil with slightly fewer gravel inclusions. Excavation of the shovel test was terminated at $40 \mathrm{~cm}$ bs. It appears most of the soil has eroded from the surface of the site as most of the area is covered in a pebble and cobble pavement.

Site 41MV221 is interpreted as a quarry site consisting of a surficial, low-density scatter of lithic artifacts, including flakes, shatter, tested cobbles, and cores, that extends over an area of exposed gravels and cobbles. Site integrity has been impacted by road and fence construction, and by heavy erosion that has left the surface deflated. Although shovel testing revealed there may be a shallow subsurface component, the sparse nature of the site, the lack of features, and the disturbances caused by erosion and road and fence construction indicate the research potential of the evaluated area of 41MV221 is minimal. Based on these observations, the portion of the site within the ROW is recommended as ineligible for inclusion in the NRHP. The remainder of the site could not be investigated. No further work within the assessed portion of site $41 \mathrm{MV} 221$ is recommended. 


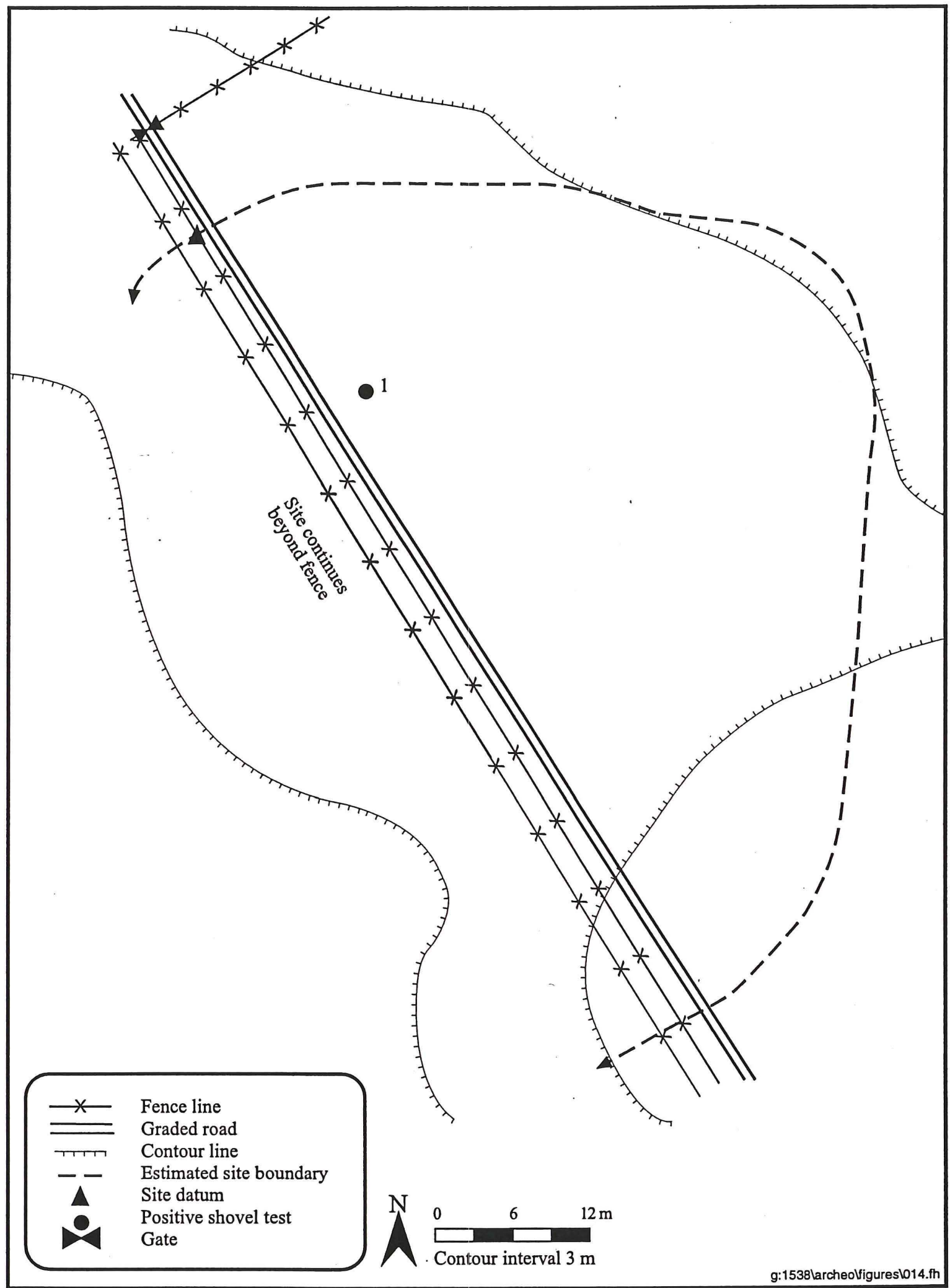

Figure 117. Plan map of site 41MV221. 


\section{Site $41 M V 222$}

Site 41MV222 is located on the western side of Swartz Ranch and covers a series of ridges and terraces overlooking the Rio Grande, $350 \mathrm{~m}$ to the southwest (Figure 118; see Figure 100). The site is located along an existing northwest-southeast-trending fence line and road, and it is approximately $175 \mathrm{~m}$ south of 41MV221. Elevation at the site ranges from 189 to $201 \mathrm{~m} \mathrm{(620} \mathrm{to} 660 \mathrm{ft}$ ) amsl. Deep gullies cut across the site from northeast to southwest, and an unnamed seasonal drainage runs inside the northwestern edge of the site. A smaller, unnamed drainage has cut through the center of the site. Vegetation in the area includes mesquite, acacia, tasajillo, prickly pear, and short grasses. The vegetation cover is sparse and ground visibility is about 95 percent.

The site is a high-density scatter of lithic artifacts measuring $300 \mathrm{~m}$ northwest to southeast and at least $375 \mathrm{~m}$ northeast to southwest - the site may extend somewhat beyond the fence that marked the limit of the current survey area-and covers an area of approximately $112,500 \mathrm{~m}^{2}$. The lithic assemblage consists of primary and secondary flakes, shatter, tested cobbles, cores, bifaces, and scrapers. Raw material of the artifacts is primarily chert and quartzite available onsite in the form of exposed cobble and gravel lenses. The density of these artifacts is highest on the ridges, where two concentrations were identified (see Figure 118). In these concentrations, there were 20 to 30 artifacts per $25-\mathrm{m}^{2}$ area, while densities over the remainder of the site were approximately three to four artifacts per $25-\mathrm{m}^{2}$ area. Two possible hearths were identified in the central portion of the site, each containing eight to 10 burned cobbles in an area $50 \mathrm{~cm}$ in diameter (Figure 119). No artifacts were associated with either of these two possible hearths.

Two shovel tests were excavated at the 41MV222 to determine the approximate depth of soil at the site and whether subsurface cultural deposits were present. Both were placed in areas where there was some soil remaining; one was excavated in the vicinity of the possible hearths. The soil at the site is predominantly brown silt with gravel inclusions to a depth of $20 \mathrm{~cm}$ bs, followed by a similar soil type though more compact and containing caliche concentrations. Excavation of Shovel Tests 1 and 2 was terminated at 60 and $40 \mathrm{~cm}$, respectively. Neither shovel test revealed subsurface cultural remains. Very few areas of soil accumulation were identified at the site; most of the ground surface is composed of exposed chert gravels.

The site is interpreted as an extensive quarry site and consists of a large, high-density scatter of lithic artifacts that includes flakes, tested cobbles, cores, scrapers, and bifaces. Site integrity has been impacted by the construction and maintenance of the road and fence on the southwest edge, and by extensive erosion that has left the surface deflated, especially on the ridge tops. Although shovel testing revealed no subsurface cultural deposits, two possible hearth features were identified on the surface of the site. Given the presence of possible features, there is the potential for additional features and subsurface deposits, indicating the research potential of site 41MV222 is unknown. Therefore, the site is recommended as potentially eligible for inclusion in the NRHP. Avoidance of the site is recommended by prohibiting additional grading, reworking, or ground disturbance within the limits of the site. The presence of an archeological monitor is recommended in order to keep equipment off of undisturbed portions of site $41 \mathrm{MV} 222$ and to ensure that intact portions of the site are not impacted by road improvement activities. 


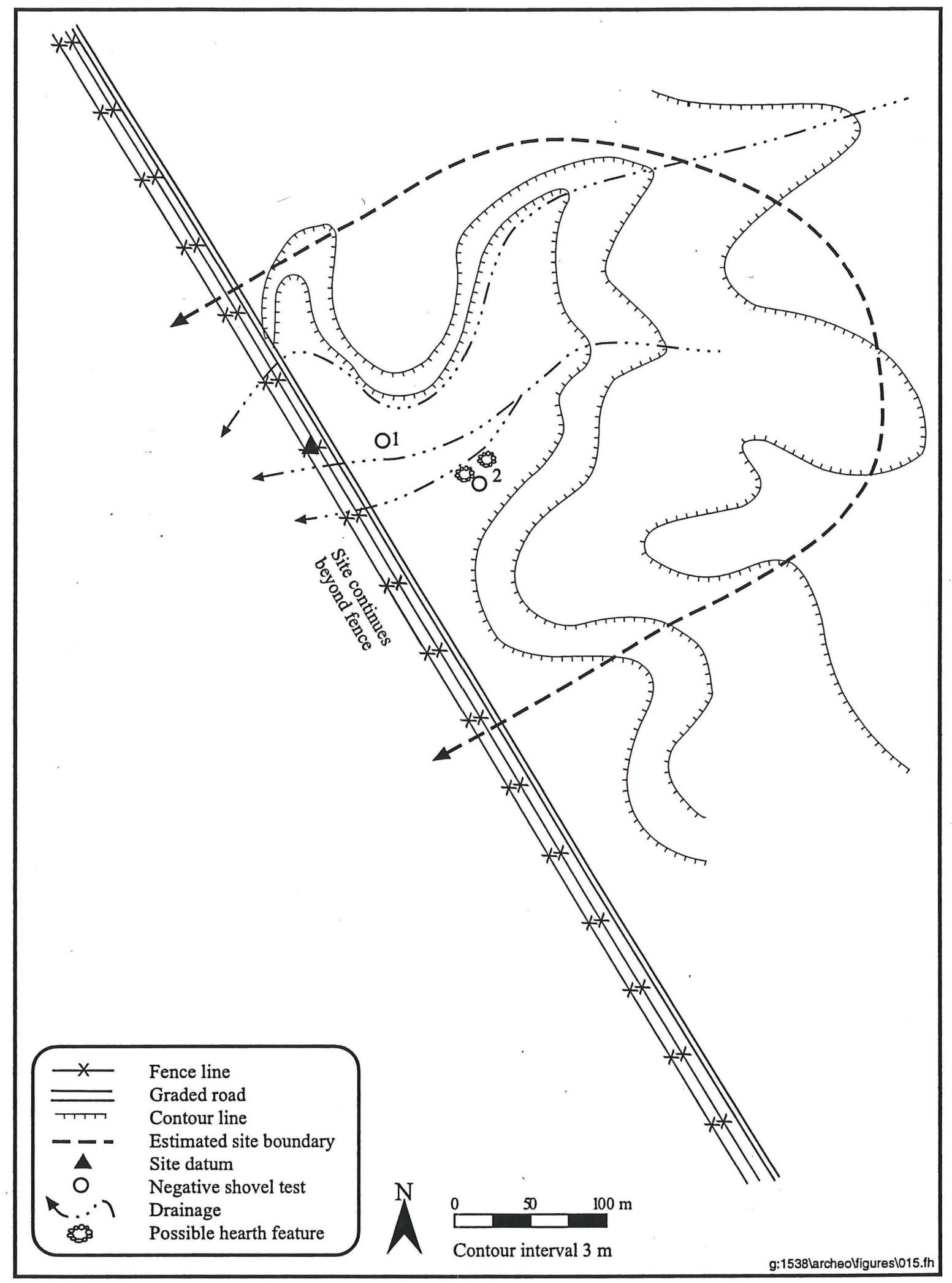

Figure 118. Plan map of site 41MV222. 


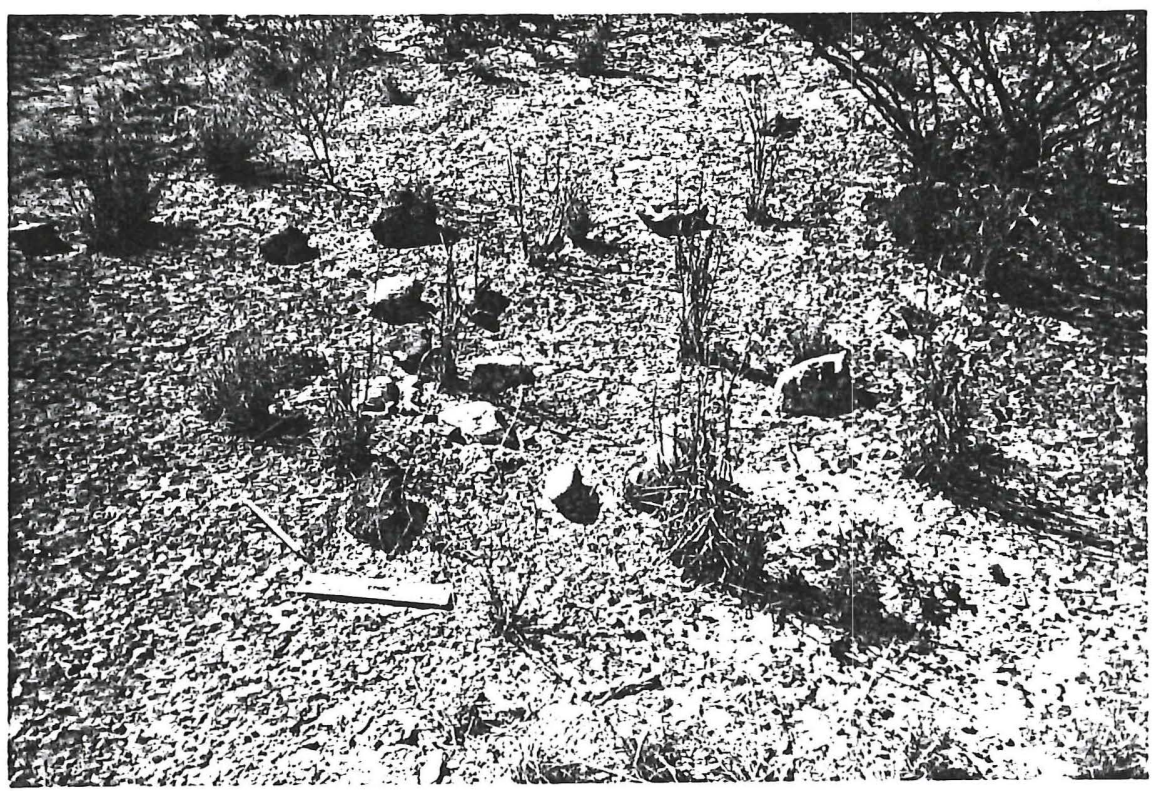

Figure 119. View of feature at site $41 \mathrm{MV} 222$.

\section{Site $41 M V 223$}

Site 41MV223 is located in the southwestern portion of the Swartz Ranch project area, at the west edge of a terrace overlooking the Rio Grande to the southwest (Figure 120; see Figure 100). It is located along an existing northwest-southeast-trending fence line and road, approximately $150 \mathrm{~m}$ northwest of a sharp turn in both the fence and road. The site elevation is $186 \mathrm{~m}(610 \mathrm{ft})$ amsl. Small gullies cross the site in places and an unnamed seasonal drainage lies about $50 \mathrm{~m}$ to the southwest. The Rio Grande is about $250 \mathrm{~m}$ southwest of the site. Vegetation in the area consists of mesquite, acacia, and short grasses, all of which are sparse enough to allow about 60 percent ground surface visibility.

Site 41MV223 is a low-density lithic scatter that measures $175 \mathrm{~m}$ northwest to southeast and at least $50 \mathrm{~m}$ northeast to southwest, extending farther to the southwest beyond the limits of the current survey area. The identified portion of the site covers a total area of about $8,750 \mathrm{~m}^{2}$. The lithic assemblage consists of tertiary flakes and one biface of locally available chert; most of the artifacts were observed in the road cut. Grading and construction of the road has cut into the surrounding ground surface approximately 30 $\mathrm{cm}$, exposing the buried cultural materials. No distinctive artifact concentrations were observed at the site, nor were any cultural features identified.

One shovel test was excavated at 41MV223 to determine the depth of the subsurface cultural deposits. The soil at the site is a medium brown, very fine, loose silt to a depth of $60 \mathrm{~cm}$ bs. Excavation of the shovel test was terminated at $60 \mathrm{~cm}$ bs. One flake was observed in each of the upper two 20-cm levels; no cultural materials were observed between 40 and $60 \mathrm{~cm}$ bs. 


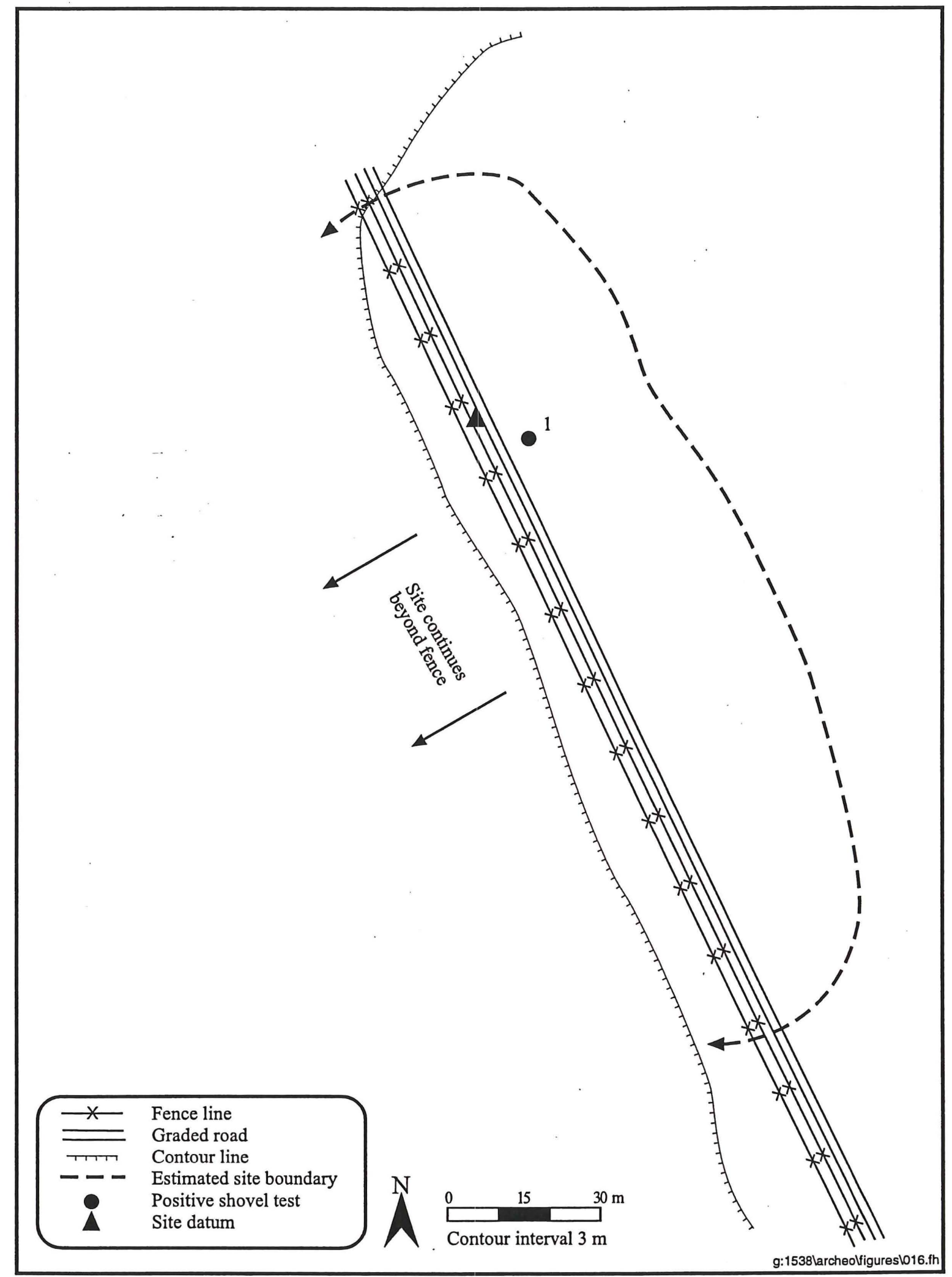

Figure 120. Plan map of site 41MV223. 
The site is interpreted as an open campsite and consists of a low-density surface scatter of lithic artifacts with a subsurface component. Most of the artifacts were identified in the road cut, and shovel testing revealed a cultural deposit extending to a depth of $40 \mathrm{~cm}$. Disturbances at the site include the construction and maintenance of the road and fences that bisect the area, as well as erosion and possibly flooding. Because of the subsurface aspect of the site, the research potential of 41MV223 is unknown; therefore, the site is recommended as potentially eligible for inclusion in the NRHP. Avoidance of the site is recommended by prohibiting additional grading, reworking, or ground disturbance within the limits of the site. The presence of an archeological monitor is recommended in order to keep equipment off of undisturbed portions of site 41MV223 and to ensure that intact portions of the site are not impacted by road improvement activities.

\section{Site 41MV224}

Site 41MV224 is located in the southwestern portion of the Swartz Ranch project area, on the west end of a terrace overlooking the Rio Grande (Figure 121; see Figure 100). It is located at the southwestern end of the road that runs primarily north to south just west of Bueno Aqua Tank. The site was identified in the existing road at an elevation of $186 \mathrm{~m}(610 \mathrm{ft})$ amsl. An unnamed seasonal drainage is located about $50 \mathrm{~m}$ west of the site, and the Rio Grande is located about $200 \mathrm{~m}$ to the southwest. Vegetation in the area is moderately dense, composed of mesquite, acacia, and dense short grasses, reducing ground visibility to about 60 percent.

Site 41MV224 is a low-density lithic scatter that shows up most prominently in the road cut that bisects the site. The site extends about $100 \mathrm{~m}$ northeast to southwest and about $75 \mathrm{~m}$ northwest to southeast, covering an area of about $7,500 \mathrm{~m}^{2}$. The lithic assemblage observed at the site consists almost entirely of tertiary flakes of locally available chert. No definite artifact concentrations were noted, and no evidence of cultural features was identified.

One shovel test was excavated near the center of $41 \mathrm{MV} 224$ to determine whether subsurface cultural deposits were present. A single flake was observed in the shovel test at between 60 and $80 \mathrm{~cm}$ bs, indicating subsurface deposits may be present; however, it is likely that the flake fell into the shovel test during excavation, originating from an upper level or the ground surface. The soil in the area is primarily composed of medium brown fine, powdery silt that extends to at least $80 \mathrm{~cm}$ in depth. Excavation of the shovel test was terminated at $80 \mathrm{~cm}$ bs and no variation in stratigraphy was identified.

The site is interpreted as an open campsite consisting of a surficial, low-density scatter of lithic artifacts, primarily flakes. One flake was recovered from a shovel test at a depth of between 60 and $80 \mathrm{~cm}$, but it is believed to have fallen in during excavation. No artifacts were recovered from the overlying strata in this shovel test. The site integrity has been impacted by disturbances that include the construction and maintenance of the road and fence across the site, and by erosion, and possibly by flooding. The sparse nature of the site, the lack of features, and the disturbances caused by erosion and road and fence line construction indicate the research potential of site 41MV224 is minimal. Based on these observations, the site is recommended as ineligible for inclusion in the NRHP. No further work at site 41MV224 is recommended. 


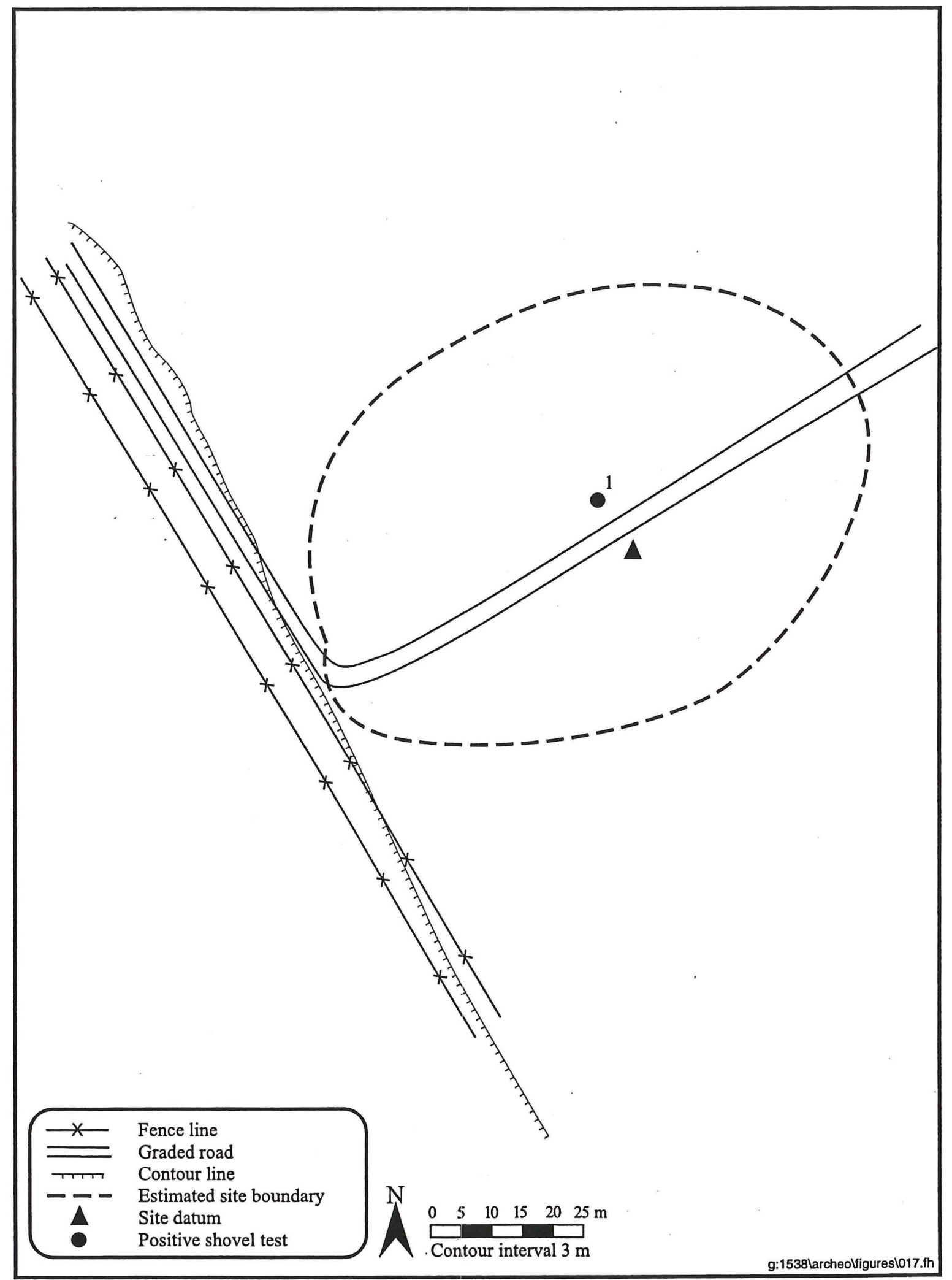

Figure 121. Plan map of site 41MV224. 


\section{Site $41 M V 225$}

Site 41MV225 is located in the southwestern portion of the Swartz Ranch project area, on a southwestfacing, gradual slope of a terrace overlooking the Rio Grande just northeast of a small seasonal drainage (Figure 122; see Figure 100). It is located near the southwestern end of the road that runs primarily north to south just west of Bueno Aqua Tank. Site 41MV225 is between sites 41MV224 and 41MV226. The site is at an elevation of $186 \mathrm{~m} \mathrm{(610} \mathrm{ft)} \mathrm{amsl.} \mathrm{An} \mathrm{unnamed} \mathrm{seasonal} \mathrm{drainage} \mathrm{is} \mathrm{located} \mathrm{about} 30 \mathrm{~m}$ southwest of the site, and Tovar Creek is about $350 \mathrm{~m}$ to the east. The Rio Grande is $600 \mathrm{~m}$ southwest of the site. Vegetation in the area is moderately dense and consists of mesquite, acacia, short grasses, tasajillo, and prickly pear. Ground visibility is about 70 percent.

Site $41 \mathrm{MV} 225$ is a low-density scatter of lithics that extends over a fairly limited area, measuring $50 \mathrm{~m}$ northeast to southwest and $20 \mathrm{~m}$ northwest to southeast, covering an area of about $1,000 \mathrm{~m}^{2}$. The lithic assemblage consists primarily of primary and secondary flakes and one biface, with a density of approximately five to six artifacts per $25-\mathrm{m}^{2}$ area. Raw material of the artifacts consists of chert available onsite in the form of cobbles and gravel; most of the artifacts were observed in areas where these gravels were exposed. No definite artifact concentrations were identified, nor were any cultural features observed.

One shovel test was excavated at the site to determine the possible existence of subsurface cultural materials. The shovel test was placed near the center of the site close to a small concentration of lithic artifacts and excavated to $40 \mathrm{~cm}$ bs; no cultural materials were identified. The soil at the site consists mostly of dark brown, very fine silt to a depth of over $40 \mathrm{~cm}$. Gravel and cobble lenses are exposed throughout the site.

The site is interpreted as a quarry site consisting of a surficial, low-density scatter of lithic artifacts, including flakes and a biface, on an exposed gravel bed. Site integrity has been greatly impacted by the construction and maintenance of the road and fence that bisect the site, as well as by erosion and flooding. The sparse, surficial nature of the site, the lack of features, and the disturbances caused by erosion and road and fence line construction indicate the research potential of site $41 \mathrm{MV} 225$ is minimal. Based on these observations, the site is recommended as ineligible for inclusion in the NRHP. No further work at site 41MV225 is recommended.

\section{Site 41MV226}

Site 41MV226 is located in the southwestern portion of the Swartz Ranch project area, on a small terrace between prominent ridges to the north and west (Figure 123; see Figure 100). It is located on the southern end of the road that runs primarily north and south and passes just west of Bueno Aqua Tank. The site is approximately $200 \mathrm{~m}$ northeast of site 41MV225. Elevation at the site ranges from 189 to 192 $\mathrm{m}(620$ to $630 \mathrm{ft})$ amsl. Gullies have cut into the ground in some areas, and definable drainages exist on the south and east sides. An unnamed seasonal drainage is less than $100 \mathrm{~m}$ east of the site, Tovar Creek is located about $250 \mathrm{~m}$ to the southeast, and the Rio Grande is $800 \mathrm{~m}$ to the southwest. Vegetation in the site area is fairly sparse, and consists of mesquite, acacia, cholla, prickly pear, tasajillo, and short grasses. Ground visibility averages about 90 percent. 


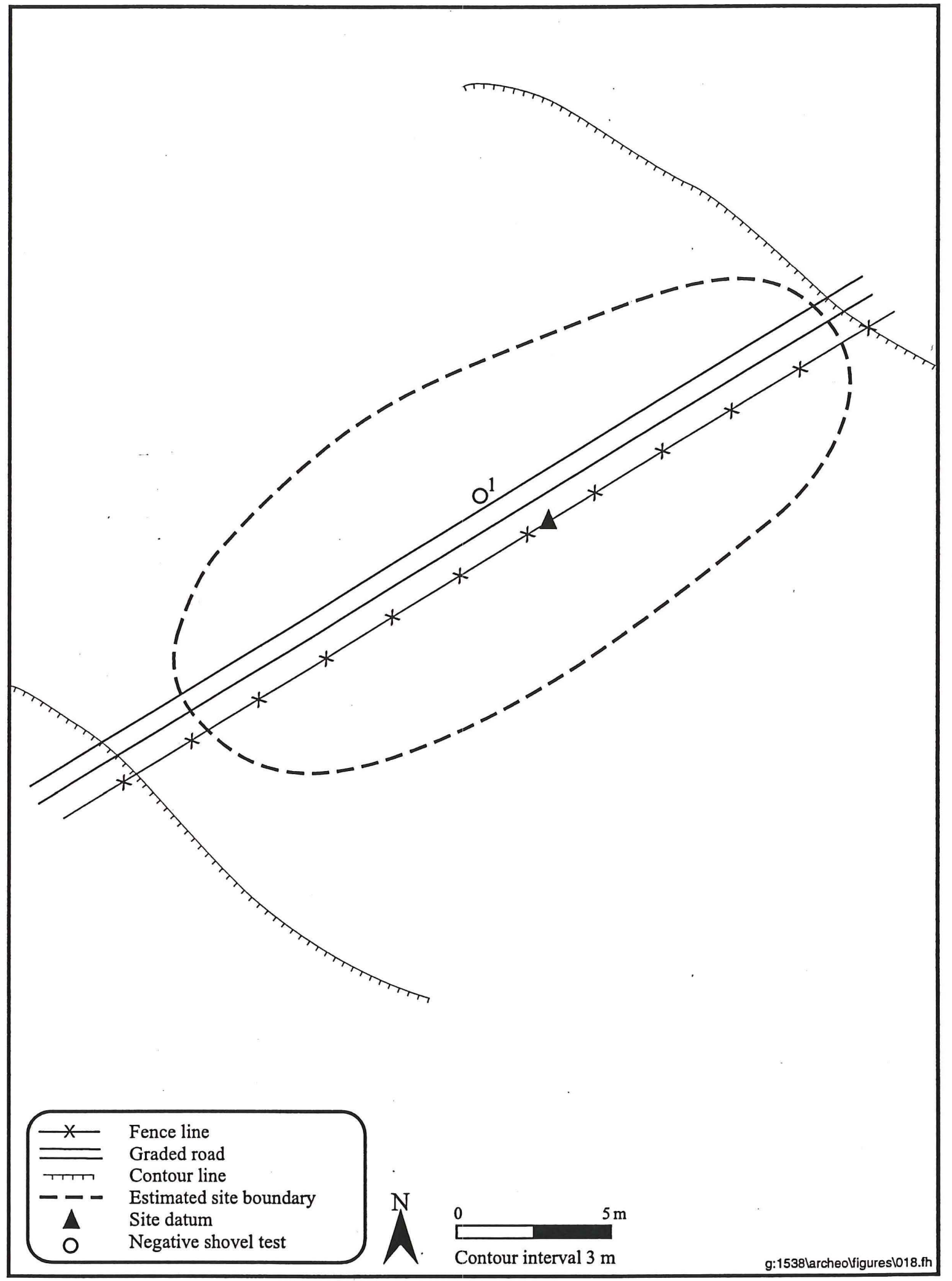

Figure 122. Plan map of site 41MV225. 


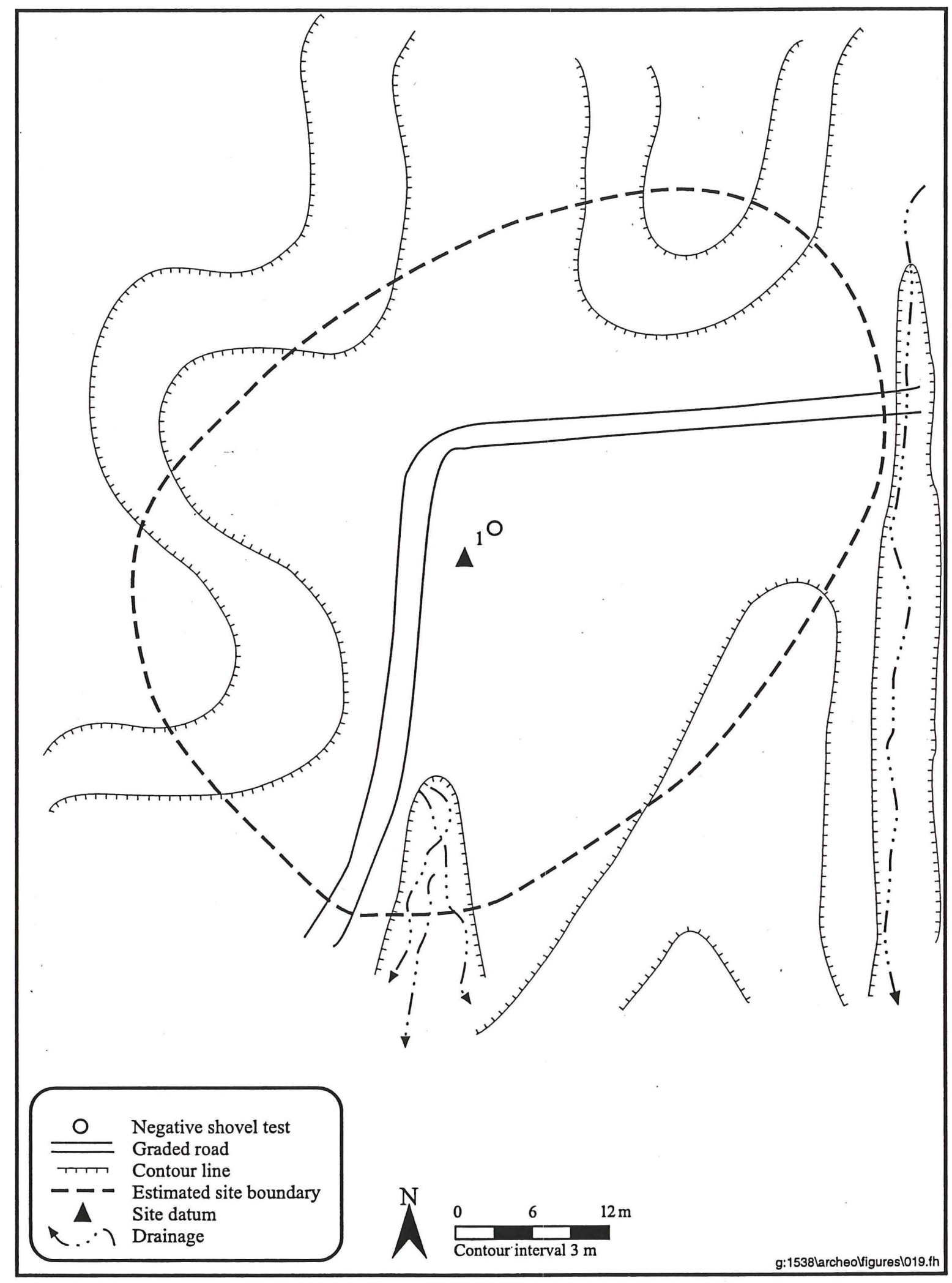

Figure 123. Plan map of site 41MV226. 
Site 41MV226 is a moderately dense lithic scatter that extends for $65 \mathrm{~m}$ northeast to southwest and $45 \mathrm{~m}$ northwest to southeast, covering an area of about $2,925 \mathrm{~m}^{2}$. The artifact assemblage observed at the site was made up of primary and secondary flakes, shatter, tested cobbles, and cores, most of which were located in areas where gravels were exposed. Raw material consists of chert and some quartzite available onsite in the gravel lenses. Artifact density ranges between 15 and 20 items per $25-\mathrm{m}^{2}$ area. Artifact density was greater in areas where gravels were exposed, but no well-defined concentrations were noted at the site. No features were identified.

One shovel test was excavated at the site to determine the depth of the soil and to see if subsurface cultural remains were present. The shovel test, excavated near the center of the site, extended to a depth of $35 \mathrm{~cm}$ bs, the point at which the gravels in the soil increased significantly. The soil at the site is primarily medium brown compact silt with gravels to a depth of $20 \mathrm{~cm}$ bs; an increase in gravels was noted below $20 \mathrm{~cm}$ bs. Excavation of the shovel test was terminated at $35 \mathrm{~cm}$ bs. No cultural materials were identified.

The site is interpreted as a quarry site and consists of a surficial, moderate-density scatter of lithic artifacts, including flakes, tested cobbles, and cores. Gravels and cobbles are exposed on the terrace and on surrounding slopes. The integrity of the site has been impacted by road construction and maintenance, as well as by bioturbation and erosion that have left the site surface highly deflated. The deflated and heavily eroded condition of the site, the lack of features, and the disturbances caused by road construction indicate the research potential of site 41MV226 is minimal. Based on these observations, the site is recommended as ineligible for inclusion in the NRHP. No further work at site 41MV226 is recommended.

\section{Site 41MV227}

Site 41MV227 is located in the central portion of the Swartz Ranch project area on the south-facing, very gradual slope of a ridge directly west of Bueno Aqua Tank (Figure 124; see Figure 100). The site was identified in the existing north-south road that runs along the top of this ridge and through the site. Elevation at the site ranges from 212 to $219 \mathrm{~m}(695$ to $720 \mathrm{ft})$ amsl. Unnamed seasonal drainages are located about $250 \mathrm{~m}$ east of the site and $300 \mathrm{~m}$ west of the site. Mesquite and short grasses make up most of the vegetation in the area, and ground surface visibility is about 90 percent.

Site 41MV227 is a large, moderate-density scatter of lithics that extends $350 \mathrm{~m}$ north to south and at least $150 \mathrm{~m}$ east to west. The east and west boundaries of the site were not identified because they lie beyond the limits of the current survey area. The site covers an area of at least $52,500 \mathrm{~m}^{2}$. Artifacts were observed at the site in densities of between 10 and 15 per $25-\mathrm{m}^{2}$ area. The artifact assemblage was composed of primary and secondary flakes, shatter, tested cobbles, and cores, all of chert and quartzite available onsite. No definable concentrations of artifacts were identified at the site, nor were any cultural features observed.

One shovel test was excavated at 41MV227 to determine the depth of soil at the site and to see if subsurface cultural materials were present. The shovel test was placed north of the site center, about 20 $\mathrm{m}$ east of the road. The soil at the site is medium brown compact silt with abundant gravels. The shovel test was excavated to $30 \mathrm{~cm}$ depth, and no cultural materials were identified. 


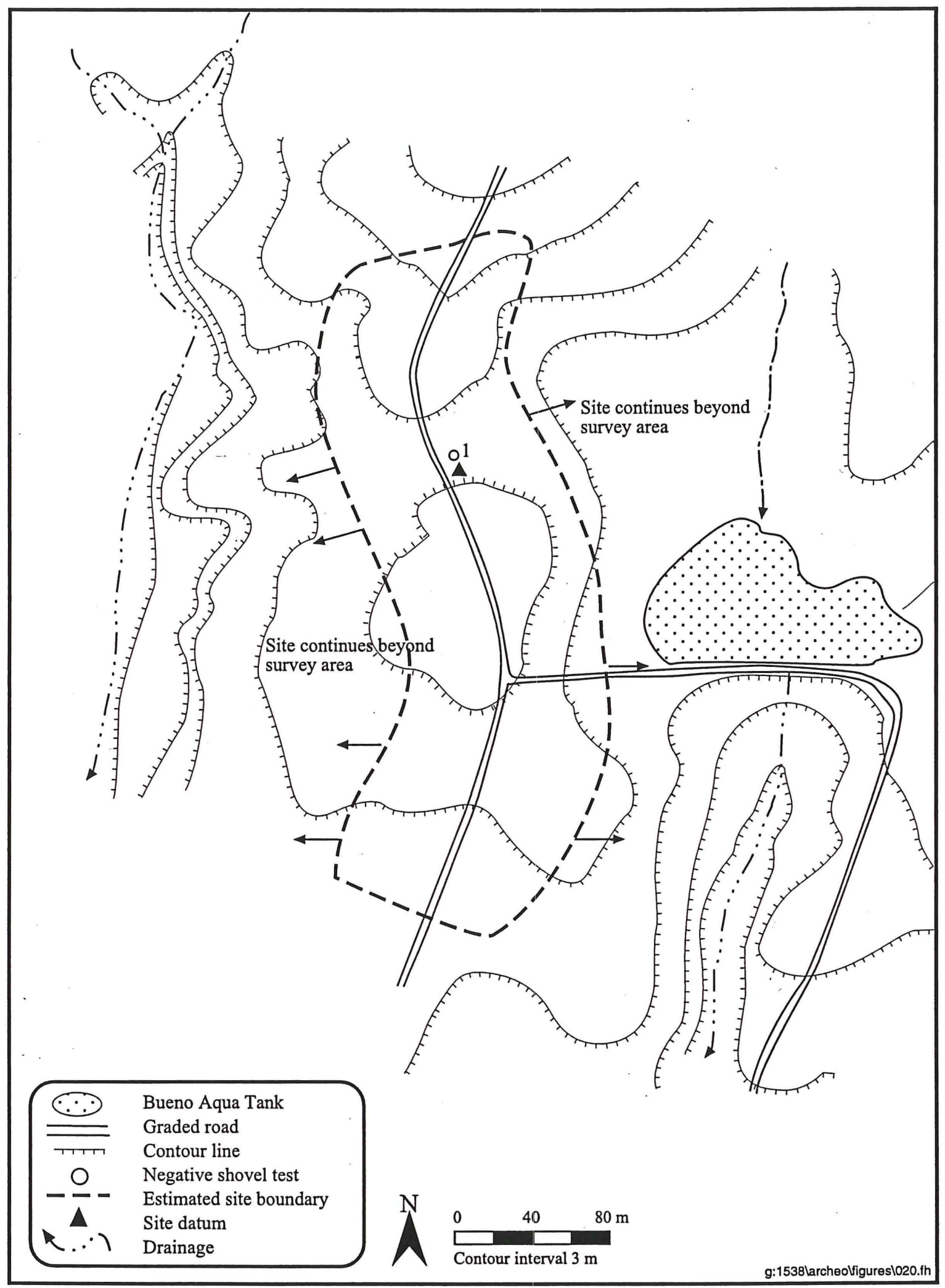

Figure 124. Plan map of site 41MV227. 
The site is interpreted as a quarry site consisting of an extensive, moderate-density scatter of lithic artifacts, primarily flakes, tested cobbles, and cores. An exposed gravel bed extends across the length of the site. Shovel testing yielded no evidence of subsurface deposits. Site integrity has been compromised by the construction and maintenance of the road that bisects the site north to south, and by bioturbation and extensive erosion that have left the surface in the site area deflated. The sparse, surficial nature of the site, the lack of features, and the disturbances caused by road construction indicate the research potential of the evaluated area of site 41MV227 is minimal. Based on these observations, the portion of the site within the ROW is recommended as ineligible for inclusion in the NRHP. The remainder of the site could not be investigated. No further work within the assessed portion of site 41MV227 is recommended.

\section{Site $41 M V 228$}

Site 41MV228 is located just north of the center of the Swartz Ranch project area, on the west-facing slope and terrace of a large hill south of Cuervo Creek (Figure 125; see Figure 100). The site spans the area between the southern end of the proposed new road ROW and the eastern portion of Mid-Pasture Road. Elevation at the site ranges from 204 to $229 \mathrm{~m}$ (670 to $750 \mathrm{ft}$ ) amsl. Unnamed intermittent drainages parallel the north and south boundaries of the site, and Cuervo Creek is about $900 \mathrm{~m}$ north of the site. The Rio Grande is about $2.5 \mathrm{~km}$ to the west. Vegetation at the site varies from sparse to dense, and is composed of mesquite, acacia, tasajillo, and short grasses. The vegetation cover is light on the gradual slopes in the western portions of the site, where there are more short grasses; progressing east across the site, the vegetation becomes more dense as the slope increases. Ground surface visibility ranges accordingly, from 60 to 90 percent, and short grasses provide much of the heavier ground cover.

The site is a large lithic scatter of low to moderate density, extending for about $300 \mathrm{~m}$ north to south and $600 \mathrm{~m}$ east to west. The total area covered by the site is about $180,000 \mathrm{~m}^{2}$. The artifact assemblage observed at the site consists of flakes, shatter, tested cobbles, cores, and flake tools. The density of artifacts ranged from approximately five in a $25-\mathrm{m}^{2}$ area on the higher elevations, where the collection is dominated by primary flakes, cores, and tested cobbles, to between 15 and 20 in a $25-\mathrm{m}^{2}$ area on the lower slopes to the west, where the collection consists primarily of tertiary flakes and flake tools. Raw material consists of chert and quartzite available onsite in the form of cobbles and gravels exposed throughout the area. In spite of this great variance in density, no well-defined artifact concentrations were observed at the site. In general, the density was greater on the terraces below the top of the ridge. No cultural features were identified at the site.

One shovel test was excavated at 41MV228, in an area on top of the hill where some soil remained, to determine the existence of subsurface cultural materials. One flake was identified in the top $5 \mathrm{~cm}$ of the shovel test, which was excavated to a depth of $25 \mathrm{~cm}$. The soil in the shovel test was gray brown compact silt with gravel inclusions to a depth of approximately $20 \mathrm{~cm}$, followed by subsoil which consisted of light gray brown, very compact silty loam with gravel and caliche inclusions. Erosion has resulted in very little soil remaining in the western portion of the site, which is composed of exposed gravel lenses and isolated pockets of compact silt with abundant gravels.

Site 41MV228 is interpreted as both a quarry and an open campsite, consisting of a low-density scatter of flakes, tested cobbles, and cores on the higher slopes of the hill and a moderate-density scatter of lithic artifacts on the terrace and its slopes on the west side of the site. Shovel testing revealed a very shallow (less than $5 \mathrm{~cm}$ ), localized subsurface deposit. Extensive deflation of the soil is evident throughout the remainder of the site. Other disturbances that have impacted site integrity include the construction and 


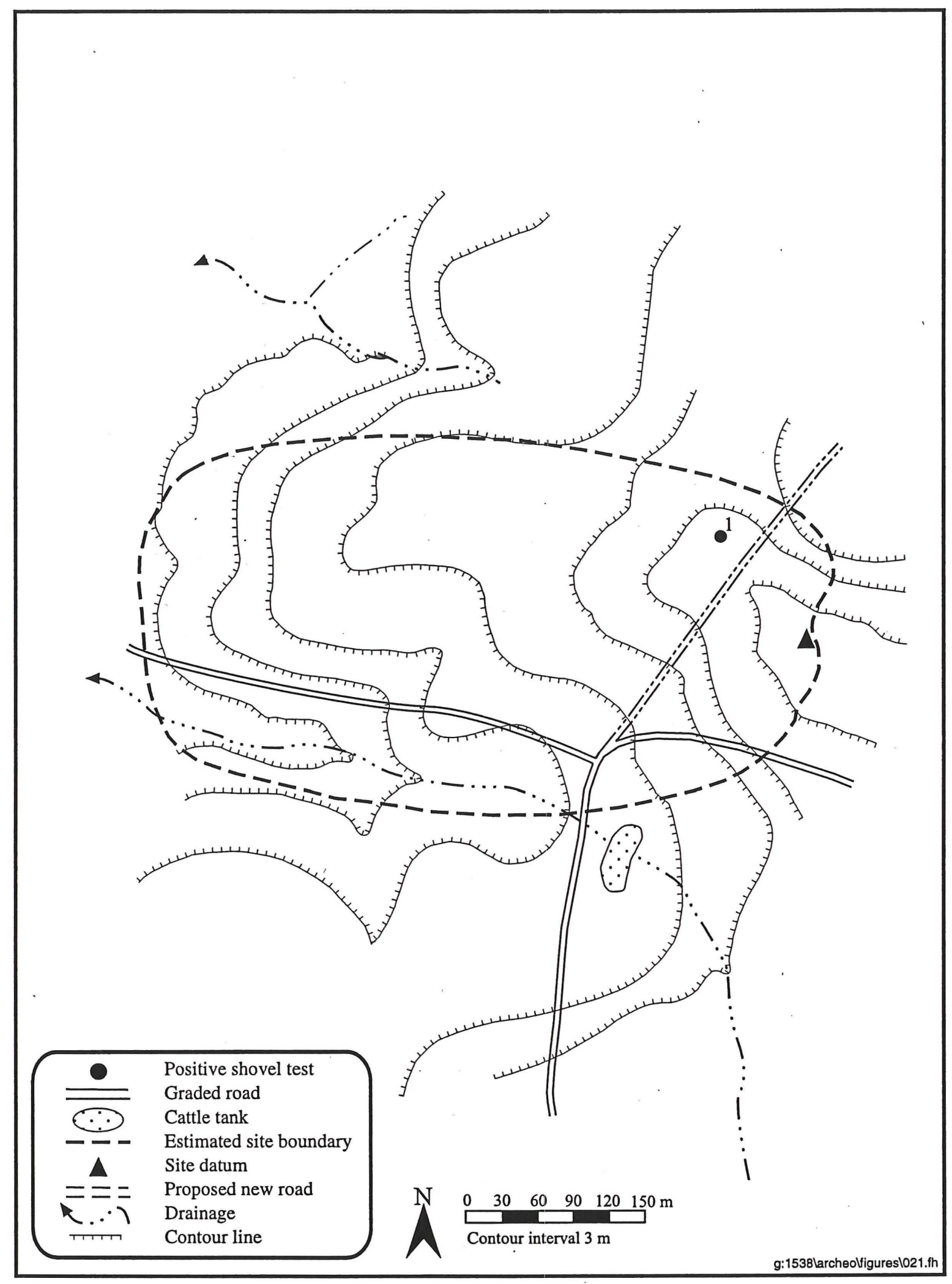

Figure 125. Plan map of site 41MV228. 
maintenance of the road that runs along the western end of the site, and earthmoving activities associated with the construction of a pond near the southeast corner of the site. The surficial nature of the site, the lack of features, and the disturbances caused by construction and earthmoving activities in the site area indicate the research potential of $41 \mathrm{MV} 228$ is minimal. Based on these observations, the site is recommended as ineligible for inclusion in the NRHP. No further work at site 41MV228 is recommended.

\section{Site $41 M V 229$}

Site 41MV229 is located in the northern portion of the Swartz Ranch project area, on a northeast-facing slope and the floodplain between that slope and Cuervo Creek (Figure 126; see Figure 100). The site lies along the proposed route for the new road cut. An existing north-south two-track road is located just east of the eastern site boundary. Elevation at the site ranges from 201 to $213 \mathrm{~m}$ (660 to $700 \mathrm{ft}$ ) amsl. Cuervo Creek is located about $50 \mathrm{~m}$ north of the north boundary of the site. Mesquite, acacia, tasajillo, and short grasses are present, growing more densely on the hill in the southwest portion of the site, but only sparsely on the terrace. Ground surface visibility ranges from about 60 percent on the terrace to 80 percent on the slope to the southwest.

Site 41MV229 is a low- to moderate-density lithic scatter that extends $300 \mathrm{~m}$ northeast to southwest and $225 \mathrm{~m}$ northwest to southeast, covering an area of about $67,500 \mathrm{~m}^{2}$. The lithic assemblage on the hill and the slope is distinctly different from the scatter on the floodplain in the northeast portion of the site. Large cortical flakes and tested cobbles compose the majority of the artifacts on the hilltop, occurring in densities of approximately five artifacts per $25-\mathrm{m}^{2}$ area. The artifact scatter on the floodplain is composed primarily of smaller, noncortical flakes and bifaces and lacks the larger flakes and tested cobbles found at the higher elevation. Artifact density is also greater on the floodplain at approximately 10 to 15 artifacts per $25-\mathrm{m}^{2}$ area. The highest density of artifacts on the floodplain is found in an area that encompasses about 100 by $75 \mathrm{~m}$ (see Figure 126). The qualitative difference in the artifact assemblages between the two areas suggests the differences are activity-related rather than due to depositional processes. Raw material consists of chert available in the form of cobbles on the higher elevations of the site. No cultural features were identified at 41MV229.

One shovel test was excavated in the floodplain portion of the site to determine the presence of subsurface cultural deposits. The shovel test was excavated to approximately $60 \mathrm{~cm}$ bs, at which depth the soil becomes quite compact. Five flakes were identified in the upper $20 \mathrm{~cm}, 10$ in the next $20 \mathrm{~cm}$, and six between 40 and $58 \mathrm{~cm}$ bs. The soil in the shovel test consists of a fine, light yellowish brown silt with a few large fragments of caliche to a depth of $40 \mathrm{~cm}$ bs. Below $40 \mathrm{~cm}$, the soil becomes a very pale brown compact silt. Excavation was terminated due to the extremely compact soils at $60 \mathrm{~cm}$ bs.

Site 41MV229 is interpreted as both a quarry and an open campsite. The majority of the site appears to be a quarry consisting of a surficial, low- to moderate-density scatter of flakes and tested cobbles on the higher elevations above the floodplain. The portion of the site situated on the lower levels of the northeast-facing slope and on the floodplain in the northeast portion of the site is interpreted as an open campsite, the artifact assemblage here including flakes, flake tools, and bifaces. A subsurface deposit was identified on the floodplain portion of the site. Disturbances at the site are estimated to be fairly minimal and due primarily to erosion and slope wash on the hilltop and sides and to periodic flooding in the floodplain area. Since buried cultural deposits are present in a portion of the site, the research potential of site 41MV229 is unknown. The site is therefore recommended as potentially eligible for inclusion in the NRHP. Since any construction-related activities in the proposed ROW will probably impact the buried portion of this site, it is recommended that the site be avoided. 


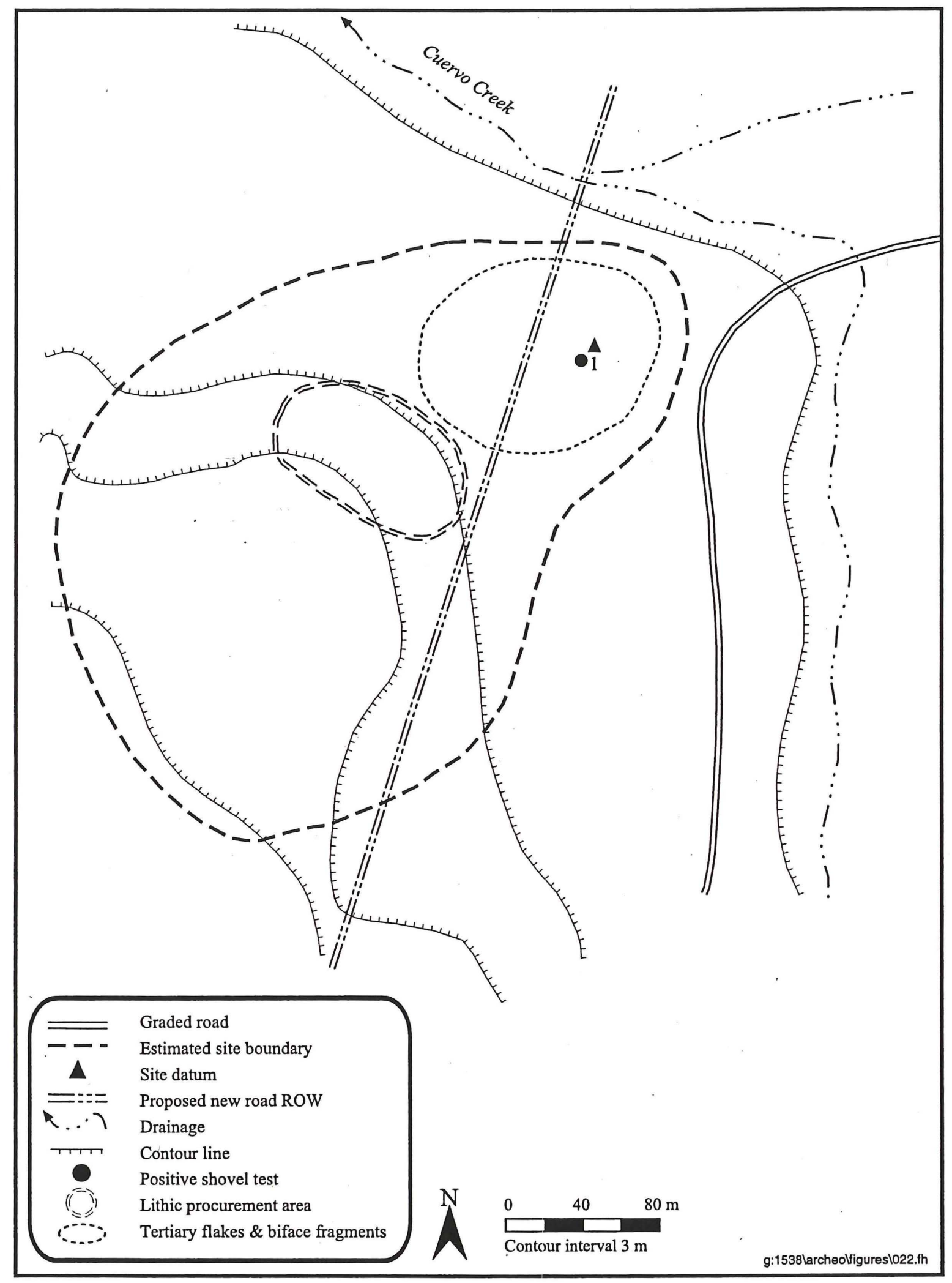

Figure 126. Plan map of site 41MV229. 
Because the site is located along a portion of the proposed new road segment that is critical for the road improvement project, JTF- 6 requested than an alternate route for the new road be surveyed. The alternate proposed new road ROW passes west of 41MV229 and would not impact any cultural deposits that may remain at the site. No cultural resources were observed along the reroute. The presence of an archeological monitor is recommended in order to keep equipment off of 41MV229 and to ensure that existing cultural resources in this area are not impacted by construction-related activities.

\section{Site $41 M V 230$}

Site 41MV230 is located in the northern portion of the Swartz Ranch project area, on a southwest-facing, very gradual slope overlooking Cuervo Creek, approximately $100 \mathrm{~m}$ northeast of site 41MV229 (Figure 127; see Figure 100). The site was identified in the road that bisects it lengthwise. Elevation at the site ranges from 201 to $210 \mathrm{~m} \mathrm{(660} \mathrm{to} 690 \mathrm{ft}$ ) amsl. Cuervo Creek is about $50 \mathrm{~m}$ to the south and roughly parallels a portion of the southern site boundary. Vegetation in the area is sparse, primarily consisting of mesquite, acacia, and short grasses. Ground surface visibility averages about 80 percent.

Site $41 \mathrm{MV} 230$ is a large, low- to moderate-density lithic scatter that extends $550 \mathrm{~m}$ northeast to southwest and $275 \mathrm{~m}$ southeast to northwest, covering a total area of about $151,250 \mathrm{~m}^{2}$. The lithic assemblage in the southern portion of the site consists primarily of tertiary flakes and shatter, in densities of about six to eight artifacts per $25-\mathrm{m}^{2}$ area. In the northern portion of the site, larger secondary and tertiary flakes, shatter, and bifaces are evident in densities of 15 to 20 artifacts per $25-\mathrm{m}^{2}$ area. Raw material consists of chert and quartzite available locally. No well-defined concentrations of cultural material were observed, and no cultural features were identified at the site.

Two shovel tests were excavated at 41MV230 to determine the depth of soil and to see if subsurface cultural deposits were present. One shovel test was placed in the approximate center of the northern half of the site, the other near the center of the southern half. Soil at the site consists of fine, brown silt with increasing amounts of caliche as depth increases. Shovel Test 1 , in the southern portion of the site, produced 12 flakes (one heat-treated and retouched) in the upper $20 \mathrm{~cm}$ and three between 20 and $30 \mathrm{~cm}$ bs. No additional cultural materials were observed between $30 \mathrm{~cm}$ bs and the bottom of Shovel Test 1 at $50 \mathrm{~cm}$ bs. Shovel Test 2 in the northern portion of the site produced two flakes in the upper $20 \mathrm{~cm}$ and was excavated to a depth of $30 \mathrm{~cm}$ bs where subsoil was encountered. Since there was less depth to the soil in the north shovel test, upslope from the southern portion of the site, it appears that the north part of the site has been subjected to heavier erosion, and the south part to heavier colluviation.

The site is interpreted as an open campsite and consists of an extensive low- to moderate-density scatter of lithic artifacts-including flakes, shatter, and bifaces-and a subsurface deposit that extends to a depth of $30 \mathrm{~cm}$ bs. Site integrity has been impacted by the construction and maintenance of a road that bisects the site along its northeast-southwest axis, by erosion that has left the upslope portions of the site somewhat deflated, by bioturbation, and possibly by periodic flooding in the southern portion of the site. However, an estimated 75 percent of the site remains intact. The presence of potentially significant subsurface deposits indicates that the research potential of site 41MV230 is unknown. Therefore, the site is recommended as potentially eligible for inclusion in the NRHP. Avoidance of the site is recommended by prohibiting additional grading, reworking, or ground disturbance within the limits of the site. An alternate avoidance option would be the use of the proposed new road reroute discussed in connection with site 41MV229 above. The presence of an archeological monitor is recommended in order to keep equipment off of site $41 \mathrm{MV} 230$ and to ensure that intact portions of the site are not impacted by road improvement activities. 


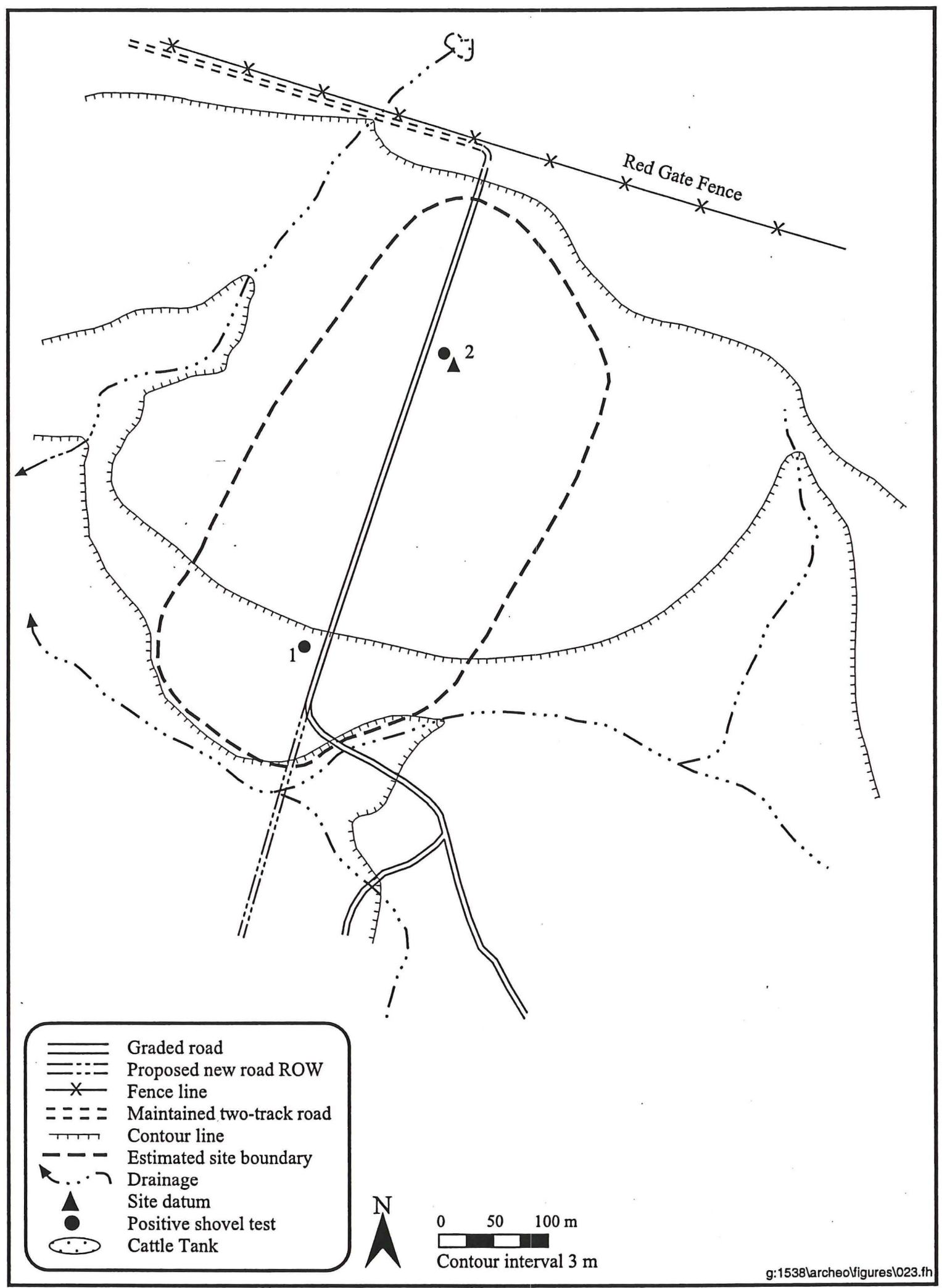

Figure 127. Plan map of site 41MV230. 


\section{Site 41MV231}

Site 41MV231 is located in the northwest portion of the Swartz Ranch project area, along Mid-Pasture Road (Figure 128; see Figure 100). It is visible along the very heavily eroded, generally west-facing slope of a hill, the upper portions of which are occupied by site 41MV228. The site lies on either side of a maintained two-track at an elevation of $198 \mathrm{~m}(650 \mathrm{ft}) \mathrm{amsl}$, and an unnamed seasonal drainage parallels most of the northern boundary of the site. Vegetation in the area is composed of mesquite, acacia, tasajillo, and short grasses, and the ground surface visibility averages about 90 percent.

Site 41MV231 is a low-density lithic scatter that extends $45 \mathrm{~m}$ northeast to southwest and $40 \mathrm{~m}$ northwest to southeast, covering a total area of about $1,800 \mathrm{~m}^{2}$. The scatter is composed primarily of primary and secondary flakes, shatter, and tested cobbles, most of which lie within an area of exposed pebbles and cobbles. Raw materials consist exclusively of chert and quartzite available onsite in the form of cobbles and gravels. Artifact density ranges between five and six items per $25-\mathrm{m}^{2}$ area. No distinct artifact concentrations were identified at the site. No cultural features were observed.

Due to extensive erosion, little soil remained at the site. Since the ground surface in the site area was so deflated, a shovel test was not deemed necessary or feasible.

The site is interpreted as a small quarry site and consists of a surficial, low-density scatter of lithic artifacts, primarily flakes, tested cobbles, and cores. An exposed gravel bed dominates the site. The integrity of the site has been diminished by the construction and maintenance of the two-track road that bisects it, and by heavy erosion that has left the ground surface very deflated. The sparse nature of the site, the lack of features, and the disturbances caused by road construction and extensive erosion indicate the research potential of site 41MV231 is minimal. Based on these observations, the site is recommended as ineligible for inclusion in the NRHP. No further work at site 41MV231 is recommended.

\section{Site 41MV232}

Site 41MV232 is located just north of the central east-west road that bisects the Swartz Ranch project area, along the northwest-facing slope of an extensive ridge system running across the middle of the project area south of Cuervo Creek (Figure 129; see Figure 100). The site lies along an existing northsouth road approximately $50 \mathrm{~m}$ south of site $41 \mathrm{MV} 228$ and is separated from that site by an unnamed seasonal drainage. Another drainage parallels the western boundary of the site, and a stock pond has been constructed immediately northeast of the site. The elevation of 41MV232 ranges from 210 to $226 \mathrm{~m}$ (690 to $740 \mathrm{ft}$ ) amsl. Vegetation composed of mesquite, creosote, acacia, tasajillo, and short grasses provides a moderately dense ground cover over most of the site and increases nearer the drainages. Ground visibility is about 75 percent.

The site is a low-density lithic scatter that extends about $350 \mathrm{~m}$ north to south and at least $300 \mathrm{~m}$ east to west; the eastern boundary was not determined because it lies outside the limits of the current survey. The identified portion of the site covers a total of about $105,000 \mathrm{~m}^{2}$. The lithic assemblage includes primary and secondary flakes, shatter, tested cobbles, and cores, all in an area of exposed pebbles and cobbles. Raw material consists of chert and quartzite available onsite. Artifact density is approximately six to eight specimens per $25-\mathrm{m}^{2}$ area. No distinctive artifact concentrations were observed and no cultural features were identified. 


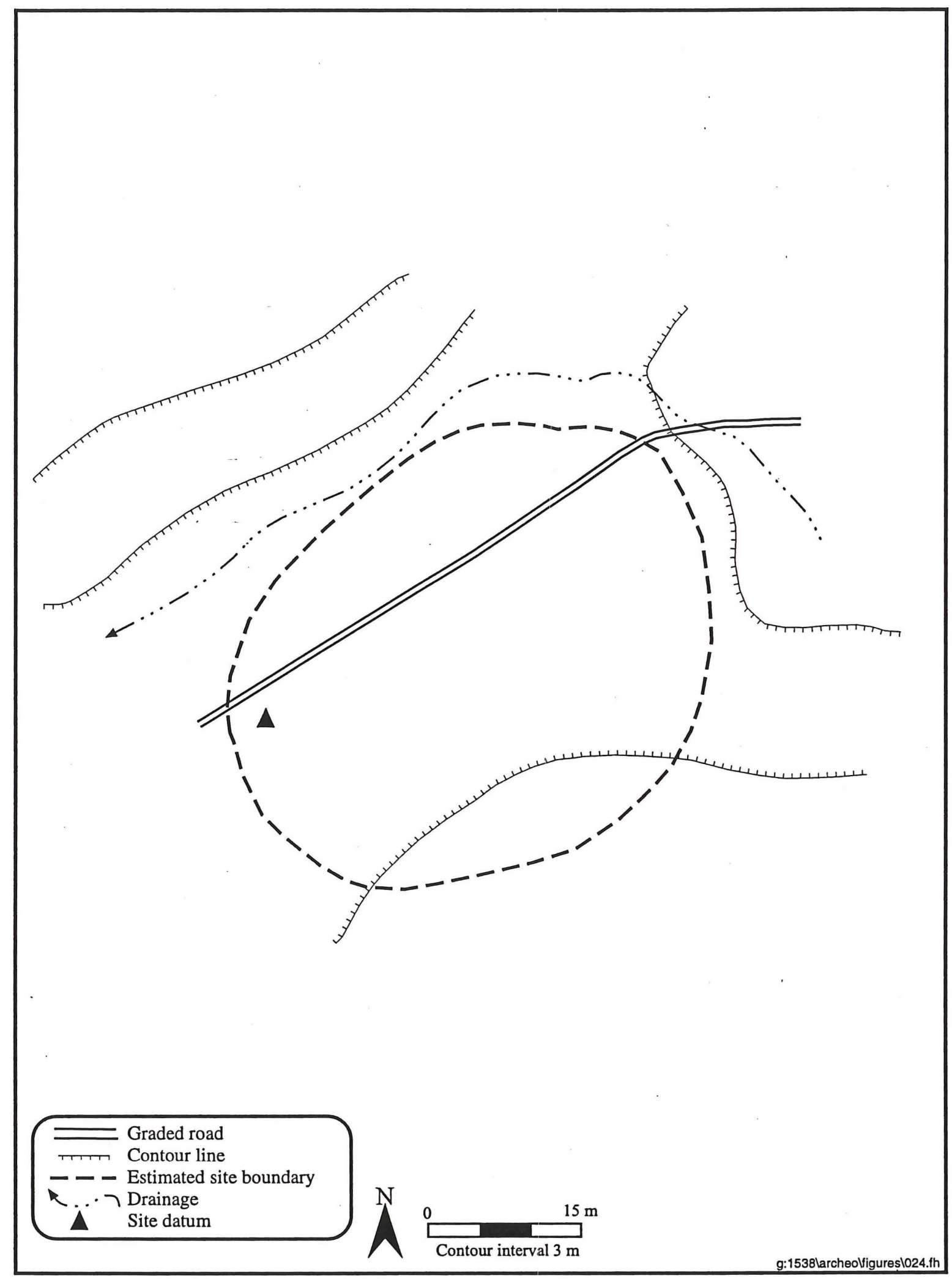

Figure 128. Plan map of site 41MV231. 


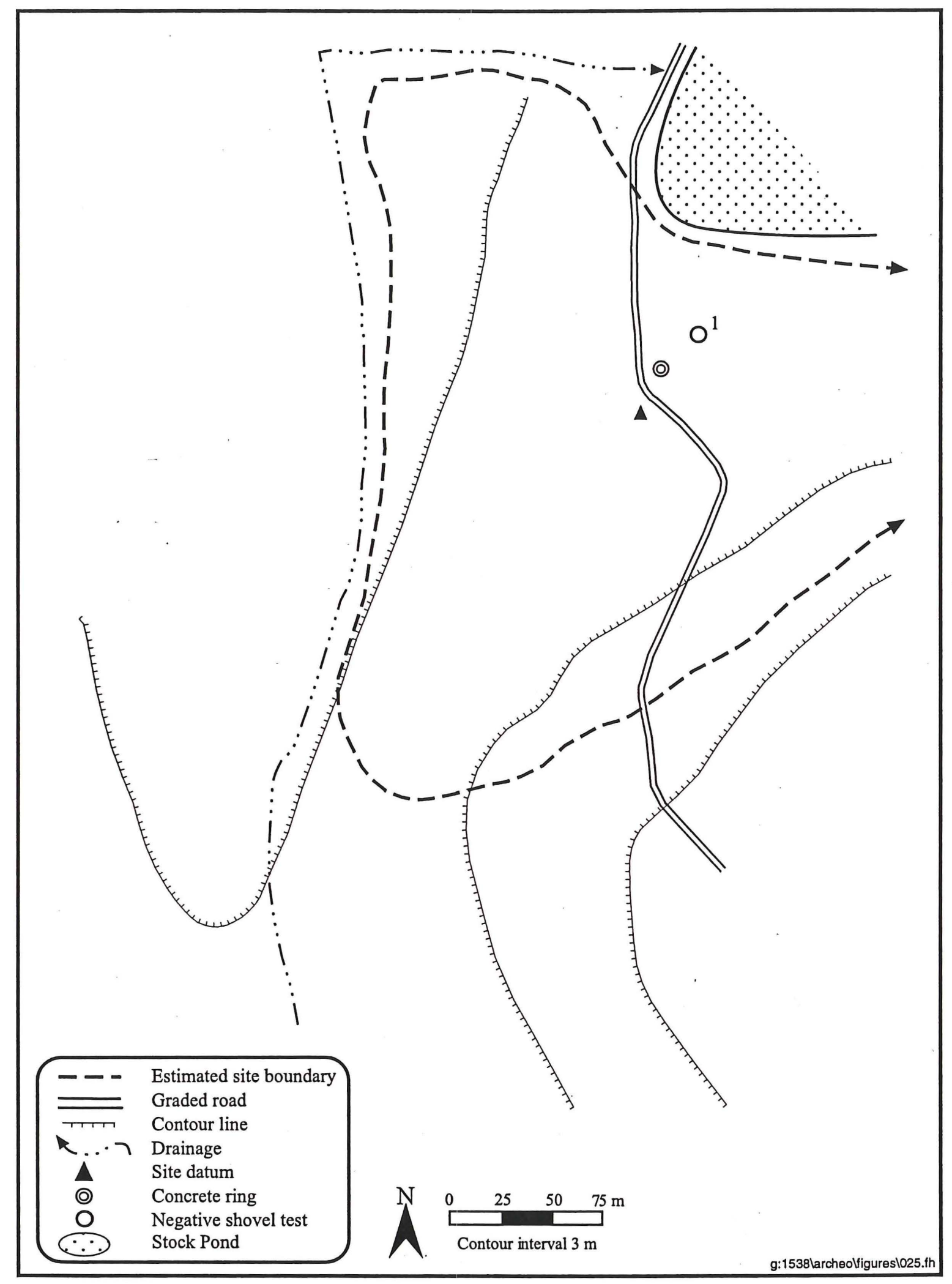

Figure 129. Plan map of site 41MV232. 
One shovel test was excavated at 41MV232 to determine the depth of soil remaining in the site area and to see if there was a possibility that subsurface cultural deposits were present. The shovel test was placed slightly northeast of the site center in an area that appeared to have some soil remaining. The soil is composed of medium dark brown silty loam with a few gravel inclusions in the upper $13 \mathrm{~cm}$, changing to lighter, more compact, clayey silt subsoil. Excavation was terminated $5 \mathrm{~cm}$ into subsoil at a depth of 25 $\mathrm{cm}$ bs; no artifacts were noted.

The site is interpreted as a quarry site and consists of a surficial, low-density scatter of lithic artifacts, primarily flakes, tested cobbles, and cores. An exposed gravel bed extends the length of the site. Disturbances that have impacted the integrity of the site include the construction and maintenance of the road that bisects the site north to south, as well as the earthmoving activities associated with the construction of the pond and dam on the northeast side of the site. In addition, a concrete ring apparently associated with ranching activities is present on the east side of the graded road near the site datum. Several gullies have cut into the site area; extensive erosion has left the ground surface at the site very deflated. Only about 40 percent of the site is estimated to remain intact. The sparse, surficial nature of the site, the lack of features, and the disturbances caused by road construction and other earthmoving activities indicate the research potential of the evaluated area of site 41MV232 is minimal. Based on these observations, the portion of the site within the ROW is recommended as ineligible for inclusion in the NRHP. The remainder of the site could not be investigated. No further work within the assessed portion of site $41 \mathrm{MV} 232$ is recommended.

\section{Site $41 M V 233$}

Site 41MV233 is located on the southern and southwestern slopes of a prominent hill on the west side of Swartz Ranch, along the central east-west road through the project area (Figure 130; see Figure 100). Seasonal drainages are located on the north, south, and west sides of the site, and the elevation ranges from 201 to $229 \mathrm{~m} \mathrm{(660} \mathrm{to} 750 \mathrm{ft}$ ) amsl. Vegetation in the area is of moderate density and is composed of mesquite, prickly pear, tasajillo, creosote, and short grasses. Ground surface visibility averages about 80 percent.

The site is a moderate-density lithic scatter that measures $800 \mathrm{~m}$ east to west and at least $250 \mathrm{~m}$ north to south. The north and south boundaries were not determined because both extend far beyond the limits of the current survey area. The identified portion of the site covers a total of approximately $200,000 \mathrm{~m}^{2}$. The lithic scatter includes primary and secondary flakes, shatter, tested cobbles, cores, bifaces, and scrapers. Raw material consists of chert and quartzite available onsite in the form of gravel and cobble lenses exposed throughout the site. One biface observed at the site had a small notch at the tip that had been unifacially flaked from the tool. Artifact density at $41 \mathrm{MV} 233$ was approximately 15 to 20 items per $25-\mathrm{m}^{2}$ area. No definitive artifact concentrations were noted within the site boundaries, and no cultural features were identified.

Two shovel tests were excavated to determine the depth of soils at the site and to see if subsurface cultural deposits were present. Because the site is dominated by exposed cobble and gravel lenses, few areas of intact soil accumulation could be identified. Shovel Test 1 was positioned in the western portion of the site and Shovel Test 2 in the eastern end of the site. The soil at the site is yellowish brown silt with gravel inclusions; the frequency of gravels increases below $20 \mathrm{~cm}$ bs. Excavation of both shovel tests were terminated at approximately $25 \mathrm{~cm}$ in depth due to the high percentage of gravels; neither produced cultural materials. 


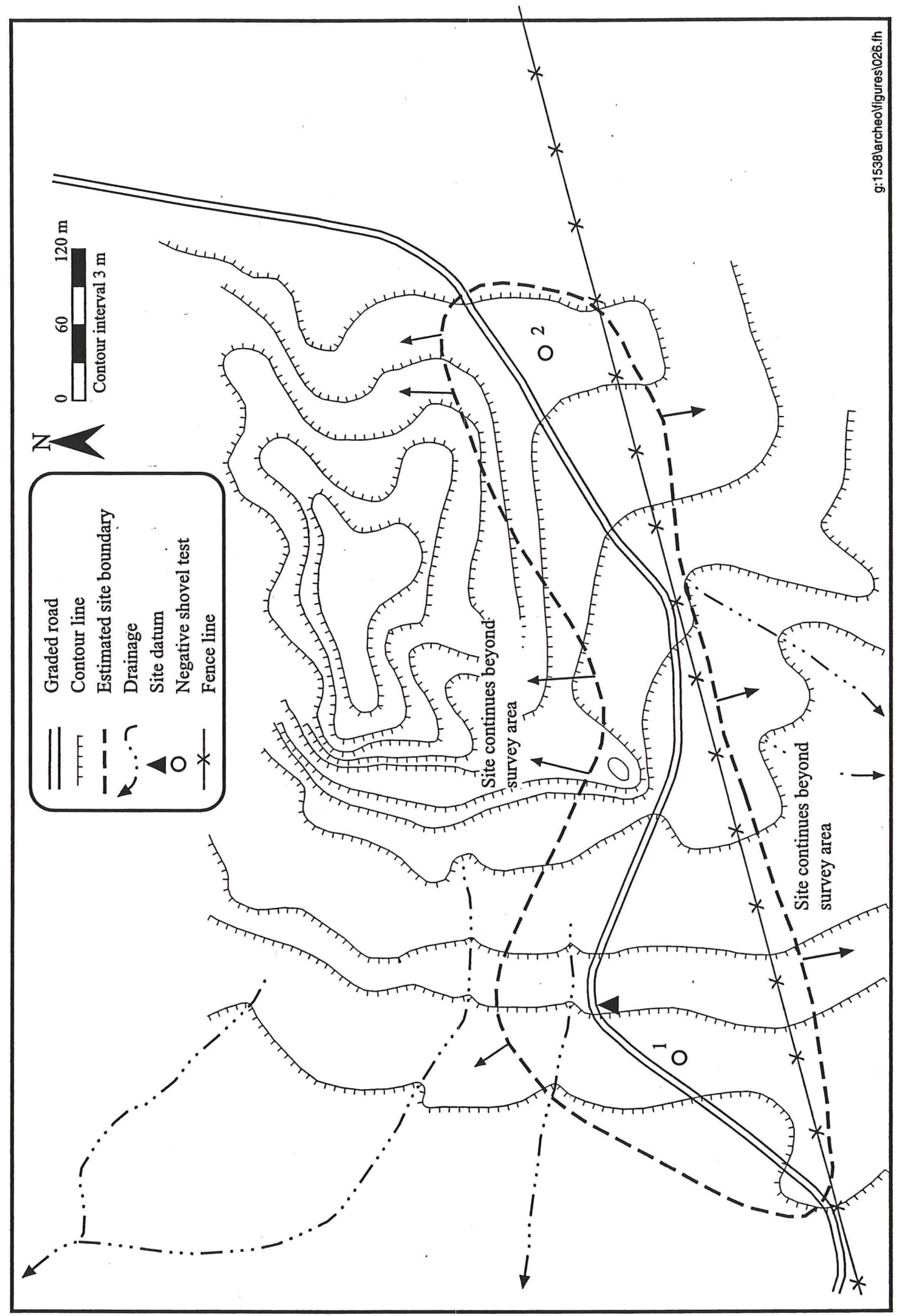

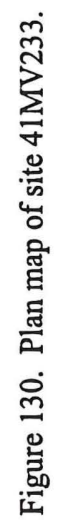


The site is interpreted as a moderate-density quarry site consisting primarily of flakes, tested cobbles, and cores. Exposed gravels extend the length of the site and beyond the project boundary, both over the hill to the north and along the slopes to the south. No subsurface deposits were identified. Disturbances that have impacted site integrity include the construction and maintenance of a road and fence that run the length of the site, and the extensive erosion and slope wash that has left the ground surface in the area very deflated. Only an estimated 20 percent of the site remains intact. The surficial nature of the site, the lack of features, and the disturbances caused by the existing road and erosion indicate the research potential of the evaluated area of site 41MV233 is minimal. Based on these observations, the portion of the site within the ROW is recommended as ineligible for inclusion in the NRHP. The remainder of the site could not be investigated. No further work within the assessed portion of site 41MV233 is recommended.

\section{Site $41 M V 234$}

Site 41MV234 is located on the east side of the Swartz Ranch project area, on a south-trending ridge directly northwest of Mansfield Tank, along an existing north-south road (Figure 131; see Figure 100). Two other ranch roads intersect the main north-south road in the central portion of 41MV234. Elevation at the site ranges from 219 to $226 \mathrm{~m}$ (720 to $740 \mathrm{ft}$ ) over the whole of the site. An unnamed seasonal drainage is located about $50 \mathrm{~m}$ west of the site and parallels the western boundary the entire length of the site. Another drainage runs parallel to the site about 150 to $200 \mathrm{~m}$ to the east. Vegetation in the area is moderate on top of the ridge, becoming more dense near the drainages. Mesquite, creosote, acacia, tasajillo, and short grasses predominate, reducing ground surface visibility to between 60 and 70 percent.

Site 41MV234 is a moderate-density scatter of lithics that occurs over a ridge of exposed pebbles and cobbles. The site extends $800 \mathrm{~m}$ north to south and at least $225 \mathrm{~m}$ east to west; the eastern boundary was not determined since it is situated beyond the limits of the survey area defined for the project. The area covered by the site encompasses at least $180,000 \mathrm{~m}^{2}$. The artifact assemblage includes primary and secondary flakes, shatter, tested cobbles, cores, bifaces, and retouched flakes, all of chert available onsite. Densities vary across the site, from two to three artifacts per $25-\mathrm{m}^{2}$ area in the northern half, to as many as 15 per $25-\mathrm{m}^{2}$ area in a portion of the site near the datum. Other than this gradual increase in density, no well-defined artifact concentrations were observed at the site, and no cultural features were identified.

One shovel test was excavated at 41MV234 to determine the depth of the soil and the presence or absence of subsurface cultural remains. The shovel test was placed near the datum, where artifact densities were highest. The soil consisted of a thin $(5 \mathrm{~cm})$ layer of light brown silty loam followed by dark brown silty clay. Excavation of the shovel test was terminated at $40 \mathrm{~cm}$ bs. No cultural features or artifacts were identified in the shovel test.

Site 41MV234 is interpreted as a quarry site and consists of a surficial, moderate-density scatter of lithic artifacts, primarily flakes, tested cobbles, cores, retouched flakes, and bifaces. An exposed gravel bed extends the length of the site. The integrity of the site has been impacted by the construction and maintenance of the four ranch roads that cross the site, by gullies that have cut into the ground surface from near the top of the ridge toward the drainages to the east and west, and by extensive erosion that has left the ground surface in the area very deflated. Only about 25 percent of the site is estimated to remain intact. The surficial nature of the site, the lack of features, and the disturbances caused by road construction indicate the research potential of the evaluated area of site 41MV234 is minimal. Based on these observations, this portion of the site is recommended as ineligible for inclusion in the NRHP. The remaining portion of the site located beyond the survey area was not investigated. No further work within the assessed portion of site 41MV234 is recommended. 


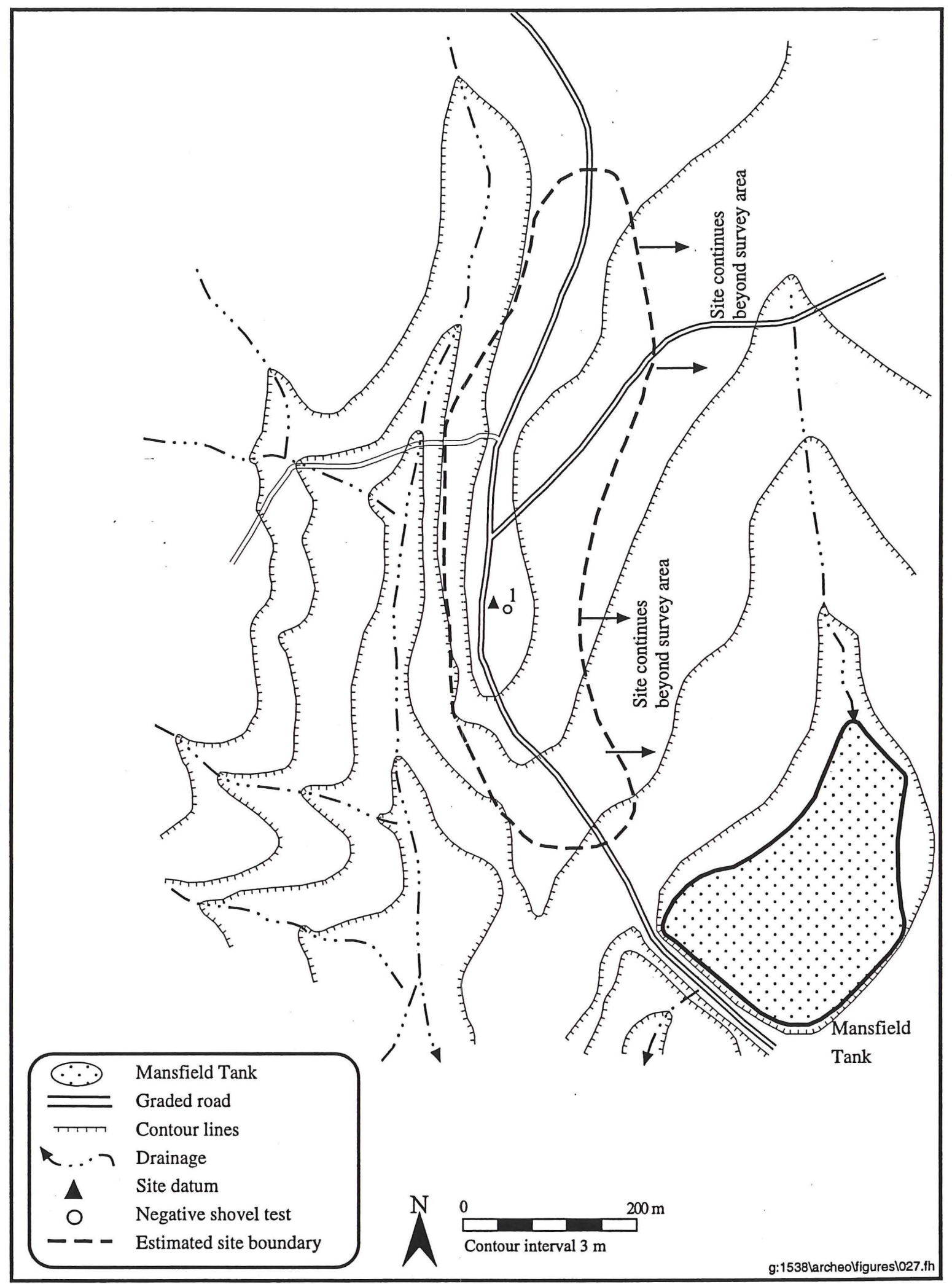

Figure 131. Plan map of site 41MV234. 
Site $41 M V 235$

Site 41MV235 is located on the east side of the Swartz Ranch project area, on a small terrace and southfacing slope overlooking Tovar Creek, directly east of Mansfield Tank and along an existing road (Figure 132; see Figure 100). Unnamed seasonal drainages are located about $150 \mathrm{~m}$ southeast and $200 \mathrm{~m}$ southwest of the site; Tovar Creek is about $300 \mathrm{~m}$ south of the site. The elevation of $41 \mathrm{MV} 235$ is $226 \mathrm{~m}$ $(730 \mathrm{ft})$ amsl. Vegetation in the site area is sparse along the terrace, becoming moderately dense toward the south boundary, where the slope increases; mesquite, acacia, tasajillo, prickly pear, and short grasses are found in the area. An average of about 95 percent of the ground surface is visible at the site.

Site 41MV235 is a low-density lithic scatter that measures $50 \mathrm{~m}$ north to south and $40 \mathrm{~m}$ east to west, covering an area of about $2,000 \mathrm{~m}^{2}$. Artifacts observed at the site include tertiary flakes, cores, retouched flakes, scrapers, and two bifaces, all of locally available chert. Artifact density varied from about six to eight artifacts per $25-\mathrm{m}^{2}$ area, with the higher densities noted in the terrace area. No welldefined artifact concentrations were observed at the site. No cultural features were identified. Due to extensive erosion, little soil remained in the area; surface soils consisted of a thin layer (less than $5 \mathrm{~cm}$ ) of medium brown silty loam with a high frequency of gravels. Shovel testing was not conducted due to the high degree of surface erosion.

The site is interpreted as a small open campsite and consists of a surficial, low-density scatter of lithic artifacts, primarily flakes, cores, retouched flakes, scrapers, and two bifaces. Disturbances that have impacted the integrity of the site include the construction and maintenance of the road that bisects the site, heavy vehicular use of that road, and erosion. In addition, an aluminum siding equipment building has been constructed at the eastern edge of the site. Only an estimated 20 percent of the site remains intact. The surficial nature of the site, the lack of features, and the disturbances related to the construction and use of the existing road indicate the research potential of site 41MV235 is minimal. Based on these observations, the site is recommended as ineligible for inclusion in the NRHP. No further work at site $41 \mathrm{MV} 235$ is recommended.

\section{STATE HIGHWAY 277 AND FARM-TO-MARKET ROAD 2644 SEGMENTS}

One previously documented archeological site encroaches upon the northeastern side of SH 277 approximately $4.0 \mathrm{mi}$ northwest of Carrizo Springs, Texas. This site, 41DM59, is described as a scatter of artifacts, including dart and arrow points indicating occupations from the Paleo-Indian through Late Prehistoric periods, knives, and scrapers in a highly disturbed context. The USGS Carrizo Springs West 7.5' quadrangle map on file at TARL depicts this site as situated along a terrace remnant abutting on Peña Creek and approaching the northeastern side of SH 277. This map does not depict 41DM59 crossing the pavement and continuing into the survey corridor on the southwestern side of the road. A careful inspection of the right-of-way was made for any indication of this site, but none was observed. No cultural resources were located on either the SH 277 or FM 2644 segments as a result of the cultural resources survey. No further work is recommended for this segment of this action. 


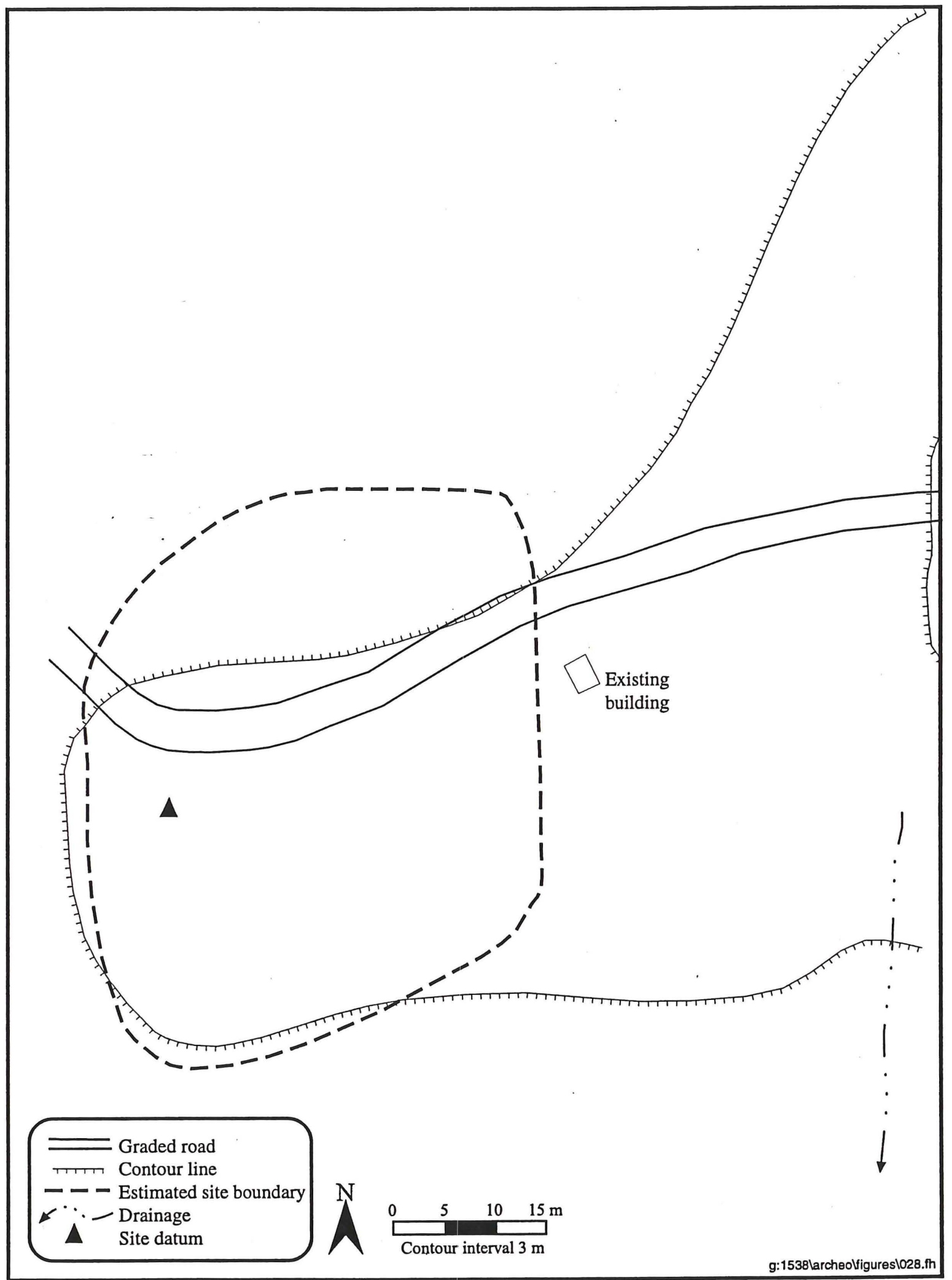

Figure 132. Plan map of site 41MV235. 


\section{STATE HIGHWAY 83 AND FARM-TO-MARKET ROAD 3338 SEGMENTS}

Previous cultural resources investigations resulted in the documentation of one archeological site along the SH 83 segment and three sites along the FM 3338 segment. TARL site files describe all four sites (41WB214, 41WB295, 41WB456, and 41WB457) as open campsites and raw material quarries consisting of low-density lithic scatters without associated cultural features. These sites were revisited by GMI field personnel in order to determine the potential impact that the proposed action would have on extant cultural deposits.

Site 41 WB214 is located at the intersection of FM 3338 and FM 1472 in Webb County, Texas. This site consists of a low-density lithic scatter that includes several isolated, low-density artifact concentrations. The site was originally recorded as encompassing 15 acres, and is plotted on the USGS Cuervo Creek, Texas, 7.5' quadrangle on file at TARL as extending over a somewhat larger area, measuring approximately $400 \mathrm{~m}$ northwest-southeast and $220 \mathrm{~m}$ northeast-southwest (totaling $22 \mathrm{acres}$ ). However, the site appears to extend farther to the northwest, terminating in the vicinity of the intermittent drainage that separates this site from 41WB456. It is likely that these two sites form an essentially continuous scatter of lithic debris broken only by the drainage. The total length of the site along the northwestsoutheast axis appears to measure a total of $700 \mathrm{~m}$. The condition of the site appears to have changed little since it was originally recorded in 1990. A drag lane parallels FM 3338 on the northeast side of the road. This area had most likely already been impacted by the construction of FM 3338, the adjacent fence line, and by frequent devegetation between the fence and existing pavement.

Sites 41WB456 and 41WB457 are located a short distance northwest of 41WB214 along FM 3338. As already discussed, 41WB456 may represent the northern portion of 41WB214. Site forms and accompanying maps for $41 \mathrm{WB} 456$ and $41 \mathrm{WB} 457$ could not be located at TARL. Both of these sites appear to represent open campsites and raw material quarries consisting of low-density scatters of lithic debris. The current dimensions of both sites appear to correlate very well with the dimensions plotted on the USGS Cuervo Creek, Texas, 7.5' quadrangle on file at TARL, and no changes in site size are recommended. A drag lane parallels the existing fence line and existing pavement on the northeast side of FM 3338, but it is likely that any extant cultural deposits in this area had already been destroyed by the construction of FM 3338, the adjacent fence line, and by frequent devegetation between the fence and paved road.

Site 41 WB295 is located at the intersection of SH 83 and a two-track road approximately 4.6 mi north of the point at which SH 83 diverges from I-35. This site consists of a scatter of lithic debris, projectile points, scrapers, and knives, with diagnostic artifacts indicating occupations ranging in time from the Archaic to Late Prehistoric periods. This site was originally recorded in conjunction with a cultural resources survey for the two-track road that currently bisects the site. The site was not recommended as eligible for inclusion in the NRHP, and the construction of the two-track road does not appear to have impacted the integrity of the site beyond the immediate right-of-way. The portion of the site lying between the existing pavement of SH 83 and the fence lines on either side has been heavily impacted by road construction, fence construction, and by associated road maintenance activities, such as devegetation. This site will not experience any additional impacts as a result of the proposed action. 


\title{
CHAPTER 5 \\ SUMMARY AND RECOMMENDATIONS
}

\author{
SUMMARY \\ Introduction
}

A cultural resources inventory survey of approximately $387.7 \mathrm{~km}(240.9 \mathrm{mi})$ of existing and proposed new road rights-of-way in Webb, Maverick, and Dimmit counties, Texas, was performed in order to assess the potential impact of proposed road construction and improvement activities on any cultural properties in the proposed impact area. The total project area consists of nine separate segments in the U.S. Border Patrol Laredo and Carrizo Springs Sectors, Texas. A 20-m-wide survey corridor on either side of existing roads $(211.0 \mathrm{~km}$ [131.1. mi] $)$ and a 40-m-wide corridor along the proposed new road rights-of-way $(176.7 \mathrm{~km}$ [109.8 mi]) were thoroughly examined for cultural resources. When limiting physical barriers, such as fence lines, were encountered along existing road segments, the survey corridor was narrowed. Three segments of the project area, the Laredo River Road $(9.7 \mathrm{~km}$ [6.0 mi]), U.S. Highway 83 (90.2 km [56.0 mi]), and FM 3338 (25.8 km [16.0 mi]) had already been surveyed for cultural resources in connection with an earlier JTF-6 action (Austin et al. 1994; USACE 1990). Of these three segments, only the Laredo River Road, which included the existing road in addition to a 1.0mi-long segment of proposed new road right-of-way at the northern end of the segment, was resurveyed for cultural resources. The remaining six survey segments consisted of $5.4 \mathrm{~km}(3.4 \mathrm{mi})$ along Rio Bravo, $153.7 \mathrm{~km}$ (95.5 mi) on Galvan Ranch, $8.4 \mathrm{~km}$ (5.3 mi) on Stone Ranch, $30.9 \mathrm{~km}(19.2 \mathrm{mi})$ on Swartz Ranch, 29.8 km (18.5 mi) along State Highway 277, and $33.8 \mathrm{~km}(21.0 \mathrm{mi})$ along FM 2644.

\section{Records Search Results}

A records search conducted prior to archeological fieldwork at TARL identified five previously documented cultural properties on the project segments covered by the cultural resources survey. One previously documented historic property, Star Fort (part of Historic District 41WB11), occurs on the Laredo River Road segment of this proposed action. This segment of the project area consists of an existing gravel road that JTF-6 proposes to regrade. Provided that road improvement activities are restricted to the existing roadbed on the terrace below Star Fort, this NRHP property will not be impacted as a result of the proposed action. No additional archeological work is recommended for this segment. In addition, three known archeological sites are situated toward the southern end of the FM 3338 segment (41WB214, 41WB456, and 41WB457). These sites consist of low-density lithic scatters 
that have been interpreted as prehistoric open campsites and lithic quarries on TARL site forms. These sites were revisited by GMI field personnel and site form updates were made. The condition of these sites does not appear to have changed from the date of their original recording. An existing drag lane parallels the FM 3338 pavement, and no new impacts will be introduced to these sites as a result of the proposed road improvement activities. One previously documented archeological site (41WB295) on the U.S. Highway 83 segment was also revisited by field personnel. This site consists of a prehistoric open campsite that was identified in connection with a cultural resources survey for a new road that now intersects with U.S. Highway 83 at this location. No new impacts will result from the proposed action.

\section{Survey Results}

A total of 97 archeological sites was identified as a result of the cultural resources survey of the various segments of this action (Table 4). All of these cultural resources occur on the Galvan, Stone, and Swartz ranches segments of the project area. All but one of these sites are attributable solely to prehistoric occupations. One site on the Galvan Ranch segment (41WB478) contains both prehistoric and historic components.

In addition to the newly documented archeological sites, 349 nonsite localities were identified as a result of the survey (see Figures 10, 92, and 101). Two types of localities were encountered during the survey. The first type consists of isolated artifact occurrences or concentrations of less than five artifacts. The second type consists of extensive, very-low-density lithic scatters characterized by an average artifact density of less than five artifacts per $25-\mathrm{m}^{2}$ area. This type of locality highlights a particular problem in assessing the significance of the cultural resources encountered on the Galvan, Stone, and Swartz ranches project segments. Throughout this region, low-density lithic scatters are almost continuous across the entire upland landscape. The majority of the gently to strongly undulating upland landscape consists of old, eroding alluvial terraces composed of deposits of pebbles and cobbles of chert. This type of material represents the primary source of stone for the manufacture of prehistoric stone tools in this area.

Thus, almost the entire region represents a potential raw material resource, and indications of lowintensity lithic procurement activities are ubiquitous across the landscape. Practically the only places where such activities are not indicated are lowland areas adjacent to drainages, where otherwise continuous distributions of lithic debris generally disappear for a distance of 10 to $50 \mathrm{~m}$ on either side of the drainage. Although it is possible that the banks and terraces of drainages were not favored locations for even temporary prehistoric episodes, it is likely that sedimentation and vegetation growth simply obscure the visibility of cultural remains in these areas. Consequently, many of the localities recorded during this survey measure hundreds or even thousands of meters across.

If these extensive, sparse lithic scatters were documented as archeological sites, the resulting map of the region would produce a negative image of a map of the drainages in the region. In fact, it would practically be necessary to document the entire county as a single archeological site. Consequently, these cultural manifestations were generally documented as localities, regardless of the extent of the distribution of lithic debris, unless one of three criteria for designation as a site was met: subsurface cultural deposits, artifact densities exceeding five artifacts per $25 \mathrm{~m}^{2}$, or the presence of cultural features or recognizable activity areas. Shovel tests were excavated on approximately 25 percent of these extensive, very low-density localities in order to determine if surface scatters were associated with subsurface cultural deposits. All of the tested localities failed to exhibit any indication of subsurface context that might have warranted designation as an archeological site. On occasion, higher-density 
Table 4

Summary of 97 Newly Recorded Archeological Sites on the Galvan, Storie, and Swartz Ranch Segments

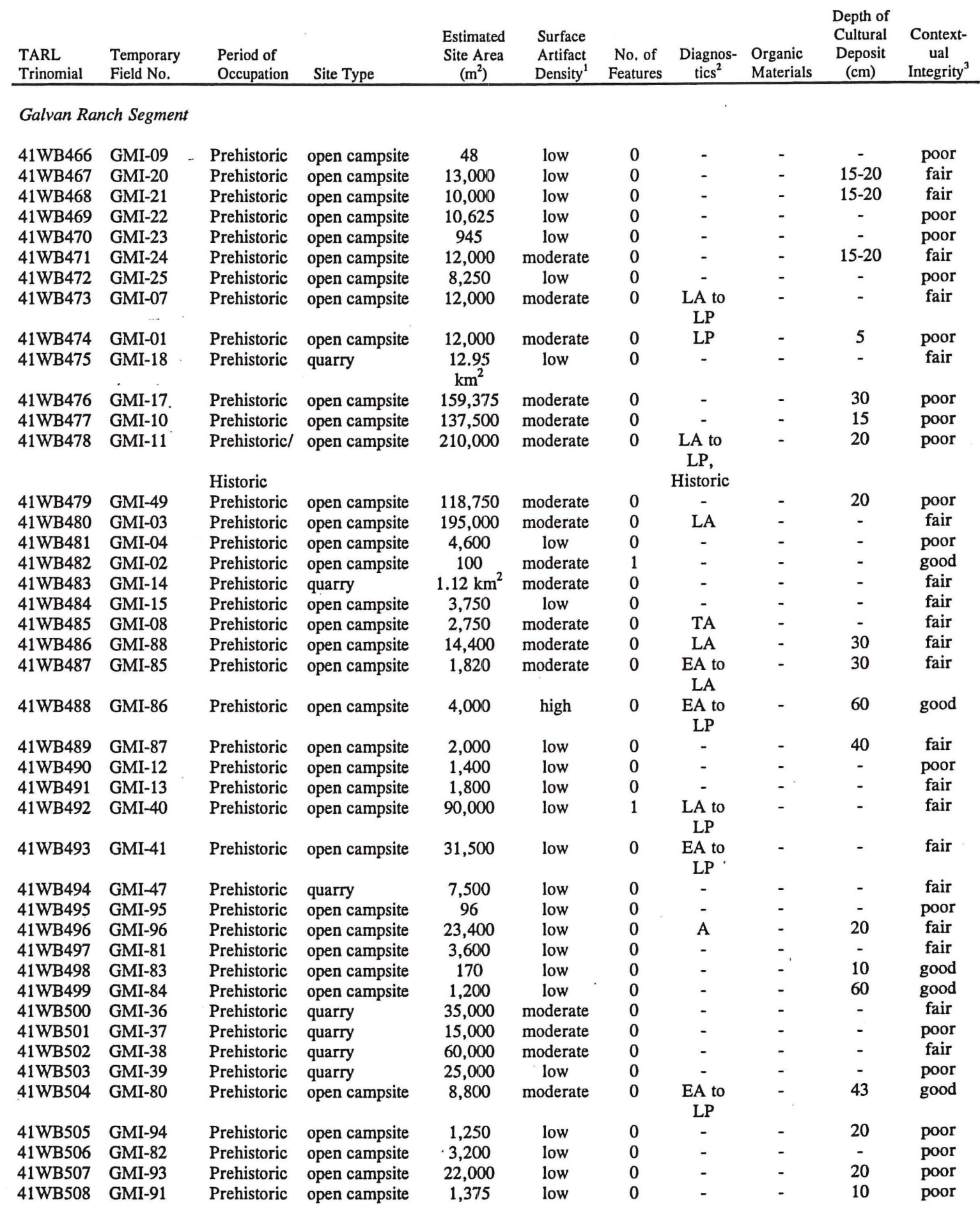


Table 4 (cont'd)

\begin{tabular}{|c|c|c|c|c|c|c|c|c|c|c|}
\hline $\begin{array}{l}\text { TARL } \\
\text { Trinomial } \\
\end{array}$ & $\begin{array}{l}\text { Temporary } \\
\text { Field No. }\end{array}$ & $\begin{array}{l}\text { Period of } \\
\text { Occupation }\end{array}$ & Site Type & $\begin{array}{c}\text { Estimated } \\
\text { Site Area } \\
\left(\mathrm{m}^{2}\right)\end{array}$ & $\begin{array}{l}\text { Surface } \\
\text { Artifact }^{1} \\
\text { Density }^{1} \\
\end{array}$ & $\begin{array}{l}\text { No. of } \\
\text { Features }\end{array}$ & $\begin{array}{r}\text { Diagno } \\
\text { s-tics }\end{array}$ & $\begin{array}{l}\text { Organic } \\
\text { Materials }\end{array}$ & $\begin{array}{c}\text { Depth of } \\
\text { Cultural } \\
\text { Deposit } \\
\text { (cm) }\end{array}$ & $\begin{array}{c}\text { Context- } \\
\text { ual } \\
\text { Integrity }^{3}\end{array}$ \\
\hline 41WB509 & GMI-92 & Prehistoric & open campsite & 150 & moderate & 0 & $\begin{array}{l}\text { PI to } \\
\text { LP }\end{array}$ & - & 20 & poor \\
\hline 41WB510 & GMI-34 & Prehistoric & open campsite & 250,000 & high & 16 & $\begin{array}{l}\text { PI to } \\
\text { MA }\end{array}$ & - & 10 & good \\
\hline 41WB511 & GMI-35 & Prehistoric & quarry & 150,000 & high & 0 & - & - & - & fair \\
\hline 41WB512 & GMI-27 & Prehistoric & quarry & 80,000 & low & 0 & A & - & - & fair \\
\hline 41 WB513 & GMI-28 & Prehistoric & quarry & 90,000 & low & 0 & - & - & - & fair \\
\hline 41WB514 & GMI-29 & Prehistoric & quarry & 65,000 & low & 0 & $\begin{array}{c}\text { MA to } \\
\text { LA }\end{array}$ & - & - & fair \\
\hline 41 WB515 & GMI-32 & Prehistoric & quarry & 43,750 & low & 0 & - & - & - & fair \\
\hline 41WB516 & GMI-33 & Prehistoric & quarry & 18,000 & low & 0 & - & - & - & fair \\
\hline 41WB517 & GMI-31 & Prehistoric & quarry & $\begin{array}{c}11.47 \\
\mathrm{~km}^{2}\end{array}$ & low & 0 & $\begin{array}{l}\text { MA to } \\
\text { LP }\end{array}$ & - & - & fair \\
\hline 41WB518 & GMI-48 & Prehistoric & quarry & 6,000 & low & 0 & - & - & - & poor \\
\hline 41 WB519 & GMI-46 & Prehistoric & open campsite & 90,000 & low & 0 & $\begin{array}{c}\text { EA to } \\
\text { LP }\end{array}$ & - & - & fair \\
\hline 41WB520 & GMI-45 & Prehistoric & quarry & 6,000 & low & 0 & - & - & - & fair \\
\hline 41 WB521 & GMI-44 & Prehistoric & quarry & 330,000 & high & 0 & - & - & 5 & fair \\
\hline 41WB522 & GMI-42 & Prehistoric & quarry & 240,000 & moderate & 0 & - & - & - & poor \\
\hline 41 WB523 & GMI-43 & Prehistoric & open campsite & 3,300 & low & 0 & - & - & - & fair \\
\hline 41WB524 & GMI-06 & Prehistoric & open campsite & 8,800 & low & 0 & LP & - & - & fair \\
\hline 41WB525 & GMI-05 & Prehistoric & open campsite & 46,375 & moderate & 0 & $\begin{array}{l}\text { MA to } \\
\text { LP }\end{array}$ & - & - & good \\
\hline 41WB526 & GMI-19 & Prehistoric & quarry & 97,500 & low & 0 & $\begin{array}{l}\text { LA to } \\
\text { LP }\end{array}$ & - & - & fair \\
\hline 41WB527 & GMI-26 & Prehistoric & open campsite & 16,875 & high & 0 & - & - & - & poor \\
\hline 41WB528 & GMI-90 & Prehistoric & open campsite & 20,250 & low & 0 & $\begin{array}{l}\text { LA to } \\
\text { LP }\end{array}$ & - & - & poor \\
\hline 41WB529 & GMI-89 & Prehistoric & open campsite & 21,600 & low & 0 & $\begin{array}{l}\text { PI to } \\
\text { MA }\end{array}$ & - & - & fair \\
\hline 41WB530 & GMI-30 & Prehistoric & open campsite & 62,000 & moderate & 0 & A & $\begin{array}{c}\text { Mussel } \\
\text { shell }\end{array}$ & - & fair \\
\hline
\end{tabular}

Stone Ranch Segment

\begin{tabular}{|c|c|c|c|c|c|c|c|c|c|c|}
\hline 41MV205 & GMI-221 & Prehistoric & open campsite & 14,400 & moderate & 0 & - & $\begin{array}{l}\text { Mussel } \\
\text { shell }\end{array}$ & 30 & good \\
\hline 41MV206 & GMI-222 & Prehistoric & quarry & 75,000 & low & 0 & $\sim-$ & - & - & fair \\
\hline 41MV207 & GMI-223 & Prehistoric & quarry & 10,000 & low & 0 & - & - & - & fair \\
\hline 41MV208 & GMI-224 & Prehistoric & open campsite & 15,000 & moderate & 2 & - & $\begin{array}{l}\text { Mussel } \\
\text { shell }\end{array}$ & 40 & good \\
\hline 41MV209 & GMI-225 & Prehistoric & open campsite & 57,500 & $\begin{array}{l}\text { low to } \\
\text { moderate }\end{array}$ & 0 & $\begin{array}{l}\text { MA to } \\
\text { LA }\end{array}$ & $\begin{array}{l}\text { Mussel } \\
\text { shell }\end{array}$ & 40 & good \\
\hline 41MV236 & GMI-300 & Prehistoric & open campsite & 2,600 & $\begin{array}{l}\text { low to } \\
\text { moderate }\end{array}$ & 0 & - & - & 40 & good \\
\hline
\end{tabular}

Swartz Ranch Segment

\begin{tabular}{|c|c|c|c|c|c|c|c|c|c|c|}
\hline $41 \mathrm{MV} 210$ & GMI-210 & Prehistoric & open campsite & 4,800 & moderate & 0 & - & $\begin{array}{c}\text { Mussel } \\
\text { shell }\end{array}$ & - & poor \\
\hline $41 \mathrm{MV} 211$ & GMI-211 & Prehistoric & open campsite & 200,000 & moderate & 1 & LA & - & $110+$ & good \\
\hline $41 \mathrm{MV} 212$ & GMI-212 & Prehistoric & open campsite & 12,600 & low & 0 & - & - & - & poor \\
\hline $41 \mathrm{MV} 213$ & GMI-213 & Prehistoric & open campsite & 20,400 & low & 0 & - & - & - & poor \\
\hline 41MV214 & GMI-214 & Prehistoric & open campsite & 9,900 & low & 0 & $\mathrm{TA}$ & - & - & poor \\
\hline 41MV215 & GMI-215 & Prehistoric & open campsite & 2,000 & low & 0 & - & - & 10 & poor \\
\hline
\end{tabular}


Table 4 (cont'd)

\begin{tabular}{|c|c|c|c|c|c|c|c|c|c|c|}
\hline $\begin{array}{l}\text { TARL } \\
\text { Trinomial } \\
\end{array}$ & $\begin{array}{l}\text { Temporary } \\
\text { Field No. }\end{array}$ & $\begin{array}{l}\text { Period of } \\
\text { Occupation }\end{array}$ & Site Type & $\begin{array}{c}\text { Estimated } \\
\text { Site Area } \\
\left(\mathrm{m}^{2}\right)\end{array}$ & $\begin{array}{l}\text { Surface } \\
\text { Artifact }^{1} \\
\text { Density }^{1} \\
\end{array}$ & $\begin{array}{c}\text { No. of } \\
\text { Features }\end{array}$ & $\begin{array}{l}\text { Diagno } \\
\text { s-tics }^{2}\end{array}$ & $\begin{array}{l}\text { Organic } \\
\text { Materials } \\
\end{array}$ & $\begin{array}{c}\text { Depth of } \\
\text { Cultural } \\
\text { Deposit } \\
\text { (cm) }\end{array}$ & $\begin{array}{c}\text { Context- } \\
\text { ual } \\
\text { Integrity }^{3}\end{array}$ \\
\hline 41MV216 & GMI-216 & Prehistoric & open campsite & 400 & low & 0 & $\begin{array}{l}\text { PI to } \\
\text { MA }\end{array}$ & - & - & poor \\
\hline 41MV217 & GMI-217 & Prehistoric & open campsite & 3,375 & low & 0 & - & - & 30 & good \\
\hline 41MV218 & GMI-218 & Prehistoric & open campsite & 11,000 & low & 0 & - & - & 23 & fair \\
\hline $41 \mathrm{MV} 219$ & GMI-219 & Prehistoric & open campsite & 1,350 & low & 0 & - & - & - & good \\
\hline $41 \mathrm{MV} 220$ & GMI-226 & Prehistoric & quarry & 1,000 & low & 0 & - & - & - & poor \\
\hline $41 \mathrm{MV} 221$ & GMI-227 & Prehistoric & quarry & 3,750 & low & 0 & - & - & 20 & poor \\
\hline 41MV222 & GMI-228 & Prehistoric & quarry & 112,500 & high & 2 poss & - & - & - & fair \\
\hline $41 \mathrm{MV} 223$ & GMI-229 & Prehistoric & open campsite & 8,750 & low & 0 & - & - & 40 & fair \\
\hline $41 \mathrm{MV} 224$ & GMI-230 & Prehistoric & open campsite & 7,500 & low & 0 & - & - & $80 ?$ & fair \\
\hline 41MV225 & GMI-231 & Prehistoric & quarry & 1,000 & low & 0 & - & - & - & fair \\
\hline 41MV226 & GMI-232. & Prehistoric & quarry & 2,925 & moderate & 0 & - & - & - & poor \\
\hline 41MV227 & GMI-233 & Prehistoric & quarry & 52,500 & moderate & 0 & - & - & - & fair \\
\hline $41 \mathrm{MV} 228$ & GMI-234 & Prehistoric & $\begin{array}{l}\text { open campsite } \\
\text { and quarry }\end{array}$ & 180,000 & $\begin{array}{l}\text { low to } \\
\text { moderate }\end{array}$ & 0 & - & - & 5 & fair \\
\hline 41MV229 & GMI-235 & Prehistoric & $\begin{array}{l}\text { open campsite } \\
\text { and quarry }\end{array}$ & 67,500 & $\begin{array}{l}\text { low to } \\
\text { moderate }\end{array}$ & 0 & - & - & 60 & good \\
\hline 41MV230 & GMI-236 & Prehistoric & open campsite & 151,250 & $\begin{array}{l}\text { low to } \\
\text { moderate }\end{array}$ & 0 & - & - & 30 & fair \\
\hline 41MV231 & GMI-237 & Prehistoric & quarry & 1,800 & low & 0 & - & - & - & poor \\
\hline $41 \mathrm{MV} 232$ & GMI-238 & Prehistoric & quarry & 105,000 & low & 0 & - & - & - & fair \\
\hline $41 \mathrm{MV} 233$ & GMI-239 & Prehistoric & quarry & 200,000 & moderate & 0 & - & - & - & poor \\
\hline $41 \mathrm{MV} 234$ & GMI-240 & Prehistoric & quarry & 180,000 & moderate & 0 & - & - & - & poor \\
\hline 41MV235 & GMI-241 & Prehistoric & open campsite & 2,000 & low & 0 & - & - & - & poor \\
\hline
\end{tabular}

'Criteria for density categories:

High $=$ Average surface artifact density exceeds 20 artifacts per $25 \mathrm{~m}^{2}$

Moderate $=$ Average surface artifact density ranges from 11 to 20 artifacts per $25 \mathrm{~m}^{2}$

Low $=$ Average surface artifact density is five to 10 artifacts per $25 \mathrm{~m}^{2}$

${ }^{2}$ PI (Paleo-Indian), A (Archaic, general), EA (Early Archaic), MA (Middle Archaic), LA (Late Archaic), TA (Terminal Archaic), LP (Late Prehistoric)

${ }^{3}$ Criteria for levels of contextual integrity:

Excellent $=$ Site judged to be largely intact; identifiable well-preserved archeological features or deposits, with faunal preservation, buried stratified deposits, and/or intact spatial artifact patterning; minimal disturbance limited to bioturbation, peripheral erosion, or very limited human disturbance.

Good = Site judged to be largely intact; only identifiable disturbances due to bioturbation, erosion, and localized or limited cultural activity; possible intact artifact patterning; no evidence for features, faunal remains, or buried deposits.

Fair = Site judged to be only partially intact; several types of limited cultural disturbances may be present, including

light-duty roads, fences, possible machine disturbance, erosion and deflation, and bioturbation.

Poor = Site judged to be only minimally intact; evidence of heavy disturbance or destruction of the site due to bulldozing, earthmoving, erosion, or other processes.

concentrations could be identified within one of the extensive, low-density scatters. These concentrations were documented as archeological sites, but the surrounding "background noise" retained the status of a locality. Finally, the presence of a cultural feature within an extensive lithic scatter would automatically have warranted site status, but the only cultural features encountered in the project area were observed in association with high-density lithic concentrations that warranted definition as sites based on other criteria.

No archeological sites or nonsite localities were identified as a result of the cultural resources survey of the Rio Bravo, SH 277, or FM 2644 segments of the project area. No additional archeological work is recommended for these segments of the proposed action. 


\section{Cultural Features}

A total of 23 cultural features was recorded on archeological sites during the cultural resources survey (Table 5). Of this total, 21 represent either excellent or possible examples of fire hearths. The majority of the hearth features are composed of concentrations of small fire-cracked rock fragments that appear to have recently eroded out of near-surface buried contexts. Scatters of lithic debris and occasional stone tools, including retouched flakes and bifaces, are associated with these fire-cracked rock concentrations. Fifteen of these hearth features were recorded on a single site (41WB510) on Galvan Ranch, where they are grouped into three feature clusters. One possible hearth feature on site 41MV211 on Swartz Ranch is composed of three large and approximately 10 smaller fire-cracked rock fragments arranged in a rough circle. The remaining five hearth features, one at site 41WB482 on Galvan Ranch, two at site 41MV208 on Stone Ranch, and two at site 41MV222 on Swartz Ranch, are represented by small concentrations of fire-cracked rock fragments associated with flaking debris.

The remaining two features consist of an indeterminate circular stain observed in the right-of-way of an existing two-track road on the Galvan Ranch segment after a rainstorm (41WB492) and a concentration of noncortical flakes of a single raw material that appears to represent a single flintknapping episode or activity area on the Galvan Ranch segment (41WB510). The stain on 41WB492 represents the only possible feature on this site, but the flintknapping activity locus on 41WB510 is located in proximity to two clusters of hearth features.

Overall, cultural features were observed on only six of the archeological sites documented during this survey. This overall lack of cultural features in the project area can probably be explained in terms of two natural processes. Deflation, bioturbation, and other erosional processes on the upland sites, combined with the artificial impacts resulting from road and fence line construction, have probably destroyed any cultural features that may once have been exposed on the surface. In contrast, sedimentation on the sites associated with creek or stream valleys has probably resulted in the burial of any extant features, obscuring them from view on the surface. The lack of cultural features on the Galvan, Stone, and Swartz ranches sites stands somewhat in contrast to a tendency observed on the sites documented during the Trevino Mining Permit survey to the west of the Galvan survey area. During this investigation, lithic scatters were found to be associated with substantial numbers of hearth features (TARL site files). Unfortunately, no information aside from that provided on the site forms on file at TARL is available on the Trevino Mining Permit sites as a final report does not appear to have been produced. Quite possibly, the overall dearth of features on sites on the Galvan, Stones, and Swartz ranches segments may be a function of the limited scope of investigations on most of the sites. The portions of sites immediately adjacent to existing roads were commonly the only parts of larger sites that could be investigated due to time and budgetary constraints. Artificial and natural disturbances were generally more severe next to the roadways, and features near the existing roads are more likely to have been destroyed than any features that might exist beyond the survey corridor in uninvestigated areas of the sites.

\section{Chronology}

Twenty-four sites on the Galvan Ranch segment of the project area yielded diagnostic projectile points or tools (see Table 5). The most common diagnostics identified at Galvan Ranch are Catán and Early Triangular/ Tortugas/Matamoros-like projectile points. Catán points-recovered from seven sites on the Galvan Ranch-are generally dated from the Late Archaic up to the Late Prehistoric in South Texas (Turner and Hester 1993:89). The points identified as Early Triangular and Tortugas/Matamoros-type 
Table 5

Features and Diagnostic Artifacts from the Survey Area

\begin{tabular}{|c|c|c|c|c|}
\hline Site & $\begin{array}{l}\text { Survey } \\
\text { Segment }\end{array}$ & Feature Type & Diagnostic Artifacts & Temporal Period \\
\hline 41WB473 & Galvan & & 1 Catán & L Archaic-L Prehistoric \\
\hline 41WB474 & Galvan & & 1 Perdiz & L Prehistoric \\
\hline 41WB478 & Galvan & - & $\begin{array}{l}1 \text { Catán-like; } \\
\text { bottle \& window glass, whiteware }\end{array}$ & $\begin{array}{l}\text { L Archaic-L Prehistoric; } \\
\text { Historic }\end{array}$ \\
\hline $41 \mathrm{WB} 480$ & Galvan & & 1 Desmuke & L Archaic \\
\hline 41WB482 & Galvan & 1 hearth ( $20 \mathrm{FCR}, .5$-m diam.) & & \\
\hline 41WB485 & Galvan & & 1 Frio & Trans Archaic \\
\hline 41WB486 & Galvan & & 1 Lange & L Archaic \\
\hline 41WB487 & Galvan & & $\begin{array}{l}1 \text { Gower; } \\
1 \text { Refugio; }\end{array}$ & $\begin{array}{l}\text { E Archaic; } \\
\text { Archaic; }\end{array}$ \\
\hline &.- & & $\begin{array}{l}1 \text { Palmillas(?) } \\
3 \text { poss Nueces unifaces }\end{array}$ & $\begin{array}{l}\text { M-L Archaic } \\
\text { M-L Archaic }\end{array}$ \\
\hline 41WB488 & Galvan & & $\begin{array}{l}1 \text { E Triangular/Matamoras/Tortugas; } \\
1 \text { Nueces biface }\end{array}$ & $\begin{array}{l}\text { E Archaic-L Prehistoric; } \\
\text { M-L Archaic }\end{array}$ \\
\hline 41WB492 & Galvan. & 1 charcoal stain (20-cm diam) & $\begin{array}{l}1 \text { Catán; } \\
1 \text { Perdiz; } \\
1 \text { Caracara }\end{array}$ & $\begin{array}{l}\text { L Archaic-L Prehistoric; } \\
\text { L Prehistoric; } \\
\text { L Prehistoric }\end{array}$ \\
\hline 41WB493 & Galvan & & 2 E Triangular/Matamoras/Tortugas & E Archaic-L Prehistoric \\
\hline 41WB496 & Galvan & & 1 Refugio & Archaic \\
\hline 41WB504 & Galvan & & $\begin{array}{l}1 \text { E Triangular/Matamoras/Tortugas; } \\
1 \text { Catán }\end{array}$ & $\begin{array}{l}\text { E Archaic-L Prehistoric; } \\
\text { L Archaic-L Prehistoric }\end{array}$ \\
\hline 41WB509 & Galvan & & $\begin{array}{l}1 \text { Clear Fork uniface; } \\
1 \text { Catán/Refugio-like }\end{array}$ & $\begin{array}{l}\text { Paleo-Indian-M Archaic; } \\
\text { L Archaic-L Prehistoric }\end{array}$ \\
\hline $41 \mathrm{WB} 510$ & Galvan & $\begin{array}{l}1 \text { knapping locus; } \\
15 \text { hearths (10-70 FCR, } .5-1.5-\mathrm{m} \\
\text { diams) }\end{array}$ & 1 Clear Fork uniface & Paleo-Indian-M Archaic \\
\hline 41WB512 & Galvan & 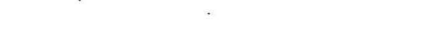 & 1 Refugio & Archaic \\
\hline 41WB514 & Galvan & & 1 Carrizo & M-L Archaic \\
\hline 41WB517 & Galvan & & 1 Matamoras/Tortugas & M Archaic-L Prehistoric \\
\hline $41 \mathrm{WB} 519$ & Galvan & & $\begin{array}{l}1 \text { E Triangular/Matamoras/Tortugas; } \\
1 \text { Ensor }\end{array}$ & $\begin{array}{l}\text { E Archaic-L Prehistoric } \\
\text { Trans Archaic }\end{array}$ \\
\hline 41 WB524 & Galvan & & 1 Scallorn & L Prehistoric \\
\hline 41WB525 & Galvan & & $\begin{array}{l}1 \text { Pandora; } \\
1 \text { Fresno/McGloin-like }\end{array}$ & $\begin{array}{l}\text { M Archaic; } \\
\text { L Prehistoric }\end{array}$ \\
\hline 41WB526 & Galvan & & $\begin{array}{l}1 \text { Refugio; } \\
1 \text { Catán }\end{array}$ & $\begin{array}{l}\text { Archaic; } \\
\text { L Archaic-L Prehistoric }\end{array}$ \\
\hline 41WB528 & Galvan & & 1 Catán & L Archaic-L Prehistoric \\
\hline 41WB529 & Galvan & & 1 Clear Fork uniface & Paleo-Indian-M Archaic \\
\hline 41WB530 & Galvan & & 1 Refugio & Archaic \\
\hline $41 \mathrm{MV} 208$ & Stone & 2 possible hearths & & \\
\hline 41MV209 & Stone & & $\begin{array}{l}2 \text { Pandora } \\
1 \text { Lange }\end{array}$ & $\begin{array}{l}\text { M-L Archaic } \\
\text { L Archaic }\end{array}$ \\
\hline 41MV211 & Swartz & $\begin{array}{l}1 \text { hearth (.5-m diam, } 3 \text { large and } 10 \\
\text { smaller FCR in circle })\end{array}$ & 1 Lange & L Archaic \\
\hline $41 \mathrm{MV} 214$ & Swartz & & 1 Figueroa & Trans Archaic \\
\hline 41MV216 & Swartz & & 1 Clear Fork tool & Paleo-Indian-M Archaic \\
\hline 41MV222 & Swartz & $\begin{array}{l}2 \text { possible hearths (each w/8-10 } \\
\text { burned cobbles, } 50 \text {-cm diams) }\end{array}$ & & \\
\hline
\end{tabular}

Note: Unidentified dart points were recorded at three Galvan Ranch sites (41WB513, 41WB519, and 41WB525) and at one Swartz Ranch site (41MV215). 
points include unstemmed, straight-based triangular points that are difficult to distinguish from one another and may even represent a morphological continuum. Dates on this group of points range from Early Archaic (Early Triangular points) through the late Middle Archaic (Tortugas), and from the Late Archaic to the Late Prehistoric (Matamoros [Turner and Hester 1993:110, 153, 188]). The Archaic period is also represented at Galvan Ranch by Refugio points, which were identified at five sites. A single Early Archaic point, a Gower point, was also identified. The Middle to Late Archaic is represented by a single Carrizo point, a possible Palmillas point, possible Nueces tools at two sites, and a single Pandora point. Additional Late Archaic points identified include a Desmuke and a Lange point. The Transitional Archaic is represented by a Frio and an Ensor point. In addition to the Catán points mentioned above, other late Prehistoric points identified at the Galvan Ranch include two Perdiz points, a Caracara, a Scallorn, and a Fresno/McGloin-like point. Clear Fork tools, typically dated from the PaleoIndian period to the Middle Archaic, were identified on three sites on the Galvan Ranch.

Of the 24 sites at which diagnostic artifacts were identified on the Galvan Ranch, 15 of the sites (41WB473, 41WB478, 41WB487, 41WB488, 41WB492, 41WB493, 41WB504, 41WB509, 41WB510, 41WB517, 41WB519, 41WB525, 41WB526, 41WB528, and 41WB529) contained artifacts which spanned more than one temporal period. These sites either contained points which themselves date to a range of periods, such as Catán points (the Late Archaic to the Late Prehistoric), or contained several different types of diagnostic artifacts spanning different periods. Of the remaining nine sites, two produced only Clear Fork tools (sites 41WB510 and 41WB529), seven contained only Archaic projectile points and tools (sites 41WB480, 41WB485, 41WB486, 41WB496, 41WB512, 41WB514, and 41WB530), and two contained only Late Prehistoric projectile points (sites 41WB474 and 41WB524).

Diagnostic artifacts were identified at only one site on the Stone Ranch-two Middle to Late Archaic Pandora points and a Late Archaic Lange point were identified at site 41MV209. Three sites on the Swartz Ranch yielded a single diagnostic artifact each. A Lange point identified at site 41MV211 represents the Late Archaic, while a Figueroa point represents the Transitional Archaic identified at site 41MV214. A single Clear Fork tool, generally dated from the Paleo-Indian to the Middle Archaic, was identified at site $41 \mathrm{MV} 216$.

The presence of temporally diagnostic tools on a site broadly indicates that an occupation dating to the appropriate time period may have occurred at the site, but it does not limit the range of occupations to that time period. Evidence indicating occupations dating to other time horizons may not be apparent because no diagnostic tools were left at the sites, because tools dating to earlier periods were reworked and utilized during later periods, or because diagnostic items have been vandalized by artifact collectors.

Considering the vast quantities of lithic artifacts observed on the sites on the Galvan, Stone, and Swartz ranches segments, surprisingly few diagnostic artifacts were observed. Overall, the Archaic period is much more strongly represented than any other single period. Aside from a single Clear Flork tool (Paleo-Indian to Middle Archaic) on one site on the Swartz Ranch (41MV216), all of the diagnostic artifacts on the Swartz Ranch $(n=2)$ date to the Late Archaic period. A similar situation pertains on the Stone Ranch, where all three diagnostic artifacts indicate Middle to Late Archaic occupations (41MV209). More temporal variability is apparent on the Galvan Ranch, but the relative proportions of Archaic to earlier and later occupations are similar, suggesting that this variability is a function of the larger size of the diagnostic artifact assemblage observed on this ranch (Table 6). Of the 38 diagnostic tools observed on the Galvan Ranch, all but five artifacts can be associated with a phase of the Archaic period. Within this general time frame, there appears to be a slightly greater number of diagnostic items from the latter portions of the Archaic period, grading into the Late Prehistoric, represented on the Galvan Ranch. This overwhelming representation of the Archaic period undoubtedly arises, in part, 


\author{
Paleo-Indian - Middle Archaic \\ Archaic (general) \\ Early Archaic \\ Early Archaic - Late Prehistoric \\ Middle Archaic \\ Middle Archaic - Late Archaic \\ Middle Archaic - Late Prehistoric \\ Late Archaic \\ Late Archaic - Late Prehistoric \\ Late Prehistoric \\ Total
}

No. of Artifacts

\begin{tabular}{l}
3 \\
5 \\
1 \\
5 \\
1 \\
6 \\
1 \\
4 \\
7 \\
5 \\
\hline 38
\end{tabular}

from the length of this period of time. In south Texas, the Archaic period lasted from roughly 6000 B.C. to A.D. 800 and covers most of the prehistoric sequence. That a proportionately large number of diagnostic artifacts should fall within this temporal framework is far from surprising. It is also possible that vandalism has had a greater impact upon the remaining assemblage of finely crafted arrow and dart points of later time periods than the larger, often broken, specimens representing earlier time periods.

No ground stone tools or objects crafted from organic materials, such as mussel shell or bone, were observed on any sites during this survey.

\title{
ELIGIBILITY OF SITES FOR INCLUSION IN THE NATIONAL REGISTER OF HISTORIC PLACES
}

Based exclusively on the limited data available from the survey and small-scale shovel testing, full assessments for listing in the NRHP of the cultural properties located during this project could not be made. In addition to the limitations inherent in survey-level data, vandalism of sites in the project area has resulted in an overall scarcity of diagnostic tools. Without such temporal markers, period-specific regional research issues cannot be adequately addressed. Under such circumstances, NRHP Criterion D, Information Potential, is most applicable. Criterion D has two requirements, both of which must be met for a property to qualify for inclusion in the NRHP (United States Department of the Interior [USDI] 1990:21):

1. The property must have or have had information to contribute to our understanding of human history or prehistory, and

2. the information must be considered important. 
To properly address the first requirement, limited test excavations would be the most advantageous course of action. In lieu of excavation data, however, sufficient observation and limited shovel testing must be relied upon to determine whether or not sites "may be likely to yield information important in prehistory" (USDI 1990:21). This is not to suggest that surface artifact assemblages lack such information, but several processes observed in the project area compound the problem of isolating temporal components on cultural properties. First, extensive vandalism is indicated by the overall lack of temporally diagnostic stone tools throughout the project area, and it may be safely surmised that surface artifact scatters do not currently represent complete assemblages. Thus, the presence of intact subsurface deposits is a crucial requirement to qualify these sites for the NRHP. Specifically, such deposits need to express the potential to yield important information. Deflation and other erosional processes have removed the surficial soils on most of the sites in the project area, but valuable artifact assemblage and cultural feature information may be buried on those sites that do exhibit some depth to cultural deposits. Several cultural properties in the project area contain intact hearth features exposed on the surface that had recently eroded out of a shallow buried context. Buried features may contain charcoal-enriched subsurface deposits. These remains may not only contain organic material suitable for radiocarbon dating, but also for botanical and pollen sample analysis. Macrobotanical and pollen data retrieved from in situ features could provide a wealth of important information regarding feature function, fuel usage, seasonal resource scheduling, and, more generally, local prehistoric economics.

The potential eligibility of each archeological site in the project area for inclusion in the NRHP was assessed by determining whether the site appeared to possess sufficient contextual integrity to contribute significant information about the prehistoric past. In order to meet this criterion, a historic property generally needs to contain cultural features (such as hearths), discrete activity areas (such as flintknapping loci), or subsurface depth. Most of the deposits identified on these sites were fairly surficial (5 to $10 \mathrm{~cm}$ deep) and did not appear to retain much stratigraphic integrity (see Table 4). Given the high-energy erosional environments that characterize most of the site locations, artifacts observed in the uppermost 10 to $15 \mathrm{~cm}$ of each shovel test are not considered to be in primary context. Assessments of the potential eligibility of sites containing subsurface deposits measuring more than 10 to $15 \mathrm{~cm}$ in depth were made based on the degree of disturbance from erosion, fence and road construction, and other natural impacts evident at the site. None of the nonsite localities is considered eligible for inclusion in the NRHP.

Of the newly recorded sites, 30 smaller sites that fell entirely or almost entirely within the ROW and the ROW-evaluated areas of 41 very large sites with undetermined site limits (i.e., those sites extending well beyond the project area) are considered to be ineligible for inclusion in the NRHP (Table 7). These small sites and the ROW-evaluated areas of the extensive sites generally consist of surficial, very lowdensity lithic artifact scatters that appear to possess little potential to contribute any significant information about the past. No cultural features or intact activity areas were recognized on the smaller sites or within the ROW-evaluated areas of the large sites. Furthermore, many of the smaller sites and the ROW-evaluated areas of the large sites have experienced heavy impacts from erosion and previous road and fence line construction and appear to retain relatively little contextual integrity. No significant impacts will occur to the 30 evaluated smaller sites nor to the ROW-evaluated areas of the 41 large sites (noting that the areas outside the ROW at these 41 sites have not been assessed for significance) as a result of the proposed road construction and improvement activities. No additional archeological work is recommended for these sites or for the ROW-evaluated areas. It should be noted, however, that the unassessed portions of the larger sites may yet retain some limited research potential, and should probably be investigated further in the future in the event that future construction projects or other efforts that might affect the sites are planned. 
Table 7

National Register of Historic Places Assessment and Recommendations for Archeological Sites Recorded on the Galvan, Stone, and Swartz Ranch Segments

\begin{tabular}{|c|c|c|c|c|}
\hline $\begin{array}{l}\text { TARL } \\
\text { Trinomial }\end{array}$ & $\begin{array}{l}\text { Temporary } \\
\text { Field No. }\end{array}$ & $\begin{array}{l}\text { Recommended } \\
\text { NRHP Eligibility }\end{array}$ & Existing and Potential Impacts & Recommendations \\
\hline \multicolumn{5}{|c|}{ Galvan Ranch Segment } \\
\hline 41WB466 & GMI-09 & ineligible & existing road - no new ROW & no further work \\
\hline 41WB467 & GMI-20 & Potentially Eligible & existing road - no new ROW & Avoidance/monitoring \\
\hline 41WB468 & GMI-21 & Potentially Eligible & existing road - no new ROW & Avoidance/monitoring \\
\hline $41 \mathrm{WB} 469 *$ & GMI-22 & ineligible * & existing road - no new ROW & no further work \\
\hline 41WB470 & GMI-23 & ineligible & existing road - no new ROW & no further work \\
\hline 41WB471 & GMI-24 & Potentially Eligible & existing road - no new ROW & Avoidance/monitoring \\
\hline 41WB472 * & GMI-25 & ineligible * & existing road - no new ROW & no further work \\
\hline $41 \mathrm{WB} 473 *$ & GMI-07 & ineligible * & existing road - no new ROW & no further work \\
\hline $41 \mathrm{WB} 474 *$ & GMI-01 & ineligible * & existing road - no new ROW & no further work \\
\hline $41 \mathrm{WB} 475 *$ & GMI-18 & ineligible * & existing road - no new ROW & no further work \\
\hline 41WB476 & GMI-17 & ineligible & New road ROW & no further work \\
\hline $41 \mathrm{WB} 477 *$ & GMI-10 & ineligible * & existing road - no new ROW & no further work \\
\hline 41WB478 & GMI-11 & ineligible & existing road - no new ROW & no further work \\
\hline 41WB479 & GMI-49 & ineligible & New road ROW & no further work \\
\hline $41 \mathrm{WB} 480 *$ & GMI-03 & ineligible * & existing road - no new ROW & no further work \\
\hline 41WB481 & GMI-04 & ineligible & existing road - no new ROW & no further work \\
\hline $41 \mathrm{WB} 482$ & GMI-02 & Potentially Eligible & existing road - no new ROW & Avoidance/monitoring \\
\hline 41 WB483 * & GMI-14 & ineligible * & existing road - no new ROW & no further work \\
\hline 41WB484 * & GMI-15 & ineligible * & existing road - no new ROW & no further work \\
\hline $41 \mathrm{WB} 485 *$ & GMI-08 & ineligible * & existing road - no new ROW & no further work \\
\hline $41 \mathrm{WB} 486$ & GMI-88 & Potentially Eligible & existing road - no new ROW & Avoidance/monitoring \\
\hline 41WB487 & GMI-85 & Potentially Eligible & existing road - no new ROW & Avoidance/monitoring \\
\hline 41WB488 & GMI-86 & Potentially Eligible & existing road - no new ROW & Avoidance/monitoring \\
\hline 41WB489 & GMI-87 & Potentially Eligible & existing road - no new ROW & Avoidance/monitoring \\
\hline 41WB490 & GMI-12 & ineligible & existing road - no new ROW & no further work \\
\hline 41WB491 & GMI-13 & ineligible & existing road - no new ROW & no further work \\
\hline 41WB492 & GMI-40 & Potentially Eligible & existing road - no new ROW & Avoidance/monitoring \\
\hline $41 \mathrm{WB} 493 *$ & GMI-41 & ineligible * & existing road - no new ROW & no further work \\
\hline 41WB494 & GMI-47 & ineligible & existing road - no new ROW & no further work \\
\hline $41 \mathrm{WB} 495$ & GMI-95 & ineligible & existing road - no new ROW & no further work \\
\hline 41WB496 * & GMI-96 & ineligible * & existing road - no new ROW & no further work \\
\hline 41 WB497 * & GMI-81 & ineligible * & existing road - no new ROW & no further work \\
\hline 41WB498 & GMI-83 & ineligible & existing road - no new ROW & no further work \\
\hline 41WB499 & GMI-84 & Potentially Eligible & exilsting road - no new ROW & Avoidance/monitoring \\
\hline $41 \mathrm{WB} 500 *$ & GMI-36 & ineligible * & existing road - poss. new ROW & no further work \\
\hline 41WB501 & GMI-37 & ineligible & New road ROW & no further work \\
\hline $41 \mathrm{WB} 502 *$ & GMI-38 & ineligible * & existing road - no new ROW & no further work \\
\hline 41WB503 & GMI-39 & ineligible & existing road - no new ROW & no further work \\
\hline 41WB504 & GMI-80 & Potentially Eligible & existing road - no new ROW & Avoidance/monitoring \\
\hline 41WB505 & GMI-94 & ineligible & existing road - no new ROW & no further work \\
\hline 41WB506 * & GMI-82 & ineligible * & existing road - no new ROW & no further work \\
\hline 41WB507 & GMI-93 & ineligible & existing road - no new ROW & no further work \\
\hline 41WB508* & GMI-91 & ineligible * & existing road - no new ROW & no further work \\
\hline
\end{tabular}


Table 7 (cont'd)

TARL Temporary Recommended

\begin{tabular}{|c|c|c|c|c|}
\hline Trinomial & Field No. & NRHP Eligibility & Existing and Potential Impacts & Recommendations \\
\hline 41WB509* & GMI-92 & ineligible $*$ & existing road - no new ROW & no further work \\
\hline 41WB510 & GMI-34 & Potentially Eligible & existing road - poss. new ROW & $\begin{array}{l}\text { Avoidance/reroute } \\
\text { proposed new road } \\
\text { ROW/monitoring }\end{array}$ \\
\hline 41WB511 & GMI-35 & ineligible & existing road - poss. new ROW & no further work \\
\hline $41 \mathrm{WB} 512 *$ & GMI-27 & ineligible * & existing road - no new ROW & no further work \\
\hline 41 WB513 * & GMI-28 & ineligible * & existing road - no new ROW & no further work \\
\hline 41 WB514 * & GMI-29 & ineligible * & existing road - no new ROW & no further work \\
\hline 41 WB515 * & GMI-32 & ineligible * & existing road - no new ROW & no further work \\
\hline 41 WB516 * & GMI-33 & ineligible * & existing road - no new ROW & no further work \\
\hline 41 WB517 * & GMI-31 & ineligible * & existing road - no new ROW & no further work \\
\hline $41 \mathrm{WB} 518$ & GMI-48 & ineligible & existing road - no new ROW & no further work \\
\hline 41 WB519 * & GMI-46 & ineligible * & existing road - no new ROW & no further work \\
\hline $41 \mathrm{WB} 520 *$ & GMI-45 & ineligible * & existing road - no new ROW & no further work \\
\hline 41WB521* & GMI-44 & ineligible * & existing road - no new ROW & no further work \\
\hline 41 WB522 * & GMI-42 & ineligible * & existing road - no new ROW & no further work \\
\hline 41 WB523 * & GMI-43 & ineligible * & existing road - no new ROW & no further work \\
\hline 41 WB524 & GMI-06 & ineligible & existing road - no new ROW & no further work \\
\hline 41WB525 & GMI-05 & Potentially Eligible & $\begin{array}{l}\text { existing road - no new ROW } \\
\text { (site lies beyond proposed } \\
\text { impact area) }\end{array}$ & Avoidance/monitoring \\
\hline 41WB526 * & GMI-19 & ineligible * & existing road - no new ROW & no further work \\
\hline 41WB527* & GMI-26 & ineligible * & existing road - no new ROW & no further work \\
\hline 41 WB528 * & GMI-90 & ineligible * & existing road - no new ROW & no further work \\
\hline 41WB529 & GMI-89 & Potentially Eligible & existing road - no new ROW & Avoidance/monitoring \\
\hline 41WB530 & GMI-30 & Potentially Eligible & existing road - no new ROW & Avoidance/monitoring \\
\hline \multicolumn{5}{|c|}{ Stone Ranch Segment } \\
\hline 41MV205 & GMI-221 & Potentially Eligible & existing road - no new ROW & Avoidance/monitoring \\
\hline 41MV206 & GMI-222 & ineligible & existing road - no new ROW & no further work \\
\hline 41MV207 & GMI-223 & ineligible & existing road - no new ROW & no further work \\
\hline 41MV208 & GMI-224 & Potentially Eligible & existing road - New road ROW & $\begin{array}{l}\text { Avoidance/reroute } \\
\text { proposed new road } \\
\text { ROW/monitoring }\end{array}$ \\
\hline 41MV209 & GMI-225 & Potentially Eligible & New road ROW & $\begin{array}{l}\text { Reroute proposed ROW/ } \\
\text { monitoring }\end{array}$ \\
\hline 41MV236 & GMI-300 & Potentially Eligible & New road ROW & Avoidance/monitoring \\
\hline
\end{tabular}

Swartz Ranch Segment

$\begin{array}{lll}41 \text { MV210 } & \text { GMI-210 } & \text { ineligible } \\ 41 \text { MV211 } & \text { GMI-211 } & \text { Potentially Eligible } \\ 41 \text { MV212 * } & \text { GMI-212 } & \text { ineligible * } \\ 41 \text { MV213 * } & \text { GMI-213 } & \text { ineligible * } \\ 41 \text { MV214 * } & \text { GMI-214 } & \text { ineligible * } \\ 41 \text { MV215 } & \text { GMI-215 } & \text { ineligible } \\ 41 \text { MV216 } & \text { GMI-216 } & \text { ineligible } \\ 41 \text { MV217 } & \text { GMI-217 } & \text { Potentially Eligible } \\ 41 \text { MV218 } & \text { GMI-218 } & \text { Potentially Eligible }\end{array}$

existing road - no new ROW existing road - no new ROW existing road - no new ROW existing road - no new ROW existing road - no new ROW existing road - no new ROW existing road - no new ROW existing road - no new ROW existing road - no new ROW no further work Avoidance/monitoring no further work no further work no further work no further work no further work Avoidance/monitoring Avoidance/monitoring 
Table 7 (cont'd)

\begin{tabular}{|c|c|c|c|c|}
\hline $\begin{array}{l}\text { TARL } \\
\text { Trinomial }\end{array}$ & $\begin{array}{l}\text { Temporary } \\
\text { Field No. }\end{array}$ & $\begin{array}{l}\text { Recommended } \\
\text { NRHP Eligibility }\end{array}$ & Existing and Potential Impacts & Recommendations \\
\hline 41MV219 & GMI-219 & ineligible & existing road - no new ROW & no further work \\
\hline $41 \mathrm{MV} 220 *$ & GMI-226 & ineligible * & existing road - no new ROW & no further work \\
\hline $41 \mathrm{MV} 221 *$ & GMI-227 & ineligible $*$ & existing road - no new ROW & no further work \\
\hline 41MV222 & GMI-228 & Potentially Eligible & existing road - no new ROW & Avoidance/monitoring \\
\hline $41 \mathrm{MV} 223$ & GMI-229 & Potentially Eligible & existing road - no new ROW & Avoidance/monitoring \\
\hline $41 \mathrm{MV} 224$ & GMI-230 & ineligible & existing road - no new ROW & no further work \\
\hline $41 \mathrm{MV} 225$ & GMI-231 & ineligible & existing road - no new ROW & no further work \\
\hline 41MV226 & GMI-232 & ineligible & existing road - no new ROW & no further work \\
\hline $41 \mathrm{MV} 227 *$ & GMI-233 & ineligible * & existing road - no new ROW & no further work \\
\hline $41 \mathrm{MV} 228$ & GMI-234 & ineligible & New road ROW & no further work \\
\hline $41 \mathrm{MV} 229$ & GMI-235 & Potentially Eligible & New road ROW & $\begin{array}{l}\text { Reroute proposed new road } \\
\text { ROW/monitoring }\end{array}$ \\
\hline 41MV230 & GMI-236 & Potentially Eligible & existing road - no new ROW & Avoidance/monitoring \\
\hline 41MV231 & GMI-237 & ineligible & existing road - no new ROW & no further work \\
\hline $41 \mathrm{MV} 232 *$ & GMI-238 & ineligible * & existing road - no new ROW & no further work \\
\hline $41 \mathrm{MV} 233 *$ & GMI-239 & ineligible $*$ & existing road - no new ROW & no further work \\
\hline $41 \mathrm{MV} 234 *$ & GMI-240 & ineligible $*$ & existing road - no new ROW & no further work \\
\hline 41MV235 & GMI-241 & ineligible & existing road - no new ROW & no further work \\
\hline
\end{tabular}

The remaining 26 sites are considered to be potentially eligible for inclusion in the NRHP based on their potential to contribute significant information about the prehistoric past (see Table 6). These sites have been considered potentially eligible because there appears to be some depth to the cultural deposits, and insufficient information is available about them to assess their research potential based exclusively on the results of the survey and limited shovel testing. These sites are generally located on lower terraces adjacent to major stream channels or on the Rio Grande terrace, and have received some deposits of alluvial silts from periodic flooding that have resulted in the burial of cultural deposits (see Table 4). Most of these sites have experienced relatively little deposition (less than $20 \mathrm{~cm}$ ), but several sites appear to contain moderately deep cultural deposits $(60 \mathrm{~cm}$ ) and one exhibits a very deep deposit (over $1 \mathrm{~m}$ deep). Of the four potentially eligible sites containing mussel shell, three of them also exhibit cultural deposits extending to between 30 and $40 \mathrm{~cm}$ bs, raising the possibility that organic remains may have been preserved on other sites with buried deposits as well. Several sites either have or may have features eroding out of near-surface buried contexts (upper $5 \mathrm{~cm}$ ), raising the possibility that more deeply buried cultural features, such as hearths, activity areas, and even burials, may be present on sites that have experienced more substantial sedimentation. In contrast, most of the upland portions of the project area have undergone extensive erosion through deflation, bioturbation, and a variety of natural and artificial impacts. Soil surfaces exposed on the modern ground surface appear to be relatively old in these areas, consisting of sediments mottled with decomposing bedrock. Most surficial soils on the higher elevations throughout the project area appear to have eroded away, and artifacts resting on these upland surfaces are not considered to retain any contextual integrity. Thus, the buried sites are generally considered to represent the only cultural properties in the project area with any substantive research potential.

In general, the preferred treatment for all historic properties is preservation and protection. Avoidance represents one approach to ensuring that any extant cultural deposits on the 26 potentially eligible historic properties are not impacted by the proposed road construction and improvement activities: It is 
recommended that these properties be avoided during the deployment for this action. Most $(n=23)$ of the potentially eligible sites are already traversed by existing roads. In order to avoid any impacts to these cultural properties, it is recommended that no road improvement activities, including road grading, filling, construction of shoulders or drainage ditches, devegetation in the form of grubbing, or any other ground disturbance, occur within the boundaries of the sites. Additionally, the movement of vehicles and heavy equipment along the existing roads through these sites should be restricted to the existing roadbed, with no equipment staging or turn-arounds occurring within the site boundaries.

A total of four potentially eligible sites are located in the proposed rights-of-way of new road segments, including two sites (41WB510 and 41MV208) that also have a segment of existing road passing through them and two sites (41MV209 and 41MV229) that are traversed only by proposed new road rights-ofway. At the request of JTF-6 and USACE, possible road reroutes that would ensure that these properties would not be impacted by the construction of new roads were designed and inspected for cultural resources. In all four cases, it was possible to locate potential reroute rights-of-way that would not impact any cultural resources. The presence of an archeological monitor is recommended during all phases of construction on and in the vicinity of the 26 potentially eligible historic properties. Monitoring is recommended on these properties so that these properties do not experience any impacts as a result of the proposed action: 


\section{REFERENCES CITED}

Anderson, A. E:

1932 Artifacts of the Rio Grande Delta Region. Bulletin of the Texas Archaeological and Paleontological Society 4:29-31.

Anonymous

n.d. Laredo History, from First Settlements to 1899. Part 1. Typescript in the collections of Laredo Public Library, Laredo, Texas.

Austin, S. P., S. Ferguson, S. M. Hunt, F. B. Largent, Jr., and M. H. Sale

1994 Cultural Resources Survey and Monitoring of Joint Task Force Six (JTF-6) Actions in Webb, Zapata, Dimmit, La Salle, Duvall, and Jim Hogg Counties, Texas. Miscellaneous Report of Investigations No. 63. Geo-Marine, Inc., Plano, Texas.

Bell, R. E.

1958 Guide to the Identification of Certain American Indian Projectile Points. Special Bulletin No.

1. Oklahoma Anthropological Society, Norman.

1960 Guide to the Identification of Certain American Indian Projectile Points. Special Bulletin No. 2. Oklahoma Anthropological Society, Norman.

Black, S. L.

1986 The Clemente and Herminia Hinojosa Site, 41JW8: A Toyah Horizon Campsite in Southern Texas. Special Report 18. Center for Archaeological Research, The University of Texas at San Antonio.

1989 South Texas Plains. In From the Gulf to the Rio Grande: Human Adaptation in Central, South, and Lower Pecos, Texas, edited by T. R. Hester, S. L. Black, D. G. Steele, B. W. Olive, A. A. Fox, K. J. Reinhard, and L. C. Bement, pp. 39-62. Research Series No. 33. Arkansas Archeological Survey, Fayetteville.

Blair, W. F.

1950 The Biotic Provinces of Texas. Texas Journal of Science 2:93-117. 
Briggs, A. K.

1982 Archaeological Investigations of an Area Proposed for Vegetation Management at Fort McIntosh, USA (1849-1946), Laredo, Webb County, Texas. Report No. 19. Lone Star Archaeological Services, Georgetown, Texas.

Brown, D. O.

1983. The Berger Bluff Site (41GD30A): Excavations in the Upper Deposits. Archaeological Survey Report 115. Center for Archaeological Research, The University of Texas at San Antonio.

Brown, K. M.

1987 Early Occupations at Berger Bluff, Goliad County, Texas. Current Research in the Pleistocene 4:3-5.

Campbell, T. N.

1947 The Johnson Site: Type Site of the Aransas Focus of the Texas Coast. Bulletin of the Texas Archaeological and Paleontological Society 18:40-75.

1952 The Kent-Crane Site: A Shell Midden on the Texas Coast. Bulletin of the Texas Archaeological and Paleontological Society 23:36-77.

1956 Archeological Materials from Five Islands in the Alaguna Madre, Texas Coast. Bulletin of the Texas Archeological Society 27:7-46.

1958 Archeological Remains from the Live Oak Point Site, Aransas County, Texas. The Texas Journal of Science 10:432-442.

1962 Origin of Pottery Types from the Coastal Bend Region of Texas. Bulletin of the Texas Archeological Society 32:331-336.

Campbell, T. N., and J. Q. Frizzell

1949 Notes on the Ayala Site, Lower Rio Grande Valley, Texas. Bulletin of the Texas Archaeological and Paleontological Society 20:63-72.

Carlson, D. L., D. G. Steele, and H. L. Bruno

1982 Archeological Investigations at the Allison Site (41NU185), Nueces County, Texas. Reports of Investigations 1. Archeological Research Laboratory, Texas A\&M University, College Station.

Cason, J. F.

1952 Report on Archaeological Salvage in Falcon Reservoir, Season of 1952. Bulletin of the Texas Archaeological Society 23:218-259.

Clark, J. W., Jr., and A. M. Juarez

1986 Urban Archeology: A Cultural History of a Mexican-American Barrio in Laredo, Webb County, Texas. In Background, Methods, Lot Descriptions, Features, Neighborhood Historical Overview, vol. I. Publications in Archeology Report No. 31. Texas State Department of Highways and Public Transportation, Highway Design Division. Austin. 
Corbin, J. E.

1963 Archeological Materials from the Southern Shore of Corpus Christi Bay, Texas. Bulletin of the Texas Archeological Society 34:5-30.

Fitzpatrick, W. S., J. Fitzpatrick, and T. N. Campbell

1964 A Rockport Black-on-Gray Vessel from the Vicinity of Corpus Christi, Texas. Bulletin of the Texas Archeological Society 35:193-204.

Folan, W. J., P. Cox, A. A. Fox, and G. M. Hinojosa

1986 Laredo, Texas: Gateway Community on the Texas Borderlands, Archaeological and Historical Investigations for the Laredo City Toll Plaza. Archeological Survey Report No. 116. Center for Archaeological Research, The University of Texas at San Antonio.

Fox, A. A.

1979 Archaeological and Historical Investigations at 41BX180, Walker Ranch, San Antonio, Texas: Phase 1. Archaeological Survey Report No. 83. Center for Archaeological Research, The University of Texas at San Antonio.

1989 Historic Anglo-European Exploration and Colonization. In From the Gulf to the Rio Grande: Human Adaptation in Central, South, and Lower Pecos, Texas, edited by T. R. Hester, S. L. Black, D. G. Steele, B. W. Olive, A. A. Fox, K. J. Reinhard, and L. C. Bement, pp. 85-92. Research Series No. 33. Arkansas Archeological Survey, Fayetteville.

Fox, A. A., S. L. Black, and S. James

1979 Intensive Survey and Testing of Archaeological Sites on Coleto r., Victoria and Goliad Counties, Texas. Archaeological Survey Report No. 67. Center for Archaeological Research, The University of Texas at San Antonio.

Fox, A. A., and T. R. Hester

1976 An Archaeological Survey of Coleto Creek, Victoria and Goliad Counties, Texas. Archaeology Survey Report No. 18. Center for Archaeological Research, The University of Texas at San Antonio.

Fox, D. E.

1974 Archaeological Resources of the Proposed Cuero I Reservoir, DeWitt and Gonzales Counties, Texas. Archaeological Survey Report 12. Texas Historical Commission and Texas Water Development Board. Austin.

1982 An Archaeological Reconnaissance at City of Laredo, Webb County, Texas. Letter report on file, Texas Archeological Research Laboratory, The University of Texas at Austin.

Fox, D. E., and H. G. Vecker

1977 The Archaeological Study of the McPherson Road Extension Project, Laredo, Texas. Archaeological Survey Report No. 45. University of Texas at San Antonio.

Frazer, R. W.

1972 Forts of the West: Military Forts and Presidios and Posts Commonly Called Forts West of the Mississippi River to 1898. University of Oklahoma Press, Norman. 
Hall, G. D., S. L. Black, and C. Graves

1982 Archaeological Investigations at Choke Canyon Reservoir, South Texas: The Phase I Findings. Choke Canyon Series 5. Center for Archeological Research, The University of Texas at San Antonio.

Hartle, D. D., and R. L. Stephenson

1951 Archaeological Excavations at the Falcon Reservoir, Starr County, Texas. River Basins Survey, Smithsonian Institution. Unpublished manuscript on file at the Center for Archaeological Research, The University of Texas at San Antonio.

Hester, T. R.

1968a Paleo-Indian Artifacts from Sites along San Miguel Creek: Frio, Atascosa, and McMullen Counties, Texas. Bulletin of the Texas Archeological Society 39:147-161.

1968b Notes on Some Pottery-bearing Sites in Southern Texas. The Bull-Roarer 3(2):9-11. The University of Texas Anthropological Society, Austin.

1968c Folsom Points from Southwest Texas. Plains Anthropologist 13(4):117.

1969 Archeological Investigations in Kleburg and Kenedy Counties, Texas. Archaeological Program Report 13. State Building Commission.

1980 Digging into South Texas Prehistory. Corona Publishing, San Antonio.

1983 Late Paleo-Indian Occupations at Baker Cave, Southwestern Texas. Bulletin of the Texas Archeological Society 53:101-119.

1989a Introduction. In From the Gulf to the Rio Grande: Human Adaptation in Central, South, and Lower Pecos, Texas, edited by T. R. Hester, S. L. Black, D. G. Steele, B. W. Olive, A. A. Fox, K. J. Reinhard, and L. C. Bement, pp. 1-4. Research Series No. 33. Arkansas Archeological Survey, Fayetteville.

1989b Historic Native American Populations. In From the Gulf to the Rio Grande: Human Adaptation in Central, South, and Lower Pecos, Texas, edited by T. R. Hester, S. L. Black, D. G. Steele, B. W. Olive, A. A. Fox, K. J. Reinhard, and L. C. Bement, pp. 79-84. Research Series No. 33. Arkansas Archeological Survey, Fayetteville.

Hester, T. R., M. B. Collins, F. A. Weir, and F. Ruecking, Jr.

1969 Two Prehistoric Cemetery Sites in the Lower Rio Grande Valley of Texas. Bulletin of the Texas Archeological Society 40:119-166.

Hester, T. R., S. L. Black, D. G. Steele, B. W. Olive, A. A. Fox, K. J. Reinhard, and L. C. Bement 1989 From the Gulf to the Rio Grande: Human Adaptation in Central, South, and Lower Pecos, Texas. Research Series No. 33. Arkansas Archeological Survey, Fayetteville.

Hester, T. R., and T. C. Hill, Jr.

1969 Mogollon Artifacts from Southern Texas. The Artifact 7(3):11-15. 
Highley, C. L.

1986 Archaeological Investigations at 41CK201, Choke Canyon.Reservoir, Southern Texas. Choke Canyon Series 11. Center for Archaeological Research, The University of Texas at San Antonio.

Jackson, A. T.

1940 Tubular Pipes and Other Tubes in Texas. Bulletin of the Texas Archaeological Paleontological Society 12:99-137.

Jelks, E. B.

1952 The River Basin Surveys Archeological Salvage Program in Texas. Texas Journal of Science 4(2):131-138.

1953 The River Basin Surveys: Recent Archeological Investigations in Texas, Arkansas, and Kansas. Texas Journal of Science 5(3):341-347.

John, E. A. H.

1975 Storms Brewed in Other Men's Worlds: The Confrontation of Indians, Spanish, and French in the Southwest, 1540-1795. University of Nebraska Press, Lincoln and London.

Kreiger, A. D.

n.d. Archeology, Ethnography, and Early Spanish History of Falcon Reservoir Area. Unpublished manuscript on file, Texas Archeological Research Laboratory, The University of Texas at Austin.

Kreiger, A. D., and J. T. Hughes

1950 Archaeological Salvage in the Falcon Reservoir Area: Progress Report 1. Mimeographed. On file, Texas Archeological Research Laboratory, The University of Texas at Austin.

Largent, F. B., Jr., M. R. Waters, and D. L. Carlson

1991 The Spatiotemporal Distribution of Folsom Projectile Points in Texas. Plains Anthropologist 36(137):323-341.

Lynn, J. M., D. E. Fox, and N. O'Malley

1977 Cultural Resource Survey of Choke Canyon Reservoir, Live Oak and McMullen Counties, Texas. Archeological Survey Report 20. Office of the State Archeologist, Texas Historical Commission, Austin.

McGraw, J. A.

1983 Arroyo de los Muertos and other Prehistoric Terrace Sites Along the Rio Grande, Laredo, Texas. Archaeological Survey No. 106, University of Texas at Austin.

MacNeish, R. S.

1947 A Preliminary Report on Coastal Tamaulipas. American Anthropologist 13:1-15.

1958 Preliminary Archeological Investigations in Sierra de Tamaulipas, Mexico. Transactions of the American Philosophical Society 48:6. 
Mallouf, R. J., B. J. Baskin, and K. L. Killen

1977 A Predictive Assessment of Cultural Resources in Hidalgo and. Willacy Counties, Texas. Survey Report 25, Office of the State Archeologist, Texas Historical Commission. Austin.

Martin, G. C.

1929 Notes on Some Texas Coast Campsites and Other Remains. Bulletin of the Texas Archaeological and Paleontological Society 1:50-57.

1930a Two Sites on Callo Del Oso, Nueces County, Texas. Bulletin of the Texas Archaeological and Paleontological Society 2:7-17.

1930b A Vase and Some Carved Stones and Pebbles from Nueces County, Texas. Bulletin of the Texas Archaeological and Paleontological Society 2:18-30.

1931 Texas Coastal Pottery. Bulletin of the Texas Archaeological and Paleontological Society 3:5356.

Martin, G. C., and W. H. Potter

n.d. Preliminary Archaeological Survey of a Portion of the Texas Coast. Privately printed, ca. 1931. On file, Texas Archeological Research Laboratory, The University of Texas at Austin.

Meltzer, D. J.

1986 The Clovis Paleoindian Occupation of Texas: Results of the Texas Fluted Point Survey. Bulletin of the Texas Archeological Society 57:27-86.

Nunley, P., and T. R. Hester

1966 Preliminary Archeological Investigations in Dimmit County, Texas. Texas Journal of Science 18(3):233-253.

Patterson, J. T.

1936 The Corner-Tang Flint Artifacts of Texas. Bulletin 3618, Anthropological Papers 1(4). The University of Texas, Austin.

Poteet, $S$.

1938 The Occurrence and Distribution of Beveled Knives. Bulletin of the Texas Archaeological and Paleontological Society 10:245-262.

Potter, W. H.

1930 Ornamentation on the Pottery of the Texas Coastal Tribes. Bulletin of the Texas Archaeological and Paleontological Society 2:41-44.

Sanders, R. R., and W. J. Gabriel

1985 Soil Survey of Webb County, Texas. Soil Conservation Service, United States Department of Agriculture.

Sellards, E. H.

1940 Pleistocene Artifacts and Associated Fossils' from Bee County, Texas. Bulletin of the Geological Survey of America 51:1627-1657. 
Shafer, H. J., and C. L. Bond

1985 An Archeological Review of the Central Texas Coast. Bulletin of the Texas Archeological Society 54:271-286.

Story, D. A.

1968 Archeological Investigations at Two Central Texas Gulf Coast Sites. Report 13. Archeological Program, State Building Commission. Austin.

Suhm, D. A., A. D. Kreiger, and E. B. Jelks

1954 An Introductory Handbook of Texas Archeology. Bulletin 25. Texas Archeological Society.

Thompson, J.

1986 Laredo A Pictorial History. The Donning Company Publishers, Norfolk, Virginia.

Turner, E. S., and T. R. Hester

1985 A Field Guide to Stone Artifacts of Texas Indians. Texas Monthly Press, Austin.

1993 A.Field Guide to Stone Artifacts of Texas Indians. 2nd Edition. Texas Monthly Press, Austin.

U. S. Army Corps of Engineers

1990 Environmental Assessment of Joint Task Force Six Operation 3-90, Webb, La Salle, Jim Hogg, and Duval Counties, Texas. U. S. Army Corps of Engineers, Fort Worth District, Texas.

U. S. Department of the Interior

1990 National Register Bulletin 15.

Usrey, S.

1980 Archeological Investigations at Seven Sites in Atascosa County, Texas. Report 48. Anthropology Laboratory, Texas A\&M University, College Station.

Wakefield, W.

1968 Archeological Survey of Palmetto Bend and Choke Canyon Reservoir, Texas. Survey Report 5. Texas Archeological Survey, The University of Texas. Austin.

Warren, J. E.

1987 A Comprehensive Plan for Investigation and Preservation at Field Fort McIntosh in Laredo, Webb County, Texas. Webb County Historical Commission.

1988 Historical Archaeology at Fort McIntosh in Laredo, Webb County, Texas. Report No. 175. The Golf Driving Range Project, Texas Antiquities Committee, Austin.

1989a Historical Archaeology at Fort McIntosh in Laredo, Webb County, Texas. Report No. 180. The Texas-Israel Exchange Project, Greenhouse Location, Texas Antiquities Committee, Austin.

1989b A Cultural Resource Survey of the City of San Ygnacio Wastewater Improvement Project, Zapata County, Texas. Report No. 188, Texas Antiquities Committee, Austin.

1991 Historical Archaeology at Fort McIntosh in Laredo, Webb County, Texas. Report No. 240. Texas Antiquities Committee, Austin. 


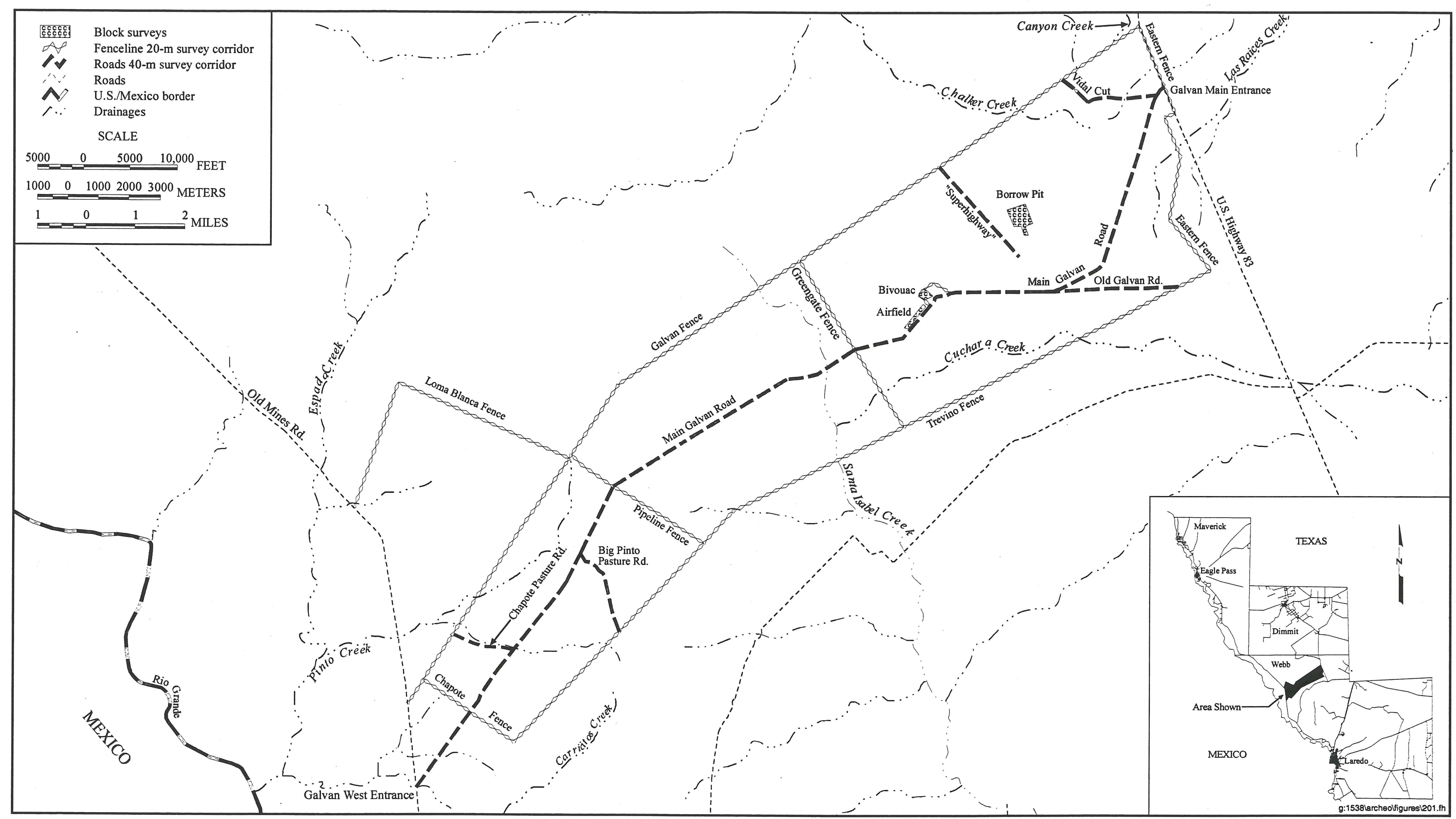

Figure 4. Galvan Ranch segment. 


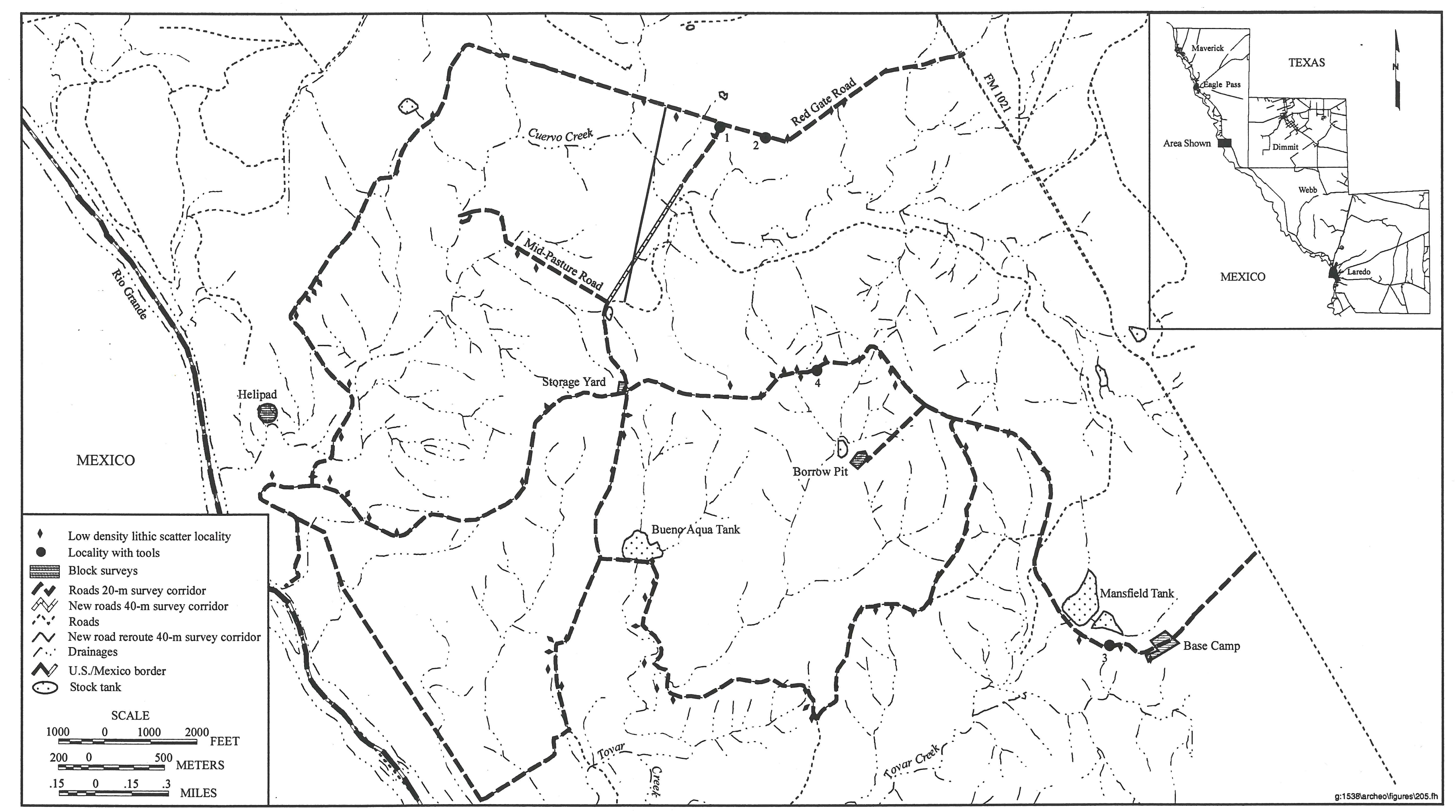

Figure 101. Location of nonsite localities on the Swartz Ranch segment. 


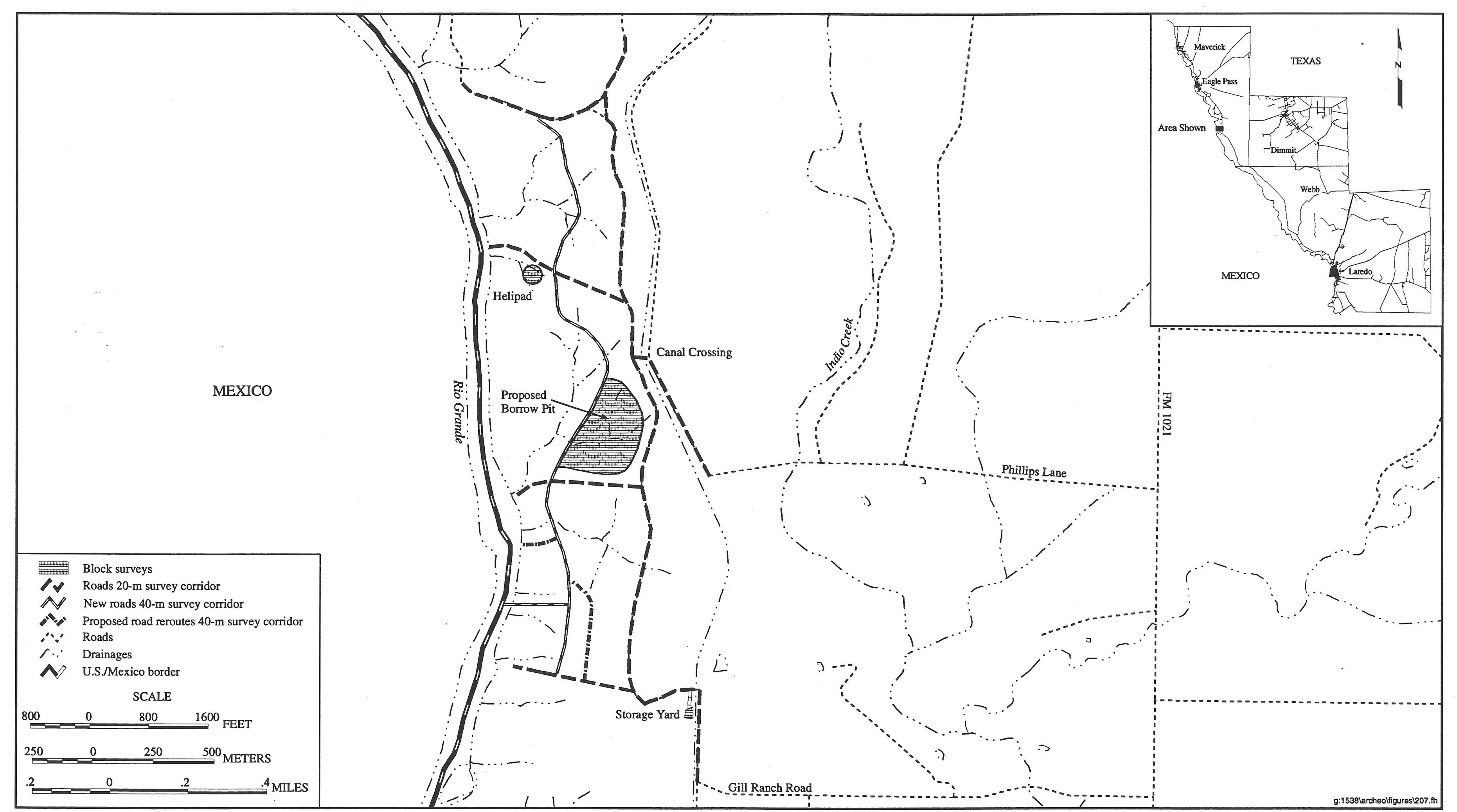

Figure 5. Stone Ranch segment. 


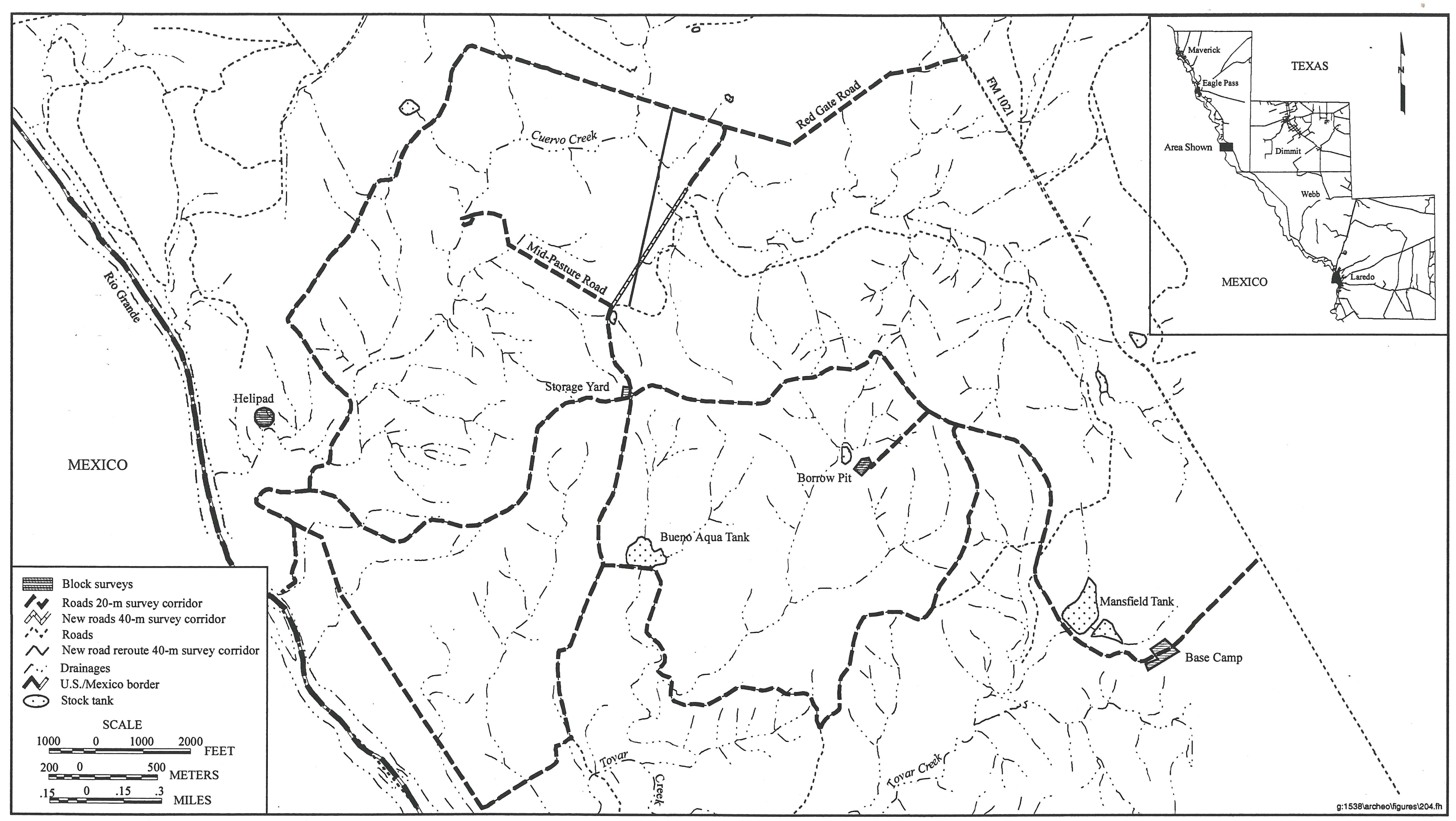

Figure 6. Swartz Ranch segment 
Figure Redacted

Figure 100. Location of sites on the Swartz Ranch segment. 


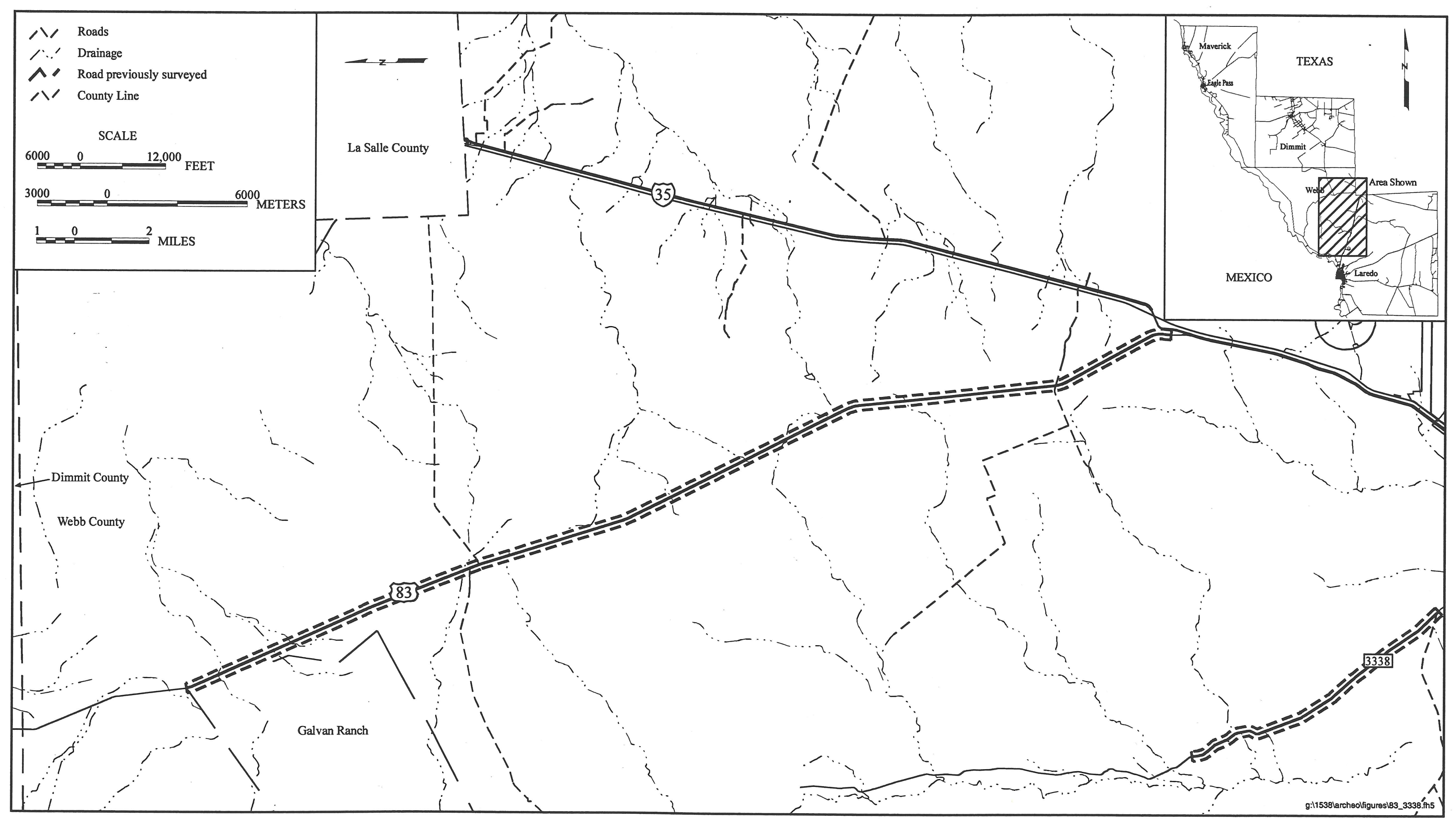

Figure 8. State Highway 83 and Farm-to-Market Road 3338 segments. 
Figure Redacted

Figure 9. Location of sites on the Galvan Ranch segment. 


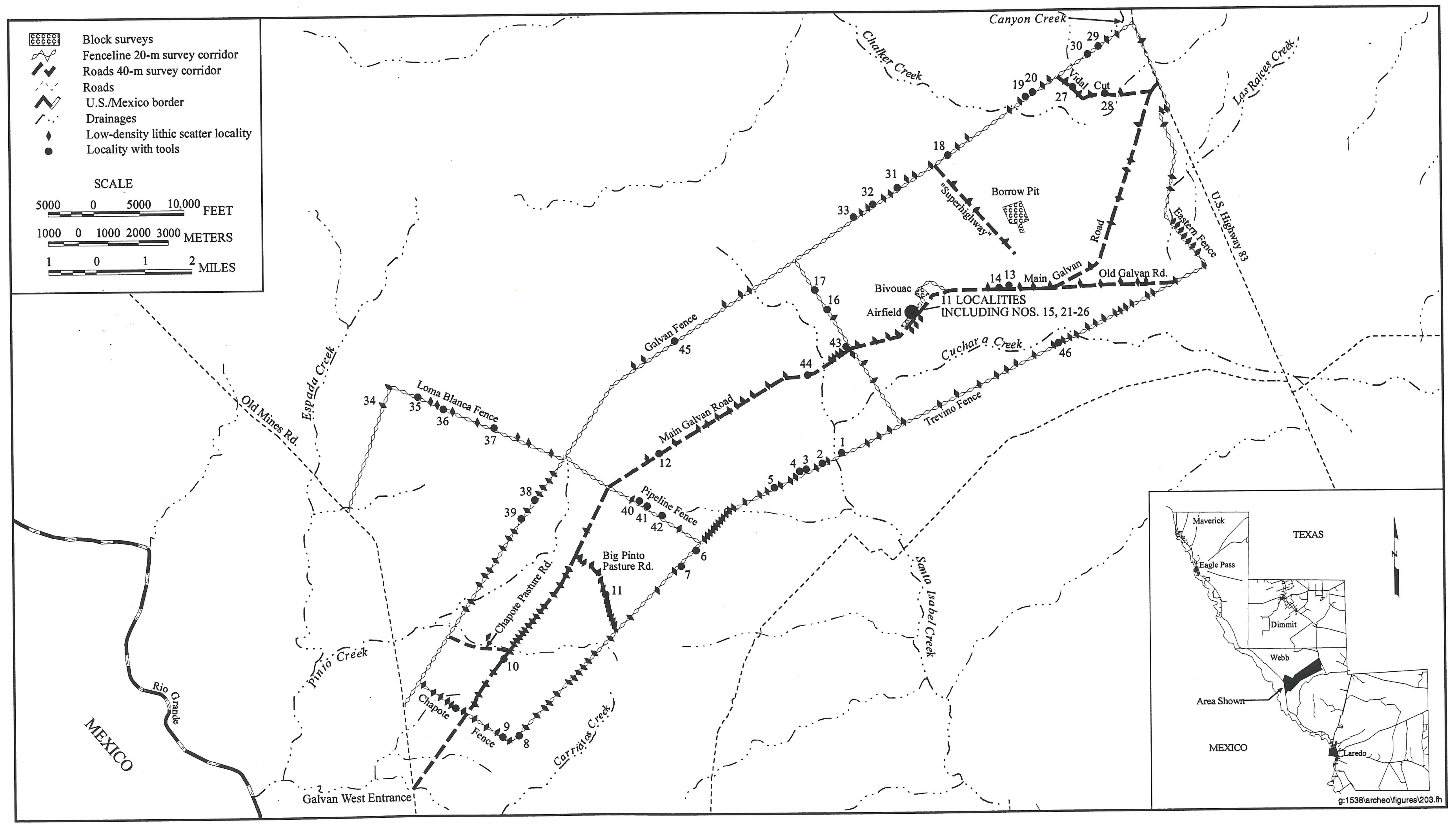

Figure 10. Nonsite localities on the Galvan Ranch segment. 


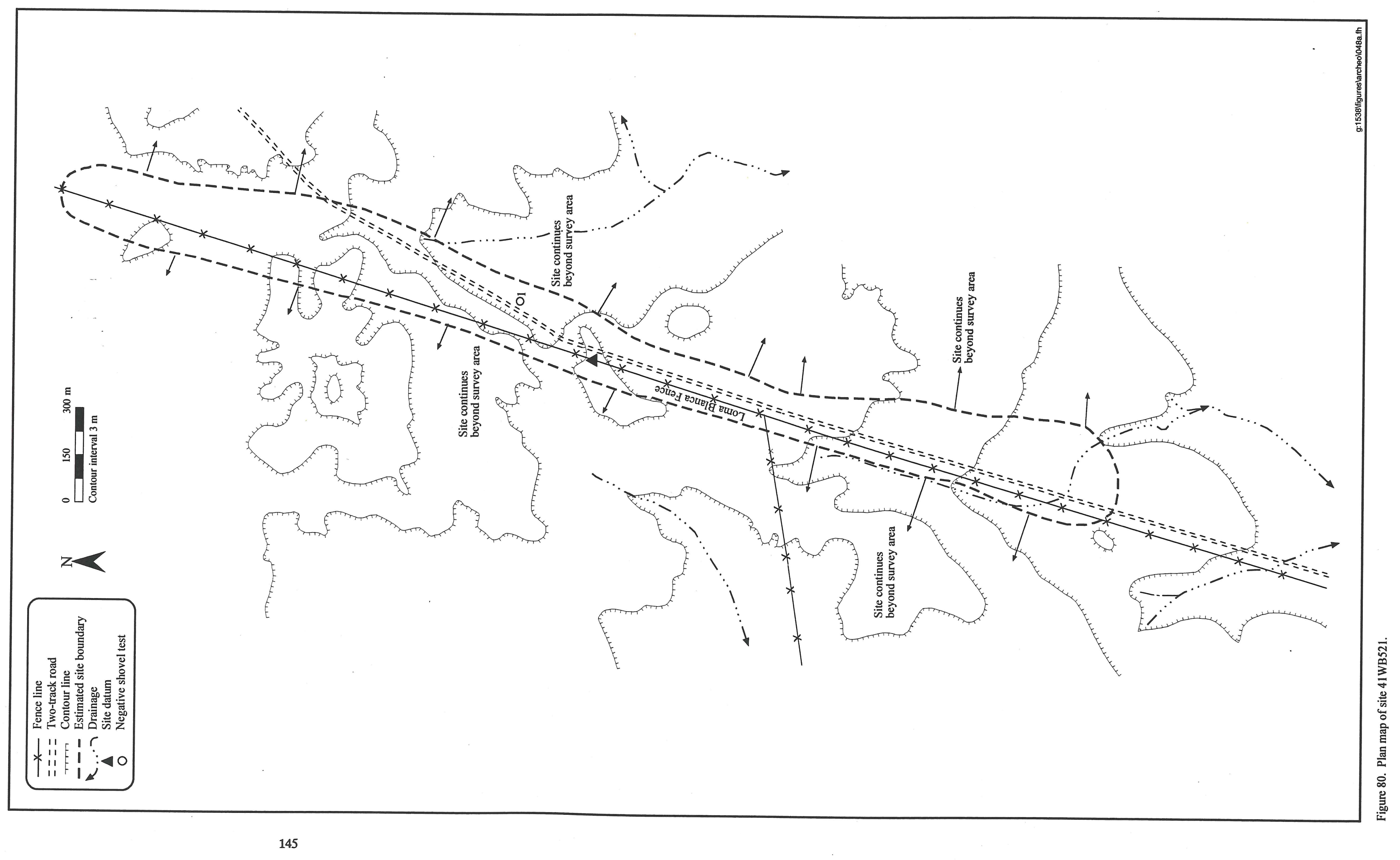


Figure 92. Location of sites and nonsite localities on the Stone Ranch segment. 


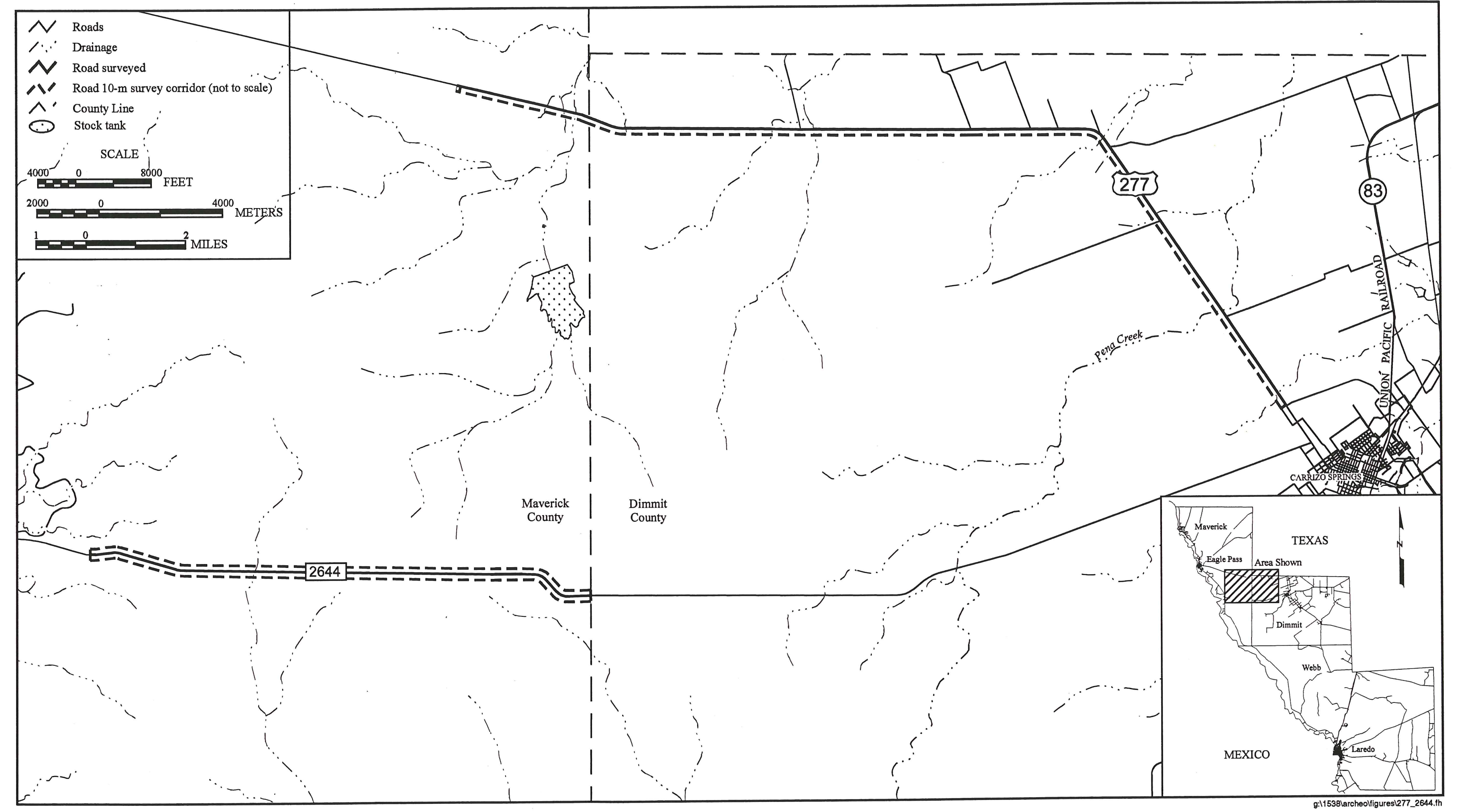

Figure 7. State Highway 277 and Farm-to-Market Road 2644 segments. 